\title{
Draft Title 40 CFR 191 \\ Compliance Certification Application for the Waste Isolation Pilot Plant
}

\author{
Volume III
}

Appendix BIR Vol. I

March 31, 1995

United States Department of Energy Waste Isolation Pilot Plant

\author{
Carlsbad Area Office \\ Carlsbad, New Mexico
}




\section{Waste Isolation Pilot Plant Transuranic Waste Baseline Inventory Report}

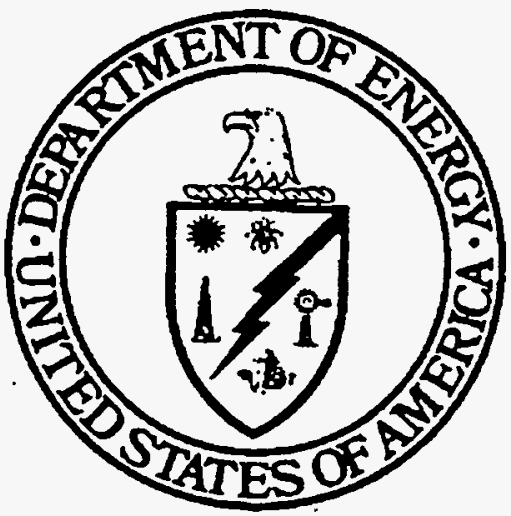

February 1995

Prepared by WIPP Technical Assistance Contractor for U.S. Department of Energy under Contract No. DE-AC04-93AL-96904

\section{Volume 1}




\section{DISCLA.IMER}

This report was prepared as an account of work sponsored by an agency of the United States Government. Neither the United States Government nor any agency thereof, nor any of their employees, makes any warranty, express or implied, or assumes any legal liability or responsibility for the accuracy, completeness, or usefulness of any information, apparatus, product, or process disclosed, or represents that its use would not infringe privately owned rights. Reference herein to any specific commercial product, process, or service by trade name, trademark, manufacturer, or otherwise does not necessarily constitute or imply its endorsement, recommendation, or favoring by the United States Government or any agency thereof. The views and opinions of authors expressed herein do not necessarily state or reflect those of the United States Government or any agency thereof. 


\section{DISCLAIMER}

Portions of this document may be illegible in electronic image products. Images are produced from the best available original document. 


\section{TABLE OF CONTENTS}

Section

Page

VOLUME 1

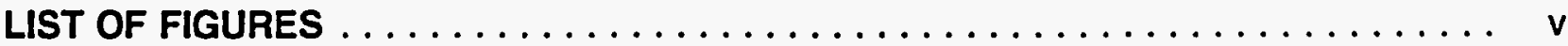

LIST OF TABLES $\ldots \ldots \ldots \ldots \ldots \ldots \ldots \ldots \ldots \ldots \ldots \ldots \ldots \ldots \ldots$

ACRONYMS AND ABBREVIATIONS $\ldots \ldots \ldots \ldots \ldots \ldots \ldots \ldots \ldots \ldots$

PREFACE $\ldots \ldots \ldots \ldots \ldots \ldots \ldots \ldots \ldots \ldots \ldots \ldots \ldots \ldots \ldots \ldots \ldots \ldots \ldots$

EXECUTIVE SUMMARY $\ldots \ldots \ldots \ldots \ldots \ldots \ldots \ldots \ldots \ldots \ldots$

1. INTRODUCTION $\ldots \ldots \ldots \ldots \ldots \ldots \ldots \ldots \ldots \ldots \ldots \ldots \ldots \ldots \ldots$

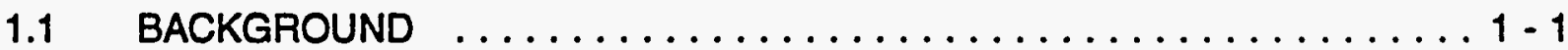

1.2 PURPOSE $\ldots \ldots \ldots \ldots \ldots \ldots \ldots \ldots \ldots \ldots \ldots \ldots \ldots \ldots \ldots \ldots$

1.3 WASTE INVENTORY TERMINOLOGY $\ldots \ldots \ldots \ldots \ldots \ldots \ldots \ldots \ldots \ldots$

1.3.1 Inventory Terminology ...................... 1-4

1.3.2 Waste Matrix Code Terminology ..................... 1 - 4

1.3.3 Waste Profile Terminology ..................... 1-5

1.3.4 Database Terminology ....................... 1-12

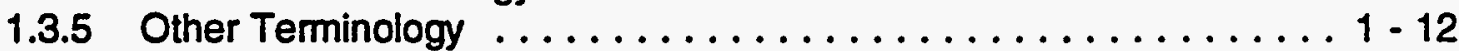

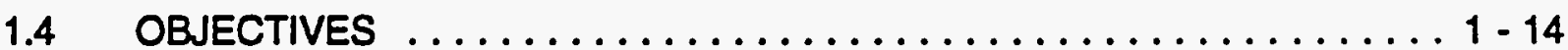

1.5 TRU SYSTEM-WIDE DATA ASSUMPTIONS . . . . . . . . . . . . 1 - 14

1.5.1 Waste Material Parameter Assumptions . . . . . . . . . . . . . . . . 1 - 14

1.5 .2 Inventory Volume Assumptions .................. 1 - 15

1.5.3 Packaging Material Assumptions .................. 1-15

1.5.4 Radionuclide Information Assumptions ................ 1 - 17

1.5.5 Comparison of IDB versus WTWBIR Waste Volumes ........ . 1 - 17

1.6 BASELINE INVENTORY UPDATES $\ldots \ldots \ldots \ldots \ldots \ldots \ldots \ldots$

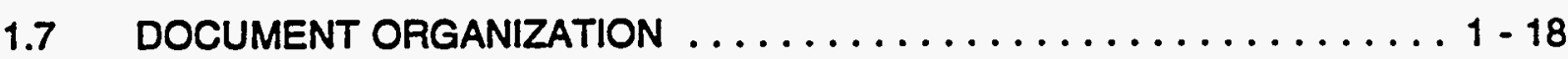

2. TRU WASTE DISPOSAL INVENTORY $\ldots \ldots \ldots \ldots \ldots \ldots \ldots \ldots$

2.1 INTRODUCTION .......................... 2 1

2.2 SOURCE OF TRU WASTE INFORMATION $\ldots \ldots \ldots \ldots \ldots \ldots \ldots \ldots \ldots$

2.2.1 Site-Specific Waste Information ................... 2 - 1

2.2.2 Existing Summary Documents on TRU Waste Information . . . . . . . 2 - 2 
2.3 METHODOLOGY FOR DEVELOPMENT OF DISPOSAL INVENTORY . . . . 2 - 4

3. WASTE PROFILE METHODOLOGY $\ldots \ldots \ldots \ldots \ldots \ldots \ldots \ldots \ldots \ldots$

3.1 WASTE STREAM PROFILE METHODOLOGY $\ldots \ldots \ldots \ldots \ldots \ldots \ldots$

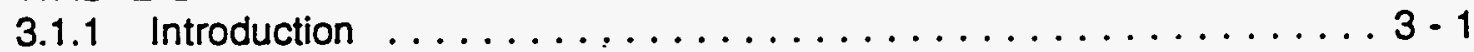

3.1.2 Waste Stream Profile Description .................. 3 - 1

3.1.3 Assignment of the Waste Matrix Code Group .............. . 3-1

3.2 SITE-SPECIFIC WASTE PROFILE METHODOLOGY $\ldots \ldots \ldots \ldots \ldots$

3.3 WIPP WASTE PROFILE METHODOLOGY $\ldots \ldots \ldots \ldots \ldots \ldots \ldots \ldots$

3.3.1 Introduction and Methodology $\ldots \ldots \ldots \ldots \ldots \ldots \ldots \ldots \ldots \ldots$

3.3.2 WIPP Waste Profile Roll-Ups .................. $3-8$

4. WIPP DISPOSAL RADIONUCLIDE INVENTORY $\ldots \ldots \ldots \ldots \ldots \ldots \ldots$

4.1 INTRODUCTION $\ldots \ldots \ldots \ldots \ldots \ldots \ldots \ldots \ldots \ldots \ldots \ldots \ldots \ldots$

4.2 METHODOLOGY .........................4-1

5. WASte MATERIAL PARAMETERS $\ldots \ldots \ldots \ldots \ldots \ldots \ldots \ldots \ldots \ldots$

5.1 INTRODUCTION ........................ $5-1$

5.2 PARAMETER DESCRIPTION .................... $5 \cdot 1$

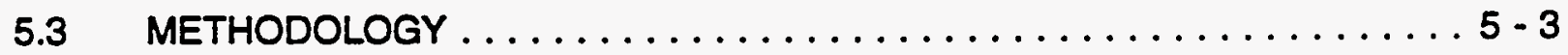

5.4 WIPP WASTE MATERIAL PARAMETER ROLLUPS $\ldots \ldots \ldots \ldots \ldots$

5.5 UTILIZATION OF WASTE MATERIAL PARAMETER DATA
IN APPLICATIONS $\ldots \ldots \ldots \ldots \ldots \ldots \ldots \ldots \ldots \ldots \ldots \ldots \ldots \ldots \ldots \ldots$

6. STORED AND PROJECTED CH-TRU AND RH-TIRU INVENTORIES BY SITE . . . 6 - 1

7. WIPP TRANSURANIC WASTE BASELINE INVENTORY DATABASE $\ldots \ldots \ldots$

7.1 DATABASE DESCRIPTION $\ldots \ldots \ldots \ldots \ldots \ldots \ldots \ldots \ldots \ldots \ldots$

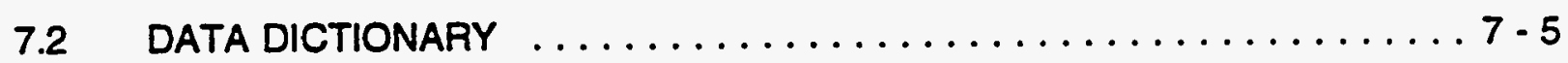

7.3 DATABASE OPERATING INSTRUCTIONS $\ldots \ldots \ldots \ldots \ldots \ldots \ldots$

7.4 WTWBID QUALTY CONTROL $\ldots \ldots \ldots \ldots \ldots \ldots \ldots \ldots \ldots \ldots$

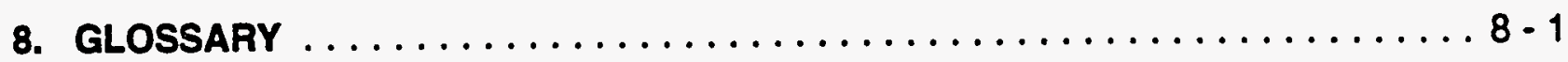

9. REFERENCES $\ldots \ldots \ldots \ldots \ldots \ldots \ldots \ldots \ldots \ldots \ldots \ldots \ldots \ldots \ldots$ 
VOLUME 2

APPENDIX A. WASTE STREAM PROFILES

A - 1

VOLUME 3

APPENDIX B. SITE-SPECIFIC WASTE PROFILES $\ldots \ldots \ldots \ldots \ldots \ldots \ldots \ldots \ldots$

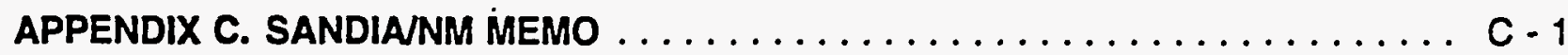

APPENDIX D. WTWBIR REVISION 1 QUESTIONNAIRE . . . . . . . . . . . D - 1

APPENDIX E. SITE-SPECIFIC STORED RADIONUCLIDE

INVENTORIES FROM DRAFT REVISION 10 IDB $\ldots \ldots \ldots \ldots \ldots \ldots \ldots$. . 1

APPENDIX F. WASTE STREAM IDENTIFICATION

CROSS-CORRELATION TABLE ..................F - 1

APPENDIX G. MWIR CODE DESIGNATIONS AND DESCRIPTIONS . . . . . . . . G - 1

APPENDIX H. WTWBIR RADIONUCLIDE ISOTOPIC MIXTURES $\ldots \ldots \ldots \ldots \ldots$

APPENDIX I. DRAFT INTEGRATED DATA BASE FOR 1995:

REVISION $10 \ldots \ldots \ldots \ldots \ldots \ldots \ldots \ldots \ldots \ldots \ldots \ldots$

APPENDIX J. WEST VALLEY DEMONSTRATION PROJECT

WASTE STREAM PROFILES .................. J - 1 


\section{LIST OF FIGURES}

Figure

Page

1-1 U.S. Department of Energy Transuranic

Waste Generator/Storage Sites ........................ 1 . 2

1-2 Blank Waste Stream Profile Form . . . . . . . . . . . . . . . . . . 1 . 9

1-3 Blank Site-Specific Waste Profile Form $\ldots \ldots \ldots \ldots \ldots \ldots \ldots \ldots \ldots \ldots$

$1-4 \quad$ Blank WIPP Waste Profile Form $\ldots \ldots \ldots \ldots \ldots \ldots \ldots \ldots \ldots \ldots$

3-1 Example of TRU Waste Stream Profile from Idaho National

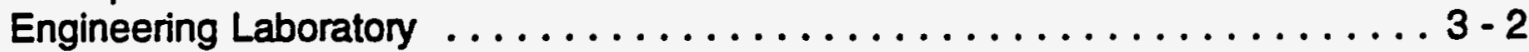

3-2 Schematic of Waste Stream Profile Methodology . . . . . . . . . . . . . 3 - 9

3-3 Example of Site-Specific Waste Profile ................... $3-10$

3-4 WIPP CH-TRU Waste Profile for Final Waste.

Form Combustible $\ldots \ldots \ldots \ldots \ldots \ldots \ldots \ldots \ldots \ldots \ldots \ldots \ldots$

3-5 WIPP $\mathrm{CH}-\mathrm{TRU}$ Waste Profile for Final Waste Form Filter $\ldots \ldots \ldots \ldots$

3-6 WIPP CH-TRU Waste Profile for Final Waste Form Graphite $\ldots \ldots \ldots$. . . 3 - 18

3-7 WIPP CH-TRU Waste Profile for Final Waste Form Heterogeneous . . . . . . 3 - 19

3-8 WIPP CH-TRU Waste Profile for Final Waste Form

Inorganic Non-metal ............................ 3 - 21

3-9 WIPP CH-TRU Waste Profile for Final Waste Form

Lead/Cadmium Metal Waste . . . . . . . . . . . . . . . . . . . . 3 - 22

3-10 WIPP CH-TRU Waste Profile for Final Waste Form Salt Waste . . . . . . . 3 - 23

3-11 WIPP CH-TRU Waste Profile for Final Waste Form Soils . . . . . . . . . . . 3 - 24

3-12 WIPP CH-TRU Waste Profile for Final Waste Form Solidified

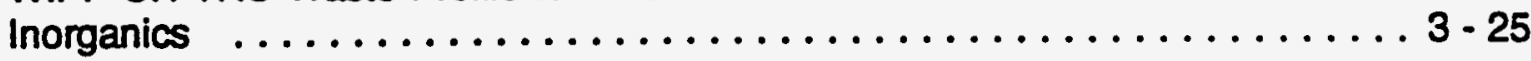

3-13 WIPP CH-TRU Waste Profile for Final Waste Form Solidified

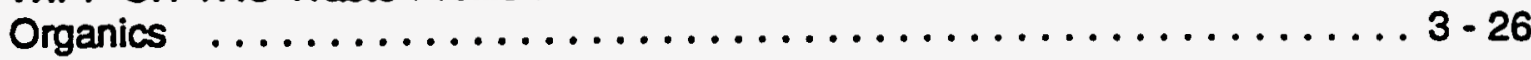

3-14 WIPP CH-TRU Waste Profile for Final Waste Form

Uncategorized Metal ........................... 3-27

3-15 WIPP CH-TRU Waste Profile for Final Waste Form Unknown $\ldots \ldots \ldots \ldots$ 
3-16 WIPP RH-TRU Waste Profile for Final Waste Form Combustible . . . . . . . 3 - 29

3-17 WIPP RH-TRU Waste Profile for Final Waste Form Filter $\ldots \ldots \ldots \ldots$

3-18 WIPP RH-TRU Waste Profile Final Waste Form Heterogeneous . . . . . . . 3 - 31

3-19 WIPP RH-TRU Waste Profile for Final Waste Form Lead/Cadmium Metal Waste . . . . . . . . . . . . . . . . . . . 3 - 32

3-20 WIPP RH-TRU Waste Profile for Final Waste Form Salt Waste $\ldots \ldots \ldots \ldots \ldots \ldots \ldots \ldots \ldots \ldots \ldots \ldots \ldots \ldots \ldots \ldots \ldots$

3-21 WIPP RH-TRU Waste Profile for Final Waste Form Solidified Inorganics ............................... 34

3-22 WIPP RH-TRU Waste Profile for Final Waste Form

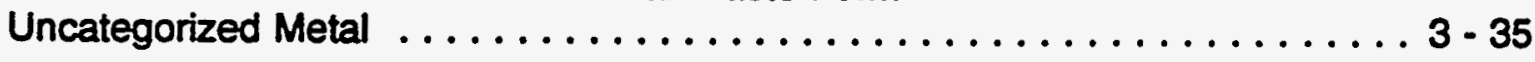

3-23 WIPP RH-TRU Waste Profile for Final Waste Form Unknown . . . . . . . . 3 - 36 


\section{LIST OF TABLES}

Table

Page

1-1 Technical Data Needs for Systems Prioritization Methodology/Performance Assessment Waste Material Parameters ...................... 1 . 3

1-2 Waste Matrix Code Group Names ... . . . . . . . . . . . . . . . . 1 - 6

1-3 Packaging Material Assumptions . . . . . . . . . . . . . . . . 1 - 17

3-1 Sources of Information Used in Waste Stream Profiles . . . . . . . . . . . 3 - 4 .

3-2 Toxic Substances Control Act (TSCA) TRU Waste $\ldots \ldots \ldots \ldots \ldots . . . . . .3$. . . . . .

3-3 Sources of Information Used in Site-Specific Waste Profiles . . . . . . . . . . 3 - 12

3-4 Sources of Information Used in WIPP Waste Profiles . . . . . . . . . . . . 3 - 13

3-5 Transuranic Waste Disposal Inventory for WIPP ... . . . . . . . . . . . 3 - 15

4-1 CH-TRU and RH-TRU IDB Waste inventories . . . . . . . . . . . . . $4-5$

4-2 Disposal Radionuclide Inventory .......................4 6

5-1 WIPP CH-TRU Waste Material Parameter Disposal Inventory . . . . . . . . 5 - 4

5-2 WIPP RH-TRU Waste Material Parameter Disposal Inventory . . . . . . . . 5 - 5

6-1 Contact-Handled Transuranic Waste Disposal Inventory by Site . . . . . . . . . . 6 - 2

6-2 Remote-Handled Transuranic Waste Disposal Inventory by Site . . . . . . . . . 6 - 3

6-3 AMES LAB Final Waste Form Volumes . . . . . . . . . . . . . . . . 6 - 4

6-4 ANL-E Final Waste Form Volumes . . . . . . . . . . . . . . . . 6 - 5

6-5 ANL-W Final Waste Form Volumes $\ldots \ldots \ldots \ldots \ldots$

6-6 BCDLP Final Waste Form Volumes $\ldots \ldots \ldots \ldots \ldots \ldots \ldots \ldots$

$6-7$ BT Final Waste Form Volumes . . . . . . . . . . . . . . . . . 6 - 8

$6-8$ ETEC Final Waste Form Volumes $\ldots \ldots \ldots \ldots \ldots \ldots \ldots \ldots$

6-9 HANFORD Final Waste Form Volumes . . . . . . . . . . . . . . . . . . 6 - 10

6-10 INEL Final Waste Form Volumes ...................... 6 - 11 
6-11 KAPL Final Waste Form Volumes . . . . . . . . . . . . . . . . 6 - 12

$6-12$ LANL Final Waste Form Volumes ..................... 6 - 13

$6-13 \quad$ LBL Final Waste Form Volumes . . . . . . . . . . . . . . . . . . . . 6 6 - 14

6-14 LLNL Final Waste Form Volumes .......................6-15

6-15 MOUND Final Waste Form Volumes . . . . . . . . . . . . . . . . . . 6 - 16

6-16 MU Final Waste Form Volumes ... . . . . . . . . . . . . . . . . 6 - 17

6-17 NTS Final Waste Form Volumes ..................... 6 - 18

6-18 ORNL Final Waste Form Volumes $\ldots \ldots \ldots \ldots \ldots \ldots \ldots$

6-19 PA Final Waste Form Volumes ......................... 6 - 20

6-20 PANTEX Final Waste Form Volumes ...................... 6 - 21

6-21 RFP Final Waste Form Volumes . . . . . . . . . . . . . . . . . 6 - 22

$6-22$ SNLNM Final Waste Form Volumes ..................... 6 - 23

6-23 SRS Final Waste Form Volumes ........................ 6 - 24

7-1 Table of Materials for $\mathrm{CH}$ and $\mathrm{RH}$ Waste Containers $\ldots \ldots \ldots \ldots \ldots$

$7-2 \quad$ WTWBID Data Dictionary ......................... $7 \cdot 5$ 


\section{ACRONYMS AND ABBREVIATIONS}

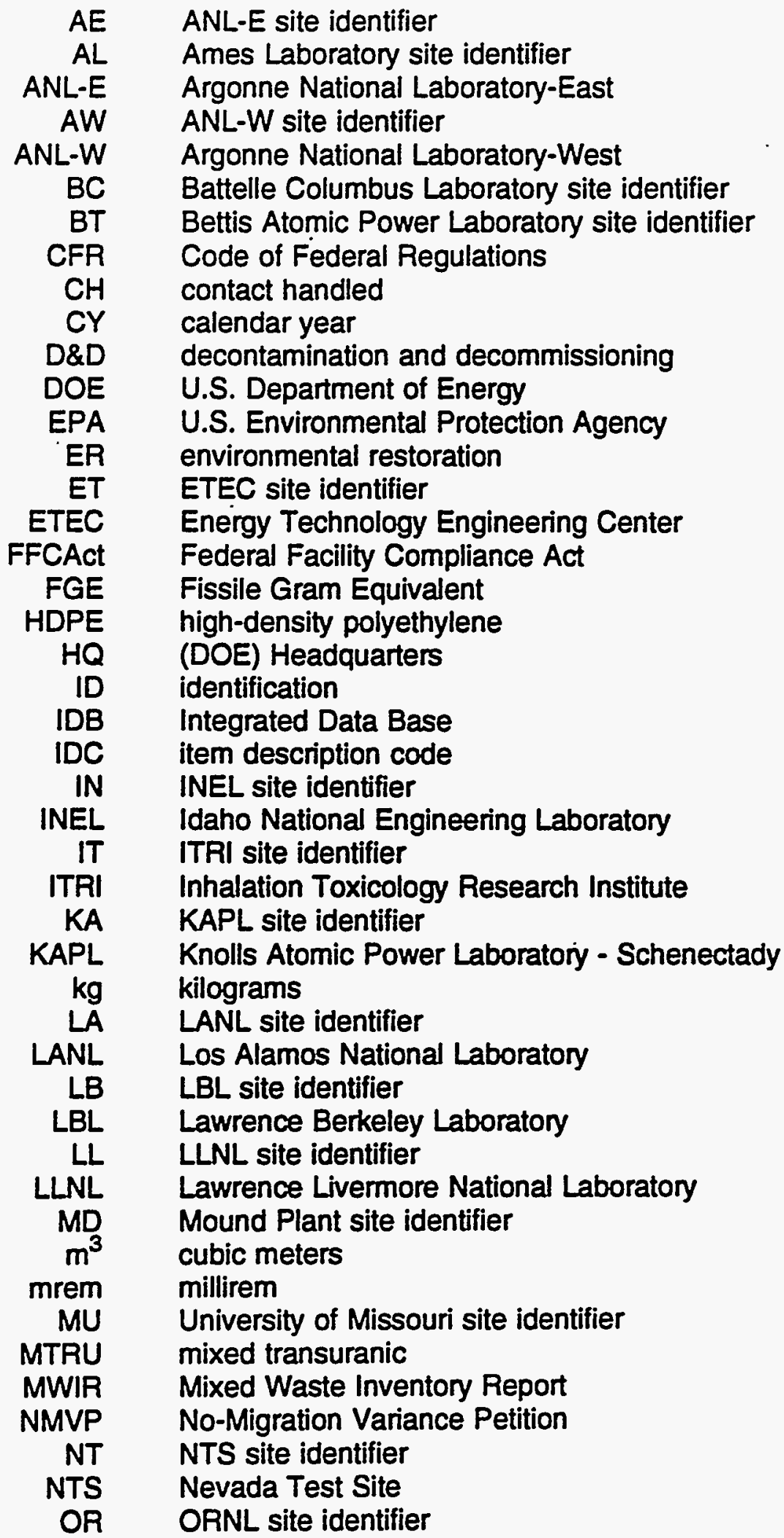




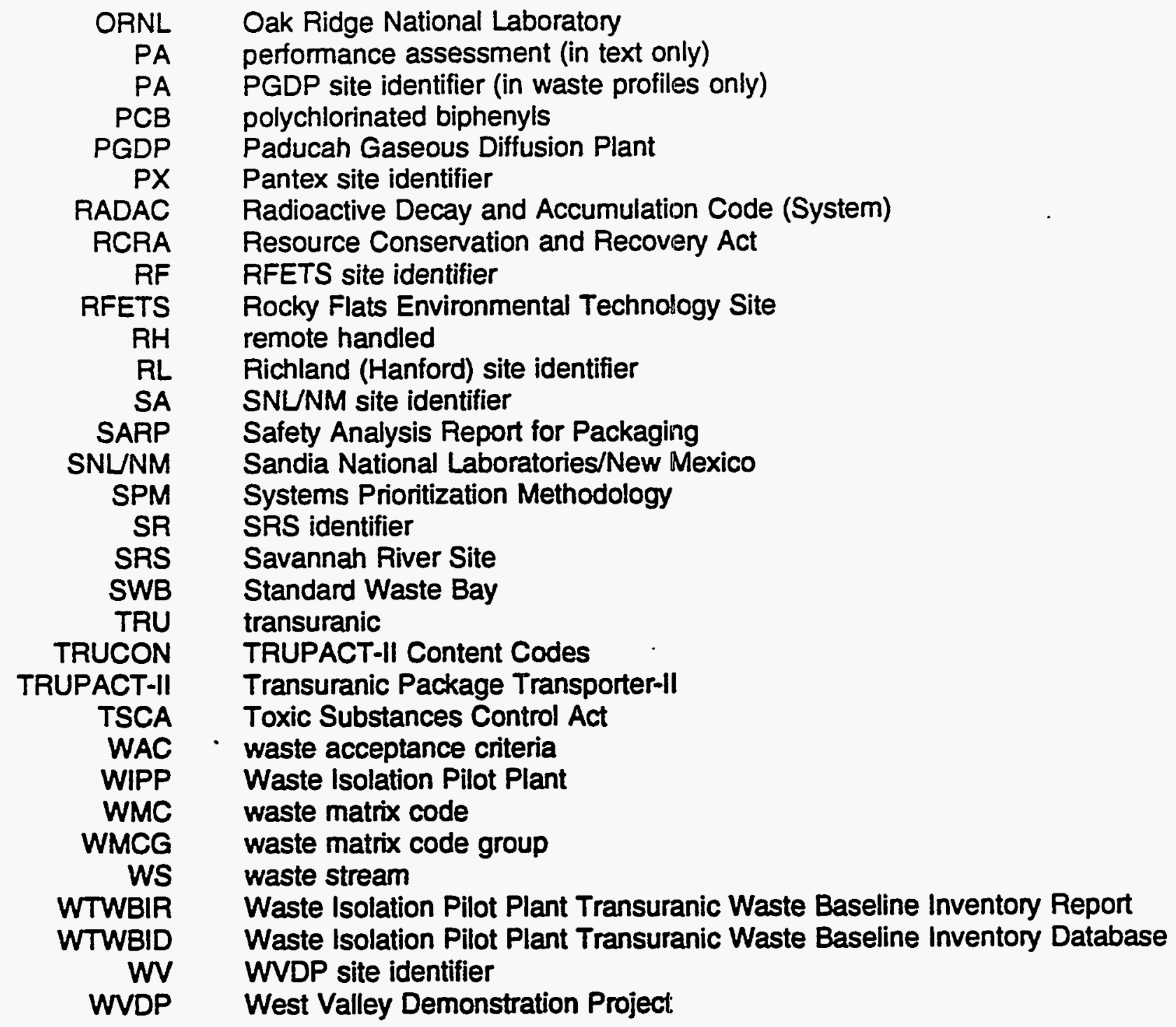




\section{PREFACE}

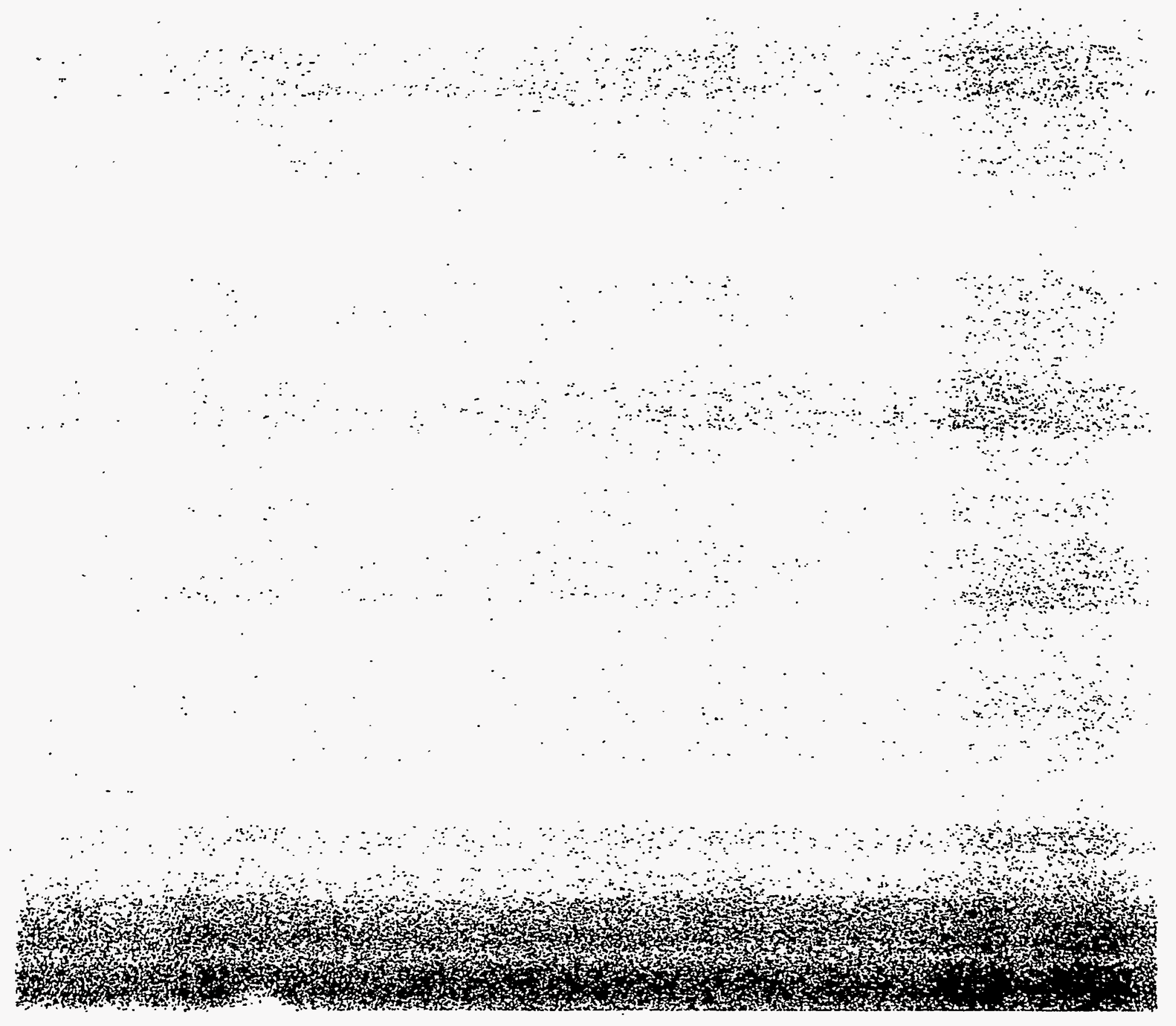




\section{PREFACE}

The information in this report summarizes the U.S. Department of Energy's (DOE) transuranic (TRU) waste inventory, projections, and characteristics. Revision 0 of the Waste Isolation Pilot Plant (WIPP) Transuranic Waste Baseline Inventory Report (WTWBIR) published in June 1994, was the first attempt ever made by the DOE complex to report all of its TRU waste at the waste stream level. The waste data reported in Revision 0 was considered preliminary until quality checks of the data were completed by the DOE TRU waste generator/storage sites. Data changes resulting from the site reviews are contained herein.

The primary differences between Revision 0 and Revision 1 of the WTWBIR are as follows:

- The WIPP baseline inventory reported in Revision 0 was complied from three existing DOE databases, whereas, inventory data in Revision 1 was collected directly from the sites through a request made by the National TRU Program Office.

- The nonmixed, TRU waste streams reported in Revision 0 were derived from the volume differences between the Integrated Data Base (IDB) and Mixed Waste Inventory Report (MWIR), while the nonmixed TRU waste streams contained in Revision 1 are as reported by the TRU waste generator/storage sites.

- Revision 1 of the WTWBIR reports radionuclide data at the waste stream level. Where sites provided radionuclide data as the waste stream level, it is replicated in Appendix A. A WIPP radionuclide inventory is provided in Table 4-2. This table is derived from the data submitted to support the IDB. Revision 0 reported the radionculide data at the WIPP level.

- Revision 1 reports the waste volumes in the final waste form that will be sent to WIPP. All previous databases, including Revision 0 of WTWBIR, report the waste in terms of volumes in storage before processing to meet WIPP requirements.

- The total radionuclide inventory for contact-handled $(\mathrm{CH})$ TRU waste is much higher in Revision 1 than reported in Revision 0 . This is due to two reasons: 1) Savannah River Site waste that was previously reported as "unknown" had not been included in the estimates, and 2) the "projected" part (1993-2022) of the CH-TRU radionuclide inventory was inadvertently left out of the totals reported in Revision 0 , causing the inventory to be approximately $25 \%$ low. Revision 1 corrects the inventory reporting error.

- The total radionuclide inventory for remote-handled (RH) TRU waste is also much higher in Revision 1. During calculation of the RH-TRU inventory the volume defined by the sites included more waste than the repository is authorized to accept. During those calculations, the IDB radionuclide numbers only covered the "stored" part of the inventory. This made the RH-TRU inventory reported in Revision 0 to be low by a factor of approximately 3-4. Revision 1 corrects the inventory reporting error.

- Oak Ridge National Laboratory has reported a very conservative inventory for U-235 in its RH-TRU waste ( $=367$ curies). In order to provide a more realistic estimate of the U-235 inventory, an anticipated transportation requirement for the RH-TRU cask was imposed in Revision 1. This requirement modifies the U-235 estimate reported in Revision 0. 


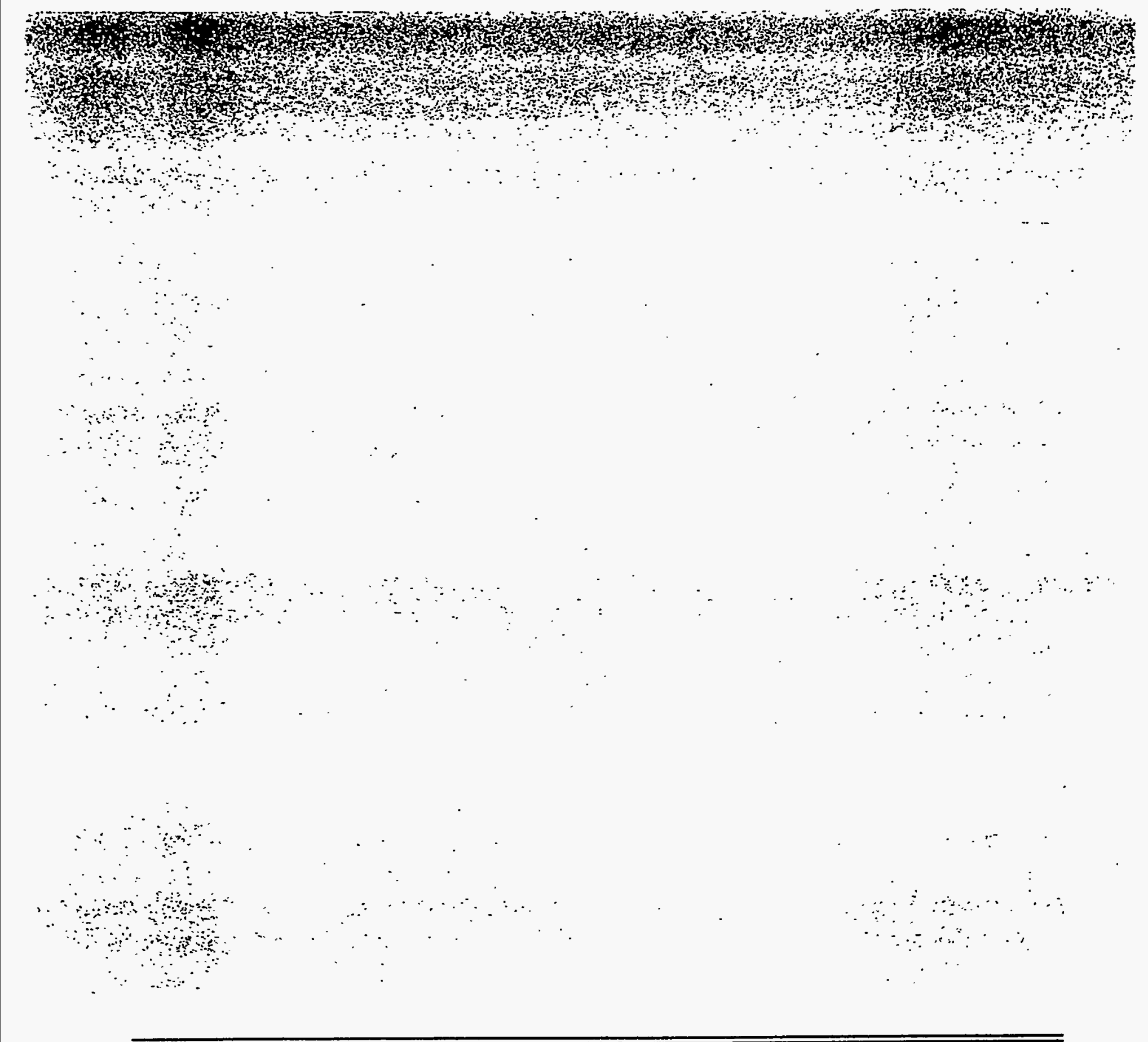

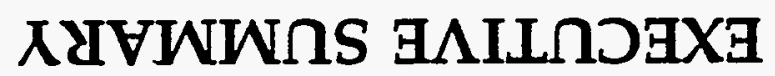




\section{EXECUTIVE SUMMARY}

The Waste Isolation Pilot Plant (WIPP) Transuranic Waste Baseline Inventory Report (WTWBIR) establishes a methodology for grouping wastes of similar physical and chemical properties, from across the U.S. Department of Energy (DOE) transuranic (TRU) waste system, into a series of "waste profiles" that can be used as the basis for waste form discussions with regulatory agencies. The majority of this document reports TRU waste inventories of DOE defense sites. An appendix is included which provides estimates of commercial TRU waste from the West Valley Demonstration Project.

The WIPP baseline inventory is estimated using waste streams identified by the DOE TRU waste generator/storage sites, supplemented by information from the Mixed Waste Inventory Report (MWIR) and the 1994 Integrated Data Base (IDB). The sites provided and/or authorized all information in the Waste Stream Profiles except the EPA (hazardous waste) codes for the mixed inventories. These codes were taken from the MWIR (if a WTWBIR mixed waste stream was not in MWIR, the sites were consulted). The IDB was used to generate the WIPP radionuclide inventory. Each waste stream is defined in a waste stream profile and has been assigned a waste matrix code (WMC) by the DOE TRU waste generator/storage site. Waste stream profiles with WMCs that have similar physical and chemical properties can be combined into a waste matrix code group (WMCG), which is then documented in a site-specific waste profile for each TRU waste generator/storage site that contains waste streams in that particular WMCG.

Based on methodology presented in this WTWBIR, a maximum of 11 site-specific waste profiles have been identified for contact-handled (CH) TRU waste and a maximum of 11 have been identified for remote-handled (RH) TRU waste for each site. Each of these site-specific waste profiles have unique WMCG criteria and they are developed, if appropriate, for each of the TRU waste generator/storage sites. A particular site-specific waste profile, with a specific WMCG, can be combined with other site-specific waste profiles having identical WMCGs from the TRU waste generator/storage sites to derive a WIPP waste profile.

The anticipated inventory of TRU waste is defined as the sum of retrievably stored waste (waste generated after 1970) plus currently projected TRU waste volumes. The anticipated inventory for CH-TRU waste is not sufficient to fill the maximum allowed capacity of WIPP (calculated: 6.2 million cubic feet [ $=176,000$ cubic meters]), and scaling has been developed as a means for Sandia National Laboratories' model to examine the impacts of the full repository. Scaling has also been applied to the RH-TRU inventory since sufficient volume has not been identified in the anticipated RH-TRU inventory to fill WIPP to the RH-TRU design capacity ( $=7080$ cubic meters). Additionally, there is a high uncertainty in and a current lack of data on wastes produced from decontamination and decommissioning (D\&D) and environmental restoration (ER) activities. Therefore, the anticipated $\mathrm{CH}-T R U$ inventory has been "scaled" to the maximum allowed WIPP capacity and the RH-TRU to the design capacity. The scaling of the inventories in this and future revisions of the WTWBIR will be derived from the best available data and assumptions.

An example of five waste streams at two sites (Figure 3-2 in the main body of the report) has been used to illustrate the waste profile methodology. Total WIPP inventory volumes for the WIPP waste profiles are provided. 
Using the same waste profile methodology, the WTWBIR also estimates the WIPP disposal inventory (anticipated inventory that has been scaled to WIPP design capacity) in terms of 10 waste material parameters and additional packaging materials that have been identified as inputs needed for the system prioritization methodology (SPM) and performance assessment (PA) calculations. The 10 waste material parameters and additional packaging materials are waste constituents that occur in TRU waste and are input parameters for one or more SPM and PA models or are required to adequately describe the waste form. These parameters may change as a result of SPM and PA efforts.

The 10 waste material parameters have been grouped by their chemical/physical properties and are indicated in bold lettering. The 10 waste material parameters and additional packaging materials that are defined and included in the WTWBIR are:

- Inorganics

- Iron-based metals/alloys

- Aluminum-based metals/alloys

- Other metals

- Other inorganic materials

- Organics

- Cellulosics

- Rubber

- Plastics

- Solidified Materials

- Inorganic matrix

- Organic matrix

- Soils

- Packaging Materials

- Steel

- Plastic

- Lead

The waste material parameter information is reported in kilograms per cubic meter of waste matrix $\left(\mathrm{kg} / \mathrm{m}^{3}\right)$. The waste material parameters in the waste stream, site-specific, and WIPP waste profiles are expressed on a weighttvolume basis. However, the occurrence of more than one waste material parameter at the maximum value within a waste stream is highly unlikely. If needed, during SPM and PA (Tables 5-1 and 5-2) calculations, the sampling statistics (if used) must be controlled so that several waste material parameters do not get sampled all at their maximum value (weight/volume), lest the average weight/volume is exceeded. To illustrate the waste profile methodology, five waste streams from two sites are used as examples. This revision of the WTWBIR provides a diskette that contains the WIPP TRU Waste Baseline Inventory Database in Microsoft Access ${ }^{\circledR}$.

Although the initial purpose of this report is to provide data to be included in the Sandia National Laboratories/New Mexico SPM and PA processes, all data are presented and explained in such a way that they can be adapted as needed for other applications. The WTWBIR, Revision 1, is presented in three parts: Volume 1 contains this Executive Summary through Chapter 9 and the WTWBID diskette; Volume 2 contains Appendix A, Waste Stream Profiles; and Volume 3 Appendices $\mathrm{B}$ through $\mathrm{J}$. 
CHAPTER 1

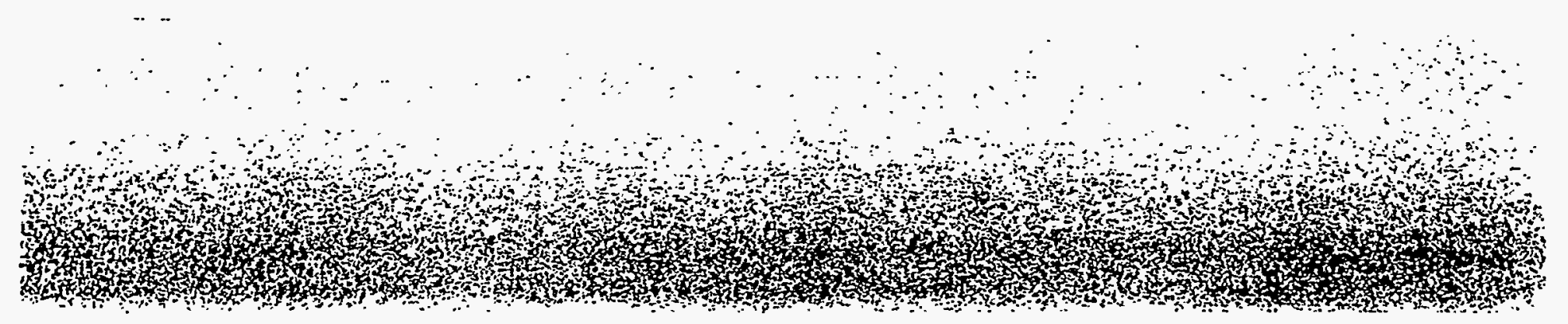




\section{INTRODUCTION}

\subsection{BACKGROUND}

The Waste Isolation Pilot Plant (WIPP) is a transuranic (TRU) waste management facility operated by the U.S. Department of Energy (DOE). The WIPP is currently identified as the permanent disposal site for DOE TRU waste.

TRU waste is defined as waste that is contaminated with alpha-emitting radionuclides with an atomic number greater than 92 , with half-lives greater than 20 years, and concentrations of TRU isotopes greater than 100 nanocuries per gram of waste (DOE, 1988). TRU wastes are classified as either contact-handled $(\mathrm{CH})$ waste or remote-handled $(\mathrm{RH})$ waste, depending on the dose rate at the surface of the waste container. CH-TRU wastes are packaged TRU wastes with an external surface dose rate of 200 millirems (mrem) or less per hour, while RH-TRU wastes are packaged TRU wastes with an external surface dose rate exceeding 200 mrem per hour. Unless otherwise indicated, for purposes of this document, all references to TRU waste include TRU waste and mixed TRU waste (waste that contains both radioactive and hazardous components, as defined by the Atomic Energy Act and the Resource Conservation and Recovery Act [RCRA] as codified in Title 40 Code of Federal Regulations [CFR] Parts 264, 265, 268, and 270 [EPA, 1980a; 1980b; 1986; and 1983]).

The DOE is committed to demonstrating compliance with all applicable regulations prior to permanent disposal of TRU wastes in the WIPP repository. These regulations are the environmental standards for management and disposal of TRU wastes as mandated in 40 CFR Part 191 (EPA, 1993) and Part 194 (DOE, 1995), and the RCRA regulations. Compliance will be demonstrated through Sandia National Laboratory/New Mexico (SNL/NM) performance assessment (PA) calculations based on the inventory of existing and currently projected waste streams developed in this document, as reported by the DOE TRU waste generator/storage sites. The WIPP is scheduled to receive and dispose of TRU wastes from 10 major and several minor DOE TRU waste generator/storage sites (see Figure 1-1).

\subsection{PURPose}

The purpose of this report, the Waste Isolation Pilot Plant Transuranic Waste Baseline Inventory Report (WTWBIR), is to document the disposal inventory of TRU waste to be emplaced in WIPP as defined by the DOE TRU waste generator/storage sites. This inventory of CH-TRU and RHTRU waste will be used in the SNLNM systems prioritization methodology (SPM)/PA calculations and sensitivity analyses that will support the development of compliance applications to the appropriate regulatory agencies regarding the operations and post-closure timeframes of the WIPP repository.

To accomplish this purpose, the WTWBIR has been developed from the best available information and process knowledge provided by the DOE TRU waste generator/storage sites. In support of SPM/PA, the WTWBIR describes a process for grouping individual waste streams with similar physical and chemical properties into waste profiles, based on their waste matrix code (WMC) (DOE, 1993a) assigned by the DOE TRU waste generator/storage sites. Waste profiles with similar WMCs, are then combined across the DOE TRU waste system to provide estimated total volumes and total waste material parameters. The methodology for this grouping and combining is discussed in detail in Section 2.3, Methodology for Development of Disposal Inventory. 


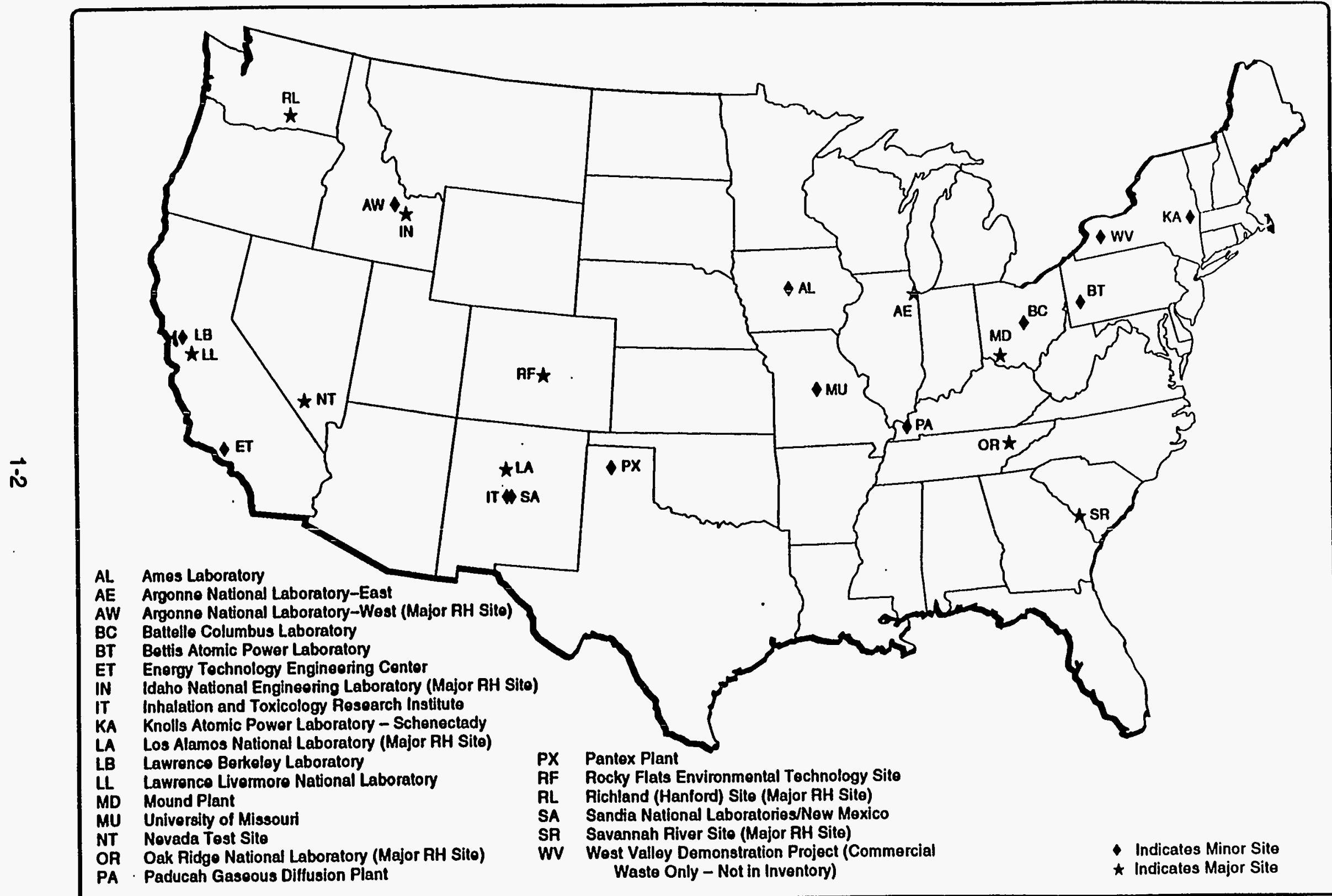

Figure 1-1. U.S. Department of Energy Transuranic Waste Generator/Storage Sites. 
The individual waste streams also are evaluated to estimate the occurrence and quantities of nonradioactive waste material parameters as defined in Appendix $C$ and listed in Table 1-1 (e.g., cellulosics, plastics, iron-based metals/alloys, etc.) that have been identified by SNLNM as being potentially important to the performance of the WIPP repository. The methodology, assumptions, and totals of these waste material parameters are described in Chapter 5, Waste Material Parameters.

TABLE 1-1. TECHNICAL DATA NEEDS FOR SYSTEMS PRIORITIZATION METHODOLOGY/PERFORMANCE ASSESSMENT WASTE MATERIAL PARAMETERS

\begin{tabular}{|c|c|c|c|c|}
\hline \multirow[t]{2}{*}{$\begin{array}{l}\text { Waste Material } \\
\text { Parameter }\end{array}$} & \multicolumn{2}{|c|}{$\begin{array}{c}\text { Input Variable in Current } \\
\text { SPMPPA Models }\end{array}$} & \multirow{2}{*}{$\begin{array}{l}\text { Input Variable } \\
\text { in SPM/PA } \\
\text { Models Under } \\
\text { Development }\end{array}$} & \multirow{2}{*}{$\begin{array}{c}\begin{array}{c}\text { Input Variable } \\
\text { in Possible }\end{array} \\
\text { Future SPM/PA } \\
\text { Models }\end{array}$} \\
\hline & $\begin{array}{c}\text { Gas } \\
\text { Generation }\end{array}$ & $\begin{array}{l}\text { Mechanical } \\
\text { Characteristics }\end{array}$ & & \\
\hline $\begin{array}{l}\text { Iron-Based } \\
\text { Metals/Alloys }\end{array}$ & YES & YES & YES & YES \\
\hline $\begin{array}{l}\text { Aluminum-Based } \\
\text { Metals/Alloys }\end{array}$ & $Y_{E S^{(2)}}$ & YES & YES & YES \\
\hline Other Metals & & YES & & YES \\
\hline $\begin{array}{l}\text { Other Inorganic } \\
\text { Materials }\end{array}$ & & YES & YES & YES \\
\hline Cellulosics & YES & YES & YES & YES \\
\hline Plastics & YES $^{(2)}$ & YES & YES & YES \\
\hline Rubber & YES $^{(1)}$ & YES & YES & YES \\
\hline $\begin{array}{l}\text { Solidified Inorganic } \\
\text { Matrix }\end{array}$ & & YES & YES & YES \\
\hline $\begin{array}{l}\text { Solidified Organic } \\
\text { Matrix }\end{array}$ & & YES & YES & YES \\
\hline Soils & & YES & & \\
\hline
\end{tabular}

(1) Only 50 weight percent included

(2) Added for SPM-2 (Sanchez, 1995)

The information/data presented in this report is derived from the WIPP Transuranic Waste Baseline Inventory Database (WTWBID). The only currently defined application of the WTWBID in this revision of the WTWBIR is in support of the SPMPA calculations. However, the WTWBID can support other projects and applications requiring waste information in formats different than that used in the WTWBIR. The WTWBID structure and a data dictionary are included in Chapter 7 of this report. 


\subsection{WASTE INVENTORY TERMINOLOGY}

The derivation of a disposal inventory from individual waste streams is a formidable and complex process. To document each step of this process, a system of waste inventory terminology needs to be defined so the reader may more easily follow the process. The following sections provide definitions of terminology used throughout the WTWBIR. These definitions also are summarized in Chapter 8, Glossary. A list of acronyms and abbreviations used are provided in the front of the document.

\subsubsection{Inventory Terminology}

Stored Inventory - That part of the TRU inventory currently in retrievable storage at the time of the last data call for inventory information is known as "stored inventory." For Revision 1, stored waste includes that waste in storage as of December 31, 1993. Retrievably stored waste includes waste stored since approximately 1970 in buildings or in berms with earthen cover and does not include any waste that was buried prior to 1970 (DOE, 1994b).

Projected Inventory - That part of the TRU inventory that has not been generated but is currently estimated to be generated at some time in the future by the TRU waste generator/storage sites is considered "projected inventory." Because of the uncertainty associated with ER and D\&D waste inventory projections, the ER and D\&D wastes are not included in the projected inventory. For Revision 1, a projected inventory includes waste scheduled for generation between calendar years (CY) 1994 and 2022. "Newly generated waste" also is sometimes used as a synonym for the projected inventory.

Anticipated Inventory - For the WTWBIR, this is the sum of the stored and projected inventories, calculated:

$$
\underset{\text { Stored }}{\text { Inventory }}+\underset{\text { Projected }}{\text { Inventory }}=\begin{gathered}
\text { Anticipated } \\
\text { Inventory }
\end{gathered}
$$

Scaling - The process for adjusting, if needed, the projected inventory to the design limit (disposal inventory) of the WIPP repository is called "scaling." Section 2.3, describes the scaling process used for developing the WTWBIR.

Projected Inventory $\underset{\text { Scaling }}{\longrightarrow}+$ Stored Inventory = Disposal Inventory

Disposal Inventory - The total design $\left(\approx 176,000 \times 10^{5} \mathrm{~m}^{3}\right.$ for $\mathrm{CH}-\mathrm{TRU}$ and $7080 \mathrm{~m}^{3}$ for RHTRU) inventory defined for WIPP emplacement (after scaling, if necessary) to be used for SPM and PA calculations is the "disposal inventory."

\subsubsection{Waste Matrix Code Terminology}

Waste Matrix Code (WMC) - The WMCs were developed by DOE, in response to the Federal Facilities Compliance Act (FFCACt)(Public Law 102-386, 1992), as a methodology to aid in classifying mixed waste streams in the DOE system into a series of four-digit codes (e.g., 5400; Heterogeneous Waste) that represent different physical/chemical matrices. The WMC is assigned 
by the TRU waste generator/storage sites. The WTWBIR has adopted this system to remain consistent with the Mixed Waste Inventory Report (MWIR)(DOE, 1994a) which was a databasederived report to meet the first deliverable under the FFCAct. The WMC methodology has been applied to nonmixed TRU waste streams for consistency.

Waste Matrix Code Group (WMCG) - A WMCG consists of a series of WMCs that for SPM or PA purposes have similar physical and chemical properties. An example of combining three WMCs which either contain particulates or are cemented particulate waste is presented below:

WMC 3100 (inorganic process residues)

WMC 3110 (inorganic particulates)

WMC 3150 (solidified process residues)

Solidified Inorganics

Because of the restriction on particulate wastes in the TRU Waste Acceptance Criteria (WAC) for the Waste Isolation Pilot Plant, Revision 4 (DOE, 1991), all particulate waste will usually be immobilized prior to shipment to WIPP. Therefore, all three of these WMCs would be the same basic waste form when emplaced in WIPP and have similar physical and chemical properties. The combined WMCG for this example is solidified inorganics. Table 1-2 presents all anticipated WMCs for TRU waste and indicates in which WMCG each WMC occurs for the WTWBIR. There are 11 WMCGs used in this WTWBIR. The last two rows in Table 1-2 group WMCs that will not be accepted at WIPP unless additional characterization and/or processing occurs to meet the WIPP WAC (DOE, 1991).

\subsubsection{Waste Profile Terminology}

Waste Stream Profile - This is a description of a CH-TRU or RH-TRU waste stream potentially destined for shipment to and disposal in WIPP, if authorized under permits and certifications by appropriate regulatory agencies. The waste stream profile is presented in tabular format and is intended to provide a summary of important information about a particular waste stream. Examples of information included in a waste stream profile are:

- Currently used identification codes, including the DOE TRU waste site matrix description;

- WMC assigned by the TRU waste generator/storage sites;

- Volumes of waste currently in retrievable storage and waste projected to be generated: estimated minimum, average, and maximum weights of waste material parameters per cubic meter of waste volume (e.g., iron-based metals/alloys, aluminum-based metals/alloys, cellulosics, etc.);

- Indication as to whether the waste is CH-TRU or RH-TRU; and

- Hazardous waste codes (EPA codes) from MWIR or as assigned by the DOE TRU waste generator/storage sites for the RCRA regulated portion of the waste stream. Some waste streams (waste stream profiles) contain hazardous waste codes that would not be currently acceptable for disposal in WIPP (e.g., D001, D002, and D003) under the most recent WIPP Part B Permit Application (DOE, 1993b). These hazardous waste codes are applied to the waste in its current physical form. These waste streams will have to be treated for any unacceptable hazardous waste codes prior to transport to WIPP for disposal. 
TABLE 1-2. WASTE MATRIX CODE GROUP NAMES

\begin{tabular}{|c|c|}
\hline $\begin{array}{l}\text { Waste Matrix } \\
\text { Code Group }\end{array}$ & Waste Matrix Codes \\
\hline Solidified Inorganics & $\begin{array}{l}1000^{1}, 1100^{1}, 1110^{1}, 1120^{1}, 1130^{1}, 1140^{1}, 1190^{1}, 1200^{1}, 1210^{1}, 1220^{1}, \\
1230^{1}, 1240^{1}, 1290^{1}, 3000^{2}, 3100,3110^{3}, 3111^{3}, 3112^{3}, 3113,3115^{3}, \\
3116^{3}, 3119^{3}, 3120,3121,3122,3123,3124,3125,3129,3130,3131^{3}, \\
3132^{1}, 3139^{1} \text { or } 3,3150,3190,3900^{2}, 6100^{4}, 6120^{5}, 6130^{6}, 6140^{5}, \\
6190^{4}, 6200^{7}, 6210^{8}, 6230^{8}, 6290^{7}, 7300^{3}, 9100^{2}, 9200^{2}\end{array}$ \\
\hline Salt Waste & $3000^{2}, 3140,3141,3142,3143,3149,3900^{2}$ \\
\hline Solidified Organics & $\begin{array}{l}2000^{1}, 2100^{1}, 2110^{1}, 2120^{1}, 2190^{1}, 2200^{1}, 2210^{1}, 2220^{1}, 2290^{1}, 2900^{1}, \\
3000^{2}, 3114,3200,3210,3211,3212,3213,3219,3220,3221,3222, \\
3223,3229,3230,3290,3900^{2}, 6100^{4}, 6110^{5}, 6190^{4}, 6200^{7}, 6290^{7}, \\
9100^{2}, 9200^{2}\end{array}$ \\
\hline Soils & $4000,4100,4200,4900$ \\
\hline $\begin{array}{l}\text { Uncategorized Metal } \\
\text { (Metal Waste Other } \\
\text { Than Lead and/or } \\
\text { Cadmium) }\end{array}$ & $5000^{9}, 5100,5110,5190,6200^{7}, 6220^{8}, 7000^{10}, 7490^{11}, 9300^{10}$ \\
\hline Lead/Cadmium Metal & $\begin{array}{l}5000^{9}, 5120,5130,6200^{7}, 6220^{8}, 7000^{10}, 7200,7210,7220,7400^{11}, \\
7410^{11}, 7420^{11}, 9300^{10}\end{array}$ \\
\hline $\begin{array}{l}\text { Inorganic Non-Metal } \\
\text { Waste }\end{array}$ & $5000^{9}, 5200,5210,5220,5230,5240,5290$ \\
\hline Combustible & $5000^{\circ}, 5300,5310,5311,5312,5313,5319,5320,5330,5390$ \\
\hline Graphite & $5000^{\circ}, 5340$ \\
\hline Heterogeneous & $5000^{9}, 5400,5420,5430,5440,5450,5490,6200^{7}, 6220^{8}, 6290^{7}$ \\
\hline Filter & $5000^{9}, 5410$ \\
\hline $\begin{array}{l}\text { Excluded Waste } \\
\text { Streams }^{12}\end{array}$ & $5250,5350,6300,6400,7100$ \\
\hline Unknown $^{13}$ & $8000,8100,8200,8900$ \\
\hline
\end{tabular}




\section{TABLE 1-2. WASTE MATRIX CODE GROUP NAMES (CONTINUED)}

${ }^{1}$ Liquid waste streams are assumed to be solidified prior to sending to WIPP.

2 WMCs 3000, 3900, 9100, and 9200 are placed in "solidified inorganics," "salt waste," or "solidified organics," depending on the information provided by the TRU waste generator/storage site.

${ }^{3}$ Particulate waste streams are assumed to be solidified prior to sending to WIPP.

${ }^{4}$ WMCs 6100 and 6190 are placed in "solidified organics," or "solidified inorganics," depending on the information provided by the TRU waste generator/storage site.

5 Liquid lab pack waste is assumed to be solidified prior to sending to WIPP.

${ }^{6}$ Solid lab packs are assumed to be solidified prior to sending to WIPP.

7 WMCs 6200 and 6290 are placed in "solidified organics," "solidified inorganics," or "heterogeneous" if the waste stream must be solidified per the generator/storage site. They are placed in "uncategorized metal," or "lead/cadmium metal waste" if they are primarily nonreactive metal contaminated with reactive metal. Reactive waste streams must be treated prior to shipment to WIPP.

${ }^{8}$ Waste stream is assumed to be treated prior to sending to WIPP. Volume change is provided by the TRU waste generator/storage site .

${ }^{9}$ WMC 5000 is placed in "uncategorized metal," "lead/cadmium metal," "inorganic non-metal," "combustible," "graphite," "heterogeneous," or "filter," depending on the information provided by the generator/storage site.

${ }^{10}$ WMC 7000 and 9300 are placed in "uncategorized metal" or "lead/cadmium metal," depending on the information provided by the generator/storage site.

${ }^{11}$ WMCs $7400,7410,7420$, and 7490 are assumed to be drained of liquid and contain only metal waste.

12 These waste streams are excluded from disposal in WIPP at this time, e.g., PCB and asbestos wastes (see Table 3-2).

13 If adequate information is provided by the generator/storage site, these WMCs are changed. If there is not enough information, these waste streams remain as "unknown" and are excluded from disposal in WIPP until characterized. 
- Comments provided by the TRU waste generator/storage sites to further explain the data provided.

- Footnotes generated by the WTWBIR team to explain information provided by the generator/storage sites.

- TRUPACT-II Content (TRUCON) Codes (DOE, 1992) and No Migration Variance Petition (NMVP) (DOE, 1990) identifiers.

Figure 1-2 provides an example of a blank waste stream profile form. The methodology for developing waste stream profiles is provided in Chapter 3 and printouts of TRU waste stream profiles are provided in Appendix A.

Site-Specific Waste Profile - This represents a WMCG at a particular DOE TRU waste generator/storage site. That is, one or more waste stream profiles at a particular DOE TRU waste site, that have been placed in the same WMCG, are surnmarized in the site-specific waste profile. Examples of information included in a site-specific waste profile are:

- DOE TRU waste generator/storage site identification;

- The WMCG that the profile represents;

- Listing of the waste streams (represented by waste stream profiles provided by the TRU waste generator/storage sites) that are included in the site-specific waste profile, including the waste stream identification;

- Volumes of stored and currently projected waste; and

- Summary of minimum, volume weighted average, and maximum weights of waste material parameters per cubic meter of waste volume (1..9., iron-based metals/alloys, aluminumbased metals/alloys, cellulosics, etc.).

Figure 1-3 provides an example of a blank site-specific waste profile form. The methodology for developing site-specific waste profiles is provided in Chapter 3 and printouts of TRU site-specific waste profiles are provided in Appendix B.

WIPP Waste Profile - The WIPP waste profile represents a summary of TRU waste at all DOE TRU waste generator/storage sites that have an identical WMCG. Examples of information included in a WIPP waste profile are:

- Profile name;

- The WMCG that the profile represents;

- Listing of the DOE TRU waste sites (represented by the same WMCG) that are included in the WIPP waste profile, including the name of the DOE TRU waste site;

- Volumes of stored and currently projected waste for each site for the particular WMCG represented; and

- Summary of minimum, volume weighted average, and maximum weights of waste material parameters per cubic meter of waste volume (e.g., iron-based metals/alloys, aluminumbased metals/alloys, cellulosics, etc.). 


\section{WASTE STREAM PROFILE FOR THE WIPP TRU WASTE BASELINE INVENTORY REPORT}

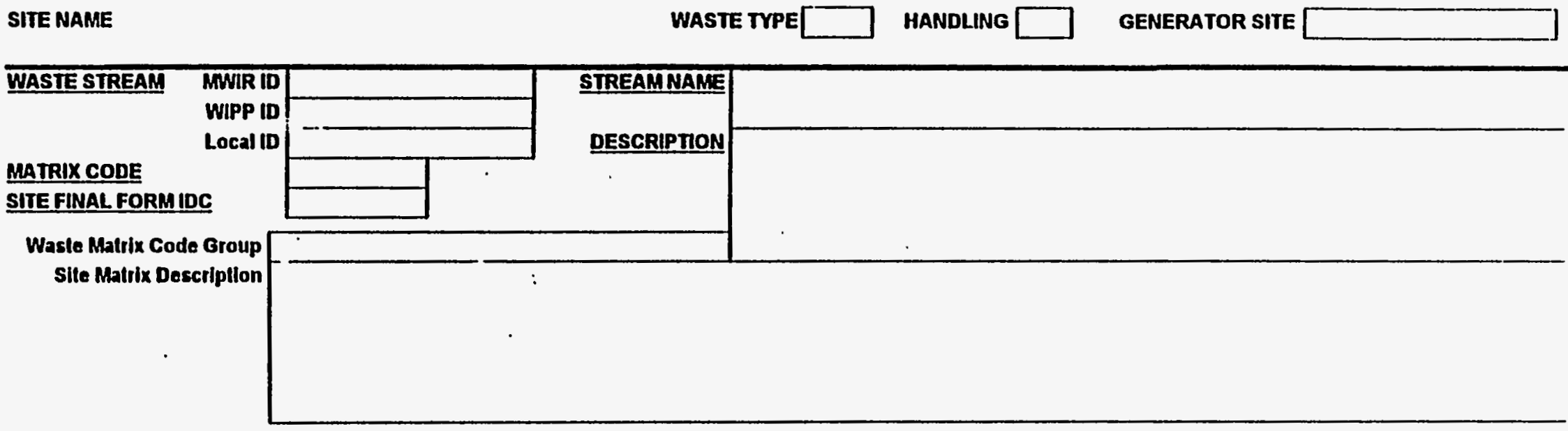

\section{NO MGRATION UARIANCE PETIMON ASSIGNMENT}

IRUCÓN CODE

FINAL WASTE FORMDESCRIPTORS:

\section{Defense TRU Wasle}

Non-Defense TRU Waste

Commerclal TRU Wasle

Unknown
Mixed TRU

Non-Mixed TRU

Suspect Mixed TRU

Unknown
Rsearch and Devel. Waste

Operations Waste

Resldues

Decon and Decommissioning Environmental Restoration From Trealment ol Waste Maintenance
TSCA Asbeslos

PCBs

Olher

N/A

Unknown

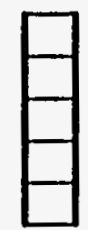

Figure 1-2. Blank Waste Stream Profile Form 


\section{WASTE STREAM PROFILE FOR THE WIPP TRU WASTE BASELINE INVENTORY REPORT}

CONTALNER:

TYPICAL WASTE DENSITIES FOR FINAL WASTE FORM (kg/m3)

Material Parameters

Iron-based Metals/AMoys

Aluminum-Based ARetals/Aknoys

Olther Melals

Other Inorganic Malerials

Cellunstres

Rubber

Plastics

Soltidified, Inorganle matrix

Solidiried, Organic matrix

Soils

Packaging Malerials, Steel

Packaging Materlal, Plastlc

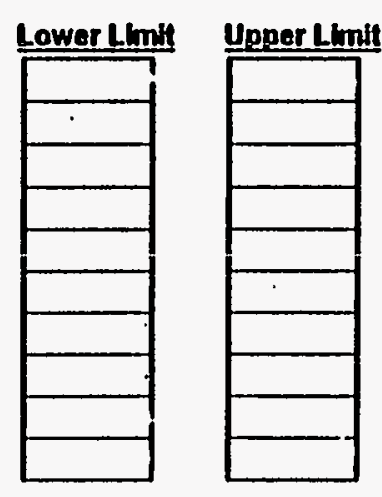

Contalner Mall:

Int. VolvCtnr:

$\mathrm{m}^{\mathrm{m} 3}$

GTORED TRU WASTE ESTIMATED RATES OF WASTE GENERATION
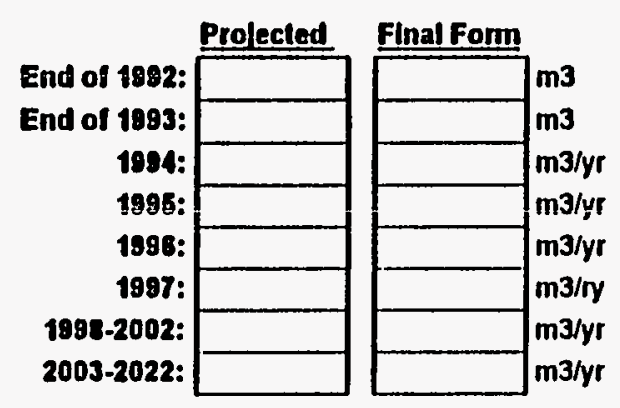

TYPICAL EPA CODES APPLICABLE
Number Stored: Number Projected:

TYPICAL ISOTOPIC COMPOSITION

Nucllde Activily

Figure 1-2. Blank Waste Stream Profile Form (continued) 


\section{Site-Specific Contact Handled Waste Profiles}

Site Name:

Final Waste Form:

Waste Stream ID
Retrievahly

Stored (m3)

Projected (m3)

Total (m3)

Total Volume:

Material Parameters (kg/m3)

Inorganics Iron Based

Aluminum Based

Other Metals

Other Inorganics

Organics

Cellulose

$\begin{array}{rr}\text { Rubber } \\ \text { Plastics } \\ \text { Solidified Materials } & \text { Inorganic } \\ \text { Organic }\end{array}$

$\begin{array}{rr}\text { Rubber } \\ \text { Plastics } \\ \text { Solidified Materials } & \text { Inorganic } \\ \text { Organic }\end{array}$

$\begin{array}{rr}\text { Rubber } \\ \text { Plastics } \\ \text { Solidified Materials } & \text { Inorganic } \\ \text { Organic }\end{array}$

$\begin{array}{rr}\text { Rubber } \\ \text { Plastics } \\ \text { Solidified Materials } & \text { Inorganic } \\ \text { Organic }\end{array}$

Soils

Maximum

Average

Minimum

Figure 1-3. Blank Site-Specific Waste Profile Form

$$
1-11
$$


Figure 1-4 provides an example of a blank WIPP waste profile form. The methodology and assumptions for developing WIPP waste profiles and printouts of the WIPP profiles are provided in Chapter 3.

\subsubsection{Database Terminology}

Mixed Waste Inventory Report (MWIR) - The MWIR refers to the latest release of information from the MWIR database that supports requirements under the FFCAct of 1992 (Public Law 102 386). The latest version of the MWIR documentation/files is Distribute [Distribution] of Phase II Mixed Waste Inventory Report Data, dated May 17, 1994 (DOE, 1994a).

Integrated Data Base (IDB) - The IDB refers to the latest version of the Integrated Data Base: U.S. Spent Fuel and Radioactive Waste Inventories, Projections, and Characteristics (DOE, 1994b).

WIPP Transuranic Waste Baseline Inventory Database (WTWBID) - The WTWBID is the database specifically developed to support the WTWEIR and any other applications that might need waste information on a waste-stream basis or for higher-level roll-ups.

\subsubsection{Other Terminology}

Waste Material Parameter - This is one or more norıradioactive waste constituents that occur in a TRU waste stream that is an input parameter into one or more current SPM or PA models, an SPM or PA model under development, a potential future model, or is required to adequately describe the waste form (see Appendix C). The 10 waste material parameters have been grouped by their chemical/physical properties and are indicated in bold lettering. The 10 waste material parameters and additional packaging materials that are reported in densities and included in the WTWBIR are:

- Inorganics

- Iron-based metals/alloys

- Aluminum-based metals/alloys

- Other metals

- Other inorganic materials

- Organics

- Cellulosics

- Rubber

- Plastics

- Solidified Materials

- Inorganic matrix

- Organic matrix

- Soils

- Packaging Materials

- Steel

- Plastic

- Lead

Definitions for these waste material parameters can be found in Chapter 5. 


\section{WIPP Contact Handled Waste Profiles}

Final Waste Form:

Site

Retrievably

Stored (m3) $\quad$ Projected (m3)

Total (m3)

Total Volume

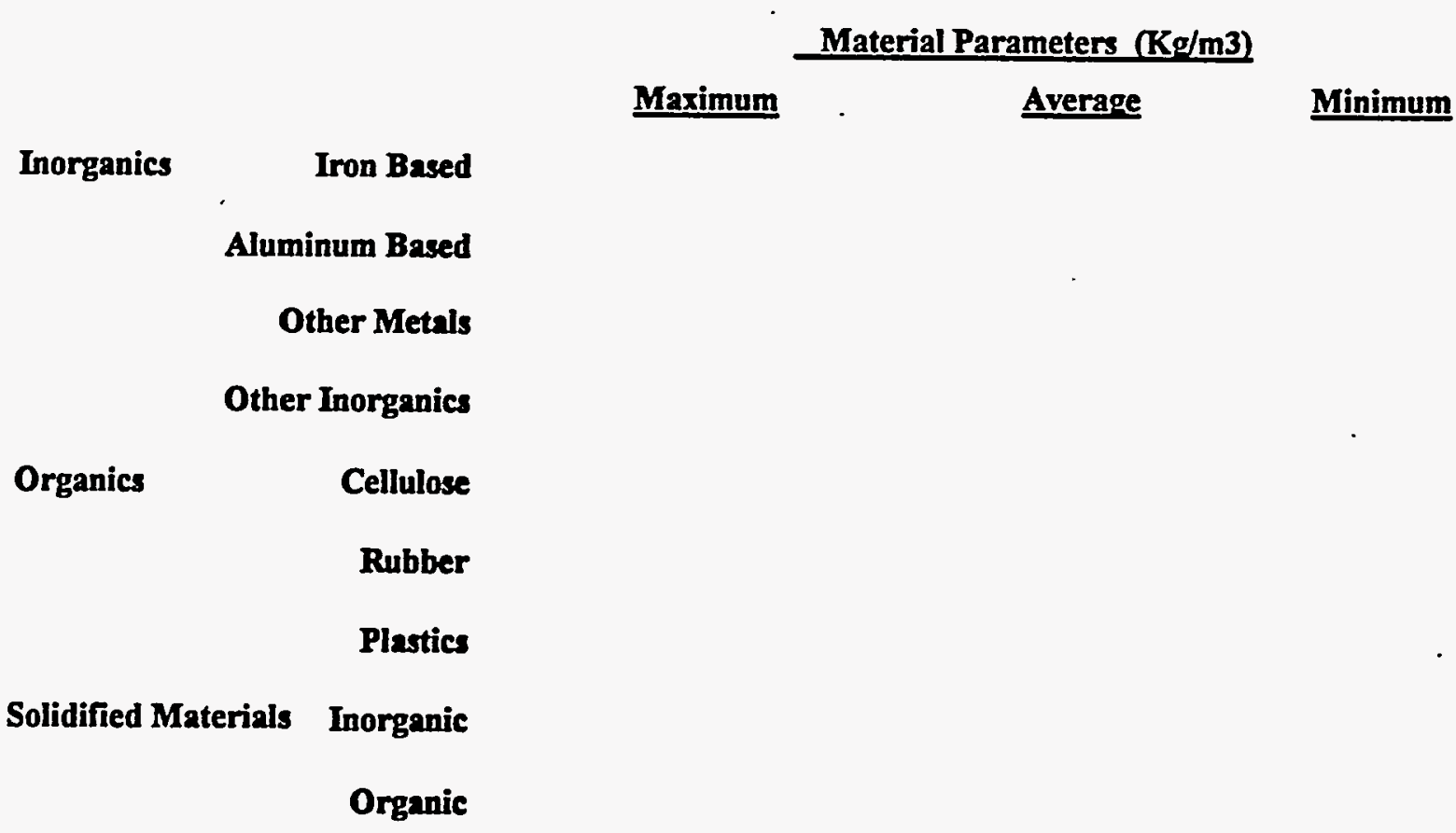

Soils

Figure 1 - 4. Blank WIPP Waste Profile Form

$1-13$ 


\subsection{OBJECTIVES}

The objectives of the WTWBIR are threefold:

1. Establish a consistent DOE complex-wide methodology for grouping wastes of similar physical and chemical composition. A consistent methodology, in support of SPM/PA, for grouping TRU wastes of similar physical and chemical properties into "waste profiles" will provide a common frame of reference for discussion of TRU waste issues with regulatory organizations.

2. Define the anticipated disposal inventory of TRU wastes destined for WIPP. The anticipated inventory of CH-TRU and RH-TRU wastes is defined as the sum of the existing volumes of stored and currently projected waste streams at each of the TRU waste generator/storage sites. The design capacities of WIPP are calculated as follows:

- Maximum CH-TRU capacity = 6.2 million cubic feet $(-176,000$ cubic meters) (Public Law 102-579, 1992),

- $\mathrm{RH}-\mathrm{TRU}$ design capacity $=7080$ cubic meters $\approx 7955$ canisters $\times 0.89$ cubic meters/canister

Scaling of the CH-TRU and RH-TRU waste projected inventories is necessary to attain the WIPP design limit. There is a high level of uncertainty in and a current lack of data on waste produced by decontamination and decommissioning (D\&D) and environmental restoration (ER) activities. Therefore, the projected inventon has been scaled to the WIPP capacity (disposal inventory). The scaling of the inventory in this and future revisions of the WTWBIR is derived from the best available data and assumptions.

3. Calculate the disposal inventory in terms of waste material parameters. Several waste material parameters (e.g., iron-based metals/alloys, rubber, plastics, etc.) have been identified by SNLNM as being potentially significant in relation to the performance of the WIPP repository (see Table 1-1). Calculating the WIPP disposal inventory in terms of these parameters provides input for the SPM and PA calculations and sensitivity analyses needed to determine compliance with federal standards.

\subsection{TRU SYSTEM-WIDE DATA ASSUMPTIONS}

As stated earlier, the WTWBIR was developed using the best available information from the TRU waste generator/storage sites. Some sites used different assumptions and methodologies for reporting its waste stream data. Because of these differences, the WTWBIR team had to make assumptions and take specific steps to ensure consistency among the sites' reported data. This section addresses the system-wide assumptions and actions taken by the WTWBIR team in rolling up the waste stream data. For a description of site-specific assumptions, see Appendix A.

\subsubsection{Waste Material Parameter Assumptions}

The waste material parameter information reported by the sites must be summed and averaged to obtain data at the site-specific and WIPP waste profile levels. For some waste streams, however, not all of the waste parameter data were available from the sites. In order to calculate 
material parameters from the waste stream data provided by the sites, the following assumptions were made by the WTWBIR team:

- If only the average waste material value was provided for a specific waste stream, the average value was assigned to the minimum and maximum values.

- If the maximum value was provided and the minimum value was zero, the average value was computed as half of the maximum value.

- If only the minimum value was provided, the minimum was assigned to both the maximum and average values.

- If only the final waste form group was provided, the average set of parameters was calculated by volume averaging the parameters from other waste streams of the same final waste form group.

Waste material parameter data contained in the body of this report are based on these assumptions, whereas, individual waste stream profiles included in Appendix A contain the original, unchanged data as reported by the generator/storage sites.

\subsubsection{Inventory Volume Assumptions}

Other assumptions had to be made by the WTWBIR team to ensure consistency in WIPP inventory volumes:

- The volume reported for the years 1992 and 1993 was supposed to be cumulative, whereas, the values for the remaining years were to be reported as generation volume per year. Since not all of the sites reported their inventory in this manner, the WTWBIR team had to recalculate the volumes provided to attain a cubic meter/year basis for some waste stream volumes;

- Many sites did not provide final waste form volumes. Final waste form volumes are used in determining the overall WIPP inventories. In those instances, the WTWBIR team assumed that the reported, current volume would be the same as the final waste form volume.

\subsubsection{Packaging Material Assumptions}

The TRU waste container data was not reported consistently. While most did, many of the sites did not provide data for final form in WIPP approved containers. Some reported their waste in current containers while others did not provide container information. Adjustments had to be made to the data to:

- Achieve consistency at the waste stream level in the presentation of data in the waste stream profiles (Appendix A)

- Produce the upper-level waste packaging rollups needed by SPM/PA as inputs to the modeling activities.

\section{Waste Profile Assumptions}

The WTWBIR team assigned the TRUCON and NMVP codes based on the best available information. Each waste stream profile in Appendix A was reviewed for consistency in reporting packaging configurations. In cases where incomplete information was submitted by the TRU 
sites, clarifications were requested from the TRU waste generator/storage sites. In those cases where clarifications were not received from the TRU sites, the following assumptions were made, concerning the waste stream profiles:

- If the site provided final form containers, the final form containers (i.e., drums, standard waste boxes [SWB], or RH canisters) were used.

- In some cases where final waste form containers were not provided a 55-gallon drum was assumed.

- If a particular waste container was reported by the sites (but no further information was provided) or was assigned by the WTWBIR team (e.g., 55-gallon drum), "standard" values of the waste container properties (see Table 1-3) were added to the waste profile forms. An example of this process is listed below for a reported 55-gallon drum without any additional information:

- Type of material used to fabricate the waste container (steel)

- The internal volume of the container $\left(0.208 \mathrm{~m}^{3}\right)$

- Inclusion of a "standard" density for the container $\left(131 \mathrm{~kg} / \mathrm{m}^{3}\right)$.

- If sites reported a "plastic" or "rigid" liner without any further definition of the liner then the values in Table 1-3 were used in the waste stream profiles:

- A 90-mil high density polyethylene (HDPE) liner was assumed

- The density for that type of liner was assumed $\left(37 \mathrm{~kg} / \mathrm{m}^{3}\right)$.

- If the container fields called "Number Stored" and "Number Projects" are left blank, it is because of one of the following reasons:

- There is a change from one type of waste container to another on the waste profile form page 2 (different internal container volumes) and therefore the number of containers stored and projected represent different volumes and a direct comparison is not possible.

- There is an unresolved discrepancy between the number of containers and the volumes quoted on the waste stream profile. It has been assumed that the waste volumes are the most accurate information provided by the TRU waste sites.

For CH-TRU waste containers, the following assumptions were also made:

- If waste was reported in containers larger tharj drums, then the waste was divided into SWBs with standard plastic bag liners. The standard intemal volume for SWBs (Table 1-3) and the reported waste stream volume were used to determine the number of SWBs.

- If the waste was reported in a liquid or sludge form (i.e., tanks), the WTWBIR team assumed that the waste will be placed in drums with rigid liners. No treatment volume expansion was included unless reported as such by the sites. 
For RH-TRU waste, the following assumptions were made:

- If the waste was reported in drums, the drums were assumed to be overpacked in $\mathrm{RH}$ canisters at three drums per canister.

- If the waste was not reported to be in drums, the waste was assumed to be direct loaded into RH canisters. The standard intemal volume for RH canisters and the reported waste stream volume were used to determine the number of RH canisters.

- The lead in the RH canister $\left(465 \mathrm{~kg} / \mathrm{m}^{3}\right)$ is assumed in the packaging rollups even if it is not stated on each $\mathrm{RH}$ waste stream profile.

Table 1-3. Packaging Material Assumptions

\begin{tabular}{||l|r|r|r|r||}
\hline \multicolumn{1}{|c|}{ Container Configuration } & $\begin{array}{r}\text { Steel } \\
\left(\mathrm{kg} / \mathrm{m}^{3}\right)\end{array}$ & $\begin{array}{r}\text { Plastic } \\
\left(\mathrm{kg} / \mathrm{m}^{3}\right)\end{array}$ & $\begin{array}{r}\text { Lead } \\
\left(\mathrm{kg} / \mathrm{m}^{3}\right)\end{array}$ & $\begin{array}{c}\text { Volume } \\
\left(\mathrm{m}^{3}\right)\end{array}$ \\
\hline \hline 55 -gallon drum & 131 & 37 & N/A & 0.208 \\
\hline SWB (direct load) & 154 & 1.2 & N/A & 1.89 \\
\hline SWB (overpack) (4 55-gallon drums) & 210 & 16 & N/A & 1.89 \\
\hline RH-TRU Canister & 435 & 0 & 465 & 0.89 \\
\hline $\begin{array}{l}\text { RH-TRU Canister (overpack of 3 55- } \\
\text { gallon drums) }\end{array}$ & 527 & 26 & 465 & 0.89 \\
\hline
\end{tabular}

\section{Assumptions to Produce Packaging Estimates on a System-Wide Basis}

In order to add up the packaging materials for the waste as it would arrive at WIPP, the following standard container configuration was used for computing waste packaging materials from all sites. If the site provided final waste form containers, the final form containers (i.e., drums, standard waste boxes [SWB], or RH Canisters) were used, but standard liners were assumed. This was done because many sites did not provide liner information. The inclusion of standard liners produces a conservative estimate for PA and SPM calculations.

\subsubsection{Radionuclide Information Assumptions}

There are some waste streams from TRU waste sites which report for some waste streams incomplete radionuclide information (e.g., some show mixed fission products but no transuranic isotopes). These waste streams are expected to be demonstrated to be TRU upon completion of the radionuclide characterization.

The waste stream profiles provided in Appendix A contain waste stream specific radionuclide information, if provided by the TRU waste sites. Some sites provided only isotopic mixes, which are explained in Appendix $\mathrm{H}$.

\subsubsection{Comparison of IDB versus WTWBIR Waste Volumes}

Differences occur between the waste volumes reported in the draft Revision 10 of the IDB (Appendix I) and those reported in Chapter 6 on a site level. Listed below is the currently-known logic for some of the differences: 
- In the IDB, $40 \%$ of the INEL CH-TRU waste and $50 \%$ of the Hanford CH-TRU waste reported is assumed to be low-level waste by INEL and Hanford and is not included in the WTWBIR

- Some of the projected waste at ANL-E in the WTWBIR is accounted for in the Hanford projections. This is not the case for the IDB.

- The ANL-W waste reported for WTWBIR is included in the INEL IDB waste volumes.

- The totals for SRS CH-TRU and RH-TRU projected waste volumes in the draft Revision 10 IDB are in error. The corrected IDB total projected $\mathrm{CH}-\mathrm{TRU}$ is $13,700 \mathrm{~m}^{3}$ and for RHTRU, $35.9 \mathrm{~m}^{3}$.

These inconsistencies and others between the WTWEIR and IDB for TRU waste volumes is a main focus of the Revision 2 data update of the WTWBIR.

\subsection{BASELINE INVENTORY UPDATES}

The WTWBIR represents the best available TRU waste inventory information in support of the WIPP Project. It is anticipated that the WTWBIR will be updated periodically. This update cycle will be modified based on the availability of additional waste information or the data needs of the WIPP Project as determined by the DOE.

\subsection{DOCUMENT ORGANIZATION}

The WTWBIR is organized into chapters of text, figures, tables and supporting appendices. It flows from specific, detailed TRU waste information (provided by the TRU waste generator/storage sites) to the top level development and description of waste profiles and waste material parameters. The contents of remaining chapters in this document are summarized below:

- Chapter 2 discusses the methodology used to define the TRU waste disposal inventory.

- Chapter 3 outlines the methodology used to clerive waste stream profiles, site-specific waste profiles, and WIPP waste profiles.

- Chapter 4 provides the WIPP disposal radionuclides inventory. The methodology used for deriving the inventories is also included.

- Chapter 5 rolls up the waste material parameter information assigned at the waste stream profile level in Chapter 3 to obtain parameter totals. These totals are presented as parameter weights per volume.

- Chapter 6 presents stored and projected CH-TRU and RH-TRU inventories by site and a system-wide rollup of CH-TRU and RH-TRU volumes.

- Chapter 7 contains a description of the WTWBID and a data dictionary.

- Chapter 8 contains a glossary of important terrns used in this document.

- Chapter 9 lists references cited in the WTWBIR.

- Several appendices also are provided to either present more detailed waste inventory information or to describe the methodology in more detail. The appendices are provided in Volumes 2 and 3 of this WTWBIR. 
CHAPTER 2
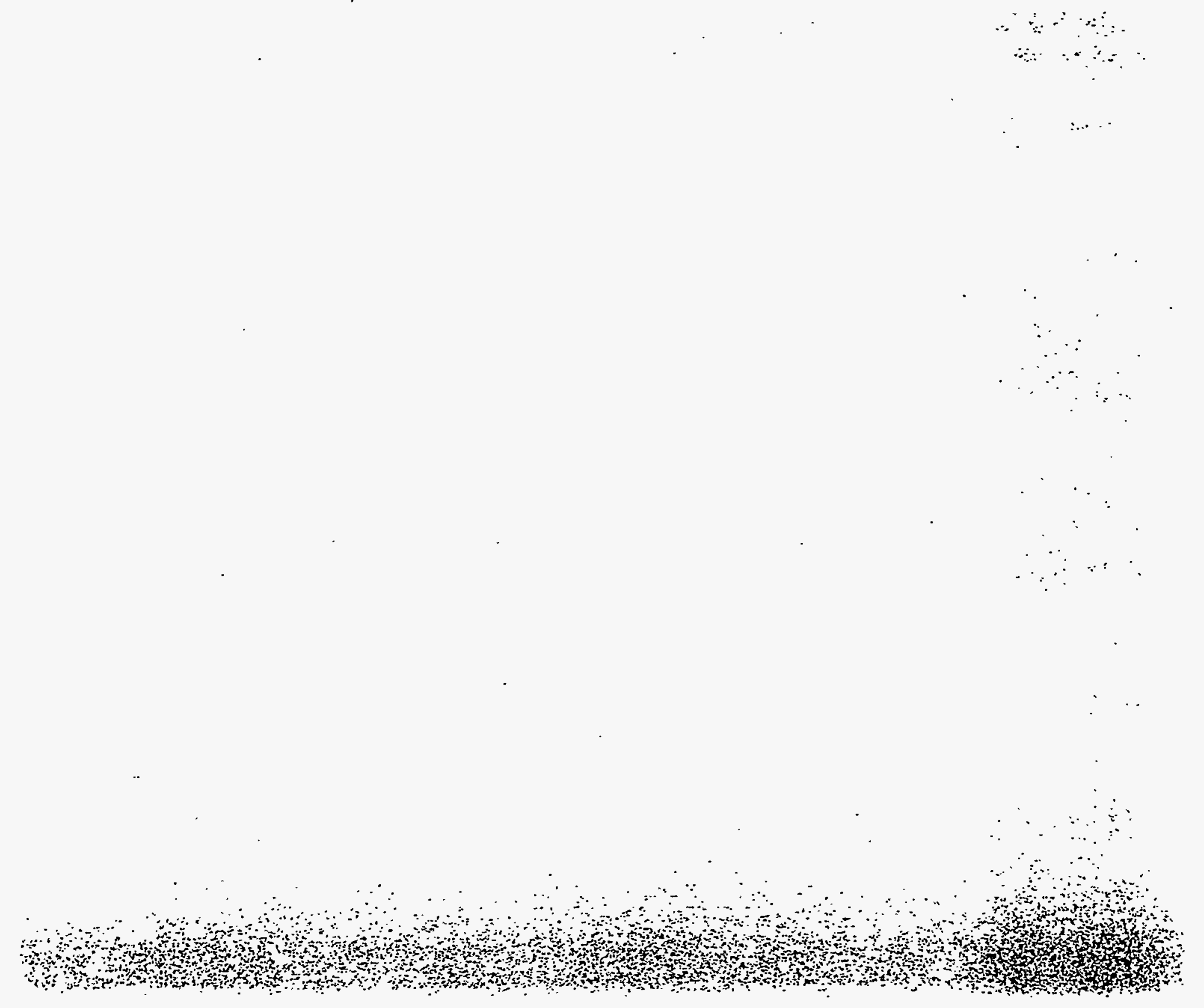


\section{TRU WASTE DISPOSAL INVENTORY}

\subsection{INTRODUCTION}

The TRU waste disposal inventory is derived from existing information on waste, which has been provided by the DOE TRU waste generator/storage sites and is predominately based on process knowledge. In addition to the general process knowledge of a waste stream for nonradionuclide parameters, the radionuclide inventories from the IDB TRU waste site submittals (DOE, 1994b) are derived from non-destructive assay, with some analytical analyses (to detect isotopes that do not lend themselves to non-destructive analyses or to evaluate waste streams that cannot be effectively analyzed through non-destructive methods), and on-site accountability and tracking records of special nuclear materials including any changes of isotopic ratios during processing. This chapter is designed to assist the reader by describing the existing waste information used to derive the inventory and the methodology used to correlate and combine the existing data into a WIPP disposal inventory.

\subsection{SOURCE OF TRU WASTE INFORMATION}

Transuranic waste information primarily exists in two forms within the DOE TRU waste system:

- On-site documentation developed by the TRU waste generator/storage sites during the history of their operations.

- Summary reports, usually prepared to support WIPP documentation requirements. These summary reports have either been generated by the DOE area office in charge of WIPP or at the DOE-Headquarters (HQ) level. The information contained in these reports is derived from the TRU waste generator/storage sites.

\subsubsection{Site-Specific Waste Information}

The TRU waste generator/storage sites use a variety of on-site documents and records in order to derive the information listed in the individual waste streams in Appendix A. The documents/records can include many different sources, some of which might be the following: procurement records, waste stream process manuals; operating procedures, on-site safety documentation, process diagrams, waste production records, storage records, on-site waste database management systems, interviews with existing and former workers, transportation records, waste container tracking records, on-site documentation prepared for local, state, or regional regulators. This list is not meant to be inclusive or representative of all records used at every site. It is intended to be used for example purposes only. The number and types of documents can vary greatly from site-to-site so it is impractical to list them as references in this document.

Each DOE TRU waste site was provided, by the WTWBIR team, WTWBIR Revision 0 data packages defining the characterization of each TRU waste stream at their site. The generator/storage sites reviewed, changed, and authorized the characterization as valid for use in developing the WIPP inventory. 


\subsubsection{Existing Summary Documents on TRU Waste Information}

In support of various programs, the DOE has published a series of documents over the years in support of various programs which contain varying amounts of waste information. Listed below are those documents that have formed the foundation of summary TRU waste information prior to the publication of the WTWBIR.

\section{Mixed Waste Inventory Report}

The FFCAct required that the DOE, within 180 days of enactment of the FFCAct, submit to the EPA Administrator and the govemor of each state in which the DOE stores or generates mixed wastes a report that contains:

- National inventory of all mixed wastes, regardless of the time they were generated, on a state-by-state basis and

- National inventory of mixed waste treatment capacities and technologies.

The FFCAct also stipulated specific reporting requirernents for each of these inventories. The DOE submitted the six-volume set entitled: U.S. Department of Energy Interim Mixed Waste Inventory Report: Waste Streams, Treatment Capacities and Technologies, DOE/NBM-1100, dated April 1993 (DOE, 1993c), to fulfill these requirements. Since issuance of the "interim" report, DOE has requested additional information frorn the DOE TRU waste generator/storage sites and published two updated reports entitled:

- Release of Phase I Mixed Waste Inventory Report Data, dated April 1, 1994 (Phase I MWIR) (DOE, 1994c), which includes a data diskette (Version .97B) and the draft Mixed Waste Inventory Report Data Base System User's Guide.

- Distribute [Distribution] of the Phase II Mixed Waste Inventory Report Data, dated May 17, 1994 (Phase II MWIR) (DOE, 1994a), which includes a data diskette (Version 1.00) and the draft User's Guide for National Data Base System for the Final Mixed Waste Inventory Report (May 1994).

The Phase II MWIR was the basis of the mixed waste streams that were included in Revision 0 of the WTWBIR. The DOE waste generator/storage sites have reviewed the existing waste streams from Revision 0 of the WTWBIR and have upidated the information. In a very few cases mixed waste streams from the Phase II MWVR have been deleted by the generating/storage sites from Revision 1 of the WTWBIR. Any waste stream that was published in the Phase II MWIR and has a waste stream profile in the WTWBIR contains an identification code in the "MWIR ID" and "WIPP ID" fields on the waste stream profile forms (see Figure 1-2). The identification codes are assigned using the following format:

- DD-WXXX;

- $D D=$ Site Identification Code (from Figure 1-1)

- $X X X=$ Three digit numerical code assigned by DOE-HQ

Some sites have submitted "new" mixed waste strearns with the Revision 1 WTWBIR datacall, which were not in the Phase II MWIR. Therefore, these waste streams have not been assigned DD-WXXX identification numbers by DOE-HQ. Those mixed TRU waste streams which have been reported for the first time in Revision 1 of the WTWBIR have been designated as: 
- DD-MXXX (DD and XXX have same meaning as for the MWIR waste streams, except that the three digit numerical code was assigned by the WTWBIR team)

Waste streams that are nonmixed TRU waste do not appear in the Phase II MWIR. Nonmixed TRU waste streams that appear in the WTWBIR have been designated as follows:

- DD-TXXX (DD and XXX have the same meaning as for MWIR waste streams, except that the three digit numerical code was assigned by the WTWBIR team)

INEL included some nonmixed waste streams in the Phase I MWIR which had the MWIR characteristic DD-WXXX identification. These have been retained in the WTWBIR, but all other nonmixed TRU waste streams have used the DD-TXXX designation, including some "new" nonmixed waste streams from INEL.

\section{Integrated Data Base}

The IDB (DOE, 1994b) is published by Oak Ridge National Laboratory (ORNL) for the DOE. The ORNL assembles radioactive waste inventories provided by DOE TRU waste generator/storage sites. This database does not report by waste stream, but rather, by the total inventory at each DOE site. The IDB also contains the radionuclide isotopic distribution for the waste stored at each site. Because consistent reporting is not available at the waste stream level, the radionuclide information in the IDB is the basis for the Revision 1 WTWBIR inventory for radionuclides (see Chapter 4). Where sites provided radionuclide data, it is replicated in Appendix A. A WIPP disposal radionuclide inventory is provided in Table 4-2. This table is derived from unpublished IDB submittals from the TRU waste sites.

\section{Other Sources of TRU Waste Information}

There are three additional summary documents that have been produced which contain extensive information about TRU waste. The amount and form of the documentation varies between documents due to the initial purpose for including waste information. These include:

- TRUCON (DOE, 1992) - The TRUPACT-Il Content (TRUCON) Code document was developed to provide waste information to the Nuclear Regulatory Commission in support of the TRUPACT-II certification application. The TRUCON concentrated on those waste parameters that were important for safe transportation of TRU waste (e.g., thermal heat loading, criticality, free liquids, etc.)

- NMVP (DOE, 1990) - The No-Migration Variance Petition (NMVP) was developed by DOE to obtain a variance from the land disposal restrictions for mixed waste as allowed under 40 CFR 268.6 (EPA, 1986). The NMVP waste information concentrated on defining the volumes of various known TRU and MTRU waste streams in the DOE system at that time, and identifying the hazardous constituents expected to be found in the MTRU waste streams. Text was provided in the NMVP on each known waste stream at that time which summarized the process knowledge and sampling and analysis information available (many WTWBIR waste streams were not defined at the time the NMVP was developed).

- WIPP RCRA Part B Permit Application (DOE, 1993b) - This document which will be revised and submitted to obtain a Part B Permit for WIPP to the State of New Mexico. This document will represent in some parts an update of the NMVP and will incorporate much information from the WTWBIR. 
TRU waste streams that are included in the TRUCON and the NMVP are cross correlated, if possible, to WTWBIR waste streams in Appendix $F$. The designation of each waste stream in the TRUCON and NMVP, if applicable, can be found on the waste stream profile (Figure 1-2). The WTWBIR should be considered the most current source of waste stream information when there is a discrepancy in information between the WTWBIR and the TRUCON or NMVP documents.

\subsection{METHODOLOGY FOR DEVELOPMENT OF DISPOSAL INVENTORY}

Development of the WIPP TRU waste disposal inventory is accomplished by a series of steps starting with the individual waste streams submitted by the TRU waste generator/storage sites that are identified in Appendix A. These waste stream profiles are grouped together, based on similar physical and chemical properties, into common "WIPP waste profiles," which should facilitate discussions conceming the disposal waste inventory with regulatory agencies and stakeholders. The waste profiles also contain information on waste material parameters that could affect the performance of the WIPP repository and that may be direct inputs to the SPM and PA models. A more detailed explanation of the waste profile methodology is found in Chapter 3.

Because the existing stored and currently projected $\mathrm{CH}$-TRU waste streams do not contain sufficient volume to fill the maximum allowed (designed) capacity of WIPP, scaling of the projected inventories is necessary to attain the following WIPP design inventory:

- Maximum CH-TRU design inventory $=6.2$ million cubic feet $(-176,000$ cubic meters) (Public Law 102-579, 1992)

The anticipated inventory (as defined in Section 1.3.1) consists of 11 overall CH-TRU WIPP waste profiles based on the physical and chemical properties of the waste streams. The CH-TRU scaling factor is computed as follows:

- For CH waste:

$$
\frac{\text { design inventory - stored inventory }}{\text { projected inventory }}=\mathrm{CH}-\text { TRU scaling factor }
$$

The RH-TRU anticipated inventory would be scaled using the same methodology. If the anticipated RH-TRU and CH-TRU inventories are less than the WIPP design limits, the projected inventory in future revisions of the WTWBIR will include volumes of waste anticipated from D\&D and ER activities as these estimates are made available.

The disposal inventory is the total inventory to be used in SPM and PA calculations. To calculate the disposal inventory by WMCG for CH-TRU waste, the projected inventory is multiplied by the scaling factor, added to the stored inventory for each WMCG and summed together. See Section 3.3.2 for further details. 


\section{WASTE PROFILE METHODOLOGY}

\subsection{WASTE STREAM PROFILE METHODOLOGY}

\subsubsection{Introduction}

The lowest tier of information in the WTWBIR is the waste stream profile, which documents specific information for each separate TRU waste stream identified by each DOE TRU waste generator/storage site. In this chapter the waste stream profile will be discussed along with the methodology for grouping waste streams into site-specific profiles and WIPP waste profiles.

\subsubsection{Waste Stream Profile Description}

Each DOE TRU waste generator/storage site was provided data packages that contained the waste material parameter characterization as defined in the WIPP disposal inventory (WTWBIR, Revision 0). Each DOE site was asked to review the data packages and update the information as necessary (see Appendix D for the WTWBIR Revision 1 Questionnaire). Additionally, the sites were required to generate data packages for waste streams that were not defined. This data submittal from the DOE generator/storage sites provided approximately 360 individual TRU waste streams that were used in developing the waste stream profiles (see Appendices $A$ and J). These waste stream profiles were developed using information from the sources listed in Section 2.2. Figure 3-1 provides an example TRU waste stream profile for an INEL waste stream.

In addition to presenting the quantity of waste material parameters in each DOE waste stream, the waste stream profile also provides a cross-reference (top of the waste stream profile form) to the different waste stream nomenclature used in previously generated DOE documents (i.e., TRUCON, NMVP). Appendix F provides a cross correlation table for a WTWBIR waste stream with the NMVP and the TRUCON. The fields utilized on the waste stream profile, the sources of the information, and a short explanation of the data located in a particular field are described in Table 3-1. A complete set of the waste stream profiles is provided in Appendices A and J. Because the West Valley Demonstration Project (WVDP) is a commercial TRU waste site, it is not part of the WIPP inventory, but the WVDP waste stream profiles are provided in Appendix $J$ for information purposes.

The sites were not requested to provide the EPA codes as this information was derived from the Phase II MWIR. EPA codes for mixed waste streams not defined in MWIR were provided by the generator/storage site. During development of the MWIR, DOE directed the TRU waste generator/storage sites to append their hazardous waste codes (EPA codes) to further define the waste in order to develop an appropriate treatment technology. These code designations and descriptions are presented in Appendix G. For example, DOO3 is defined by EPA as reactive. DOE further defined this code as D003A (reactive cyanide), D003B (reactive sulfides), D003C (explosives), D003D (water reactives), and D003E (other reactives).

\subsubsection{Assignment of the.Waste Matrix Code Group}

The DOE TRU waste generator/storage sites have assignied an overall WMC to each waste stream based on the current form of the waste. The WIPP Project has developed the WIPP WAC (DOE, 1991) for any waste packages to be shipped to WIPP to ensure the safe handling and emplacement of the waste packages in the WIPP. In general, the waste forms acceptable for emplacement in WIPP are described in Table 1-2. Each waste stream has been assigned a WMC by the TRU waste generator/storage site that defines the general physical and chemical properties of the waste. 


\section{WASTE STREAM PROFILE FOR THE WIPP TRU WASTE BASELINE INVENTORY REPORT}

\section{SITE NAME IN \\ WASTE TYPEMTRU HANDLING CH GENERATOR SITE RF}

\begin{tabular}{|c|c|c|c|c|}
\hline \multirow{4}{*}{\multicolumn{2}{|c|}{$\begin{array}{ll}\text { WASTE STREAM PMMR W } & \begin{array}{l}\text { WMPP DD } \\
\text { Local ID }\end{array} \\
\text { MATRIX CODE } & \end{array}$}} & IN-W169 & \multirow{5}{*}{$\begin{array}{l}\text { STREAMNAME } \\
\text { DESCRIPTION }\end{array}$} & \multirow[t]{2}{*}{ Predominantly Combusilible Debris } \\
\hline & & N.W16 & & \\
\hline & & TD-EGG-114T-330 & & \multirow[t]{4}{*}{ Combustibtes (TRU): Dy paper and rags } \\
\hline & & 5440 & & \\
\hline \multicolumn{3}{|c|}{ SITE FINAL FORMIOC } & & \\
\hline \multicolumn{4}{|c|}{ Waste Matrix Code Group Helerogeneous } & \\
\hline \multicolumn{2}{|c|}{ Stte Matrix Descriptlon } & \multicolumn{3}{|c|}{ 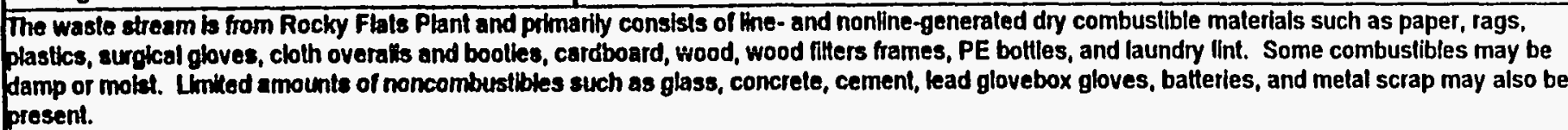 } \\
\hline \multicolumn{4}{|c|}{ NO MGGRATLON YARLANCE PETIION ASSIGNMENTID $116 ; 216 \mathrm{C}$} & IRUCON CODE $\longdiv { 1 D 2 1 6 C }$ \\
\hline
\end{tabular}

FINAL WASTE FORMDESCRIPTORS:

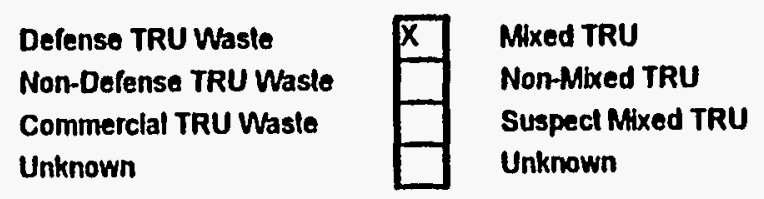

Rsearch and Devel. Waste Operations Waste

Residues

Decon and Decommissioning

Envtronmental Restoralion From Trealment of Waste Maintenance

\begin{tabular}{|c|c|c|c|}
\hline $\mathrm{x}$ & \multirow[t]{5}{*}{ TSCA } & Asbeslos & \\
\hline $\mathrm{x}$ & & PCBs & \\
\hline & & Olher & \\
\hline $\bar{x}$ & & N/A & $x$ \\
\hline & & Unknown & \\
\hline
\end{tabular}

Figure 3-1. Example of TRU Wsate Stream Profile From Idaho National Engineering Laboratory 


\section{WASTE STREAM PROFILE FOR THE WIPP TRU WASTE BASELINE INVENTORY REPORT}

SIIE NAME IN

\section{WASTE TYPEMTRU HANDLING CH GENERATOR SITE RF}

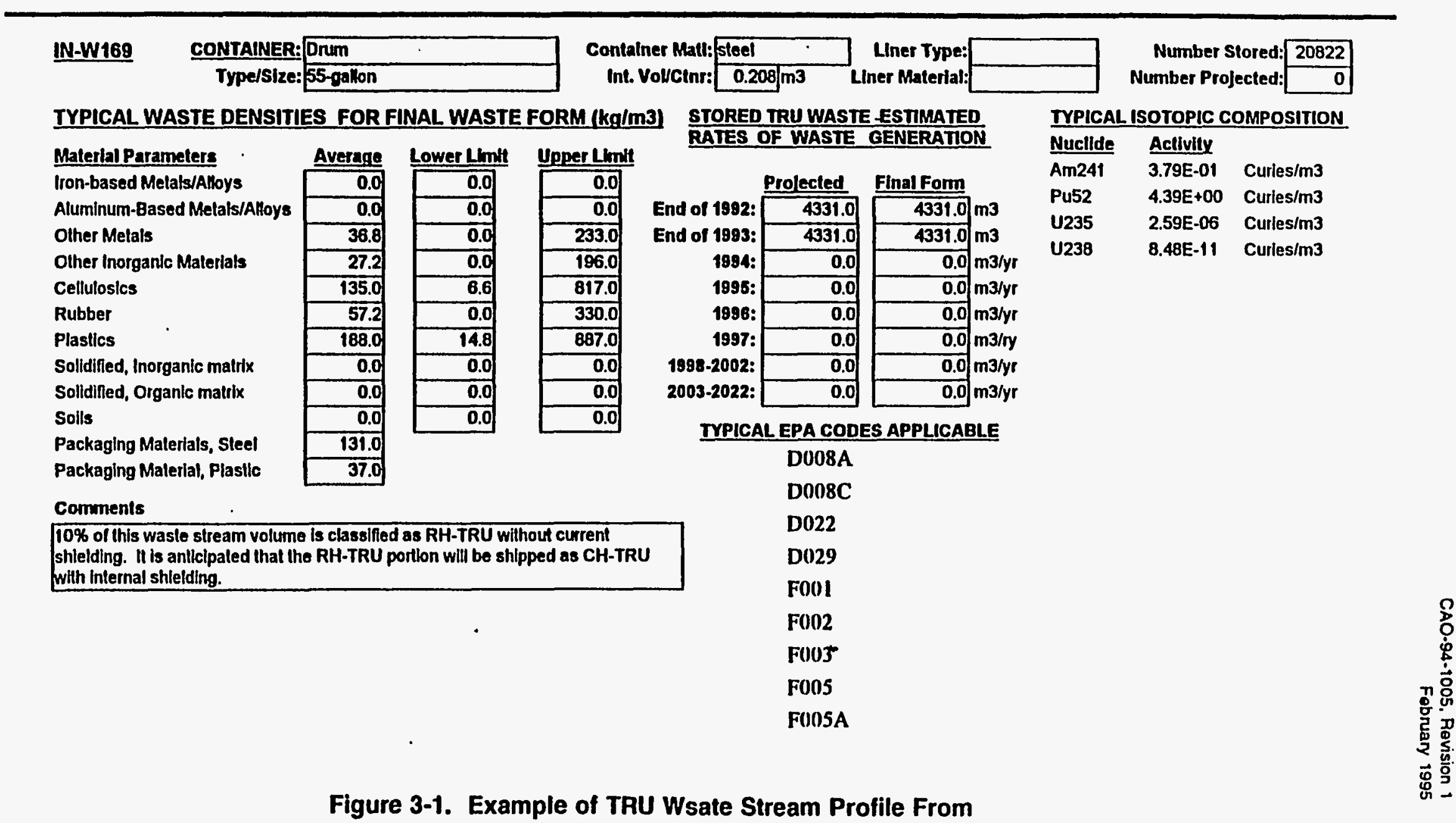

Figure 3-1. Example of TRU Wsate Stream Profile From Idaho National Engineering Laboratory (continued) 


\section{TABLE 3-1. SOURCES OF INFORMATION USED IN WASTE STREAM PROFILES}

\begin{tabular}{|c|c|c|}
\hline Information Field & $\begin{array}{c}\text { Source of } \\
\text { Information }\end{array}$ & Explanation \\
\hline \multicolumn{3}{|c|}{ PAGE 1 OF WASTE STREAM PROFILE } \\
\hline SITE NAME & TRU waste sites & $\begin{array}{l}\text { Siorage site for existing waste; } \\
\text { Generating site for projected waste }\end{array}$ \\
\hline Waste Type & TRU waste sites & $\begin{array}{l}\text { MTRU - mixed } \\
\text { TRU - nonmixed }\end{array}$ \\
\hline Handling & TRU waste sites & $\begin{array}{l}\mathrm{CH} \text { - Contact-Handled } \\
\mathrm{RH} \text { - Remote-Handled }\end{array}$ \\
\hline Generator Site & TRU waste sites & $\begin{array}{l}\text { TRU waste site that originally generated } \\
\text { waste }\end{array}$ \\
\hline$\frac{\text { WASTE STREAM }}{\text { MWIR ID }}$ & DOEHQ & MWIR identification code assigned \\
\hline$\frac{\text { WASTE STREAM }}{\text { WIPP ID }}$ & WTWBIR & $\begin{array}{l}\text { MWIR ID used if available; } \\
\text { neW mixed WS "-MXXX"; nonmixed WS } \\
\text { "-TXXX" }\end{array}$ \\
\hline$\frac{\text { WASTE STREAM }}{\text { LOCal ID }}$ & TRU waste sites & On-site ID used at TRU waste sites \\
\hline STREAM NAME & TRU waste sites & $\begin{array}{l}\text { Usual name used to identify waste } \\
\text { stream by TRU waste site }\end{array}$ \\
\hline DESCRIPTION & TRU waste sites & $\begin{array}{l}\text { Short description of waste generating } \\
\text { process }\end{array}$ \\
\hline MATRIX CODE & TRU waste sites & $\begin{array}{l}\text { Physical/chemical waste matrix code } \\
\text { assigned by each TRU waste site from } \\
\text { MWIR (DOE, 1993a) }\end{array}$ \\
\hline $\begin{array}{l}\text { Waste Matrix Code } \\
\text { Group }\end{array}$ & $\begin{array}{l}\text { TRU waste sites } \\
\text { and/or WTWBIR }\end{array}$ & $\begin{array}{l}\text { Grouping of wastes in } 11 \text { WIPP profiles } \\
\text { (see Table 1-2) }\end{array}$ \\
\hline Site Matrix Description & TRU waste sites & $\begin{array}{l}\text { Usually a description of the } \\
\text { physicalchemical matrix of WS }\end{array}$ \\
\hline $\begin{array}{l}\text { NO-MIGRATION } \\
\text { VARIANCE PETITION } \\
\text { ASSIGNMENT }\end{array}$ & $\begin{array}{l}\text { TRU waste sites } \\
\text { and/or WTWBIR }\end{array}$ & $\begin{array}{l}\text { If applicable, what a waste stream is } \\
\text { called in the NMVP }\end{array}$ \\
\hline
\end{tabular}




\section{Table 3-1. SOURCES OF INFORMATION USED IN} WASTE STREAM PROFILES (continued)

\begin{tabular}{|c|c|c|}
\hline Information Fiold & $\begin{array}{l}\text { Source of } \\
\text { Information }\end{array}$ & +ै। Explanation $\quad \because \cdots$ \\
\hline TRUCON CODE & $\begin{array}{l}\text { TRU waste sites } \\
\text { and/or WTWBIR }\end{array}$ & $\begin{array}{l}\text { If applicable, what a waste stream is } \\
\text { called in the TRUCON }\end{array}$ \\
\hline CHECK OFF BOXES & TRU waste sites & $\begin{array}{l}\text { Categorization fields for TRU waste } \\
\text { stream }\end{array}$ \\
\hline Comments & TRU waste sites & $\begin{array}{l}\text { Lists comments/assumptions provided } \\
\text { by TRU waste sites on the waste } \\
\text { description. }\end{array}$ \\
\hline Footnotes & WTWBIR & $\begin{array}{l}\text { Explain data provided by the TRU waste } \\
\text { generator/storage site and/or list } \\
\text { assumptions made by WTWBIR. }\end{array}$ \\
\hline \multicolumn{3}{|c|}{ PAGE 2 OF WASTE STREAM PROFILE } \\
\hline $\begin{array}{l}\text { SITE NAME } \\
\text { Waste Type } \\
\text { Handling } \\
\text { Generator Site }\end{array}$ & TRU waste sites & Same as Page 1 of form \\
\hline CONTAINER & TRU waste sites & $\begin{array}{l}\text { Type of waste container that information } \\
\text { on page two is based on (e.g., Drum) }\end{array}$ \\
\hline$\frac{\text { CONTAINER }}{\text { Container Matl }}$ & TRU waste sites & $\begin{array}{l}\text { Type of material that a waste container } \\
\text { is constructed from (e.g., steel) }\end{array}$ \\
\hline$\frac{\text { CONTAINER }}{\text { Liner Type }}$ & TRU waste sites . & $\begin{array}{l}\text { Description of the liner, if used in the } \\
\text { waste container (e.g., rigid, plastic liner } \\
\text { bags) }\end{array}$ \\
\hline$\frac{\text { CONTAINER }}{\text { Type/Size }}$ & TRU waste sites & $\begin{array}{l}\text { Common designation for size (e.g., } \\
55 \text {-gallon) }\end{array}$ \\
\hline$\frac{\text { CONTAINER }}{\text { Int. VoVCtnr }}$ & TRU waste sites & $\begin{array}{l}\text { Internal volume of empty waste } \\
\text { container }\end{array}$ \\
\hline$\frac{\text { CONTAINER }}{\text { Liner Material }}$ & TRU waste sites & $\begin{array}{l}\text { Type of material that a liner is } \\
\text { constructed from (e.g., HDPE) }\end{array}$ \\
\hline$\frac{\text { CONTAINER }}{\text { Number Stored }}$ & TRU waste sites & $\begin{array}{l}\text { Number of containers stored as of last } \\
\text { data call (for Revision } 1=\text { end of 1993) }\end{array}$ \\
\hline$\frac{\text { CONTAINER }}{\text { Number Projected }}$ & TRU waste sites & $\begin{array}{l}\text { Number of containers projected to be } \\
\text { produced from 1994- } 2022\end{array}$ \\
\hline
\end{tabular}


Table 3-1. SOURCES OF INFORMATION USED IN WASTE STREAM PFIOFILES (continued)

\begin{tabular}{|c|c|c|}
\hline Information Field & $\begin{array}{l}\text { Source of } \\
\text { : Information }\end{array}$ & - Explanation \\
\hline $\begin{array}{l}\text { MATERIAL } \\
\text { PARAMETERS }\end{array}$ & TRU waste sites & $\begin{array}{l}\text { Record the "Upper Limit"; "Lower Limit"; } \\
\text { and "Average" in } \mathrm{kg} / \mathrm{m}^{3} \text { for each waste } \\
\text { material parameter, if known }\end{array}$ \\
\hline $\begin{array}{l}\text { STORED TRU WASTE } \\
\text { AND ESTIMATED } \\
\text { RATES OF WASTE } \\
\text { GENERATION }\end{array}$ & TRU waste sites & $\begin{array}{l}\text { Provides estimate of stored volumes of } \\
\text { waste at the "End of } 1992^{" ;} \text { "End of } \\
1993^{\prime} \text { and estimated projections for } \\
\text { waste generation. Information is } \\
\text { recorded for waste stream volumes as } \\
\text { stored or generated and in terms of } \\
\text { "final volume" for shipment to WIPP. }\end{array}$ \\
\hline $\begin{array}{l}\text { TYPICAL ISOTOPIC } \\
\text { COMPOSITION }\end{array}$ & TRU waste sites & $\begin{array}{l}\text { Provides estimate of "typical" } \\
\text { radionuclide concentration expected in } \\
\text { waste stream in a curies } / \mathrm{m}^{3} \text { basis; if } \\
\text { concentrations are unknown, only } \\
\text { isotopes may be listed. }\end{array}$ \\
\hline $\begin{array}{l}\text { TYPICAL EPA CODES } \\
\text { APPLICABLE }\end{array}$ & $\begin{array}{l}\text { MWIR or TRU } \\
\text { generator/storage } \\
\text { site }\end{array}$ & $\begin{array}{l}\text { Identifies the applicable EPA codes for } \\
\text { waste for as it exists at sites;. }\end{array}$ \\
\hline COMMENTS & TRU waste sites & $\begin{array}{l}\text { Lists comments/assumptions on the } \\
\text { container information provided by TRU } \\
\text { waste sites. }\end{array}$ \\
\hline FOOTNOTES & WTWBIR & $\begin{array}{l}\text { Explain data provided by TRU waste } \\
\text { generating/storage sites and/or list } \\
\text { assumptions made by the WTWBIR. }\end{array}$ \\
\hline
\end{tabular}

The WMC is located on the first page of each waste stream profile. The assignment of the WMC is based on DOE guidance document (DOE, 1993a).

For the purpose of this document, TRU waste generator/storage sites were requested to provide WMCGs for final waste forms; that is, after the sites process, treat, or repackage the waste. The WMCG is indicated on page 1 of the waste stream profile. For most waste stream profiles, the TRU waste generator/storage sites have provided estimates of the waste material parameters (e.g., an INEL waste stream profile is used for illustrative purposes in Figure 3-1). However, in some cases the TRU waste generator/storage sites were unable to provide waste material parameter values for some waste streams. This resulted in two possible changes to the overall methodology presented in this chapter.

- In many cases the TRU waste generator/storage site could categorize the waste stream profile into one of the final 11 WIPP WMCGs (Table 1-2) but could not give any waste material parameter information. In these cases, the WTWBIR assumes the same range and average waste material parameters for the particular WIPP waste profile. For example, if a salt waste stream did not contain any waste material parameter information, but has been 
identified by a TRU waste generator/storage site as being a salt waste form, then the volume of that waste stream was added to the total volume of all other salt waste streams.

- In a few cases, TRU waste generator/storage sites were unable to categorize a TRU waste stream into one of the final WIPP WMCGs (Table 1-2). In these cases the waste stream profile is placed in the "unknown" category. The "unknown" waste streams are documented as part of the WIPP inventory, but are not used in any of the scaling of CH-TRU waste volumes necessary to fill WIPP to its design capacity. "Unknown" wastes will have to be characterized and may require treatment prior to emplacement in WIPP.

The TRU waste generator/storage sites have identified several waste streams that are regulated under the Toxic Substances Control Act (TSCA) (i.e., containing asbestos or polychlorinated biphenyls [PCBs]). Because the concentration of the asbestos and/or PCBs is unknown, it is assumed that these waste streams cannot be accepted at WIPP under the proposed draft WIPP RCRA Part B Permit Application. These waste streams are summarized in Table 3-2 and are not included in the WTWBIR.

\subsection{SITE-SPECIFIC WASTE PROFILE METHODOLOGY}

Waste streams at each TRU waste generator/storage site with similar WMCs can be grouped together into WMCGs (Table 1-2) for a site-specific waste profile. The methodology for grouping waste streams from two different generator/storage sites is shown in Figure 3-2. The grouping of individual waste stream profiles into a site-specific waste profile is based on the similar physical and chemical properties of the waste streams and how that information is used in the SPM and PA models. In the example in Figure 3-2, due to their similar mechanical properties, concrete waste, glass waste, firebrick waste, and ceramic waste mainly influence the estimation of porosity and permeability in the SPMPA calculations. Therefore, the three waste streams at DOE TRU Waste Site \#1 and the two at DOE TRU Waste Site \#2 can be grouped together at each site based on similar physical and chemical properties and placed into the site-specific waste profile "inorganic non-metal" waste, with the WMCG defined in Table 1-2.

A site-specific waste profile is developed at each of the TRU waste generator/storage sits for each of the WMCGs that have individual waste streams at the site. These site-specific waste profiles provide a roll-up of the waste material parameter and volume information found in the waste stream profiles for each site. Since there are 11 WMCGs, there are a maximum of 11 possible CH-TRU and 11 possible RH-TRU site-specific waste profiles at any generator/storage site; however, most sites have fewer profiles due to differences in waste segregation practices. An example site-specific waste profile is provided in Figure 3-3. Table 3-3 lists the sources of information for site-specific waste profiles. All the site-specific waste profiles for TRU waste are provided in Appendix $B$.

\subsection{WIPP WASTE PROFILE METHODOLOGY}

\subsubsection{Introduction and Methodology}

The WIPP waste profiles are the highest tier of information in the WTWBIR. Site-specific waste profiles with the same WMCGs are combined across the TRU waste generator/storage sites into what is defined as an overall WIPP waste profile. 
TABLE 3-2. TOXIC SUBSTANCES CONTFIOL ACT (TSCA) TRU WASTE

\begin{tabular}{|c|c|c|c|}
\hline WIPP ID & WASTE STREAM NAME & ASBESTOS & PCBs \\
\hline IN-W309 & Absorbed Organic Liquids & No & Yes \\
\hline MD-W002 & Absorbed Aqueous Liquids & No & Yes \\
\hline LL-T005 & HEPA filters & Yes & No \\
\hline MD-M001 & Asbestos Debris & Yes & No \\
\hline MD-T013 & Leaded gloves/aprons & No & Yes \\
\hline MD-T008 & Uncategorized plastics/rubber debris & No & Yes \\
\hline MD-T012 & Uncategorized heterogeneous debris & Yes & No \\
\hline RL-M005 & $\begin{array}{l}\text { TRU Mixed Inorganic Homogeneous } \\
\text { Solids with Mercury }\end{array}$ & No & Yes \\
\hline RL-M021 & $\begin{array}{l}\text { TRU Mixed Inorganic Debris PClßs with } \\
\text { Mercury }\end{array}$ & No & Yes \\
\hline $\mathrm{RL}-\mathrm{M} 022$ & $\begin{array}{l}\text { TRU Mixed Leaded Gloves/Aprons } \\
\text { PCBs with Mercury }\end{array}$ & No & Yes \\
\hline RL-M023 & $\begin{array}{l}\text { TRU Mixed Organic Debris PCBs with } \\
\text { IGN, CORR, REAC }\end{array}$ & No & Yes \\
\hline RL-M024 & $\begin{array}{l}\text { TRU Mixed Organic Labpacks with } \\
\text { PCBs }\end{array}$ & No & Yes \\
\hline RL-T030 & Non-mixed Inorganic Debris with PCBs & No & Yes \\
\hline
\end{tabular}

As described in Sections 3.1 and 3.2, each waste strean from each TRU waste generator/storage site is defined in a waste stream profile, then grouped by site WMCGs into site-specific waste profiles. These site-specific waste profiles are then rolled-up into WIPP waste profiles by combining identical WMCGs from all the TRU waste generator/storage sites. For example, all site-specific waste profiles for "inorganic non-metal" weste are grouped together to generate the WIPP waste profile, "inorganic non-metal" waste. The WIPP waste profiles are presented in Figures 3-4 through 3-23 at the end of this chapter:

\subsubsection{WIPP Waste Profile Roll-Ups}

To illustrate the methodology for grouping similar site-specific waste profiles into WIPP waste profiles, the WIPP waste profile for "inorganic non-metal" waste (exemplified in Figure 3-2) is provided in Figure 3-8. As with site-specific waste profiles, there can be a maximum of 11 possible WIPP waste profiles for CH-TRU and 11 possible WIPP waste profiles for RH-TRU 


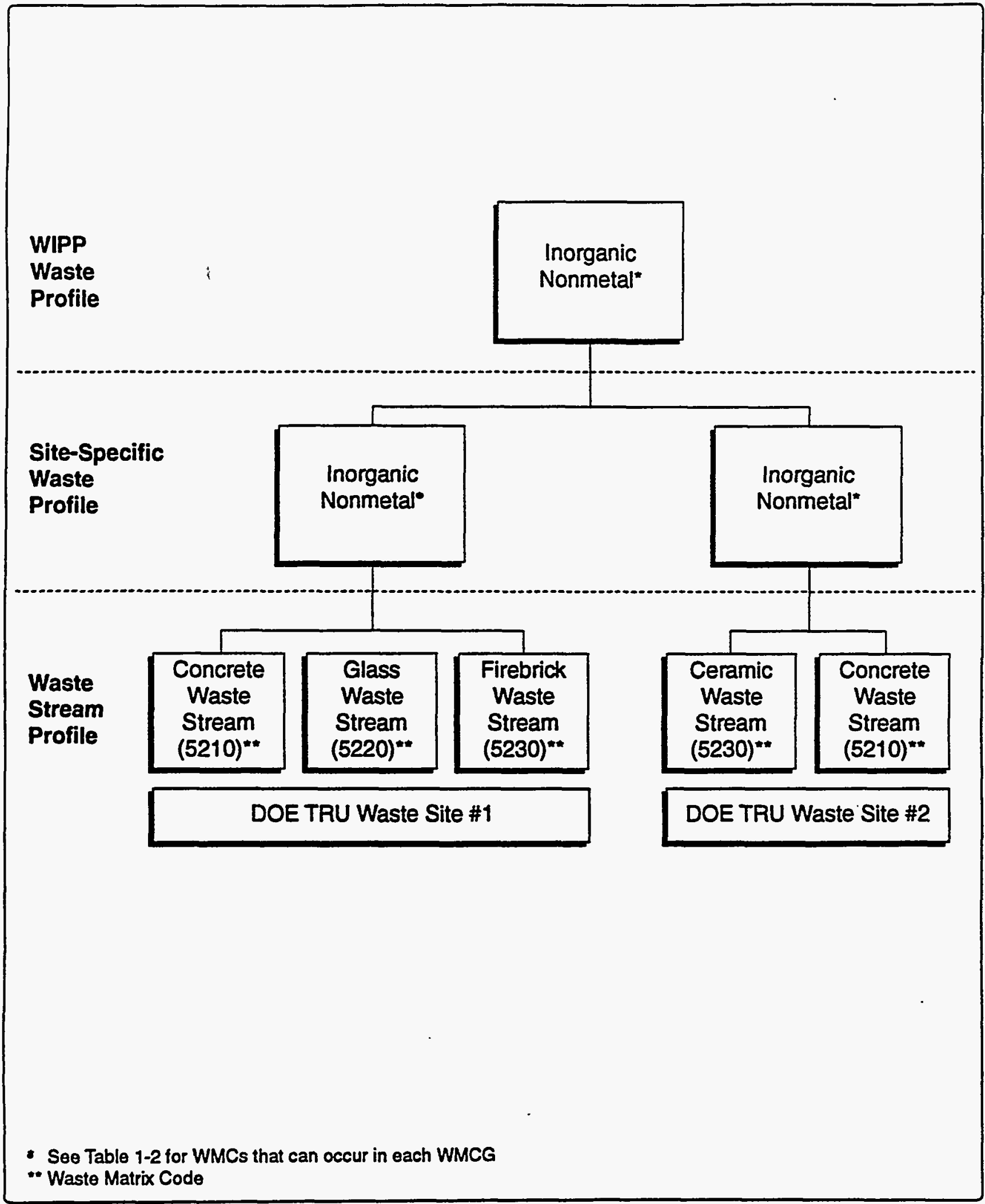

Figure 3-2. Schematic of Waste Stream Profile Methodology. 
Site-Specific Contact Handled Waste Profiles

\begin{tabular}{|c|c|c|c|}
\hline $\begin{array}{l}\text { Site Name: INEL } \\
\text { Final Waste Form: } \\
\text { Waste Stream ID }\end{array}$ & $\begin{array}{l}\text { Heterogeneous } \\
\qquad \begin{array}{l}\text { Retrievably } \\
\text { Stored (m3) }\end{array}\end{array}$ & Projected (m3) & $\begin{array}{r}\text { Total ner } \\
\text { Stream (m3) }\end{array}$ \\
\hline IN-WI69 & 4331 & 0 & 4331 \\
\hline $\mathrm{NN}-\mathrm{W} 170$ & 0.44 & 1 & 1.44 \\
\hline IN-W171 & 3.6 & 0 & 3.6 \\
\hline IN-W172 & 165.57 & 0 & 165.57 \\
\hline IN-W186 & 2695.1 & 0 & 2695.1 \\
\hline IN-W189 & 8.2 & 0 & 8.2 \\
\hline IN-W197 & 632.7 & 0 & 632.7 \\
\hline IN-W203 & 71.9 & 0 & 71.9 \\
\hline IN-W204 & 3.2 & 0 & 3.2 \\
\hline IN-W225 & 6.1 & 0 & 6.1 \\
\hline IN-W259 & 58.8 & 0 & 58.8 \\
\hline IN-W265 & 47.8 & 0 & 47.8 \\
\hline $\mathrm{IN}-\mathrm{W} 269 \mathrm{~A}$ & 34.8 & 0 & 34.8 \\
\hline IN-W271 & 0.42 & 0 & 0.42 \\
\hline IN-W281 & 348 & 0 & 348 \\
\hline IN-W283 & 1 & 0 & 1 \\
\hline $\mathbb{N}$-W285 & 85 & 0 & 85 \\
\hline IN-W289 & 25.4 & 0 & 25.4 \\
\hline IN-W291 & 639 & 0 & 639 \\
\hline IN-W302 & 144.1 & 0 & 144.1 \\
\hline IN-W306.3 & 322.67 & 0 & 322.67 \\
\hline IN-W329 & 1.14 & 0 & 1.14 \\
\hline IN-W334 & 7.48 & 0 & 7.48 \\
\hline
\end{tabular}

Figure 3-3; Erample of Site Specific Waste Profile 


\section{Site-Specific Contact Handled Waste Profiles}

\begin{tabular}{|c|c|c|c|c|}
\hline NN-W345 & & 14.6 & 0 & 14.6 \\
\hline IN-W351 & & 1.48 & 0 & 1.48 \\
\hline Total Volume: & & 9649.5 & 1 & 9650.5 \\
\hline \multicolumn{2}{|c|}{ Material Parameters $(\mathrm{kg} / \mathrm{m} 3)$} & Maximum & Average & Minimum \\
\hline \multirow[t]{4}{*}{ Inorganics } & Iron Based & 1634.6 & 38.0 & 0.0 \\
\hline & inum Based & 38.2 & 1.2 & 0.0 \\
\hline & ther Metals & 233.0 & 17.2 & 0.0 . \\
\hline & - Inorganics & 1442.3 & 17.9 & 0.0 \\
\hline \multirow[t]{3}{*}{ Organics } & Cellulose & 961.5 & 245.1 & 0.0 \\
\hline & Rubber & 330.0 & 43.7 & 0.0 \\
\hline & Plastics & 887.0 & 148.1 & 0.0 \\
\hline \multirow[t]{2}{*}{ Solidified Materials } & Inorganic & 0.0 & 0.0 & 0.0 \\
\hline & Organic & 0.0 & 0.0 & 0.0 \\
\hline Soils & & .144 .2 & 0.2 & 0.0 \\
\hline
\end{tabular}

Figure 3-3 (cont); Example of Site Specific Waste Profile $3 \cdot 11$ 
TABLE 3-3. SOURCES OF INFORMATION USED IN SITE-SPECIFIC WASTE PROFILES

\begin{tabular}{|c|c|c|}
\hline Information Field & Source of information & Explanation \\
\hline DOE TRU Site & TRU Waste Sites & $\begin{array}{l}\text { The code for the DOE site. Codes are as follows: } \\
\text { AL - Ames Laboratory } \\
\text { AE - Argonne National Laboratory - East } \\
\text { AW - Argonne National Laboratory - West } \\
\text { BC - Battelle Columbus } \\
\text { BT - Bettis Atomic Power Laboratory } \\
\text { ET - Energy Technology Engineering } \\
\text { IN - Center } \\
\text { IT - Inhalation Toxicology Research Institute } \\
\text { KA - Knolls Atomic Power Laboratory - } \\
\text { LA - Los Alamos National Laboratory } \\
\text { LB - Lawrence Berkeley Laboratory } \\
\text { LL - Lawrence Livermore National } \\
\text { MD - Laboratory } \\
\text { MU - University of Missouri } \\
\text { NT - Nevada Test Site } \\
\text { OR - Oak Ridge National Laboratory } \\
\text { PA - Pactucah Gaseous Diffusion Plant } \\
\text { PX - Pantex Plant } \\
\text { RF - Rocky Flats Environmentel Technology Site } \\
\text { RL - Richland (Hanford) Sito } \\
\text { SA - Sandia National Laboratories/NM } \\
\text { SR - Savannah River Site } \\
\text { WV - West Valley Demonstration Project }\end{array}$ \\
\hline WMCG & WTWBIR or TRU waste sites & $\begin{array}{l}\text { Groups waste streams that have similar chemical } \\
\text { and physical propertios (see Table 1-2). }\end{array}$ \\
\hline $\begin{array}{l}\text { Waste Stream } \\
\text { Volume }\end{array}$ & TRU waste sites & $\begin{array}{l}\text { Provides estimates of retrievably stored, projected, } \\
\text { and total volumes of TRU and mixed TRU wastes } \\
\text { by waste stream. }\end{array}$ \\
\hline $\begin{array}{l}\text { Waste Material } \\
\text { Parameters }\end{array}$ & TRU wasto sites & $\begin{array}{l}\text { Provides total density estimates of selected waste } \\
\text { matoriais in a particular WMCG for the entire site. }\end{array}$ \\
\hline
\end{tabular}

waste. Table 3-4 lists the sources of information used for the WIPP waste profiles. Using volumes for all the TRU waste streams (including the mixed and non-mixed TRU waste volumes) in the WTWBID, a disposal inventory of TRU waste has been developed using the methodology described in this and the preceding sections. This inventory is presented in Table 3-5 (by WMCGs) and depicts both the anticipated and disposal inventory volumes. 
TABLE 3-4. SOURCES OF INFORMATION USED IN WIPP WASTE PROFILES

\begin{tabular}{|l|l|l|}
\hline \multicolumn{1}{|c|}{ Information Field } & \multicolumn{1}{|c|}{$\begin{array}{c}\text { Source of } \\
\text { Information }\end{array}$} & \multicolumn{1}{|c|}{ Explanation } \\
\hline \hline $\begin{array}{l}\text { Waste Matrix Code } \\
\text { Group (WMCG) }\end{array}$ & $\begin{array}{l}\text { WTWBIR or } \\
\text { TRU waste sites }\end{array}$ & $\begin{array}{l}\text { Groups waste streams that have similar } \\
\text { chemical and physical properties (Table 1-2) }\end{array}$ \\
\hline DOE Site Volumes & TRU waste sites & $\begin{array}{l}\text { Provides estimates of retrievably stored, } \\
\text { projected, and total volumes of TRU and TRU } \\
\text { mixed wastes by DOE site }\end{array}$ \\
\hline $\begin{array}{l}\text { Waste Material } \\
\text { Parameters }\end{array}$ & TRU waste sites & $\begin{array}{l}\text { Provides weight estimates of selected waste } \\
\text { materials in a particular WMCG for the DOE } \\
\text { Complex }\end{array}$ \\
\hline
\end{tabular}

The anticipated $\mathrm{CH}$-TRU inventory volumes are the sum of the "stored" and "projected" volumes in Table 3-5. The procedure to scale to the disposal inventory is summarized below:

- The target design volume of $\mathrm{CH}$-TRU waste beyond that identified by the generator/storage sites is decreased by the "unknown" waste volume $(176,000-1700=176,000$ [there is no significant increase due to rounding]).

The "unknown" volume of waste in Table 3-5 is subtracted from the stored inventory and from the projected inventory.

- The "unknown" waste will have to be added back into the total scaled inventory because it is assumed that this waste will be characterized and then shipped to WIPP.

- Applying a modified version of the formula given in Section 2.3:

$$
\frac{\begin{array}{c}
1.76 \times 10^{5} \\
\text { (modified design inventory) }- \text { (modified stored inventory) }
\end{array}}{5.1 \times 10^{4} \text { (modified projected inventory) }}
$$

- Multiply the CH-TRU waste projected inventory volumes by the scaling factor 2.05 for all the WMCGs, except for the "unknown" waste and add the stored volumes (which results in the numbers in the "Disposal inventory" column of Table 3-5).

- Add the CH-TRU waste volumes in the fourth column, including the "unknown" waste, to attain the estimated WIPP disposal inventory volume).

The $\mathrm{CH}$-TRU waste stream volume on a system-wide WMCG basis is increased by 42 percent to account for the difference between the anticipated inventory and the repository design limit. 
A similar methodology has been developed to scale the RH-TRU inventory. The anticipated RH-TRU inventory volumes are the sum of the "stored" and "projected" volumes in Table 3-5. The procedure to scale to the disposal inventory is summarized below:

- The target design volume of RH-TRU waste beyond that identified by the generator/storage sites is decreased by the "unknown" waste volume $(7080-35=7045)$.

The "unknown" volume of waste in Table 3-5 is subtracted from the stored inventory and from the projected inventory.

- The "unknown" waste will have to be added back into the total scaled inventory because it is assumed that this waste will be characterized and then shipped to WIPP.

- Applying a modified version of the formula given in Section 2.3:

$\frac{\begin{array}{c}7045 \\ \text { (modified design inventory) }- \text { (modified stored inventory) }\end{array}}{3595 \text { (modified projected inventory) }}=1.64$ (scaling factor)

- Multiply the RH-TRU waste projected inventory volumes by the scaling factor 1.64 for all the WMCGs, except for the "unknown" waste and add the stored volumes (which results in the numbers in the "Disposal inventory" column of Table 3-5).

- Add the RH-TRU waste volumes in the fourth column, including the "unknown" waste, to attain the estimated WIPP disposal inventory volume).

The RH-TRU waste stream volume on a system-wide WMCG basis is increased by 48 percent to account for the difference between the anticipated inventory and the repository design limit. 
Table 3-5

\section{TRANSURANIC WASTE DISPOSAL INVENTORY FOR WIPP}

Contact Handled Waste

\begin{tabular}{|c|c|c|c|c|}
\hline Waste Matrix Groups & $\begin{array}{r}\text { Stored } \\
\text { Volumes }\end{array}$ & $\begin{array}{r}\text { Projected } \\
\text { Volumes } \\
\end{array}$ & $\begin{array}{r}\text { Anticipated } \\
\text { Volumes } \\
\end{array}$ & $\begin{array}{r}\text { WIPP Disposal } \\
\text { Volumes } \\
\end{array}$ \\
\hline Combustible & $7.1 E+03$ & $2.7 \mathrm{E}+04$ & $3.4 E+04$ & $6.2 \mathrm{E}+04$ \\
\hline Filter & $4.3 E+02$ & $1.1 E+03$ & $1.5 E+03$ & $2.6 \mathrm{E}+03$ \\
\hline Graphite & $6.7 E+02$ & $4.3 \mathrm{E}+01$ & $7.1 E+02$ & $7.6 \mathrm{E}+02$ \\
\hline Heterogeneous & $3.0 \mathrm{E}+04$ & $4.6 \mathrm{E}+03$ & $3.5 E+04$ & $3.9 E+04$ \\
\hline Inorganic Non-metal & $1.2 E+03$ & $3.2 \mathrm{E}+02$ & $1.5 E+03$ & $1.8 \mathrm{E}+03$ \\
\hline Lead/Cadmium Metal Waste & $5.6 \mathrm{E}+01$ & $1.3 \mathrm{E}+02$ & $1.8 \mathrm{E}+02$ & $3.1 E+02$ \\
\hline Salt Waste & $3.3 \mathrm{E}+01$ & $6.0 \mathrm{E}+01$ & $9.2 \mathrm{E}+01$ & $1.5 E+02$ \\
\hline Soils & 3. $7 \mathrm{E}+02$ & 4.5E+02 & $8.3 E+02$ & $1.3 E+03$ \\
\hline Solidified Inorganics & $1.7 E+04$ & $8.0 \mathrm{E}+03$ & $2.5 \mathrm{E}+04$ & $3.4 \mathrm{E}+04$ \\
\hline Solidified Organics & $1.5 E+03$ & $3.0 \mathrm{E}+02$ & $1.8 \mathrm{E}+03$ & 2.1E+03 \\
\hline Uncategorized Metal & $1.2 E+04$ & $8.6 \mathrm{E}+03$ & $2.1 E+04$ & $3.0 \mathrm{E}+04$ \\
\hline Unknown & $1.7 E+03$ & $0.0 \mathrm{E}+00$ & $1.7 \mathrm{E}+03$ & $1.7 E+03$ \\
\hline Total CH Volumes & $7.3 E+04$ & $5.1 \mathrm{E}+04$ & $1.2 \mathrm{E}+05$ & $1.8 \mathrm{E}+05$ \\
\hline \multicolumn{5}{|l|}{ Remote Handled Waste } \\
\hline Combustible & $1.5 E+01$ & $3.2 E+00$ & $1.8 \mathrm{E}+01$ & $2.0 \mathrm{E}+01$ \\
\hline Filter & 8.9E-01 & $2.1 E+00$ & $3.0 \mathrm{E}+00$ & $4.3 \mathrm{E}+00$ \\
\hline Heterogeneous & $4.4 E+02$ & $3.3 E+03$ & $3.8 E+03$ & $5.9 E+03$ \\
\hline Lead/Cadmium Metal Waste & $0.0 \mathrm{E}+00$ & $6.0 \mathrm{E}+00$ & $6.0 \mathrm{E}+00$ & $9.8 \mathrm{E}+00$ \\
\hline Salt Waste & $0.0 \mathrm{E}+00$ & $2.8 \mathrm{E}+00$ & $2.8 \mathrm{E}+00$ & $4.6 \mathrm{E}+00$ \\
\hline Solidified Inorganics & $6.1 E+02$ & 1.7E+02 & $7.9 \mathrm{E}+02$ & $9.0 \mathrm{E}+02$ \\
\hline Uncategorized Metal & $8.8 E+01$ & $8.6 E+01$ & $1.7 E+02$ & $2.3 E+02$ \\
\hline Unknown & $1.1 E+01$ & $2.4 \mathrm{E}+01$ & $3.5 \mathrm{E}+01$ & $3.5 E+01$ \\
\hline Total RH Volumes & $1.2 E+03$ & $3.6 \mathrm{E}+03$ & $4.8 \mathrm{E}+03$ & $7.1 \mathrm{E}+03$ \\
\hline Total TRU Waste Volumes & $7.4 E+04$ & $5.4 E+04$ & $1.3 E+05$ & $1.8 \mathrm{E}+05$ \\
\hline
\end{tabular}




\section{WIPP Contact Handled Waste Profiles}

Final Waste Form: Combustible

\begin{tabular}{lrrr}
\multicolumn{1}{c}{ Site } & $\frac{\text { Retrievablv }}{\text { Stared (m3) }}$ & Proiected (m3) & Total (m3) \\
INEL & 670.90 & 0.00 & 670.90 \\
LANL & 1768.33 & 2464.60 & 4232.93 \\
MOUND & 5.61 & 0.00 & 5.61 \\
HANFORD & 526.48 & 12269.03 & 12795.51 \\
LLNL & 48.88 & 372.32 & 421.20 \\
SRS & 4066.80 & 11962.50 & 16029.30 \\
\multicolumn{1}{r}{ Total Volume } & 7087.00 & 27068.45 & 34155.45
\end{tabular}

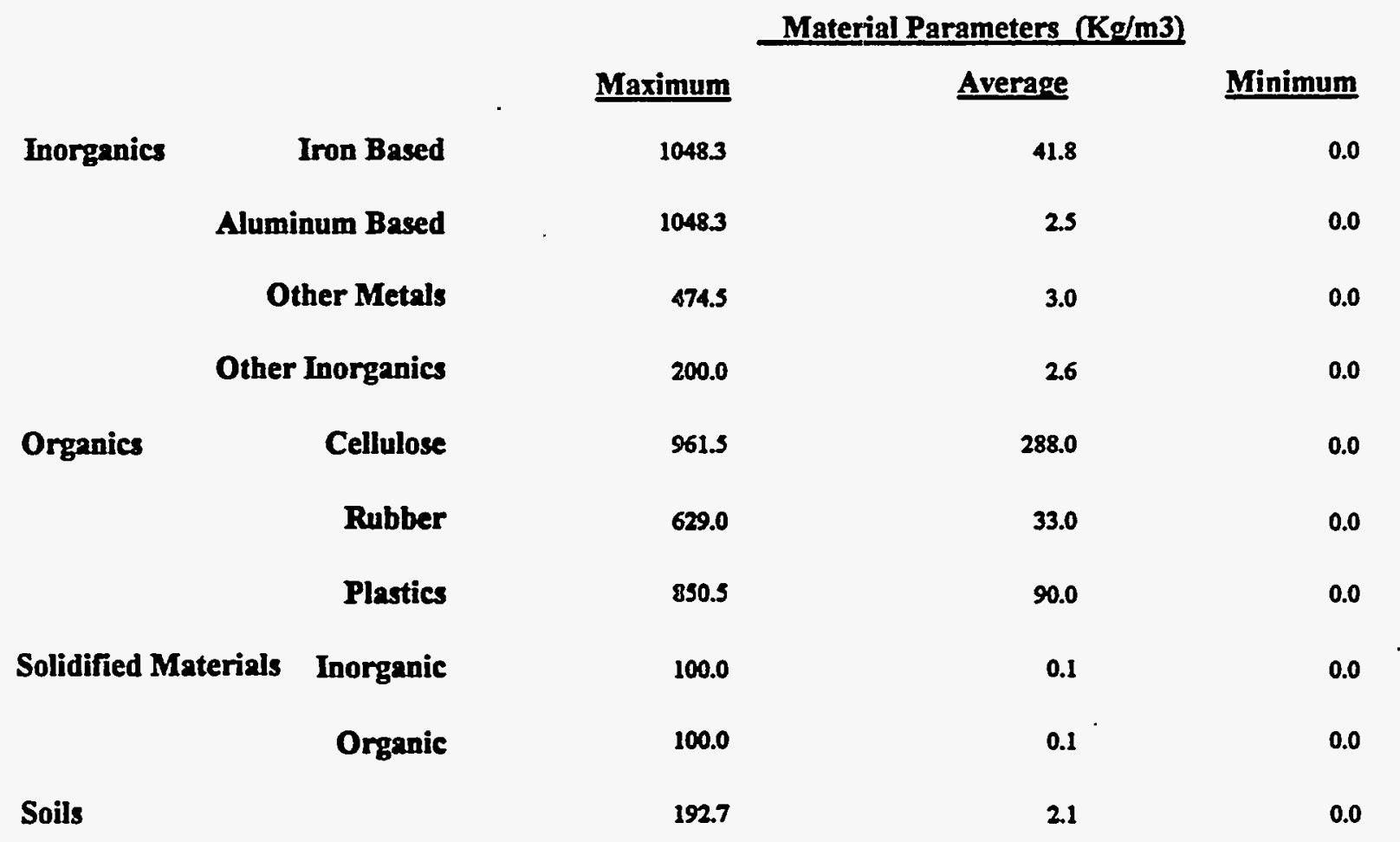




\section{WIPP Contact Handled Waste Profiles}

Final Waste Form: Filter

\begin{tabular}{lrrr}
\multicolumn{1}{l}{ Site } & $\frac{\text { Retrievahlv }}{\text { Stored (m3) }}$ & Projected (m3) & Total (m3) \\
INEL & 323.56 & 0.00 & 323.56 \\
RFP & 103.96 & 1087.59 & 1191.55 \\
\cline { 2 - 4 } Total Volume & 427.52 & 1087.59 & 1515.11
\end{tabular}

Material Parameters $(\mathrm{Kg} / \mathrm{m} 3)$

Maximum Average Minimum

Inorganics

Iron Based

395.3

6.7

0.0

Aluminum Based

440.7

11.9

0.0

Other Metals

0.0

0.0

0.0

Other Inorganics

500.0

72.9

0.0

Organics

Cellulose

496.1

15.9

0.0

Rubber

11.3

0.6

0.0

Plastics

$\$ 96.6$

21.2

0.0

Solidified Materials Inorganic

427.6

42.6

0.0

Organic

0.0

0.0

0.0

Soils

0.0

0.0

0.0

Figure 3 - 5

WIPP CH-TRU Waste Profile for Final Waste Form Filter 


\section{WIPP Contact Handled Waste Profiles}

Final Waste Form: Graphite

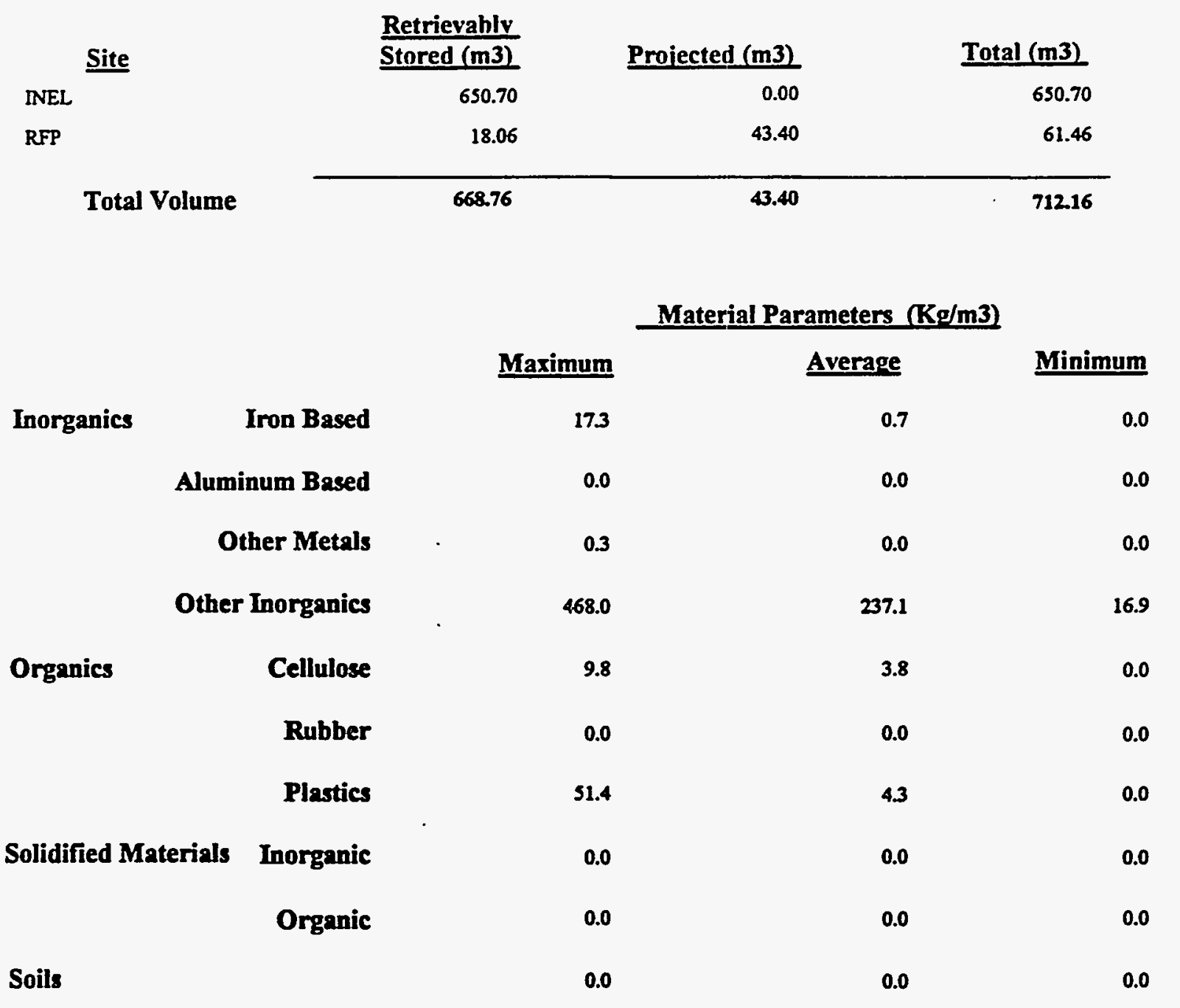




\section{WIPP Contact Handled Waste Profiles}

Final Waste Form: Heterogeneous

\begin{tabular}{|c|c|c|c|}
\hline Site & $\frac{\text { Retrievablv }}{\text { Stored (m3) }}$ & Proiected (m3) & Total (m3) \\
\hline LBL & 0.84 & 4.42 & 5.26 \\
\hline INEL & 9649.50 & 1.00 & 9650.50 \\
\hline ORNL & 672.98 & 263.90 & 936.88 \\
\hline HANFORD & 8568.55 & 827.16 & 9395.71 \\
\hline NTS & 619.50 & 0.00 & 619.50 \\
\hline KAPL & 2.40 & 0.00 & 2.40 \\
\hline MOUND & 0.42 & 0.00 & 0.42 \\
\hline BT & 0.00 & 123.82 & 123.82 \\
\hline ETEC & 1.66 & 5.20 & 6.86 \\
\hline PANTEX & 0.62 & 0.00 & 0.62 \\
\hline RFP、 & 312.86 & 804.58 & 1117.44 \\
\hline SRS & 10132.20 & 2563.60 & 12695.80 \\
\hline SNLNM & 8.04 & 7.00 & 15.04 \\
\hline ANLWW & 0.00 & 3.36 & 3.36 \\
\hline MU & 0.06 & 1.60 & 1.66 \\
\hline Total Volume & 29969.63 & 4605.64 & 34575.27 \\
\hline
\end{tabular}

Figure 3-7

WIPP CH-TRU Waste Profile for Final Waste Form Heterogeneous 


\section{WIPP Contact Handled Waste Profiles}

\begin{tabular}{|c|c|c|c|c|}
\hline & & & rameters 0 & \\
\hline & & Maximum & Average & Minimum \\
\hline Inorganics & Iron Based & 1716.4 & 168.4 & 0.0 \\
\hline Alum & inum Based & 512.0 & 30.5 & 0.0 \\
\hline & ther Metals & 850.0 & 5.0 & 0.0 \\
\hline Othe & Inorganics & 2100.0 & 16.9 & 0.0 \\
\hline Organics & Cellulose & 961.5 & 301.7 & 0.0 \\
\hline & Rubber & 681.8 & 39.7 & 0.0 \\
\hline & Plastics & 887.0 & 123.6 & 0.0 \\
\hline Solidified Materials & Inorganic & 177.0 & 2.9 & 0.0 \\
\hline & Organic & 400.0 & 0.2 & 0.0 \\
\hline Soils & & 865.8 & 2.7 & 0.0 \\
\hline
\end{tabular}




\section{WIPP Contact Handled Waste Profiles}

Final Waste Form: Inorganic Non-metal

\begin{tabular}{lrrr}
\multicolumn{1}{l}{ Site } & $\frac{\text { Retrievahly }}{\text { Stored (m3) }}$ & Projected (m3) & Total (m3) \\
INEL & 1052.89 & 0.00 & 1052.89 \\
RFP & 110.68 & 318.68 & 429.36 \\
\cline { 2 - 4 } Total Volume & 1163.57 & 318.68 & 1482.25
\end{tabular}

Material Parameters (Kg/m3)

Maximum $\quad$ Average $\quad$ Minimum

Inorganics

Iron Based

23.8

0.0

0.0

Aluminum Based

0.0

0.0

0.0

Other Metals

13.1

0.2

0.0

Other Inorganics

1250.0

214.3

0.0

'Organics

Cellulose

850.0

41.9

0.0

Rubber

8.7

0.4

0.0

Plastics

69.9

13.6

0.0

Solidified Materials Inorganic

69.9

3.7

0.0

Organic

8.3

0.0

0.0

Soils

865.8

0.4

0.0 


\section{WIPP Contact Handled Waste Profiles}

Final Waste Form: Lead/Cadmium Metal Waste

\begin{tabular}{lrrr}
\multicolumn{1}{c}{ Site } & $\frac{\text { Retrievahiv }}{\text { Stored }(\mathrm{m} 3)}$ & Projected $(\mathrm{m} 3)$ & Total (m3) \\
ANLEE & 1.10 & 0.00 & 1.10 \\
ANLW & 0.02 & 2.48 & 2.50 \\
ETEC & 0.21 & 0.00 & 0.21 \\
RFP & 51.87 & 124.18 & 176.05 \\
HANFORD & 3.13 & 0.29 & 3.42 \\
\multicolumn{1}{r}{ Total Volume } & 56.33 & 126.95 & 183.28
\end{tabular}

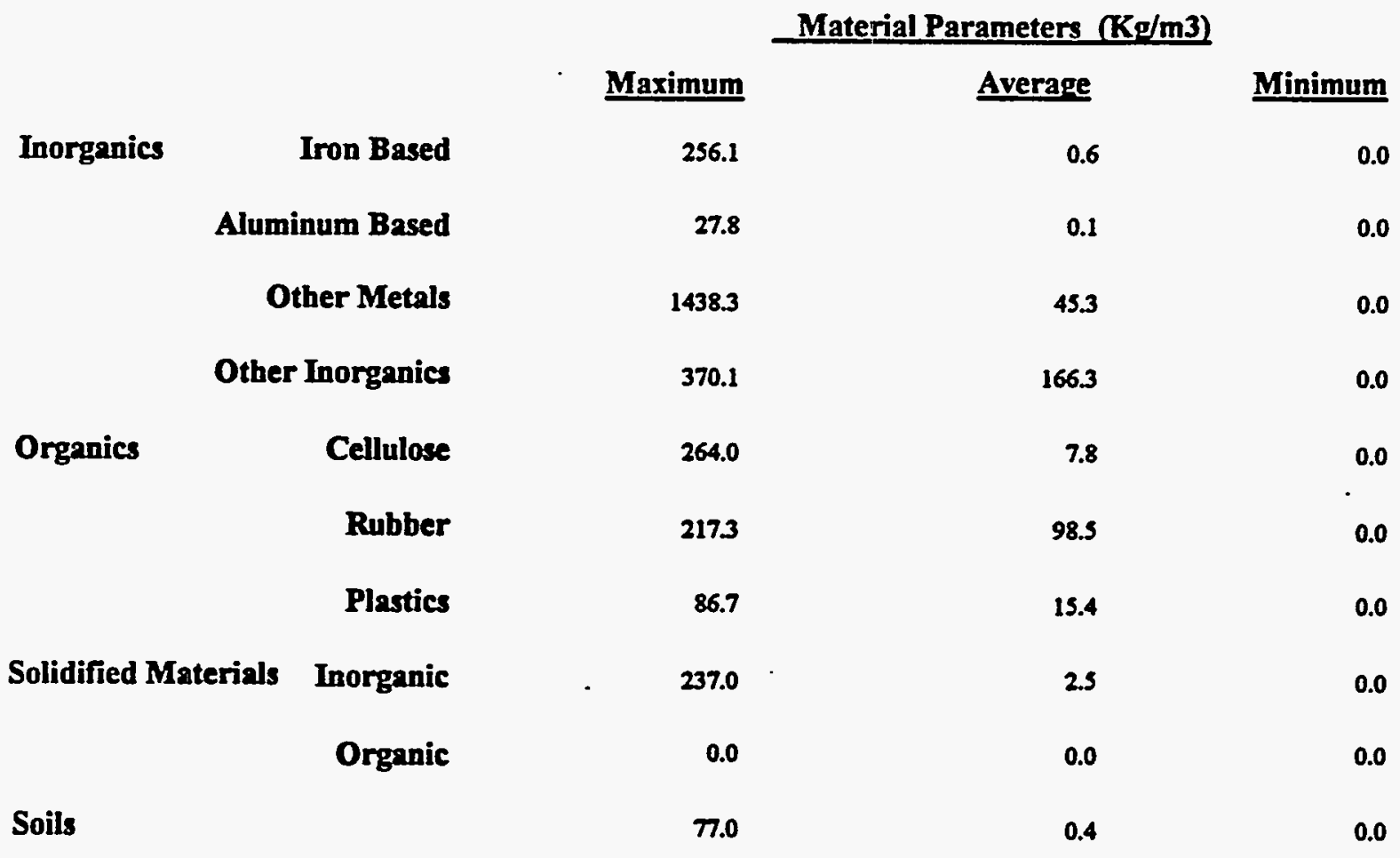




\section{WIPP Contact Handled Waste Profiles}

Final Waste Form: Salt Waste

\begin{tabular}{|c|c|c|c|}
\hline Site & $\frac{\text { Retrievahlv }}{\text { Stored }(\mathrm{m} 3)}$ & Projected (m3) & Total (m3) \\
\hline RFP & 9.45 & 56.60 & 66.05 \\
\hline INEL & 22.91 & 0.00 & 22.91 \\
\hline LLNL & 0.62 & 2.91 & 3.54 \\
\hline Total Volume & 32.98 & 59.51 & 92.50 \\
\hline
\end{tabular}

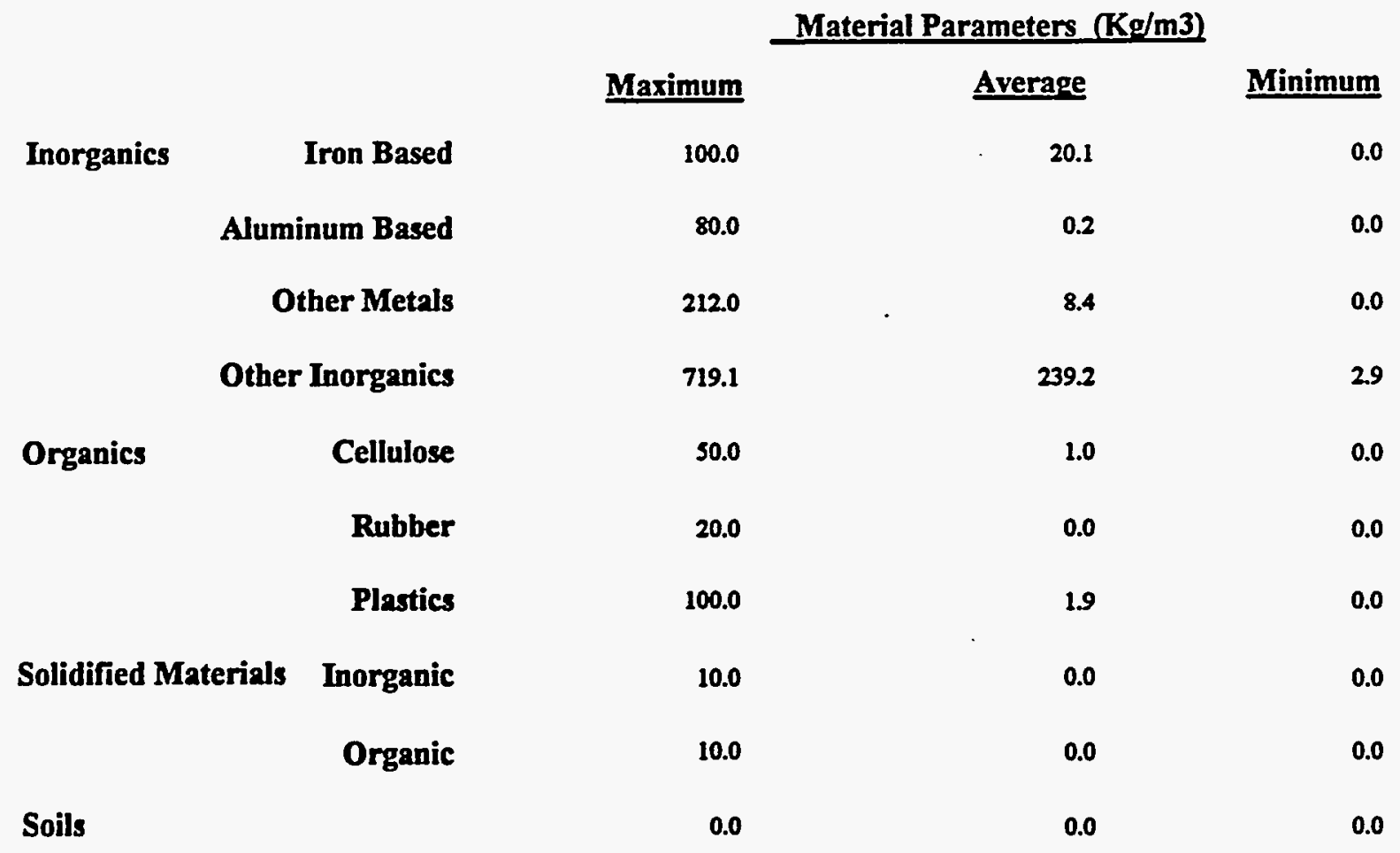




\section{WIPP Contact Handled Waste Profiles}

Final Waste Form: Soils

\begin{tabular}{lrrr}
\multicolumn{1}{c}{ Site } & $\frac{\text { Retrievablv }}{\text { Stored (m3) }}$ & Projected (m3) & Total (m3) \\
HANFORD & 111.69 & 309.27 & 420.96 \\
INEL & 3.80 & 0.00 & 3.80 \\
MOUND & 146.88 & 0.00 & 146.88 \\
LANL & 109.37 & 144.60 & 253.97 \\
\multicolumn{1}{r}{ Total Volume } & 371.74 & 453.87 & 825.61
\end{tabular}

\begin{tabular}{|c|c|c|c|c|}
\hline & & & rameters 1 & \\
\hline & & Maximum & Average & Minimum \\
\hline Inorganics & Iron Based & 38.8 & 1.4 & 0.0 \\
\hline Alumi & num Based & 38.8 & 0.3 & 0.0 \\
\hline & ther Metals & 0.0 & 0.0 & 0.0 \\
\hline Other & Inorganics & 33.9 & 0.0 & 0.0 \\
\hline Organics & Cellulose & 67.3 & 7.2 & 0.0 \\
\hline & Rubber & 210.4 & 1.8 & 0.0 \\
\hline & Plastica & 132.2 & 32.9 & 0.0 \\
\hline Solidified Materials & Inorganic & 0.0 & 0.0 & 0.0 \\
\hline & Organic & 0.0 & 0.0 & 0.0 \\
\hline Soils & & 1600.0 & 644.4 & 17.8 \\
\hline
\end{tabular}




\section{WIPP Contact Handled Waste Profiles}

Final Waste Form: Solidified Inorganics

\begin{tabular}{lrrr} 
& \multicolumn{1}{c}{ Retrievablv } & Projected (m3) & Total (m3) \\
\cline { 2 - 2 } & Stored $(\mathrm{m} 3)$ & 0.00 & 0.04 \\
ANLE & 0.04 & 1.12 & 24.17 \\
RFP & 23.05 & 2988.11 & 3216.74 \\
PA & 228.63 & 0.00 & 3.45 \\
ORNL & 3.45 & 0.00 & 110.00 \\
LANL & 110.00 & 2059.03 & 6907.41 \\
MOUND & 4848.38 & 0.00 & 7.28 \\
HANFORD & 7.28 & 2924.76 & 2926.22 \\
INEL & 1.46 & 0.00 & 12164.28 \\
LLNL & 12164.28 & 66.15 & 79.45 \\
AMES LAB & 13.30 & 0.10 & 0.10 \\
\multicolumn{1}{c}{ Total Volume } & 0.00 & 8039.27 & 25439.14
\end{tabular}

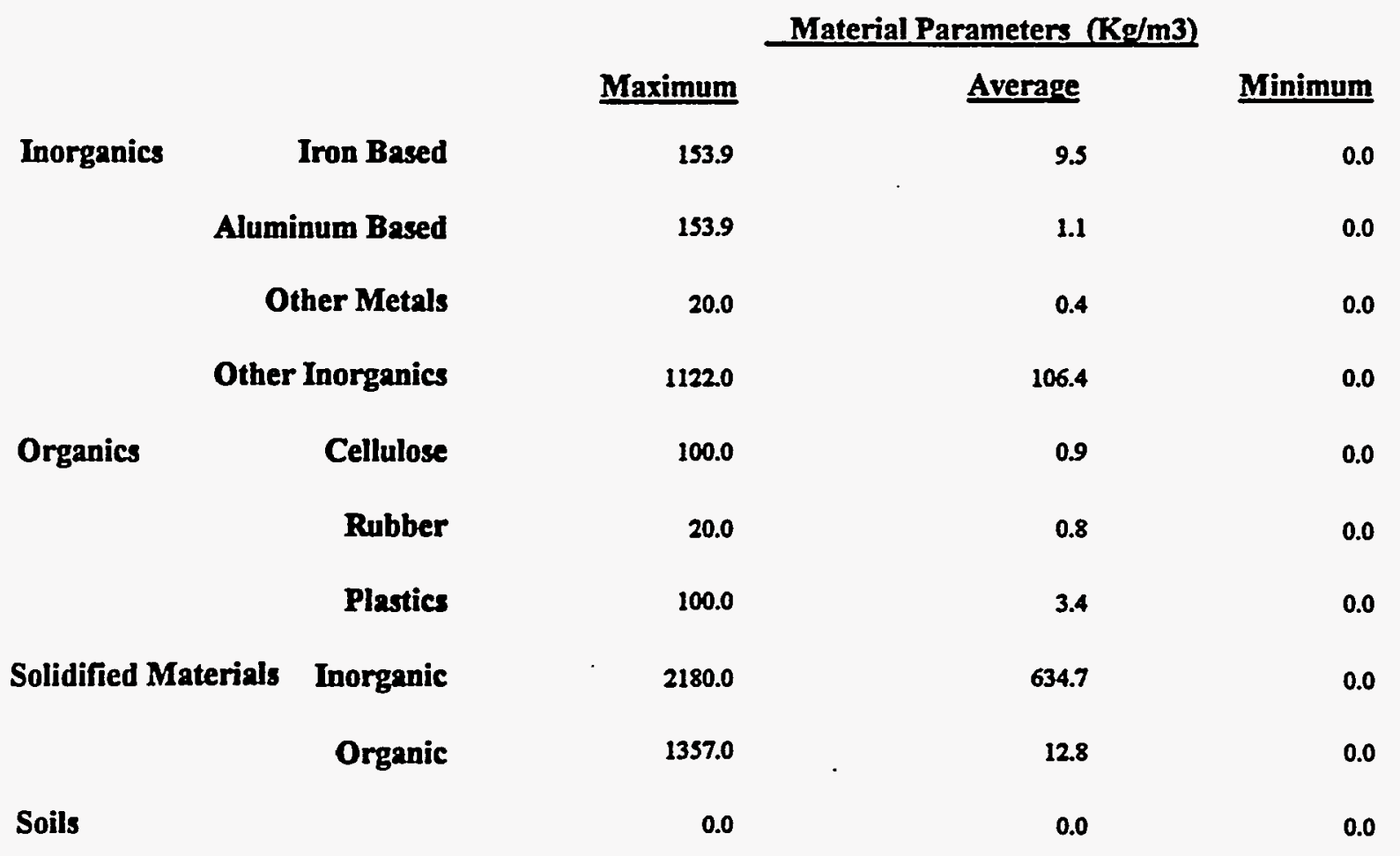

Figure 3 - 12

WIPP CH-TRU Waste Pronle for Final Waste Form Solidified Inorganics

$3-25$ 


\section{WIPP Contact Handled Waste Profiles}

Final Waste Form: Solidified Organics

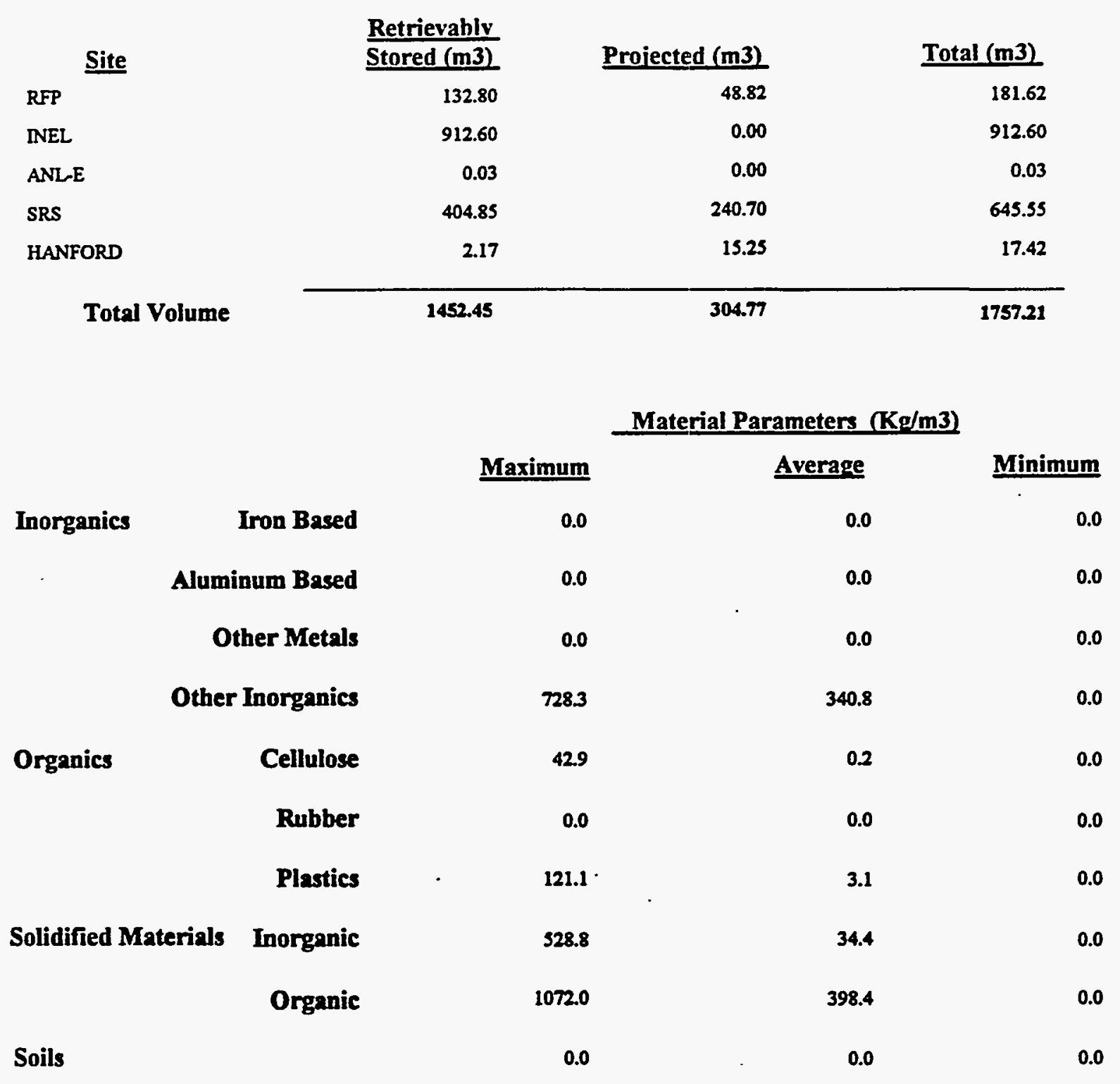




\section{WIPP Contact Handled Waste Profiles}

Final Waste Form: Uncategorized Metal

\begin{tabular}{lrrr}
\multicolumn{1}{c}{ Site } & $\frac{\text { Retrievahly }}{\text { Stored (m3) }}$ & Projected (m3) & Total (m3) \\
INEL & 7564.09 & 0.00 & 7564.09 \\
ANLE & 4.96 & 0.56 & 5.52 \\
MOUND & 102.28 & 0.00 & 102.28 \\
RFP & 164.82 & 429.50 & 594.32 \\
LANL & 4134.80 & 3006.17 & 7140.97 \\
LLNL & 144.33 & 247.00 & 391.33 \\
HANFORD & 103.35 & 4890.95 & 4994.30 \\
\multicolumn{1}{c}{ Total Volume } & 12218.62 & 8574.18 & 20792.80
\end{tabular}

\begin{tabular}{|c|c|c|c|c|}
\hline & & & rameters 1 & \\
\hline & & Maximum & Average & Minimum \\
\hline Inorganics & Iron Based & 2096.0 & 129.1 & 0.0 \\
\hline Alum & inum Based & 915.3 & 12.7 & 0.0 \\
\hline & ther Metals & 1057.7 & 146.5 & 0.0 \\
\hline Other & Inorganics & 812.5 & 11.2 & 0.0 \\
\hline Organics & Cellulose & 500.0 & 14.0 & 0.0 \\
\hline & Rubber & 245.6 & 1.0 & 0.0 \\
\hline & Plastics & 750.8 & 13.7 & 0.0 \\
\hline Solidified Materials & Inorganic & 300.0 & 0.0 & 0.0 \\
\hline & Organic & 300.0 & 0.0 & 0.0 \\
\hline Soils & & 48.7 & 0.2 & 0.0 \\
\hline
\end{tabular}

Figure 3 - 14

WIPP CH-TRU Waste Profile for Final Waste Form Uncategorized Metal 


\section{WIPP Contact Handled Waste Profiles}

Final Waste Form: Unknown

\begin{tabular}{|c|c|c|c|}
\hline Site & $\frac{\text { Retrievably }}{\text { Stored (m3) }}$ & Projected (m3) & Total (m3) \\
\hline INEL & 1655.91 & 0.00 & 1655.91 \\
\hline Total Volume & 1655.91 & 0.00 & 1655.91 \\
\hline
\end{tabular}

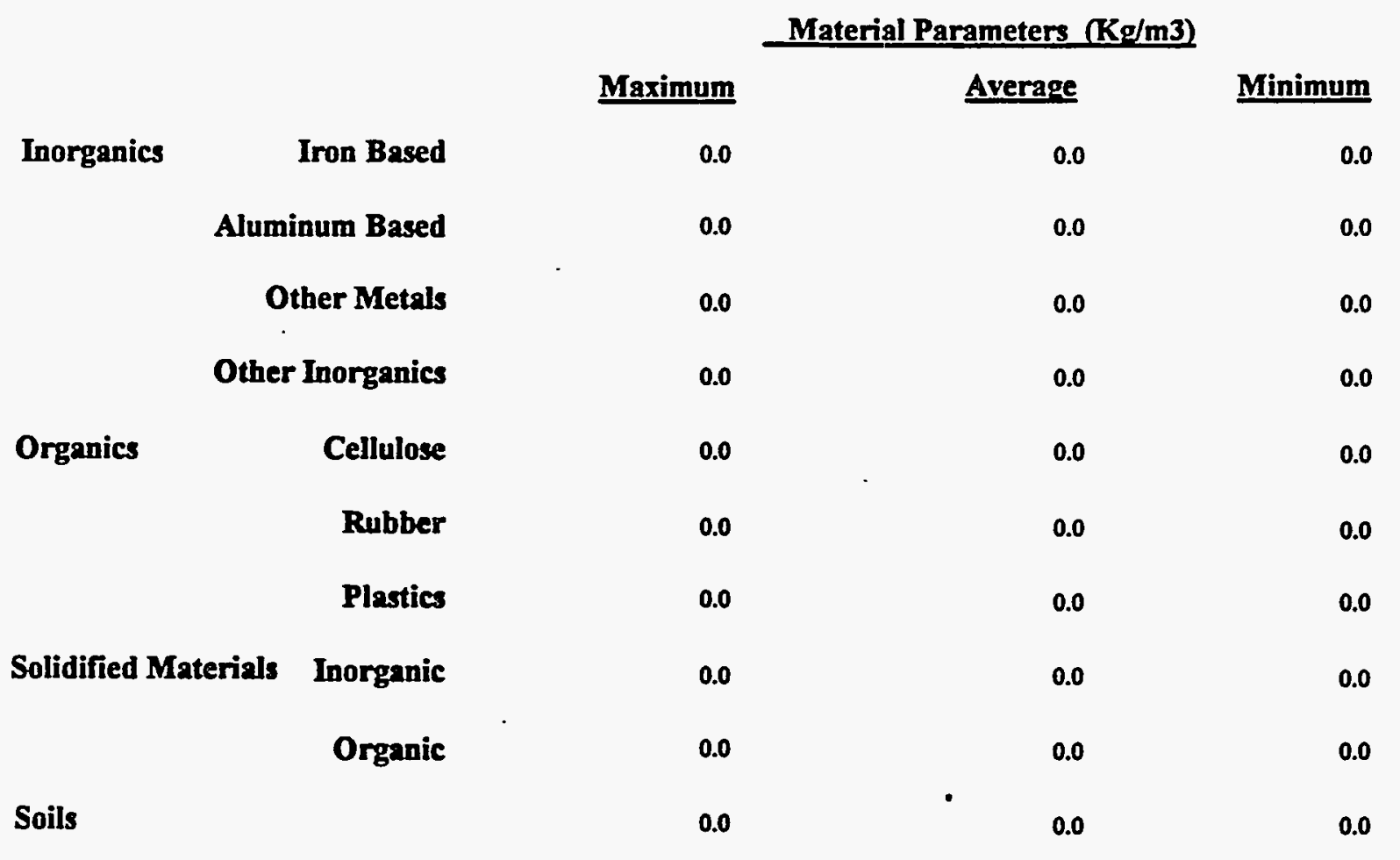

Figure 3 - 15

WIPP CH-TRU Waste Profile for Final Waste Form Unknown 


\section{WIPP Remote Handled Waste Profiles}

Final Waste Form: Combustible

\begin{tabular}{lrrr}
\multicolumn{1}{l}{ Site } & $\frac{\frac{\text { Retrievahlv }}{\text { Stored (m3) }}}{14.84}$ & $\frac{\text { Projected (m3) }}{3.16}$ & $\frac{\text { Total (m3) }}{18.00}$ \\
\cline { 2 - 4 } Total Volume & 14.84 & 3.16 & 18.00
\end{tabular}

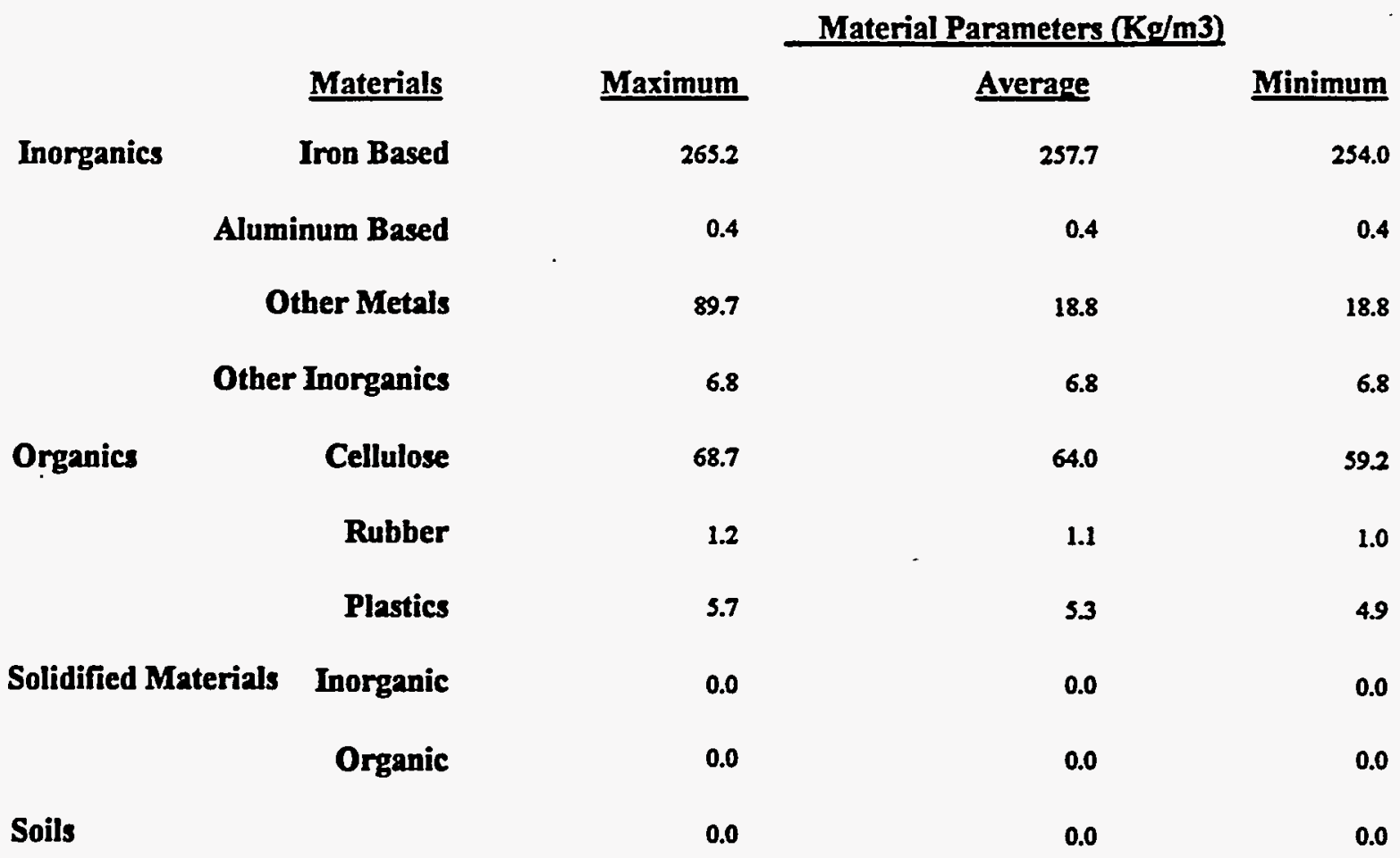




\section{WIPP Remote Handled Waste Profiles}

Final Waste Form: Filter

\begin{tabular}{lccr}
\multirow{2}{*}{ Site } & $\frac{\frac{\text { Retrievahlv }}{\text { Stored (m3) }}}{0.89}$ & $\frac{\text { Projected (m3) }}{2.09}$ & $\frac{\text { Total (m3) }}{2.98}$ \\
\cline { 2 - 4 } Total Volume & 0.89 & 2.09 & 2.98
\end{tabular}

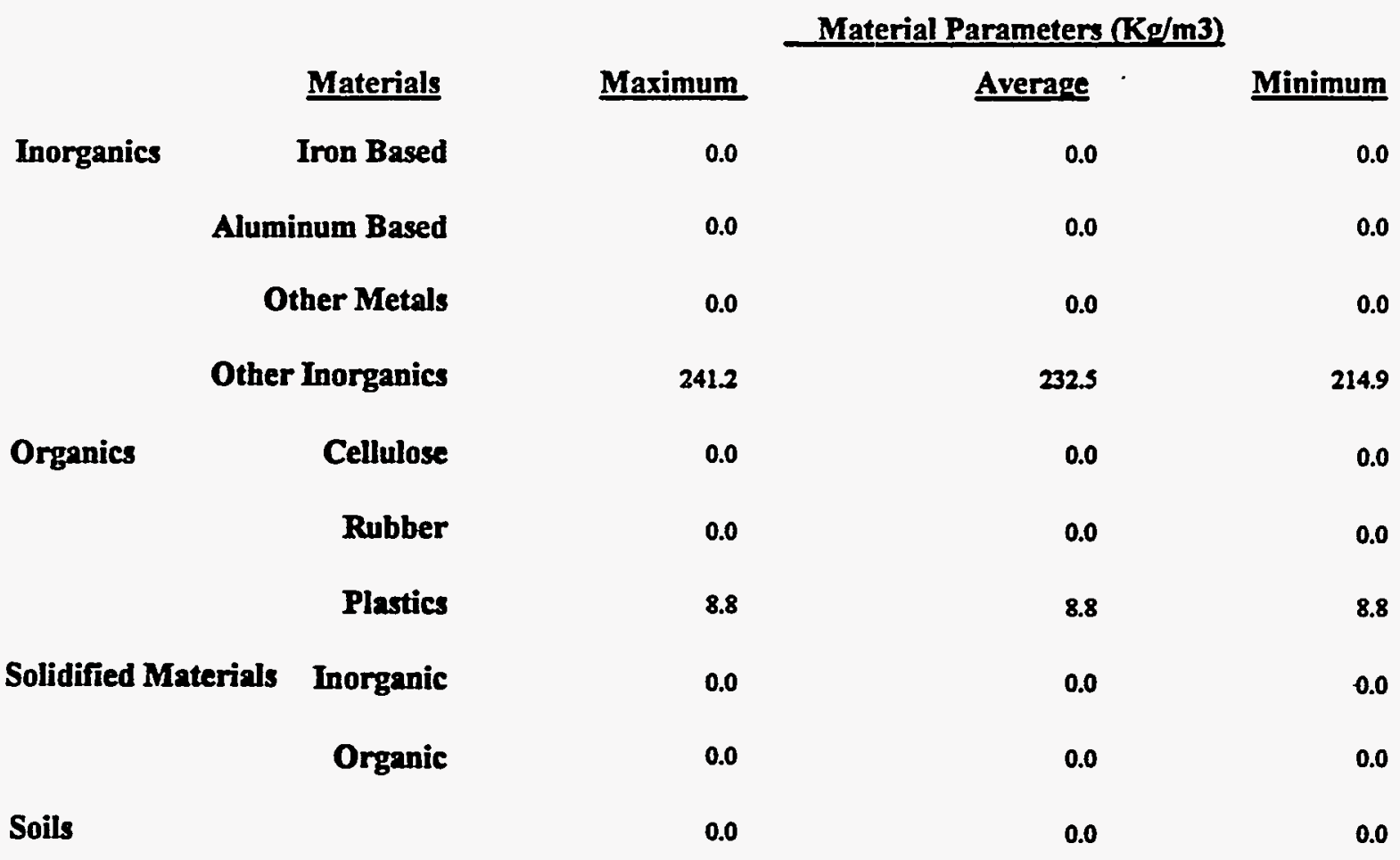

Figure 3 - 17

WIPP RH-TRU Waste Profile for Final Waste Form Filter 


\section{WIPP Remote Handled Waste Profiles}

Final Waste Form: Heterogeneous

\begin{tabular}{|c|c|c|c|}
\hline Site & $\frac{\text { Retrievahlv }}{\text { Stored (m3) }}$ & Projected (m3) & Total (m3) \\
\hline INEL & 13.63 & 2.80 & 16.43 \\
\hline ANLW & 0.59 & 0.08 & 0.67 \\
\hline BCLDP & 0.00 & 71.00 & 71.00 \\
\hline BT & 0.00 & 1.56 & 1.56 \\
\hline HANFORD & 33.16 & 2973.71 & 3006.87 \\
\hline SRS & 0.00 & 63.92 & 63.92 \\
\hline KAPL & 11.23 & 25.23 & 36.46 \\
\hline ORNL & 382.81 & 182.70 & 565.51 \\
\hline Total Volume & 441.43 & 3321.00 & 3762.42 \\
\hline
\end{tabular}

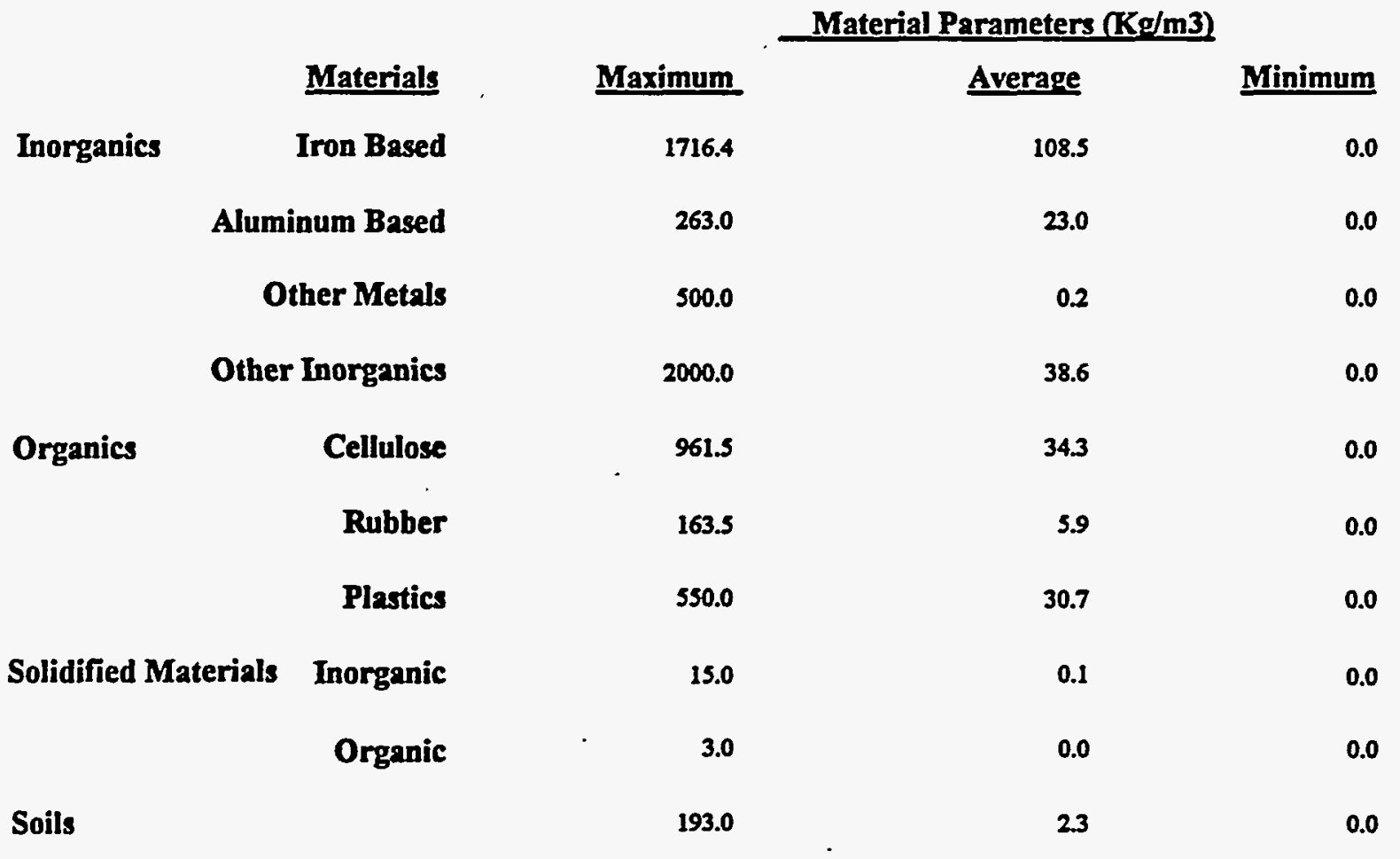

Figure 3 - 18

WIPP RH-TRU Waste Profile for Final Waste Form Heterogeneous

$3-31$ 


\section{WIPP Remote Handled Waste Profiles}

Final Waste Form: Lead/Cadmium Metal Waste

\begin{tabular}{|c|c|c|c|}
\hline Site & $\frac{\text { Retrievahlv }}{\text { Stored (m3) }}$ & Proiected (m3) & Total (m3) \\
\hline ANLW & 0.00 & 0.36 & 0.36 \\
\hline INEL & 0.00 & 5.60 & 5.60 \\
\hline Total Volume & 0.00 & 5.96 & 5.96 \\
\hline
\end{tabular}

\begin{tabular}{|c|c|c|c|c|}
\hline & & & Material Parameters & \\
\hline & Materials & Maximum & Average & Minimum \\
\hline Inorganics & Iron Based & 256.1 & 12.0 & 0.0 \\
\hline Alumi & inum Based & 27.8 & 1.3 & 0.0 \\
\hline & ther Metals & 109.6 & 43.6 & 0.0 \\
\hline Other & - Inorganics & 754.8 & 165.7 & 1.2 \\
\hline Organics & Cellulose & 45.3 & 7.7 & 0.0 \\
\hline & Rubber & 190.4 & 92.3 & 0.0 \\
\hline & Plastics & 67.6 & 15.1 & 0.0 \\
\hline Solidified Materials & Inorganic & 619.2 & 5.9 & 0.0 \\
\hline & Organic & 0.0 & 0.0 & 0.0 \\
\hline
\end{tabular}

Soils

1.2

0.4

0.0 


\section{WIPP Remote Handled Waste Profiles}

Final Waste Form: Salt Waste

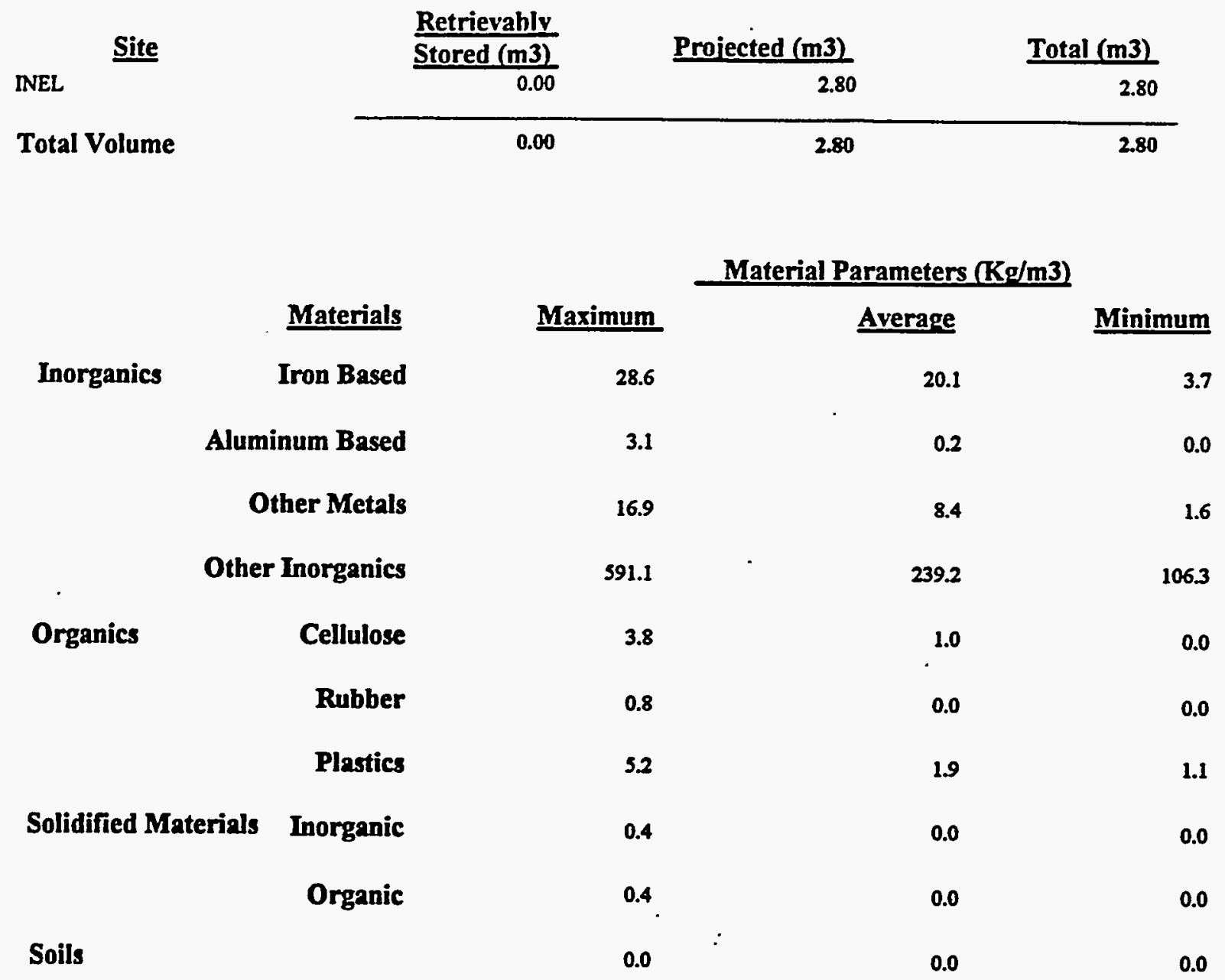




\section{WIPP Remote Handled Waste Profiles}

Final Waste Form: Solidified Inorganics

\begin{tabular}{lrrr} 
& Site & $\frac{\text { Retrievahlv }}{\text { Stored }(\mathrm{m} 3)}$ & Projected $(\mathrm{m} 3)$ \\
INEL & 2.10 & 0.00 & Total (m3) \\
ORNL & 611.00 & 174.00 & 2.10 \\
Total Volume & 613.10 & 174.00 & 785.00 \\
\cline { 2 - 4 } & & & 787.10
\end{tabular}

\begin{tabular}{|c|c|c|c|c|}
\hline & \multirow[b]{2}{*}{ Materials } & \multirow[b]{2}{*}{ Maximum } & \multicolumn{2}{|c|}{ Material Parameters (Kg/m3) } \\
\hline & & & Average & Minimum \\
\hline \multirow[t]{4}{*}{ Inorganics } & Iron Based & 0.0 & 0.0 & 0.0 \\
\hline & num Based & 0.0 & 0.0 & 0.0 \\
\hline & her Metals & 0.0 & 0.0 & 0.0 \\
\hline & Inorganics & $\$ 28.8$ & 1.1 & 0.0 \\
\hline \multirow[t]{3}{*}{ Organics } & Cellulose & 0.0 & 0.0 & 0.0 \\
\hline & Rubber & 0.0 & 0.0 & 0.0 \\
\hline & Plastics & 0.0 & 0.0 & 0.0 \\
\hline \multirow[t]{2}{*}{ Solidified Materials } & Inorganic & 1057.7 & 792.2 & 173.1 \\
\hline & Organic & 0.0 & 0.0 & 0.0 \\
\hline Soils & & 0.0 & 0.0 & 0.0 \\
\hline
\end{tabular}




\section{WIPP Remote Handled Waste Profiles}

Final Waste Form: Uncategorized Metal

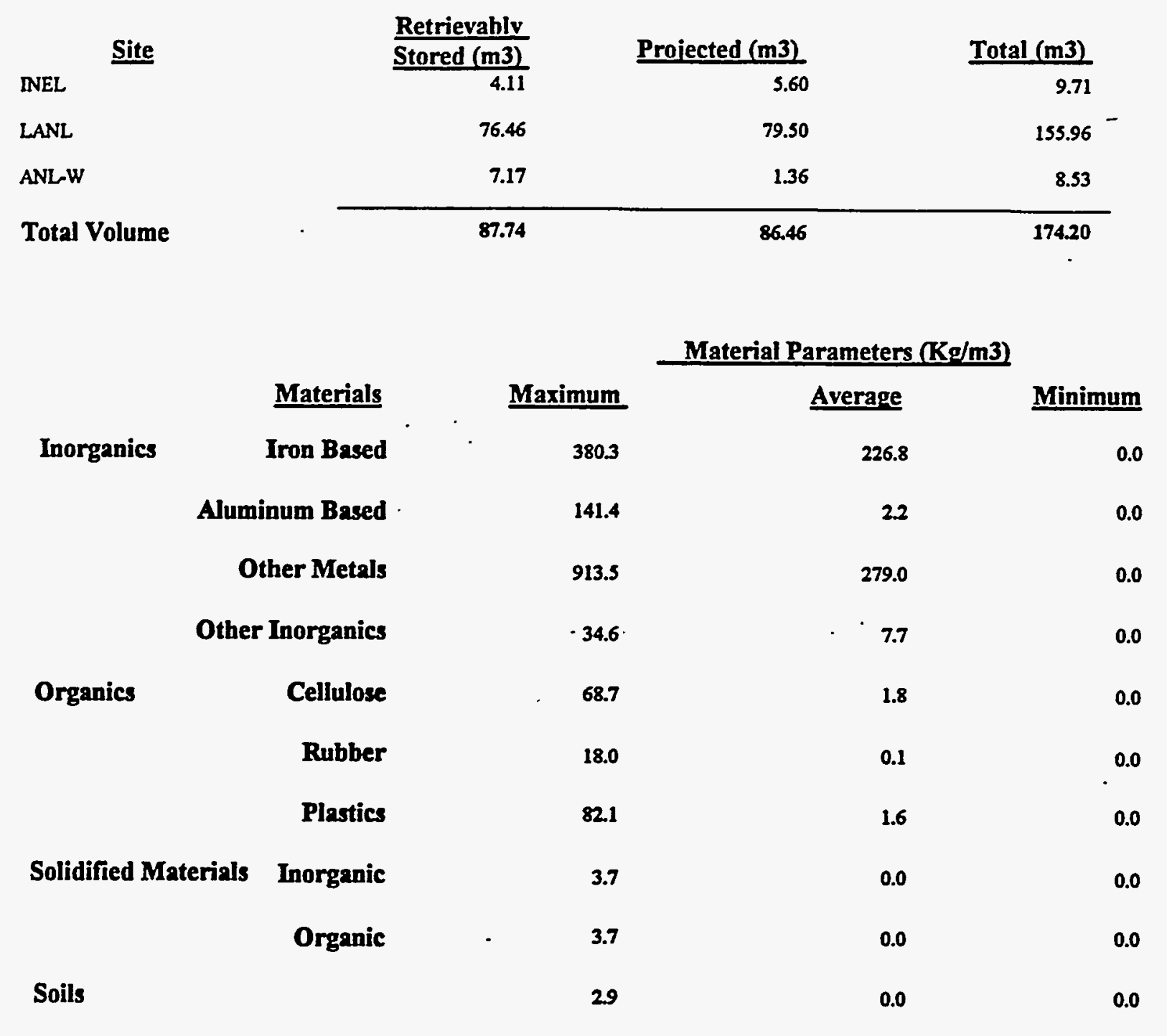

Figure 3- 22

WIPP RH-TRU Waste Profile for Final Waste Form Uncategorized Metal

$3 \cdot 35$ 


\section{WIPP Remote Handled Waste Profiles}

Final Waste Form: Unknown

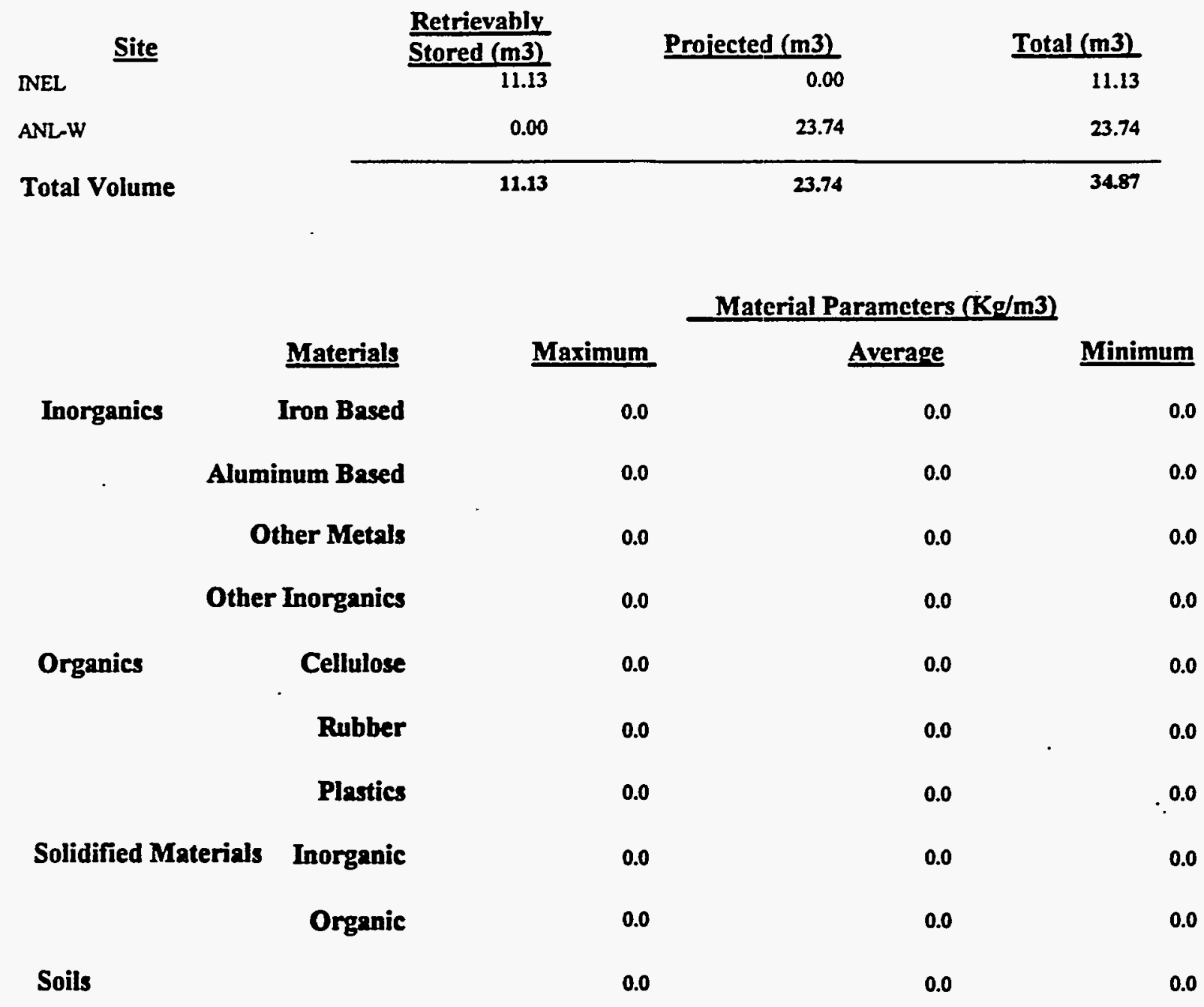

Figure 3-23

WIPP RH-TRU Waste Profile for Final Waste Form Unknown

$3-36$ 


(




\section{WIPP DISPOSAL RADIONUCLIDE INVENTORY}

\subsection{INTRODUCTION}

The TRU waste generator/storage sites were requested in the Revision 1 data call to submit estimates of the radionuclide inventory on a waste stream basis. Most sites complied with the data request, but many waste streams submitted to the WTWBID did not contain this information. Due to the short timeframe given the TRU waste generator/storage sites for the Revision 1 datacall, sufficient time was not available to derive the data to support each waste stream. The radionuclide data provided on a waste stream basis in Appendix A of the WTWBIR is currently for information purposes only.

\subsection{METHODOLOGY}

Since the waste-stream specific radionuclide data is insufficient to derive a radionuclide inventory, the site-wide radionuclide inventories reported in the Integrated Data Base (IDB) were used. The most recent IDB (DOE, 1994b) will be used which contains unpublished radionuclide data by site for stored TRU wastes as of December 31, 1993 (Appendix I).

There are still some volume differences at a TRU waste generator/storage site level between the IDB and the WTWBIR (see Section 1.5.4). Closure between the two data sets should be achieved with the Revision 2 WTWBIR data call and publication of Revision 2 of the WTWBIR. Therefore, the volume data from the IDB database (DOE, 1994b) has been used to make the estimates of stored and projected volumes used in deriving the radionuclide information. By using the volume and radionuclide data from the IDB database, there exists one intemally consistent set of data for estimating the radionuclide inventory.

IDB radionuclide data is only available for stored TRU waste. Therefore, this historical radionuclide data will also be used to make estimates of the projected radionuclide inventories and for any necessary scaling. Until estimates are available from the TRU waste generator/storage sites on projected radionuclide inventories, the IDB represents the only comprehensive database.

The WIPP radionuclide disposal inventory for $\mathrm{CH}-$ TRU waste has been calculated as follows:

- The stored and projected volumes from the IDB (DOE, 1994b) data have been used for the volume estimates and are included in Table 4-1.

- The radionuclide data included as part of the data submitted for the IDB (DOE, 1994b) represents the stored waste only. Appendix $E$ provides the radionuclide inventory by TRU waste site for the stored inventories listed in Table 4-1. These numbers have been decayed to December 1993, using the Radioactive Decay and Accumulation Code (RADAC) System (DOE, 1994d).

- For a particular site and radionuclide, divide the reported inventory for that radionuclide from the IDB (Appendix E) by the volume of stored waste at that site from the IDB (Table 4-1). This results in a curies $/ \mathrm{m}^{3}$ estimate for all reported radionuclides at each site.

- The projected volumes of waste are assumed to have the same radionuclide concentrations on a cubic meter basis as the stored waste at each site. 
- Since Bettis Atomic Power Laboratory (BT) and Ames Laboratory (AL) reported no existing $\mathrm{CH}$-TRU waste volume inventory, there is no radionuclide inventory for these sites in the IDB. The projected volumes from these two sites, BT $\left(123.5 \mathrm{~m}^{3}\right)$, and $\mathrm{AL}\left(0.09 \mathrm{~m}^{3}\right)$ have been grouped with the INEL projected $\mathrm{CH}-\mathrm{TRU}$ waste and assumed to have the same isotopic composition.

- The total volume of projected CH-TRU waste from the IDB in Table 4-1, if added to the stored waste volumes from the IDB, exceeds the capacity of WIPP $\left(176,000 \mathrm{~m}^{3}\right)$

- To calculate the radionuclide inventory the total projected $\mathrm{CH}$-TRU waste is adjusted as follows:

- Maximum design capacity for $\mathrm{CH}-\mathrm{TRU}=176,000 \mathrm{~m}^{3}$

- Stored CH-TRU volume $=104,000 \mathrm{~m}^{3}$

- Allowable projected volume $=(176,000-104,000) \times 10^{5} \mathrm{~m}^{3}=72,000 \mathrm{~m}^{3}$

- Projected waste adjustment factor $=$

$\frac{\text { Allowable projected volume }}{\text { Projected volume reported by sites }}=\frac{72,000 \mathrm{~m}^{3}}{64,600 \mathrm{~m}^{3}}=1.11$

- Therefore, the projected radionuclide inventory for each radionuclide at each site is calculated as follows:

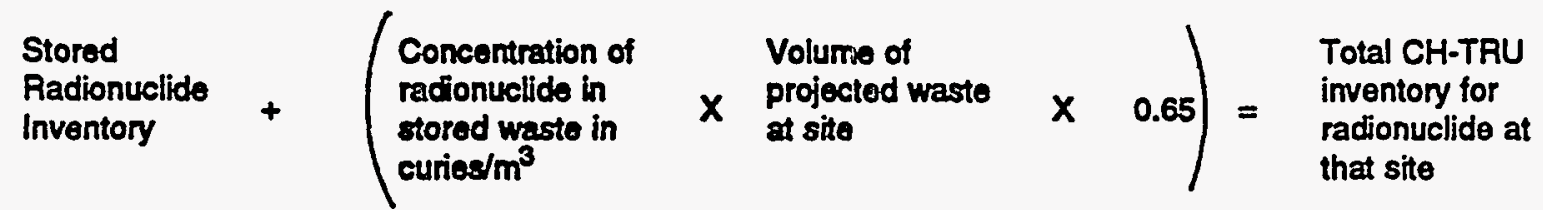

The building of the WIPP radionuclide disposal inventory for RH-TRU waste has been calculated similar to the $\mathrm{CH}-\mathrm{TRU}$ radionuclide inventory, with the exception of the following:

- Three RH-TRU waste streams that are projected waste streams only were submitted with no accompanying isotopic information: RL-M201, RL-T202, and SR-T001. THESE WASTE STREAMS, WHICH ACCOUNT FOR THE PROJECTED HANFORD AND SRS RH-TRU WASTE VOLUMES, HAVE BEEN OMITTED FFIOM THE RADIONUCLIDE INVENTORY CALCULATIONS due to the lack of radionuclide information. The RH-TRU projected volumes in the Draft Revision 10 IDB (Appendix I) include both the reported volumes in the two projected Hanford RH-TRU waste streams and the "suspect" volumes reported in the comment field of the two Hanford waste streams (RL-M201 and RL-T202 Appendix A).

- BT did not report stored RH-TRU inventories and the projected inventories have been omitted because no radionuclide information is available.

- The sum of the stored and projected volumes of RH-TRU waste from the TRU waste sites is less than the design capacity of WIPP $\left(7080 \mathrm{~m}^{3}\right)$ for RH-TRU waste. 
- To calculate the radionuclide inventory the total projected RH-TRU waste is adjusted as follows:

- Design capacity for RH-TRU $=7080 \mathrm{~m}^{3}$

- Stored RH-TRU volume $=941 \mathrm{~m}^{3}$

- Therefore the needed projected waste volume is:

$7080 m^{3}-941 m^{3}=6139 m^{3}$

- The projected RH-TRU waste volume (excluding the $2 \mathrm{RL}$ and SR waste streams) is $957 \mathrm{~m}^{3}$

- The projected waste volume must be increase by the following factor to "scale" to fill the RH-TRU design capacity:

$6139 \mathrm{~m}^{3}$ $=6.41$.

$957 \mathrm{~m}^{3}$

- Therefore, the projected radionuclide inventory for each radionuclide at each site is calculated as follows:

\begin{tabular}{|c|c|c|c|c|c|c|c|c|}
\hline $\begin{array}{l}\text { Stored } \\
\text { Radionuclide } \\
\text { Inventory }\end{array}$ & + & $\begin{array}{l}\text { Concentration } \\
\text { of radionuclide } \\
\text { in stored waste } \\
\text { in curies } / \mathrm{m}^{3}\end{array}$ & $x$ & $\begin{array}{l}\text { Volume of } \\
\text { projected } \\
\text { waste at site }\end{array}$ & $x$ & 6.41 & $=$ & $\begin{array}{l}\text { Total RH-TRU } \\
\text { inventory for } \\
\text { radionuclide at } \\
\text { that site }\end{array}$ \\
\hline
\end{tabular}

Table 4-2 represents the total radionuclide inventory for $\mathrm{CH}-\mathrm{TRU}$ and $\mathrm{RH}-\mathrm{TRU}$ wastes as derived from the Revision 10 IDB database, including any adjustment needed to the projected volumes of waste in order to fill the WIPP to the maximum $\mathrm{CH}-\mathrm{TRU}$ and RH-TRU design limit.

A comparison of the disposal radionuclide inventories in Revision 0 and in Revision 1 of the WTWBIR shows large changes. Listed below are the dominant reasons for these changes:

- The total radionuclide inventory for $\mathrm{CH}$-TRU waste is much higher than that included in the Revision 0 of the WTWBIR. This is primarily due to two changes:

- The SR has reported a large volume of CH-TRU projected waste in the IDB $\left(\approx 62,000 \mathrm{~m}^{3}\right)$, which was previously reported as "unknown." With the historically high Pu- 238 content, this considerably raises the total curies in the $\mathrm{CH}-\mathrm{TRU}$ inventory.

- During the calculations for the Revision 0 inventory, the "projected" part (1994-2022) of the CH-TRU radionuclide inventory was inadvertently left out of the totals reported, causing the inventory numbers to be low $(\approx 25 \%)$. This has been corrected in this inventory definition. 
- The total radionuclide inventory for RH-TRU waste is also much higher than that included in the Revision 0 of the WTWBIR. During calculation of the RH-TRU inventory the volume defined by the sites included more waste than the repository could hold. During those calculations, a misunderstanding occurred about the fact that the IDB radionuclide numbers only covered the "stored" part of the inventory. This caused the Revision 0 WTWBIR reported RH-TRU inventory to be low by a factor of approximately $3-4$. This has been corrected in this inventory definition.

- Oak Ridge National Laboratory (ORNL) has reported a very conservative inventory for U-235 in RH-TRU waste ( $\approx 367$ curies before scaling). In order to provide a less conservative estimate of the U-235 inventory, an anticipated transportation requirement of the RH-TRU cask has been imposed.

The new estimate for U-235 in ORNL RH-TRU waste has been calculated from the anticipated initial transportation limit in the RH-TRU cask of 325 grams (DOE, 1991) of Pu-239 fissile gram equivalent (FGE). Assuming a 1:1 equivalence of U-235 FGE (as required by the TRUPACT-II SARP; Nuclear Packaging, 1991) to Pu-239, this provides a bounding limit of 325 grams of U-235/canister $\times 7955$ canisters $\times 2.19 \times 10^{-6}$ curies/gram = 5.66 curies of U-235 in RH-TRU waste inventory. This number has been substituted in Table 4-2 to replace the overly conservative datia reported by ORNL. 
Table 4-1. CH-TRU and RH-TRU IDB Waste Inventories

\begin{tabular}{|c|c|c|}
\hline CH-TRU Site & Stored IDB-ORNL $\left(\mathrm{m}^{3}\right)$ & Projected IDB-ORNL $\left(\mathrm{m}^{3}\right)$ \\
\hline $\begin{array}{l}A E \\
A L \\
B T \\
E T \\
I N^{1} \\
K A \\
L A \\
L B \\
L L \\
M D \\
M U \\
N T \\
\text { OR } \\
P A \\
P X \\
\text { RF } \\
\text { RL } \\
\text { SA } \\
\text { SR4 } \\
\text { Sum CH-TRU }\end{array}$ & $\begin{array}{r}29.1 \\
0.0 \\
0.0 \\
1.9 \\
64774.0 \\
0.0 \\
10810.9 \\
0.9 \\
235.0 \\
11.9 \\
0.1 \\
607.1 \\
2015.2 \\
4.3 \\
0.6 \\
1040.0 \\
15608.9 \\
0.9 \\
8925.9 \\
104066.7\end{array}$ & $\begin{array}{r}180.0 \\
0.06 \\
123.5 \\
10.4 \\
0.0 \\
0.0 \\
14475.0 \\
2.7 \\
2442.3 \\
0.0 \\
0.0 \\
0.0 \\
654.7 \\
0.0 \\
0.0 \\
3765.4 \\
29198.0 \\
36.0 \\
13700.0 \\
64588.06\end{array}$ \\
\hline RH-TRU Site & Stored IDB-ORNL $\left(\mathrm{m}^{3}\right)$ & Projected IDB-ORNL $\left(\mathrm{m}^{3}\right)$ \\
\hline $\begin{array}{l}A E \\
B T \\
\text { IN } \\
K A \\
L A \\
\text { OR } \\
\text { RL } \\
\text { SA } \\
\text { SR }\end{array}$ & $\begin{array}{r}1.7 \\
0.0 \\
79.8 \\
2.4 \\
91.3 \\
563.9 \\
201.0 \\
0.9 \\
0.0\end{array}$ & $\begin{array}{r}45.9 \\
1.54 \\
162.0 \\
25.0 \\
280.0 \\
442.3 \\
41232.0^{*} \\
7.0^{*} \\
35.9^{*}\end{array}$ \\
\hline Sum RH-TRU & $241.0^{3}$ & 956.74 \\
\hline
\end{tabular}

- Excluded from the IDB-based RH-TRU radionuclide inventory rollups because no radionuclide information was submitted.

1. $40 \%$ of this stored inventory assumed to be low-level waste.

2. $50 \%$ of this stored inventory assumed to be low-level waste.

3. Does not include $5.3 \mathrm{~m}^{3}$ of RH-TRU. at NTS which is anticipated to be CH-TRU after repackaging.

4. The IDB volumes for SRS projected CH-TRU and RH-TRU waste have been corrected since issuance of the Draft Revision 10 IDB (Appendix I). 
Table 4-2. Disposal Radionuclide Inventory

\begin{tabular}{|c|c|c|}
\hline Nuclide & Total $\mathrm{CH}$ & Total RH \\
\hline AC-225 & $2.03 E+00$ & 3.28E-01 \\
\hline AC-227 & $6.55 \mathrm{E}-01$ & 1.52E-02 \\
\hline AC-228 & 5.27E-01 & $4.08 \mathrm{E}-03$ \\
\hline$A G-109 M$ & 4.85E+01 & NR \\
\hline AG-110 & 5.61E-06 & 1.07E-05 \\
\hline$A G-110 M$ & 4.21E-04 & 8.06E-04 \\
\hline AM-241 & $2.23 E+05$ & $5.30 E+02$ \\
\hline AM-242 & 4.93E-02 & NR \\
\hline AM-242M & 4.96E-02 & NR \\
\hline AM-243 & $2.94 E+01$ & $1.22 \mathrm{E}-02$ \\
\hline AM-245 & $9.07 E-09$ & 2.52E-14 \\
\hline AT-217 & $2.03 E+00$ & 3.28E-01 \\
\hline BA-137M & $5.03 E+03$ & $3.10 E+05$ \\
\hline B1-210 & $1.01 E+00$ & 4.09E-11 \\
\hline Bl-211 & $6.57 \mathrm{E}-01$ & 1.46E-02 \\
\hline $\mathrm{Bl}-212$ & $2.77 E+01$ & $9.03 E+00$ \\
\hline $\mathrm{Bl}-213$ & $2.03 E+00$ & 3.28E-01 \\
\hline $\mathrm{Bl}-214$ & $5.84 E+\infty 0$ & $7.23 E-10$ \\
\hline BK-249 & $6.25 E-04$ & $1.74 E-09$ \\
\hline BK-250 & 2.35E-06 & NR \\
\hline C-14 & $1.83 E+01$ & $1.51 E+02$ \\
\hline CD-109 & $4.85 E+01$ & NR \\
\hline$C D-113 M$ & 4.65E-05 & 2.36E-05 \\
\hline CE-144 & $8.22 \mathrm{E}+01$ & $5.58 E+02$ \\
\hline CF-249 & $1.56 \mathrm{E}+00$ & 8.11E-02 \\
\hline CF-250 & 3.54E-01 & NR \\
\hline
\end{tabular}

NR $=$ Not reported by sites. 
Table 4-2. Disposal Radionuclide Inventory (continued)

\begin{tabular}{||l|c|c||}
\hline \multicolumn{1}{|c|}{ Nuclide } & Total CH & Total RH \\
\hline \hline CF-251 & $3.93 E-03$ & NR \\
\hline CF-252 & $1.85 E+02$ & $5.11 E+01$ \\
\hline CM-242 & $1.48 E-02$ & NR \\
\hline CM-243 & $1.33 E+00$ & $2.01 E+03$ \\
\hline CM-244 & $5.40 E+03$ & $1.07 E+04$ \\
\hline CM-245 & $5.16 E+01$ & $1.32 E-05$ \\
\hline CM-246 & $1.10 E-01$ & NR \\
\hline CM-247 & $2.98 E-09$ & NR \\
\hline CM-248 & $5.06 E-02$ & $2.34 E-03$ \\
\hline CO-58 & $5.50 E-05$ & $7.92 E-07$ \\
\hline CO-60 & $1.53 E+02$ & $1.08 E+04$ \\
\hline CR-51 & NR & $2.54 E-31$ \\
\hline CS-134 & $5.88 E+00$ & $2.15 E+03$ \\
\hline CS-135 & $7.90 E-03$ & $4.58 E-03$ \\
\hline CS-137 & $5.32 E+03$ & $3.28 E+05$ \\
\hline ES-254 & $2.35 E-06$ & NR \\
\hline EU-150 & $3.65 E-05$ & NR \\
\hline EU-152 & $7.41 E+00$ & $5.28 E+04$ \\
\hline EU-154 & $3.05 E+01$ & $2.76 E+04$ \\
\hline EU-155 & $4.14 E+01$ & $6.78 E+03$ \\
\hline FE-55 & $3.296 E-05$ & $1.44 E+01$ \\
\hline FE-59 & $1.96 E-02$ & $4.04 E-19$ \\
\hline FR-221 & $2.03 E+00$ & $3.28 E-01$ \\
\hline FR-223 & $9.04 E-03$ & $2.10 E-04$ \\
\hline H-3 & $9.64 E-01$ & $8.23 E+01$ \\
\hline I-129 & $1.28 E-09$ & NR \\
\hline
\end{tabular}

NR $=$ Not reported by sites. 
Table 4-2. Disposal Radionuclide Inventory (continued)

\begin{tabular}{|c|c|c|}
\hline Nuclide & Total $\mathrm{CH}$ & Total RH \\
\hline KR-85 & 2.24E-01 & $9.58 E+01$ \\
\hline$M N-54$ & 1.12E-02 & $2.76 E+00$ \\
\hline NB-95 & 4.96E-01 & $9.90 E+00$ \\
\hline NB-95M & 1.66E-03 & 3.41E-02 \\
\hline $\mathrm{N} 1-59$ & 3.38E-03 & NR \\
\hline NI-63 & 4.19E-01 & $5.03 E+01$ \\
\hline NP-237 & $8.82 E+01$ & $1.18 \mathrm{E}-02$ \\
\hline NP-238 & $2.48 E-04$ & NR \\
\hline NP-239 & $2.94 E+01$ & 1.22E-02 \\
\hline NP-240 & $1.10 E-09$ & $1.78 \mathrm{E}-13$ \\
\hline NP-240M & $1.00 E-06$ & $1.62 \mathrm{E}-10$ \\
\hline PA-231 & 4.08E-03 & $1.78 \mathrm{E}-01$ \\
\hline PA-233 & $3.32 E+01$ & $1.18 \mathrm{E}-02$ \\
\hline PA-234 & 2.44E-02 & 1.70E-02 \\
\hline PA-234M & $1.88 E+01$ & $1.31 E+01$ \\
\hline PB-209 & $2.03 E+00$ & $3.28 E-01$ \\
\hline PB-210 & $1.01 E+\infty 0$ & $4.09 E-11$ \\
\hline PB-211 & 6.57E-01 & 1.46E-02 \\
\hline PB-212 & $2.77 E+01$ & $9.03 E+00$ \\
\hline PB-214 & $5.84 E+\infty$ & $7.23 E-10$ \\
\hline PD-107 & 1.17E-03 & 6.77E-04 \\
\hline PM-147 & $1.26 \mathrm{E}+03$ & $4.10 E+03$ \\
\hline PO-210 & 8.92E-01 & $3.05 E-11$ \\
\hline PO-211 & $1.79 E-0.3$ & $3.98 E-05$ \\
\hline PO-212 & $1.78 E+01$ & $5.78 E+00$ \\
\hline PO-213 & $1.99 E+00$ & 3.21E-01 \\
\hline
\end{tabular}

NR $=$ Not reported by sites. 
Table 4-2. Disposal Radionuclide Inventory (continued)

\begin{tabular}{||l|l|l||}
\hline \multicolumn{1}{|c|}{ Nuclide } & Total CH & Total RH \\
\hline \hline PO-214 & $5.84 \mathrm{E}+00$ & $7.23 \mathrm{E}-10$ \\
\hline PO-215 & $6.57 \mathrm{E}-01$ & $1.46 \mathrm{E}-02$ \\
\hline PO-216 & $2.77 \mathrm{E}+01$ & $9.03 \mathrm{E}+00$ \\
\hline PO-218 & $5.84 \mathrm{E}+00$ & $7.23 \mathrm{E}-10$ \\
\hline PR-144 & $8.22 \mathrm{E}+01$ & $5.58 \mathrm{E}+02$ \\
\hline PU-236 & $1.69 \mathrm{E}-02$ & NR \\
\hline PU-238 & $1.89 \mathrm{E}+06$ & $3.53 \mathrm{E}+03$ \\
\hline PU-239 & $3.85 \mathrm{E}+05$ & $6.41 \mathrm{E}+03$ \\
\hline PU-240 & $7.22 \mathrm{E}+04$ & $1.74 \mathrm{E}+02$ \\
\hline PU-241 & $1.01 \mathrm{E}+06$ & $9.06 \mathrm{E}+02$ \\
\hline PU-242 & $1.27 \mathrm{E}+03$ & $1.48 \mathrm{E}-02$ \\
\hline PU-243 & $2.98 \mathrm{E}-09$ & NR \\
\hline PU-244 & $1.00 \mathrm{E}-06$ & $1.62 \mathrm{E}-10$ \\
\hline RA-223 & $6.57 \mathrm{E}-01$ & $1.46 \mathrm{E}-02$ \\
\hline RA-224 & $2.77 \mathrm{E}+01$ & $9.03 \mathrm{E}+00$ \\
\hline RA-225 & $2.04 \mathrm{E}+00$ & $3.31 \mathrm{E}-01$ \\
\hline RA-226 & $5.84 \mathrm{E}+00$ & $7.23 \mathrm{E}-10$ \\
\hline RA-228 & $5.27 \mathrm{E}-01$ & $4.08 \mathrm{E}-03$ \\
\hline RH-106 & $4.02 \mathrm{E}+01$ & $8.42 \mathrm{E}+02$ \\
\hline RN-219 & $6.57 \mathrm{E}-01$ & $1.46 \mathrm{E}-02$ \\
\hline RN-220 & $2.77 \mathrm{E}+01$ & $9.03 \mathrm{E}+00$ \\
\hline RN-222 & $5.84 \mathrm{E}+00$ & $7.23 \mathrm{E}-10$ \\
\hline RU-106 & $4.02 \mathrm{E}+01$ & $8.42 \mathrm{E}+02$ \\
\hline SB-125 & $1.58 \mathrm{E}+01$ & $2.46 \mathrm{E}+03$ \\
\hline SB-126 & $2.13 \mathrm{E}-03$ & $1.23 \mathrm{E}-03$ \\
\hline SB-126M & $1.52 \mathrm{E}-02$ & $8.80 \mathrm{E}-03$ \\
\hline & & \\
\hline & & 0.03 \\
\hline
\end{tabular}

NR $=$ Not reported by sites. 
Table 4-2. Disposal Radionuclide Inventory (continued)

\begin{tabular}{|c|c|c|}
\hline Nuclide & Total $\mathrm{CH}$ & Total RH \\
\hline SE-79 & $6.86 \mathrm{E}-03$ & $3.97 \mathrm{E}-03$ \\
\hline SM-151 & $2.50 E+01$ & $1.42 \mathrm{E}+01$ \\
\hline$S N-119 M$ & $6.80 E-03$ & 1.37E-02 \\
\hline$S N-121 M$ & 4.82E-01 & $2.69 E-01$ \\
\hline SN-126 & 1.52E-02 & $.8 .80 \mathrm{E}-03$ \\
\hline SR-90 & 4.07E+03 & $6.68 E+05$ \\
\hline TA-182 & NR & 1.72E-04 \\
\hline TC-99 & $2.46 E+01$ & 2.28E-01 \\
\hline TE-125M & 6.55E-04 & $1.01 E+03$ \\
\hline TE-127 & 3.07E-02 & 1.13E-01 \\
\hline TE-127M & $3.15 \mathrm{E}-02^{\circ}$ & 1.15E-01 \\
\hline TH-227 & $6.56 \mathrm{E}-01$ & 1.48E-02 \\
\hline TH-228 & $2.77 E+01$ & $9.04 E+00$ \\
\hline TH-229 & $2.05 E+00$ & 3.36E-01 \\
\hline TH-230 & 4.90E-02 & 8.79E-07 \\
\hline TH-231 & $2.88 E+00$ & $2.21 E+03$ \\
\hline TH-232 & 6.07E-01 & 7.09E-03 \\
\hline TH-234 & $1.88 E+01$ & $1.31 E+01$ \\
\hline TL-207 & $6.56 \mathrm{E}-01$ & 1.45E-02 \\
\hline TL-208 & $9.96 E+\infty$ & $3.24 E+00$ \\
\hline TL-209 & 4.39E-02 & 7.08E-03 \\
\hline TL-210 & $1.23 E-03$ & $1.52 E-13$ \\
\hline U-232 & $2.63 E+01$ & $1.16 E+01$ \\
\hline U-233 & $1.38 E+03$ & $8.57 E+02$ \\
\hline$U-234$ & $2.50 E+02$ & 4.18E-02 \\
\hline U-235 & $2.88 E+\infty 0$ & $5.66 E+00$ \\
\hline
\end{tabular}

$N R=$ Not reported by sites. 
Table 4-2. Disposal Radionuclide Inventory (continued)

\begin{tabular}{||l|c|c||}
\hline \multicolumn{1}{|c|}{ Nuclide } & Total CH & Total RH \\
\hline \hline$U-236$ & $1.34 \mathrm{E}-01$ & $4.11 \mathrm{E}-05$ \\
\hline $\mathrm{U}-237$ & $2.47 \mathrm{E}+01$ & $2.22 \mathrm{E}-02$ \\
\hline $\mathrm{U}-238$ & $1.88 \mathrm{E}+01$ & $1.31 \mathrm{E}+01$ \\
\hline $\mathrm{U}-240$ & $1.00 \mathrm{E}-06$ & $1.62 \mathrm{E}-10$ \\
\hline $\mathrm{Y}-90$ & $4.07 \mathrm{E}+03$ & $6.68 \mathrm{E}+05$ \\
\hline ZN-65 & $1.21 \mathrm{E}-08$ & NR \\
\hline ZR-93 & $8.87 \mathrm{E}-02$ & $5.14 \mathrm{E}-02$ \\
\hline ZR-95 & $2.24 \mathrm{E}-01$ & $4.60 \mathrm{E}+00$ \\
\hline Total & $3.60 \mathrm{E}+06$ & $2.11 \mathrm{E}+06$ \\
\hline
\end{tabular}

$N R=$ Not reported by sites. 
CHAPTER 5

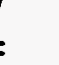




\section{WASTE MATERIAL PARAMETERS}

\subsection{INTRODUCTION}

Some waste materials that occur in TRU waste may degrade over the 10,000-year regulatory period and estimates of masses/volume are needed for performance modeling (Table 1-1). Some of these waste materials may produce gas by either chemical, microbial, or radiolytic processes (WIPP PA, 1993). These types of processes need to be evaluated as part of the WIPP SPM and PA modeling effort to analyze their impact on repository behavior.

\subsection{PARAMETER DESCRIPTION}

This chapter identifies and defines the waste material parameters to be evaluated in performance assessment calculations. The same methodology used for defining waste stream profiles and combining them into site-specific and WIPP waste profiles is used to develop a disposal inventory for WIPP by waste material parameters (see Figure 3-2). Waste material parameter information is provided for each waste stream profile by the TRU waste generator/storage sites (Figure 1-2). In those cases where waste material parameter information could not be provided by the TRU waste generator/storage sites, an altemative methodology was adopted as described in Section 3.1.3. This waste material parameter information is used to estimate the anticipated WIPP inventory, which is then scaled to obtain the repository design limit (disposal inventory), if needed. This inventory is presented as a weighted average with a maximum and minimum expected weight/volume for each waste material parameter.

The waste material parameter information, which is provided by the TRU waste generator/storage sites, consists of 10 waste material parameters and additional packaging materials that are direct inputs into the SPM and PA models. These are presented below.

\section{Inorganics}

- Iron-based metals/alloys - This designation is meant to include iron and steel alloys in the waste and does not include the waste container materials.

- Aluminum-based metals/alloys - Aluminum or aluminum-based alloys in the waste materials.

- Other Metals - All other metals found in the waste materials (e.g., copper, lead, zirconium, tantalium, etc.). The lead portion of lead rubber gloves/aprons is also included in this category.

- Other Inorganic Materials - Include inorganic non-metal waste materials such as concrete, glass, firebrick, ceramics, sand, and inorganic sorbents.

\section{Organics}

- Cellulosics - Includes those materials generally derived from high polymer plant carbohydrates. Examples are paper, cardboard, kimwipes, wood, cellophane, cloth, etc.

- Rubber - Includes natural or manmade elastic latex materials. Examples are Hypalon ${ }^{(}$, neoprene, surgeons' gloves, leaded-rubber gloves (rubber part only), etc. 
- Plastics - Includes generally manmade materials, often derived from petroleum feedstock. Examples are polyethylene, polyvinylchloride, Lucite, Teflon, etc.

Solidified Materials

- Inoraanic Matrix - This includes any homogenous materials consisting of sludge or aqueous-based liquids that are solidified with cernent, Envirostone ${ }^{\circledR}$, or other solidification agents. Examples are wastewater treatment sludge, cemented aqueous liquids, and inorganic particulates, etc.

- Organic Matrix - This includes cemented organic resins, solidified organic liquids, and sludges.

Soils

- Generally consists of naturally occurring soils that have been contaminated with inorganic waste materials.

\section{Packaging Materials}

The TRU waste generator/storage sites have been asked to define waste streams in each waste stream profile expressed as final waste form and volumes in containers that are currently approved for shipment. Listed below are the currently approved CH-TRU packaging configurations for TRUPACT-II (DOE, 1991) and anticipated approved RH-TRU packaging configurations (DOE, 1991):

- TRUPACT-II

- 55-gallon drum

- Standard Waste Box (SWB)

- 55-gallon drums overpacked in SWB.

- RH-TRU cask (anticipated acceptable packaging configurations for the RH-TRU cask)

- RH-TRU canister

- three 55-gallon or 30-gallon drums overpacked in a RH-TRU canister.

In cases where the sites defined a type of waste container, but not the weight/volume of the packaging, assumptions were made about the weight of the containers in order to include these estimates as part of the overall inventory destined or WIPP. If overpacking a waste container was necessary for transport in a shipping cask, overpacking was assumed. The densities assumed are included as part of the "TRU system-wide data assumptions" included in Section 1.5.

- Steel - The weight of the steel part of the packaging from container information provided by the TRU waste generator/storage sites. Any necessary overpacking is included in the weight.

- Plastics - The weight of any plastic packaging submitted by the TRU sites. When weight of a rigid liner is not given a 90-mil HDPE liner is assumed. 
- Lead - The weight of the Pb shielding in a RH canister is assumed if not provided by the TRU waste sites. The weight is included in the "Packaging Material Assumptions" in Chapter 1.5.3.

\subsection{METHODOLOGY}

The rollups of waste material parameters by WMCGs or by site use the volumes from the WTWBID. The roll ups by WMCGs or by site require combining data from several WTWBID waste streams. The averages for the material parameters are calculated from the average densities provided by the TRU waste generator/storage sites modified by the WTWBID volume fractions and summed as follows:

Average Density
of waste material $=$ Average Density

parameter
(Volume WTWBIR

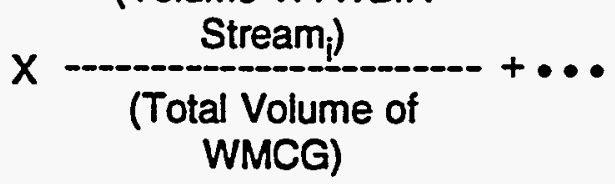

where $i$.is an index representing individual waste streams of the same WMCG

The minimum density is chosen as the smallest minimum density of a particular waste material parameter in the WTWBID waste streams in a particular site-specific rollup. The maximum density is chosen in a similar manner, except that the largest maximum density was chosen.

In many cases, the TRU waste generator/storage sites did not have data for minimum and maximum percentages, even though average percentages are provided. In these cases, for rollup purposes only, the minimum is assumed to be zero and the maximum is assumed to be equal to the average. This ensures that the calculated and rolled up maximum densities are greater than the average densities. However, the maximum density may not be a true maximum but the maximum average density (see Chapter 7 for further WTWBID information).

\subsection{WIPP WASTE MATERIAL PARAMETER ROLLUPS}

The waste material parameters that are inputs into the SPM process and PA models are presented in Table 5-1 for CH-TRU waste and Table 5-2 for RH-TRU waste. These tables represent the WIPP disposal inventory of waste material parameters. These waste material parameters are the final rollups of the WIPP waste profiles in Figures 3-4 to 3-23.

\subsection{UTILIZATION OF WASTE MATERIAL PARAMETER DATA IN APPLICATIONS}

The waste material parameter data presented in Tables 5-1 and 5-2 must be used with certain limitations. If the "average" weight/volume (density) composition of CH-TRU and RH-TRU wastes in terms of the waste material parameters is needed then the middle column of Tables 5-1 and 5-2 labelled "Average" should be used in the calculations. If the task requires a distribution of values then the "Maximum" and "Minimum" columns should be used in conjunction with the "Average" column with the following limitations: 
Table 5-1

WIPP CH-TRU Waste Material Parameter Disposal Inventory

\begin{tabular}{|c|c|c|c|c|}
\hline & \multirow[b]{2}{*}{ Materials } & \multicolumn{3}{|c|}{$(\mathrm{Kg} / \mathrm{m} 3)$} \\
\hline & & Maximum & Average & Minimum \\
\hline \multirow[t]{4}{*}{ Inorganics } & Iron Based & $2.1 E+03$ & 8.3E+01 & $0.0 E+\infty$ \\
\hline & inum Based & $1.0 \Xi+03$ & $1.2 E+01$ & $0.0 E+\infty$ \\
\hline & ther Metals & $1.4 E+03$ & 2.7E+09 & $0.0 E+\infty$ \\
\hline & Inorganics & $2.1 E+03$ & $3.9 E+01$ & $0.0 E+\infty 0$ \\
\hline \multirow[t]{3}{*}{ Organics } & Cellulose & $9.6 E+02$ & $1.7 E+02$ & $0.0 E+\infty$ \\
\hline & Rubber & $6.8 E+02$ & $2.1 E+01$ & $0.0 E+00$ \\
\hline & Plastics & $8.9 E+02$ & $6.3 E+01$ & $0.0 E+\infty$ \\
\hline \multirow[t]{2}{*}{ Solidified Materials } & Inorganic & $2.2 E+03$ & $1.3 E+02$ & $\cdot 0.0 E+\infty$ \\
\hline & Organic & $1.4 E+03$ & $8.4 E+\infty$ & $0.0 E+\infty$ \\
\hline Soils & & $1.6 E+03$ & $5.7 E+\infty 0$ & $0.0 E+\infty$ \\
\hline
\end{tabular}

\section{Container Materials}

Steel 
Table 5-2

\section{WIPP RH-TRU Waste Material Parameter Disposal Inventory}

\begin{tabular}{|c|c|c|c|c|}
\hline & \multirow[b]{2}{*}{ Materials } & \multicolumn{3}{|c|}{$(\mathrm{Kg} / \mathrm{m} 3)$} \\
\hline & & Maximum & Average & Minimum \\
\hline \multirow[t]{4}{*}{ Inorganics } & Iron Based & $1.7 E+03$ & $9.4 E+01$ & $0.0 E+\infty$ \\
\hline & inum Based & $2.6 E+02$ & $1.8 E+01$ & $0.0 E+\infty$ \\
\hline & ther Metals & $9.1 E+02$ & $1.0 E+01$ & $0.0 E+\infty$ \\
\hline & Inorganics & $2.0 E+03$ & $3.1 E+01$ & $0.0 E+\infty$ \\
\hline \multirow[t]{3}{*}{ Organics } & Cellulose & $9.6 \mathrm{E}+02$ & $2.7 E+01$ & $0.0 E+\infty$ \\
\hline & Rubber & $1.9 E+02$ & $4.8 E+\infty$ & $0.0 E+\infty$ \\
\hline & Plastics & $5.5 E+02$ & $2.4 E+01$ & $0.0 E+\infty$ \\
\hline \multirow[t]{2}{*}{ Solidified Materials } & Inorganic & $1.1 E+03$ & $1.3 E+02$ & $0.0 E+\infty$ \\
\hline & Organic & $3.7 E+\infty$ & $1.7 E-03$ & $0.0 E+\infty 0$ \\
\hline Soils & & $1.9 E+02$ & $1.8 \mathrm{E}+\infty$ & $0.0 E+\infty$ \\
\hline
\end{tabular}

Contxiner Materials

Steel

447

Plastic/Liners $\quad 3.2$

Lead 465

Steel Plug $\quad 2145$ 
- The sum of all the waste material parameters in the "average" column represents the "average" weight of a cubic meter of $\mathrm{CH}-T R U$ or RH-TRU expected at WIPP. For instance, the "average" cubic meter of CH-TRU waste expected at WIPP is (see Table 5-1):

$559.5 \mathrm{~kg} / \mathrm{m}^{3} \mathrm{CH}-$ TRU waste $+173 \mathrm{~kg} / \mathrm{m}^{3}$ of packaging $=732.5 \mathrm{~kg} / \mathrm{m}^{3}$

- The weight of packaging is not expected to vary, so if any "sampling" of distributions of densities is required, the sampling should only be on the waste part of the above equation.

- If sampling of the waste material parameters is needed, the sum of the densities of all waste material parameters sampled for any iteration SHOULD NOT EXCEED THE AVERAGE DENSITY OF THE WASTE AS DEFINED IN THE "AVERAGE" COLUMN SUMMATION. That is, one cannot sample on the upper range for all waste material parameters or sample all waste material parameters at the lower end of the range. By default, if some waste material parameters are sampled at higher values than the average some will have to be sampled at lower values than average so that the density of the waste always remains the same (sum of the "average" column).

The same sampling methodology, if needed, should be used for the RH-TRU waste as reported in Table 5-2.

TO OBTAIN THE TOTAL WASTE MATERIAL PARAMETER WEIGHTS FOR THE DISPOSAL INVENTORY, USERS OF THE DATA SHOULD MULTIPLE THE AVERAGE DENSITIES OF THE WASTE MATERIAL PARAMETERS FOR CH-TRU (TABLE 5-1) AND RH-TRU (TABLE 5-2) BY THE DESIGN BASIS VOLUME.

For example:

The expected (average) CH-TRU inventory of combustibles for WIPP is (Table 5-1):

$170 \mathrm{~kg} / \mathrm{m}^{3} \times 176,000 \mathrm{~m}^{3}$ (design basis) $=29,900,000 \mathrm{~kg}$ combustibles

For steel in CH-TRU waste:

$83 \mathrm{~kg} / \mathrm{m}^{3}$ (waste) $+140 \mathrm{~kg} / \mathrm{m}^{3}$ (container) $=223 \mathrm{~kg} / \mathrm{m}^{3}$

$223 \mathrm{~kg} / \mathrm{m}^{3} \times 176,000 \mathrm{~m}^{3}=3,900,000 \mathrm{~kg}$ steel 


\section{CHAPTER 6}

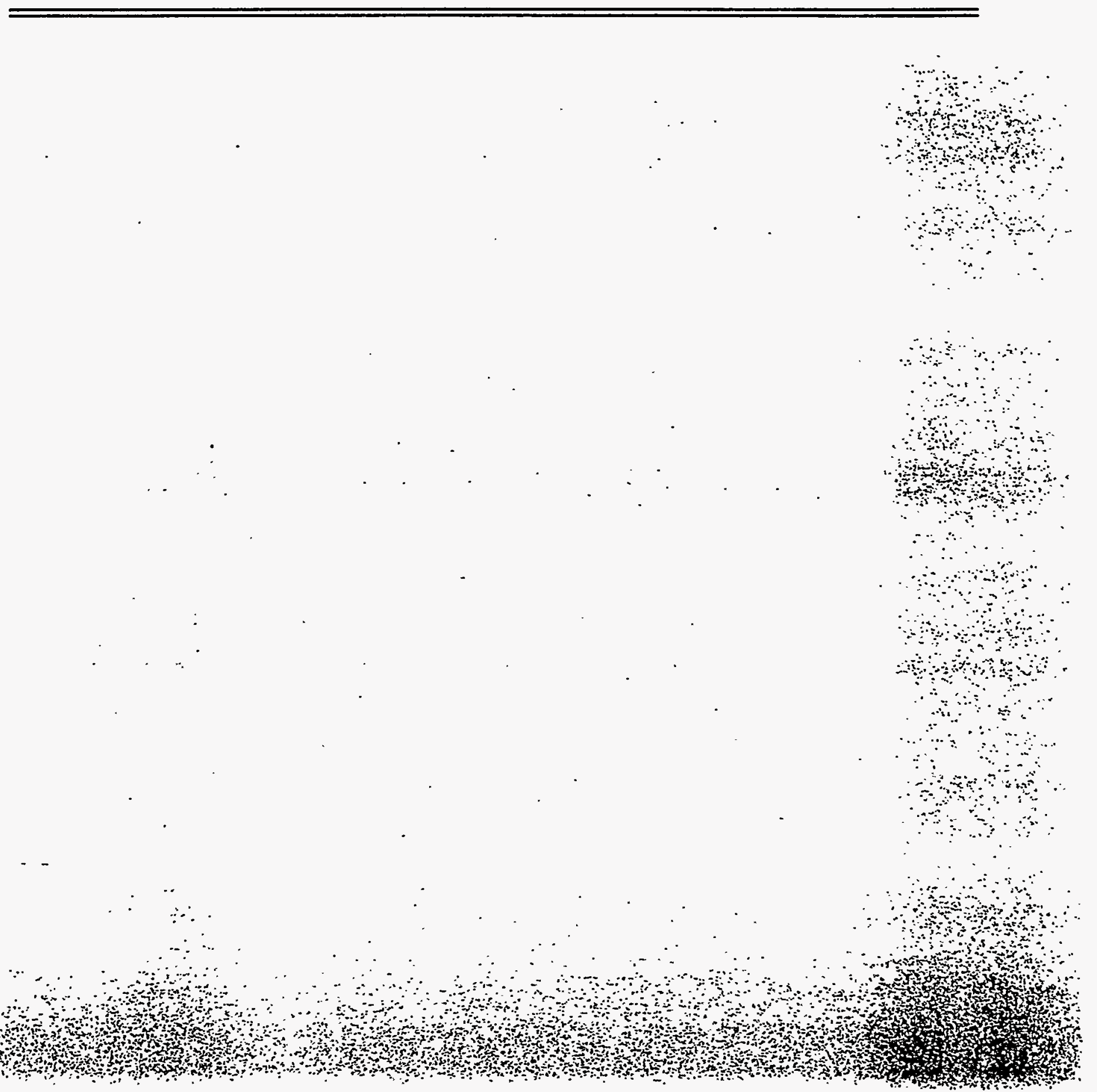




\section{STORED AND PROJECTED CH-TRU AND RH-TRU INVENTORIES BY SITE}

As described in Chapter 3, each waste stream from each waste generating/storage site is characterized in a waste stream profile (Appendix A). These waste stream profiles are rolled up by WMCGs for each generator/storage site. Summary tables of contact-handled and remotehandled waste volumes are provided in Tables 6-1 and 6-2. Summary profiles of waste volumes by WMCG for each site are provided in Tables 6-3 through 6-22. 


\section{TRANSURANIC WASTE DISPOSAL INVENTORY BY SITE}

\section{Contact Handled Waste}

\begin{tabular}{lccc}
\hline \hline Storage/Generator Site & $\begin{array}{c}\text { Stored } \\
\text { Volumes }\end{array}$ & $\begin{array}{c}\text { Projected } \\
\text { Volumes }\end{array}$ & $\begin{array}{c}\text { Anticipated } \\
\text { Volumes }\end{array}$ \\
\hline \hline AMES LAB & $0.0 \mathrm{E}+00$ & $1.0 \mathrm{E}-01$ & $1.0 \mathrm{E}-01$ \\
ANL-E & $2.9 \mathrm{E}+01$ & $1.7 \mathrm{E}+00$ & $3.1 \mathrm{E}+01$ \\
ANL-W & $2.0 \mathrm{E}-02$ & $5.8 \mathrm{E}+00$ & $5.9 \mathrm{E}+00$ \\
BT & $0.0 \mathrm{E}+00$ & $1.2 \mathrm{E}+02$ & $1.2 \mathrm{E}+02$ \\
ETEC & $1.9 \mathrm{E}+00$ & $5.2 \mathrm{E}+00$ & $7.1 \mathrm{E}+00$ \\
HANFORD & $9.3 \mathrm{E}+03$ & $2.1 \mathrm{E}+04$ & $3.1 \mathrm{E}+04$ \\
INEL & $3.5 \mathrm{E}+04$ & $1.0 \mathrm{E}+00$ & $3.5 \mathrm{E}+04$ \\
KAPL & $2.4 \mathrm{E}+00$ & $0.0 \mathrm{E}+00$ & $2.4 \mathrm{E}+00$ \\
LANL & $1.1 \mathrm{E}+04$ & $7.7 \mathrm{E}+03$ & $1.9 \mathrm{E}+04$ \\
LBL & $8.4 \mathrm{E}-01$ & $4.4 \mathrm{E}+00$ & $5.3 \mathrm{E}+00$ \\
LLNL & $2.1 \mathrm{E}+02$ & $6.9 \mathrm{E}+02$ & $9.0 \mathrm{E}+02$ \\
MOUND & $2.6 \mathrm{E}+02$ & $0.0 \mathrm{E}+00$ & $2.6 \mathrm{E}+02$ \\
MU & $6.0 \mathrm{E}-02$ & $1.6 \mathrm{E}+00$ & $1.7 \mathrm{E}+00$ \\
NTS & $6.2 \mathrm{E}+02$ & $0.0 \mathrm{E}+00$ & $6.2 \mathrm{E}+02$ \\
ORNL & $7.8 \mathrm{E}+02$ & $2.6 \mathrm{E}+02$ & $1.0 \mathrm{E}+03$ \\
PA & $3.5 \mathrm{E}+00$ & $0.0 \mathrm{E}+00$ & $3.5 \mathrm{E}+00$ \\
PANTEX & $6.2 \mathrm{E}-01$ & $0.0 \mathrm{E}+00$ & $6.2 \mathrm{E}-01$ \\
RFP & $1.1 \mathrm{E}+03$ & $5.9 \mathrm{E}+03$ & $7.0 \mathrm{E}+03$ \\
SNLNM & $8.0 \mathrm{E}+00$ & $7.0 \mathrm{E}+00$ & $1.5 \mathrm{E}+01$ \\
SRS & $1.5 \mathrm{E}+04$ & $1.5 \mathrm{E}+04$ & $2.9 \mathrm{E}+04$ \\
Total CH Volumes & $7.3 \mathrm{E}+04$ & $5.1 \mathrm{E}+04$ & $1.2 \mathrm{E}+05$ \\
& & &
\end{tabular}

- A amall amound of Henford stored CH wnste (2.0E+02 cubic meters) is expected to be recrieved and packaged as RH waste

Table 6-1: Contact Handled Transuranic Waste Disposal Inventory by Site $6-2$ 


\section{TRANSURANIC WASTE DISPOSAL INVENTORY BY SITE}

\begin{tabular}{lccc}
\multicolumn{3}{c}{ Remote Handled Waste } & \multicolumn{3}{c}{ (Cubic Meters) } \\
\hline Storage/Generator Site & $\begin{array}{c}\text { Stored } \\
\text { Volumes }\end{array}$ & $\begin{array}{c}\text { Projected } \\
\text { Volumes }\end{array}$ & $\begin{array}{c}\text { Anticipated } \\
\text { Volumes }\end{array}$ \\
\hline ANL-W & $8.7 \mathrm{E}+00$ & $2.8 \mathrm{E}+01$ & $3.6 \mathrm{E}+01$ \\
BCLDP & $0.0 \mathrm{E}+00$ & $7.1 \mathrm{E}+01$ & $7.1 \mathrm{E}+01$ \\
BT & $0.0 \mathrm{E}+00$ & $1.6 \mathrm{E}+00$ & $1.6 \mathrm{E}+00$ \\
HANFORD & $3.3 \mathrm{E}+01$ & $3.0 \mathrm{E}+03$ & $3.0 \mathrm{E}+03$ \\
INEL & $3.1 \mathrm{E}+01$ & $1.7 \mathrm{E}+01$ & $4.8 \mathrm{E}+01$ \\
KAPL & $1.1 \mathrm{E}+01$ & $2.5 \mathrm{E}+01$ & $3.6 \mathrm{E}+01$ \\
LANL & $9.1 \mathrm{E}+01$ & $8.3 \mathrm{E}+01$ & $1.7 \mathrm{E}+02$ \\
ORNL & $9.9 \mathrm{E}+02$ & $3.6 \mathrm{E}+02$ & $1.4 \mathrm{E}+03$ \\
SRS & $0.0 \mathrm{E}+00$ & $6.4 \mathrm{E}+01$ & $6.4 \mathrm{E}+01$ \\
Total RH Volumes & $1.2 \mathrm{E}+03$ & $3.6 \mathrm{E}+03$ & $4.8 \mathrm{E}+03$
\end{tabular}

Table 6-2: Remote Handled Transuranic Waste Disposal Inventory by Site

$$
\text { 6-3 }
$$




\section{SITE TRANSURANIC WASTE VOLUMES}

Site Name: AMES LAB

(Cubic Meters)

\begin{tabular}{llll}
\hline \hline Final Waste Form & Retrievably Stored & Projected & Total \\
\hline \hline
\end{tabular}

\section{Contact Handled Waste}

Solidified Inorganics

Total CH Volumes

0
0.00 $\frac{0.1}{0.10} \quad 0.1$




\section{SITE TRANSURANIC WASTE VOLUMES}

\begin{tabular}{lrrr}
\hline \multicolumn{5}{c}{ Site Name: ANL-E } & (Cubic Meters) \\
\hline Final Waste Form & Retrievably Stored & Projected & Total \\
\hline \hline Contact Handled Waste & & & \\
Lead/Cadmium Metal Waste & 1.1 & 0 & 1.1 \\
Solidified Inorganics & 23.045 & 1.12 & 24.165 \\
Solidified Organics & 0.025 & 0 & 0.025 \\
Uncategorized Metal & 4.96 & 0.56 & 5.52 \\
Total CH Volumes & 29.13 & 1.68 & 30.81
\end{tabular}




\section{SITE TRANSURANIC WASTE VOLUMES}

\begin{tabular}{|c|c|c|c|}
\hline \multicolumn{4}{|c|}{ (Cubic Meters) } \\
\hline Final Waste Form & Retrievably Stored & Projected & Total \\
\hline \multicolumn{4}{|l|}{ Contact Handled Waste } \\
\hline Heterogeneous & 0 & 3.36 & 3.36 \\
\hline Lead/Cadmium Metal Waste & 0.02 & 2.48 & 2.5 \\
\hline Total CH Volumes & 0.02 & 5.84 & 5.86 \\
\hline \multicolumn{4}{|l|}{ Remote Handled Waste } \\
\hline Filter & 0.89 & 2.09 & 2.98 \\
\hline Heterogeneous & 0.59 & 0.08 & 0.67 \\
\hline Lead/Cadmium Metal Waste & 0 & 0.36 & 0.36 \\
\hline Uncategorized Metal & 7.172 & 1.36 & 8.532 \\
\hline Unknown & 0 & 23.736 & 23.736 \\
\hline Total RH Volumes & 8.65 & 27.63 & 36.28 \\
\hline
\end{tabular}




\section{SITE TRANSURANIC WASTE VOLUMES}

\section{Site Name: BCLDP}

\begin{tabular}{llcc} 
& & (Cubic Meters) & \\
\hline \hline Final Waste Form & Retrievably Stored & Projected & Total \\
\hline \hline
\end{tabular}

Contact Handled Waste

\section{Total CH Volumes}

Remote Handled Waste

Heterogeneous

0

71

71

Total RH Volumes

0
0.00 $\frac{71}{71.00}$

71.00 


\section{SITE TRANSURANIC WASTE VOLUMES}

\section{Site Name: BT}

(Cubic Meters)

\begin{tabular}{lllc}
\hline \hline Final Waste Form & Retrievably Stored & Projected & Total \\
\hline \hline
\end{tabular}

Contact Handled Waste

Heterogeneous

Total CH Volumes

\section{Remote Handled Waste}

Heterogeneous

Total RH Volumes

$\begin{array}{rrr}0 & 123.816 & 123.816 \\ & 123.82 & 123.82\end{array}$

0

1.557

1.557

0.00

1.56

1.56 


\section{SITE TRANSURANIC WASTE VOLUMES}

Site Name: ETEC

(Cubic Meters)

\begin{tabular}{lcrr}
\hline \multicolumn{1}{c}{ Final Waste Form } & Retrievably Stored & Projected & Total \\
\hline \hline Contact Handled Waste & & & \\
Heterogeneous & 1.66 & 5.2 & 6.86 \\
Lead/Cadmium Metal Waste & 0.21 & 0 & 0.21 \\
Total CH Volumes & 1.87 & 5.20 & 7.07
\end{tabular}




\section{SITE TRANSURANIC WASTE VOLUMES}

\section{Site Name: HANFORD}

(Cubic Meters)

\begin{tabular}{|c|c|c|c|}
\hline Final Waste Form & Retrievably Stored & Projected & Total \\
\hline \multicolumn{4}{|l|}{ Contact Handled Waste } \\
\hline Combustible & 526.48 & 12269.027 & 12795.507 \\
\hline Heterogeneous & 8568.55 & 827.157 & 9395.707 \\
\hline Lead/Cadmium Metal Waste & 3.13 & 0.29 & 3.42 \\
\hline Soils & 111.69 & 309.27 & 420.96 \\
\hline Solidified Inorganics & 1.46 & 2924.759 & 2926.219 \\
\hline Solidified Organics & 2.17 & 15.248 & 17.418 \\
\hline Uncategorized Metal & 103.35 & 4890.948 & 4994.298 \\
\hline Total CH Volumes & 9316.83 & 21236.70 & 30553.53 \\
\hline \multicolumn{4}{|l|}{ Remote Handled Waste } \\
\hline Heterogeneous & 33.163 & 2973.71 & 3006.873 \\
\hline Total RH Volumes & 33.16 & 2973.71 & 3006.87 \\
\hline
\end{tabular}




\section{SITE TRANSURANIC WASTE VOLUMES}

Site Name: INEL

(Cubic Meters)

\begin{tabular}{|c|c|c|c|}
\hline Final Waste Form & Retrievably Stored & Projected & Total \\
\hline \multicolumn{4}{|l|}{ Contact Handled Waste } \\
\hline Combustible & 670.9 & 0 & 670.9 \\
\hline Filter & 323.56 & 0 & 323.56 \\
\hline Graphite & 650.7 & 0 & 650.7 \\
\hline Heterogeneous. & 9649.5 & 1 & 9650.5 \\
\hline Inorganic Non-metal & 1052.89 & $\mathbf{0}$ & 1052.89 \\
\hline Salt Waste & 22.91 & 0 & 22.91 \\
\hline Soils & 3.8 & 0 & 3.8 \\
\hline Solidified Inorganics & 12164.28 & 0 & 12164.28 \\
\hline Solidified Organics & 912.6 & 0 & 912.6 \\
\hline Uncategorized Metal & 7564.09 & 0 & 7564.09 \\
\hline Unknown & 1655.91 & 0 & 1655.91 \\
\hline Total CH Volumes & 34671.14 & 1.00 & 34672.14 \\
\hline Remote Handled Waste & & & \\
\hline Heterogeneous & 13.634 & 2.8 & 16.434 \\
\hline Lead/Cadmium Metal Waste & $\mathbf{0}$ & 5.6 & 5.6 \\
\hline Salt Waste & $\mathbf{0}$ & 2.8 & 2.8 \\
\hline Solidified Inorganics & 2.1 & 0 & 2.1 \\
\hline Uncategorized Metal & 4.11 & 5.6 & 9.71 \\
\hline Unknown & 11.13 & 0 & 11.13 \\
\hline Total RH Volumes & 30.97 & 16.80 & 47.77 \\
\hline
\end{tabular}

Table 6 - 10; INEL Final Waste Form Volumes 


\section{SITE TRANSURANIC WASTE VOLUMES}

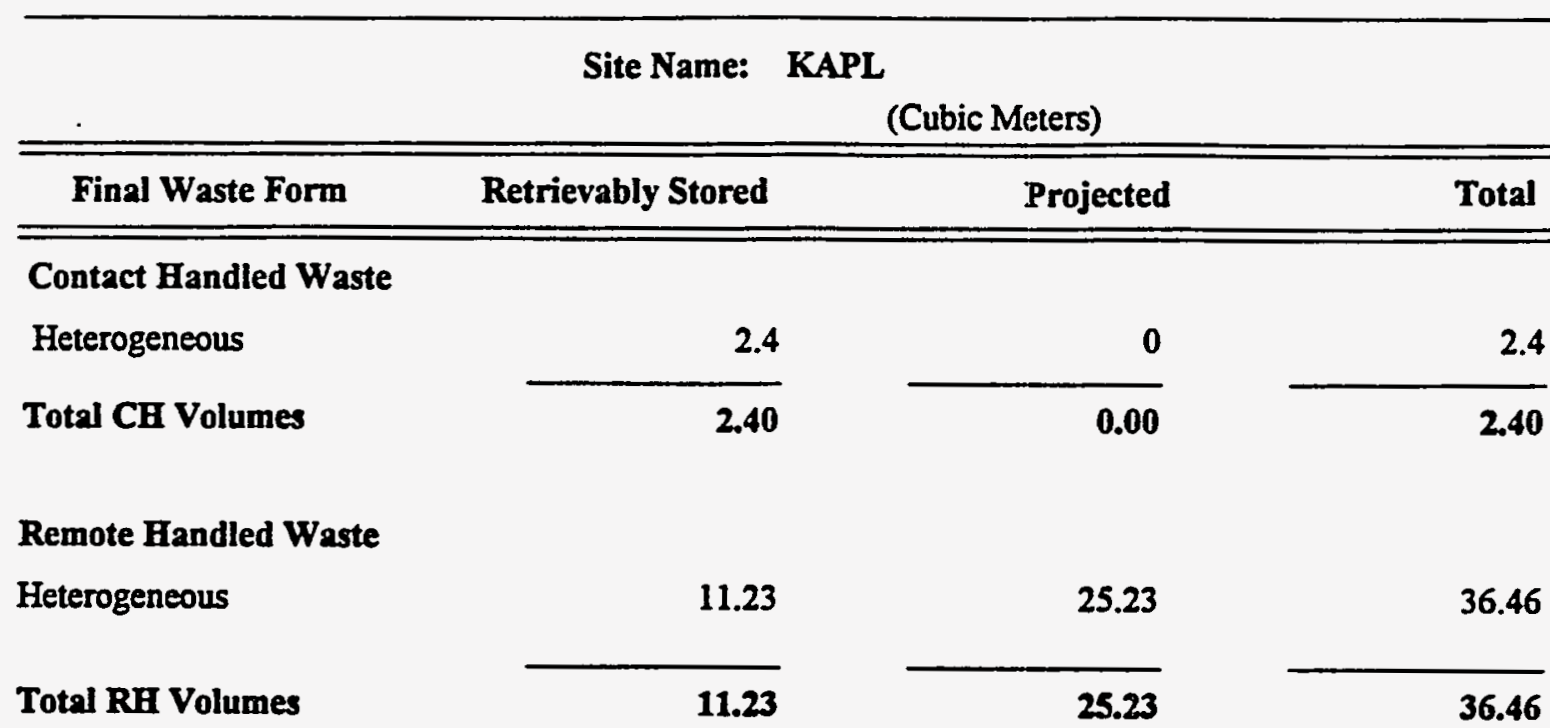




\section{SITE TRANSURANIC WASTE VOLUMES}

\begin{tabular}{|c|c|c|c|}
\hline & \multicolumn{3}{|c|}{ (Cubic Meters) } \\
\hline Final Waste Form & Retrievably Stored & Projected & Total \\
\hline \multicolumn{4}{|c|}{ Contact Handled Waste } \\
\hline Combustible & 1768.33 & 2464.6 & 4232.93 \\
\hline Soils & 109.37 & 144.6 & 253.97 \\
\hline Solidified Inorganics & 4848.38 & 2059.03 & 6907.41 \\
\hline Uncategorized Metal & 4134.8 & 3006.17 & 7140.97 \\
\hline Total CH Volumes & 10860.88 & 7674.40 & 18535.28 \\
\hline \multicolumn{4}{|l|}{ Remote Handled Waste } \\
\hline Combustible & 14.84 & 3.16 & 18 \\
\hline Uncategorized Metal & 76.46 & 79.5 & 155.96 \\
\hline Total RH Volumes & 91.30 & 82.66 & 173.96 \\
\hline
\end{tabular}




\section{SITE TRANSURANIC WASTE VOLUMES}

\begin{tabular}{|c|c|c|c|}
\hline & \multicolumn{2}{|c|}{ (Cubic Meters) } & \multirow[b]{2}{*}{ Total } \\
\hline Final Waste Form & Retrievably Stored & Projected & \\
\hline \multicolumn{4}{|l|}{ Contact Handled Waste } \\
\hline Heterogeneous & 0.84 & 4.42 & 5.26 \\
\hline Total CH Volumes & 0.84 & 4.42 & 5.26 \\
\hline
\end{tabular}




\section{SITE TRANSURANIC WASTE VOLUMES}

\begin{tabular}{lrrr}
\hline \multicolumn{5}{c}{ Site Name: } & LLNL & \\
\hline \multicolumn{1}{c}{ (Cubic Meters) } \\
\hline Final Waste Form & Retrievably Stored & Projected & Total \\
\hline Contact Handled Waste & & & \\
Combustible & 48.882 & 372.32 & 421.202 \\
Salt Waste & 0.624 & 2.912 & 3.536 \\
Solidified Inorganics & 13.303 & 66.148 & 79.451 \\
Uncategorized Metal & 144.326 & 247 & 391.326 \\
Total CH Volumes & 207.14 & 688.38 & 895.52
\end{tabular}

Table 6 - 14; LLNL Final Waste Form Volumes

$6-15$ 


\section{SITE TRANSURANIC WASTE VOLUMES}

\begin{tabular}{lrrr}
\hline \multicolumn{5}{c}{ Site Name: } & $\begin{array}{r}\text { MOUND } \\
\text { (Cubic Meters) }\end{array}$ \\
\hline \multicolumn{1}{c}{ Final Waste Form } & Retrievably Stored & Projected & Total \\
\hline \hline Contact Handled Waste & & & \\
Combustible & 5.61 & 0 & 5.61 \\
Heterogeneous & 0.416 & 0 & 0.416 \\
Soils & 146.88 & 0 & 146.88 \\
Solidified Inorganics & 7.28 & 0 & 7.28 \\
Uncategorized Metal & 102.276 & 0 & 102.276 \\
Total CH Volumes & 262.46 & 0.00 & 262.46
\end{tabular}

$$
6 \cdot 16
$$




\section{SITE TRANSURANIC WASTE VOLUMES}

\begin{tabular}{lcccc}
\hline & Site Name: & & \\
& MU & (Cubic Meters) & \\
\hline \hline \multicolumn{1}{c}{ Final Waste Form } & Retrievably Stored & Projected & Total \\
\hline \hline $\begin{array}{l}\text { Contact Handled Waste } \\
\text { Heterogeneous }\end{array}$ & 0.06 & & 1.604 & \\
Total CH Volumes & $\mathbf{0 . 0 6}$ & 1.60 & 1.664 \\
\cline { 2 - 4 }
\end{tabular}




\section{SITE TRANSURANIC WASTE VOLUMES}

\section{Site Name: NTS}

(Cubic Meters)

\begin{tabular}{llll}
\hline \hline Final Waste Form & Retrievably Stored & Projected & Total \\
\hline \hline
\end{tabular}

Contact Handled Waste

Heterogeneous

$\begin{array}{rrr}619.5 & 0 & 619.5 \\ & 0.00 & 619.50\end{array}$

Total CH Volumes 19.50

0.00

619.50 


\section{SITE TRANSURANIC WASTE VOLUMES}

\begin{tabular}{|c|c|c|c|}
\hline . & \multicolumn{3}{|c|}{ (Cubic Meters) } \\
\hline Final Waste Form & Retrievably Stored & Projected & Total \\
\hline \multicolumn{4}{|l|}{ Contact Handled Waste } \\
\hline Heterogeneous & 672.98 & 263.9 & 936.88 \\
\hline Solidified Inorganics & 110 & 0 & 110 \\
\hline Total CB Volumes & 782.98 & 263.90 & 1046.88 \\
\hline \multicolumn{4}{|l|}{ Remote Handled Waste } \\
\hline Heterogeneous & 382.81 & 182.7. & 565.51 \\
\hline Solidified Inorganics & 611 & 174 & 785 \\
\hline Total RH Volumes & 993.81 & 356.70 & 1350.51 \\
\hline
\end{tabular}




\section{SITE TRANSURANIC WASTE VOLUMES}

Site Name: PA

(Cubic Meters)

\begin{tabular}{l}
\hline Final Waste Form \\
\hline Contact Handled Waste
\end{tabular}

Solidified Inorganics

Total CH Volumes

$\frac{3.45}{3.45}$

Projected

Total

Retrievably Stored

3.45

3.45

$\frac{0}{0.00}$

3.45

3.45 


\section{SITE TRANSURANIC WASTE VOLUMES}

\begin{tabular}{lccc}
\hline \multicolumn{5}{c}{ Site Name: PANTEX } \\
(Cubic Meters) \\
\hline Final Waste Form & Retrievably Stored & Projected & Total \\
\hline \hline $\begin{array}{l}\text { Contact Handled Waste } \\
\text { Heterogeneous }\end{array}$ & 0.624 & 0 & \\
Total CH Volumes & 0.62 & 0.00 & 0.624 \\
\cline { 2 - 4 } & & & 0.62
\end{tabular}




\section{SITE TRANSURANIC WASTE VOLUMES}

Site Name: RFP

(Cubic Meters)

\begin{tabular}{lrrr}
\hline \hline \multicolumn{1}{c}{ Final Waste Form } & Retrievably Stored & Projected & Total \\
\hline Contact Handled Waste & 103.96 & & 1191.55 \\
Filter & 18.06 & 1087.59 & 61.46 \\
Graphite & 312.86 & 43.4 & 1117.44 \\
Heterogeneous & 110.68 & 804.58 & 429.36 \\
Inorganic Non-metal & 51.87 & 318.68 & 176.05 \\
Lead/Cadmium Metal Waste & 9.45 & 124.18 & 66.05 \\
Salt Waste & 228.63 & 56.6 & 3216.74 \\
Solidified Inorganics & 132.8 & 2988.11 & 181.62 \\
Solidified Organics & 164.82 & 48.82 & 594.32 \\
Uncategorized Metal & 1133.13 & 429.5 & 7034.59 \\
Total CH Volumes & & 5901.46 &
\end{tabular}




\section{SITE TRANSURANIC WASTE VOLUMES}

\section{- Site Name: SNL/NM}

\begin{tabular}{|c|c|c|c|}
\hline & \multicolumn{3}{|c|}{ (Cubic Meters) } \\
\hline Final Waste Form & Retrievably Stored & Projected & Total \\
\hline \multicolumn{4}{|c|}{ Contact Handled Waste } \\
\hline Heterogeneous & 8.04 & 7 & 15.04 \\
\hline Total CH Volumes & 8.04 & 7.00 & 15.04 \\
\hline
\end{tabular}


SITE TRANSURANIC WASTE VOLUMES

\begin{tabular}{|c|c|c|c|}
\hline & \multicolumn{3}{|c|}{ (Cubic Meters) } \\
\hline Final Waste Form & Retrievably Stored & Projected & Total \\
\hline \multicolumn{4}{|l|}{ Contact Handled Waste } \\
\hline Combustible & 4066.8 & 11962.5 & 16029.3 \\
\hline Heterogeneous & 10132.2 & 2563.6 & 12695.8 \\
\hline Solidified Inorganics & 0.04 & $\mathbf{0}$ & 0.04 \\
\hline Solidified Organics & 404.85 & 240.7 & 645.55 \\
\hline Total CH Volumes & 14603.89 & 14766.80 & 29370.69 \\
\hline \multicolumn{4}{|l|}{ Remote Handled Waste } \\
\hline Heterogeneous & 0 & 63.92 & 63.92 \\
\hline Total RH Volumes & $\overline{0.00}$ & $\overline{63.92}$ & 63.92 \\
\hline
\end{tabular}


CHAPTER 7

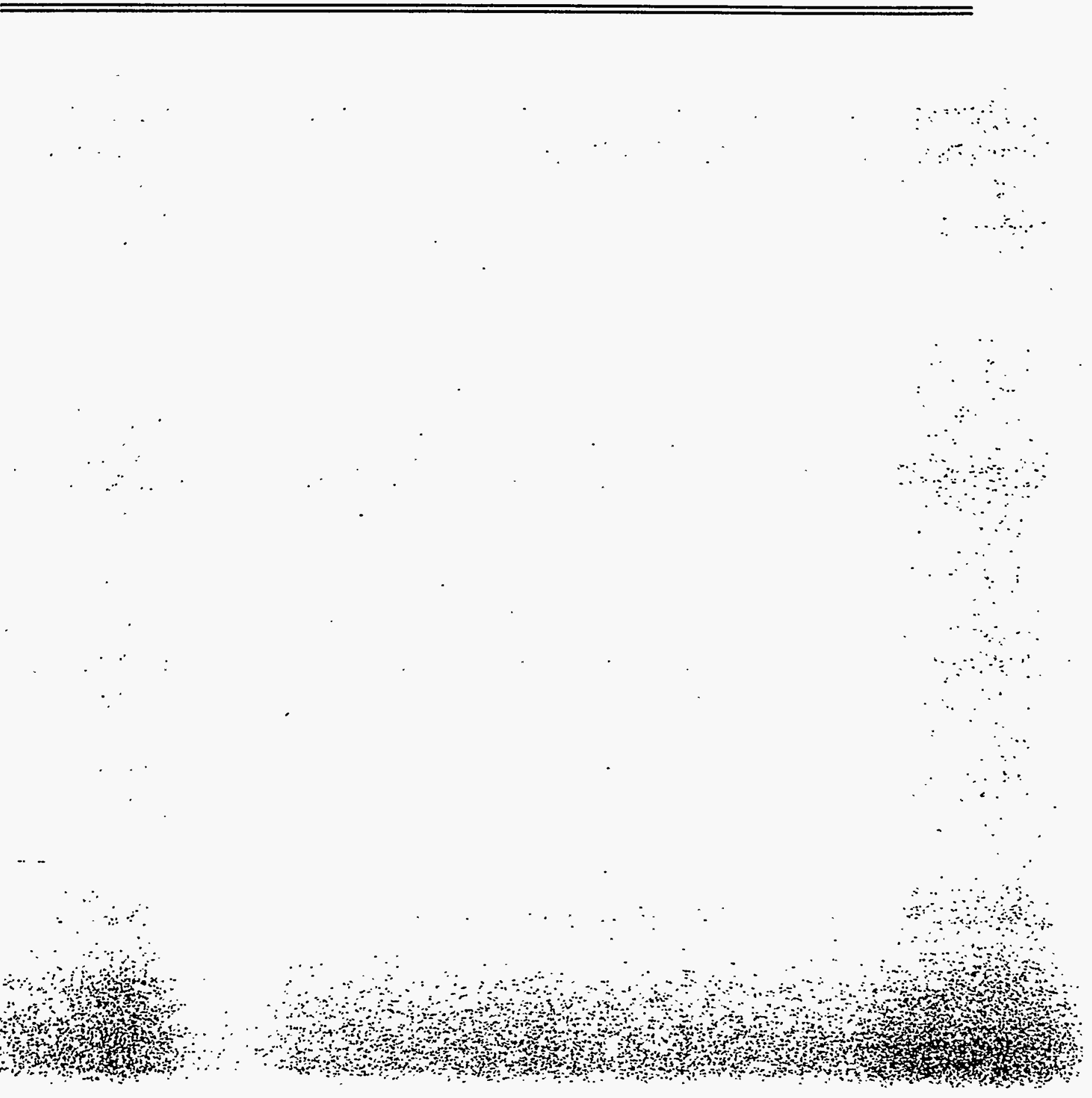




\section{WIPP TRANSURANIC WASTE BASELINE INVENTORY DATABASE}

A WIPP Transuranic Waste Baseline Inventory Database (WTWBID) has been developed to support the Waste Isolation Pilot Plant Transuranic Waste Baseline Inventory Report (WTWBIR). This database was used to roll up the waste data and print out the various tables and reports used in the WTWBIR. The database is operated in the Microsoft Access Vs. 2.0 system.

\subsection{DATABASE DESCRIPTION}

The database actually consists of two databases with essentially the same primary data tables. The first database is WTWBIR.MDB. This database contains the original data submitted by the sites or agreed with the sites through discussions with WTWBIR personnel. This database is used to produce the forms in Appendix A. The second database is called REPORTS.MDB and is used to produce the tables and figures in the rest of the report. There are two databases because the basic data in WTWBIR.MDB must be manipulated to produce rational roll ups of the data for the reports and figures. These manipulations are described in this section of the report.

Each record in the database represents one waste stream as defined by a unique waste stream ID (WIPP_ID). In the case where the WTWBIR waste stream is the same as a waste stream reported in phase 2 of the MWIR, the WIPP_ID is the same as the MWIR ID (UNIQUE_WS). Some streams, primarily non mixed and a few mixed waste streams, were not reported in the MWIR. In these cases, if the site did not assign a proper ID, a WIPP_ID was assigned by the WTWBIR team.

The reports and tables produced for the WTWBIR are produced from different data sorts based on the WTWBIR-ID, Site_Name, Handling and Final_Waste_Form fields. The Site_Name refers to the sites as defined in the field WS_SITE. The Site_Name specifies the site which reported and is typically storing the waste. The generator site may differ from the storage site. The Handling field defines whether the waste is categorized as $\mathrm{CH}$ or RH waste. The Final_Waste_Form defines a general grouping based on the physical and chemical properties in the waste stream. These are broader waste matrix code groupings (WMCG) (Table 1-2) based generally on the MWIR treatability groups which are described in the MWIR form instructions. In Revision 0 of the WTWBIR, these Final_Waste_Forms were referred to as Matrix_Names.

The volumes are rolled up from the cumulative stored volumes and projected volumes provided by the sites. The stored volumes are based on the cumulative end of 1993 volumes in the database. Some sites provided stored volumes for 1992 and projected volumes for 1993 while other sites provided stored volumes for 1993. In order to be consistent, the stored volumes for sites that based their stored volumes on 1992 were calculated by adding the 1992 volume to the 1993 projected volume. Projected volumes were calculated by adding the volumes for 1994 through 2022.

In Table 3-5, a column was calculated to match the maximum design capacity of WIPP for $\mathrm{CH}$ waste. This was done by increasing all the Final_Waste_Form projected volumes proportionately, except Unknown, so that the total $\mathrm{CH}$ volume. would equal the maximum WIPP capacity. Additional waste volume was calculated for each waste stream proportionate to the projected volumes for each stream such that the sum of the scaled volumes for contact handled waste equaled 175,600 cubic meters. Enough waste is already identified to fill the WIPP to capacity for remote handled waste. 
The other fields used to develop roll ups for the tables in the reports are the waste material parameters. The sites were asked to estimate an average, minimum and maximum concentration of materials in each waste stream. For example, weights of metals such as brass, copper, tantalum and materials simply described as metals were rolled up under the field OM_xxx (where $x x x$ is min, max, or avg) which stands for "Other Metals" (see the data dictionary; Table 7-1). Note that because some materials are described only as metals, aluminum and iron can be in the $O M \_x x x$ field as well as in the $I B \_x x x$ or $A B \_x x x$ fields.

Two categories of sludges and solidified materials are represented by fields. These are solidified inorganic solids (SIM_xxx) and solidified organic solids (SOM_xxx). The particular category into which a sludge or solidified material is placed is determined by the overall matrix of the resulting material after any solidification or stabilization steps. For example, a small amount of organic liquids/sludges solidified in cement would be placed in the solidified inorganics category and a drum of organic based resin beads solidified would be placed in the solidified organics category.

The rest of the fields are reasonably self explanatory, but additional discussion on Cel_xxx, Rub_xxx, and Plas_xxx, may be helpful. Cel_xxx includes all cellulose base materials and will typically include paper, cloth, wood, kimwipes and other materials derived from plant based materials. It is assumed that cloth is plant derived material such as cotton and not plastic based such as rayon or nylon. Rub_ $\times \times \times$ consists of rubber based materials. Included in this category are Hypalon ${ }^{\circledast}$, neoprene, and surgeons gloves. Plas_ $x 0 \times$ represents plastics such as Lucite ${ }^{\circledast}$, polyethylene, Tyvek ${ }^{\otimes}$, tefion and polyvinyl chloride. Plastic bags are used extensively in packaging the waste and would be included in this category. The plastic drum or container liners were not included in this category and were requested separately.

The parameter information is manipulated so that the waste material parameters can be added up and averaged at WIPP, site and Final Waste Form levels. Waste streams for which no waste parameters are provided or for which average, minimum and maximum parameters are not all provided cannot be rationally averaged and summed. Therefore, in order to calculate averaged parameters from the waste stream data provided, certain manipulations on the data are necessary. These manipulations are summarized below. If the parameters for a particular waste material were incomplete, the following assumptions were used to adjust the data so that rational averages and sums could be accomplished:

- If no minimum was provided, but a maximum was provided, the minimum was assumed to be zero.

- If a maximum was provided, but no average, the average was assumed to be one half the sum of the maximum and minimum.

- If an average was provided but no minimum or maximum, the average was assigned to the minimum and maximum.

- If only a minimum was provided, the minimum was assigned to both the maximum and the average.

For those waste streams that did not have any waste parameter information provided, but which could be assigned to a final waste form, an average set of parameters was calculated and used. This average set of parameters was calculated by volume averaging the parameters provided for other waste streams with the same final waste form. 
The data that is printed out on all the tables in the report is based on these calculations and assumptions. The individual stream data printed out in Appendix $A$ is the original unmanipulated data submitted by the generator/storage sites or agreed to by the sites through discussions and questions with the WTWBIR team.

The roll ups of these material parameters for tables in the report by Final_Waste_Form or by site were performed using a volume weighted averaging procedure. The averages for the material parameters for a Final_Waste_Forms (FWF) are calculated as follows:

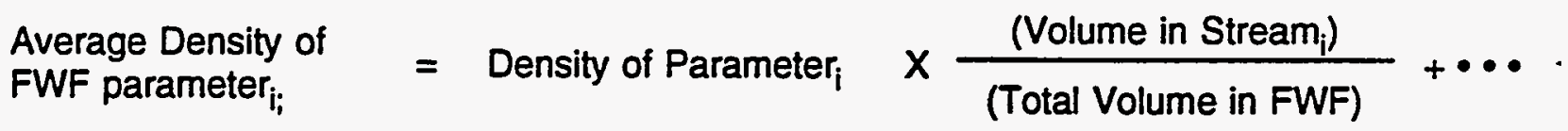

where $i$ is an index representing individual waste streams of the same FWF.

The minimum density is chosen as the smallest minimum density of a particular material parameter in the WTWBIR streams in a particular Final_Waste_Form. The maximum density is chosen in a similar manner except that the largest maximum density was chosen. Note that the maximum and minimum densities apply to individual containers and cannot be used to directly calculate a maximum and minimum density of particular material parameters for the entire WIPP inventory. Also note, that it is possible, that the maximum density may not be a true maximum but a maximum average density, if a site provided only averages and no maximums and these averages are higher than other sites' maximums.

The amount of and type of materials in the containers and liners was requested separately in the waste stream profiles. Many of the sites did not provide data for final form WIPP approved containers. Some sites provided current containers, some did not provide containers and some provided final form containers. In order to add up packaging materials for the waste as it would arrive at WIPP, standard container configurations were assumed for waste from all sites.

If the site provided final form containers, the final form containers (drums, SWBs, or RH Canisters) were used, but standard liners were assumed. This was done because many sites did not provide liner information and assuming standard liners will generally maximize the amount of liner material.

For $\mathrm{CH}$ waste containers, the following assumptions were used:

- If the type of container was unclear, it was assumed to be drums. (This was rare.)

- If drums were reported they are assumed to be WIPP approved drums with rigid liners. Many sites have a mixture of liner types in a stream or are unsure of liners.

- If waste was reported in containers larger than drums, then the waste was divided into (Standard Waste Boxes) SWBs with standard plastic bag liners; using the standard intemal volume for SWBs and the reported waste stream volumes to determine the number of SWBs.

- If the waste was reported in a liquid or sludge form (i.e. tanks), it was assumed to be placed in drums with rigid liners. No treatment volume expansion was included unless provided by the site. 
For RH waste, the following assumptions were used:

- If the waste was reported in drums, the drums were assumed to be overpacked in RH canisters at 3 drums per canister.

- If the waste was not reported to be in drums, the waste was assumed to be direct loaded into RH canisters; using the standard intemal volume for RH canisters and the reported waste stream volumes to determine the number of RH canisters.

Packaging material weights used in the WTWBIR report are shown in the table below:

Table 7-1. Table of Materials for $\mathrm{CH}$ and RH Waste Containers

(Weights in $\mathrm{kg}$ per container, Volume in $\mathrm{m}^{3}$ per container)

\begin{tabular}{|c|c|c|c|c|}
\hline \multicolumn{5}{|c|}{ CH Waste } \\
\hline $\begin{array}{c}\text { Container } \\
\text { Characteristic }\end{array}$ & \multicolumn{2}{|c|}{ Drum } & SWB & SWB Overpack ${ }^{1}$ \\
\hline $\begin{array}{l}\text { Steel Weight } \\
\text { Liner Type } \\
\text { Liner Material } \\
\text { Liner Weight } \\
\text { Volume (Capacity) } \\
\text { Payload Volume }\end{array}$ & \multicolumn{2}{|c|}{$\begin{array}{l}27.3 \\
\text { Rigid Drum Liner } \\
90 \text { mil HDPE } \\
7.7 \\
0.208 \\
0.208\end{array}$} & $\begin{array}{l}290.9 \\
\text { Bag } \\
\text { Plastic } \\
2.2 \\
1.89 \\
1.89\end{array}$ & $\begin{array}{l}400.1 \text { (include. } 4 \text { drums } \\
\text { Rigid Drum Liners and Bag } \\
90 \text { mil HDPE and Plastic } \\
33 \\
1.89 \\
0.832 \text { (4 drums) }\end{array}$ \\
\hline \multicolumn{5}{|c|}{ RH Waste } \\
\hline \multicolumn{2}{|c|}{ Container Characteristics } & \multicolumn{2}{|c|}{ RH Canister } & RH Canister Overpack ${ }^{3}$ \\
\hline \multicolumn{2}{|l|}{$\begin{array}{l}\text { Steel Weight } \\
\text { Lead Weight } \\
\text { Steel Plug Weight } \\
\text { Liner Type } \\
\text { Liner Material } \\
\text { Liner Weight } \\
\text { Volume (Capacity) } \\
\text { Payload Volume }\end{array}$} & \multicolumn{2}{|c|}{$\begin{array}{c}387.3 \\
413.6 \\
1909.1 \\
\text { None } \\
\text { N/A } \\
\text { N/A } \\
0.89 \\
0.89\end{array}$} & $\begin{array}{l}469.2 \text { (3 drums) } \\
413.6 \\
1909.1 \\
\text { Rigid Liner in Drums } \\
90 \text { mil HDPE } \\
23.1 \\
0.89 \\
0.624 \text { (3 drums) }\end{array}$ \\
\hline
\end{tabular}

1 Four drums overpacked in an SWB

2 Payload volume is the actual volume of waste which can be placed in the container.

3 Three drums overpacked in an RH Canister

The tables and reports for the WTWBIR were produced using the facilities provided by the Microsoft Access Vs 2.0 database system. These tables and reports consist primarily of various sorts based on waste streams, final waste forms, sites, etc. and summations of volumes and material parameter weights. 


\subsection{DATA DICTIONARY}

Table 7-2. WTWBID Data Dictionary

\begin{tabular}{|c|c|c|}
\hline Field/Table Name & Notes & Description \\
\hline $\begin{array}{l}\text { Table: Container_Data } \\
\text { WIPP_ID }\end{array}$ & $\begin{array}{l}\text { Key Field Index } \\
\text { Relating from } \\
\text { Page_1 data table }\end{array}$ & $\begin{array}{l}\text { The unique waste stream identification number as } \\
\text { assigned by the WTWBIR Team }\end{array}$ \\
\hline MWIR_ID & & $\begin{array}{l}\text { The unique waste stream identification number as listed in } \\
\text { the Mixed Waste Inventory Report }\end{array}$ \\
\hline Cont & $\begin{array}{l}\text { Key Field to relate } \\
\text { to Nuclides data } \\
\text { table }\end{array}$ & Container (SWB, Stnd Drum, or RH Canister) \\
\hline Counter & & Access 2.0-generated record identifier \\
\hline MWIR_Cont & • & The type of container as listed in the MWIR \\
\hline Type/Size & & type and/or size of container \\
\hline Param & & Parameter Information Reported? \\
\hline RAD & & $\begin{array}{l}\text { Yes - Isotopes listed; No - None Listed; Quan - } \\
\text { Concentrations listed }\end{array}$ \\
\hline Container Material & & Material of which the waste container is made \\
\hline Ext_Volume & & cubic meters per container \\
\hline Liner_type & & Nomenclature identifying the type and size of liner. \\
\hline Liner_material & & composition of liner \\
\hline Nbr_Stored & & number of this type of container stored. \\
\hline Nbr_Projected & & $\begin{array}{l}\text { Total number of this container for this waste stream } \\
\text { projected through the life of the WIPP }\end{array}$ \\
\hline IB_avg & & Iron-based constituents, Average, in $\mathrm{kg} / \mathrm{m} 3$ \\
\hline IB_min & & Iron-based constituents, Minimum, in $\mathrm{kg} / \mathrm{m3}$ \\
\hline IB_max & & Iron-based constituents, Maximum, in $\mathrm{kg} / \mathrm{m} 3$ \\
\hline$A B \_a v g$ & & Aluminum-based constituents, Average, in $\mathrm{kg} / \mathrm{m} 3$ \\
\hline AB_min & & Aluminumbased constituents, Minimum, in $\mathrm{kg} / \mathrm{m3}$ \\
\hline$A B \_$max & & Aluminumbased constituents, Maximum, in $\mathrm{kg} / \mathrm{m} 3$ \\
\hline OM_avg & & Other metals constituents, Average, in $\mathrm{kg} / \mathrm{m} 3$ \\
\hline OM_min & & Other metals constituents, Minimum, in $\mathrm{kg} / \mathrm{m3}$ \\
\hline OM_max & & Other metals constituents, Maximum, in $\mathrm{kg} / \mathrm{m} 3$ \\
\hline Ol_avg & & Other inorganics constituents, Average, in $\mathrm{kg} / \mathrm{m} 3$ \\
\hline
\end{tabular}


Table 7-2. WTWBID Data Dictionary (continued)

\begin{tabular}{|c|c|c|}
\hline Field/Table Name & Notes & Description \\
\hline Ol_Min & & Other inorganics constituents, Minimum, in $\mathrm{kg} / \mathrm{m} 3$ \\
\hline OI_max & & Other inorganics constituents, Maximum, in $\mathrm{kg} / \mathrm{m} 3$ \\
\hline Cel_avg & & Cellulosics constituents, Average, in $\mathrm{kg} / \mathrm{m} 3$ \\
\hline Cel_min & & Cellulosics constituents, Minimum, in $\mathrm{kg} / \mathrm{m} 3$ \\
\hline Cel_max & & Cellulosics constituents, Maximum, in $\mathrm{kg} / \mathrm{m3}$ \\
\hline Rub_avg & & Rubber constituents, Average, in $\mathrm{kg} / \mathrm{m} 3$ \\
\hline Rub_min & & Rubber constituents, Minimum, in $\mathrm{kg} / \mathrm{m} 3$ \\
\hline Rub_max & & Rubber constituents, Maximum, in $\mathrm{kg} / \mathrm{m} 3$ \\
\hline Plas_avg & & Plastic constituents, Average, in $\mathrm{kg} / \mathrm{m} 3$ \\
\hline Plas_min & & Plastic constituents, Minimum, in $\mathrm{kg} / \mathrm{m} 3$ \\
\hline Plas_max & & Plastic constituents, Maximum, in $\mathrm{kg} / \mathrm{m3}$ \\
\hline SIM_avg & & $\begin{array}{l}\text { Solidified Inorganic Materials constituents, Average, in } \\
\mathrm{kg} / \mathrm{m3}\end{array}$ \\
\hline SIM-min & & $\begin{array}{l}\text { Solidified Inorganic Materials constituents, Minimum, in } \\
\mathrm{kg} / \mathrm{m3}\end{array}$ \\
\hline SIM_max & & $\begin{array}{l}\text { Solidified Inorganic Materials constituents, Maximum, in } \\
\mathrm{kg} / \mathrm{m} 3\end{array}$ \\
\hline SOM_avg & & $\begin{array}{l}\text { Solidified Organic Materials constituents, Average, in } \\
\mathrm{kg} / \mathrm{m3}\end{array}$ \\
\hline SOM_min & & $\begin{array}{l}\text { Solidfied Organic Materials constituents, Minimum, in } \\
\mathrm{kg} / \mathrm{m3}\end{array}$ \\
\hline SOM_max & & $\begin{array}{l}\text { Solidfied Organic Materials constituents, Maximum, in } \\
\mathrm{kg} / \mathrm{m} 3\end{array}$ \\
\hline SL_avg & & Soils, Average, $\mathrm{kg} / \mathrm{m} 3$ \\
\hline SL_min & & Soils, Minimum, $\mathrm{kg} / \mathrm{m3}$ \\
\hline SL_max & & Soils, Maximum, $\mathrm{kg} / \mathrm{m3}$ \\
\hline PM_Steel & & Packaging materials, steel, $\mathrm{kg} / \mathrm{m} 3$ \\
\hline PM_Plastic & & Packaging materials, plastic, $\mathrm{kg} / \mathrm{m} 3$ \\
\hline End_of_92 & & Volume of this waste stream as of the end of 1992 \\
\hline Projected_end_of_92 & & $\begin{array}{l}\text { Projected volume of this waste stream as of the end of } \\
1992\end{array}$ \\
\hline FF_End_of_92 & & $\begin{array}{l}\text { The Volurne of this waste stream on hand at end of } 1992 \\
\text { in it's estimated final waste form to ship to the WIPP }\end{array}$ \\
\hline FF_Projected_end_of_92 & & Not used. \\
\hline End_of_93 & & The cumulative waste volume at the end of the year. \\
\hline
\end{tabular}


Table 7-2. WTWBID Data Dictionary (continued)

\begin{tabular}{|c|c|c|}
\hline Field/Table Name & Notes & Description \\
\hline FF_End_of_93 & & $\begin{array}{l}\text { The cumulative waste volume of the waste on hand at } \\
\text { end of year in its estimated final form for shipment to the } \\
\text { WIPP. }\end{array}$ \\
\hline End_of_94 & & $\begin{array}{l}\text { The new waste volume at the end of the year; the } \\
\text { increment added during the year }\end{array}$ \\
\hline FF_End_of_94 & & $\begin{array}{l}\text { The new waste volume of the waste on hand at end of } \\
\text { year in its estimated final form for shipment to the WIPP. } \\
\text { the increment added during the year }\end{array}$ \\
\hline End_of_95 & & $\begin{array}{l}\text { The new waste volume at the end of the year; the } \\
\text { increment added during the year }\end{array}$ \\
\hline FF_End_of_95 & & $\begin{array}{l}\text { The new waste volume of the waste on hand at end of } \\
\text { year in its estimated final form for shipment to the WIPP, } \\
\text { the increment added during the year }\end{array}$ \\
\hline End_of_96 & & $\begin{array}{l}\text { The waste volume at the end of the year; the increment } \\
\text { added during the year }\end{array}$ \\
\hline FF_End_of_96 & & $\begin{array}{l}\text { The new waste volume of the waste on hand at end of } \\
\text { year in its estimated final form for shipment to the WIPP, } \\
\text { the increment added during the year }\end{array}$ \\
\hline End_of_97 & & $\begin{array}{l}\text { The waste volume at the end of the year, the increment } \\
\text { added during the year }\end{array}$ \\
\hline FF_End_of_97 & . & $\begin{array}{l}\text { The new waste volume of the waste on hand at end of } \\
\text { year in its estimated final form for shipment to the WIPP, } \\
\text { the increment added during the year }\end{array}$ \\
\hline $98-2002$ & & The waste volume added per year during the period. \\
\hline FF_98-2002 & & $\begin{array}{l}\text { The waste volume added per year during the period in its } \\
\text { estimated final form for shipment to the WIPP. }\end{array}$ \\
\hline $03-2022$ & & The waste volume added per year during the period. \\
\hline FF_03-2022 & & $\begin{array}{l}\text { The waste volume added per year during the period in its } \\
\text { estimated final form for shipment to the WIPP. }\end{array}$ \\
\hline Comments & & $\begin{array}{l}\text { Miscellaneous comments applicable to page } 2 \text { of the data } \\
\text { form }\end{array}$ \\
\hline $\begin{array}{l}\text { Container_- } \\
\text { Footnotes }\end{array}$ & & $\begin{array}{l}\text { Footnotes applicable to a specific container type in a } \\
\text { waste stream. }\end{array}$ \\
\hline $\begin{array}{l}\text { Table: Page_1 } \\
\text { Sito_Name }\end{array}$ & & $\begin{array}{l}\text { Name of site, text spelled out as specified in a look-up } \\
\text { table (ANL-E, Hanford, INEL, AMES, etc.). }\end{array}$ \\
\hline MWIR_ID & & $\begin{array}{l}\text { Unique Waste Stream Number derived from the Mixed } \\
\text { Waste Inventory Report. }\end{array}$ \\
\hline WIPP_ID & $\begin{array}{l}\text { Key field to relate } \\
\text { to container_data } \\
\text { and EPACodes } \\
\text { data tables }\end{array}$ & $\begin{array}{l}\text { WIPP specitic identification number assigned by WTWBIR } \\
\text { Team. }\end{array}$ \\
\hline
\end{tabular}


Table 7-2. WTWBID Data Dictionary (continued)

\begin{tabular}{|c|c|c|}
\hline FieldrTable Name & Notes & Description \\
\hline LOCAL_ID & & Locally assigned ID number for the waste stream \\
\hline Gen_Site & & $\begin{array}{l}\text { The name of the site that generated the waste, regardless } \\
\text { of the actual storage site. }\end{array}$ \\
\hline Waste_Type & & MTRU or TRU \\
\hline Handling & & $\mathrm{CH}$ or $\mathrm{RH}$ \\
\hline Stream_Name & & Abbreviation Description/Name of the Stream \\
\hline Stream_description & & Memo field to describe the type of stream \\
\hline MWIR_matrix_code & & Matrix Code, from MWIR if applicable and relevant \\
\hline Assigned_matrix_code & & $\begin{array}{l}\text { Matrix Code assigned by WTWBIR analysts... to be left } \\
\text { blank by sites }\end{array}$ \\
\hline Final_Waste_Form & & $\begin{array}{l}\text { This is the code of the final (to WIPP) form of the waste } \\
\text { stream }\end{array}$ \\
\hline Matrix_Description & & $\begin{array}{l}\text { Description and comments for the waste matrix in its final } \\
\text { form for the WIPP }\end{array}$ \\
\hline TRUCON & & Assigned TRUCON Code \\
\hline NoMigrationAssign & & $\begin{array}{l}\text { Code assigned for purposes of the WIPP No Migration } \\
\text { Variance Petition. }\end{array}$ \\
\hline $\begin{array}{l}\text { IDC_from_Site_- } \\
\text { Final_Form }\end{array}$ & & IDC supplied by Site for this stream. \\
\hline $\begin{array}{l}\text { IDC_Assigned_Final_ } \\
\text { Form }\end{array}$ & & $\begin{array}{l}\text { Equivalen? IDC assigned by WTWBIR analysts based on } \\
\text { their judgement }\end{array}$ \\
\hline Waste_Ownership & & Defense, non-defense, commercial, or unknown \\
\hline Waste_mixed_type & & Mixed, non-mixed, suspect mixed, or unknown \\
\hline Waste_source & & $\begin{array}{l}\text { R\&D, Operational, Residues, ER and D\&D, EA, D\&D, or } \\
\text { Unknown }\end{array}$ \\
\hline
\end{tabular}


Table 7-2. WTWBID Data Dictionary (continued)

\begin{tabular}{|c|c|c|}
\hline Field/Table Name & Notes & Description \\
\hline TSCA_data & & $\begin{array}{l}\text { Asbestos, PCBs, Asbestos \& PCBs, Other (describe in } \\
\text { comment), No, N/A, or Unknown }\end{array}$ \\
\hline Storage_data & · & $\begin{array}{l}\text { Retrievably stored, Buried, Building Storage, or Bermed } \\
\text { Storage }\end{array}$ \\
\hline Page 1_Footnotes & & Footnotes applicable to the whole waste stream. \\
\hline $\begin{array}{l}\text { Table: epacodes } \\
\text { UNIQUE_WS }\end{array}$ & $\begin{array}{l}\text { Key Field, related } \\
\text { to Page_1, } \\
\text { WIPP_ID }\end{array}$ & Unique waste stream identifier number. \\
\hline EPA_CODE & & EPA code associated with a specific waste stream. \\
\hline $\begin{array}{l}\text { Table: Nuclides } \\
\text { Cont_Counter }\end{array}$ & $\begin{array}{l}\text { Key Field related to } \\
\text { Container_Data, } \\
\text { Counter }\end{array}$ & $\begin{array}{l}\text { Relation to Container data counter, lock the record to a } \\
\text { specific container/stream record in Container_Data. }\end{array}$ \\
\hline Nuclide & & $\begin{array}{l}\text { Nuclide designation in form Element Abbreviation, Atomic } \\
\text { Weight, and excitation indicator if applicable (Ba137M). }\end{array}$ \\
\hline Activity & & $\begin{array}{l}\text { Scientific notation of activity in Pu239 equivalents in } \\
\text { Curies/m3. }\end{array}$ \\
\hline
\end{tabular}

\subsection{DATABASE OPERATING INSTRUCTIONS}

The WIPP Transuranic. (TRU) Waste Baseline inventory Report (WTWBIR), Revision 1, database is a Microsoft Access 2.0 database. It requires the user to possess a copy of Access 2.0 and be running under the Windows 3.1 operating system. Access, unlike most other databases, provides a single structure that contains objects such as queries, reports, program segments, macros, indexes, relations, and multiple data tables. This means there is only one file to work with, one with the suffix, .MDB. A second file normally accompanies the database file, one with the suffix .LDB and having the same name. It is not normally used except for certain file maintenance operations.

Two databases are provided as part of the compressed file on the distribution disk. The first database is WTWBIR_1, which contains the original data by waste streams from all generator/storage sites. This is the database used to print out the individual stream data in 
Appendix A. The second database is called REPORTS. This is the database used to produce the other tables and figures in Volume 1 and Appendix B of the report. The databases are separate because the roll ups of data require some changes to the data to produce rational numbers in the tables and figures. These changes were described in section 7.2.

INSTALLATION: The two databases are compressed into a file on the distribution disk called WTWBIR.EXE. Approximately 6 megabytes of hard disc space should be available to install the database. To install the WTWBIR Rev. 1 database, copy WTWBIR.EXE to a convenient directory on your hard disk, go to the directory containing WTWBIR.EXE, type WTWBIR and press the enter key. The database should be expanded into the directory. The directory should now contain WTWBIR.EXE, WTWBIR1.MDB, WTWBIR1.LDB, WTWBIR.HLP, REPORTS.MDB, and REPORTS.LDB. WTWBIR.HLP contains the data field descriptions. This procedure can be performed either in DOS, a DOS prompt in Windows or from File Manager in Windows. Enter Windows and start Access, and open the WTWB!R_1 or REPORTS database. See the Access User's Manual in case of difficulty.

WTWBIR_1 INSTRUCTIONS: The WTWBIR Rev. 1 database has a built-in program (a macro called "autoexec") which takes control immediately upon opening the database file. It brings up a screen from which the user can view, edit, and locate various waste streams using the normal Access 2.0 tool bar features. In addition, a large printer icon button appear midway down the left side of the screen. This button affords the user the opportunity of printing the waste stream being viewed, waste streams for a specific site, or waste streams for all sites in the database. Scroll bars are provided to scroll between waste streams at the bottom left of the screen. For a given waste stream, the gray section contains waste container data for the various containers used to store this stream, and a scroll bar is provided in the bottom left to scroll among the types of containers for that waste stream. For a given type of container, the typical nuclides for that type of container are listed in a white area inset into the gray and a scroll bar provided.

Mirroring the contraction of the view screen, the WTWBIR data table set consists of the main table, Page_1, which contains site and stream data applicable to all container types used for the stream. Using the waste stream identification code (WIPP_ID) as a key, container-specific data in the Container_Data data table is related to the Page._1 table. Where radionuclides exist in a waste stream, they are listed in the Nuclides table and related to the Container_Data using record counters. For mixed streams, another data table, EPACodes, is related from Page_1's MWIR_ID field to EPACodes' UNIQUE_WS field. This structure affords a considerable savings in database size and is implemented in Access in such a way that they effectively function as one large, compact table.

Descriptions of the data fields can be viewed by opening the desired data table in Access's Table Mode, Design View. If the WTWBIR_1.HLP file was copied into the directory occupied by the WTWBIR database files, limited descriptions of the data fields in the WTWBIR database are available when you place the cursor in a data box and then press the F1 function key.

\section{Reports Instructions:}

Open the database REPORTS.MDB. An "autoexec" macro executes when the database opens. This macro presents a form, titled "Figure and Table Viewer", listing the reports available for viewing. 
The reports and tables available for review are listed with a number on the left side. There should be eleven entries. If all entries cannot be seen, the scrolling arrows on the right side of the form can be used to scroll the entries. On the bottom of the form is a series of buttons numbered 1 to 11. Each form can be viewed (in report preview mode) by clicking on the command button with the same number as the number to the left of the list of figures and tables.

When the table appears on screen, the size of the window for viewing the table can be adjusted by clicking on the upper right corner up or down arrow in the report window. The report preview window also permits moving between pages of multi-page sets of figures and tables by using the arrows on the lower left comer.

The table or figure can be printed from the report preview window. The tales and figures were originally printed from and formatted for a Laserjet III. When printing the tables and figures, make sure the margins are set so that the entire table or figure is contained on one page, other wise blank pages may be printed.

The first 8 tables and figures are the same as the tables and figures printed in volume 1 and Appendix $B$ of this report. The figure and table numbers listed are the same as the figure and table numbers in the report. Figures number 9 and 10 show the average material parameters by site for contact handled and remote handled waste. These figures were not used in the report. The last table shows the estimated WIPP packaging material parameters. These numbers are also presented on Tables 5-1 and 5-2 in this viewer and in Volume 1 of the report.

\subsection{WTWBID QUALITY CONTROL}

To ensure that proper controls and documentation were in place during development and population of the WTWBID, several quality control activities were implemented by the WTWBIR Team. Project quality control objectives were to:

- Define a method for receiving, tracking, reviewing, updating, and documenting data received from the waste generator/storage sites.

- Identify and document the contents of each project baseline.

- Establish and implement a process for releasing and maintaining the WTWBID.

- Create a master library for WTWBID software and documentation.

- Ensure that WTWBID-generated reports and database copies are produced from released database revisions.

The activities performed to meet these objectives are described in the Waste Isolation Pilot Plant Baseline Inventory Report Database Management Procedure (DOE, 1995). The procedure identifies the responsible individuals and required actions for developing, populating, and maintaining the WTWBID, and for managing the data used to produce the WTWBIR and other summary documents. 
CHAPTER 8

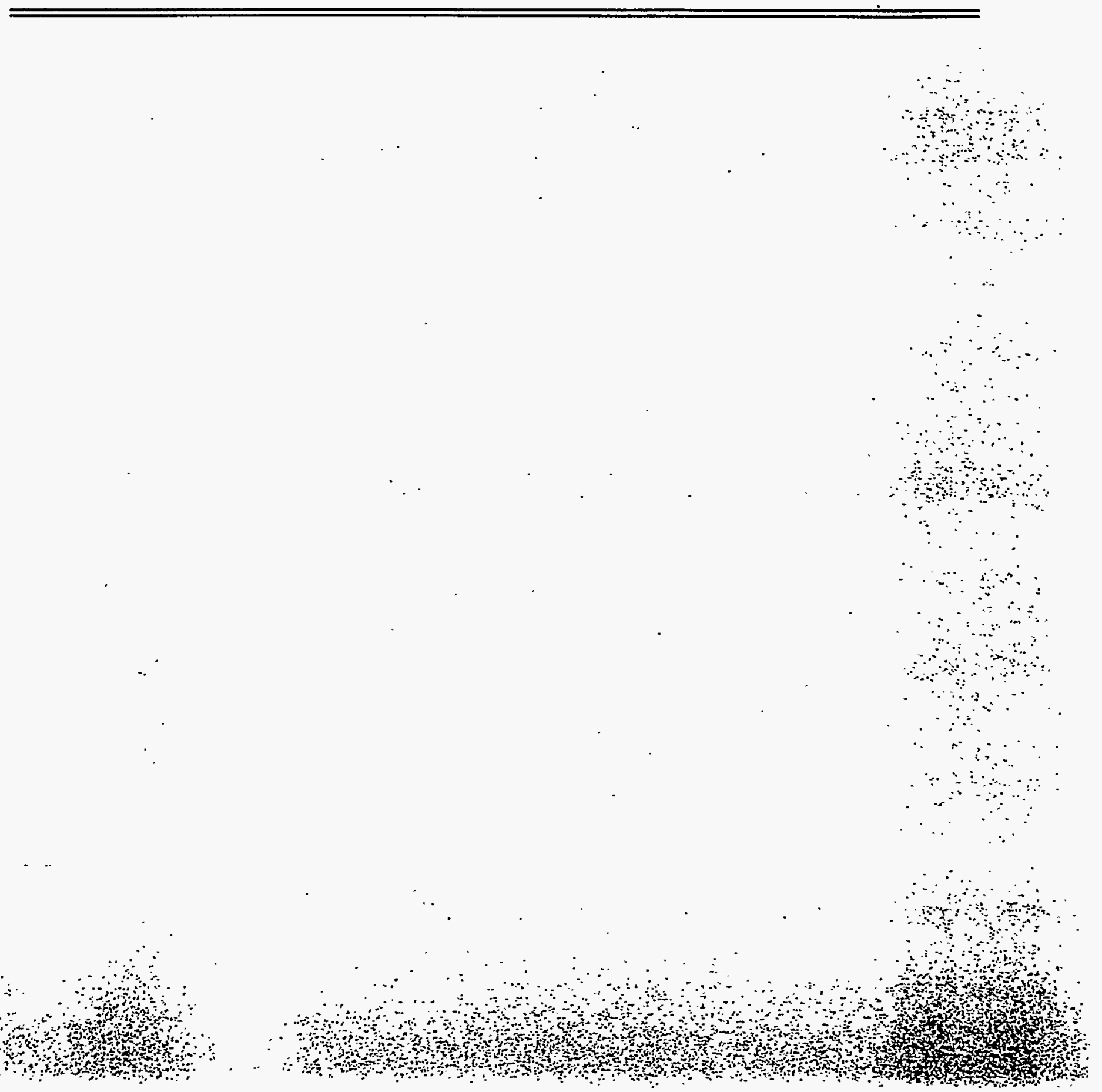




\section{GLOSSARY}

40 CFR Part 191, Protection of Environment. EPA: Environmental Radiation Protection Standards for Management and Disposal of Spent Nuclear Fuel, High-Level and TRU Radioactive Wastes - The EPA's environmental standards for the storage (Subpart A) and disposal (Subpart B) of spent nuclear fuel, and high-level and TRU radioactive wastes. This is the primary post-closure standard that applies to WIPP. It limits annual radiation doses to the public from waste management storage and disposal facilities.

40 CFR Part 268, Protection of Environment. EPA: Land Disposal Restrictions - Restricts the land disposal of all hazardous wastes and specifies strict treatment standards that must be met before these wastes can be land-disposed.

Americium (Am) - A TRU radionuclide having an atomic number of 95, containing 95 electrons and 95 protons. Am-241 (half-life $432.7 \mathrm{y}$ ) results from the decay of Pu-241 (half-life $14.4 \mathrm{y}$ ). Waste initially rich in Pu-241 will therefore "grow" in Am-241 for several decades as the Pu decays. Am-241 exists in finite amounts in TRU waste at some DOE sites.

Anticipated Inventory - The sum of the stored and projected inventories, as defined in this document.

Buried Waste - TRU waste buried in shallow trenches prior to the 1970 Atomic Energy Commission policy that required TRU waste to be retrievably stored.

Californium (Cf) - A TRU element having an atomic number 98 (the number of protons in the nucleus). An alpha emitter (half-life $2.64 \mathrm{y}$ ), Cf-252 also spontaneously fissions, thus making it desirable as a neutron source. C $\mathrm{C}-252$ is created by neutron bombardment of $\mathrm{Cm}-244$ targets. OR is the only production agency for Cf. As a result, the OR inventory is the only TRU waste inventory showing finite quantities of this element.

Code of Federal Regulations (CFR) - (1) A codification of the general and permanent rules published in the Federal Register by the department and agencies of the federal govemment. The CFR is divided into $\mathbf{5 0}$ titles that represent broad areas subject to federal regulation. It is issued quarterly and revised annually. (2) All federal regulations in force are published annually in codified form in the CFR.

Contact-Handled (CH) TRU Waste - Packaged TRU wastes with an extemal surface dose rate of 200 mrem or less per hour.

Curie - A quantitative measure of radioactivity equal to $3.7 \times 10^{10}$ disintegrations per second.

Curium (Cm) - A TRU element having an atomic number of 96 (the number of protons in the nucleus). An alpha emitter (half-life $18.1 \mathrm{y}$ ), $\mathrm{Cm}-244$ is used for neutron bombardment of targets for the production of $\mathrm{Cf}-252$ at OR. In spite of its half-life being less than 20 years, OR considers and handles Cm-244 as a TRU nuclide. Some TRU waste at both OR and SR contains Cm-244. 
Decontamination and Decommissioning (D\&D) - The process through which DOE facilities which are no longer operational are cleared of contamination and removed from service. In particular, a reference to D\&D waste is a reference to the waste materials that are generated during D\&D activities.

Defense Waste - (1) Radioactive waste from any activily performed in whole or in part in support of DOE atomic energy defense activities; excludes waste under purview of the Nuclear Regulatory Commission or generated by the commercial nuclear power industry. (2) Nuclear waste derived mostly from the manufacture of nuclear weapons, weapons-related research programs, the operation of naval reactors, and the decontamination of production facilities.

Department of Energy Site - A DOE-owned or -controlled tract used for DOE operations. Either a tract owned by DOE or a tract leased or otherwise made available to the federal govemment under terms that afford to DOE rights of access and control substantially equal to those that DOE would possess if it were the holder of the fee (or pertinent interest therein) as agent of and on behalf of the government. One or more DOE operations/program activities are carried out within the boundaries of the described tract.

Design Capacity - The planned waste capacity of the Waste Isolation Pilot Plant.

Disposal - Emplacement of waste in a manner that assures isolation from the biosphere for the foreseeable future with no intent of retrieval and that requires deliberate action to regain access to the waste. For example, disposal of wastes in a mined geologic repository occurs when all of the shafts to the repository area are backfilled and sealed.

Disposal Inventory - The total inventory defined for WIPP emplacement (after scaling) to be used for SPM and PA calculations.

Environmental Restoration (ER) - Those activities associated with the remediation of sites contaminated with hazardous and/or radioactive materials. In particular, a reference to remediation activities conducted under the auspices of the DOE Office of Environmental Restoration and Waste Management, Office of Environmental Restoration, EM-40.

Federal Facility Compliance Act (FFCAct) - Public law 102-386, 1992.

Gas Production - Three gas generation processes are expected to be a factor in the degradation of TRU wastes in the WIPP repository. The generation of gaseous species is expected to occur through chemical (i.e., corrosion), microbial, and radiolytic processes.

Generator/Storage Sites - See Waste Generator/Storage Sites.

Hazardous Waste - Those wastes that are designated hazardous by EPA (or state) regulations through the RCRA.

Integrated Data Base (IDB) - The latest version of the IDB, the Integrated Data Base for [CY]: U.S. Spent Fuel and Radioactive Waste Inventories, Projections, and Characteristics (DOE, 1994b) 
Mixed TRU Waste - TRU waste that contains both radioactive and hazardous components as defined by the Atomic Energy Act and the RCRA as codified in 40 CFR Parts 263, 265, 268, and 270 (EPA, 1980a; 1980b; 1986; and 1983).

Mixed Waste Inventory Report (MWIR) - The latest release of information from the MWIR database that supports requirements under the FFCA of 1992 (Public Law 102-386). The latest version of the MWIR documentation/files is Distribute of Phase II Mixed Waste Inventory Report Data, dated May 17, 1994 (DOE, 1994a). This information replaces the Phase I MWIR release (DOE, 1994c).

Newly Generated Wastes - See Projected Inventory.

No-Migration Variance Petition (NMVP) - Section 3004 of RCRA allows EPA to grant a variance from the land disposal restrictions when a determination can be made that, to a reasonable degree of certainty, there will be no migration of hazardous constituents from the disposal unit for as long as the waste remains hazardous. Specific requirements for making this demonstration are found in 40 CFR 268.6, and EPA has published a draft guidance document to assist petitioners in preparing a variance request.

Non-Mixed TRU Waste - Transuranic waste that does not contain hazardous constituents or exhibit hazardous characteristics, as identified in 40 CFR 261, Subparts C and D.

Performance Assessment (PA) - (1) A systematic analysis of the potential risks posed by waste management systems to the public and environment and a comparison of those risks to established performance objectives. (2) An analysis that (a) identifies the processes and events that might affect the disposal system, (b) examines the effects of these processes and events on the performance of the disposal system, and (c) estimates the cumulative releases of radionuclides, considering the associated uncertainties, caused by all significant processes and events. These estimates shall be incorporated into an overall probability distribution of cumulative release to the extent practicable. (3) A term used to denote all activities (qualitative and quantitative) carried out to (a) determine the long-term ability of a site/facility. to effectively isolate the waste and ensure the long-term health and safety of the public and (b) provide the basis for demonstrating regulatory compliance.

Plutonium (Pu) - A radionuclide having an atomic number of 94. Pu isotopes exist in some TRU waste at all the major DOE storage facilities. The significant isotopes that may exist in measurable quantities at these facilities are Pu-238 through Pu-242. Each isotope is an alpha emitter, the respective half-lives in years are: $238=87.7,239=24,000,240=6,563,241=14.4$, $242=376,000$. Because of its high activity, Pu-238 can contribute significantly to the thermal loading on some TRU waste. Pu-241 decays, primarily by beta emission, to Am-241.

Process Knowledge - A qualitative evaluation of the contents of a waste container through the study of existing records of production history of the waste.

Projected Inventory - That part of the inventory that has not been generated but is estimated to be generated at some time in the future by the TRU waste generator/storage sites. The estimated timeframe may vary, but is usually between 20 and 30 years. "Newly generated waste" also is sometimes used as a synonym for the projected inventory. 
Radioactive - The emission of radiation from unstable atomic nuclei.

Radionuclide - (1) A species of atom having an unstable nucleus, that is subject to spontaneous decay or disintegration and usually accompanied by the emission of ionizing radiation. (2) Any nuclide that emits radiation. A nuclide is a species of atom characterized by the constitution of its nucleus and hence by the number of protons, the number of neutron, and the energy content.

Remote-Handled (RH) TRU Waste - Packaged TRU wastes with an external surface dose rate exceeding 200 mrem per hour.

Repository - Designated location for disposal of transuranic wastes; the Waste Isolation Pilot Plant.

Resource Conservation and Recovery Act (RCRA) - (1) Establishes a system for controlling hazardous waste from generation to disposal. (2) A Federal law passed in 1976, and amended under the HSWA of 1984, that established a structure to track and regulate hazardous wastes from the time of generation to disposal. The law requires safe and secure procedures to be used in treating, handling, transporting, storing, and disposing of hazardous substances. RCRA is designed to prevent new uncontrolled hazardous waste sites. The law also regulates the disposal of solid waste that may not be considered hazardous. (3) Specifically, Subtitle D of RCRA govems the management of solid waste. (Note: 40 CFR Parts 260-281 are the regulations for complying with RCRA with respect to hazardous waste and hazardous waste treatment, storage, and disposal facilities.)

Retrievable Storage - Designated storage location for transuranic wastes that is designed, operated, and maintained in such a manner that the wastes remain accessible for subsequent retrievable operations.

Scaling - The process for adjusting the anticipated inventory to the design limit (disposal inventory) of the WIPP repository.

Site-Specific Waste Profile - Represents a WMCG at a particular DOE TRU waste generator/storage site. That is, one or more waste stream profiles, at a particular DOE TRU waste site, that have been placed in the same WMCG are summarized in the site-specific waste profile.

Stakeholders - Those persons and/or groups of people and organizations who are affected or perceive they are affected by the DOE waste management program. Stakeholders include DOE management, employees, and contractors (intemal); and executive, legislative, and regulatory groups, public representatives, the general public, intervenor groups, special interest groups, contractors, suppliers, and universities (external).

Stored Inventory - That part of the TRU inventory currently in retrievable storage as of the time of the last data call for inventory information. Retrievably stored waste includes waste stored in buildings or in berms with earthen cover since 1970 and does not include any waste that was buried prior to 1970 . 
System Prioritization Methodology (SPM) - The SPM is a process formulated to identify a set of activities (required experiments, modeling, engineering design, and waste acceptance criteria) that will lead to regulatory compliance. The process is formulated such that it also: (1) addresses stakeholder and regulator concerns early and throughout the regulatory process and (2) leads to a fully defensible performance assessment to be used in demonstrating regulatory compliance. Ultimate products and associated customers are:

(1) A decision matrix containing the most likely sets of activities that will lead to compliance as a function of time and budget to be delivered to the WIPP program manager,

(2) A performance assessment built on assumptions and data that are defensible in the eyes of the stakeholders and the regulators to be delivered to the regulatory compliance branch of Carisbad Area OfficeMIPP through the Westinghouse Waste Isolation Division and ultimately to the EPA, and

(3) A set of regulatory issues and their current status that result from the SPM process and are to be included in compliance packages by the Westinghouse Waste Isolation Division.

Thorium (Th) - A radionuclide having an atomic number of 90. Although not TRU; Th-232 is an alpha emitter (half-life 14 billion years) and exists in finite amounts in some TRU waste at HA, IN, and OR. [Note: Thorium is naturally occurring and contributes to background radiation at some sites (e.g., IN)]

Transuranic - Pertaining to elements that have atomic numbers greater than 92 , including neptunium, plutonium, americium, and curium; all are radioactive, are products of artificial nuclear changes, and are members of the actinide group.

Transuranic (TRU) Waste - (1) Waste containing alpha-emitting radionuclides with an atomic number greater than 92 and half-lives greater than 20 years, at concentrations of TRU isotopes greater than 100 nanocuries per gram of waste. This core definition appears in modified form in various relevant documents as follows: (a) For purposes of management, DOE Order 5820.2A: (i) considers TRU waste, as defined above, "without regard to source or form" (The proposed revision to the Order [DOE Order 5820.2A Major Issues for Revision, May 6, 1992] contemplates removing this clause); (ii) allows head of field elements to determine that wastes containing other alpha-emitting radionuclides must be managed as TRU waste; and (iii) adds "at time of assay," implying both that the classification of a waste as TRU waste is to be made based on an assay, and that such classification can be superseded only by another assay. (b) For purposes of setting standards for management and disposal, 40 CFR 191.02(i) adds "except for: (i) high-level wastes; (ii) wastes that the DOE has determined, with the concurrence of the EPA Administrator, do not need the degree of isolation required by this part; or (iii) wastes that the Nuclear Regulatory Commission has approved for disposal on a case-by-case basis in accordance with 10 CFR 61. (2) Waste materials contaminated with U-233 (and its daughter products), with certain isotopes of plutonium, or with other nuclides with atomic numbers greater than 92. In order to be classified as TRU waste, the long-lived alpha activity from subject isotopes must exceed 100 nanocuries per gram of waste material and from the use of plutonium in the fabrication of nuclear weapons. (3) Wastes that are contaminated with radioactive elements heavier than uranium, thus the name trans-(or beyond) uranic.

TRUCON - See TRUPACT-II Content Code. 
TRUPACT-II Content Codes (TRUCON) - The document containing a description of the waste stream, waste form, and package configuration for each waste content code authorized for shipment in TRUPACT-II containers.

Unknown Waste Stream - Those waste streams for which there is insufficient process knowledge to assign a specific WMC.

Uranium (U) - A naturally radioactive element with the atomic number of 92 (number of protons in the nucleus) and an atomic weight of approximately 238. The two principal naturally occurring isotopes are the fissionable U-235 (0.7 percent of natural uranium) and the fertile U-238 (99.3 percent of natural uranium). (Note: An alpha emitter [half-life 159,000 y], U-233 also spontaneously fissions; it is present in finite quantities in some TRU waste inventories at INEL and ORNL.)

Waste Acceptance Criteria (WAC) - The criteria used to determine if waste packages are acceptable.

Waste Form - The physical form of the waste such as sludges, combustibles, metals, etc.

Waste Generator/Storage Sites - The 10 largest DOE facilities and several smaller sites throughout the U.S. that produce and store TRU waste.

Waste Isolation Pilot Plant (WIPP) - (1) The project authorized under Section 213 of the DOE National Security and Military Applications of Nuclear Energy Authorization Act of 1980 (Public Law 96-164; 93 Stat. 1259, 1265) to demonstrate the safe, and environmentally sound, disposal of radioactive waste materials generated by atomic energy defense activities. (2) A research and development facility, located near Carlsbad, New Mexico, to be used for demonstrating a practical, long-term solution to a complex problem: the safe disposal in deep geologic repositories of TRU waste resulting from DOE activities. (3) The WIPP has two primary objectives. First, the WIPP is investigating the behavior of salt rock and interactions between the salt rock and radioactive wastes in a variety of forms. Second, the WIPP seeks to demonstrate the safe and efficient handling, transportation, and disposal of TRU waste in an actual facility.

Waste Material Parameter - A waste material that occurs in TRU waste that is an input parameter into one or more current SPM or PA models, an SPM or PA model under development, a potential future model, or is required to adequately describe the waste form.

Waste Matrix Code (WMC) - A DOE-developed coding system for organizing waste streams by their physical and chemical properties. A WMC is assigned to each waste stream by the DOE TRU waste generator/storage site. The WMC for each waste stream can be found in the Mixed Waste Inventory Report (DOE, 1994a). This coding system allows waste streams within the DOE TRU waste system that have similar physical and chemical waste form properties to be categorized together. WMCs also have been called "waste treatability codes" in other DOE documents. Appendix $C$ contains the DOE guidance document to help categorize individual waste streams. An example of a WMC for "heterogeneous waste" would be 5400 .

Waste Matrix Code Group (WMCG) - Consists of a series of WMCs that for SPM or PA purposes has similar physical and chemical properties. 
Waste Stream - Individually, those stored or projected wastes that are defined by a unique identifier in the MWIR.

Waste Stream Name - A site-specific, unique descriptive identifier for a TRU waste stream.

Waste Stream Profile - A description of a CH-TRU or RH-TRU waste stream destined for shipment to and disposal in WIPP, if authorized under permits and certifications by appropriate regulatory agencies for disposal in the WIPP repository. The waste stream profile is presented in tabular format and is intended to provide a summary of the important information about a particular waste stream.

Waste Stream Site ID - A site-specific alphanumeric identification code which provides a unique identifier for an individual TRU waste stream.

WIPP Waste Profile - Represents a summary of TRU waste at all DOE TRU waste generator/storage sites that have an identical WMCG. 


\section{CHAPTER 9}

\section{-}




\section{REFERENCES}

DOE - See U.S. Department of Energy.

EG\&G Rocky Flats, 1994, Conceptual Design Report for Residue Elimination at Rocky Flats, RES-005-001, Volume IV.

EPA - See U.S. Environmental Protection Agency.

Nuclear Packaging, Inc., 1991, Safety Analysis Report for the TRUPACT-II Shipping Package, Revision 11, June 1991.

Public Law 102-386, 1992, Federal Facility Compliance Act of 1992.

Public Law 102-579, 1992, Waste Isolation Pilot Plant Land Withdrawal Act.

Sanchez, Larry, 1995, Personal Communication, SNLNM.

U.S. Department of Energy, 1995, NTPO Branch Procedure, Waste Isolation Pilot Plant Baseline Inventory Report Database Management," February 14, 1995.

U.S. Department of Energy, 1994a, Distribute of the Phase II Mixed Waste Inventory Report Data, memo from Patty Bubar to Distribution dated May 17, 1994, Washington, D.C. (includes data diskette [Version 1.00] the draft User's Guide for National Data Base System for the Final Mixed Waste Inventory Report [May, 1994] and Mixed Waste Inventory Report Data Base System User's Guide).

U.S. DOE, 1994b, Draft Integrated Data Base for 1994 (draft): U.S. Spent Fuel and Radioactive Waste Inventories, Projections, and Characteristics, DOE/RW-0006, Revision 10, December 22, 1994.

U.S. Department of Energy, 1994c, Release of Phase I Mixed Waste Inventory Report Data, memo from Patty Bubar to Distribution, dated April 1, 1994, Washington, D.C. (includes data diskette [Version .97B] and Mixed Waste Inventory Report Data Base System User's Guide).

U.S. DOE, 1994d, Integrated Data Base for 1993: U.S. Spent Fuel and Radioactive Waste Inventories, Projections and Characterization, Revision 9, April 1994.

U.S. Department of Energy, 1993a, Request for Collecting Data in Support of the Mixed Waste Inventory Report, Memorandum from Joseph A. Coleman, October 21, 1993, Exhibit A-6 [DOE Waste Treatability Group Guidance].

U.S. Department of Energy, 1993b, draft Resource Conservation and Recovery Act Part B Permit Application, Waste Analysis Plan, Revision 3, DOEMIPP 91-005.

U.S. Department of Energy, 1993c, U.S. Department of Energy Interim Mixed Waste Inventory Report: Waste Streams, Treatment Capacities and Technologies, 6 volumes, DOE/NBM-1100, April 1993. 
U.S. Department of Energy, 1992, TRUPACT-/l Content Codes (TRUCON), DOENWIPP 89-004, Revision 6.

U.S. Department of Energy, 1991, TRU Waste Acceptance Criteria for the Waste Isolation Pilot Plant, WIPP-DOE-069, Revision 4, December 1991.

U.S. Department of Energy, 1990, No-Migration Variance Petition, Volumes I through VIII, DOEWWIPP 89-011, Revision 1, Carlsbad, New Mexico.

U.S. Department of Energy, 1988, Radioactive Waste Management, DOE 5820.2A, U.S. Department of Energy, Washington, D.C.

U.S. Environmental Protection Agency, 1995, Criteria for Certification of Compliance with Environmental Radiation Protection Standards for the Management and Disposal of Spent Nuclear Fuel, High-Level, and Transuranic Wastes, 40 CFR 194, notice of proposed rulemaking, Federal Register, Vol. 58, Page 792, January 30, 1995.

U.S. Environmental Protection Agency, 1993, Environmental Radiation Protection Standards for the Management and Disposal of Spent Nuclear Fuel, High-Level and Transuranic Radioactive Wastes, 40 CFR 191, final rule, Federal Register, Vol. 58, Page 66398, December 20, 1993.

U.S. Environmental Protection Agency, 1986, Land Disposal Restrictions, 40 Code of Federal Regulations, Part 268.

U.S. Environmental Protection Agency, 1983, EPA Administered Permit Programs: The Hazardous Waste Permit Program, 40 Code of Federal Regulations, Part 270.

U.S. Environmental Protection Agency, 1980a, Interim Status Standards for Owners and Operators of Hazardous Waste Treatment, Storage and Disposal Facilities, 40 Code of Federal Regulations, Part 265.

U.S. Environmental Protection Agency, 1980b, Standards for Owners and Operators of Hazardous Waste Treatment, Storage and Disposal Facilities, 40 Code of Federal Regulations, Part 264.

WIPP Performance Assessment Division, 1993, Preliminary Performance Assessment for the Waste Isolation Pilot Plant, Volume 5: Uncertainty and Sensitivity Analyses of Gas and Brine Migration for Undisturbed Performance, SAND92-0700/5, Sandia National Laboratories, Albuquerque, New Mexico, August 1993. 


\section{Waste Isolation Pilot Plant Transuranic Waste Baseline Inventory Report}

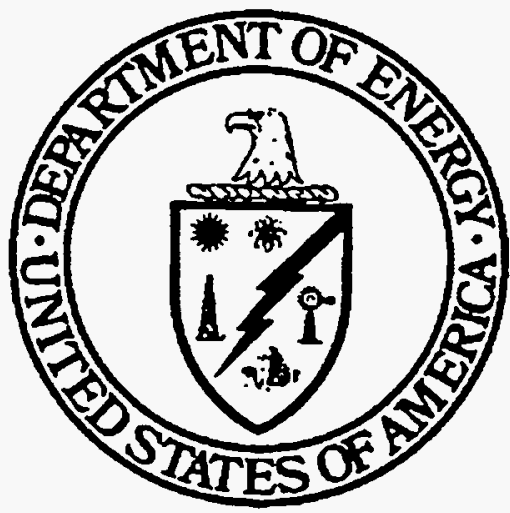

February 1995

Prepared by WIPP Technical Assistance Contractor for U.S. Department of Energy under Contract No. DE-AC04-93AL-96904 


\section{APPENDIX A}

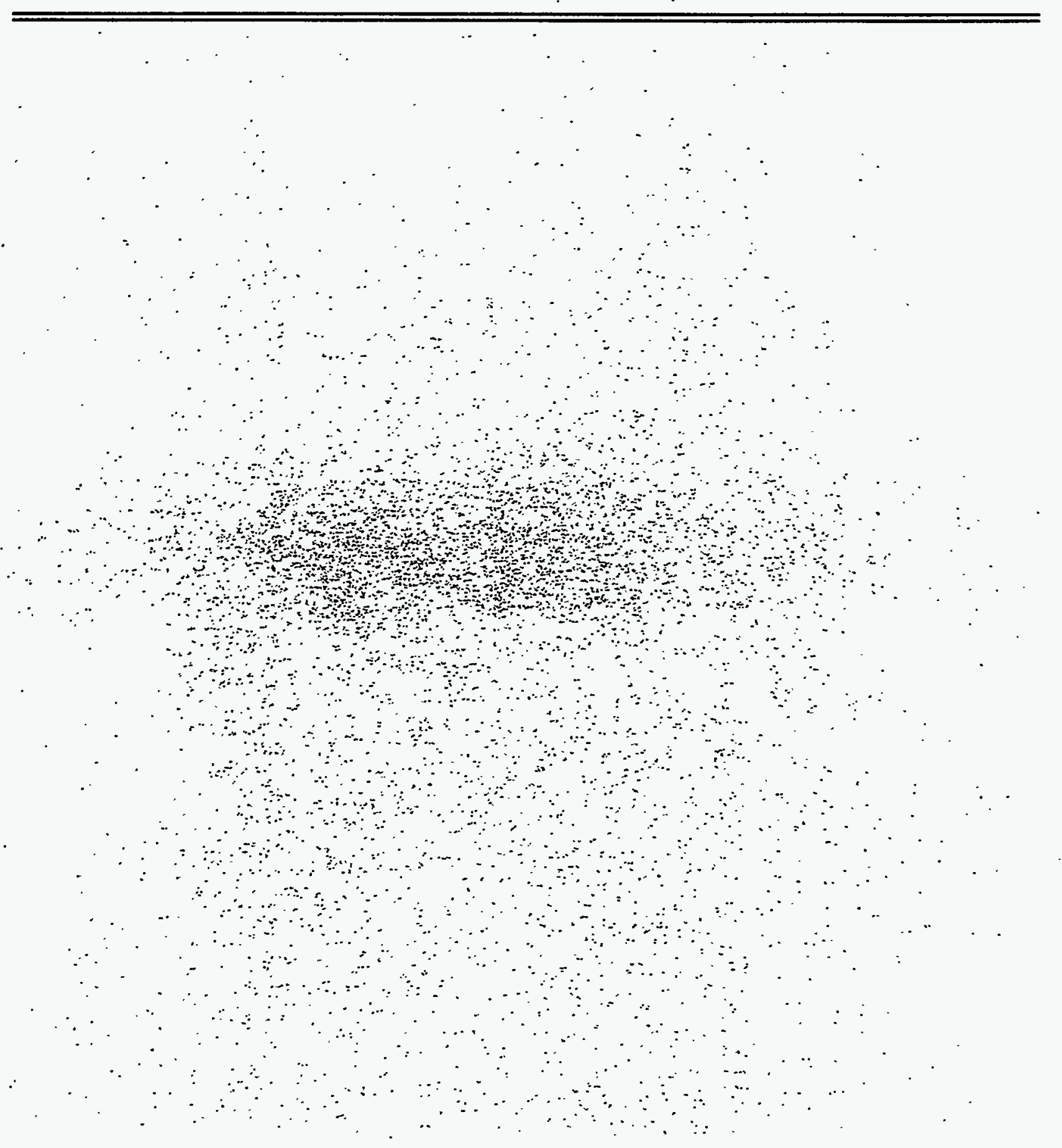


Ames Laboratory 


\title{
APPENDIX A \\ WASTE STREAM PROFILES
}

\author{
AMES LABORATORY (AL) \\ WASTE STREAM PROFILES
}

The following modifications were made by the WTWBIR team in developing the AL waste stream profiles:

- AL Final Waste Form Groups were modified to be consistent with the nomenclature used in the WTWBID. These changes included word and spelling changes. The assigned Final Waste Form Groups are consistent with the information provided by AL.

- A data entry error was made on the original form for the number of containers stored at $A L$. This error was corrected.

- The projected volumes reported by AL were not distributed to individual years. Based on the footnotes provided by AL, these volumes were distributed by the WTWBIR team for both current and final form volumes for the years 2003-2022.

- The volume of the final waste form assumes a 2.5 volume expansion factor for solidification. 


\section{WASTE STREAM PROFILE FOR THE WIPP TRU WASTE BASELINE INVENTORY REPORT}

SITE NAME AL

WASTE TYPE MTRU HANDLING CH GENERATOR SITE AL

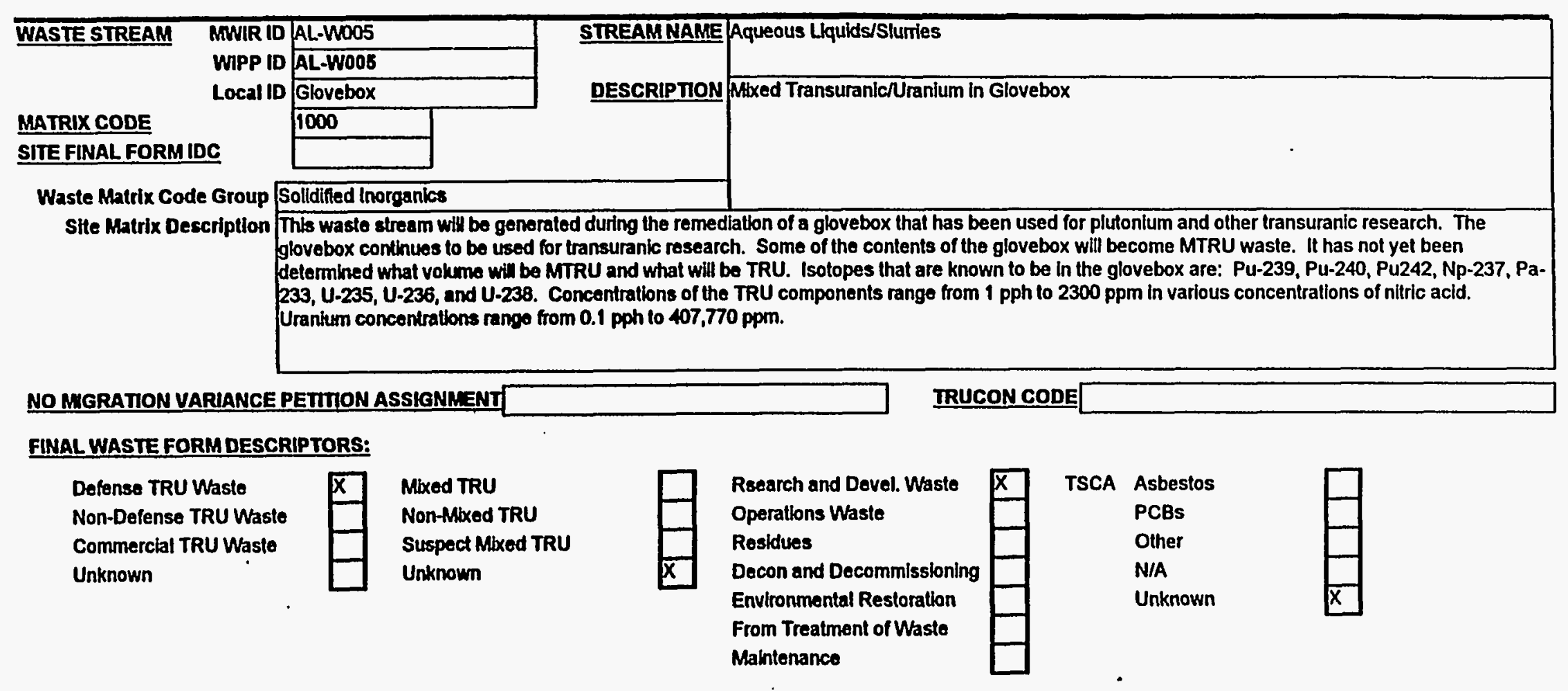




\section{WASTE STREAM PROFILE FOR THE WIPP TRU WASTE BASELINE INVENTORY REPORT}

SITE NAME AL

\section{WASTE TYPE MTRU HANDLING CH GENERATOR SITE AL}

AL-W005 $\quad \frac{\text { CONTAINER: Drum }}{\text { Type/Size: }}$

Contalner Matt: Steol Int. Volvetnr:
Number Stored

Number Projected

TYPICAL WASTE DENSITIES FOR FINAL WASTE FORM (kg/m3)

\section{Material Parameters}

Iron-based Melals/Alloys

Aluminum-Based Metals/Alloys

Other Metals

Othar Inorganic Materials

Cellulosics

Rubber

Plastics

Solidified, Inorganic malibx Solidified, Organic matrix

Soils

Packaging Materials, Steol

Packaging Matertal, Plastlo

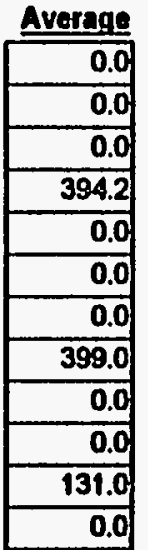

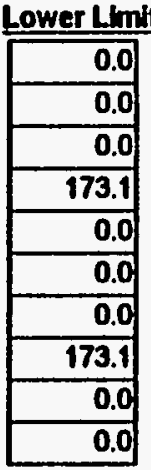

Upper Limh

Comments

\section{Assumptions:}

1. Transuranic waste will be generaled through research and development. The

isolopes are currently housed in a glovebox with the approprtate HEPA thers.

2. TRU waste with only be generated when the research project is comptete or

when the filters are replaced. Therefore, there will be no TRU waste generation

until CY2004 at the earliest.

3. Ames Laboratory plans to utilize the storage services of Hanford for TRU waste pending the opening of WiPP.
STORED TRU WASTE ESTIMATED RATES OF WASTE GENERATION

\begin{tabular}{|c|c|c|c|}
\hline & Prolected & Final Form & \\
\hline id of 1992: & $\overline{0.000}$ & 0.000 & $\mathrm{m3}$ \\
\hline Id of 1983: & 0.000 & 0.000 & m3 \\
\hline 1984: & 0.000 & 0.000 & $\mathrm{~m} 3 / y r$ \\
\hline 1985: & 0.000 & 0.000 & m3/yr \\
\hline 1998: & 0.000 & 0.000 & $\mathrm{~m} 3 / y r$ \\
\hline 1997: & 0.000 & 0.000 & $m 3 / y$ \\
\hline 8-2002: & 0.000 & 0.000 & $\mathrm{~m} 3 / y r$ \\
\hline $103-202$ & 0.005 & 0.005 & $\mathrm{~m} 3 \mathrm{hr}$ \\
\hline
\end{tabular}

IYPLCAL EPA CODES APPLKABLLE

D002B

D004A

D005A

D006A

D007A

D008A

D010A

DO11A
TYPICAL ISOTOPIC COMPOSITION

\section{Nuclide Activily}

Np237 4.00E-03 Curies/m3

Pu239 7.70E-02 Curies $/ \mathrm{m3}$

Pu242 5.30E-03 Curles $/ \mathrm{m}^{3}$

U235 1.70E-05 Curies $/ \mathrm{m3}$

U238 5.60E-10 Curies $/ \mathrm{m} 3$ 
Argonne National Laboratory - East 


\section{ARGONNE NATIONAL LABORATORY-EAST (AE) \\ WASTE STREAM PROFILES}

The following modifications were made by the WTWBIR team in developing the AE waste stream profiles:

- AE Final Waste Form Groups were modified to be consistent with the nomenclature used in the WTWBID. These changes included word and spelling changes. The assigned Final Waste Form Groups are consistent with the information provided by $A E$.

- The volumes for the year 1993 were changed from an annual rate of generation ( $\mathrm{m}^{3} / \mathrm{year}$ ) to a cumulative value $\left(\mathrm{m}^{3}\right)$.

- A data entry error was made on the original form for the number of containers stored at AE. This error was corrected. 
WASTE STREAM PROFILE FOR THE WIPP TRU WASTE BASELINE INVENTORY REPORT

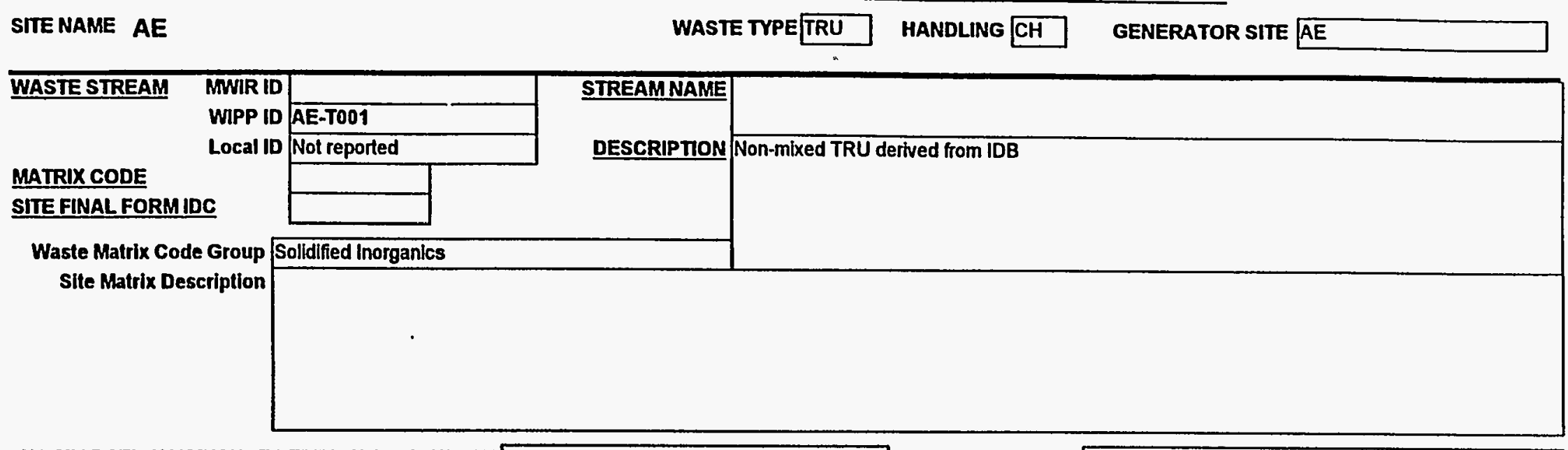

NO MGRATION VARIANCE PETIION ASSIGNMENT $\square$ IRUCON CODE

\section{FINAL WASTE FORM DESCRIPTORS:}

Defense TRU Waste

Non-Defense TRU Waste

Commercial TRU Waste

Unknown

$\square$

Mxed TRU

Non-Mlixed TRU

Suspect Mixed TRU

Unknown

$\square$

\begin{tabular}{ll|} 
TSCA Asbestos & \\
PCBs & \\
Other & \\
N/A & \\
Unknown &
\end{tabular}

From Treatment of Waste

Maintenance

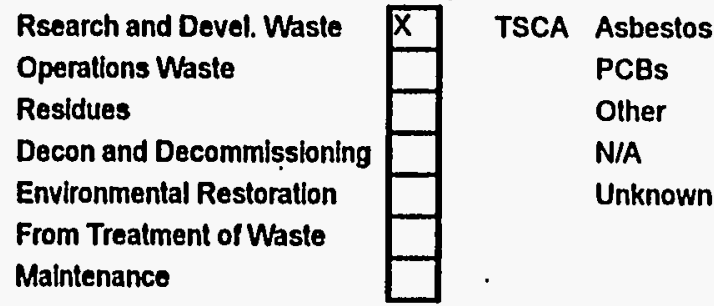




\section{WASTE STREAM PROFILE FOR THE WIPP TRU WASTE BASELINE INVENTORY REPORT}

AE-T001 CONTAINER: Drum

Type/Size: 55-gallon

Container Matt: Steel

Liner Type:

Liner Material:

IYPICAL WASTE DENSITIES FOR FINAL WASTE FORM $(\mathrm{kg} / \mathrm{m} 3)$

STORED TRU WASTE ESTIMATED

Material Parameters

Iron-based Metals/Alloys

Aluminum-Based Metals/Alloys

Other Metals

Other Inorganic Materials

Cellulosics

Rubber

Plastics

Sollidified, Inorganic matrix

Solidified, Organke matrix

Solls

Packaging Materials, Steel

Packaging Material, Plastic

\begin{tabular}{|r|}
\hline Average \\
\hline 0.0 \\
\hline 0.0 \\
\hline 0.0 \\
\hline 101.0 \\
\hline 0.0 \\
\hline 0.0 \\
\hline 0.0 \\
\hline 216.3 \\
\hline 0.0 \\
\hline 0.0 \\
\hline 131.0 \\
\hline 0.0 \\
\hline
\end{tabular}
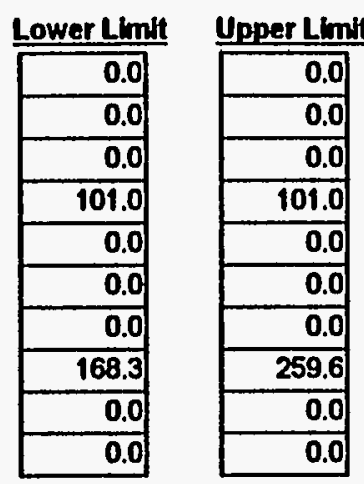
RATES OF WASTE GENERATION

\section{Comments}

Hanford, WA ette data Includes ANI-E waste forecast data for years 1995 throligh 2022. ANL-E has heluded the requested data in tis forecast to Hanford and reporting this data separately would resull in double counting of waste volumes. ANL-E plans to ship this waste to Hanford provided projects are funded,

Storage/Disposal Approval Requests are approved, estimated waste volumes are actually generated, regulations allow shipment, etc.. during that time period.

\begin{tabular}{r|r|}
\hline End of 1992: & Prolected \\
\hline End of 1993: & 17.4 \\
\hline $1994:$ & 18.0 \\
\hline $1995:$ & 0.6 \\
\hline $1996:$ & 0.0 \\
\hline $1997:$ & 0.0 \\
\hline $1988-2002:$ & 0.0 \\
\hline $2003-2022:$ & 0.0 \\
\hline 0.0 \\
\hline
\end{tabular}

\begin{tabular}{|r|l|}
\hline Final Form & \\
\hline 17.4 & $\mathrm{m3}$ \\
\hline 18.0 & $\mathrm{m3}$ \\
\hline 0.6 & $\mathrm{~m} 3 / y \mathrm{r}$ \\
\hline 0.0 & $\mathrm{~m} 3 / \mathrm{yr}$ \\
\hline 0.0 & $\mathrm{~m} 3 / \mathrm{yr}$ \\
\hline 0.0 & $\mathrm{~m} 3 / \mathrm{ry}$ \\
\hline 0.0 & $\mathrm{~m} 3 / \mathrm{yr}$ \\
\hline 0.0 & $\mathrm{~m} 3 / \mathrm{yr}$ \\
\hline
\end{tabular}

TYPICAL EPA CODES APPLICABLE
Number Stored:

Number Projected:

IYPICAL ISOTOPIC COMPOSITION

Nuclide Activity

Am241 2.13E+00 Curies $/ \mathrm{m} 3$

Am243 4.00E-02 Curies $/ \mathrm{m}^{3}$

Np237 6.43E-03 Curies/m3

Pu238 4.07E-06 Curies $/ \mathrm{m}^{3}$

Pu239 1.17E+00 Curies/m3

Pu241 6.10E-01 Curies/m3

U233 1.20E-09 Curies $/ \mathrm{m3}$

U235 2.50E-05 Curies/m3

U238 2.24E-05 Curies/m3 
WASTE STREAM PROFILE FOR THE WIPP TRU WASTE BASELINE INVENTORY REPORT

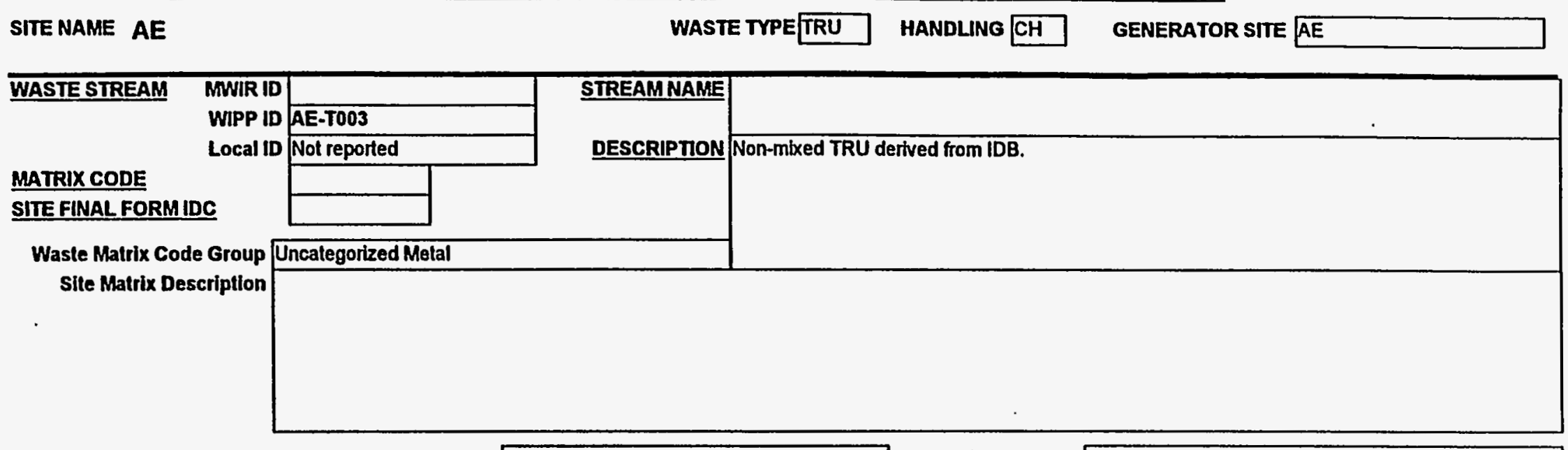

\section{NO MGRATION VARIANCE PETIMON ASSIGNMENT IRUCON CODE}

\section{FINAL WASTE FORM DESCRIPTORS:}

Defense TRU Waste

Non-Defense TRU Waste

Commercial TRU Waste

Unknown

X

Mixed TRU

Non-Mixed TRU

Suspect Mixed TRU

Unknown

Rsearch and Devel. Waste
Operations Waste
Resldues
Decon and Decommissioning
Environmental Restoration
From Treatment of Waste
Malntenance

TSCA Asbestos

PCBs

Other

N/A

Unknown 


AE-T003 CONTAINER: Drum

TYPICAL WASTE DENSITIES FOR FINAL WASTE FORM (kg/m3)

\section{Material Parameters}

Iron-based Metals/Alloys

Aluminum-Based Metals/Alloys

Other Metals

Other Inorganic Materials

Cellulosics

Rubber

Plastics

Solldified, Inorganic matrix

Solldifiad, Organic matrix

Solls

Packaging Materiaks, Steel

Packaging Material, Plastic

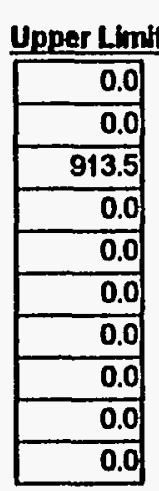

Container Matl: Steel Liner Type:
Int. VolvCinr: $0.208 / \mathrm{m} 3$

Number Stored: Number Projected:

STORED TRU WASTE ESTIMATED RATES OF WASTE GENERATION

\begin{tabular}{|c|c|c|c|}
\hline & Prolected & Final Form & \\
\hline d of 1992: & 4.4 & 4.4 & m3 \\
\hline of 1993: & $\overline{5.0}$ & 5.0 & m3 \\
\hline 1894: & $\overline{0.6}$ & 0.6 & $\mathrm{~m} 3 / \mathrm{y}$ \\
\hline 1995: & 0.0 & 0.0 & $\mathrm{~m} 3 / \mathrm{y}$ \\
\hline 1896: & 0.0 & 0.0 & $\mathrm{~m} 3 / \mathrm{yl}$ \\
\hline 1987: & 0.0 & 0.0 & $\mathrm{~m} 3 / \mathrm{ry}$ \\
\hline$-2002:$ & 0.0 & 0.0 & $\mathrm{~m} 3 / \mathrm{yl}$ \\
\hline 03-2022: & 0.0 & 0.0 & \\
\hline
\end{tabular}

IVPICAL EPA CODES APPLICABLE
TYPICAL ISOTOPIC COMPOSITION

\section{Nuclide Activily}

Am241 2.13E+00 Curles/m3

Am243 4.00E-02 Curies $/ \mathrm{m} 3$

Np237 6.43E-03 Curies/m3

Pu238 4.07E-06 Curies $/ \mathrm{m} 3$

Pu239 1.17E+00 Curies $/ \mathrm{m}^{3}$

Pu241 6.10E-01 Curies/m3

U233 1.20E-09 Curles $/ \mathrm{m}^{3}$

U235 2.50E-05 Curies $/ \mathrm{m3}$

U238 2.24E-05 Curies/m3

\section{Comments}

Hanford, WA site data includes ANL-E waste forecast data for years 1995 througin 2022. ANL-E has included the requested data in its forecast to Hanford and reporting this data separately would resulk in double counting of waste volumes. ANL-E plans to ship this waste to Hanford provided projects are funded,

Storage/DIsposal Approval Requests are approved, estimated waste volumes are

actually generated, regulations allow shipment, etc. during that time period. 


\section{WASTE STREAM PROFILE FOR THE WIPP TRU WASTE BASELINE INVENTORY REPORT}

\section{SITE NAME AE \\ WASTE TYPE MTRU HANDLING CH \\ GENERATOR SITE AE}

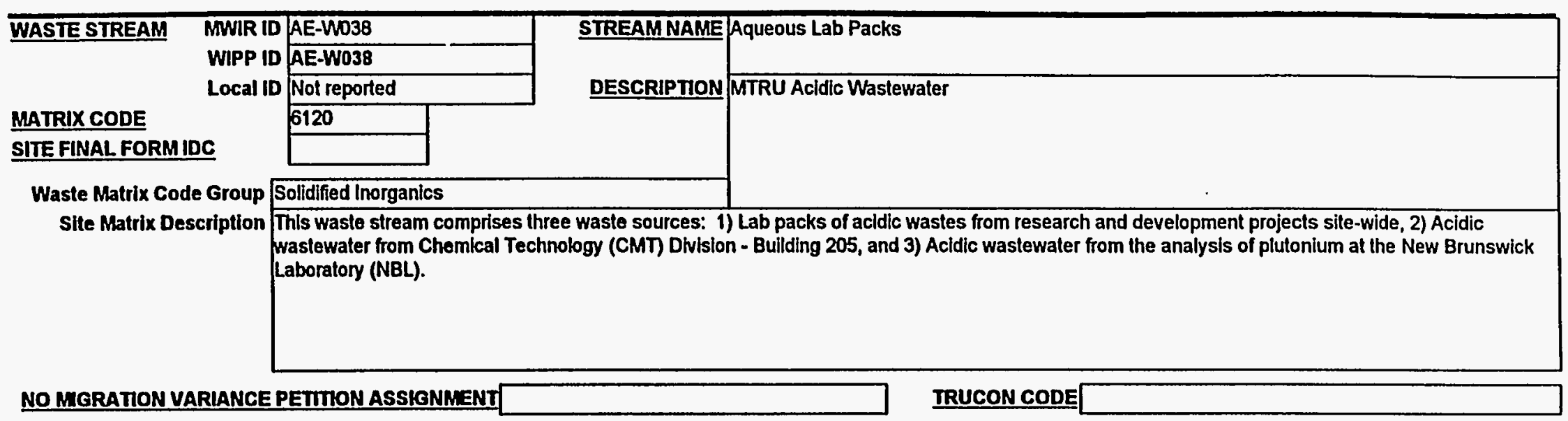

\section{FINAL WASTE FORM DESCRIPTORS:}

\begin{tabular}{l|lll} 
Defense TRU Waste \\
Non-Defense TRU Waste \\
Commercial TRU Waste \\
Unknown
\end{tabular}$\quad \square \quad \begin{aligned} & \text { Mixed TRU } \\
& \begin{array}{l}\text { Non-Mixed TRU } \\
\text { Suspect Mixed TRU } \\
\text { Unknown }\end{array}\end{aligned}$

Unknown

Unknown

Rsearch and Devel. Waste
Operations Waste
Residues
Decon and Decommissioning
Environmental Restoration
From Treatment of Waste
Maintenance

TSCA Asbestos
PCBs
Olher
N/A
Unknown




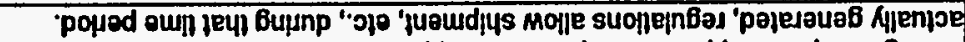
oje sounjon ojsem pojeuf|jso 'ponojdde ole sjsenboy jenojdd $\forall$ jesodsia/aBejojs

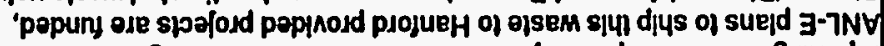

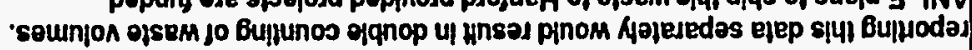

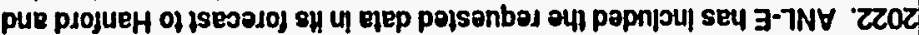

V900व

$\forall$ booa

grood

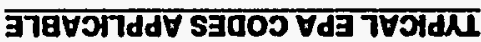

\begin{tabular}{|c|c|c|}
\hline عw/sopn & $s 0-\exists b \tau z$ & 8عZก \\
\hline Eu/sẹn & SO- $\exists 0 S^{\prime} Z$ & sezn \\
\hline Eu/sopjno & $60-30 z^{\prime} \downarrow$ & $\varepsilon \varepsilon z n$ \\
\hline Ew/soun & $10-\exists 01^{\prime} 9$ & ltzZnd \\
\hline Ew/sọ!no & $00+3<1 \div$ & 6EZnd \\
\hline 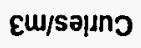 & $90-3<0^{\circ} b$ & geznd \\
\hline Ew/sojıno & С0-ЭEt' 9 & $\angle E Z d_{N}$ \\
\hline Ew/sąuno & $20-300 t$ & $\varepsilon b z \omega \forall$ \\
\hline \multirow[t]{2}{*}{ Eu/sa!ıno } & $00+\exists E l z$ & LtzuH \\
\hline & रांnाग् & $\overline{\text { Jp } \mid J n N}$ \\
\hline
\end{tabular}

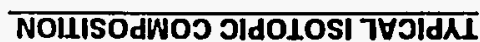

IN/EW $0^{\circ} 0$ INEU O'O N/Eul $\frac{0}{0.0}$ INEW O०O INEW $0^{\circ} 0$ IR/EW 9

Eu 20

cuा

पIIOJ leuls

\begin{tabular}{|c|c|}
\hline 00 & $: 2202-8002$ \\
\hline $0 \%$ & $: 200 z-8686$ \\
\hline 00 & :2661 \\
\hline 00 & :9861 \\
\hline 0.0 & :9661 \\
\hline 90 & :1861 \\
\hline 26 & : 8661 jo puz \\
\hline $1 \%$ & :2661 10 puz \\
\hline
\end{tabular}

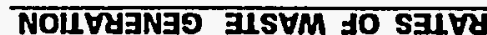

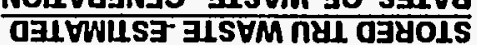

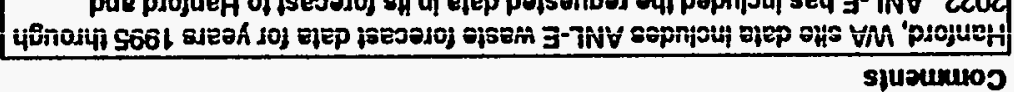
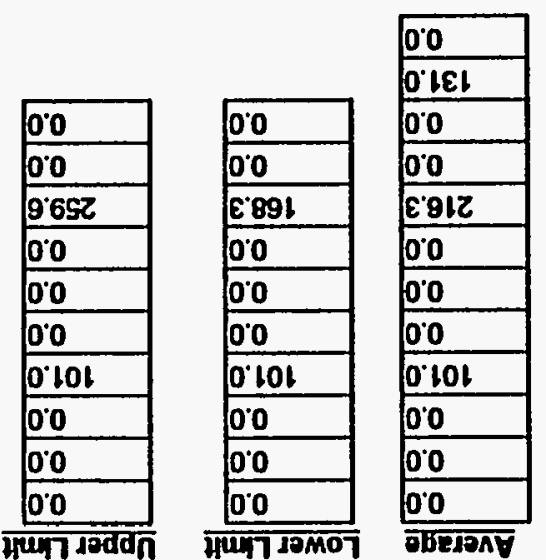

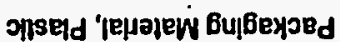

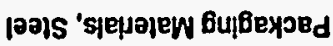

s\|os

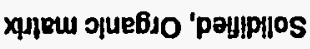

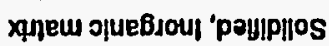

sonseld

seqquy

sग̣รo|n॥əว

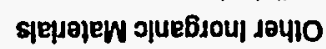

s|ejəw soulo

shoni/s|ejaw paseg-unumunjy

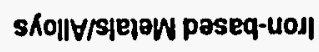

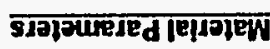


WASTE STREAM PROFILE FOR THE WIPP TRU WASTE BASELINE INVENTORY REPORT

SITE NAME AE WASTE TYPEMTRU HANDLING CH GENERATOR SITE AE

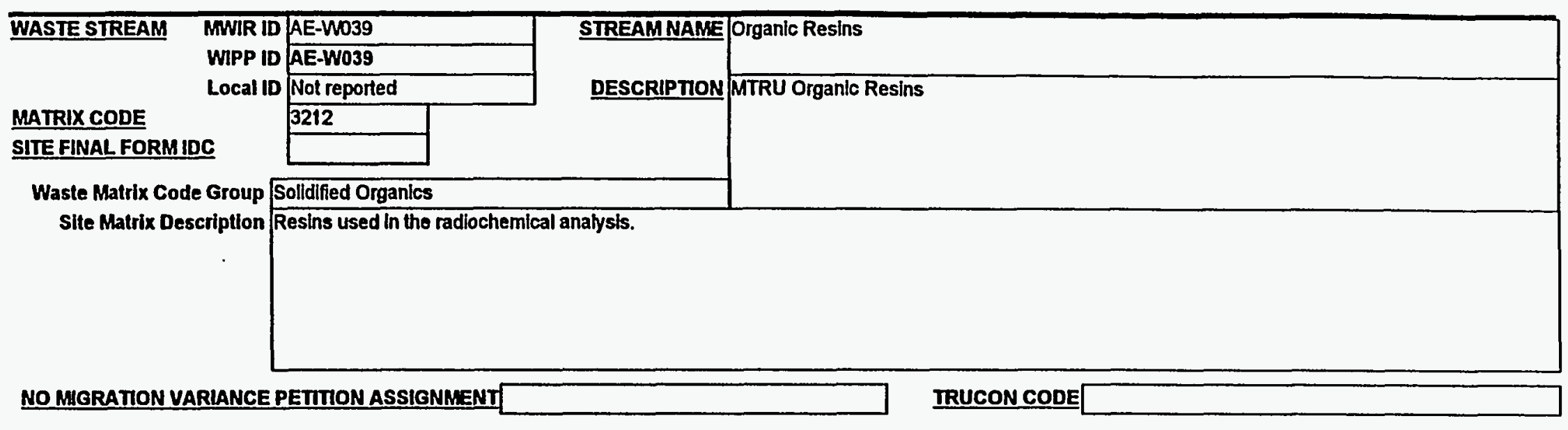

FINAL WASTE FORM DESCRIPTORS:

Defense TRU Waste

Non-Defense TRU Waste

Commercial TRU Waste

Unknown

$\square$

Mixed TRU

Non-Mixed TRU

Suspect Mixed TRU

Unknown

$\square$

$\begin{array}{lll}\text { TSCA Asbestos } & \\ & \\ \text { PCBs } & \\ \text { Other } & \\ \text { N/A } & \\ \text { Unknown } & \\ & \end{array}$

From Treatment of Waste

Malntenance

D

\section{Asbestos \\ Unknown}




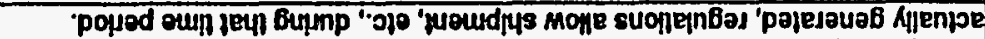
ole sounion olsem poleunjso 'ponosdde ole s|sonboy (Enoldd

'popuny ose s2ooford popinosd pjojueH of ojseM sjun djus ol suejd 3-7NH

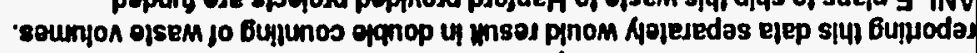

pus piojuey of ssesojol sy th ejep porsonbol ort popnjoul se4 3-7NY 'ZZOZ

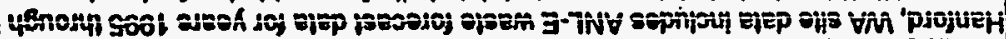

$$
\text { syucumos }
$$

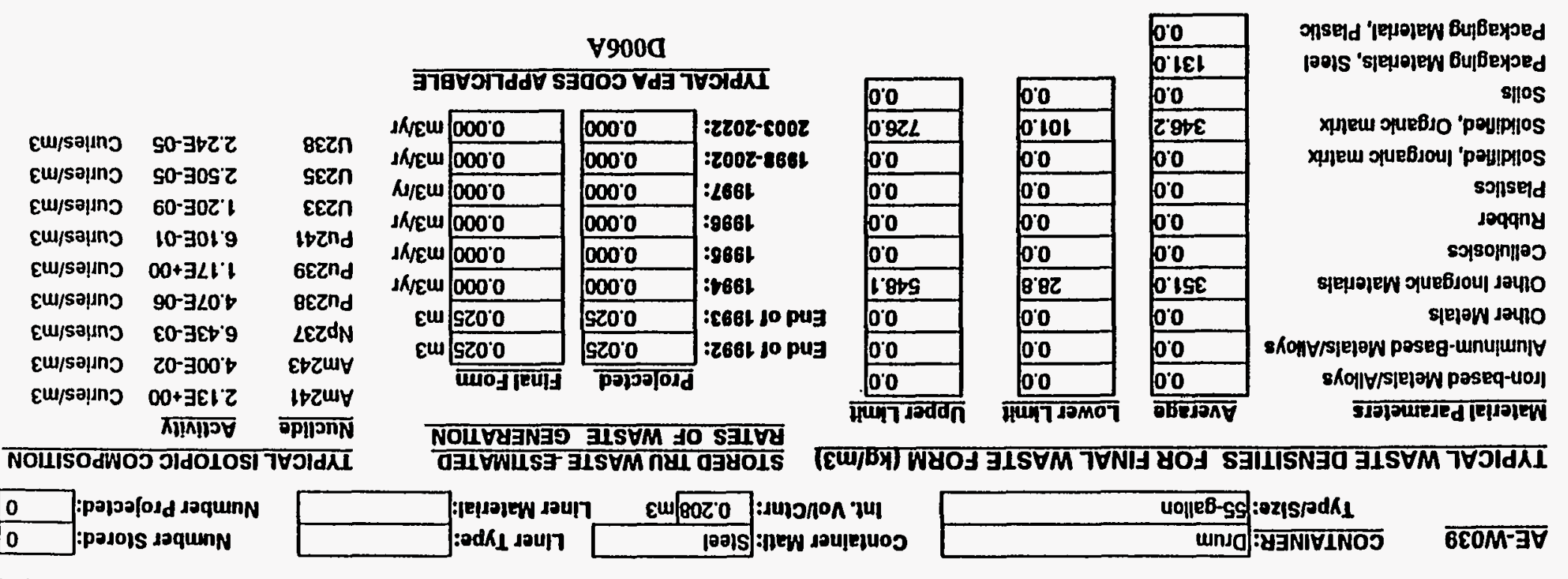




\section{WASTE STREAM PROFILE FOR THE WIPP TRU WASTE BASELINE INVENTORY REPORT}

SITE NAME AE WASTE TYPEMTRU HANDLNG CH GENERATOR SITE AE

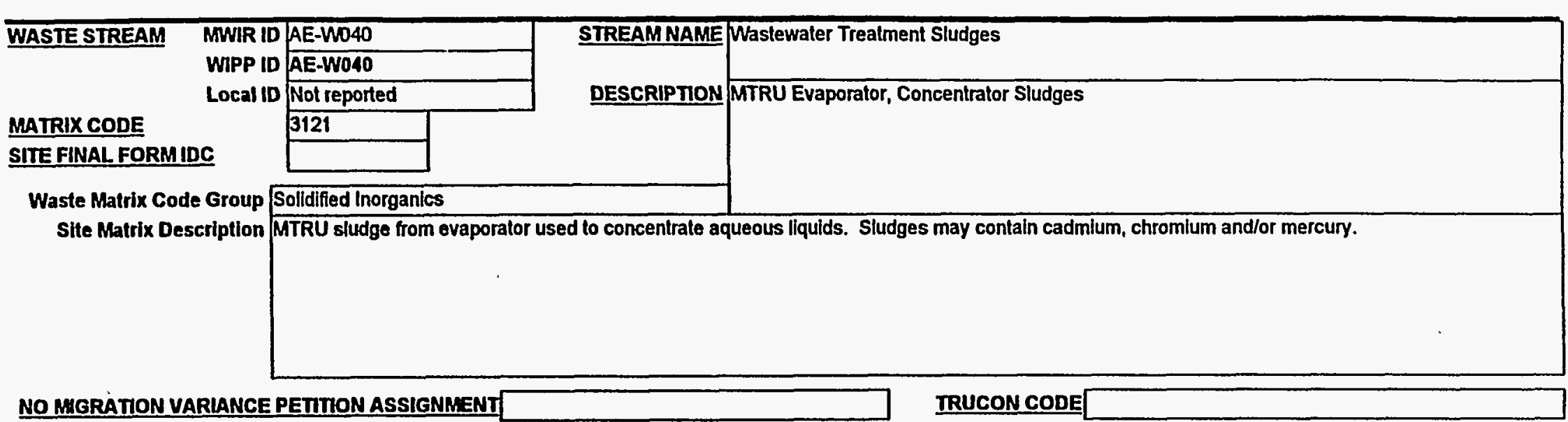

\section{FINAL WASTE FORM DESCRIPTORS:}

Defense TRU Waste Non-Defense TRU Waste

Commercial TRU Waste

Unknown

\section{Mixed TRU}

Non-Mixed TRU

Suspect Mbxed TRU

Unknown

Rsearch and Devel. Waste Operations Wasto

Residues

Decon and Decommlssioning

Environmental Restorallon

From Trealment of Waste

Maintenance

\begin{tabular}{l}
\hline \\
\hline \\
\hline \\
\hline \\
\hline
\end{tabular}

TSCA Asbestos

PCBs

Other

N/A

Unknown

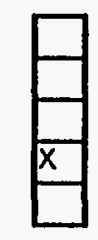


WASTE STREAM PROFILE FOR THE WIPP TRU WASTE BASELINE INVENTORY REPORT

SITE NAME AE WASTE TYPE MTRU HANDLING CH

GENERATOR SITE AE

AE-W040 CONTAINER: $\frac{\text { Drum }}{\text { Type/Size: } 55-\text { gallon }}$

Container Matl: Steel Liner Type:

Int. Vol/Ctnr: $0.208 / \mathrm{m} 3 \quad$ Liner Material:

Number Stored:

Number Projected:

TYPICAL WASTE DENSITIES FOR FINAL WASTE FORM $(\mathrm{kg} / \mathrm{m} 3)$

\section{Material Parameters}

Iron-based Metals/Alloys

Aluminum-Based Metals/Alloys

Other Metals

Other Inorganic Materials

Cellulosics

Rubber

Plastics

Solldified, Inorganic matrix

Solldified, Organic matrix

Solls

Packaging Materials, Steel

Packaging Material, Plastlc

Average
\begin{tabular}{|r}
\hline 0.0 \\
\hline 0.0 \\
\hline 0.0 \\
\hline 394.2 \\
\hline 0.0 \\
\hline 0.0 \\
\hline 0.0 \\
\hline 399.0 \\
\hline 0.0 \\
\hline 0.0 \\
\hline 131.0 \\
\hline 0.0 \\
\hline
\end{tabular}

$\begin{array}{r}\text { Lower Limit } \\ \hline 0.0 \\ \hline 0.0 \\ \hline 0.0 \\ \hline 173.1 \\ \hline 0.0 \\ \hline 0.0 \\ \hline 0.0 \\ \hline 173.1 \\ \hline 0.0 \\ \hline 0.0 \\ \hline\end{array}$

Upper Llmit

\begin{tabular}{|r|}
\hline 0.0 \\
\hline 0.0 \\
\hline 0.0 \\
\hline 528.8 \\
\hline 0.0 \\
\hline 0.0 \\
\hline 0.0 \\
\hline 528.8 \\
\hline 0.0 \\
\hline 0.0 \\
\hline
\end{tabular}

Comments

Hanford, WA site data inciudes ÂNL-E Waste forecast data foi yeẫo 1 SSS throutigh 2022. ANL-E has included the requested dala in Hs forecast to Hanford and reporting this data separately would result in double counting of waste volumes. ANL.E plans to ship this waste to Hanford provided projects are funded,

Storage/Disposal Approval Requests are approved, estimated waste volumes are actually generated, regulations allow shlpment, etc., during that time period.
STORED TRU WASTE ESTIMATED RATES OF WASTE GENERATION

\begin{tabular}{|c|c|c|c|}
\hline & Prolected & Final Form & \\
\hline id of 1992: & 0.4 & 0.4 & $\mathrm{~m} 3$ \\
\hline Id of 1983: & 0.4 & 0.4 & $\mathrm{~m} 3$ \\
\hline 1984: & 0.0 & 0.0 & $m 3 / y r$ \\
\hline 1885: & 0.0 & 0.0 & $\mathrm{~m} 3 / \mathrm{yr}$ \\
\hline 1888: & $\overrightarrow{0.0}$ & 0.0 & $m 3 / y r$ \\
\hline 1987: & 0.0 & 0.0 & $m 3 / r y$ \\
\hline $388-2002:$ & 0.0 & 0.0 & $m 3 / y r$ \\
\hline $003-2022:$ & 0.0 & 0.0 & $m 3 / y r$ \\
\hline
\end{tabular}

TYPICAL ISOTOPIC COMPOSITION

Nuclide Activity

Am241 2.13E+00 Curies/m3

Am243 4.00E-02 Curies $/ \mathrm{m} 3$

Np237 6.43E-03 Curies $/ \mathrm{m3}$

Pu238 4.07E-06 Curies $/ \mathrm{m3}$

Pu239 1.17E+00 Curies/m3

Pu241 6.10E-01 Curies/m3

U233 1.20E-09 Curies/m3

U235 250E-05 Curies/m3

U238 2.24E-05 Curles/m3
IYPICAL EPA CODES APPLICABLE

D006A

D007A

D009A 
WASTE STREAM PROFILE FOR THE WIPP TRU WASTE BASELINE INVENTORY REPORT

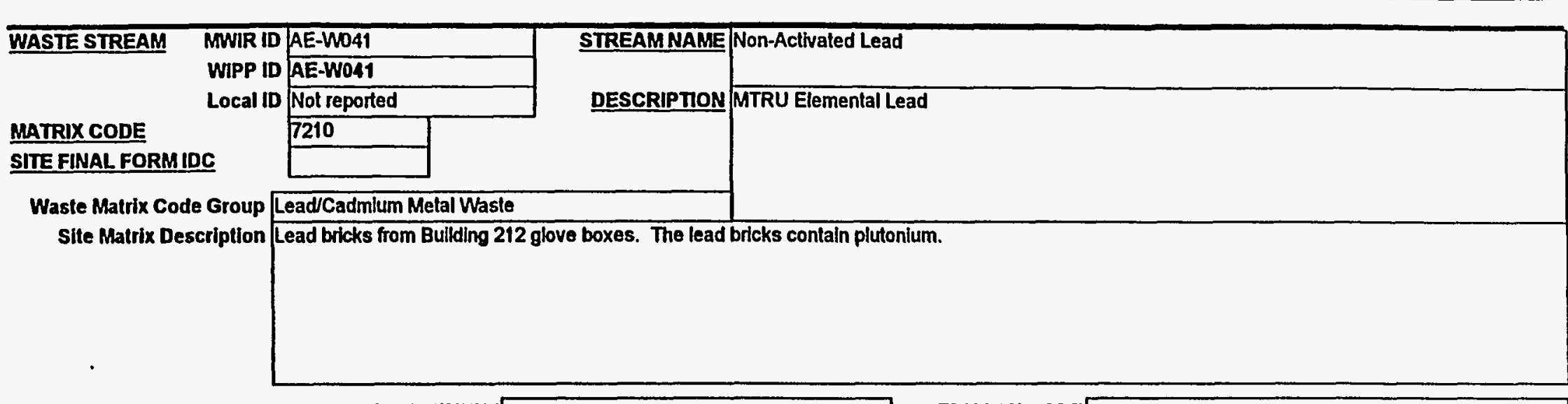

NO MGRATION VARIANCE PETIION ASSIGNMENT

IRUCON CODE

\section{FINAL WASTE FORM DESCRIPTORS:}

Defense TRU Wasle

Non-Defense TRU Waste

Commercial TRU Waste

Mbxed TRU

Non-Mbed TRU

Suspect Mixed TRU

- Unknown

Rsearch and Devel. Waste
Operatlons Waste
Residues
Decon and Decommlssioning
Environmental Restoration
From Treatment of Wasto
Maintenance

TSCA Asbestos

PCBs

Other

N/A

Unknown

Maintenance 


\section{WASTE STREAM PROFILE FOR THE WIPP TRU WASTE BASELINE INVENTORY REPORT}

AE-W041

\begin{tabular}{c|l} 
CONTAINER: & Drum \\
\hline Type/Size: & 55-gallon \\
\hline
\end{tabular}

Contalner Mati: Steel Int. Vovcinr:

\begin{tabular}{rr} 
Liner Type: \\
\hline $0.208 / \mathrm{m3}$ \\
Liner Material:
\end{tabular}

Number Stored: Number Projected:

TYPICAL WASTE DENSITIES FOR FINAL WASTE FORM $(\mathrm{kg} / \mathrm{m} 3)$

\section{Material Parameters}

Iron-based Metals/Alloys

Aluminum-Based Metals/Alloys

Other Metals

Other Inorganic Materials

Cellulosics

Rubber

Plastics

Solidified, Inorganic malrix

Solidified, Organle malitx

Soils

Packaging Materlals, Steel

Packaging Material, Plastlc

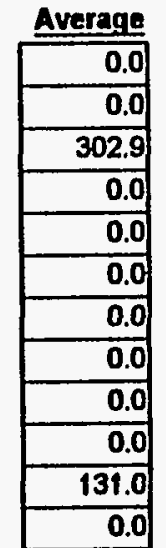

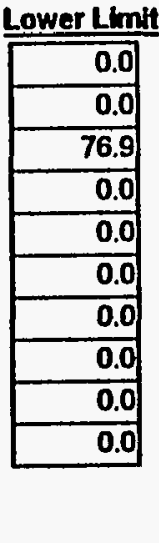

Upper Limit

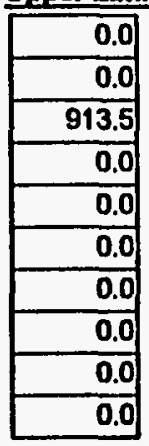

Comments

Hanford, WA slie daia inciudes ÂNL-E waste foreesst data for years iss5 throught

2022. ANL-E has included the requested data in its forecast to Hanford and

reporting this data separalety would result in doubte counting of waste volumes.

ANL.E plans to ship this wasto to Hanford provided projects are funded,

Storage/Disposal Approval Requests are approved, estimated waste volumes are

actually generated, regulations allow shipment, etc., during that time period.
STORED TRU WASTE ESTMMATED

RATES OF WASTE GENERATION

\begin{tabular}{|c|c|c|c|}
\hline & Projected & Final Form & \\
\hline End of 1992: & 0.0 & 0.0 & m3 \\
\hline End of 1993: & 0.7 & 0.7 & $\mathrm{~m} 3$ \\
\hline 1984: & 0.0 & $\overline{0.0}$ & $\mathrm{~m} 3 / \mathrm{yr}$ \\
\hline 1985: & 0.0 & 0.0 & $\mathrm{~m} 3 / \mathrm{yr}$ \\
\hline 1996: & 0.0 & 0.0 & $\mathrm{~m} 3 / \mathrm{yr}$ \\
\hline 1997: & 0.0 & 0.0 & $\mathrm{~m} 3 / \mathrm{y}$ \\
\hline 1898-2002: & 0.0 & 0.0 & $\mathrm{~m} 3 / \mathrm{yr}$ \\
\hline 2003-2022: & 0.0 & 0.0 & $\mathrm{~m} 3 / y r$ \\
\hline
\end{tabular}

IYPICAL ISOTOPIC COMPOSITION

Nuclide Activity

Am241 2.13E+00 Curies/m3

Am243 4.00E-02 Curies $/ \mathrm{m}^{3}$

Np237 6.43E-03 Curies/m3

Pu238 4.07E-06 Curies $/ \mathrm{m}^{3}$

Pu239 1.17E+00 Curies/m3

Pu241 6.10E-01 Curies $/ \mathrm{m}^{3}$

U233 1.20E-09 Curies $/ \mathrm{m} 3$

U235 2.50E-05 Curies/m3

U238 2.24E-05 Curies $/ \mathrm{m} 3$
TYPICAL EPA CODES APPLICABLE

D008C 


\section{WASTE STREAM PROFILE FOR THE WIPP TRU WASTE BASELINE INVENTORY REPORT}

SITE NAME AE

WASTE TYPE MTRU HANDLING CH GENERATOR SITE AE

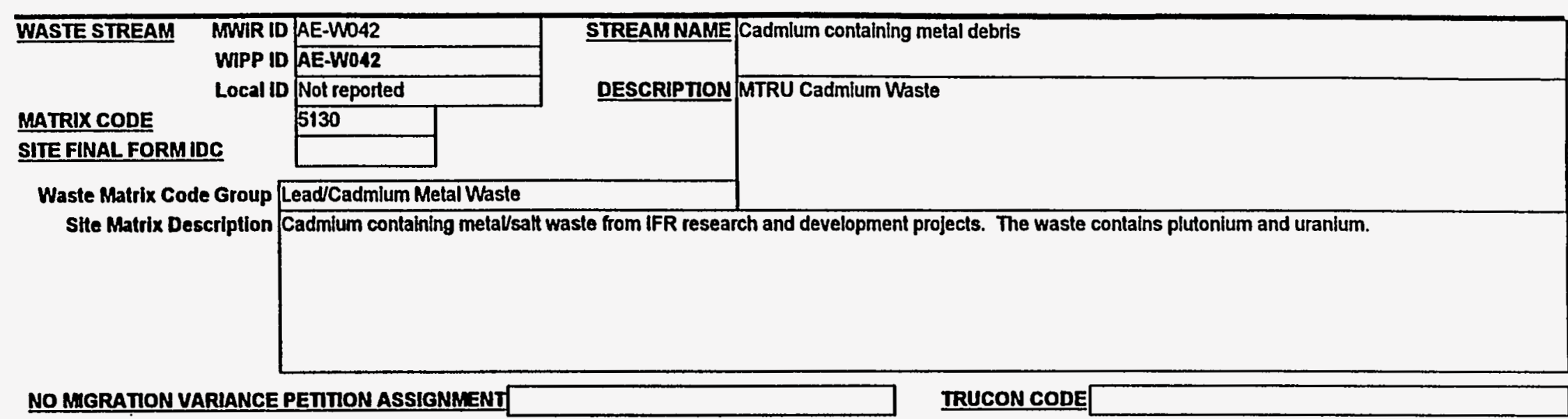

FINAL WASTE FORM DESCRIPTORS:

Defense TRU Waste

Non-Defense TRU Waste

Commerclal TRU Waste

Unknown
Mlxed TRU

Non-Mbxed TRU

Suspect Mbxed TRU

Unknown

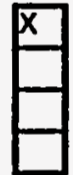

$\begin{aligned} & \text { Rsearch and Devel. Waste } \\ & \text { Operations Waste }\end{aligned}$
$\begin{aligned} & \text { Residues } \\ & \text { Decon and Decommissioning } \\ & \text { Environmental Restoration } \\ & \text { From Treatment of Waste } \\ & \text { Maintenance }\end{aligned}$

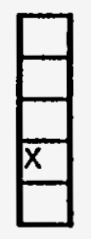




AE-W042 CONTAINER: $\frac{\text { Drum }}{\text { Type/Size: } 55 \text {-gallon }}$

Container Matt: Steel

int. Volvenr:
Number Stored: Number Projected:
TYPICAL WASTE DENSITIES FOR FINAL WASTE FORM $(\mathrm{kg} / \mathrm{m} 3)$

STORED TRU WASTE ESTMMATED RATES OF WASTE GENERATION

Material Parameters

Iron-based Metals/Alloys

Aluminum-Based Metals/Alloys

Other Melals

Other Inorganlc Materiats

Cellulosics

Rubber

Plastics

Solldified, Inorganic matrix Solidified, Organic matrix

Solls

Packaging Materials, Steel

Packaging Malerial, Plastlc

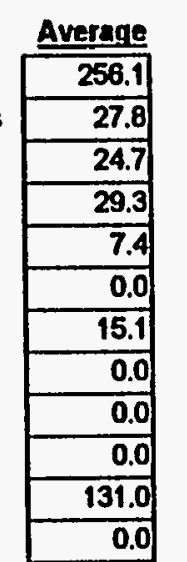

\section{Upper Limit}

\begin{tabular}{|r|}
\hline 256.1 \\
\hline 27.8 \\
\hline 24.7 \\
\hline 29.3 \\
\hline 45.3 \\
\hline 0.0 \\
\hline 67.6 \\
\hline 0.0 \\
\hline 0.0 \\
\hline 0.0 \\
\hline
\end{tabular}

TYPICAL ISOTOPIC COMPOSITION Nuclide Actlvity

Am241 2.13E+00 Curies $/ \mathrm{m} 3$

Am243 4.00E-02 Curies $/ \mathrm{m}^{3}$

Np237 6.43E-03 Curies $/ \mathrm{m3}$

Pu238 4.07E-06 Curies/m3

Pu239 1.17E+00 Curies/m3

Pu241 6.10E-01 Curies $/ \mathrm{m}^{3}$

U233 1.20E-09 Curles/m3

U235 2.50E-05 Curies/m3

U238 2.24E-05 Curies $/ \mathrm{m}^{3}$

Comments

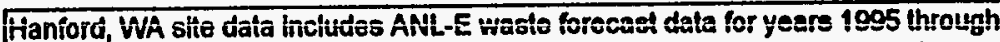
2022. ANL.E has included the requested data in its forecast to Hanford and

reporting this data separately would result in double counting of waste volumes.

ANL-E plans to ship this waste to Hanford provided projects are funded,

Storage/DIsposal Approval Requests are approved, estimated waste volumes are

actually generated, regulations allow shipment, ofc., during that time period. 


\section{ARGONNE NATIONAL LABORATORY-WEST (AW) WASTE STREAM PROFILES}

The following assumptions were made by the WTWBIR team in developing the AW waste stream profiles.

- An AW RH Canister (without any shielding) has been assumed for the $0.112 \mathrm{~m}^{3} \mathrm{RH}$ container. 
WASTE STREAM PROFILE FOR THE WIPP TRU WASTE BASELINE INVENTORY REPORT

SITE NAME AW WASTE TYPE MTRU HANDLING CH GENERATOR SITE AW

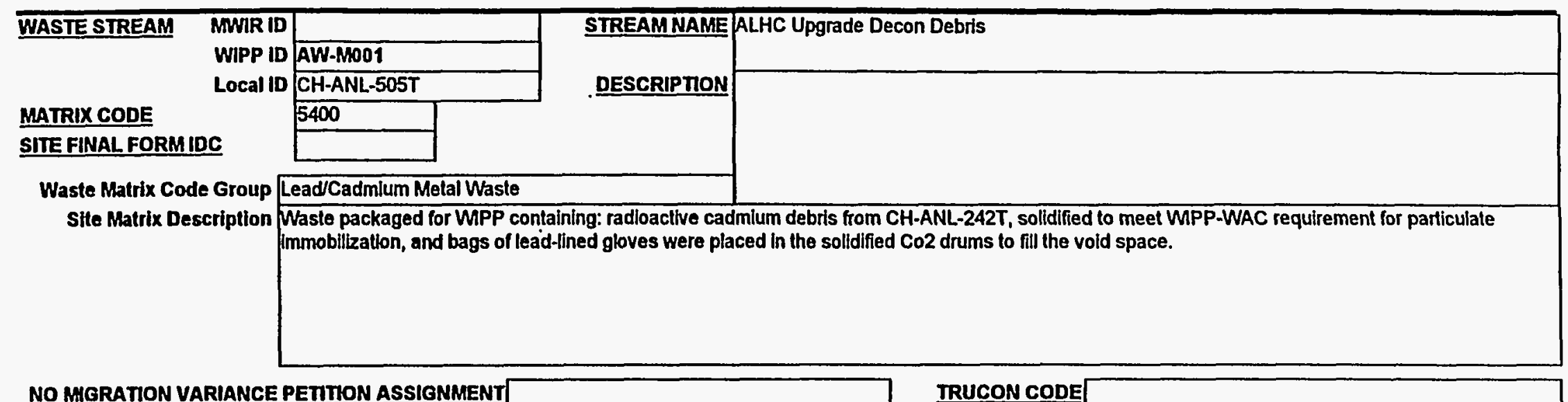

NO MGRATION VARIANCE PETITION ASSIGNMENT

IRUCON CODE

\section{FINAL WASTE FORMDESCRIPTORS:}

Defense TRU Waste

Non-Defense TRU Waste

Commercial TRU Waste

Unknown

$\square$

Mixed TRU

Non-Mixed TRU

Suspect Mixed TRU

Unknown

Rsearch and Devel. Waste
Operalions Waste
Residues
Decon and Decommissioning
Environmental Restoralion
From Trealment of Waste
Maintenance

TSCA Asbestos
PCBs
Other
N/A
Unknown




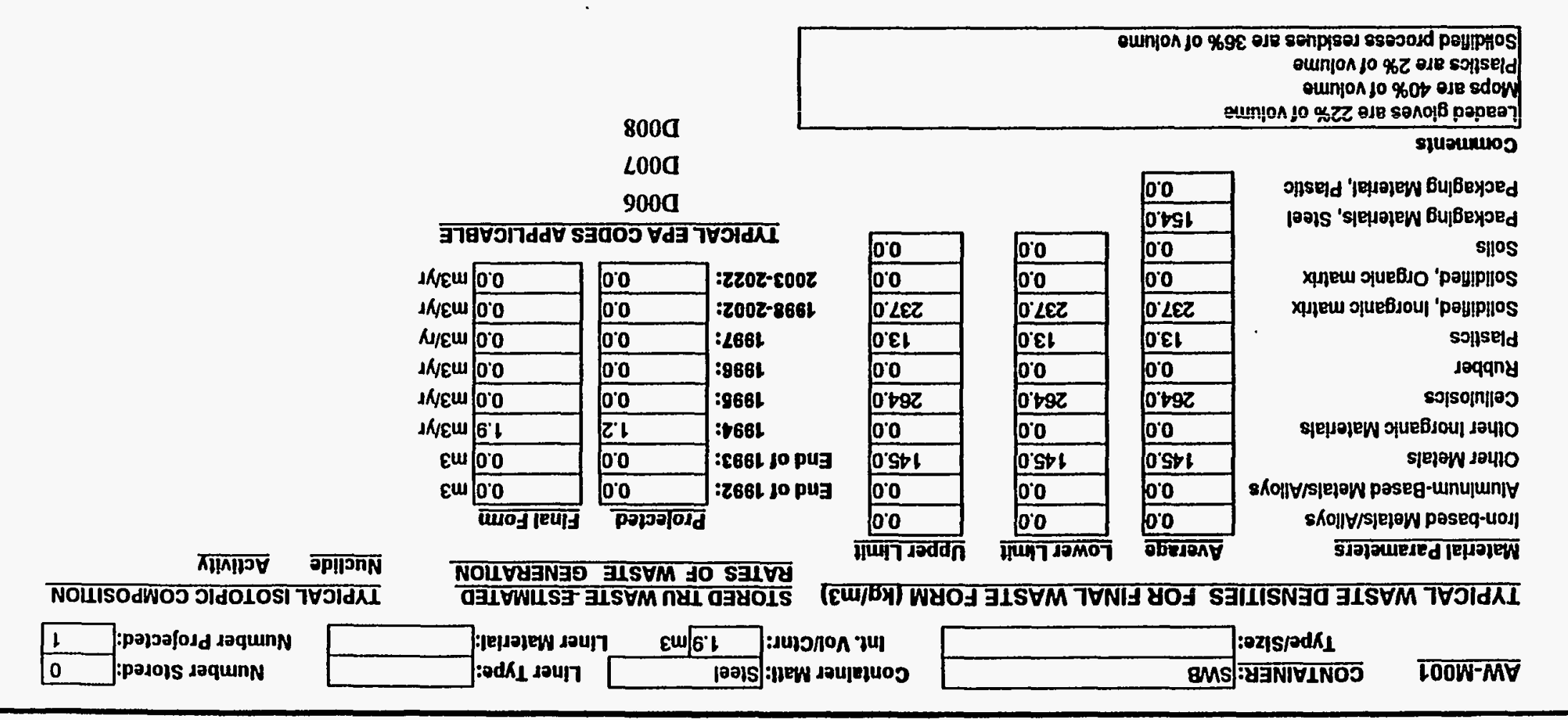


WASTE STREAM PROFILE FOR THE WIPP TRU WASTE BASELINE INVENTORY REPORT

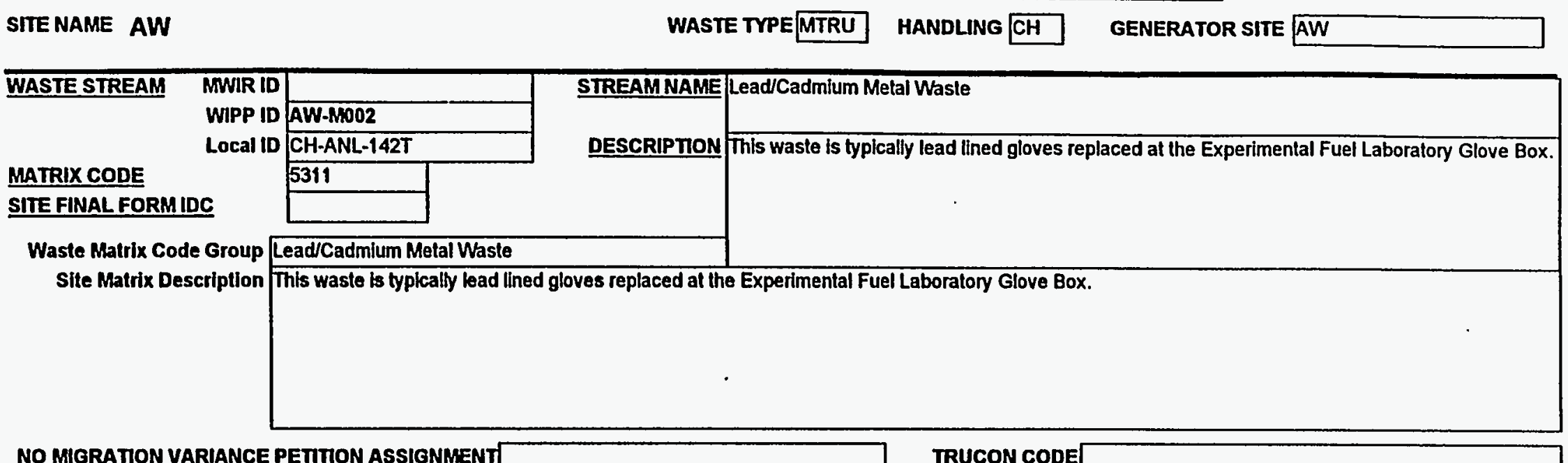

\section{FINAL WASTE FORM DESCRIPTORS:}

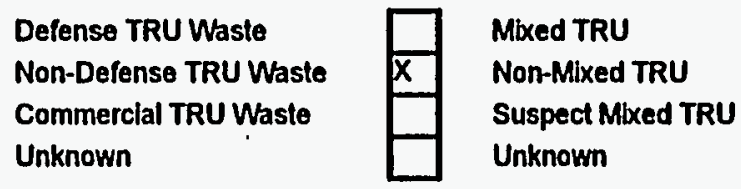

Rsearch and Devel Waste Operations Wasto

Resldues

Decon and Decommissioning

Environmental Restoralion

From Treatment of Waste

Maintenance

$\square$

TSCA Asbestos

PCBs

Other

N/A

Unknown 
WASTE STREAM PROFILE FOR THE WIPP TRU WASTE BASELINE INVENTORY REPORT

SITE NAME AW

\section{WASTE TYPE MTRU HANDLING CH GENERATOR SITE AW}

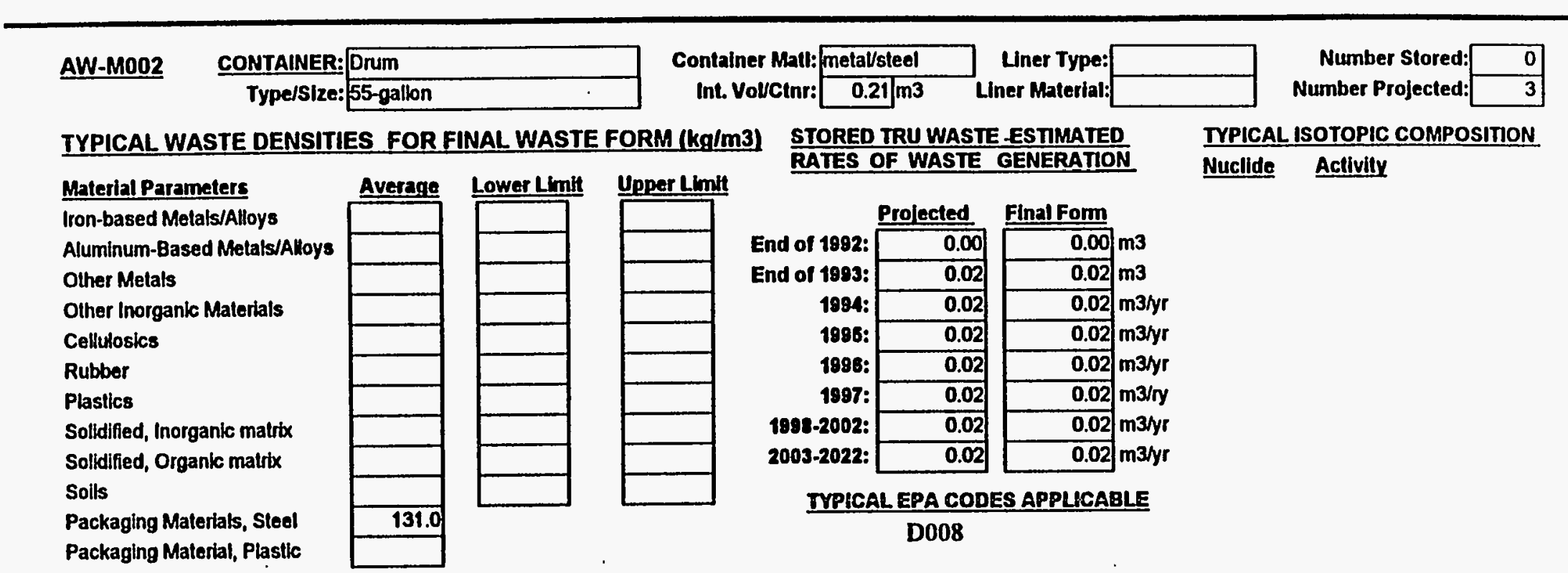




\section{WASTE STREAM PROFILE FOR THE WIPP TRU WASTE BASELINE INVENTORY REPORT}

SITE NAME AW

WASTE TYPE MTRU HANDLING RH GENERATOR SITE AW

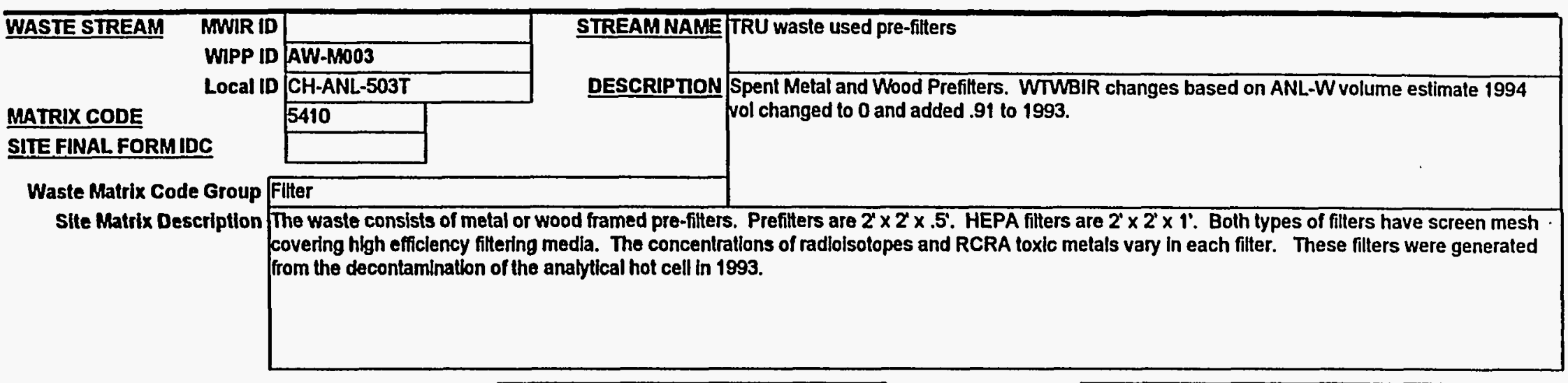

NO MMGRATION VARIANCE PETIION ASSIGNMENU

IRUCON CODE

FINAL WASTE FORM DESCRIPTORS:

Defense TRU Waste

Non-Defense TRU Waste

Commercial TRU Waste

Unknown

$\mathrm{X}$

Mibed TRU

Non-Mbed TRU

Suspect Mixed TRU

Unknown

$\square$

TSCA Asbestos

PCBs

Other

N/A

Unknown
From Treatment of Wasto

Maintenance

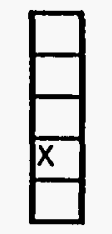




\section{WASTE STREAM PROFILE FOR THE WIPP TRU WASTE BASELINE INVENTORY REPORT}

\section{AW-MOO3}

\begin{tabular}{c|l} 
CONTAINER: RH Canister \\
\hline Type/Size: & RH Cannister \\
\hline
\end{tabular}

Container Matt: Steellead

Int. Volvetnr: $0.89 \mathrm{m3}$

\section{Liner Type:
Liner Material:}

STORED TRU WASTE -ESTIMATED RATES OF WASTE GENERATION

\section{Material Parameters}

Iron-based Metals/Alloys

Aluminum-Based Metals/Alloys

Other Metals

Other Inorganlc Materials

Cellulosics

Rubber

Plastics

Solldified, Inorganic matrix

Solidified, Organic matrbx

$$
\text { Solls }
$$

Packaging Materials, Steel

Packaging Material, Plasilc

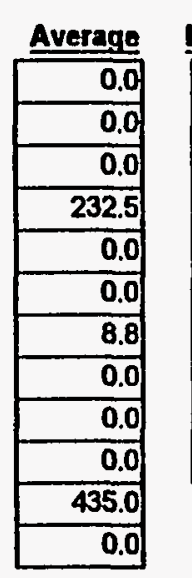

\begin{tabular}{|c|c|}
\hline Lower Lmit & Upper Lint \\
\hline 0.0 & 0.0 \\
\hline 0.0 & 0.0 \\
\hline 0.0 & 0.0 \\
\hline 214.9 & 241.2 \\
\hline 0.0 & 0.0 \\
\hline 0.0 & 0.0 \\
\hline 8.8 & 8.8 \\
\hline 0.0 & 0.0 \\
\hline 0.0 & 0.0 \\
\hline 0.0 & 0.0 \\
\hline
\end{tabular}

\begin{tabular}{|c|c|c|c|}
\hline & Prolected & Final Fomn & \\
\hline id of 1992: & 0.0 & 0.0 & m3 \\
\hline d of 1983: & 0.9 & 0.9 & m3 \\
\hline 1994: & 0.1 & 0.1 & im $3 / y r$ \\
\hline 1998: & 0.0 & 0.0 & $\mathrm{~m} 3 / \mathrm{yr}$ \\
\hline 1898: & 0.0 & 0.0 & $\mathrm{~m} 3 / \mathrm{yr}$ \\
\hline 1997: & 0.0 & 0.0 & m3/ry \\
\hline 38-2002: & 0.0 & 0.0 & m3/yr \\
\hline 2003-2022: & 0.1 & 0.1 & m3/yr \\
\hline
\end{tabular}

IYPHCAL EPA CODES APPLKABLE

Footnotes

Includes $465 \mathrm{~kg} / \mathrm{m} 3$ of lead shielding. 
WASTE STREAM PROFILE FOR THE WIPP TRU WASTE BASELINE INVENTORY REPORT

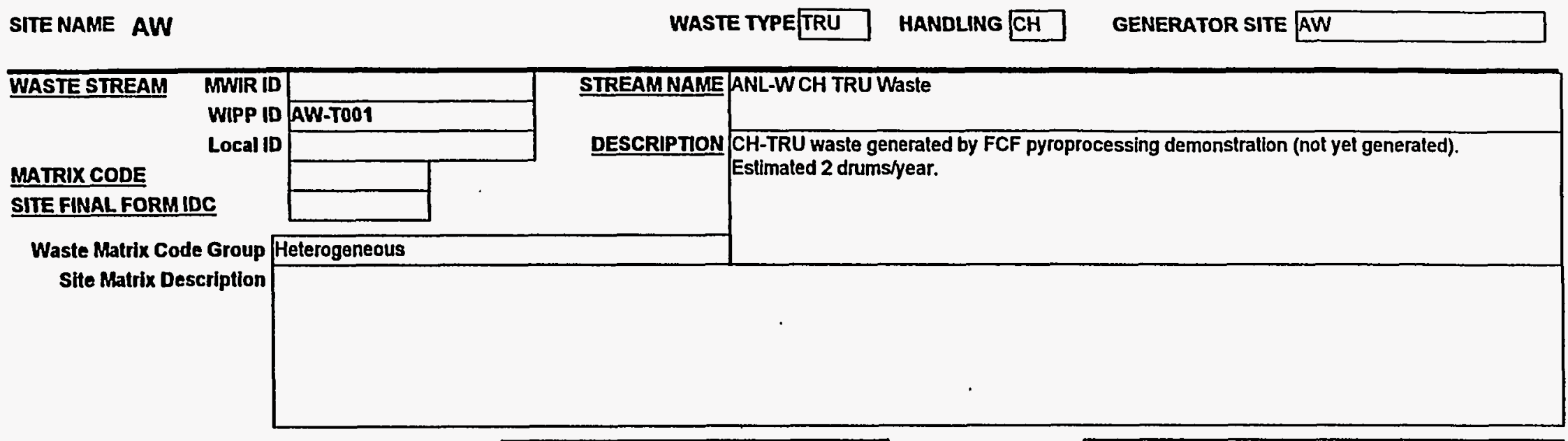

NO MIGRATION VARIANCE PETITON ASSIGNMENT

IRUCON CODE

FINAL WASTE FORM DESCRIPTORS:

Defense TRU Waste

Non-Defense TRU Waste

Commerclal TRU Wasto

Unknown

$x$

Mbxed TRU

Non-Mixed TRU

Suspect Mixed TRU

Unknown

\begin{tabular}{|l|l|}
\hline & $\begin{array}{l}\text { Rsearch and Devel. Waste } \\
\text { Operations Waste } \\
\text { Residues } \\
\text { Decon and Decommissioning } \\
\text { Environmental Restoration } \\
\text { From Treatment of Waste } \\
\text { Maintenance }\end{array}$
\end{tabular}

TSCA Asbestos

PCBs

Other

N/A

Unknown

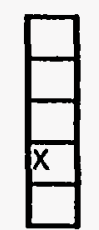




\begin{tabular}{|c|c|c|c|c|c|c|}
\hline AW-T001 & \begin{tabular}{r|l} 
CONTAINER: & Drum \\
Type/SIze: & 55 galion
\end{tabular} & $\begin{array}{r}\text { Container Matl: } \\
\text { Int. Vol/Ctnr: }\end{array}$ & $\frac{\text { Steel }}{0.208 / \mathrm{m} 3}$ & $\begin{array}{l}\text { Liner Type: } 80 \text { mil Liner HD } \\
\text { Liner Material: }\end{array}$ & $\begin{array}{r}\text { Number Stored: } \\
\text { Number Projected: }\end{array}$ & $\frac{0}{16}$ \\
\hline
\end{tabular}

TYPICAL WASTE DENSITIES FOR FINAL WASTE FORM (kg/m3) STORED TRU WASTE ESTIMATED

Materlal Parameters

Iron-based Metals/Alloys

Aluminum-Based Melals/Alloys

Other Metals

Other Inorganic Materials

Cellulosics

Rubber

Plastics

Solldified, Inorgantc matrix

Solfdified, Organic matrix

Soils

Packaging Materials, Steel

Packaging Matertal, Plastlc

\begin{tabular}{|r|} 
Average \\
\hline 0.0 \\
\hline 0.0 \\
\hline 0.0 \\
\hline 0.0 \\
\hline 0.0 \\
\hline 0.0 \\
\hline 0.0 \\
\hline 0.0 \\
\hline 0.0 \\
\hline 0.0 \\
\hline 131.0 \\
\hline 0.0 \\
\hline
\end{tabular}

\begin{tabular}{|r|}
\hline Lower Limit \\
\hline 0.0 \\
\hline 0.0 \\
\hline 0.0 \\
\hline 0.0 \\
\hline 0.0 \\
\hline 0.0 \\
\hline 0.0 \\
\hline 0.0 \\
\hline 0.0 \\
\hline 0.0 \\
\hline
\end{tabular}

\begin{tabular}{|r|}
\hline Upper Lim \\
\hline $\mathbf{0 . 0}$ \\
\hline $\mathbf{0 . 0}$ \\
\hline $\mathbf{0 . 0}$ \\
\hline $\mathbf{0 . 0}$ \\
\hline $\mathbf{0 . 0}$ \\
\hline $\mathbf{0 . 0}$ \\
\hline $\mathbf{0 . 0}$ \\
\hline $\mathbf{0 . 0}$ \\
\hline $\mathbf{0 . 0}$ \\
\hline $\mathbf{0 . 0}$ \\
\hline
\end{tabular}
RATES OF WASTE GENERATION

TYPICAL ISOTOPIC COMPOSITION Nuclide Activity

\begin{tabular}{|c|c|c|c|}
\hline & Proiected & Final Form & \\
\hline End of 1992: & 0.0 & 0.0 & $\operatorname{lm} 3$ \\
\hline End of 1993: & 0.0 & 0.0 & m3 \\
\hline 1994: & 0.0 & 0.0 & m3/yr \\
\hline 1996: & 0.4 & $\overline{0.4}$ & $\mathrm{~m} 3 / y r$ \\
\hline 1998: & 0.4 & $\overline{0.4}$ & $\mathrm{~m} 3 / y \mathrm{r}$ \\
\hline 1997: & 0.4 & 0.4 & m3/ry \\
\hline 1988-2002: & 0.4 & 0.4 & m3/yr \\
\hline 2003-2022: & 0.0 & 0.0 & m3/yr \\
\hline
\end{tabular}

Comments

Compositton le not yet known on future wasts. 


\section{WASTE STREAM PROFILE FOR THE WIPP TRU WASTE BASELINE INVENTORY REPORT}

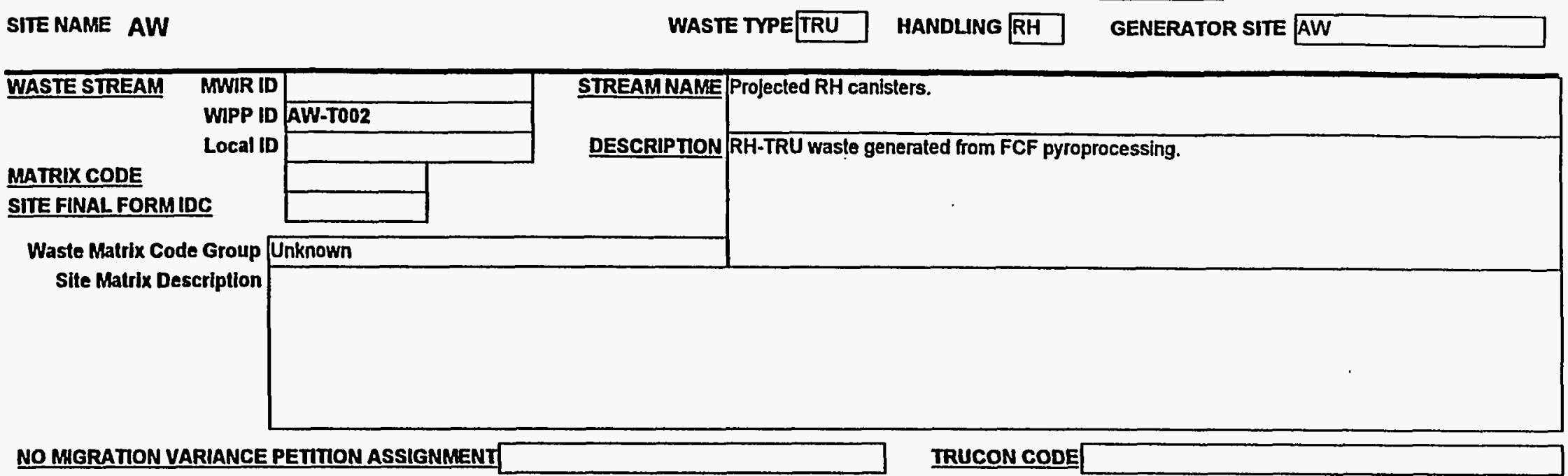

\section{FINAL WASTE FORM DESCRIPTORS:}

Defense TRU Waste

Non-Defense TRU Wasto

Commercial TRU Wasto

Mixed TRU

Non-Mlxed TRU

Suspect Mixed TRU

Unknown

Unknown

$\square$

\begin{tabular}{|c|c|c|c|}
\hline \multirow{2}{*}{\multicolumn{2}{|c|}{$\begin{array}{l}\text { Rsearch and Devel. Waste } \\
\text { Operations Waste }\end{array}$}} & \multirow[t]{2}{*}{ TSCA } & \multirow{2}{*}{ Asbestos } \\
\hline & & & \\
\hline Residues & & & Other \\
\hline Decon and Decommlssloning & & & N/A \\
\hline Environmental Restoration & & & Unknown \\
\hline From Treatment of Waste & & & \\
\hline Malntenance & & & \\
\hline
\end{tabular}




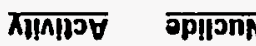
NOIISOdWOJ JIdOIOSI TVJIdM

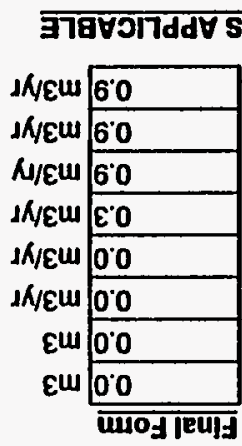

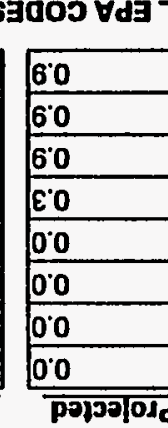

Fगdयl
$: 2202-6002$
$: 2002-8661$
$: 2661$
$: 8661$
$: 9661$
$: t 661$
$: 8661$ jo pug
$: 2661$ jo pug

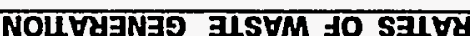

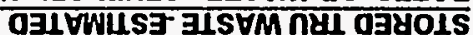

\begin{tabular}{|l|}
\hline $0^{\prime} 0$ \\
\hline $0^{\prime} 0$ \\
\hline $0^{\prime} 0$ \\
\hline $0^{\prime} 0$ \\
\hline $0^{\circ} 0$ \\
\hline $0^{\prime} 0$ \\
\hline $0^{\prime} 0$ \\
\hline $0^{\prime} 0$ \\
\hline $0^{\prime} 0$ \\
\hline $0^{\prime} 0$ \\
\hline
\end{tabular}

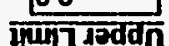

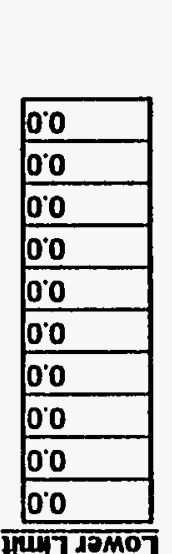

o'o

00

$\frac{00}{0.0}$

00

00

00

$0^{\circ} 0$

00

00

0

00

00

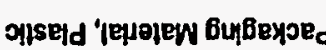

pös 'sjeןرə]еw Bu!beyord s\|los

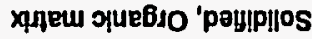

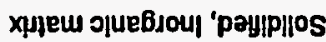

sonseld

Jeqqny

so|so!n॥eว

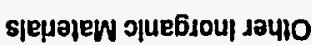

s|ejaw 1aylo

sho|| $\forall / s \mid$ ejow poseg-unufunj $\forall$

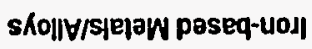

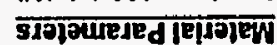

?:pojojosd saquinN 
WASTE STREAM PROFILE FOR THE WIPP TRU WASTE BASELINE INVENTORY REPORT

\section{SITE NAME AW WASTE TYPE MTRU HANDLING RH GENERATOR SITE AW}

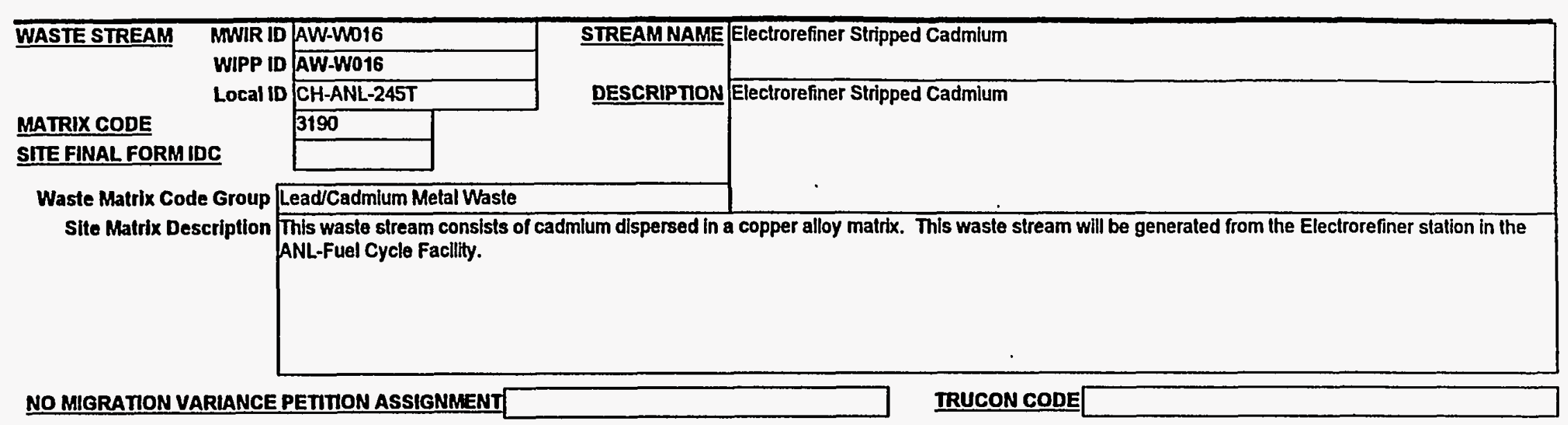

\section{FINAL WASTE FORM DESCRIPTORS:}

Defense TRU Waste

Non-Defense TRU Wasto

Commercial TRU Waste

Unknown
Mbxed TRU

Non-Mbed TRU

Suspect Mlxed TRU

Unknown

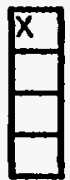

\begin{tabular}{|l|}
\hline \\
\hline \\
\hline \\
\hline \\
\hline
\end{tabular}




\section{WASTE STREAM PROFILE FOR THE WIPP TRU WASTE BASELINE INVENTORY REPORT}

SITE NAME AW

\section{WASTE TYPE MTRU HANDLINO RH GENERATOR SITE AW}

\begin{tabular}{|c|c|c|c|c|c|c|c|c|c|c|}
\hline AW-W016 $\frac{\text { CONTAINER: }}{\text { TypelSize: }}$ & \multicolumn{2}{|c|}{ ANL-WRH Canister } & \multicolumn{3}{|c|}{ Container Matl: Steel } & $\begin{array}{l}\text { Liner Type: } \\
\text { Liner Material: }\end{array}$ & & & $\begin{array}{l}\text { Number Stored: } \\
\text { Number Projected: }\end{array}$ & $\frac{0}{2}$ \\
\hline \multicolumn{4}{|c|}{ TYPICAL WASTE DENSITIES FOR FINAL WASTE FORM $(\mathrm{kg} / \mathrm{m} 3)$} & \multicolumn{4}{|c|}{ STORED TRU WASTE ESTIMATED } & \multicolumn{3}{|c|}{ TYPICAL ISOTOPIC COMPOSITION } \\
\hline Material Parameters & Average & Lower Limh & Upper Linit & RATES & OF WASTE & GENERATIO & & Nuclide & Actlvity & \\
\hline Iron-based Metals/Alloys & 256.1 & 256.1 & 256.1 & \multirow{3}{*}{$\begin{array}{l}\text { End of 1982: } \\
\text { End of 1983: }\end{array}$} & Prolected & \multicolumn{2}{|l|}{ Final form } & & & \\
\hline Aluminum-Based Metals/Alloys & 27.8 & 27.8 & 27.8 & & 0.00 & 0.00 & m3 & & & \\
\hline Other Metals & 24.7 & 24.7 & 24.7 & & 0.00 & 0.00 & m3 & & & \\
\hline Other Inorganic Materials & 29.3 & 2.3 & 29.3 & 1984: & 0.00 & 0.00 & $\mathrm{~m} 3 / y r$ & & & \\
\hline Cellulosics & 7.4 & 0.0 & 45.3 & 1998: & 0.02 & 0.02 & m3tyr & & & \\
\hline Rubber & 0.0 & 0.0 & 0.0 & 1998: & 0.02 & 0.02 & $\mathrm{~m} 3 / y \mathrm{r}$ & & & \\
\hline Plastics & 15.1 & 0.0 & 67.6 & 1987: & 0.02 & 0.02 & $m 3 / r y$ & & & \\
\hline Solidified, Inorganic matrix & 0.0 & 0.0 & 0.0 & 1998-2002: & 0.04 & 0.04 & m3ryr & & & \\
\hline Solidified, Organic matrix & 0.0 & 0.0 & 0.0 & 2093-2022: & 0.00 & 0.00 & $\mathrm{~m} 3 / \mathrm{yr}$ & & & \\
\hline Solls & 0.0 & 0.0 & 0.0 & TYPIC & LLEPACOL & DES APPLICAI & BLE & & & \\
\hline $\begin{array}{l}\text { Packaging Materials, Steel } \\
\text { Packaging Material, Plastlc }\end{array}$ & $\frac{0.0}{0.0}$ & & & & D006A & & & & & \\
\hline
\end{tabular}




\section{WASTE STREAM PROFILE FOR THE WIPP TRU WASTE BASELINE INVENTORY REPORT}

SITE NAME AW

WASTE TYPE MTRU HANDLING RH GENERATOR SITE AW

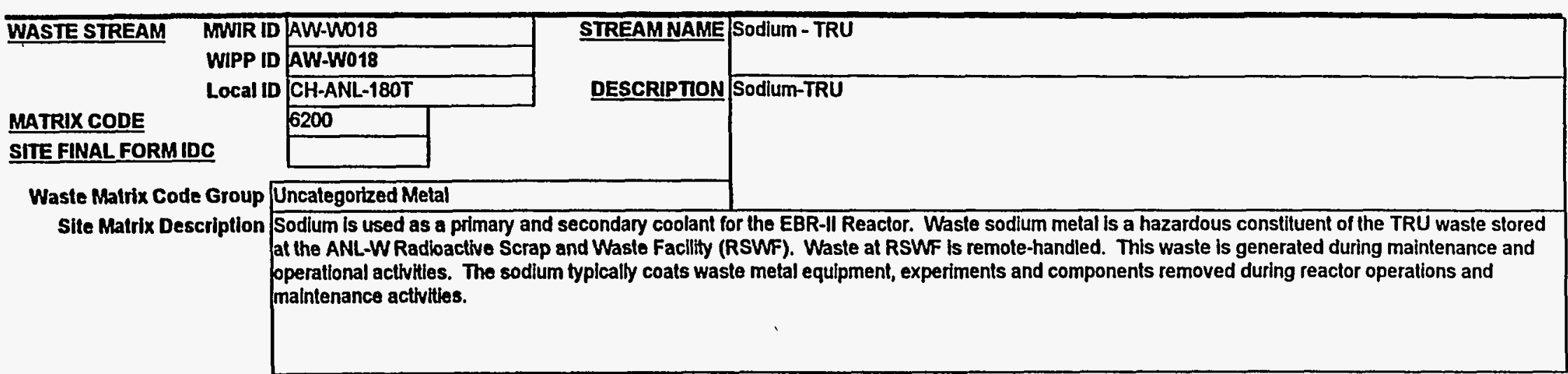

NO MGRATION VARIANCE PETIIION ASSIGNMENT

IRUCON CODE

\section{FINAL WASTE FORMDESCRIPTORS:}

\begin{tabular}{|c|c|c|}
\hline Defense TRU Waste & & Mbxed TRU \\
\hline Non-Defense TRU Waste & $\mathrm{x}$ & Non-Mixed TRU \\
\hline Commerclal TRU Waste & & Suspect Mlxed TRU \\
\hline Unknown & & Unknown \\
\hline
\end{tabular}

Rsearch and Devel Waste Operations Waste

Residues

Decon and Decommissioning

Environmental Restoration

From Trealment of Waste

Maintenance

$\square$

TSCA Asbestos

PCBs

Other

N/A

Unknown 


\section{WASTE STREAM PROFILE FOR THE WIPP TRU WASTE BASELINE INVENTORY REPORT}

AW-W018 $\quad \frac{\text { CONTAINER: }}{\text { Type/Size: }}$ Steol

Contalner Matl: Steel

Int. Volveinr: $0.112 \mathrm{m3}$

Liner Type:

Liner Material

TYPICAL WASTE DENSITIES FOR FINAL WASTE FORM $(\mathrm{kg} / \mathrm{m} 3)$

Material Parameters

Iron-based Metals/Alloys

Aluminum-Based Metals/Alloys

Other Melals

Other Inorganic Materials

Cellulosics

Rubber

Plastics

Solidified, Inorganic matix

Solidified, Organlc matrix

Soils

Packaging Materials, Steel

Packaging Material, Plastic

\begin{tabular}{|r|}
\hline Average \\
\hline 256.1 \\
\hline 27.8 \\
\hline 24.7 \\
\hline 29.3 \\
\hline 7.4 \\
\hline 0.0 \\
\hline 15.1 \\
\hline 0.0 \\
\hline 0.0 \\
\hline 0.0 \\
\hline 0.0 \\
\hline 0.0 \\
\hline
\end{tabular}

Lower Limit Upper Limit

STORED TRU WASTE ESTIMATED

RATES OF WASTE GENERATION

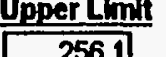

\begin{tabular}{|r|}
\hline 256.1 \\
\hline 27.8 \\
\hline 24.7 \\
\hline 2.3 \\
\hline 0.0 \\
\hline 0.0 \\
\hline 0.0 \\
\hline 0.0 \\
\hline 0.0 \\
\hline 0.0 \\
\hline 24.7 \\
\hline 29.3 \\
\hline 45.3 \\
\hline 0.0 \\
\hline 67.6 \\
\hline 0.0 \\
\hline 0.0 \\
\hline 0.0 \\
\hline
\end{tabular}

Comments

CH-ANL-180T will be treated to remove sodlum contamination from waste to meet

the WPP WAC (no reactwes). The final waste form to be sent to WPP will be

metal TRU waste matertal (no sodjum contamination).

\begin{tabular}{|c|c|c|c|}
\hline & Prolected & Final Form & \\
\hline End of 1892: & 0.0 & 0.0 & m3 \\
\hline id of 1993: & 7.1 & 7.1 & m3 \\
\hline 1984: & 0.2 & 0.2 & $\mathrm{~m} 3 / \mathrm{yr}$ \\
\hline 1995: & 0.2 & 0.2 & m3/yr \\
\hline 1898: & 0.2 & 0.2 & $\mathrm{~m} 3 / y r$ \\
\hline 1987: & 0.2 & 0.2 & $\mathrm{~m} 3 / \mathrm{ry}$ \\
\hline 1988-2002: & 0.0 & 0.0 & m3tyr \\
\hline 2003-2022: & 0.0 & 0.0 & $\mathrm{~m} 3 / \mathrm{yr}$ \\
\hline
\end{tabular}

IYPICAL EPA CODES APPLICABLE

D001C

D003D
Number Stored:

Number Projected:

TYPICAL ISOTOPIC COMPOSITION Nuclide Activity 


\section{WASTE STREAM PROFILE FOR THE WIPP TRU WASTE BASELINE INVENTORY REPORT}

SITE NAME AW

WASTE TYPE MTRU HANDLING RH GENERATOR SITE AW

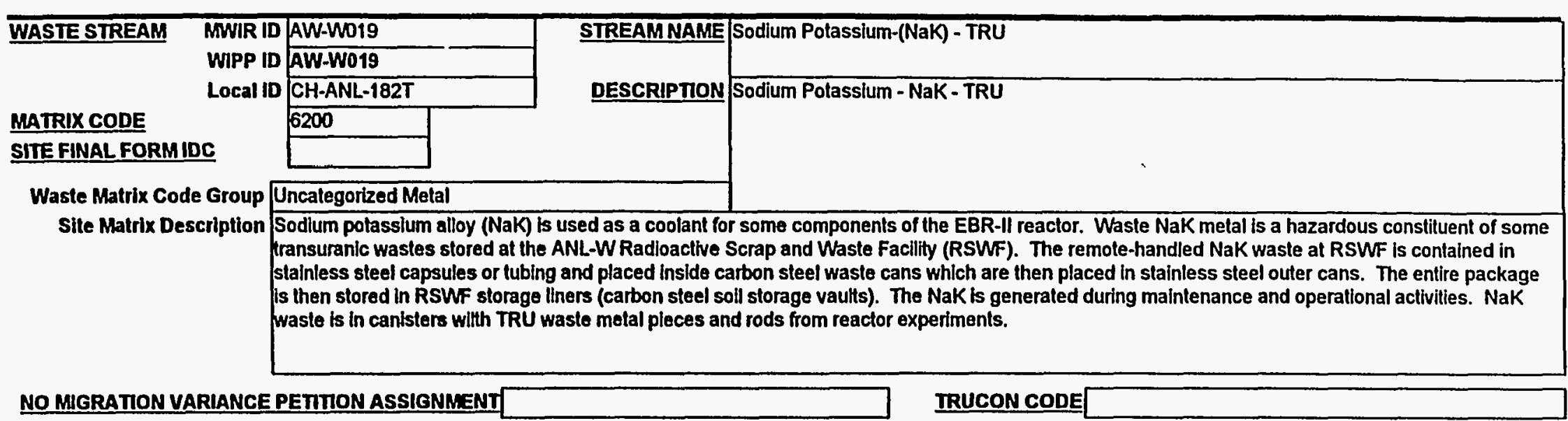

\section{FINAL WASTE FORM DESCRIPTORS:}

Defense TRU Waste

Non-Defense TRU Waste

Commercial TRU Waste

Unknown
Mixed TRU

Non-Mixed TRU

Suspect Mixed TRU

Unknown
Rsearch and Devel Waste Operations Waste

Residues

Decon and Decommissioning

Environmental Restoration From Treatment of Waste Maintenance

\begin{tabular}{|l|}
\hline \\
\hline \\
\hline \\
\hline \\
\hline \\
\hline \\
\hline
\end{tabular}

TSCA Asbestos

PCBs

Other

N/A

Unknown

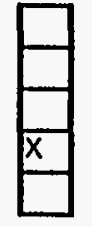




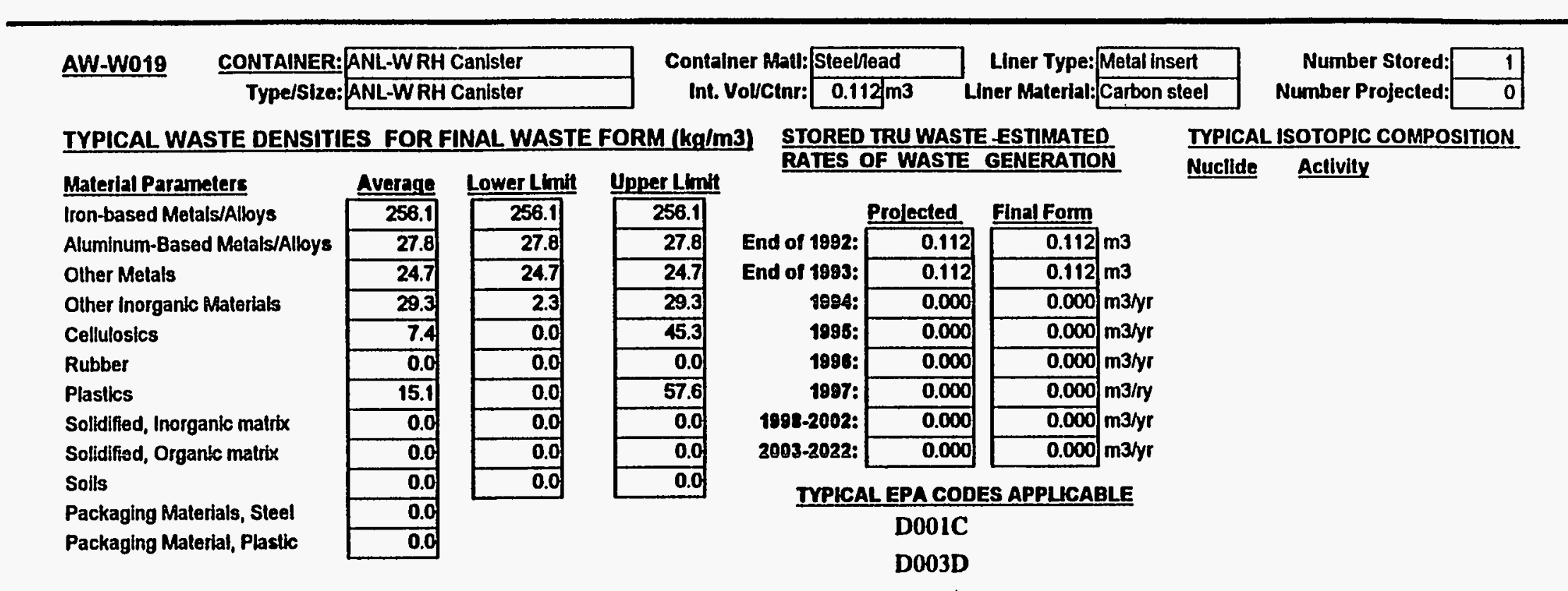


WASTE STREAM PROFILE FOR THE WIPP TRU WASTE BASELINE INVENTORY REPORT

SITENAME AW WASTE TYPEMTRU HANDLING RH GENERATOR SITE AW

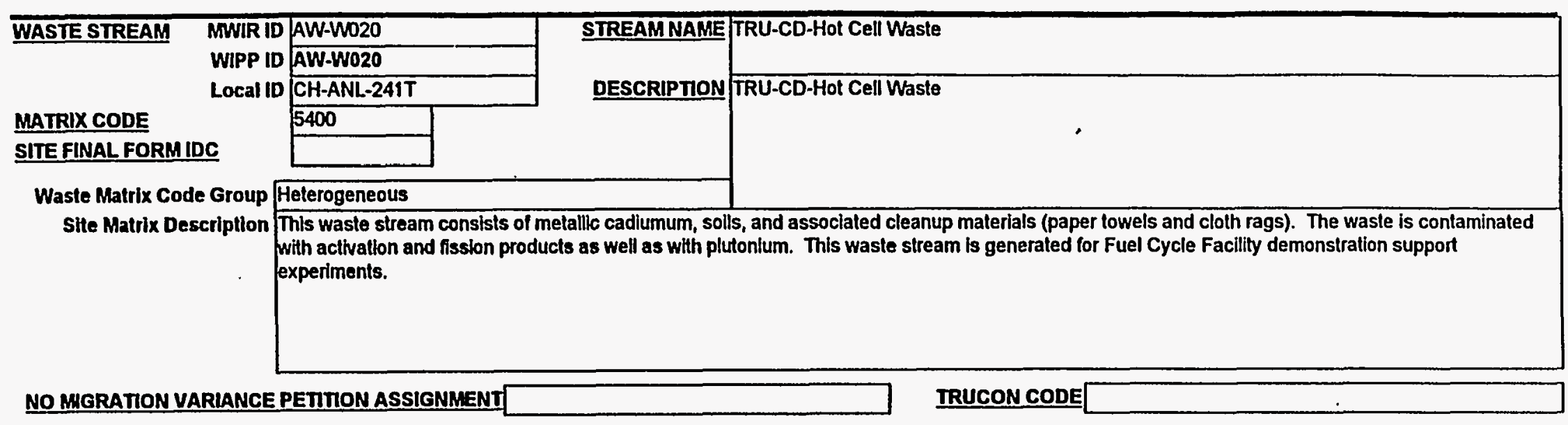

\section{FINAL WASTE FORM DESCRIPTORS:}

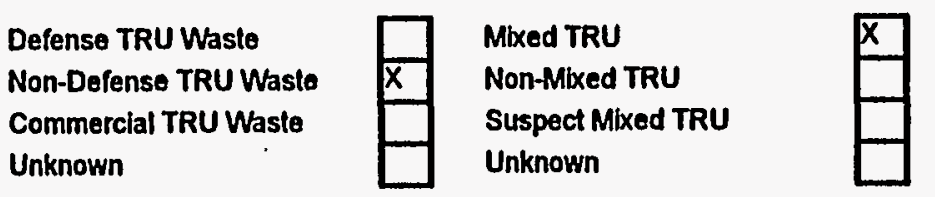

Rsearch and Devel. Waste
Operations Waste
Residues
Decon and Decommissioning
Environmental Restoration
From Treatment of Waste
Maintenance

TSCA Asbeslos
PCBs
Other
N/A
Unknown




\section{WASTE STREAM PROFILE FOR THE WIPP TRU WASTE BASELINE INVENTORY REPORT}

SITE NAME AW

WASTE TYPE MTRU HANDLING RH GENERATOR SITE AW

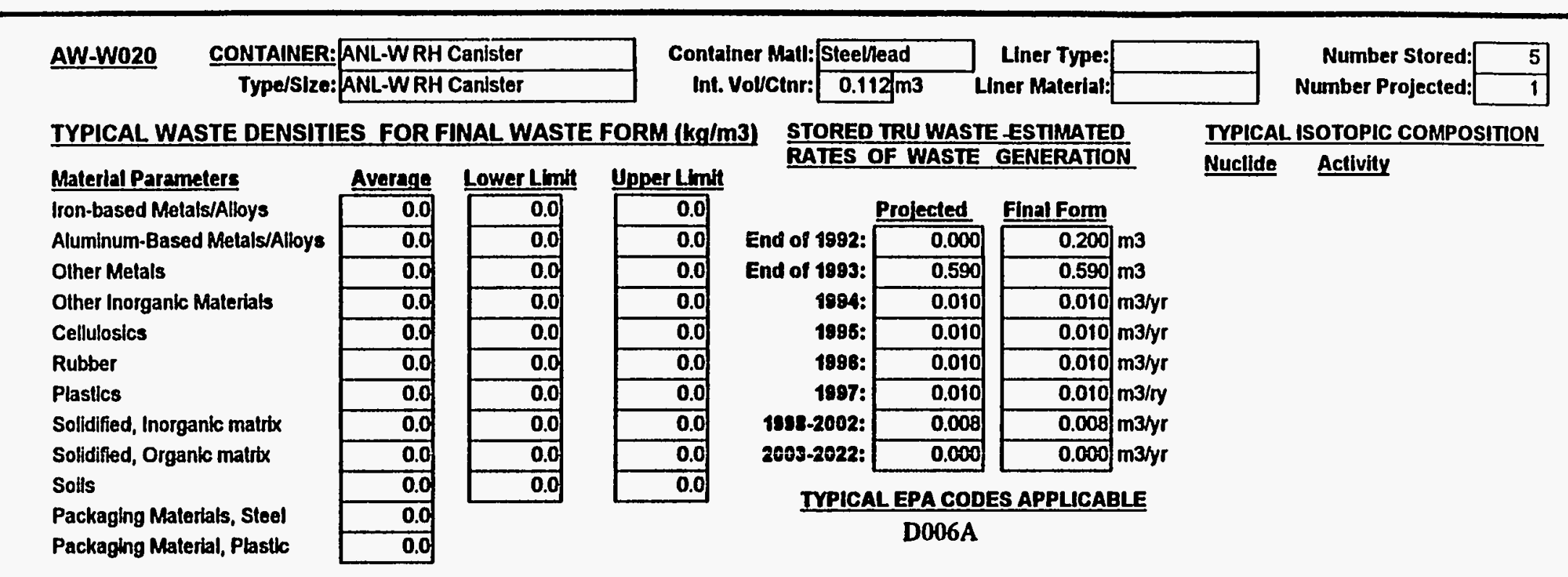


WASTE STREAM PROFILE FOR THE WIPP TRU WASTE BASELINE INVENTORY REPORT

SITE NAME AW WASTE TYPE MTRU HANDLING RH GENERATOR SITE AW

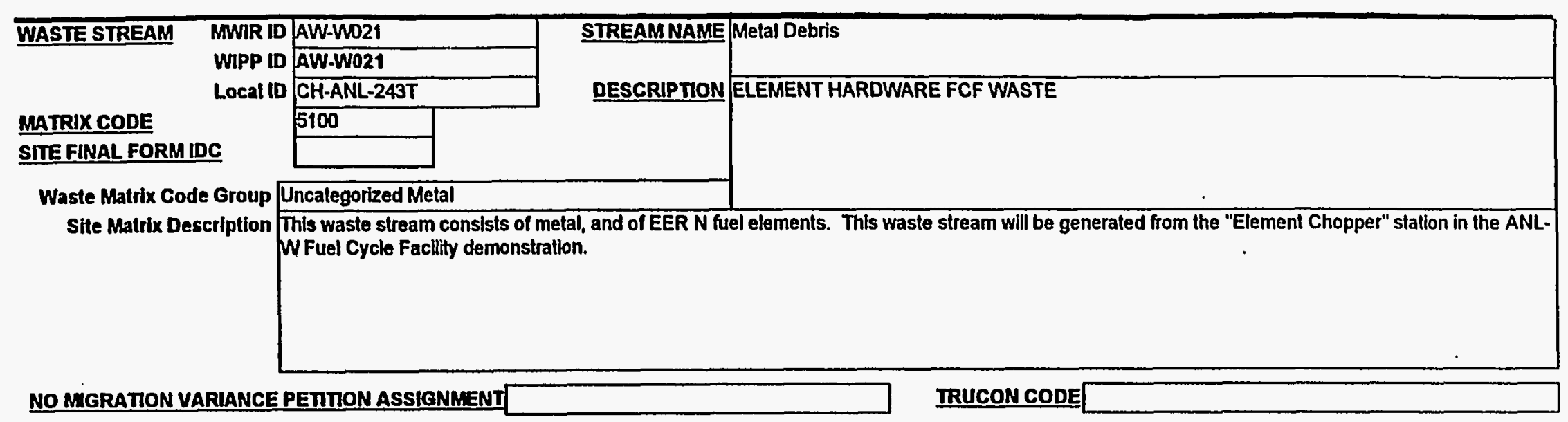

\section{FINAL WASTE FORM DESCRIPTORS:}

Defense TRU Waste

Non-Defense TRU Waste

Commerclal TRU Waste

Unknown

$\square$

Mixed TRU

Non-Mlxed TRU

Suspect Mbxed TRU

Unknown

$\square$

Rsearch and Devel. Waste
Operations Waste
Residues
Decon and Decommissioning
Environmental Restoratlon
From Treatment of Waste
Maintenance

\begin{tabular}{ll}
$x$ \\
\hline$x$ \\
\hline \\
\hline
\end{tabular}

TSCA Asbestos

PCBs

Other

N/A

Unknown 


\section{WASTE STREAM PROFILE FOR THE WIPP TRU WASTE BASELINE INVENTORY REPORT}

SITE NAME AW

\section{WASTE TYPE MTRU HANDLING RH GENERATOR SITE AW}

\section{AW-W021}

Contalner Matl: Steel

Int. VolvCtnr:

Number Stored: Number Projected

TYPICAL WASTE DENSITIES FOR FINAL WASTE FORM (kg/m3)

STORED TRU WASTE ESTMATED RATES OF WASTE GENERATION

TYPICAL ISOTOPIC COMPOSITION

Material Parameters

Iron-based Metals/Alloys

Aluminum-Based Melals/Alloys

Other Metals

Olher Inorganic Materials

Cellulosics

Rubber

Plastics

Solldified, Inorganic matrix

Solidified, Organic matrix

Soils

Packaging Materials, Steel

Packaging Material, Plastic

\begin{tabular}{|c|c|c|}
\hline Avorage & Lower Limit & Upper Limi \\
\hline 258.1 & 256.1 & 256.1 \\
\hline 0.0 & 0.0 & $\overline{0.0}$ \\
\hline 0.0 & $\overline{0.0}$ & 0.0 \\
\hline$\overline{0.0}$ & 0.0 & $\overline{0.0}$ \\
\hline 7.4 & 0.0 & 45.3 \\
\hline$\overline{0.0}$ & 0.0 & $\overline{0.0}$ \\
\hline$\overline{15.1}$ & $\overline{0.0}$ & $\overline{67.6}$ \\
\hline 0.0 & 0.0 & 0.0 \\
\hline 0.0 & 0.0 & 0.0 \\
\hline$\overline{0.0}$ & 0.0 & 0.0 \\
\hline
\end{tabular}


WASTE STREAM PROFILE FOR THE WIPP TRU WASTE BASELINE INVENTORY REPORT

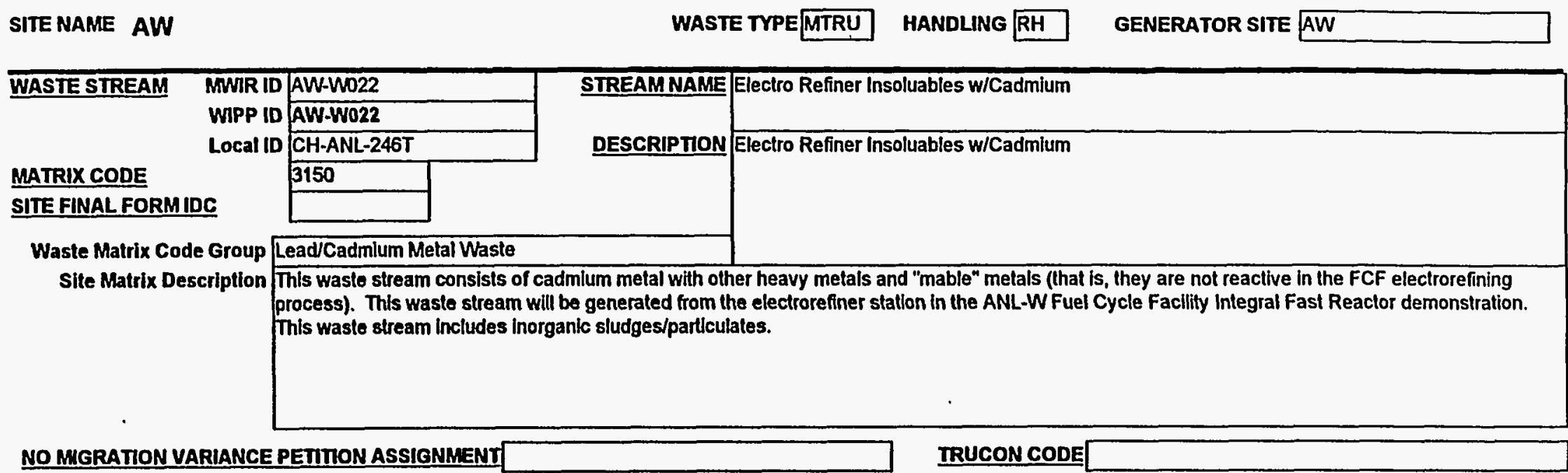

\section{FINAL WASTE FORM DESCRIPTORS:}

\begin{tabular}{l|lll|l} 
Defense TRU Waste \\
Non-Delense TRU Waste \\
Commercial TRU Waste \\
Unknown
\end{tabular}$\quad \square \quad \begin{aligned} & \text { Mixed TRU } \\
& \text { Non-Mlxed TRU } \\
& \text { Suspect Mixed TRU } \\
& \text { Unknown }\end{aligned}$

\begin{tabular}{|c|c|c|}
\hline Rsearch and Devel. Waste & TSCA & Asbestos \\
\hline $\begin{array}{l}\text { Operations Vasto } \\
\text { Residues }\end{array}$ & & $\begin{array}{l}\text { PCBS } \\
\text { Other }\end{array}$ \\
\hline Decon and Decommissioning & & N/A \\
\hline Environmental Restoration & & Unknown \\
\hline From Treatment of Waste & & \\
\hline Maintenanco & & \\
\hline
\end{tabular}


WASTE STREAM PROFILE FOR THE WIPP TRU WASTE BASELINE INVENTORY REPORT

SITE NAME AW

WASTE TYPE MTRU HANDLING RH GENERATOR SITE AW

\begin{tabular}{|c|c|c|c|c|c|c|c|}
\hline \multicolumn{3}{|c|}{$\begin{aligned} & \text { CONTAINER:ANL-WRH Canister } \text { Aype/Size: ANL-WRH Canisler } \\
& \text { ANL }\end{aligned}$} & \multicolumn{2}{|c|}{$\begin{array}{l}\text { Container Matl: } \\
\text { Int. VolvCtnr: }\end{array}$} & \begin{tabular}{|c|} 
Steellead \\
$0.112 \mathrm{~m}^{3}$
\end{tabular} & $\begin{array}{l}\text { Liner Type: } \\
\text { ner Material: }\end{array}$ & \\
\hline \multicolumn{4}{|c|}{ TYPICAL WASTE DENSITIES FOR FINAL WASTE FORM $(\mathrm{kg} / \mathrm{m} 3)$} & \multicolumn{4}{|c|}{$\begin{array}{l}\text { STORED TRU WASTE ESTIMATED } \\
\text { RATES OF WASTE GENERATION }\end{array}$} \\
\hline Material Parameters & Average & Lower Linit & Upper Limit & & & & \\
\hline Iron-based Metais/Alloys & 0.0 & 0.0 & 0.0 & \multirow{3}{*}{$\begin{array}{l}\text { End of 1992: } \\
\text { End of 1993: }\end{array}$} & Prolected & \multicolumn{2}{|l|}{ Final Form } \\
\hline Aluminum-Based Motals/Aloys & 0.0 & 0.0 & 0.0 & & 0.000 & 0.072 & m3 \\
\hline Other Metals & 0.0 & 0.0 & 0.0 & & 0.000 & 0.000 & m3 \\
\hline Other Inorganic Materials & 489.0 & 28.8 & 754.8 & 1994: & 0.000 & 0.000 & $\mathrm{~m} 3 / \mathrm{yr}$ \\
\hline Cellutosics & 0.0 & 0.0 & 0.0 & 1998: & 0.020 & 0.020 & m3/yr \\
\hline Rubber & 0.0 & 0.0 & 0.0 & 1988: & 0.020 & 0.020 & $m 3 / y r$ \\
\hline Plastics & 0.0 & 0.0 & 0.0 & 1997: & 0.020 & 0.020 & $m 3 / r y$ \\
\hline Solidified, Inorganic matrix & 206.9 & 101.0 & 619.2 & 1998-2002: & 0.008 & 0.008 & m3/yr \\
\hline Solidified, Organic matrix & 0.0 & 0.0 & 0.0 & 2003-2022: & 0.000 & 0.000 & m3/yr \\
\hline Solls & 0.0 & 0.0 & 0.0 & TYPLCA & AL. EPA COL & 5 APPLICAE & BLE \\
\hline $\begin{array}{l}\text { Packaging Materials, Steel } \\
\text { Packaging Material, Plastlc }\end{array}$ & $\frac{0.0}{0.0}$ & & & & D006A & & \\
\hline
\end{tabular}




\section{Battelle Columbus Laboratories}




\section{BATTELLE COLUMBUS LABORATORY (BC) WASTE STREAM PROFILES}

The following modifications were made by the WTWBIR team in developing the BC waste stream profiles:

- BC Final Waste Form Groups were modified to be consistent with the nomenclature used in the WTWBID. These changes included word and spelling changes. The assigned Final Waste Form Groups are consistent with the information provided by BC.

- The WTWBIR ID "RHTRU" submitted by BC was changed to BC-TO01 to be consistent with the ID's used in the WTWBIR database.

- The containers for RH-TRU waste streams were reported as drums by the site. The drums were changed to RH canisters, with three drums overpacked in each canister.

- The volumes for the years 1998-2002 were reported by the site as total volumes for each five-year period. The WTWBIR team converted the values to volume/year. 
WASTE STREAM PROFILE FOR THE WIPP TRU WASTE BASELINE INVENTORY REPORT

SITENAME BC WASTE TYPE TRU HANDLING RH GENERATOR SITE BC

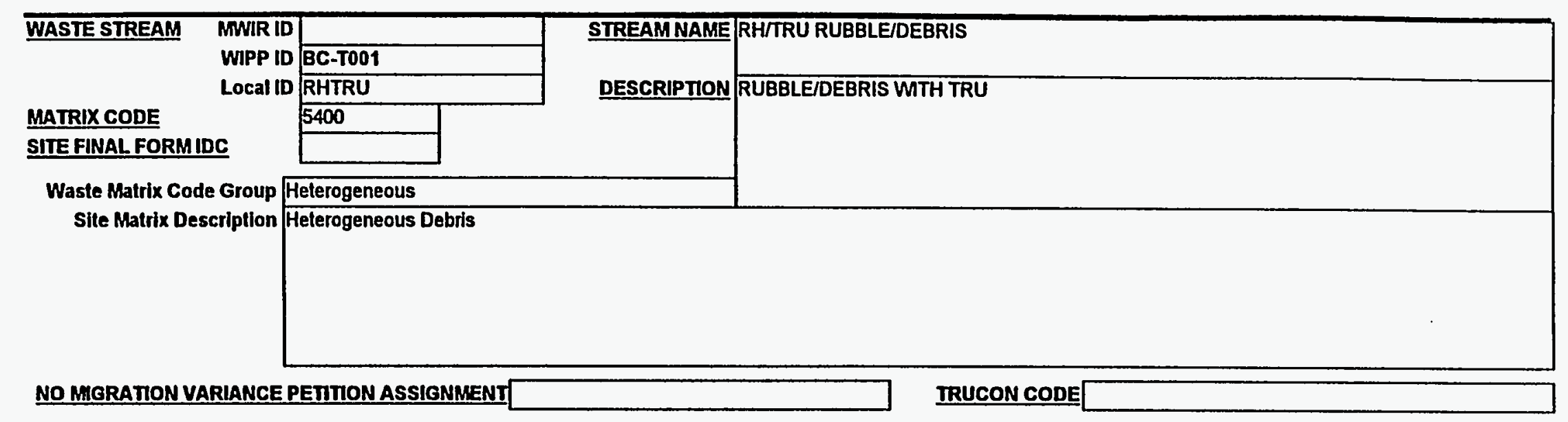

\section{FINAL WASTE FORM DESCRIPTORS:}

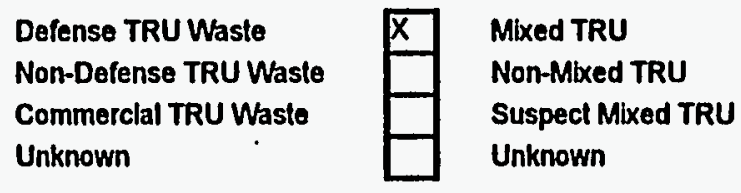

Rsearch and Devel Whsto Operations Waste

Residues

Decon and Decommissioning $x$

Environmental Restoration From Treatment of Waste

Maintenance

$\square$

TSCA Asbestos

PCBs

Other

N/A

Unknown 


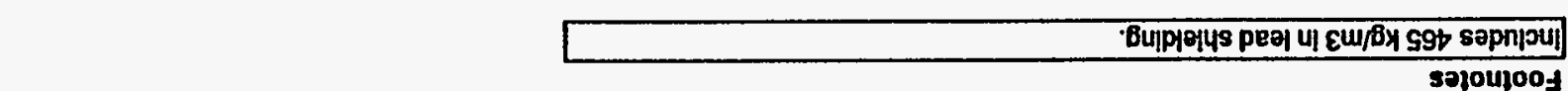

\begin{tabular}{|c|c|c|}
\hline נחכ & $10-\exists 0 t+1$ & \\
\hline 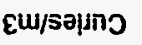 & $20-308^{\circ} \%$ & \\
\hline EW/se!!no & $00-\exists 0 L \varepsilon$ & \\
\hline$\varepsilon w / s=\mid ! n כ$ & $\varepsilon 0-306 Z$ & \\
\hline Eu/sąuno & $50-302 !$ & \\
\hline Ew/seuno & $\angle 0-30 t^{\prime} Z$ & \\
\hline Eu/sąuno & $10+300^{\prime} \varepsilon$ & \\
\hline Eu/sąıno & $00+30 L t$ & \\
\hline Ew/søuno & $10-\exists 0 z^{\prime} 9$ & \\
\hline Eu/sęınכ & 10-308's & \\
\hline Eu/sọ!ın & $20-30+2$ & \\
\hline Ew/səฺุnว & $00+3086$ & \\
\hline Ew/sapuno & $00+30<\angle$ & \\
\hline Ew/saํng & $00+\exists 00 \cdot \varepsilon$ & \\
\hline Eu/salung & $10-\exists 0 S \varepsilon$ & \\
\hline Eu/solıno & $\frac{20-300 \% 9}{\text { रालाइए }}$ & \\
\hline
\end{tabular}

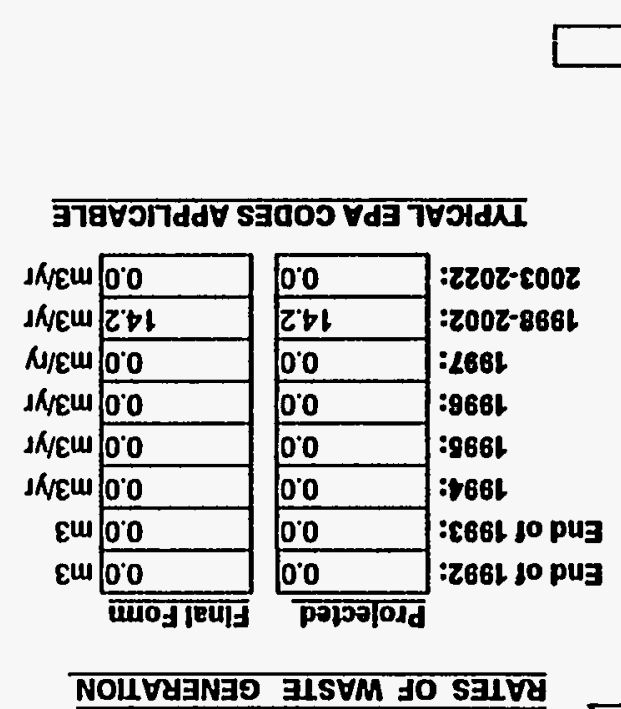

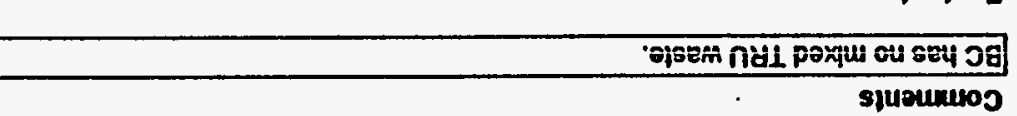

s)usuretros

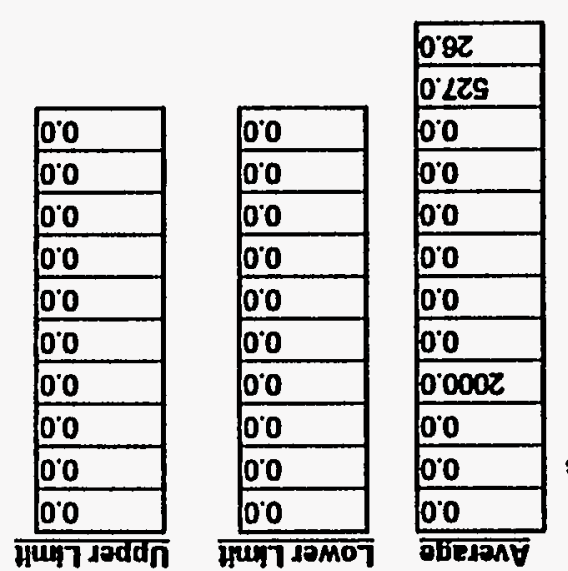

opsoqd 'jepojew buj6ryord

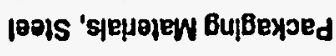
s\|os

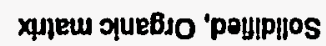

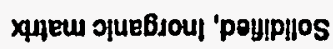

sonseld

Jeqqny

sopsoln||əo

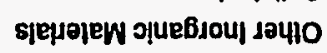

S|P1日W JaY10

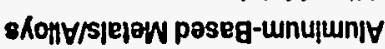

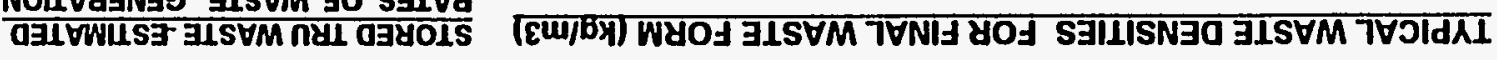




\section{Bettis Atomic Power Laboratory}




\section{BETTIS ATOMIC POWER LABORATORY (BT) WASTE STREAM PROFILES}

The following assumptions/modifications were made by the WTWBIR team in developing the BT waste stream profiles:

- The two digit site identification code used in the MWIR (BT) has been substituted for "BE." 


\section{WASTE STREAM PROFILE FOR THE WIPP TRU WASTE BASELINE INVENTORY REPORT}

SITENAME BT

WASTE TYPETRU HANDLING RH GENERATOR SITE BT

\begin{tabular}{|c|c|c|c|}
\hline WASTE STREAM MWIR ID & & STREAMNAME & Irradlated TRU material waste \\
\hline WIPP ID & BT-T001 & & \\
\hline Local ID & BT-T001 & DESCRIPTION & Specimen processing fines, material, and debris resulting from operations involving destructive \\
\hline MATRIX CODE & & & evaluations of imadiated fuel specimens. \\
\hline SITE FINAL FORMIDC & & & \\
\hline Waste Matrix Code Group $\overline{\mathrm{h}}$ & Heterogeneous & & $\cdot$ \\
\hline Site Matrix Description $\bar{R}$ & Refer to "description" above & & \\
\hline
\end{tabular}

NO MIGRATION VARIANCE PETITON ASSIGNMENT

IRUCON CODE

\section{FINAL WASTE FORM DESCRIPTORS:}

Defense TRU Waste

Non-Defense TRU Waste

Commerclal TRU Waste

Unknown

$\mathrm{X}$

Mbxed TRU

Non-Mixed TRU

Suspect Mixed TRU

Unknown

$\square$

Rsearch and Devel. Waste

Operations Waste

Residues

Decon and Decommissioning

Environmental Restoration

From Treatment of Waste

Maintenance

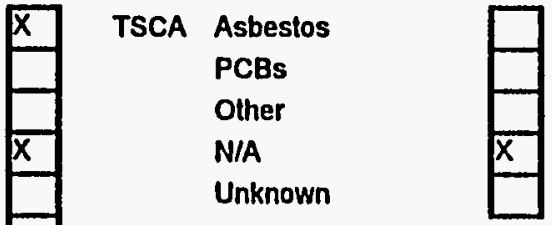

Unknown 


\begin{tabular}{|c|c|c|}
\hline$\varepsilon w / s=\mid \jmath n$ & $10+300 \mathrm{~s}$ & 8EZnd \\
\hline Ew/sa!nn & $10+300 \mathrm{~s}$ & zsing \\
\hline$\varepsilon w / s$ sajn & $20+30 S^{\prime} \varepsilon$ & $\angle t \mid w_{d}$ \\
\hline عw/sa!ıno & $20+3051$ & ESIN \\
\hline عw/sạıno & $10+300 \mathrm{~s}$ & S8IX) \\
\hline$\varepsilon w / s a \mu n$ & $10+300 \mathrm{~s}$ & SSOA \\
\hline Ew/sapn & $10+300 \mathrm{~s}$ & tSing \\
\hline Eu/sa!uno & $10+300 \mathrm{~s}$ & $b \varepsilon \mid s o$ \\
\hline Ew/są!no & $10+300 \mathrm{~s}$ & 0905 \\
\hline Ew/sę!ng & $60+\exists 50$ ' & 06/S \\
\hline$\varepsilon w / s$ equn & $\varepsilon 0+\exists S 0^{\prime \prime}$ & $06 \lambda$ \\
\hline Ew/sop]n & $80+350 \%$ & LEISO \\
\hline \multirow[t]{2}{*}{$\varepsilon \mathrm{w} / \mathrm{s} \theta \mid \mathrm{p} \mathrm{ng}$} & $\varepsilon 0+300$ & $u \angle E \mid$ Eg \\
\hline & 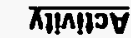 & गpाIगतN \\
\hline
\end{tabular}

NOIISOdWOJ गdOIOSI 7४गाम
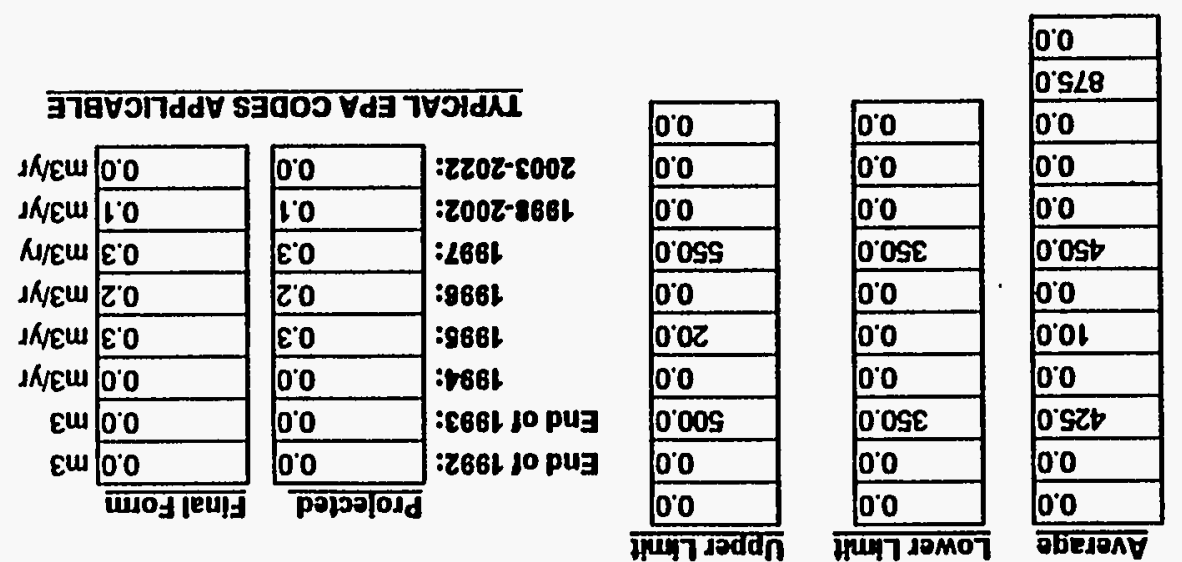

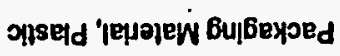

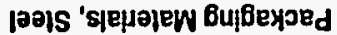

sllos

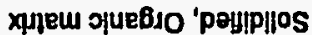

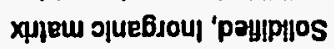

solfseld

seqqny

so|so|n|⿰习习丁

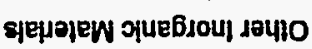

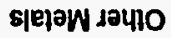

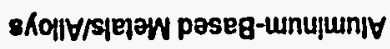

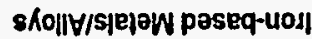

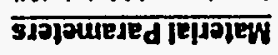

NOLVYAN39 IISWM JO SEIVY

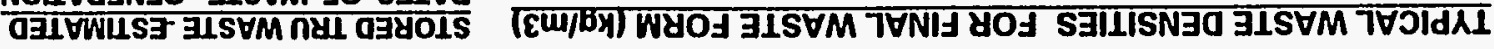

$L \quad$ :pajoajosd saqunN :pasols saqunN 
WASTE STREAM PROFILE FOR THE WIPP TRU WASTE BASELINE INVENTORY REPORT

SITE NAME BT WASTE TYPETRU HANDLING CH

GENERATOR SITE BT

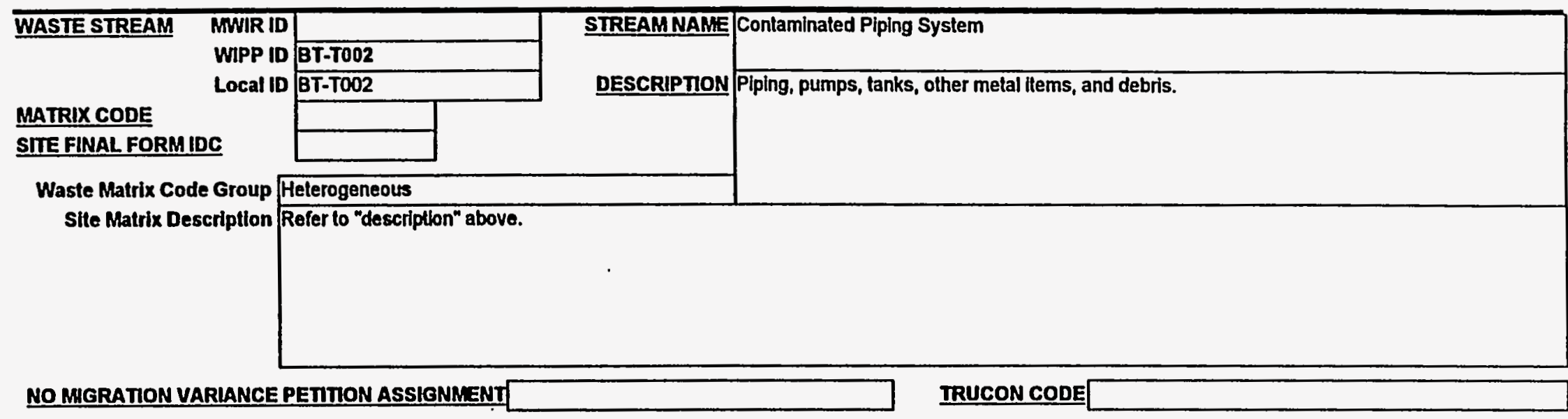

\section{FINAL WASTE FORM DESCRIPTORS:}

\begin{tabular}{l|l} 
Defense TRU Waste \\
Non-Defense TRU Waste \\
Commerclal TRU Waste \\
Unknown
\end{tabular}$\quad \square \quad \begin{aligned} & \text { Mixed TRU } \\
& \text { Non-Mbxed TRU } \\
& \text { Suspect Mlxed TRU } \\
& \text { Unknown }\end{aligned}$

$\square$

Rsearch and Devel. Waste
Operations Waste
Resldues
Decon and Decommissioning
Environmental Restoration
From Trealment of Waste
Maintenance

TSCA Asbestos

PCBs

Other

NIA

Unknown 


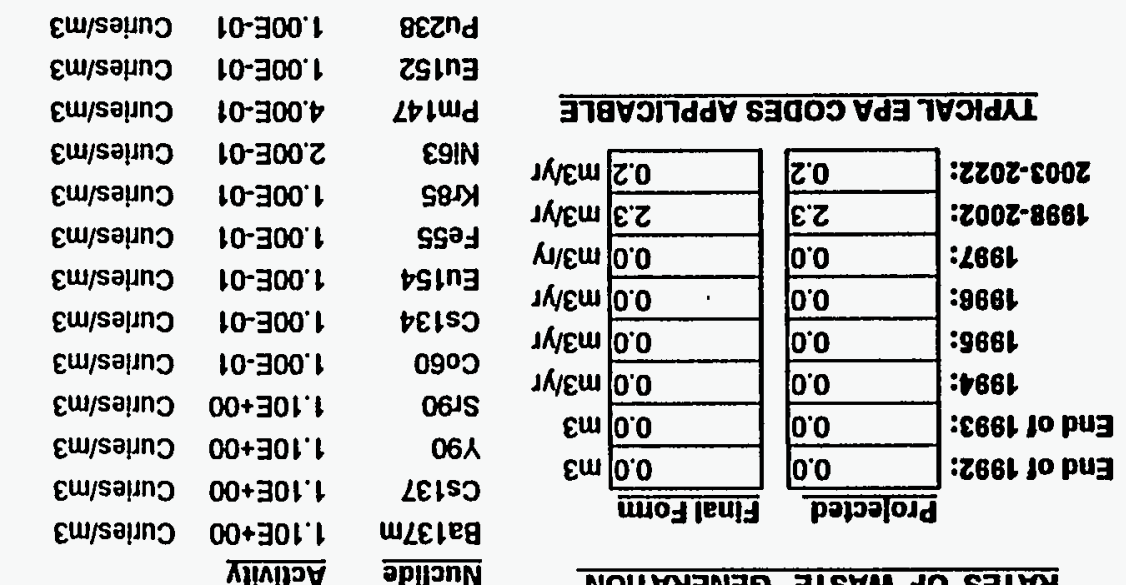
NOLISOdWOJ JIdOIOSI 78JIM

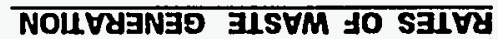

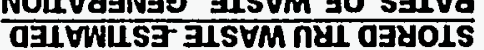
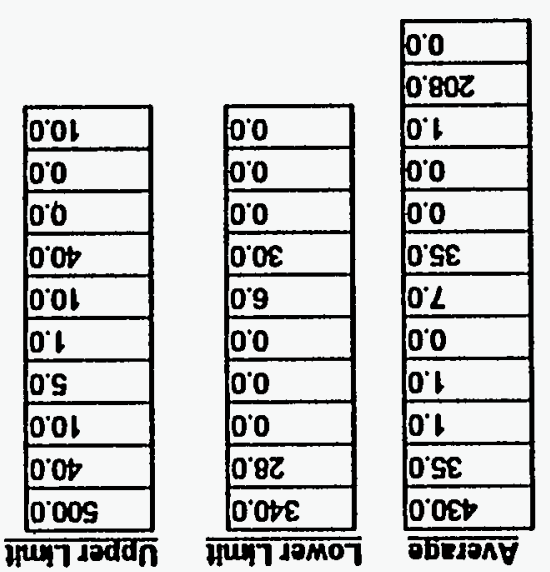

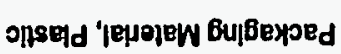

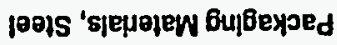
. $\quad s \| 0 S$

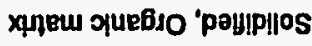

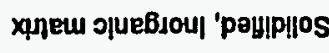

sollsetd

jeqqny

so|รo!nก|วว

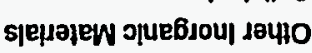

s|ejaw jouno

shoily/s|ejaw paseg-tunupunj|

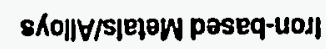

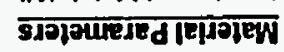
8 :pajor[osd JaquinN :อนควЕพ มอนา 
WASTE STREAM PROFILE FOR THE WIPP TRU WASTE BASELINE INVENTORY REPORT

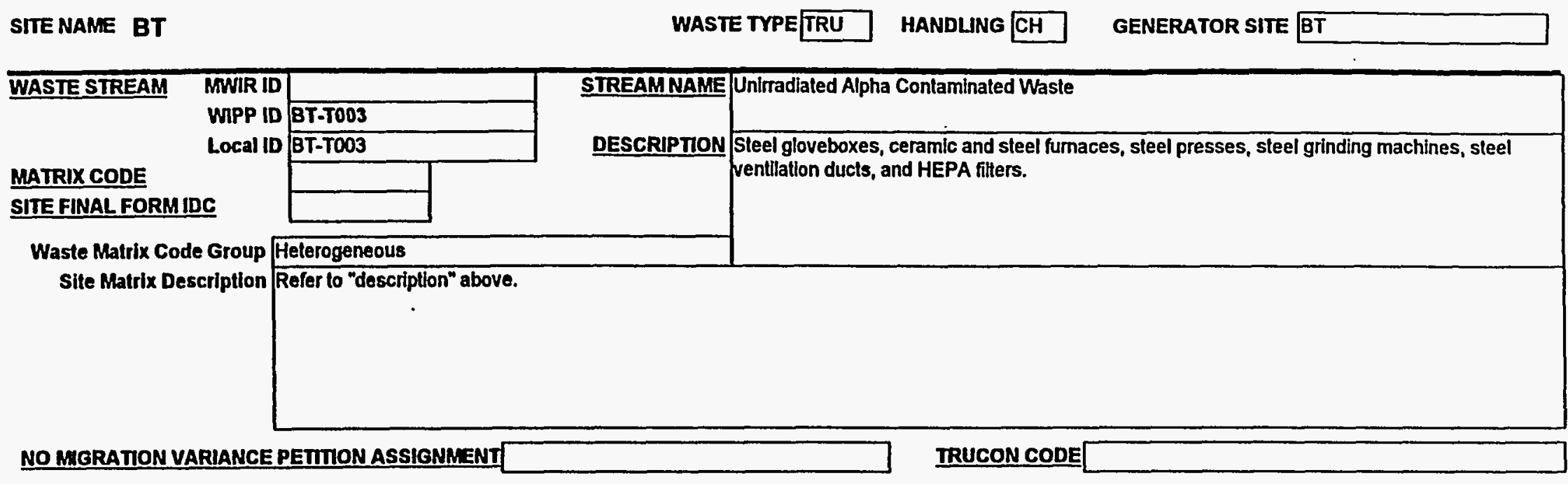

FINAL WASTE FORM DESCRIPTORS:

\begin{tabular}{l|ll} 
Defense TRU Waste & & $\begin{array}{l}\text { Mlxed TRU } \\
\text { Non-Mixed TRU } \\
\text { Non-Defense TRU Wasto } \\
\text { Commerclal TRU Waste } \\
\text { Unknown }\end{array}$ \\
Suspect Mixed TRU \\
Unknown
\end{tabular}

\begin{tabular}{|l|l|}
\hline & $\begin{array}{l}\text { Rsearch and Devel. Waste } \\
\text { Operalions Waste } \\
\text { Residues } \\
\text { Decon and Decommissioning } \\
\text { Environmental Restoration } \\
\text { From Treatment of Wasto } \\
\text { Maintenance }\end{array}$
\end{tabular}

$\begin{array}{lll}\text { TSCA Asbeslos } & \\ \text { PCBs } & \\ \text { Other } & \\ \text { N/A } & \\ \text { Unknown } & \end{array}$




\section{WASTE STREAM PROFILE FOR THE WIPP TRU WASTE BASELINE INVENTORY REPORT}

SITE NAME BT

WASTE TYPETRU HANDLING CH GENERATOR SITE BT

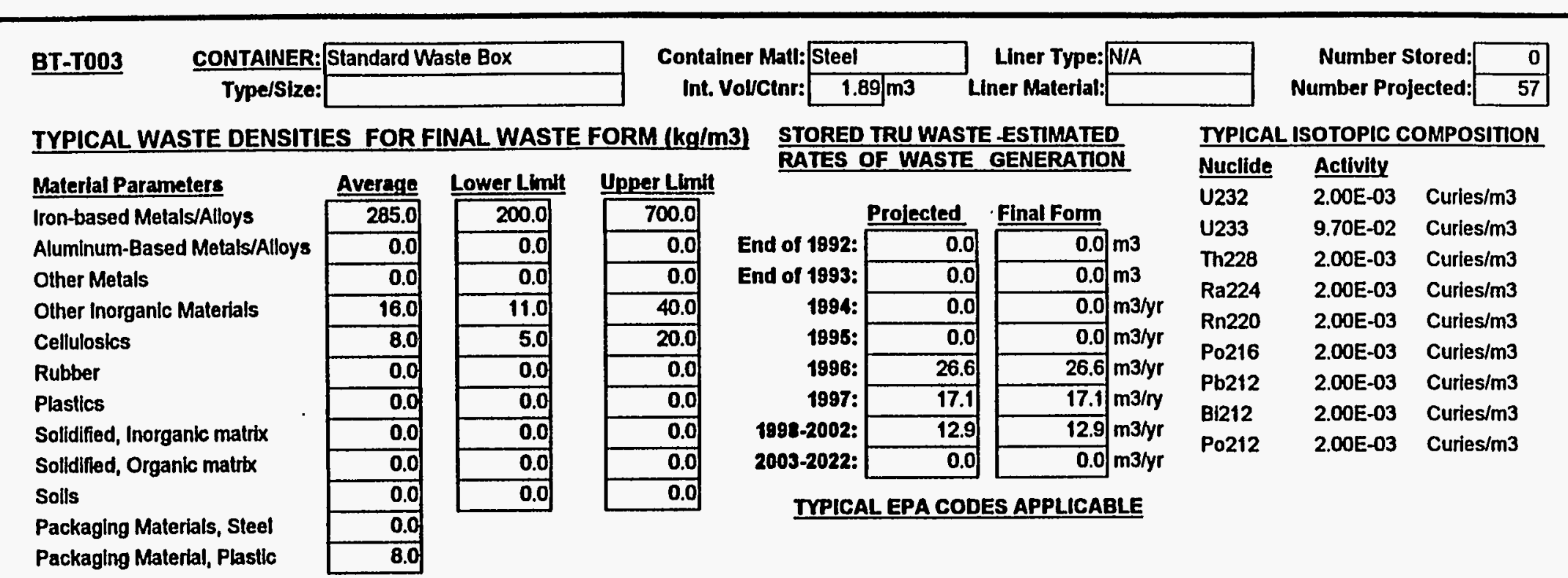


WASTE STREAM PROFILE FOR THE WIPP TRU WASTE BASELINE INVENTORY REPORT SITE NAME BT

WASTE TYPE TRU HANDLING CH GENERATOR SITE BT

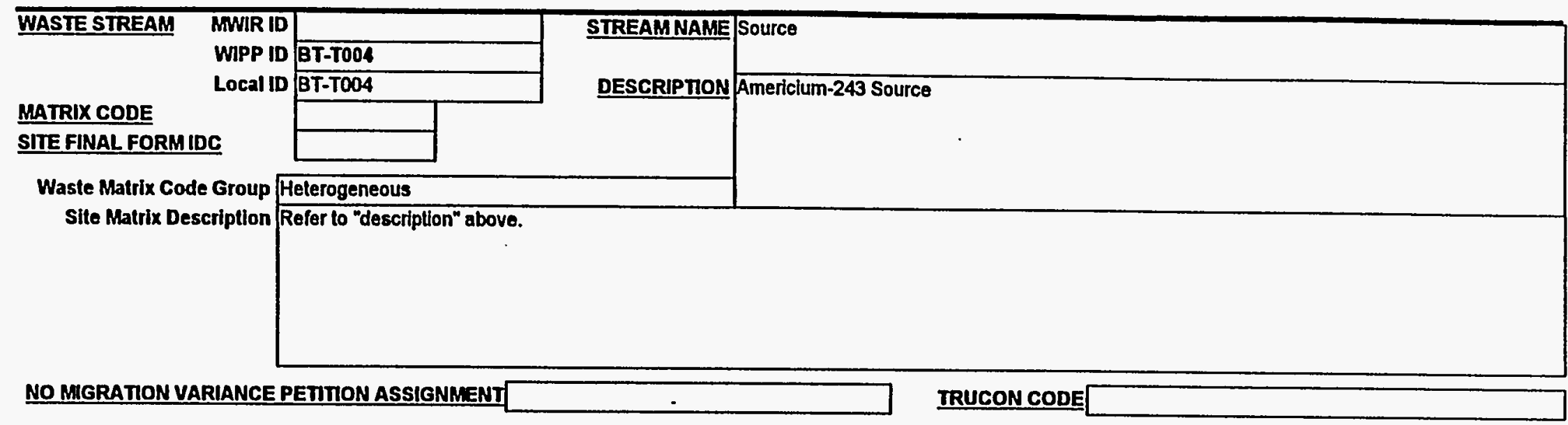

\section{FINAL WASTE FORM DESCRIPTORS:}

Defense TRU Waste

Non-Defense TRU Waste

Commerclal TRU Waste

Unknown

$\square$

Mixed TRU

Non-Mixed TRU

Suspect Mixed TRU

Unknown

Rsearch and Devel. Waste
Operatlons Wasto
Residues
Decon and Decommissioning
Environmental Restoration
From Treatment of Waste
Maintenance

Maintenance

$\square$

TSCA Asbestos

PCBs

Olher

N/A

Unknown 


\section{WASTE STREAM PROFILE FOR THE WIPP TRU WASTE BASELINE INVENTORY REPORT}

BT-T004

$$
\text { CONTAINER: } \begin{array}{ll}
\text { Drum } \\
\hline \text { Type/Size: } 55 \text {-galion }
\end{array}
$$

Container Matl: Steel

Int. Vol/Cinr: $0.208 \mathrm{~m}^{3}$

STORED TRU WASTE ESTIMATED

IYPICAL WASTE DENSITIES FOR FINAL WASTE FORM (kg/m3)

\section{Material Parameters}

Iron-based Melals/Alloys

Aluminum-Based Metals/Alloys

Other Melals

Other Inorganic Materials

Cellulosics

Rubber

Plastics

Solldified, Inorganic matrix

Solidified, Organkc matrix

Solts

Packaging Materiats, Stoel

Packaging Matertal, Plastic
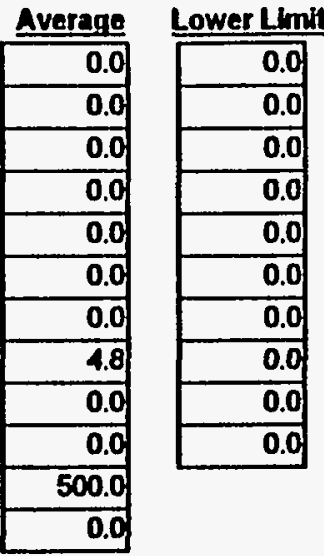

Upper Limit

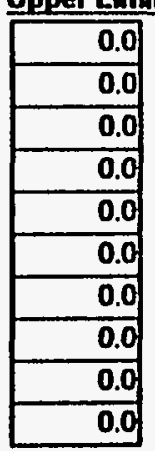

\begin{tabular}{|c|c|}
\hline & Prolected \\
\hline & 0.00000 \\
\hline & 0.00000 \\
\hline 1994: & 0.00000 \\
\hline 1985: & 0.00025 \\
\hline 1998: & 0.00000 \\
\hline 1907: & 0.00000 \\
\hline $92-200$ & 0.00000 \\
\hline 003-2022: & 0.00000 \\
\hline
\end{tabular}

RATES OF WASTE GENERATION

Final Form

$0.00000 \mathrm{m3}$

$0.00000 \mathrm{m3}$

$0.00000 \mathrm{~m} 3 / \mathrm{yr}$

$0.20800 \mathrm{~m} 3 / \mathrm{yr}$

$0.00000 \mathrm{~m} 3 / \mathrm{yr}$

$0.00000 \mathrm{~m} 3 / \mathrm{r}$

$0.00000 \mathrm{~m} 3 \mathrm{yr}$

$0.00000 \mathrm{~m} 3 / y r$
Number Stored: Number Projected

IYPICAL ISOTOPIC COMPOSITION

Nuclide Activity

Am243 3.20E+00 Curies $/ \mathrm{m} 3$

Np239 $3.20 \mathrm{E}+00$ Curies $/ \mathrm{m}^{3}$

Comments

Single source with packaging materlal. Lower and upper timlis not applicablo. 


\section{WASTE STREAM PROFILE FOR THE WIPP TRU WASTE BASELINE INVENTORY REPORT}

SITE NAME BT WASTE TYPE TRU

HANDIING $\mathrm{CH}$

GENERATOR SITE BT

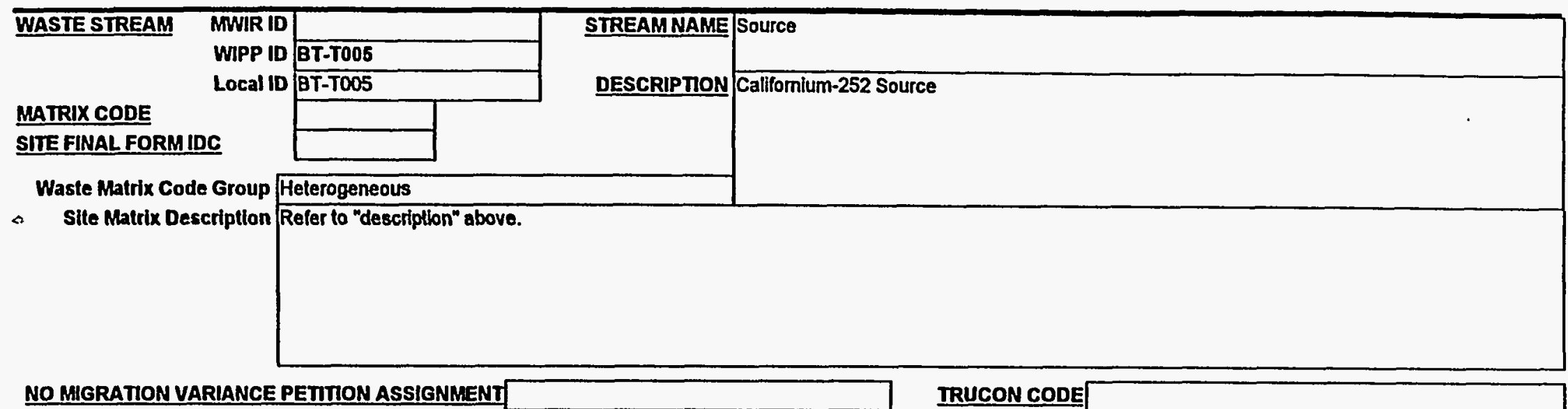

\section{FINAL WASTE FORMDESGRIPTORS:}

Defense TRU Waste

Non-Defense TRU Waste

Commercial TRU Waste

Unknown

$\square$

Mixed TRU

Non-Mixed TRU

Suspect Mixed TRU

Unknown
Rsearch and Devel. Waste

Operations Waste

Residues

Decon and Decommissloning

Environmental Restoration

From Treatment of Waste

Mainlenance

$\square$

TSCA Asbestos

PCBs

Other

N/A

Unknown 


\section{WASTE STREAM PROFILE FOR THE WIPP TRU WASTE BASELINE INVENTORY REPORT}

SITE NAME BT

WASTE TYPE TRU HANDLING CH GENERATOR SITE BT

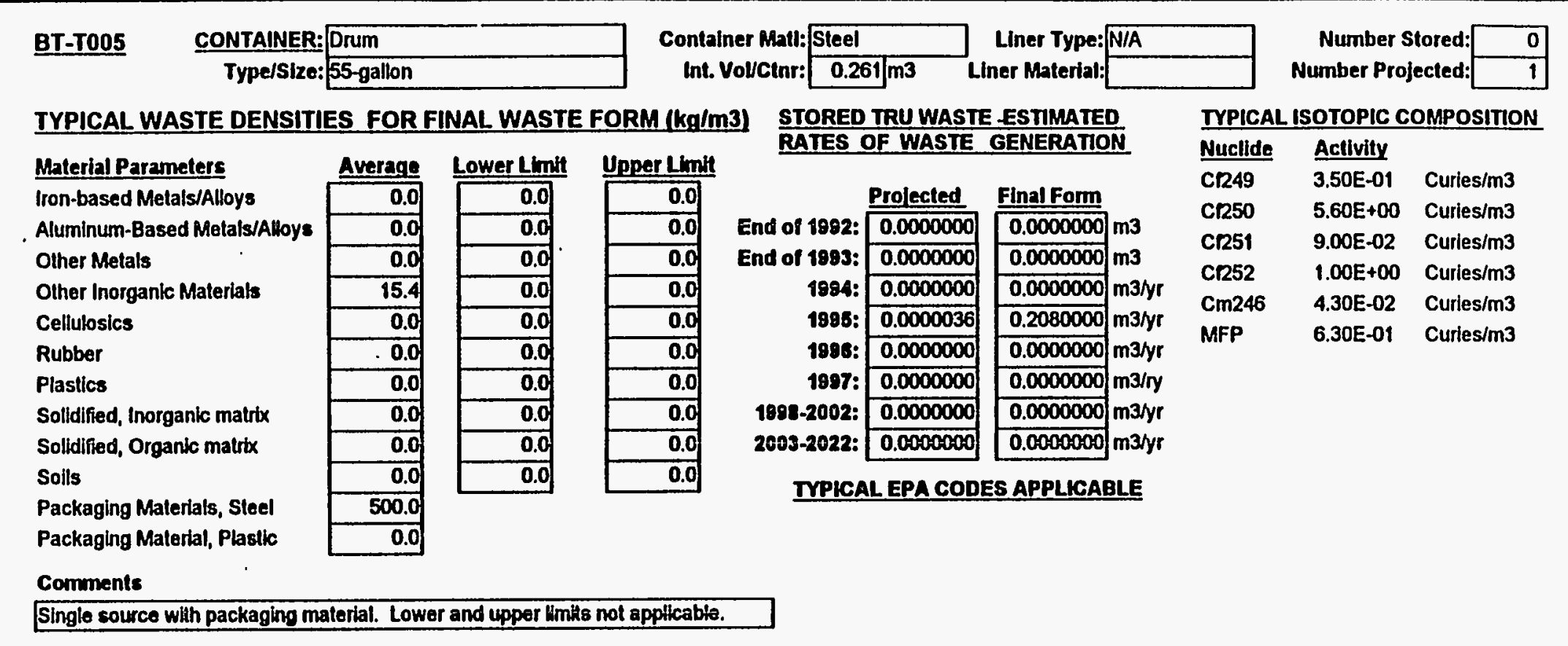




\section{Energy Technology Engineering Center}




\section{ENERGY TECHNOLOGY ENGINEERING CENTER (ET) WASTE STREAM PROFILES}

The following assumptions/modifications were made by the WTWBIR team in developing the ET waste stream profiles:

- Final Waste Form Groups were not provided by ET. In order to permit roll-ups of the data, the WTWBIR team assigned Final Waste Form Groups based on the descriptions and parameters provided by ET.

- The WTWBIR team had to assign identification numbers (IDs) to those ET waste streams not given an identifier by the site.

- Since only current volumes were provided by ET, the final form volumes were assumed to be the same as the current volumes.

- The volumes for the year 1993 were changed from an annual rate of generation ( $\mathrm{m}^{3} / y e a r$ ) to a cumulative value $\left(\mathrm{m}^{3}\right)$. 
WASTE STREAM PROFILE FOR THE WIPP TRU WASTE BASELINE INVENTORY REPORT

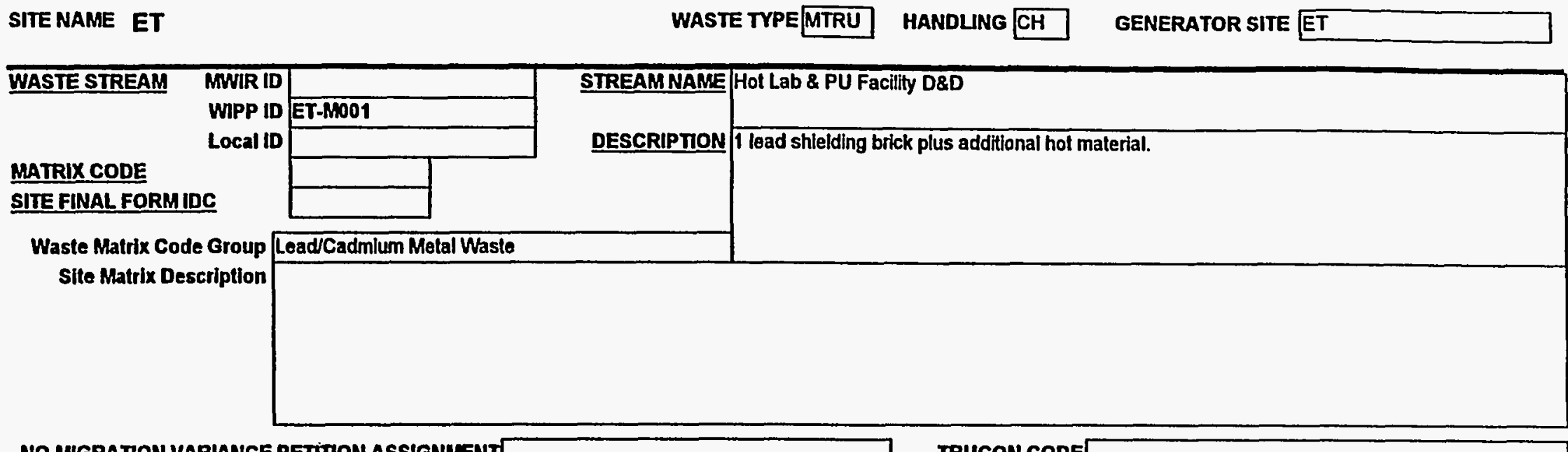

NO MUGRATION VARIANCE PETIIION ASSIGNMENT — IRUCON CODE

FINAL WASTE FORMDESCRIPTORS:

\begin{tabular}{|c|c|}
\hline Defense TRU Waste & Mixed TRU \\
\hline Non-Defense TRU Waste & Non-Mixed TRU \\
\hline Commercial TRU Waste & Suspect Mixed TRU \\
\hline Unknown & Unknown \\
\hline
\end{tabular}

Rsearch and Devel. Waste
Operatlons Waste
Residues
Decon and Decommissioning
Environmental Restoralion
From Trealment of Waste
Malntenance

TSCA Asbestos

PCBs

Other

N/A

Unknown

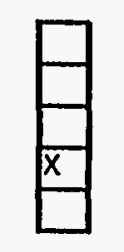




\section{WASTE STREAM PROFILE FOR THE WIPP TRU WASTE BASELINE INVENTORY REPORT}

SITE NAME ET WASTE TYPE MTRU HANDLING CH GENERATOR SITE ET

ET-M001 $\quad \frac{\text { CONTAINER: Drum }}{\text { Type/Size: } 55 \text {-gallon }}$

Contalner Matt: steel-galv.

\begin{tabular}{r|l} 
Lner Type: & Higid \\
Liner Material: & HDPE-90 mil \\
\hline
\end{tabular}
Number Stored

Number Projected:

TYPICAL ISOTOPIC COMPOSITION

Nucilide Activity

Pu238 4.60E-01 Curies/m3

Pu239 7.60E+00 Curies $/ \mathrm{m}^{3}$

Pu240 2.60E+00 Curies/m3

Pu242 1.50E-04 Curles $/ \mathrm{m}^{3}$

Am241 1.90E+00 Curles/m3

Pu241 3.50E+01 Curles $/ \mathrm{m}^{3}$

Cs137 1.10E+00 Curies/m3

Sr90 1.00E +00 Curies $/ \mathrm{m} 3$

Plastics

Solidified, Inorganic malitx

Solidified, Organic matrix

Soils

Packaging Materials, Steel

Packaging Material, Plastic

\begin{tabular}{|r|} 
Averege \\
\hline 0.0 \\
\hline 0.0 \\
\hline 185.0 \\
\hline 0.0 \\
\hline 0.0 \\
\hline 0.0 \\
\hline 0.0 \\
\hline 0.0 \\
\hline 0.0 \\
\hline 0.0 \\
\hline 168.0 \\
\hline 34.0 \\
\hline
\end{tabular}

\begin{tabular}{|r|}
\hline 0.0 \\
\hline 0.0 \\
\hline 185.0 \\
\hline 0.0 \\
\hline 0.0 \\
\hline 0.0 \\
\hline 0.0 \\
\hline 0.0 \\
\hline 0.0 \\
\hline 0.0 \\
\hline
\end{tabular}

\begin{tabular}{r|r|}
\hline & Prolected \\
\hline End of 1982: & 0.21 \\
\hline 1994: & 0.21 \\
\hline $1996:$ & 0.00 \\
\hline $1988:$ & 0.00 \\
\hline $1997:$ & 0.00 \\
\hline $1092-2002:$ & 0.00 \\
\hline $2003-2022:$ & 0.00 \\
\hline
\end{tabular}

$0.00 \mathrm{~m} 3 / \mathrm{yr}$

\begin{tabular}{|l|}
\hline 0.0 \\
\hline 0.0 \\
\hline 0.0 \\
\hline
\end{tabular}

IYPIGAL EPA CODES APPLICABLE

D008

\section{Comments}

Other metals - load.

\section{Footnotes}

Have assumed D008 EPA code due to the presence of lead. 
WASTE STREAM PROFILE FOR THE WIPP TRU WASTE BASELINE INVENTORY REPORT

SITENAME ET

WASTE TYPETRU HANDLING $\mathrm{CH}$

GENERATOR SITE ET

\begin{tabular}{|c|c|c|c|}
\hline \multirow{4}{*}{$\begin{array}{ll}\text { WASTE STREAM } & \text { MWIRID } \\
& \text { WIPP ID } \\
\text { Local ID } & \\
\text { MATRIX CODE } & \end{array}$} & & \multirow{3}{*}{$\begin{array}{l}\text { STREAMNAME } \\
\text { DESCRIPTION }\end{array}$} & \multirow[t]{2}{*}{ Hot Lab \& PU Facility D\&D } \\
\hline & ET-T001 & & \\
\hline & & & \multirow{2}{*}{$\begin{array}{l}\text { Wasles generated from the clean-up of the Plutonium Facility (BIdg 55) and the Hot Lab (Bldg } \\
\text { 20). }\end{array}$} \\
\hline & & & \\
\hline SIIE FINAL FORMIDC & & . & · \\
\hline \multirow{2}{*}{$\begin{array}{r}\text { Waste Matrix Code Group } \\
\text { Stte Matrix Descriptlon }\end{array}$} & Helerogeneous & . & \\
\hline & & & \\
\hline
\end{tabular}

NO MURATION VARIANCE PETIION ASSIGNMENT

IRUCON CODE

\section{FINAL WASTE FORMDESCRIPTORS:}

Defense TRU Waste

X Mixed TRU

Non-Defense TRU Waste

Non-Mixed TRU

Suspect Mixed TRU

Commerclal TRU Waste

Unknown

$\square$

Rsearch and Devel. Waste

Operatlons Waste

Residues

Decon and Decommissioning

Environmental Restoration

From Treatment of Waste

Maintenance

$\square$

TSCA Asbestos

PCBs

Other

N/A

Unknown

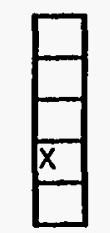




\section{WASTE STREAM PROFILE FOR THE WIPP TRU WASTE BASELINE INVENTORY REPORT}

ET-TO01 CONTAINER: Drum

Type/SIze: 55-gallon

Container Mall: Steel Liner Type: rigid

Int. Vol/Cinr: $0.21 \mathrm{~m} 3 \mathrm{~m}$ Liner Material:concrete

Number Stored

Number Projected:

TYPICAL WASTE DENSITIES FOR FINAL WASTE FORM ( $\mathrm{kg} / \mathrm{m} 3)$

STORED TRU WASTE ESTIMATED

TYPICAL ISOTOPIC COMPOSITION

Materlal Parameters

Iron-based Metals/Alloys

Aluminum-Based Metals/Alloys

Other Metals

Other Inorganic Materials

Cellulosics

Rubber

Plastlos

Solidified, Inorganic matrix

Solldified, Organic matrix

Solls

\begin{tabular}{r|} 
Average \\
\begin{tabular}{|r|}
\hline 126.0 \\
\hline 0.0 \\
\hline 0.0 \\
\hline 2040.0 \\
\hline 0.0 \\
\hline 0.0 \\
\hline 0.0 \\
\hline 28.0 \\
\hline 0.0 \\
\hline 0.0 \\
\hline 168.0 \\
\hline 0.0 \\
\hline
\end{tabular}
\end{tabular}

\begin{tabular}{|c|c|}
\hline Lower Limit & Upper Linf \\
\hline 120.0 & 130.0 \\
\hline 0.0 & 0.0 \\
\hline 0.0 & 0.0 \\
\hline 2000.0 & 2100.0 \\
\hline 0.0 & 0.0 \\
\hline 0.0 & 0.0 \\
\hline$\overline{0.0}$ & 0.0 \\
\hline 10.0 & 60.0 \\
\hline 0.0 & $\overline{0.0}$ \\
\hline 0.0 & 0.0 \\
\hline
\end{tabular}

RATES OF WASTE GENERATION

Nuclide Activity

Packaging Materials, Sleel

Packaging Material, Plastic

\begin{tabular}{|c|c|c|c|}
\hline & Projected & Final Form & \\
\hline nd of 1992: & 0.0 & 0.0 & m3 \\
\hline ad of 1993: & 0.0 & 0.0 & m3 \\
\hline 1994: & 0.0 & 0.0 & m3/yr \\
\hline 1995: & 5.2 & $\overline{5.2}$ & m3/yr \\
\hline 1986: & 0.0 & 0.0 & $\mathrm{~m} 3 / \mathrm{yr}$ \\
\hline 1997: & 0.0 & 0.0 & $\mathrm{~m} 3 / \mathrm{ry}$ \\
\hline 1998-2002: & 0.0 & 0.0 & m3/yr \\
\hline 2003-2022: & 0.0 & 0.0 & $\mathrm{~m} 3 / \mathrm{yr}$ \\
\hline
\end{tabular}

TYPICAL EPA CODES APPLICABLE

\section{Comments}

tioni-based metal - Qn dia. pipo "itich forms tho concrele annutute.

Other inorganic materials - concrete liners (shielding).

Solldified, inorganic matrix - Debris from drain line.

Typical tsatople composittion is unknown for this container.

Packaging Materials, Steel - Based on $35 \mathrm{~kg} /$ drum

Drums are for intemal transfer and storage only. Although there is no plastic liner,

R/A material is placed in one-gallon cans or plastic bags before placine in the

concrele-lined drums

Would be "RH" without concrete liner. 


\section{WASTE STREAM PROFILE FOR THE WIPP TRU WASTE BASELINE INVENTORY REPORT}

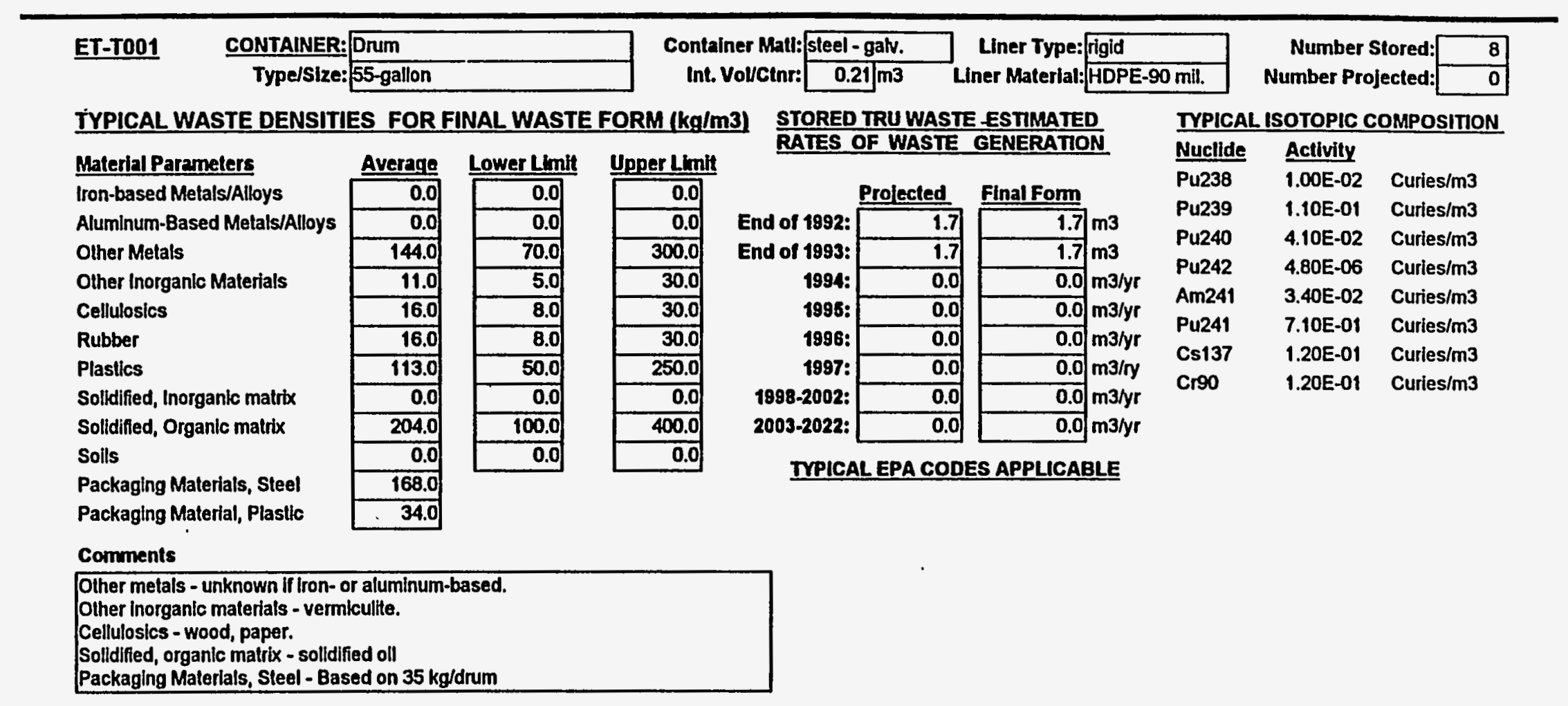




\section{Idaho National Engineering Laboratory}




\section{IDAHO NATIONAL ENGINEERING LABORATORY (IN) WASTE STREAM PROFILE METHODOLOGY}

The approach used and the assumptions made in preparing the IN waste stream profiles are as follows:

- WTWBIR, Revision 0 waste stream profile data was reviewed and updated by IN to generate Revision 1 WTWBIR data. The primary sources used for the IN review were data from the Idaho Mixed Waste Information (IMWI) system and the IN Draft Site Treatment Plan (DSTP), (Ref. 5). Other sources of information included the Radiological, Physical, and Chemical Characterization of Transuranic Wastes Stored at the IN Report (Ref. 4), the TRU Waste Sampling Program (TWSP) Report (Ref. 1), the Content Code Assessments (Ref. 2), and the Exploratory Research and Development Program (ERDP) 2802 Report (Ref. 3).

- The IMWI contains container level data on all waste stored at the IN. Although the IMWI was initially designed to inventory mixed waste, non-mixed waste is also inventoried in this system. The DSTP database is derived from the data stored in the IMWI and provides determinations and assumptions of the treatment plans and options for proper waste management. The Characterization Report (Ref. 4) contains detailed composition information on each waste stream; most of this information was also derived from the IMWI.

- To detemine volume and radionuclide inventory information for Revision 1 WTWBIR, IN corrected and updated the Revision O WTWBIR data, as needed, through manipulation and calculation of data existing in the IMWI. This consisted of calculating the volume of waste that will be available for direct shipping to WIPP, the volume of waste that will require repackaging prior to shipment, the volume resulting from treatment of waste prior to shipment to WIPP, and the average curie concentration of all contained radionuclides for each waste stream. Presently, the WTWBIR waste stream profiles sum the volumes for direct ship waste and repackaged waste to report as one volume. All calculations were made on a waste volume basis, as the method used in the IMWI and the DSTP, then converted into container counts where appropriate.

- All treated waste is grouped into a new vitrified final form waste stream number IN-M07. Volumes for wastes after vitrification are reported in this waste stream. Curie concentrations for this waste stream are weighted average of all wastes that are treated and included in the final waste form volume.

- Material parameter data entries in the "Typical Material Weights for Final Waste Form" of the waste stream profiles were determined using information from past waste examination programs and knowiedge gained in the WIPP Experimental Test Program. This consisted of reviewing past and current visual waste characterization activities and determining average, maximum, and minimum concentrations of waste constituent parameters, where possible. The majority of the data can be traced back to the TRU Waste Sampling Program (TWSP) Report (Ref. 1), the Content Code Assessments (Ref. 2), or the Characterization Report (Ref. 4). Waste volumes used to correct Revision 0 WTWBIR parameter densities were based on the Exploratory Research and Development Program (ERDP) 2802 report (Ref. 3), which includes data obtained from the TRU Waste Management Information System (TWMIS) in 1990. The Characterization Report and IN Draft Site Treatment Plan were also used to determine the typical material weights reported on the waste stream profile sheets, when information from the above sources were inadequate. 
WASTE STREAM PROFILE FOR THE WIPP TRU WASTE BASELINE INVENTORY REPORT

SITENAME IN

WASTE TYPE MTRU HANDLING RH GENERATOR SITE AW

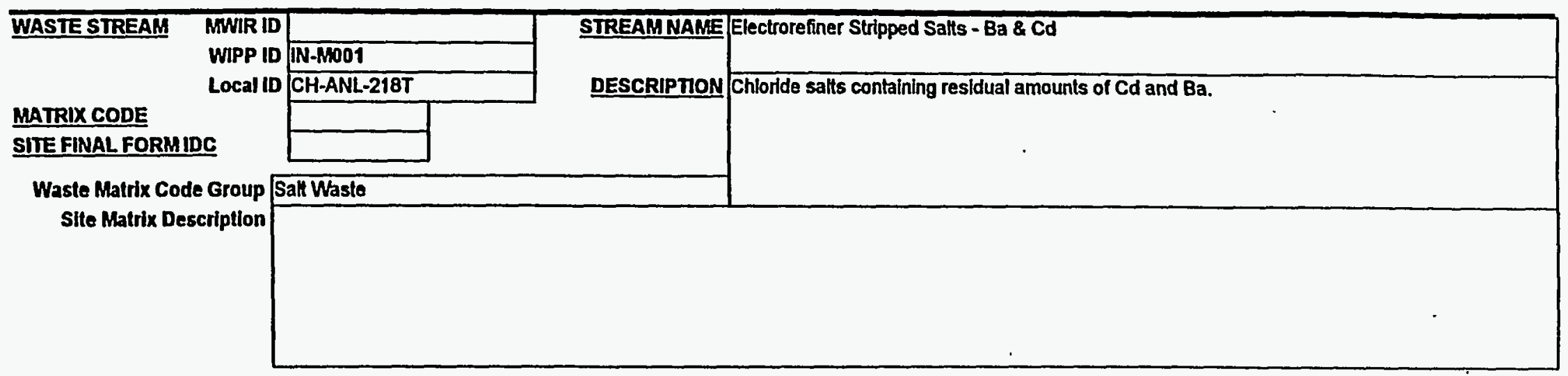

NO MIGRATION VARLANCE PETITION ASSIGNMENT

IRUCON CODE

\section{FINAL WASTE FORM DESCRIPTORS:}

\begin{tabular}{l|l|l}
$\begin{array}{l}\text { Defense TRU Waste } \\
\text { Non-Defense TRU Waste } \\
\text { Commerclal TRU Waste } \\
\text { Unknown }\end{array}$ & $\begin{array}{l}\text { Mbed TRU } \\
\text { Non-Mbxed TRU } \\
\text { Suspect Mbxed TRU } \\
\text { Unknown }\end{array}$
\end{tabular}

Rsearch and Devel. Waste

Operations Waste

Residues

Decon and Decommissioning

Environmental Restoration

From Treatment of Wasto

Maintenance

\begin{tabular}{|l|l|}
\hline TSCA Asbestos \\
PCBs \\
Other \\
N/A \\
Unknown
\end{tabular}




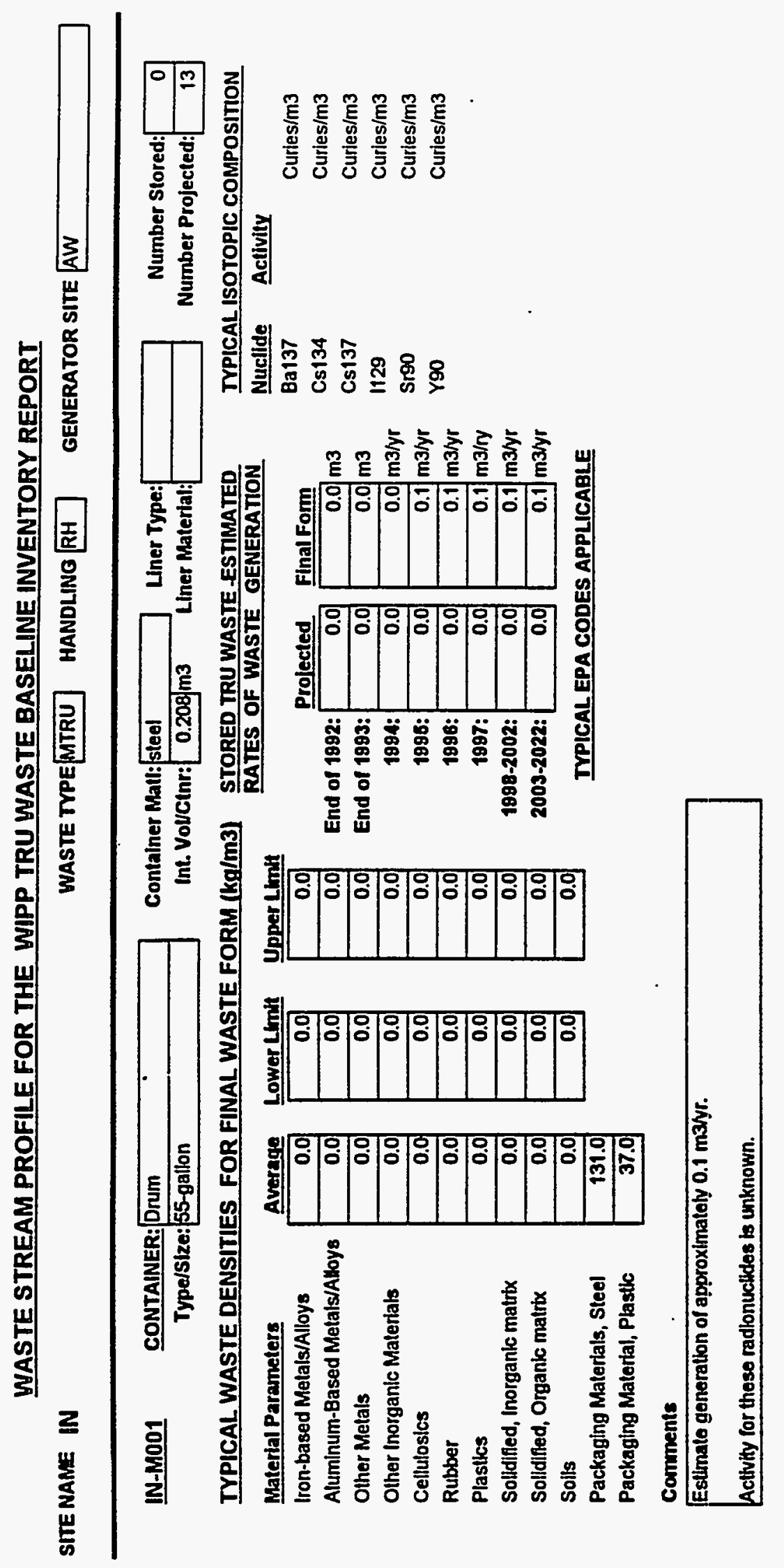

$\stackrel{N}{\vdots}$

苳 
WASTE STREAM PROFILE FOR THE WIPP TRU WASTE BASELINE INVENTORY REPORT

SITENAME IN WASTE TYPE MTRU HANDLING RH GENERATOR SITE AW

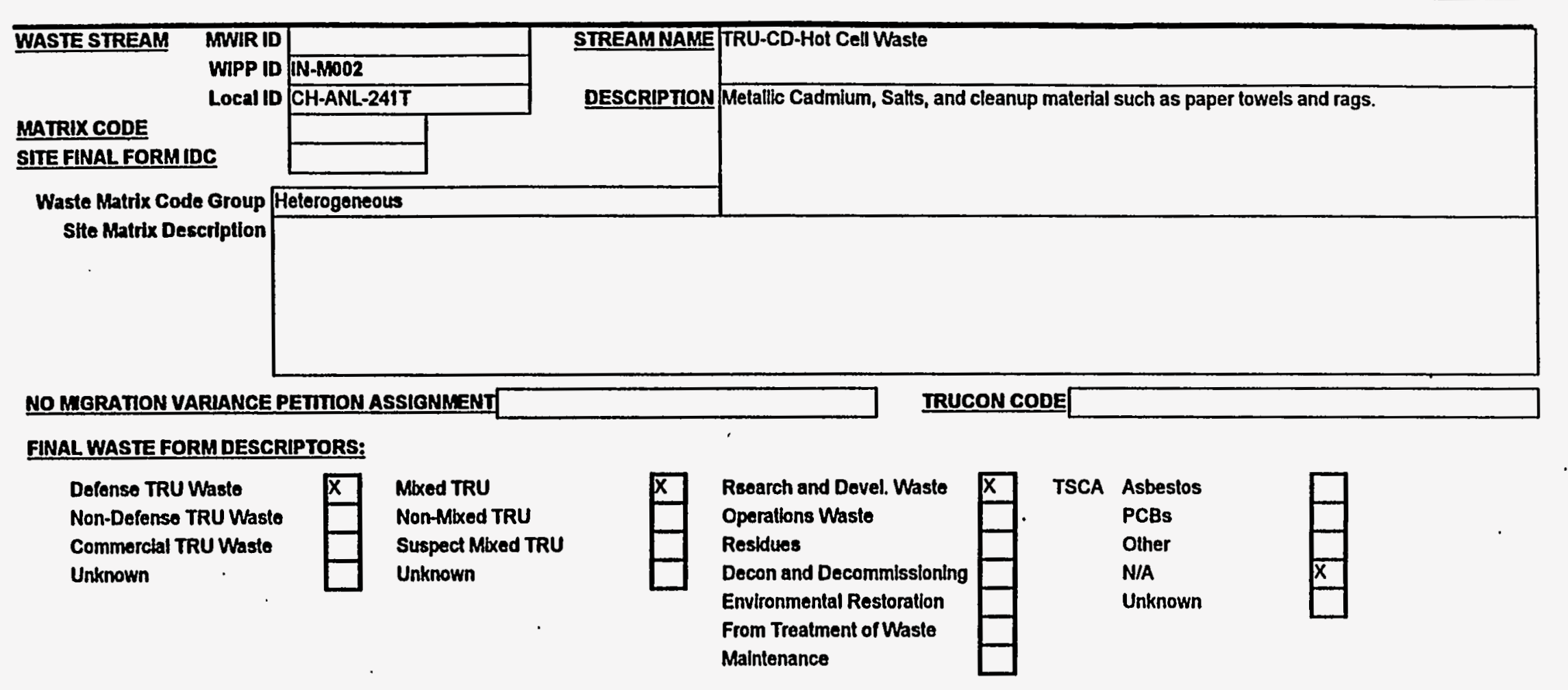




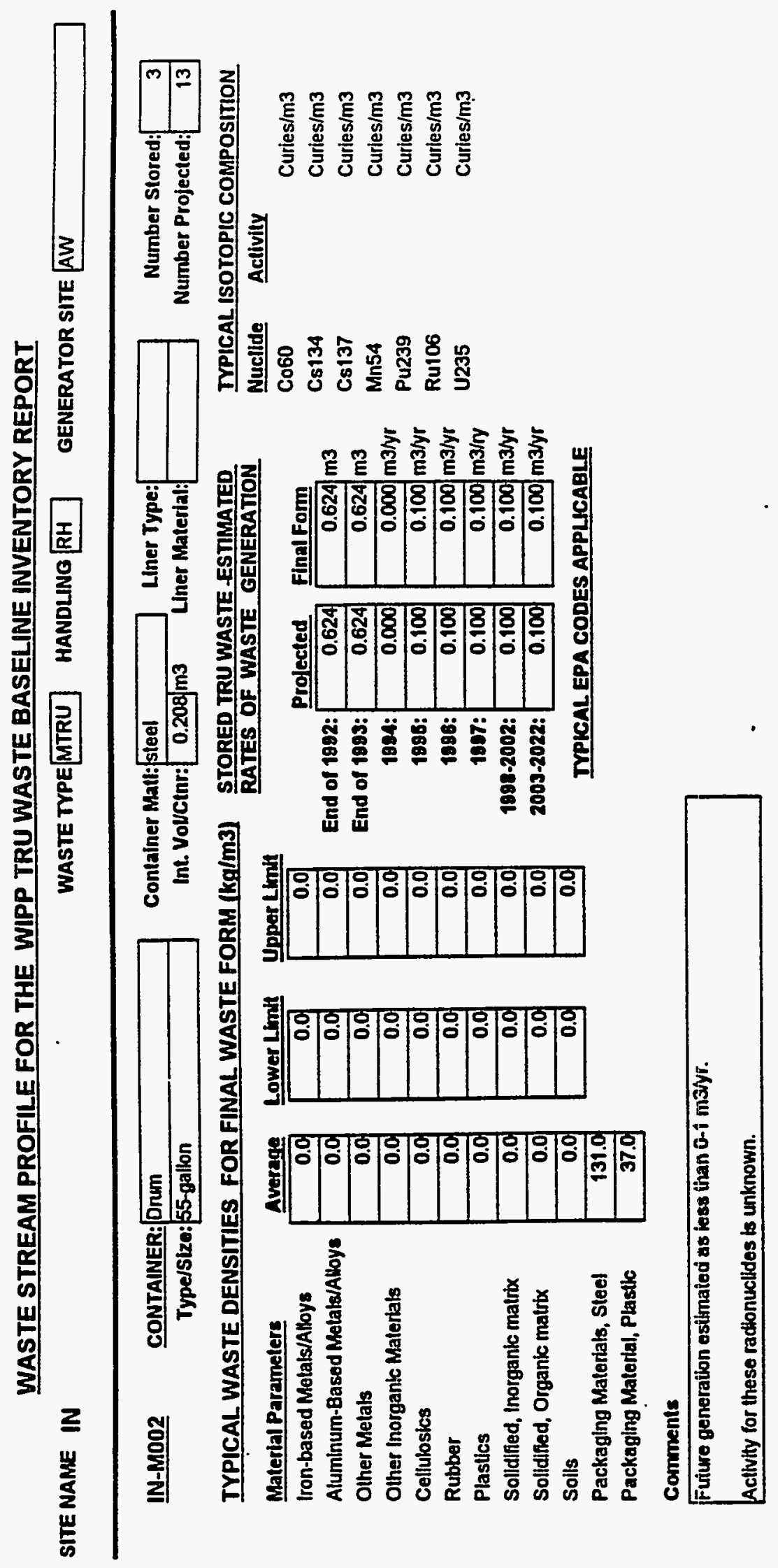




\section{WASTE STREAM PROFILE FOR THE WIPP TRU WASTE BASELINE INVENTORY REPORT}

SITENAME IN

WASTE TYPE MTRU HANDLING RH GENERATOR SITE AW

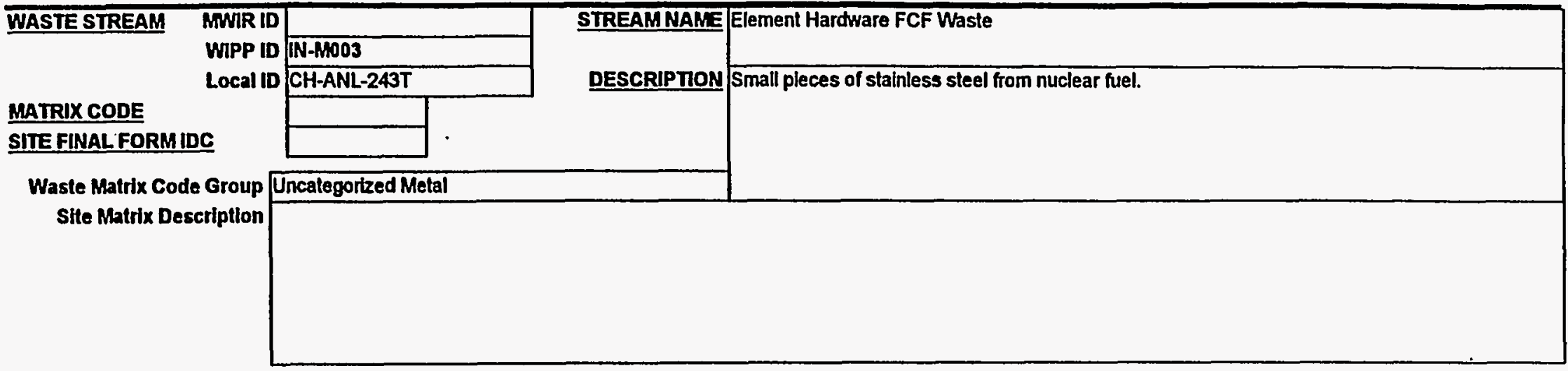

NO MIGRATION VARIANCE PETITION ASSIGNMENT IRUCON CODE

FINAL WASTE FORM OESCRIPTORS:

\begin{tabular}{|c|c|}
\hline Defense TRU Waste & Mbxed TRU \\
\hline Non-Defense TRU Waste & Non-Mixed TRU \\
\hline Commerclal TRU Waste & Suspect Mbxed TRU . \\
\hline Unknown & Unknown \\
\hline
\end{tabular}

Rsearch and Devel. Waste
Operations Wasto
Residues
Decon and Decommissioning
Environmental Restoration
From Treatment of Waste

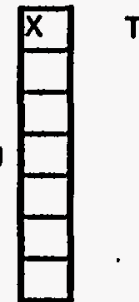

TSCA Asbestos

PCBs

Other

N/A

Unknown 


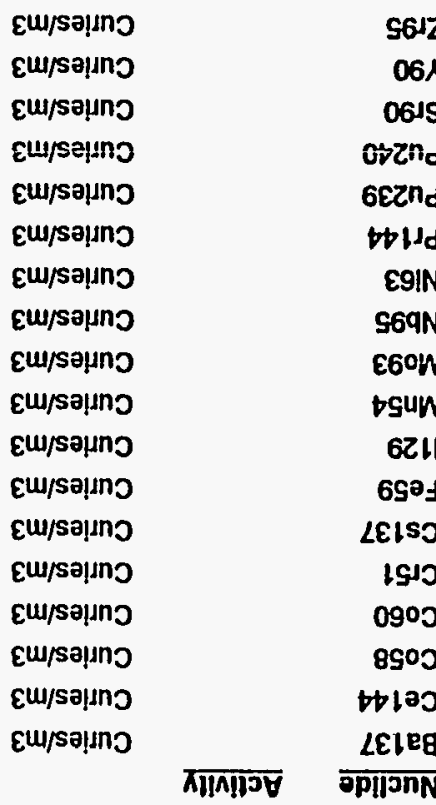

SGLZ

$06 \lambda$

orind

Geznd

tild

E9IN

S69N

c6on

suw

6211

6904

ELSO

เงว

0900

BSOJ

तारागु क्यागत

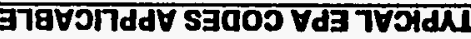

دNEW 20 ANEW 20 N/EW ZOO SNEW 20 NNEW 2'O АN/EW $0^{\prime} O$ cu $0^{\prime} 0$

sw $0^{\circ} 0$ साष्म हरणी

\begin{tabular}{|c|c|}
\hline & 0 \\
\hline & 0 \\
\hline & 0 \\
\hline & 0 \\
\hline & 0 \\
\hline & 0 \\
\hline & 0 \\
\hline & 0 \\
\hline
\end{tabular}

\section{$: 2202-8002$} :2002- 2881

\section{: $\angle 661$}

:968

:986

$\checkmark 66$

:8681 10 pus

:266। 10 pus

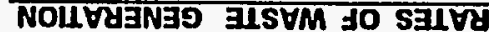

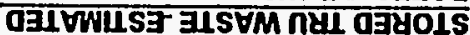

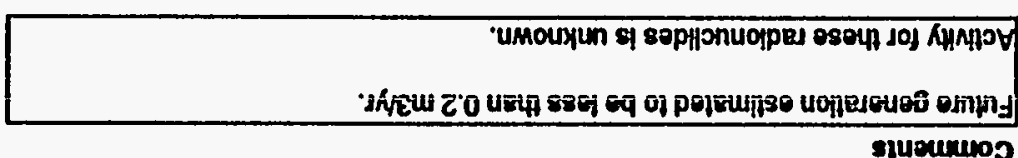

sfucumeros

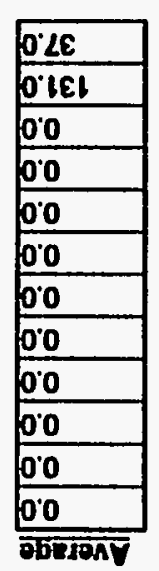

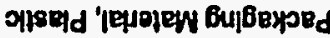

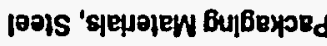

Enणs

xqyeu que610 'poyphinos

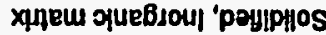

sonseid

Jeqquy

sojsopniles

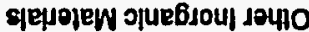

sjelaw seyto

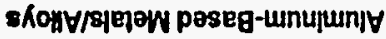

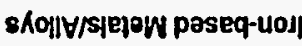

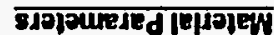

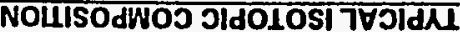

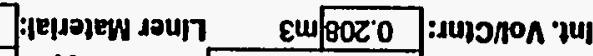
:əd/1 งəuा7 


\section{WASTE STREAM PROFILE FOR THE WIPP TRU WASTE BASELINE INVENTORY REPORT}

SITE NAME IN

WASTE TYPE MTRU HANDLING RH GENERATOR SITE AW

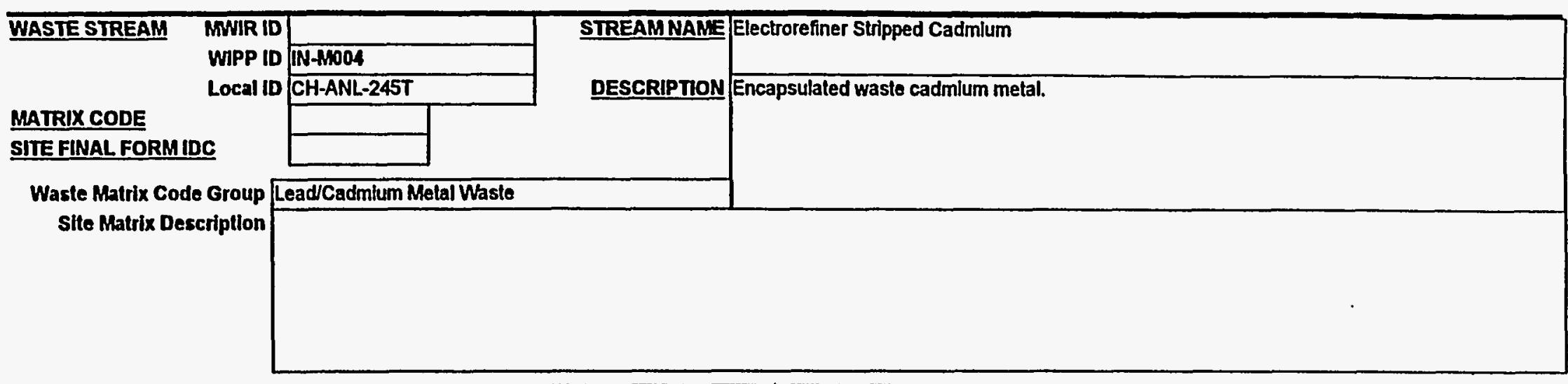

NO MGRATION VARIANCE PEITION ASSLGNMENT

IRUCON CODE

FINAL WASTE FORM DESCRIPTORS:

Defense TRU Waste

Non-Defense TRU Waste

Commercial TRU Waste

Unknown
Mbxed TRU

Non-Mbed TRU

Suspect Mbed TRU

Unknown

Rsearch and Devel Waste Operations Wasto

Residues

Decon and Decommissioning

Environmental Restoration

From Treatment of Waste

Maintenance

\begin{tabular}{ll}
$X$ \\
\hline \\
\hline \\
\hline
\end{tabular}

TSCA Asbestos

PCBs

Olher

N/A

Unknown 


\section{WASTE STREAM PROFILE FOR THE WIPP TRU WASTE BASELINE INVENTORY REPORT}

SITE NANE IN

WASTE TYPE MTRU HANDLING RH GENERATOR SITE AW

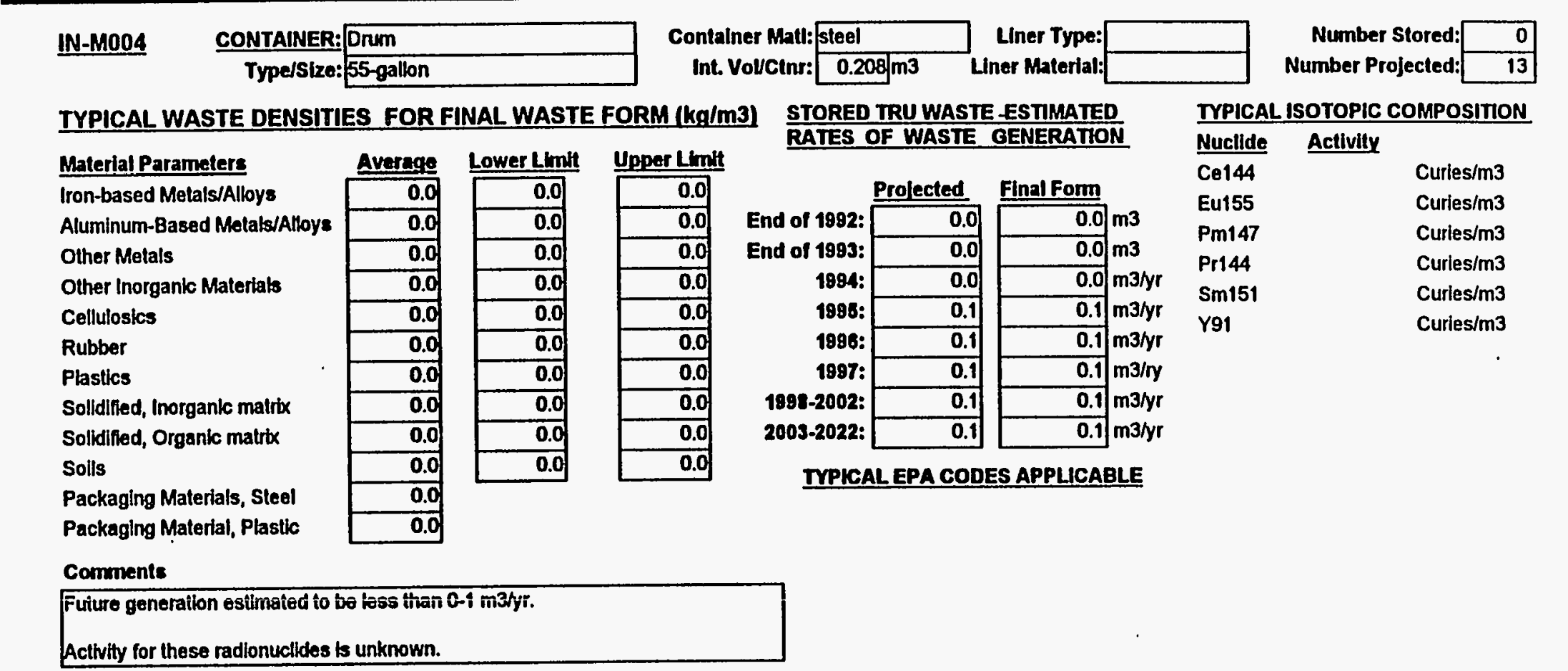


WASTE STREAM PROFILE FOR THE WIPP TRU WASTE BASELINE INVENTORY REPORT

SITE NAME IN

WASTE TYPE MTRU HANDLING RH GENERATOR SITE AW

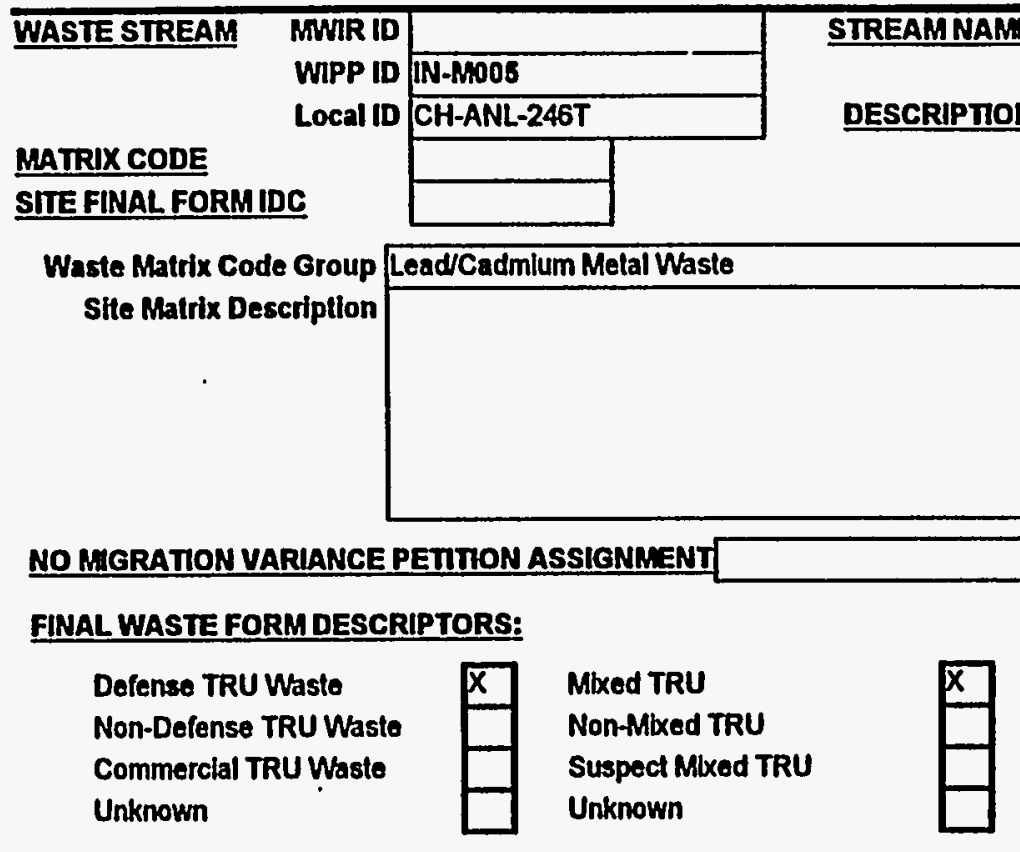

\begin{tabular}{|l|}
\hline$X$ \\
\hline \\
Rsearch and Devel. Waste \\
Residions Waste \\
Decon and Decommissioning \\
Envlronmental Restoration \\
From Treatment of Waste \\
Maintenance
\end{tabular}

TSCA Asbestos

PCBs

Other

NIA

Unknown

Maintenance

IRUCON CODE 


\section{WASTE STREAM PROFILE FOR THE WIPP TRU WASTE BASELINE INVENTORY REPORT}

SITE NAME IN WASTE TYPE MTRU HANDLING RH GENERATOR SITE AW

\begin{tabular}{|c|c|c|c|c|}
\hline IN-M005 & CONTAINER: Drum & Container Matl: 5 & teel & $\begin{array}{l}\text { Liner Type: } \\
\text { Liner Material: }\end{array}$ \\
\hline
\end{tabular}

TYPICAL WASTE DENSITIES FOR FINAL WASTE FORM (kg/m3) STORED TRU WASTE -ESTIMATED TYPICAL ISOTOPIC COMPOSITION

Material Parameters

Iron-based Metals/Alloys

Aluminum-Based Metals/Alloys

Other Metals

Other Inorganic Materials

Cellulosics

Rubber

Plastics

Solldified, Inorganic matrix

Solidified, Organic matrtx

Solts

Packaging Materials, Steel

Packaging Material, Plastic
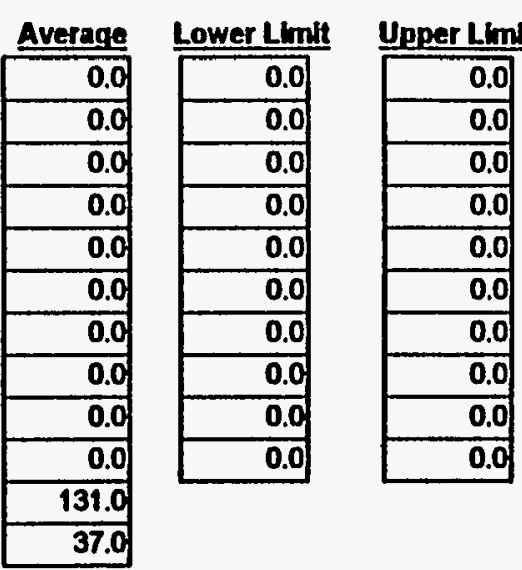

RATES OF WASTE GENERATION

\section{Cormments}

Fitite ceneration estimalod to bo lase than 0-1 m3hyr.

Acthity for these radionuclides is unknown.

\section{Nuclide Activily}

C14 Curies $/ \mathrm{m} 3$

Cd113 Curies $/ \mathrm{m}^{3}$

Nb95 Curies/m3

Rh106 Curies $/ \mathrm{m}^{3}$

Curies/m3

Curies/m3

Curies/m3

Curies/m3

Curles/m3

Curies/m3 


\section{WASTE STREAM PROFILE FOR THE WIPP TRU WASTE BASELINE INVENTORY REPORT}

SITE NAME IN WASTE TYPETTUU HANDLING CH GENERATOR SITE IN

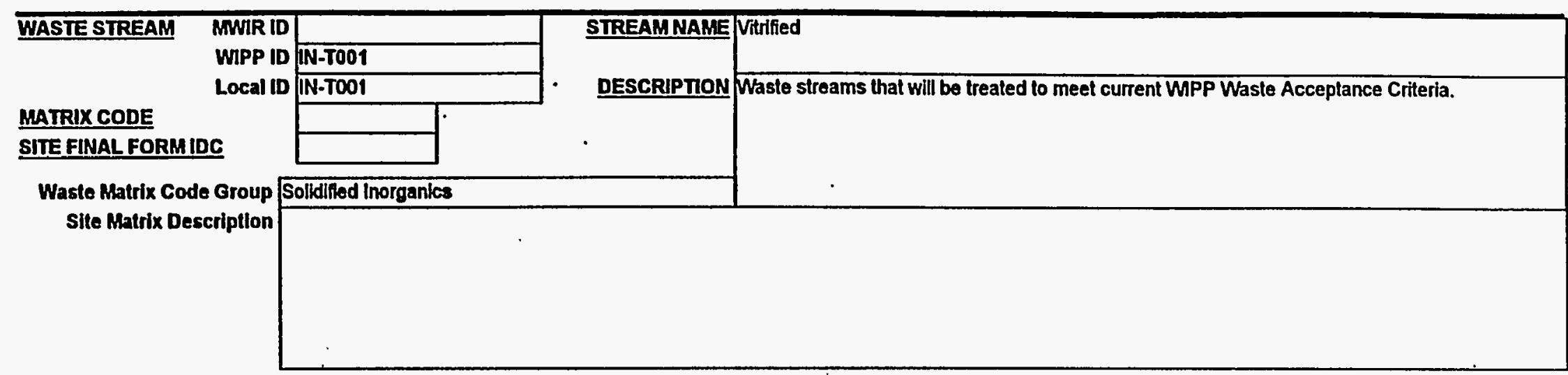

NO MGRATON VARIANCE PETMTON ASSIGNMENI

IRUCON CODE

FINAL WASTE FORM DESCRIPTORS:

Dofense TRU Waste

Non-Defense TRU Waste

Commerclal TRU Wasle

Unknown

$\square$

Milxed TRU

Non-Mixed TRU

Suspect Mbxed TRU

Unknown

Rsearch and Devel. Waste
Operations Waste
Resldues
Decon and Decommissioning
Environmental Restoration
From Treatment of Waste
Maintenance

$\square$

TSCA Asbestos

PCBs

Other

N/A

Unknown

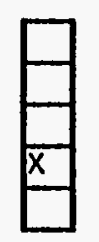


WASTE STREAM PROFILE FOR THE WIPP TRU WASTE BASELINE INVENTORY REPORT

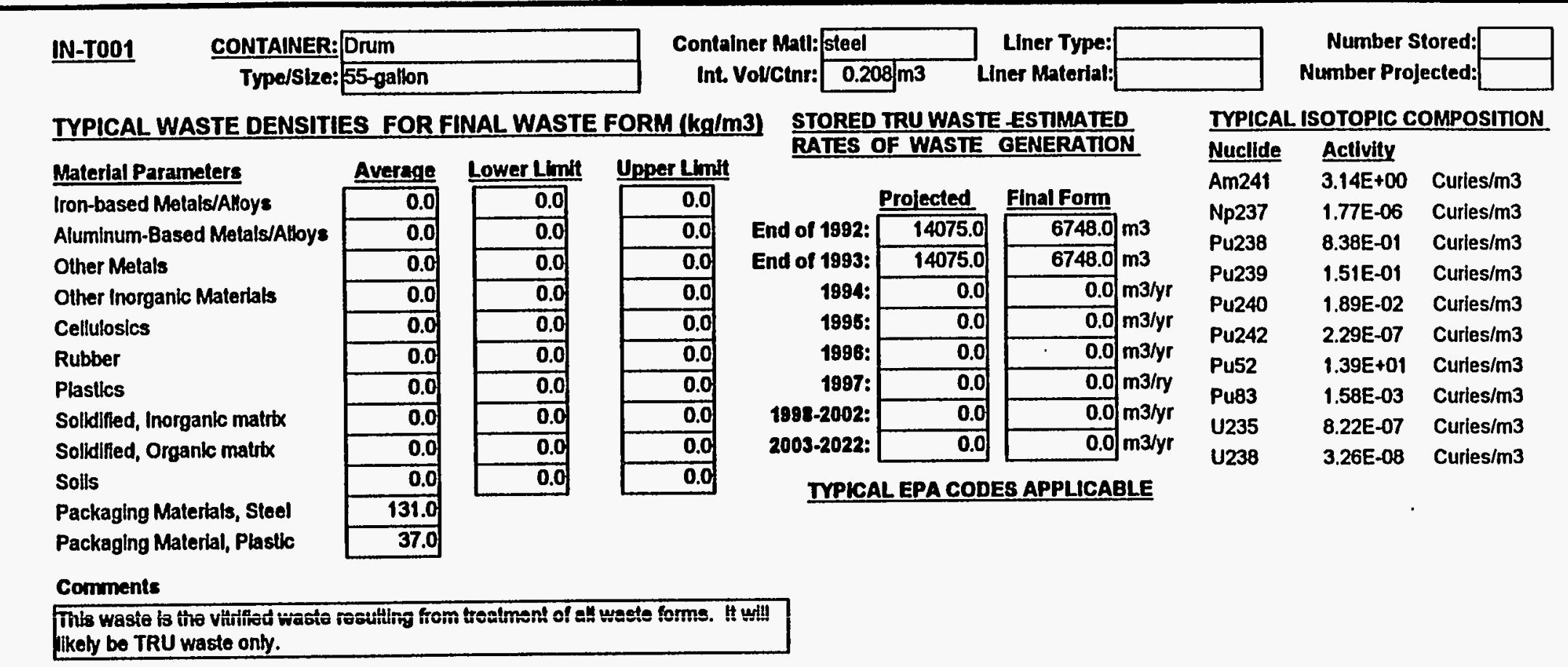




\section{WASTE STREAM PROFILE FOR THE WIPP TRU WASTE BASELINE INVENTORY REPORT}

SITENAME IN WASTE TYPE MTRU HANDLING RH GENERATOR SITE IN

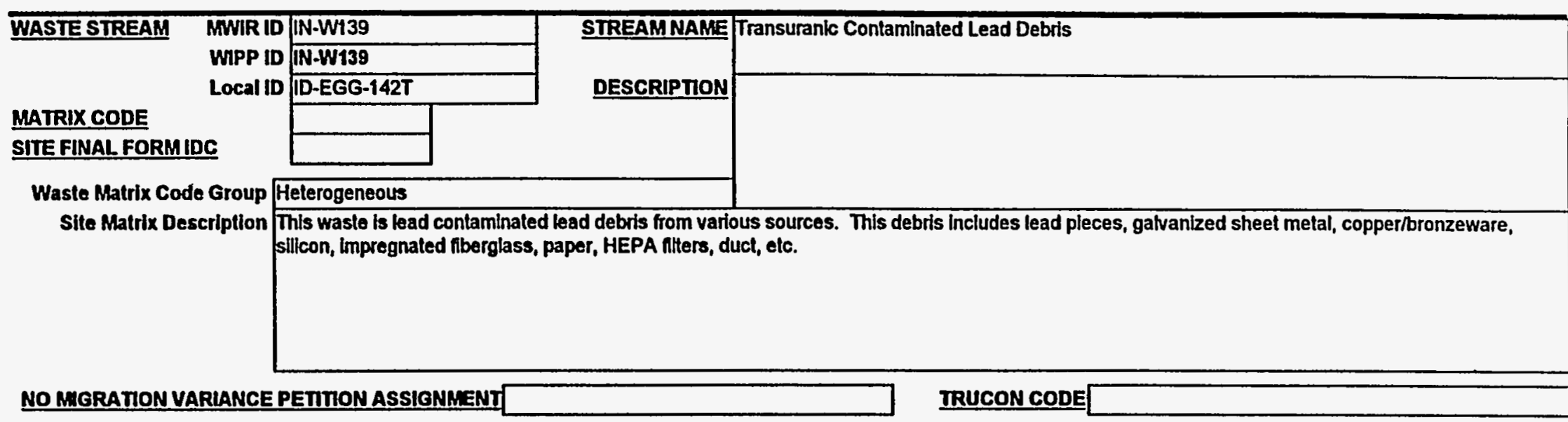

FINAL WASTE FORMDESCRIPTORS:

Dofense TRU Waste

Non-Delense TRU Waste

Commerclal TRU Waste

Unknown

$\square$

Mbxed TRU

Non-Mixed TRU

Suspect Mbxed TRU

Unknown

$\square$

Rsearch and Devel. Waste
Operations Waste
Resldues
Decon and Decommissioning
Environmental Restoration
From Treatment of Waste
Maintenance

TSCA Asbestos

PCBs

Other

N/A

Unknown 
WASTE STREAM PROFILE FOR THE WIPP TRU WASTE BASELINE INVENTORY REPORT

SITE NAME IN WASTE TYPE MTRU HANDLING RH GENERATOR SITE IN

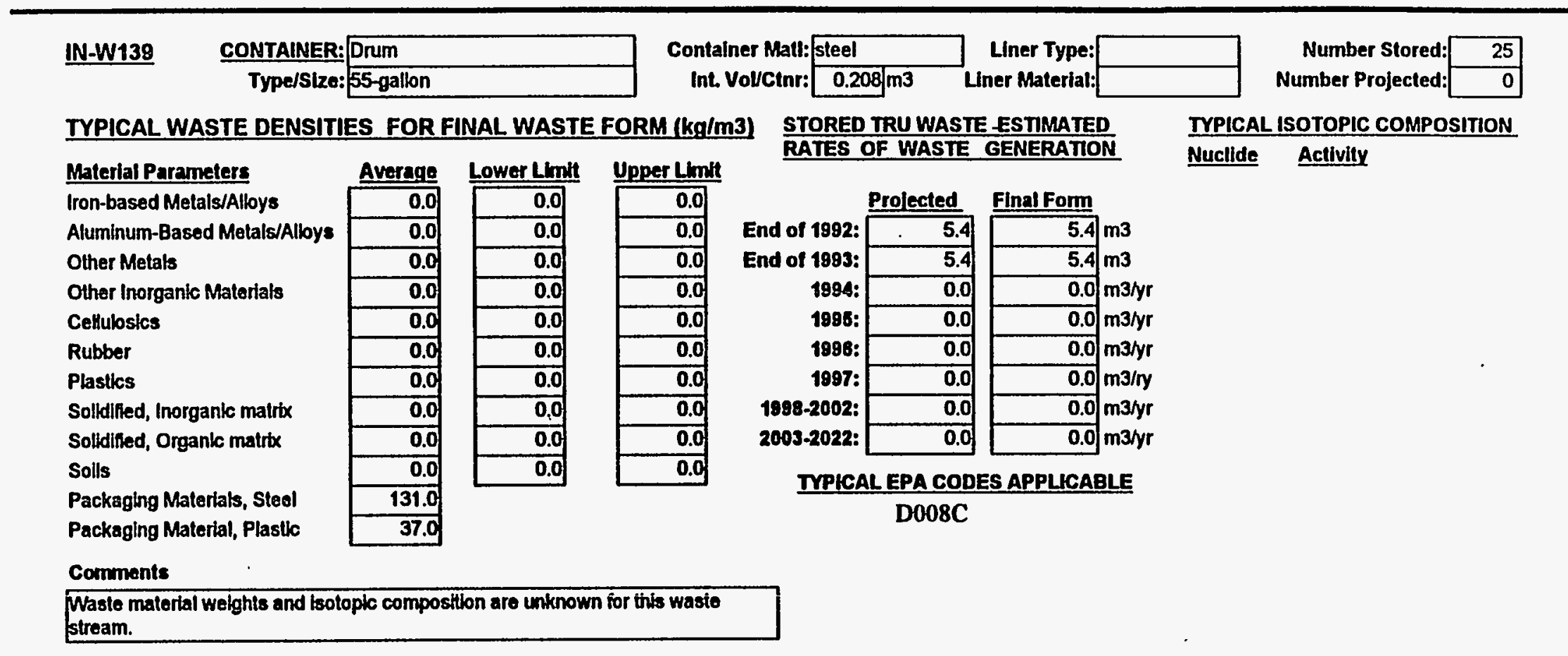




\section{WASTE STREAM PROFILE FOR THE WIPP TRU WASTE BASELINE INVENTORY REPORT}

\section{SITE NAME IN \\ WASTE TYPE MTRU HANDLING RH GENERATOR SITE IN}

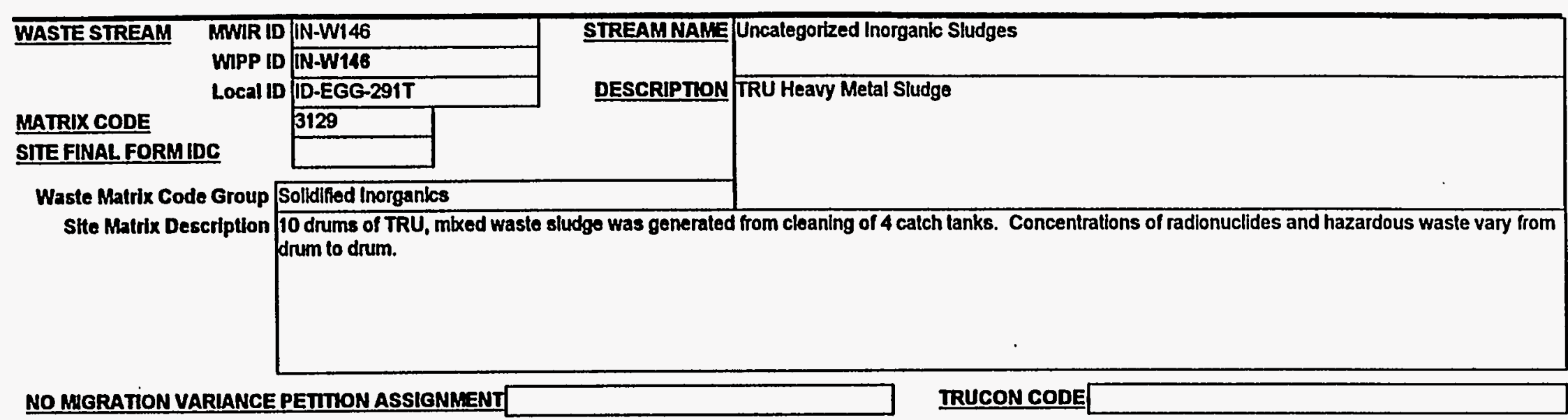

\section{FINAL WASTE FORM DESCRIPTORS:}

\begin{tabular}{|c|c|}
\hline Defense TRU Waste & Mixed TRU \\
\hline Non-Defense TRU Waste & Non-Mixed TRU \\
\hline Commerclal TRU Waste & $\begin{array}{l}\text { Suspect Mixed TRU } \\
\text { Unknown }\end{array}$ \\
\hline
\end{tabular}

Rsearch and Devel. Wasto Operations Waste

Residues

Decon and Decommissioning

Environmental Restoration

From Treatment of Waste

Malntenanco

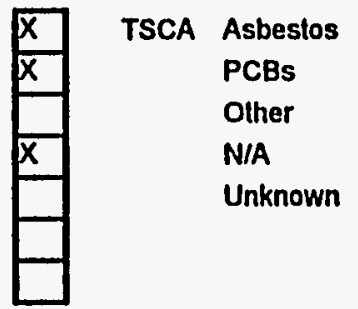

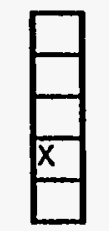




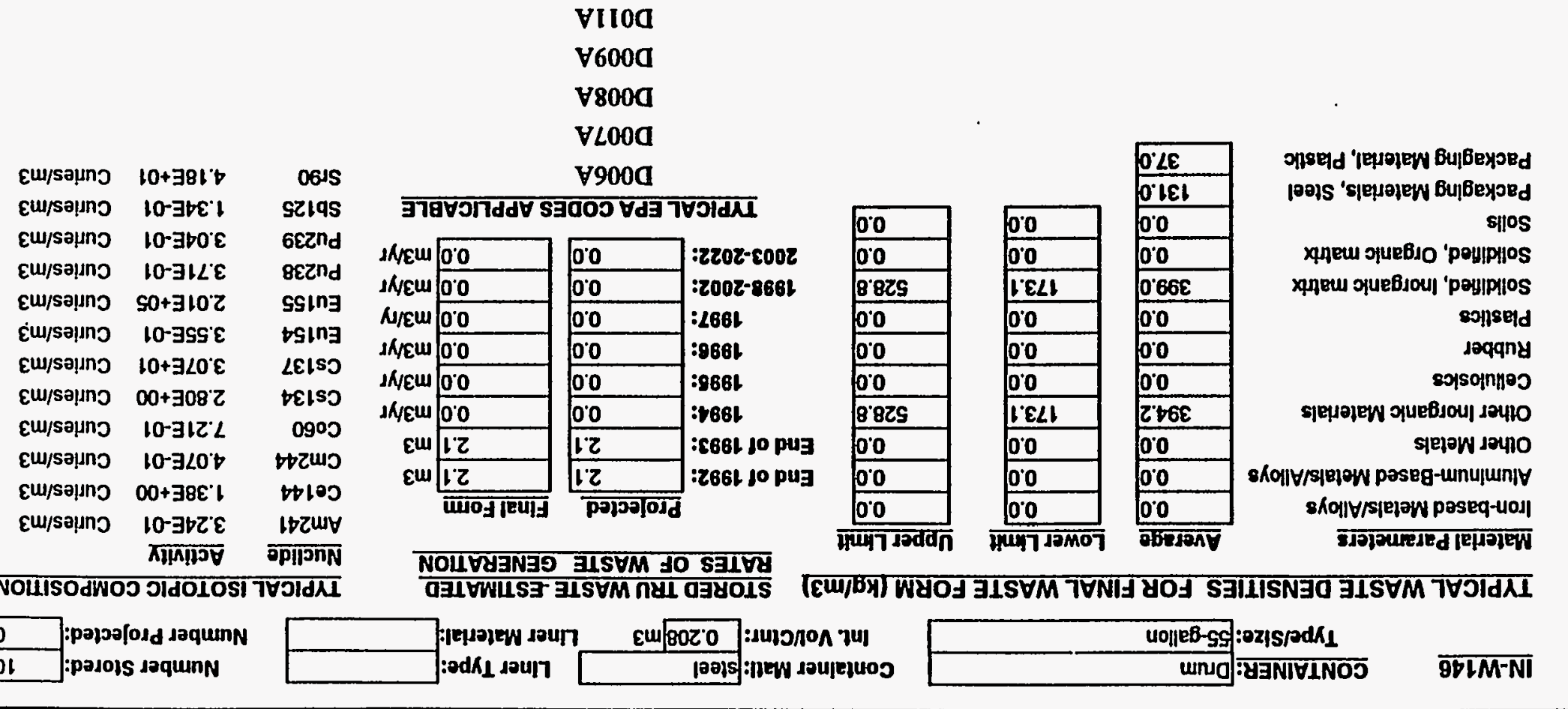




\section{WASTE STREAM PROFILE FOR THE WIPP TRU WASTE BASELINE INVENTORY REPORT}

SITE NANE IN WASTE TYPEMTRU HANDLING CH GENERATOR SITE RF

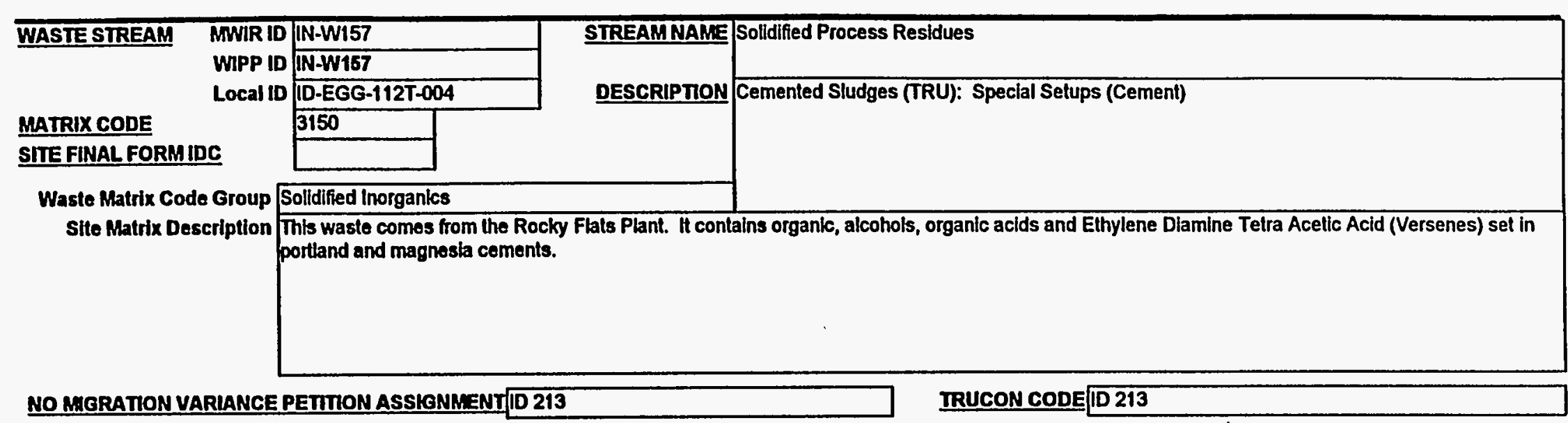

\section{FINAL WASTE FORMDESCRIPTORS:}

\begin{tabular}{l|l} 
Defense TRU Waste \\
Non-Defense TRU Waste \\
Commerclal TRU Waste \\
Unknown
\end{tabular}$\quad \begin{aligned} & \text { Mbed TRU } \\
& \text { Non-Mixed TRU } \\
& \text { Suspect Mbxed TRU } \\
& \text { Unknown . }\end{aligned}$

$\square$

Rsearch and Devel. Waste
Operations Wasto
Residues
Decon and Decommissioning
Environmental Restoration
From Trealment of Waste
Malntenance

\begin{tabular}{|l|}
\hline$x$ \\
\hline$x$ \\
\hline \\
\hline \\
\hline \\
\hline
\end{tabular}
TSCA Asbestos
PCBs
Olher
NIA
Unknown

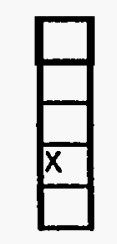




\section{WASTE STREAM PROFILE FOR THE WIPP TRU WASTE BASELINE INVENTORY REPORT}

SITE NAME IN WASTE TYPE MTRU HANDLING CH

GENERATOR SITE RF

\begin{tabular}{|c|c|c|c|c|c|c|c|c|c|c|c|}
\hline IN-W157 $\frac{\text { CONTAINER: }}{\text { Type/SIze: }}$ & SWB overp & & $\begin{array}{l}\text { Contal } \\
\text { Int. }\end{array}$ & \multicolumn{2}{|c|}{ Container Mat1: steel } & $\begin{array}{r}\text { Liner Type: } \\
\text { Liner Material: }\end{array}$ & & & \multicolumn{2}{|c|}{$\begin{array}{l}\text { Number Stored: } \\
\text { Number Projected: }\end{array}$} & $\begin{array}{r}76 \\
0\end{array}$ \\
\hline \multicolumn{4}{|c|}{ TYPICAL WASTE DENSITIES FOR FINAL WASTE FORM (kg/m3) } & \multicolumn{4}{|c|}{ STORED TRU WASTE ESTIMATED } & \multicolumn{4}{|c|}{ TYPICAL ISOTOPIC COMPOSITION } \\
\hline Material Parameters & Ayarnas & Lower Lmit & Unner Lim't & & OF WASIE & GENERAIIUI & & Nuclide & Activity & & \\
\hline Iron-based Melals/Alloys & 0.0 & 0.0 & 0.0 & & Prolected & Final Form & & Am241 & 6.74E-02 & Curles & \\
\hline Aluminum-Based Metals/Alloys & 0.0 & 0.0 & 0.0 & End of 1992: & 63.5 & 145.0 & m3 & Pusz & $2.900+100$ & Cuntes & \\
\hline Other Metals & 0.0 & 0.0 & 0.0 & End of 1983: & 63.5 & 145.0 & m3 & & & & \\
\hline Other Inorganic Materials & 11.8 & 0.0 & 142.3 & 1894: & 0.0 & 0.0 & $\mathrm{~m} 3 / y r$ & & & & \\
\hline Cellulosics & 0.0 & 0.0 & 0.0 & 1985: & 0.0 & 0.0 & m3/yr & & & & \\
\hline Rubber & 0.0 & 0.0 & 0.0 & 1996: & 0.0 & 0.0 & $\mathrm{~m} 3 / y r$ & & & & \\
\hline Plastics & 0.0 & 0.0 & 0.0 & 1997: & 0.0 & 0.0 & $\mathrm{~m} 3 / \mathrm{ry}$ & & & & ' \\
\hline Solldified, Inorganic matrix & 0.0 & 0.0 & 0.0 & 1998-2002: & 0.0 & 0.0 & $\mathrm{~m} 3 / \mathrm{yr}$ & & & & \\
\hline Solldified, Organic matrix & 381.8 & 226.4 & 594.2 & 2003-2022: & 0.0 & 0.0 & m3ryr & & & & \\
\hline Solls & 0.0 & 0.0 & 0.0 & TYPKC & AL EPA COD & DES APPLLCAB & BLE & & & & \\
\hline Packaging Matertals, Steel & 210.0 & & & & D002B & & & & & & \\
\hline Packaging Material, Plastic & 16.0 & & & & D006A & & & & & & \\
\hline Cormments & & & & & D008A & & & & & & \\
\hline $\begin{array}{l}76 \text { In number stored ts tho numb } \\
\text { drums/SWB. }\end{array}$ & or oi SWVี & 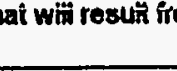 & overpacking & & F001 & & & & & & \\
\hline & & & & & F002 & & & & & & \\
\hline & & & & & F003 & & & & & & \\
\hline
\end{tabular}


WASTE STREAM PROFILE FOR THE WIPP TRU WASTE BASELINE INVENTORY REPORT

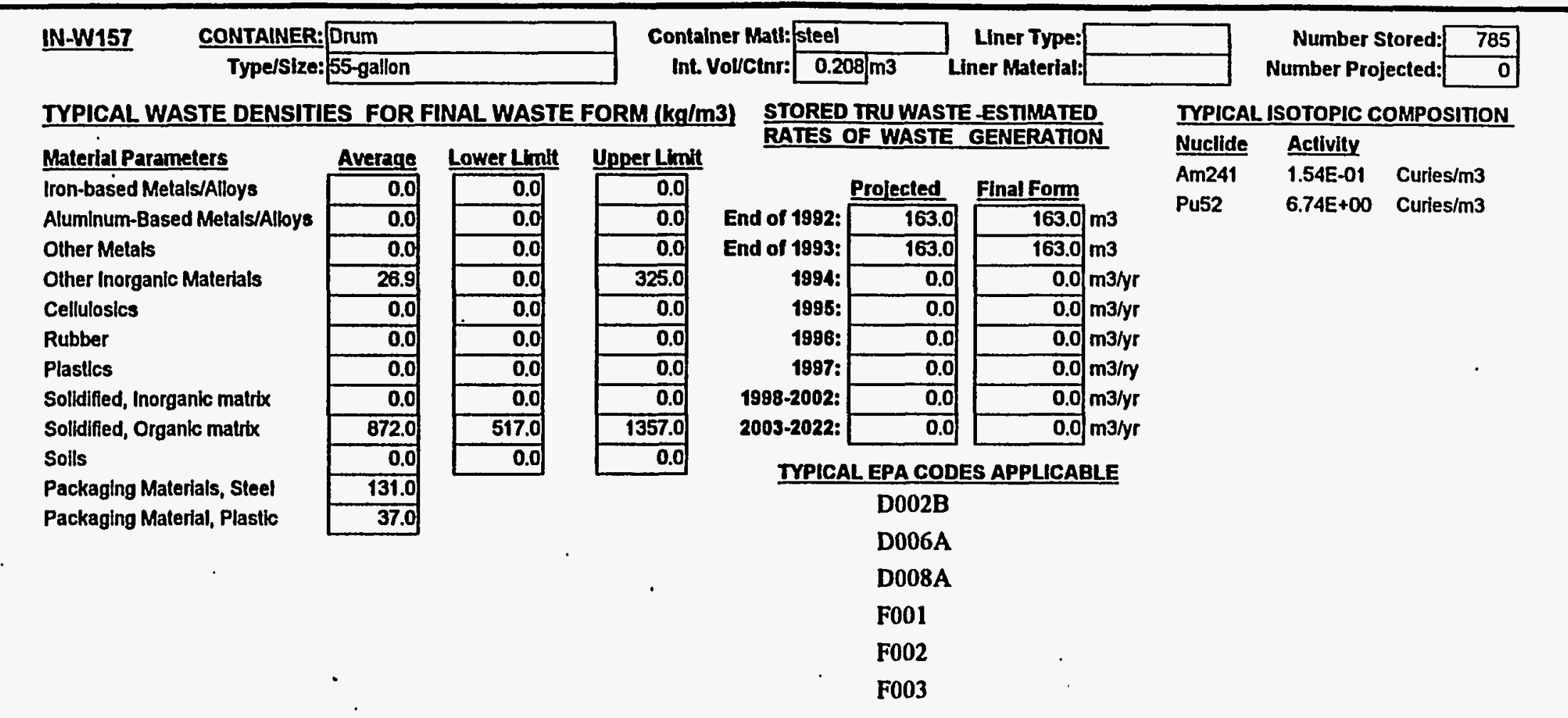




\section{WASTE STREAM PROFILE FOR THE WIPP TRU WASTE BASELINE INVENTORY REPORT}

SITE NAME IN

WASTE TYPE MTRU HANDLINO CH GENERATOR SITE RF

WASTE STREAM
$\begin{aligned} & \text { MWIR ID IN-W161 } \\ & \text { MATRIX CODE } \\ & \text { SITE FINALFORMIDC }\end{aligned}$
Waste Matrix Code Group
Site Matrix Description

NO MGRATION VARLANCE PETIHON ASSIGNMENTID 122; 2228

IRUCON CODE ID 122; 222B

\section{FINAL WASTE FORM DESCRIPTORS:}

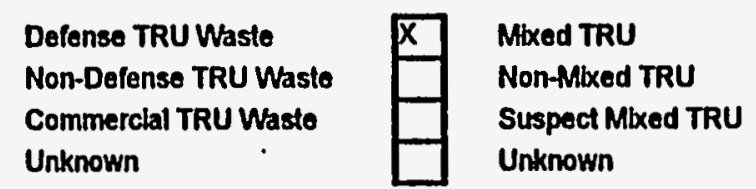

Rsearch and Devel Whsto

Operations Wasto

Residues

Decon and Decommisstoning

Environmental Restoralion

From Treatment of Waste

Malntenance

\begin{tabular}{|l|l|}
\hline$X$ \\
\hline$X$ \\
\hline$X$ \\
\hline \\
\\
\\
\end{tabular}

$\square$


WASTE STREAM PROFILE FOR THE WIPP TRU WASTE BASELINE INVENTORY REPORT

SITE NAME IN WASTE TYPE MTRU HANDLING CH GENERATOR SITE RF

IN-W161 CONTAINER: SWB overpack

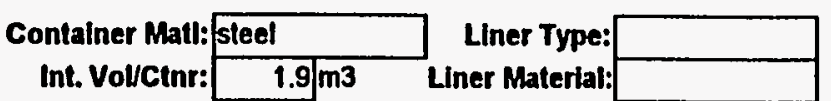

Number Stored: Number Projected:

TYPICAL ISOTOPIC COMPOSITION

TYPICAL WASTE DENSITIES FOR FINAL WASTE FORM $(\mathrm{kg} / \mathrm{m} 3)$ STORED TRU WASTE ESTIMATED

\section{Material Parameters}

Iron-based Metals/Alloys

Aluminum-Based Metals/Albys

Other Metats

Other Inorganic Matertals

Cellitiosics

Rubber

Plastics

Solkdified, Inorganic matrix

Solidified, Organic matrix

Solts

Packaging Materials, Steel

Packaging Material, Plastic

\begin{tabular}{|r|} 
Average \\
\begin{tabular}{r|r}
\hline 0.0 \\
\hline 0.0 \\
\hline 0.0 \\
\hline 183.1 \\
\hline 8.2 \\
\hline 0.0 \\
\hline 9.1 \\
\hline 0.0 \\
\hline 0.0 \\
\hline 0.0 \\
\hline 210.0 \\
\hline 16.0 \\
\hline
\end{tabular}
\end{tabular}

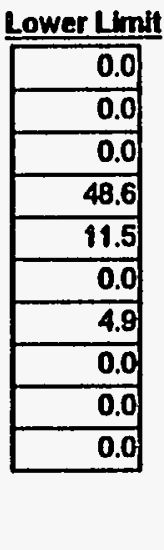

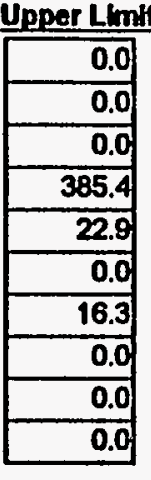

Comments

23 in number stored bs the number of SWBs that will resukf from overpacking 4 druns/SWB.
RATES OF WASTE GENERATION

\begin{tabular}{r|r|} 
& Prolected \\
\hline End of 1892: & 18.7 \\
\hline End of 1993: & 18.7 \\
\hline $1984:$ & 0.0 \\
\hline $1995:$ & 0.0 \\
\hline $1998:$ & 0.0 \\
\hline $1997:$ & 0.0 \\
\hline 1988-2002: & 0.0 \\
\hline 2003-2022: & 0.0 \\
\hline
\end{tabular}

Nuclide Activity

Am241 2.11E-02 Curies $/ \mathrm{m}^{3}$

Pu52 1.30E+01 Curles/m3

U235 1.14E-07 Curies $/ \mathrm{m} 3$

\begin{tabular}{r|r|r}
0.0 & $\mathrm{~m} 3 / \mathrm{yr}$ \\
$\mathrm{m} 3 / \mathrm{ry}$
\end{tabular}
F002

inal Form

$42.8 \mathrm{m3}$

$0.0 \mathrm{~m} 3 / \mathrm{yr}$

$0.0 \mathrm{~m} 3 / \mathrm{yr}$

$0.0 \mathrm{~m} 3 / y r$

\section{IYPICAL EPA CODES APPLLCABLE \\ F001}

$0.0 \mathrm{~m} 3 / \mathrm{yr}$

\section{N}




\section{WASTE STREAM PROFILE FOR THE WIPP TRU WASTE BASELINE INVENTORY REPORT}

SITE NAME IN

WASTE TYPE MTRU HANDLING CH GENERATOR SITE RF

IN-W161 CONTAINER: $\frac{\text { Drum }}{\text { Type/Size: } 55 \text {-gallon }}$

TYPICAL WASTE DENSITIES FOR FINAL WASTE FORM $(\mathrm{kg} / \mathrm{m} 3)$

Material Parameters

Iron-based Metals/Alloys

Aluminum-Based Metals/Alloys

Other Metals

Other Inorganic Materials

Cellutosics

Rubber

Plastics

Solldified, Inorganic matrix

Solldified, Organle matrix

Soils

Packaging Materlals, Steel

Packaging Material, Plastic

\section{Lower Limit Upper Limit}

\begin{tabular}{|r|}
\hline 0.0 \\
\hline 0.0 \\
\hline 0.0 \\
\hline 111.0 \\
\hline 26.2 \\
\hline 0.0 \\
\hline 11.3 \\
\hline 0.0 \\
\hline 0.0 \\
\hline 0.0 \\
\hline
\end{tabular}

131.0

37.0
Contalner Matl: steel

Int. VolvCtnr: $0.208 \mathrm{~m}$
Liner Type:

Liner Materia

STORED TRU WASTE -ESTIMATED RATES OF WASTE GENERATION

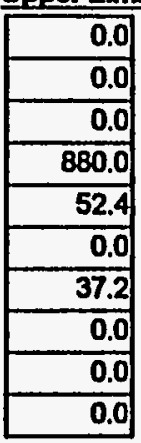

End of 1992: $\stackrel{\text { Proiected }}{92.1} \stackrel{\text { Final Form }}{\underset{92.1}{1}}$ End of 1993: $\quad 92.1$

1994.

1998:

1998:

1997

1998-2002:

2003-2022:

TYPICAL EPA CODES APPLICABLE

F001

F002
Number Stored Number Projected

443

TYPICAL ISOTOPIC COMPOSITION

\section{Nuclide Actlvity}

Am241 4.82E-02 Curies/m3

Pu52 2.97E+01 Curies/m3

U235 2.60E-07 Curies $/ \mathrm{m}^{3}$ 


\section{WASTE STREAM PROFILE FOR THE WIPP TRU WASTE BASELINE INVENTORY REPORT}

\section{SITENAME IN WASTE TYPEMTRU HANDLING CH GENERATOR SITE RF}

\begin{tabular}{|c|c|c|c|c|}
\hline \multirow{4}{*}{\multicolumn{2}{|c|}{$\begin{array}{ll}\text { WASTE STREAM MWIR ID } \\
& \begin{array}{l}\text { WIPP ID } \\
\text { Local ID }\end{array} \\
\text { MATRIX CODE } & \end{array}$}} & IN-W166 & \multirow{5}{*}{$\begin{array}{l}\text { STREAMNAME } \\
\text { DESCRIPTION }\end{array}$} & \multirow[t]{2}{*}{ Solidified Process Residues } \\
\hline & & IN-W166 & & \\
\hline & & 1D-EGG-112T-114 & & \multirow[t]{4}{*}{ Cemented Sludges (TRU): Solid Inorganic Process Solution } \\
\hline & & 3150 & & \\
\hline \multicolumn{2}{|c|}{ SITE FINAL FORMIDC } & & & \\
\hline \multirow{2}{*}{\multicolumn{2}{|c|}{$\begin{array}{l}\text { Waste Matrix Code Group } \\
\text { Slte Matrix Description }\end{array}$}} & Solidified Inorganics & & \\
\hline & & \multicolumn{3}{|c|}{$\begin{array}{l}\text { Solld horganic process solution waste consists of cemented inorganic particulates of sludge-like (not chemically precipitated) wasles from plutonium } \\
\text { recovery operations. }\end{array}$} \\
\hline
\end{tabular}

\section{FINAL WASTE FORM DESCRIPTORS:}

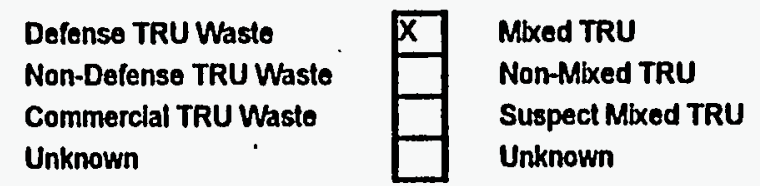

Rsearch and Devel. Wasto
Operations Wasto
Residues
Decon and Decommissioning
Environmental Resioration
From Treatment of Waste.
Malntenance

\begin{tabular}{|l|l|l|}
\hline$X$ & TSCA & \\
\hline$X$ & $\begin{array}{l}\text { Asbestos } \\
\text { PCBs } \\
\text { Other } \\
\text { N/A } \\
\text { Unknown }\end{array}$ & \\
\hline & & \\
\hline & & \\
\hline
\end{tabular}




\section{WASTE STREAM PROFILE FOR THE WIPP TRU WASTE BASELINE INVENTORY REPORT}

SITE NAME IN

WASTE TYPE MTRU HANDLING CH GENERATOR SITE RF

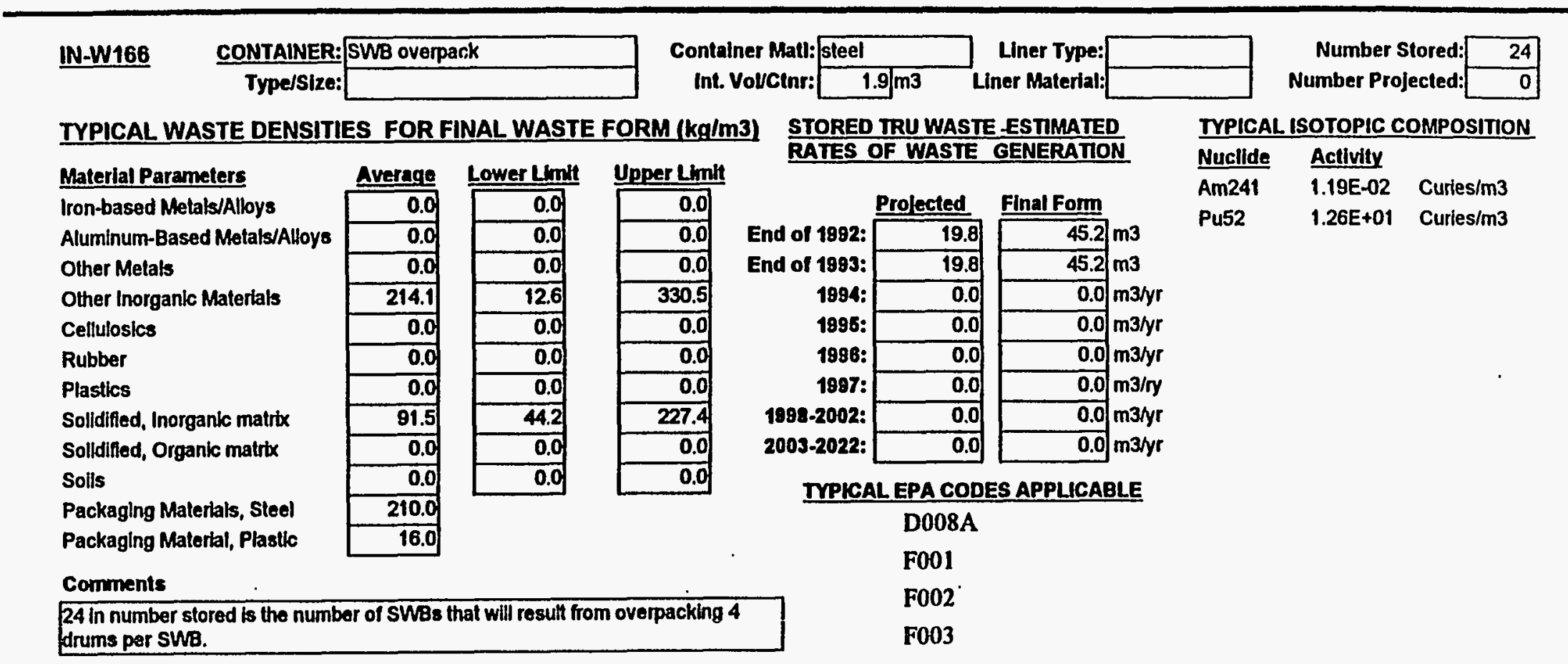


WASTE STREAM PROFILE FOR THE WIPP TRU WASTE BASELINE INVENTORY REPORT

SITE NAME IN WASTE TYPE MTRU HANDLING CH GENERATOR SITE RF

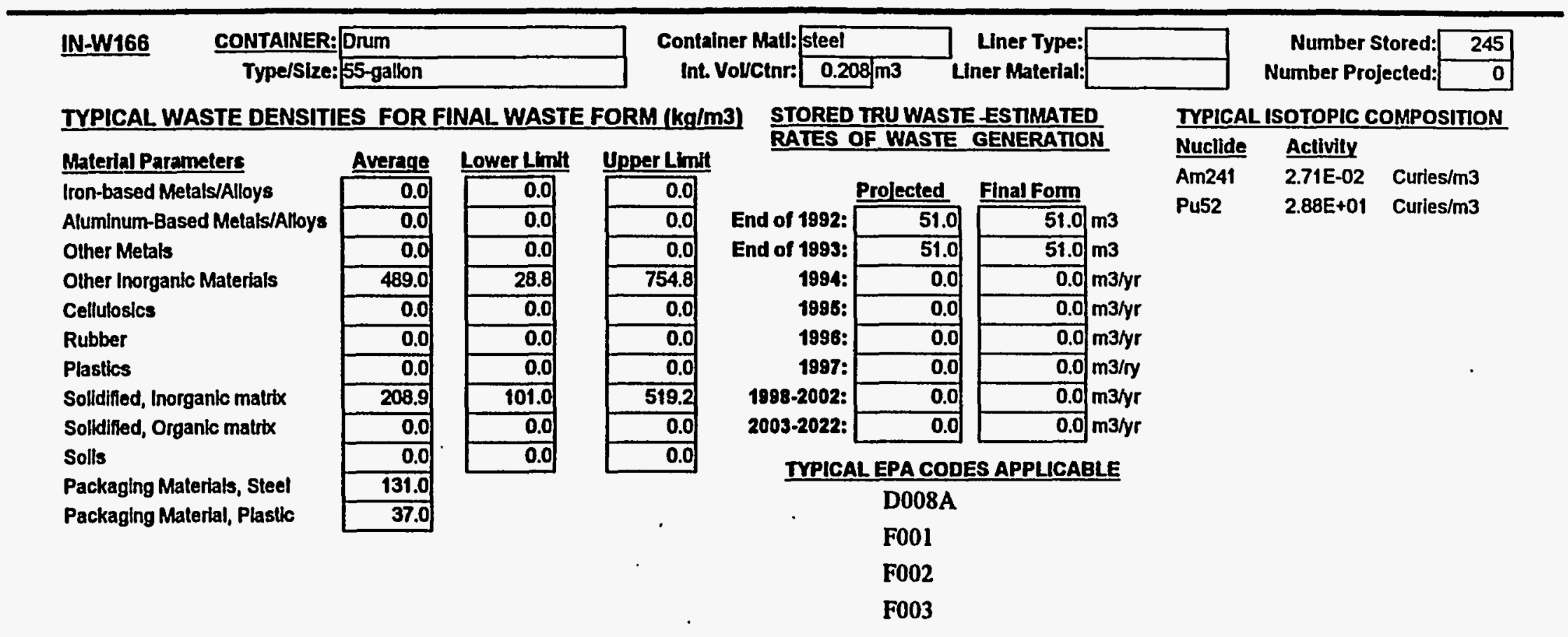




\section{WASTE STREAM PROFILE FOR THE WIPP TRU WASTE BASELINE INVENTORY REPORT}

SITE NAME IN

WASTE TYPE MTRU HANDLING CH GENERATOR SITE RF

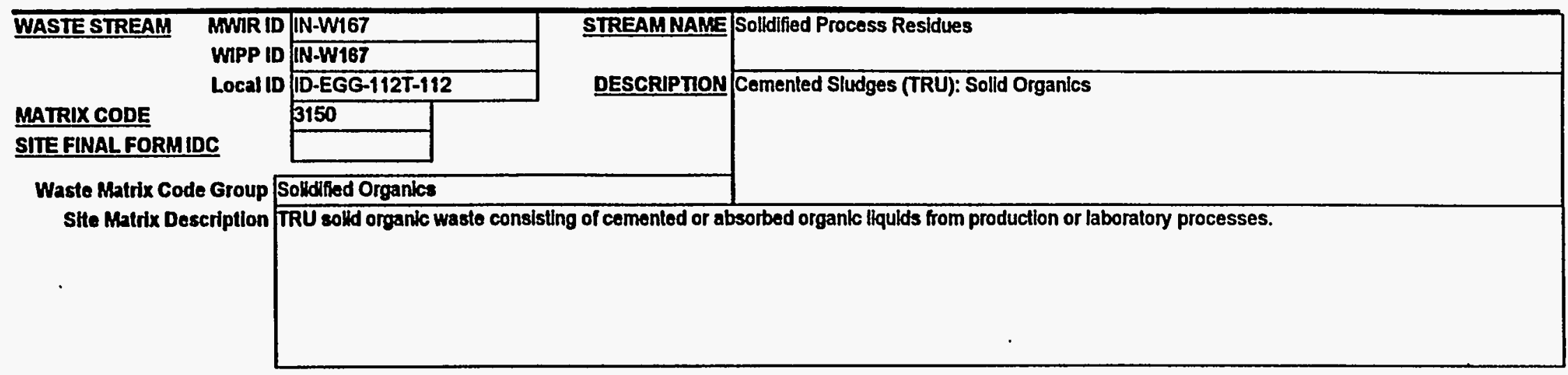

NO MGGRATION VARIANGE PETITON ASSIGNMENTID 112

IRUCON CODE ID 112

FINAL WASTE FORMDESCRIPTORS:

\begin{tabular}{l|l} 
Defense TRU Waste & $X$ \\
Non-Defonse TRU Waste \\
Commercial TRU Waste \\
Unknown
\end{tabular}$\quad \square \quad \begin{aligned} & \text { Mixed TRU } \\
& \text { Non-Mixed TRU } \\
& \text { Suspect Mixed TRU } \\
& \text { Unknown }\end{aligned}$

Rsearch and Devel. Waste
Operations Waste
Residues
Decon and Decommissioning
Environmental Restoration
From Treatment of Waste
Maintenance

\begin{tabular}{|l|l|l|}
\hline$X$ & TSCA & $\begin{array}{l}\text { Asbestos } \\
\text { PCBs } \\
\text { Other } \\
\text { N/A } \\
\text { Unknown }\end{array}$ \\
\hline & & \\
\hline & & \\
\hline & & \\
\hline
\end{tabular}




\section{WASTE STREAM PROFILE FOR THE WIPP TRU WASTE BASELINE INVENTORY REPORT}

SITE NAME IN WASTE TYPE MTRU HANDLING CH GENERATOR SITE RF

\section{IN-W167

CONTAINER: SWB overpack

Int. Volvetnr:

$\frac{1.9}{\mathrm{~m} 3}$

Liner Type:

TYPICAL WASTE DENSITIES FOR FINAL WASTE FORM $(\mathrm{kg} / \mathrm{m} 3)$

Material Parameters

Iron-based Metals/Alloys

Aluminum-Based Metals/Alloys

Other Metals

Other Inorganic Materlals

Cellulosks

Rubber

Plastics

Solidified, Inorganic matrix

Solidified, Organic matrix

Solls

Packaging Materials, Steel

Packaging Material, Plastic

\begin{tabular}{|c|c|}
\hline Averege & Lower Limi \\
\hline 0.0 & 0.0 \\
\hline$\overline{0.0}$ & 0.0 \\
\hline 0.0 & 0.0 \\
\hline 240.0 & 90.5 \\
\hline$\overline{0.0}$ & 0.0 \\
\hline 0.0 & 0.0 \\
\hline 0.0 & $\overline{0.0}$ \\
\hline 0.0 & 0.0 \\
\hline 176.6 & 65.2 \\
\hline $\overrightarrow{0.0}$ & 0.0 \\
\hline 210.0 & \\
\hline
\end{tabular}

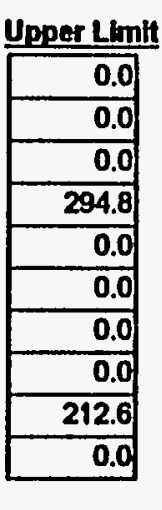

STORED TRU WASTE ESTIMATED RATES OF WASTE GENERATION

Comments

55 in number stored is the number of SWBs that will resulf from overpacking 4 drums/SWB.

\begin{tabular}{|c|c|c|c|}
\hline & Prolected & Final Form & \\
\hline End of 1992: & 45.9 & 104.5 & $\mathrm{~m} 3$ \\
\hline End of 1993: & 45.9 & 104.5 & m3 \\
\hline 1994: & 0.0 & 0.0 & $\mathrm{~m} 3 / \mathrm{yr}$ \\
\hline 1998: & 0.0 & 0.0 & $\mathrm{~m} 3 / \mathrm{yr}$ \\
\hline 1998: & 0.0 & 0.0 & $\mathrm{~m} 3 / \mathrm{yr}$ \\
\hline 1997: & 0.0 & $\overline{0.0}$ & $m 3 / r y$ \\
\hline 1988-2002: & 0.0 & 0.0 & $\mathrm{~m} 3 / y r$ \\
\hline 2003-2022: & 0.0 & 0.0 & m3/yr \\
\hline
\end{tabular}

F001

F003
Number Stored:

Number Projected:

TYPICAL ISOTOPIC COMPOSITION

Nuclide Activity

Am241 1.85E-02 Curies $/ \mathrm{m} 3$

Pu52 2.76E $+\infty$ Curies $/ \mathrm{m} 3$ 


\section{WASTE STREAM PROFILE FOR THE WIPP TRU WASTE BASELINE INVENTORY REPORT}

SITENAME IN WASTE TYPEMTRU HANDLING CH GENERATOR SITE RF

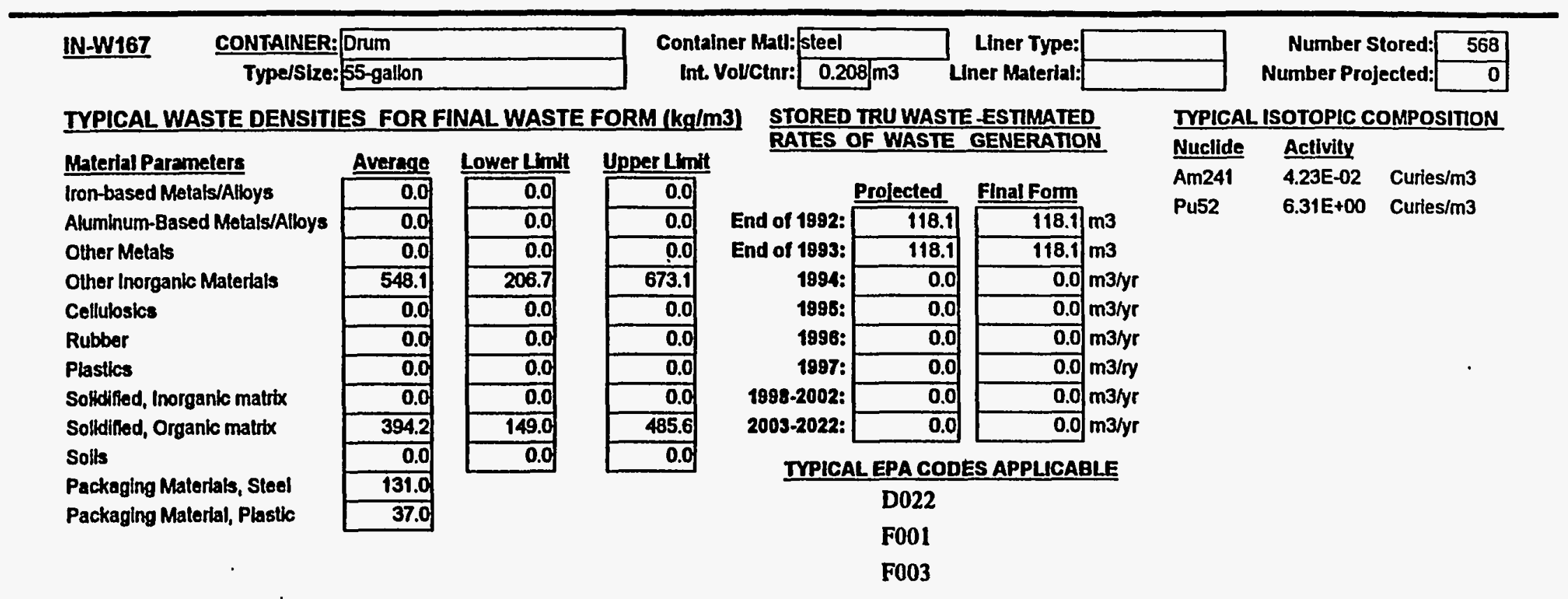




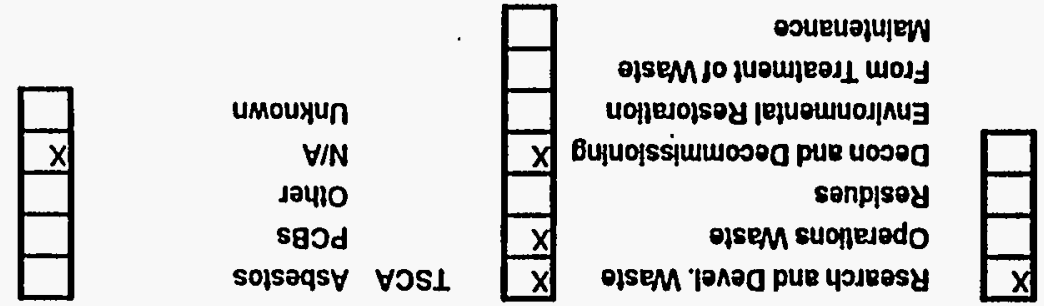

כ912 01 झ00J NOJกष्षI

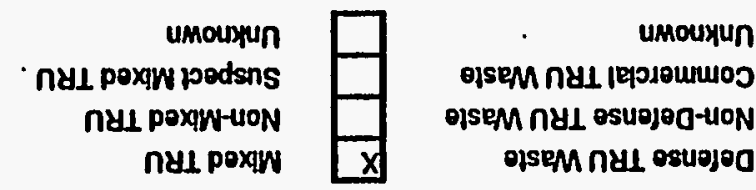

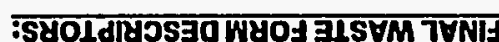

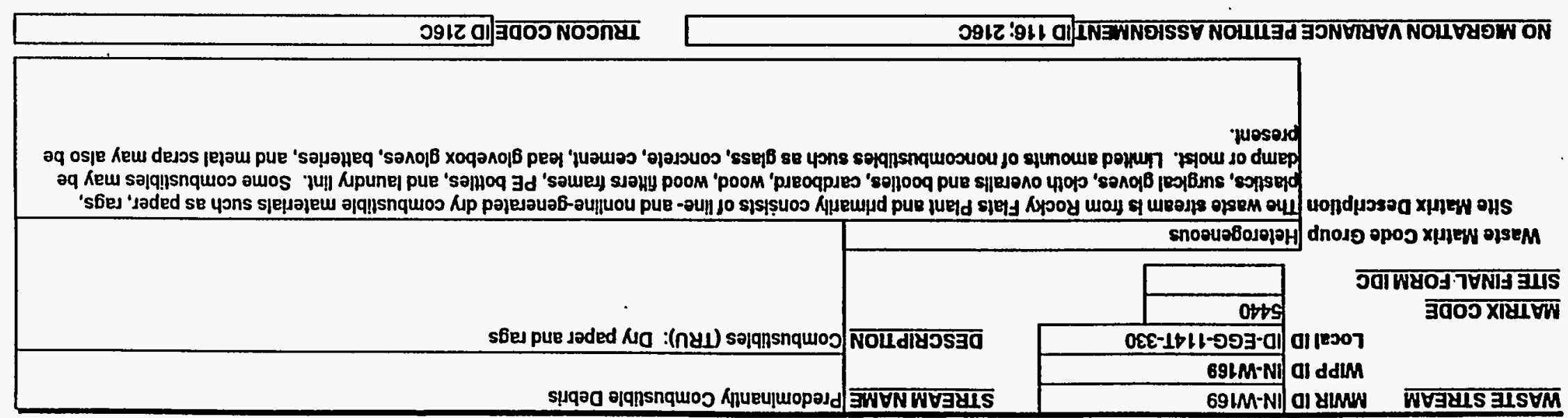

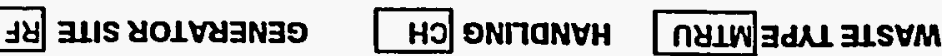

NI IW 3 MUIS 


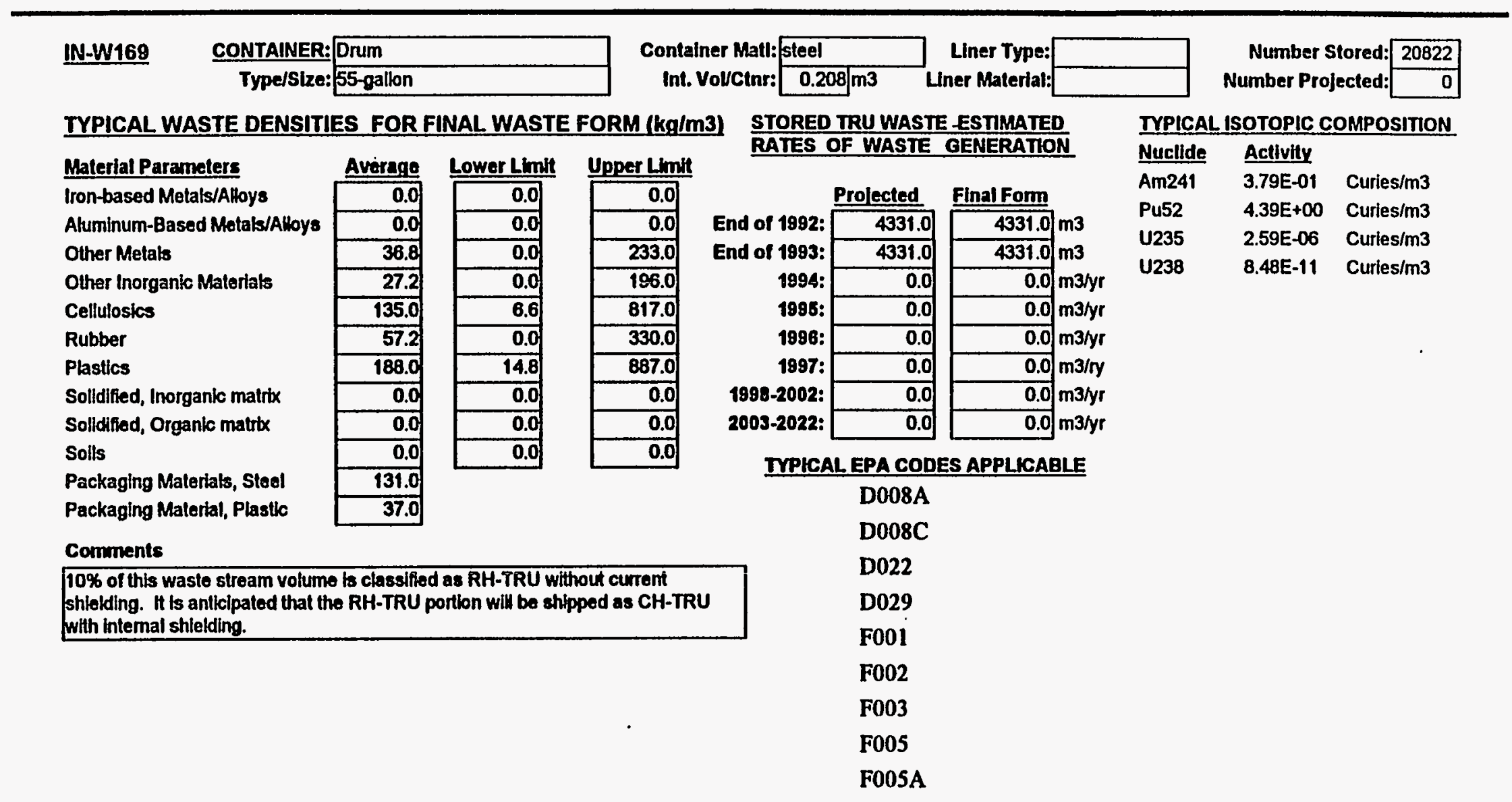




\section{WASTE STREAM PROFILE FOR THE WIPP TRU WASTE BASELINE INVENTORY REPORT}

SITENAME IN WASTE TYPEMTRU HANDLING CH GENERATOR SITE AE

\begin{tabular}{|c|c|c|c|c|}
\hline \multirow{4}{*}{\multicolumn{2}{|c|}{$\begin{array}{ll}\text { WASTE STREAM MWR ID } \\
& \begin{array}{r}\text { WIPP ID } \\
\text { Local ID }\end{array} \\
\text { MATRIX CODE } & \end{array}$}} & IN-W170 & \multirow{5}{*}{$\begin{array}{l}\text { STREAMNAME } \\
\text { DESCRIPTION }\end{array}$} & \multirow[t]{2}{*}{ Predominantly Combustible Debris } \\
\hline & & IN-W170 & & \\
\hline & & ID-EGG-114T-120 & & \multirow[t]{3}{*}{ Combustlbles (TRU): Decontamination/Decommissioning Waste Combustible Solids } \\
\hline & & 5440 & & \\
\hline \multicolumn{2}{|c|}{ SITE FINAL FORM IDC } & & & \\
\hline \multirow{3}{*}{\multicolumn{2}{|c|}{$\begin{array}{r}\text { Waste Matrix Code Group } \\
\text { Site Matrix Description }\end{array}$}} & felerogeneous & & $\cdot$ \\
\hline & & \multicolumn{3}{|c|}{$\begin{array}{l}\text { This waste is generated al Argonne National Laboralory. The waste is dertved from decontamination and disposal of facilities and ancillary systems } \\
\text { (e.g. gloveboxes). The composttion of the waste is unknown. It is expected to contain some cadmium and lead, and may contain F-listed wastes. }\end{array}$} \\
\hline & & & & $\cdot$ \\
\hline
\end{tabular}

\section{FINAL WASTE FORM DESGRIPTORS:}

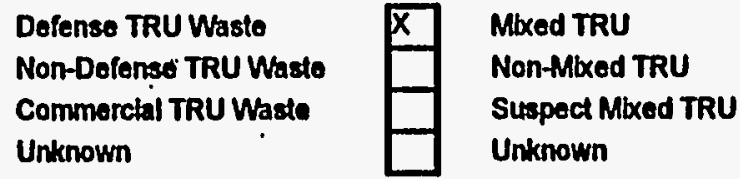

Reearch and Devel, Wasto Operaltons Wasto

Residues

Decon and Decommissioning

Environmental Restoration

From Treatment of Waste

Maintenance

\begin{tabular}{|l|l|l|}
\hline$X$ & TSCA & $\begin{array}{l}\text { Asbestos } \\
\text { PCBs } \\
\text { Other } \\
\text { N/A } \\
\text { Unknown }\end{array}$ \\
\hline$X$ & \\
\hline & & \\
\hline & & \\
\hline
\end{tabular}




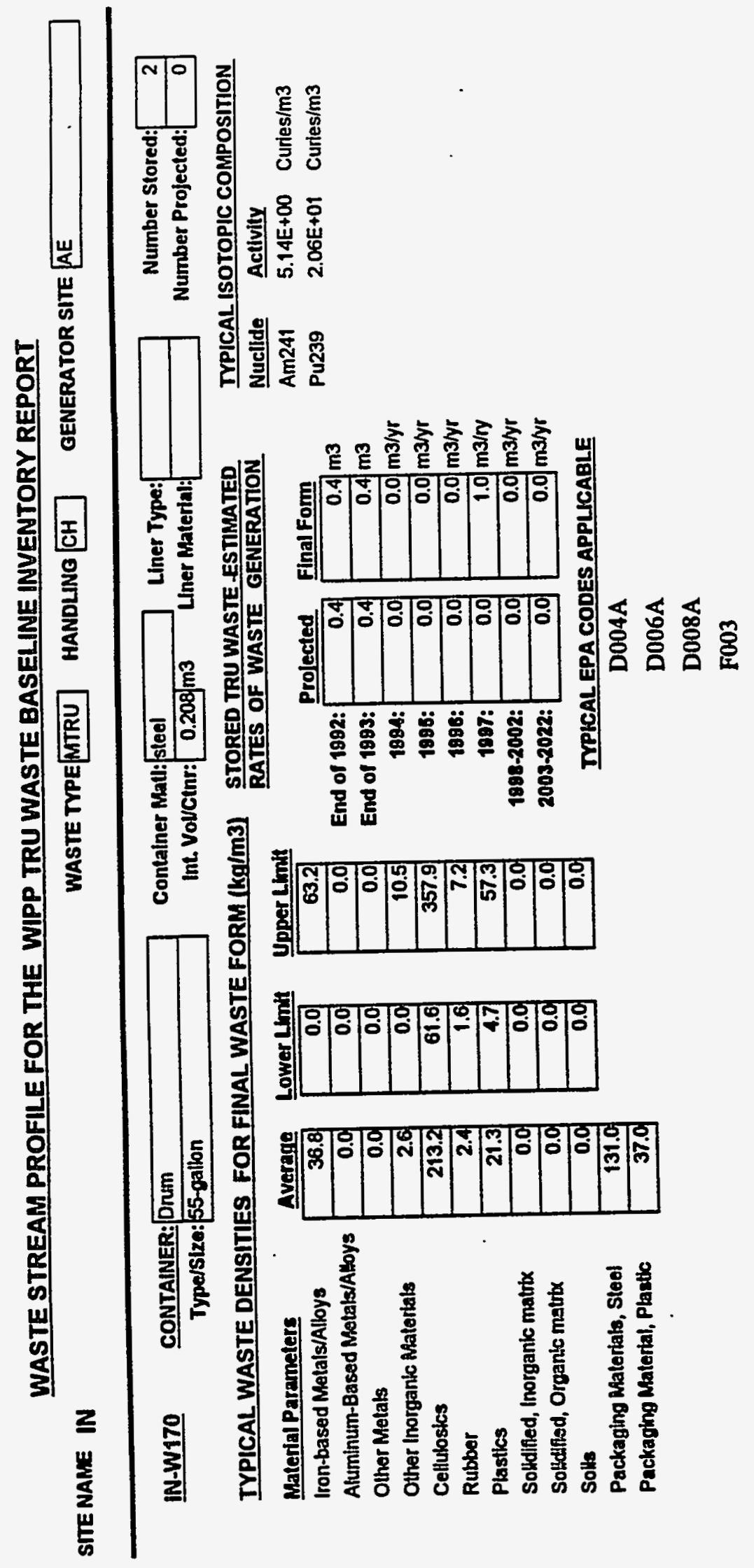


WASTE STREAM PROFILE FOR THE WIPP TRU WASTE BASELINE INVENTORY REPORT

SITENAME IN

WASTE TYPEMTRU HANDLING CH GENERATOR SITE AE

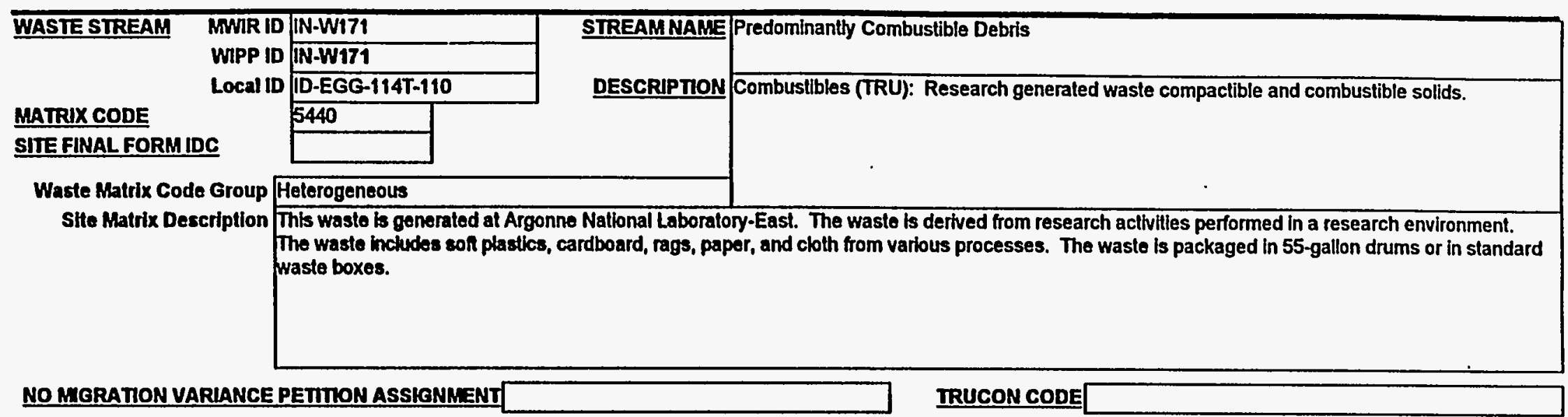

FINAL WASTE FORM DESCRIPTORS:

Dofense TRU Waste

Non-Defense TRU Waste

Commercial TRU Wasto

Unknown

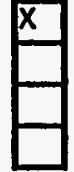

Mixed TRU

Non-Mbed TRU

Suspect Mbxed TRU

Unknown

$\square$

Rsearch and Devel. Waste
Operations Waste
Residues
Decon and Decommissioning
Environmental Restoration
From Treatment of Waste
Maintenance

TSCA Asbestos

PCBs

Other

N/A

Unknown

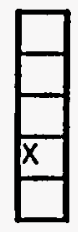




\section{WASTE STREAM PROFILE FOR THE WIPP TRU WASTE BASELINE INVENTORY REPORT}

SITE NAME IN

WASTE TYPE MTRU HANDLING CH GENERATOR SITE AE

IN-W171 $\quad \frac{\text { CONTAINER: }}{\text { Type/SIze: } 55 \text {-gallon }}$

Contalner Matl: steel

Int. VolvCinr:

\begin{tabular}{|l|}
\hline steel \\
\hline 0.208 \\
\hline
\end{tabular}

Liner Type:

Liner Material:

\section{TYPICAL WASTE DENSITIES FOR FINAL WASTE FORM $(\mathrm{kg} / \mathrm{m} 3$}

\section{Material Parameters}

Iron-based Metals/Alloys

Aluminum-Based Metals/Alloys

Other Metals

Other Inorganic Materlals

Cellulosics

Rubber

Plastics

Solidifled, Inorganic matrix

Soltdiffed, Organic matrix

Solls

Packaging Materials, Steel

Packaging Material, Plastic
STORED TRU WASTE ESTIMATED RATES OF WASTE GENERATION

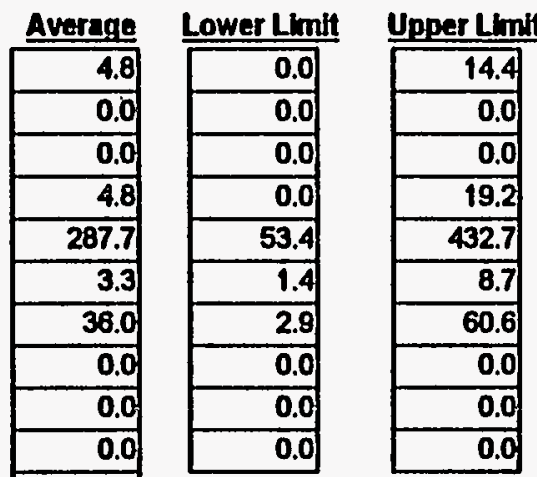

131.0

37.0

\begin{tabular}{r|r|}
\hline & Prolected \\
\hline End of 1982: & 3.6 \\
\hline End of 1993: & 3.6 \\
\hline $1998:$ & 0.0 \\
\hline $1998:$ & 0.0 \\
\hline $1997:$ & 0.0 \\
\hline $1998-2002:$ & 0.0 \\
\hline $2093-2022:$ & 0.0 \\
\hline
\end{tabular}

\begin{tabular}{|c|c|}
\hline Final Form & \\
\hline 3.6 & m3 \\
\hline 3.6 & m3 \\
\hline 0.0 & $\mathrm{~m} 3 / \mathrm{yr}$ \\
\hline 0.0 & $\mathrm{~m} 3 / \mathrm{yr}$ \\
\hline 0.0 & $\mathrm{~m} 3 / \mathrm{yr}$ \\
\hline 0.0 & m3/ry \\
\hline 0.0 & m3lyr \\
\hline 0.0 & m3tyr \\
\hline
\end{tabular}

TYPICAL EPA CODES APPLICABLE

D004A

D006A

DOO8A

F003
Number Stored Number Projected:

\section{TYPICAL ISOTOPIC COMPOSITION}

\section{Nucllde Activity}

Am241 4.00E-01 Curies $/ \mathrm{m} 3$

Am243 1.71E-03 Curies $/ \mathrm{m}^{3}$

Pu239 5.13E+00 Curles $/ \mathrm{m}^{3}$

Pu241 5.19E+01 Curies/m3 


\section{WASTE STREAM PROFILE FOR THE WIPP TRU WASTE BASELINE INVENTORY REPORT}

SIIE NAME IN

WASTE TYPEMTRU HANDLING CH GENERATOR SITE BT

\begin{tabular}{|c|c|c|c|c|}
\hline \multirow{4}{*}{\multicolumn{2}{|c|}{ 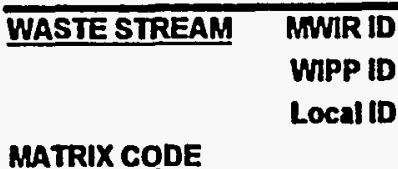 }} & D $\mid N-W 172$ & \multirow{5}{*}{$\begin{array}{l}\text { STREAMNAME } \\
\text { DESCRIPTION }\end{array}$} & \multirow{2}{*}{ Predominantly Combustlble Debris } \\
\hline & & D $\mathbb{I N - W 1 7 2}$ & & \\
\hline & & D 10 -EGG-114T-010 & & \multirow[t]{4}{*}{ Combustibles (TRU): Combustibles } \\
\hline & & 5440 & & \\
\hline \multicolumn{3}{|c|}{ SITE FINAL FORMIDC } & & \\
\hline \multirow{2}{*}{\multicolumn{2}{|c|}{$\begin{array}{l}\text { Waste Matrix Code Group } \\
\text { slte Matrix Description }\end{array}$}} & Heterogeneous & & \\
\hline & & \multicolumn{3}{|c|}{$\begin{array}{l}\text { This wasto stream, generated at Bettis Atomic Power Laboratory, consisis primarily of rags, gloves, plastic, paper, carbo-wax, filters, oil-contaminated } \\
\text { absorbent (diatomaceous earth), and rubber. The waste stream may also contain noncombustible items. Levels of hazardous materials are unknown. }\end{array}$} \\
\hline
\end{tabular}

\section{FINAL WASTE FORM DESCRIPTORS:}

\begin{tabular}{l|l|l}
$\begin{array}{l}\text { Defense TRU Waste } \\
\text { Non-Defense TRU Waste } \\
\text { Commerclal TRU Wasto } \\
\text { Unknown }\end{array}$ & \multicolumn{1}{|l|}{$\begin{array}{l}\text { Mixed TRU } \\
\text { Non-Mbxed TRU } \\
\text { Suspect Mbxed TRU } \\
\text { Unknown }\end{array}$}
\end{tabular}

$\square$

Rsearch and Dovel Waste Operations Wasto

Residues

Decon and Decommissioning

Environmental Restoration From Treatment of Waste

Maintenance

\begin{tabular}{|l|}
\hline$x$ \\
\hline$x$ \\
\hline \\
\hline \\
\hline \\
\hline
\end{tabular}

TSCA Asbestos

PCBs

Other

N/A

Unknown

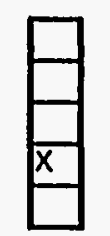


WASTE STREAM PROFILE FOR THE WIPP TRU WASTE BASELINE INVENTORY REPORT

SITE NAME IN WASTE TYPE MTRU HANDLINO CH

GENERATOR SITE BT

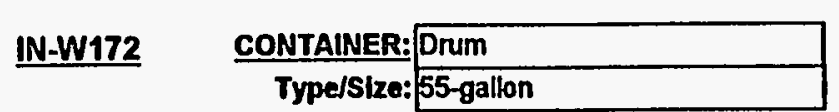

TYPICAL WASTE DENSITIES FOR FINAL WASTE FORM (kg/m3)

Material Parameters

Iron-based Metals/Alloys

Aluminum-Based Metals/Alloys

Other Metals

Other Inorganic Ahaterials

Cellulosics

Rubber

Plastics

Solidified, Inorganic matrix Solkdified, Organic matrtx

Soils

Packaging Materials, Steel

Packaging Material, Plastic

\begin{tabular}{|r|r|} 
Average & Lower Limit \\
\hline 0.0 \\
\hline 0.0 \\
\hline 0.0 \\
\hline 2.9 \\
\hline 575.6 \\
\hline 55.2 \\
\hline 165.6 \\
\hline 0.0 \\
\hline 0.0 \\
\hline 0.0 \\
\hline 0.0 \\
\hline 0.0 \\
\hline 105.8 \\
\hline 55.2 \\
\hline 105.8 \\
\hline 0.0 \\
\hline 37.0 \\
\hline 0.0 \\
\hline 0.0 \\
\hline
\end{tabular}

Comments

Typical isolopic composition is unknown for this waste stream.

\section{Contalner Matt: sleel int. Vouctnr:}

Number Stored: Number Projected

TYPICAL ISOTOPIC COMPOSITION Nucllde Activity

\begin{tabular}{r|}
\hline Upper Linit \\
\hline 0.0 \\
\hline 0.0 \\
\hline 0.0 \\
\hline 7.2 \\
\hline 961.5 \\
\hline 163.5 \\
\hline 288.5 \\
\hline 0.0 \\
\hline 0.0 \\
\hline 0.0 \\
\hline
\end{tabular}

STORED TRU WASTE ESTIMATED RATES OF WASTE GEMERATION

\begin{tabular}{|c|c|c|c|}
\hline & Prolected & Final Form & \\
\hline End of 1992: & 165.6 & $\overline{165.6}$ & $\operatorname{lm} 3$ \\
\hline id of 1893: & 165.6 & 165.6 & m3 \\
\hline 1984: & 0.0 & 0.0 & $m 3 / y r$ \\
\hline 1896: & 0.0 & 0.0 & m3lyr \\
\hline 1996: & 0.0 & 0.0 & $\mathrm{~m} 3 / \mathrm{yr}$ \\
\hline 1987: & 0.0 & 0.0 & $\mathrm{~m} 3 / \mathrm{ry}$ \\
\hline $1892-200$ & 0.0 & 0.0 & $\mathrm{~m} 3 / \mathrm{yr}$ \\
\hline $2003-202$ & 0.0 & 0.0 & $m 3 / y r$ \\
\hline
\end{tabular}

IYPICAL EPA CODES APPLICABLE

F001

F002 
WASTE STREAM PROFILE FOR THE WIPP TRU WASTE BASELINE INVENTORY REPORT

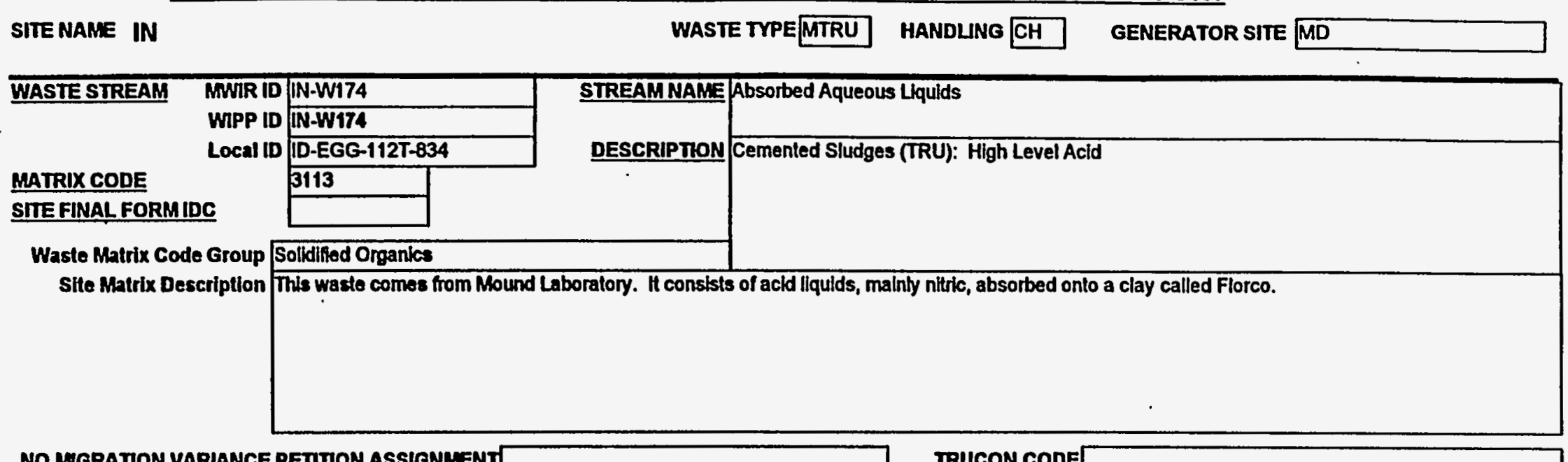

NO MGGRATION VARIANCE PETIION ASSIGNMENTI $\square$ IRUCON CODE

\section{FINAL WASTE FORM DESCRIPTORS:}

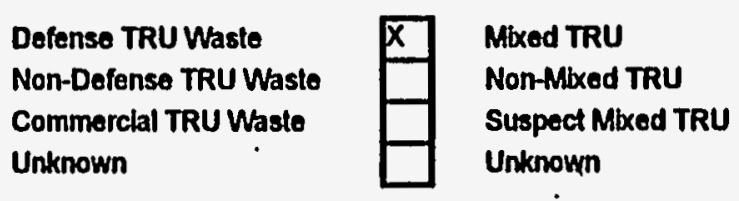

$\begin{array}{lll}\text { TSCA } & \begin{array}{l}\text { Asbestos } \\ \text { PCBs }\end{array} \\ \text { Other } & \\ \text { N/A } & \\ \text { Unknown } & \\ & & \\ & & \\ & & \\ & & \end{array}$




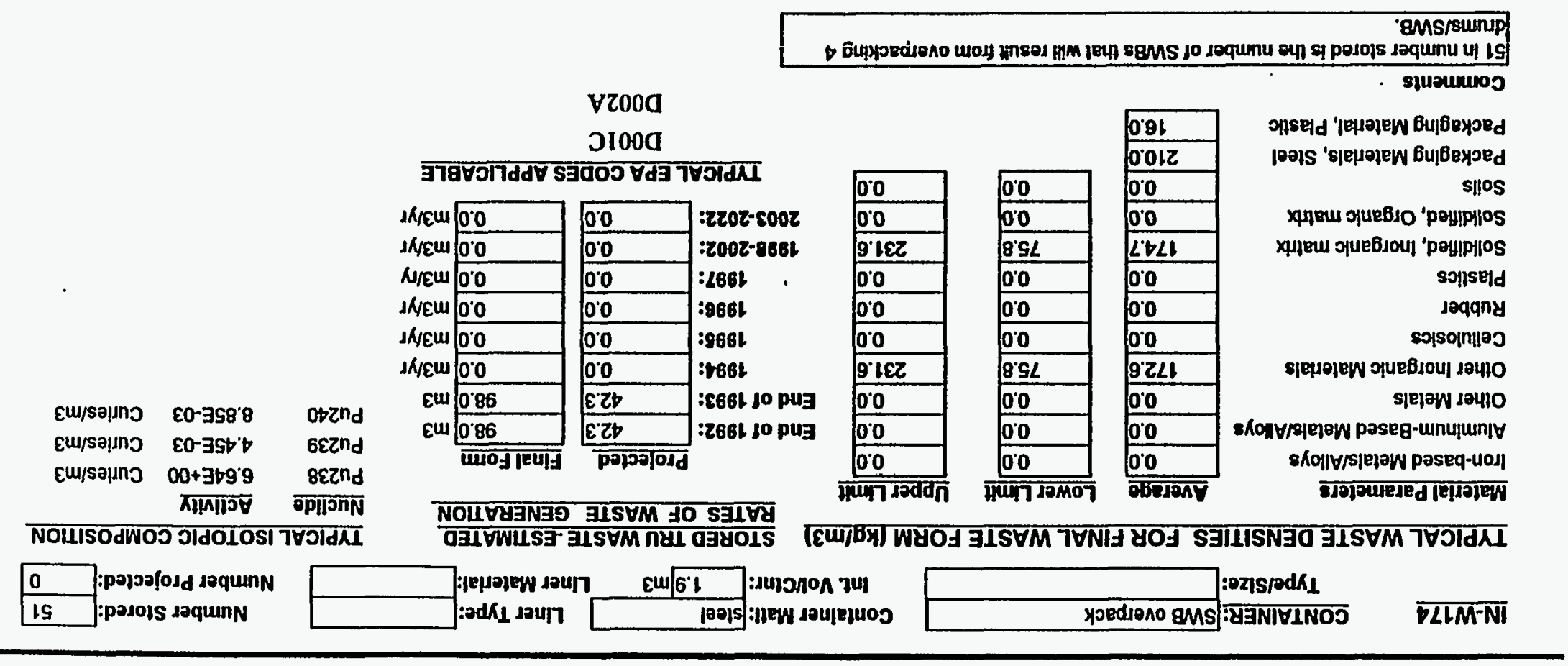


WASTE STREAM PROFILE FOR THE WIPP TRU WASTE BASELINE INVENTORY REPORT

SITE NAME IN

WASTE TYPEMTRU HANDLING CH GENERATOR SITE MD

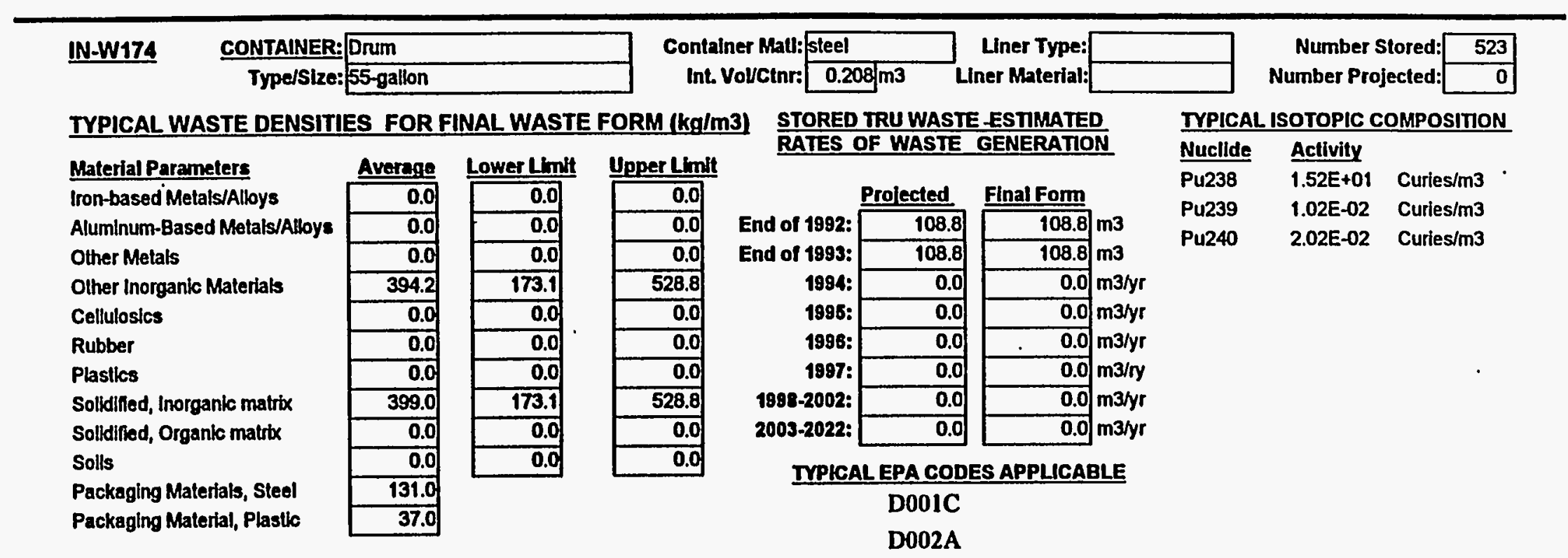


WASTE STREAM PROFILE FOR THE WIPP TRU WASTE BASELINE INVENTORY REPORT

SITE NAME IN

WASTE TYPE MTRU HANDLING CH GENERATOR SITE MD

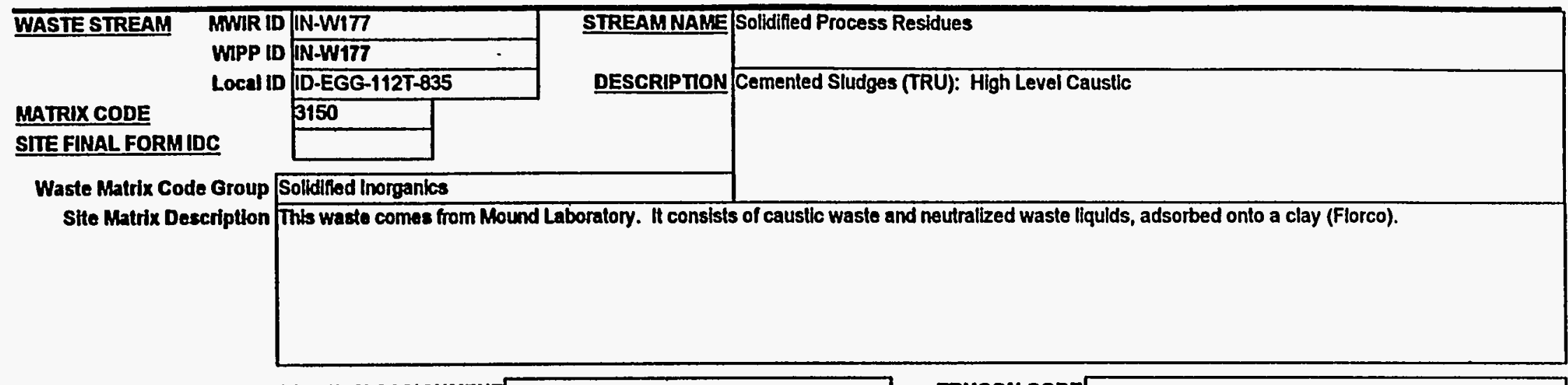

NO MGRATION VARIANCE PEIIION ASSIGNMENY

IRUCON CODE

FINAL WASTE FORM DESCRIPTORS:

\begin{tabular}{l|l} 
Defense TRU Waste \\
Non-Defense TRU Waste \\
Commerclal TRU Wasto \\
Unknown
\end{tabular}$\quad \square \quad \begin{aligned} & \text { Mbxed TRU } \\
& \begin{array}{l}\text { Non-Mbxed TRU } \\
\text { Suspect Mbxed TRU } \\
\text { Unknown }\end{array}\end{aligned}$

Unknown

Unknown

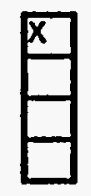

\begin{tabular}{|l|}
\hline$x$ \\
\hline$x$ \\
\hline$x$ \\
\hline \\
\hline \\
\hline
\end{tabular}

TSCA Asbestos

PCBs

Other

N/A

Unknown

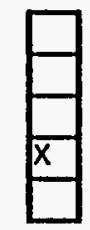

Maintenance 


\section{WASTE STREAM PROFILE FOR THE WIPP TRU WASTE BASELINE INVENTORY REPORT}

SITE NAME IN

WASTE TYPE MTRU HANDLING CH GENERATOR SITE MD

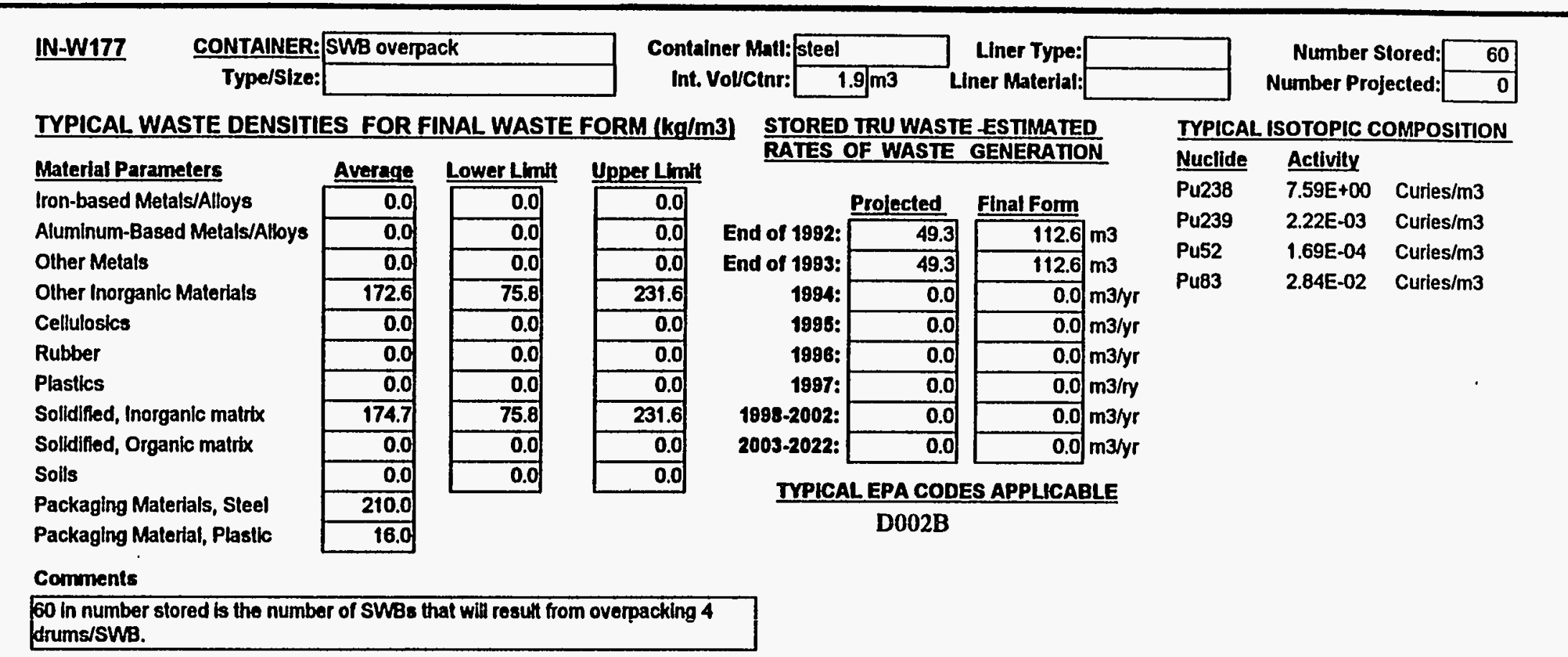




\section{WASTE STREAM PROFILE FOR THE WIPP TRU WASTE BASELINE INVENTORY REPORT}

SITENAME IN

WASTE TYPE MTRU HANDLING CH GENERATOR SITE MD

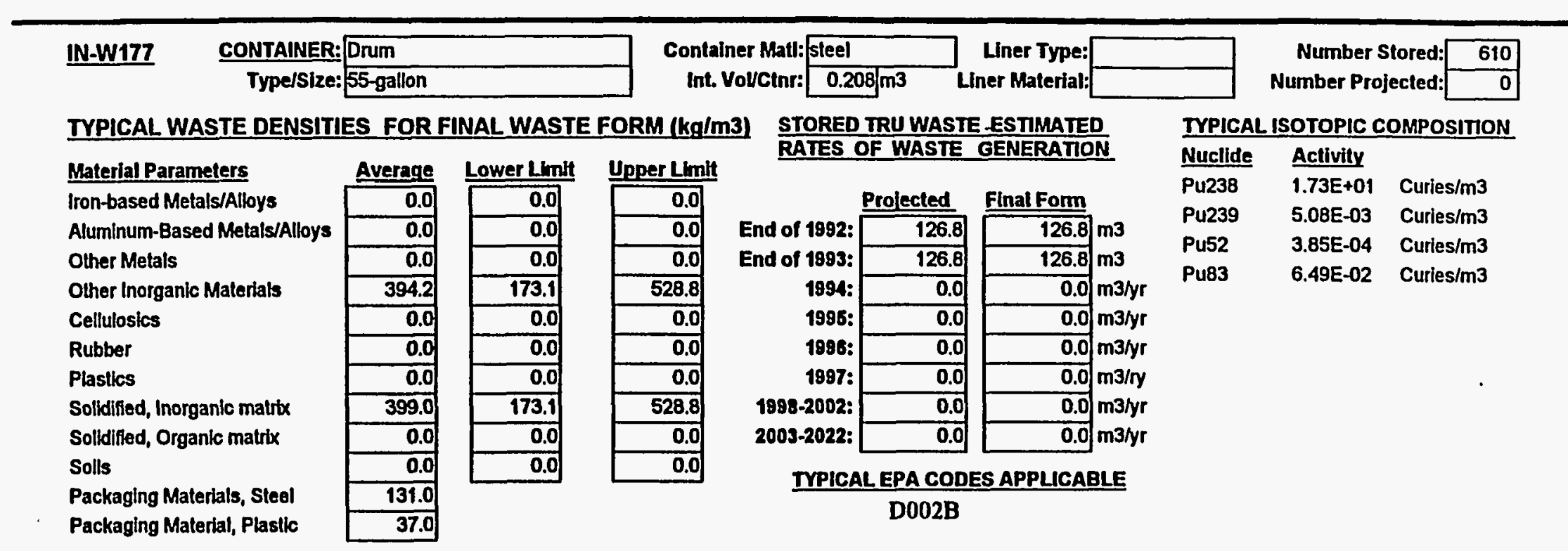




\section{WASTE STREAM PROFILE FOR THE WIPP TRU WASTE BASELINE INVENTORY REPORT}

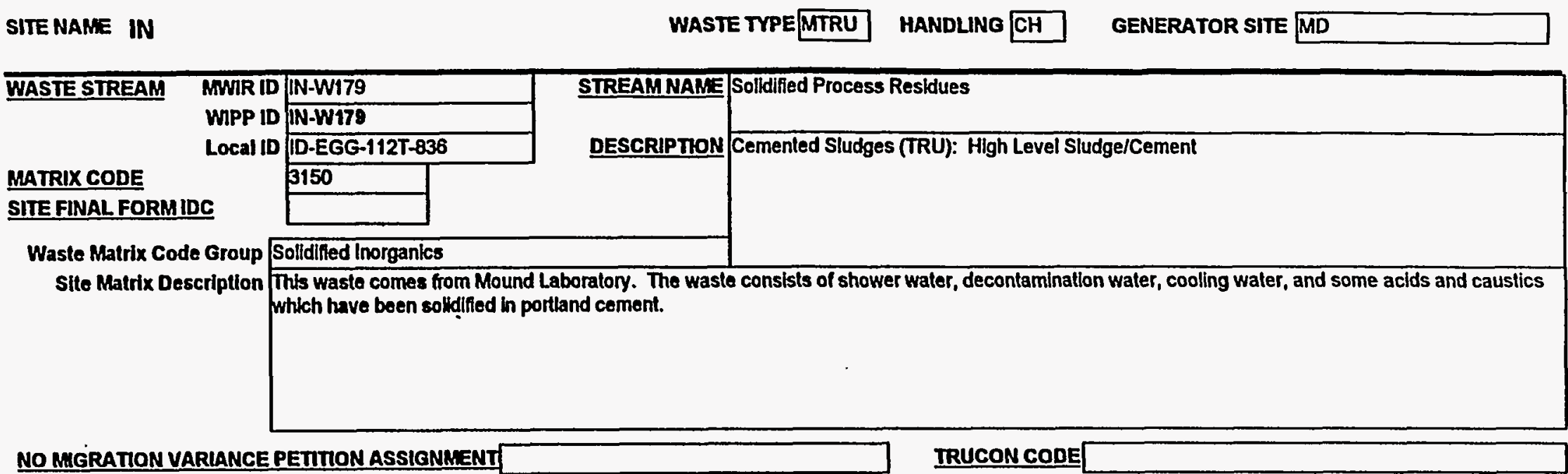

\section{FINAL WASTE FORMDESCRIPTORS:}

\begin{tabular}{l|l} 
Defense TRU Waste \\
Non-Defense TRU Waste \\
Commerclal TRU Waste \\
Unknown
\end{tabular}$\quad \square \quad \begin{aligned} & \text { Mbxed TRU } \\
& \text { Non-Mbxed TRU } \\
& \text { Suspect Mixed TRU } \\
& \text { Unknown }\end{aligned}$

$\square$

Rsearch and Devel. Wasto
Operations Waste
Residues
Decon and Decommissioning
Environmental Restoration
From Treatment of Waste
Maintenance

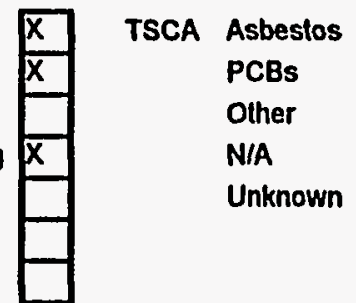

目




\section{WASTE STREAM PROFILE FOR THE WIPP TRU WASTE BASELINE INVENTORY REPORT}

SITE NAME IN

WASTE TYPE MTRU HANDLING CH GENERATOR SITE MD

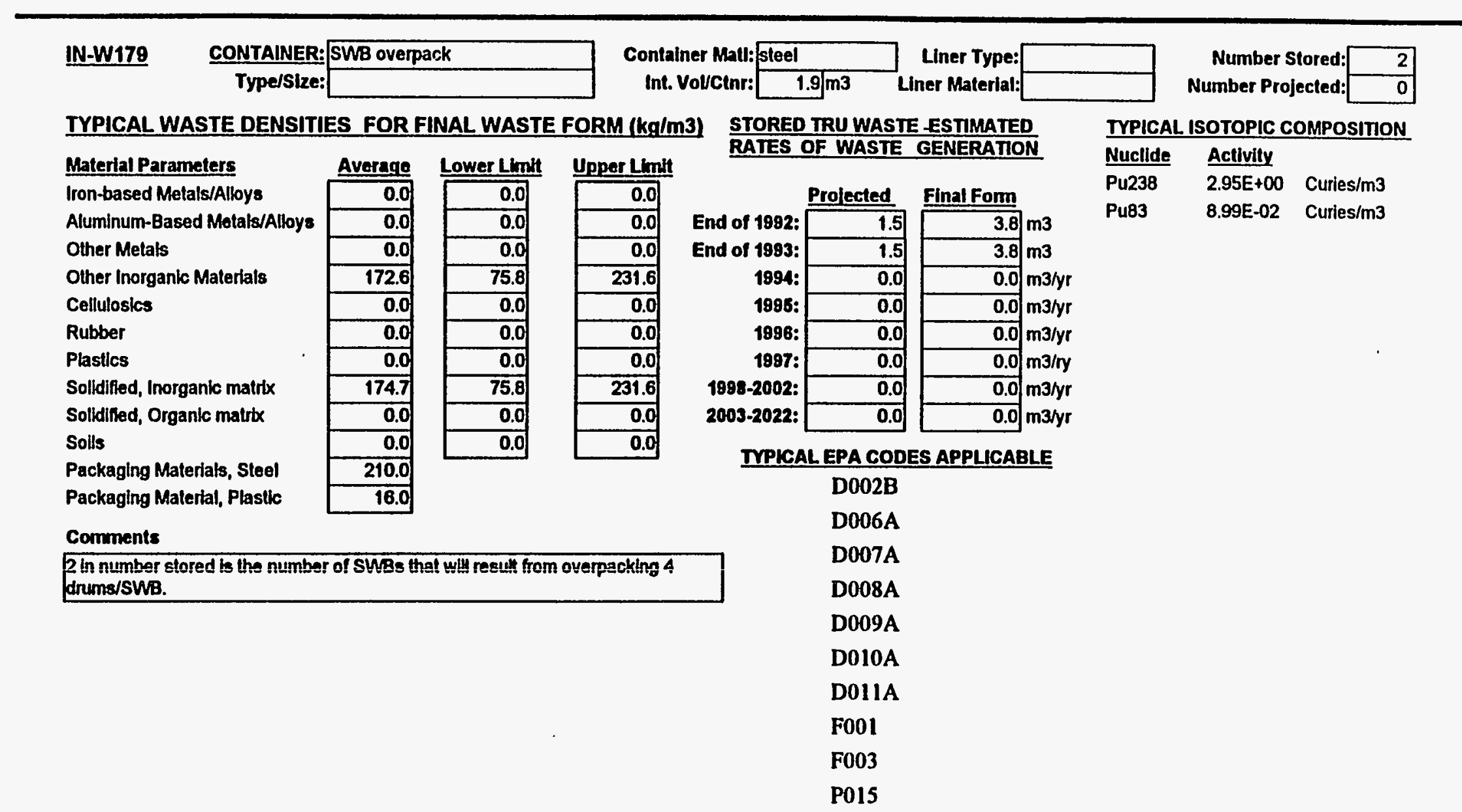




\section{WASTE STREAM PROFILE FOR THE WIPP TRU WASTE BASELINE INVENTORY REPORT}

SITE NAME IN

WASTE TYPEMTRU HANDLING CH GENERATOR SITE MD

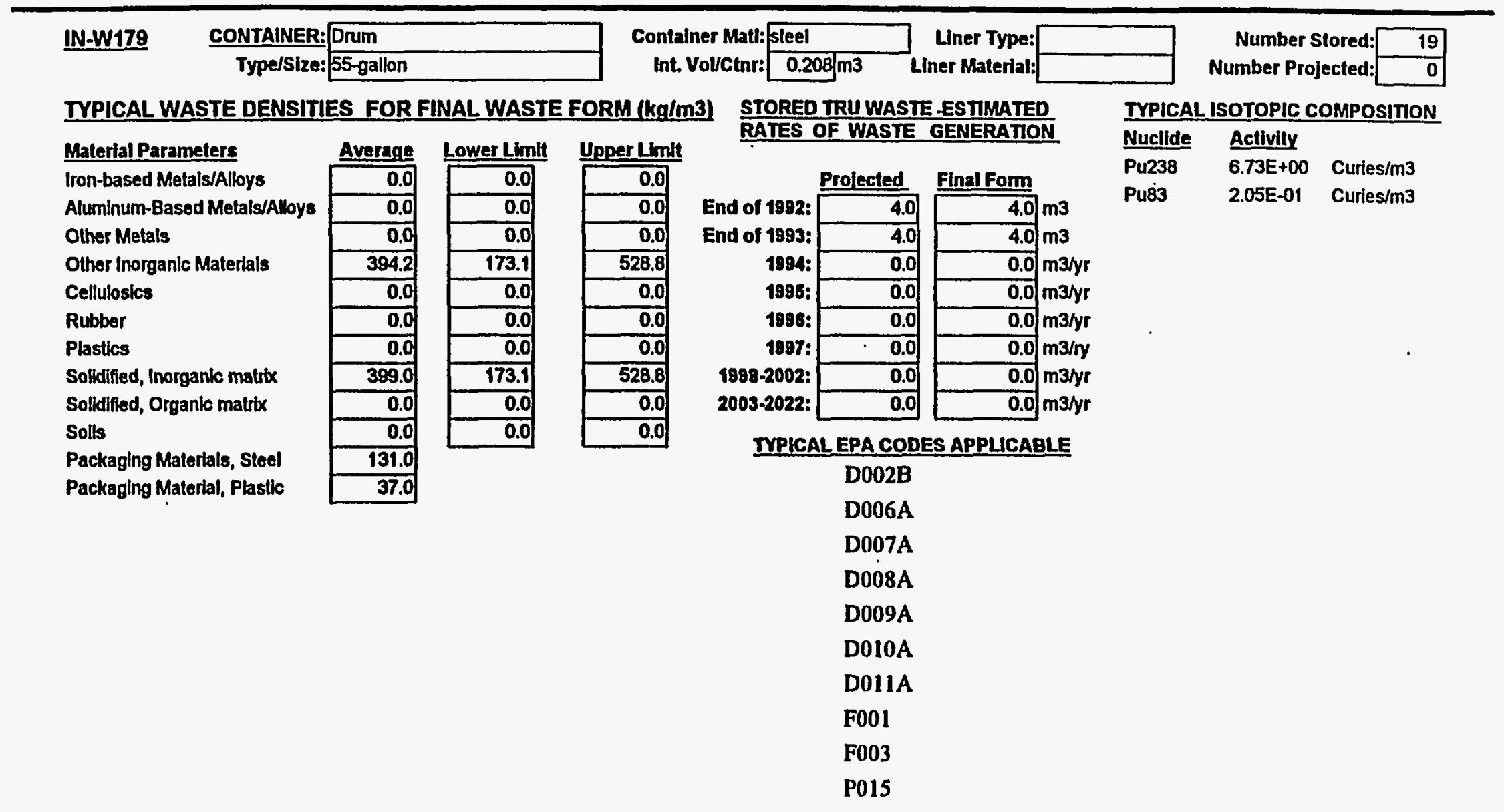




\section{WASTE STREAM PROFILE FOR THE WIPP TRU WASTE BASELINE INVENTORY REPORT}

SITENAME IN

\section{WASTE TYPE MTRU HANDLING CH GENERATOR SITE RF}

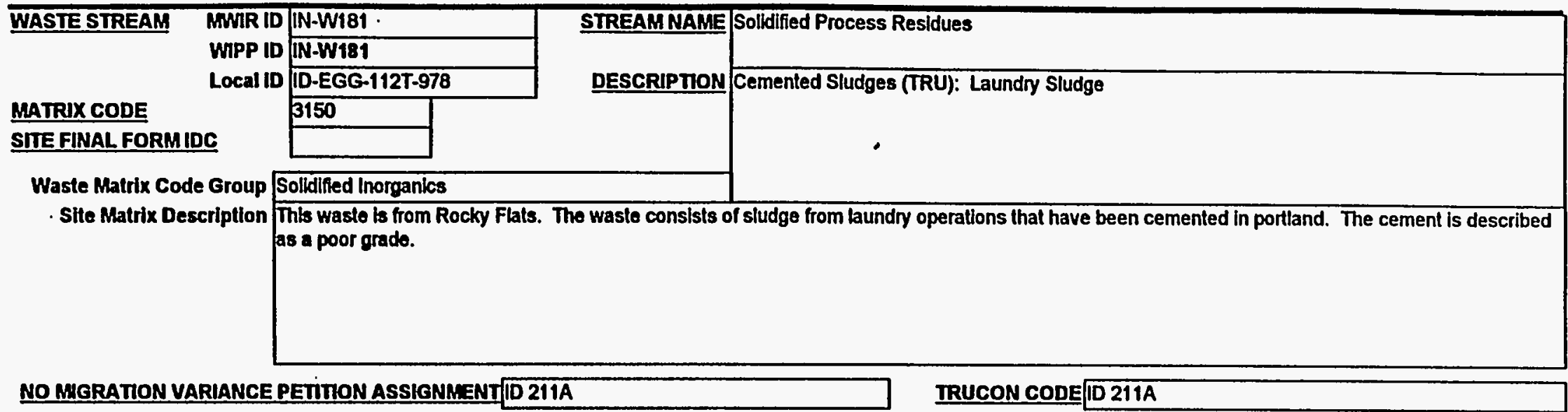

NO MIGRATION VARIANCE PETITION ASSIGNMENT ID 211A

IRUCON CODE ID 211A

FINAL WASTE FORM DESCRIPTORS:

\begin{tabular}{l|l}
$\begin{array}{l}\text { Defense TRU Waste } \\
\text { Non-Defense TRU Waste } \\
\text { Commerclal TRU Waste } \\
\text { Unknown }\end{array}$ & $\square$
\end{tabular}

Unknown
Rsearch and Devel. Waste

Operations Waste

Residues

Decon and Decommissioning Environmental Restoration From Treatment of Wasto Maintenance
TSCA Asbestos

PCBs

Other

N/A

Unknown

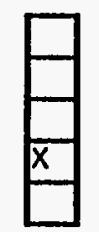




\section{WASTE STREAM PROFILE FOR THE WIPP TRU WASTE BASELINE INVENTORY REPORT}

IN-W181

$$
\begin{aligned}
\text { CONTAINER: } & \text { Orum } \\
\text { Type/Slze: } & \text { 55-gallon }
\end{aligned}
$$

Container Matl: steel

int. Vouctnr: $0.208 \mathrm{m3}$
Liner Type: Liner Material:
TYPICAL WASTE DENSITIES FOR FINAL WASTE FORM (kg/m3) STORED TRU WASTE ESTMMATED

\section{Material Parameters}

Iron-based Metals/Alloys

Aluminum-Based Metals/Alloys

Other Metals

Other Inorganic Materials

Cellulosics

Rubber

Plastics

Solidified, Inorganic matrix Solidified, Organic matrix

Solls

Packaging Materials, Steel Packaging Material, Plastic

\begin{tabular}{|r|} 
Average \\
\hline 0.0 \\
\hline 0.0 \\
\hline 0.0 \\
\hline 3.4 \\
\hline 34.0 \\
\hline 0.0 \\
\hline 0.0 \\
\hline 9.4 \\
\hline 772.0 \\
\hline 0.0 \\
\hline 131.0 \\
\hline 37.0 \\
\hline
\end{tabular}

\begin{tabular}{|c|c|c|c|}
\hline & Prolected & Final Fom & \\
\hline End of 1992: & 9.5 & 9.5 & m3 \\
\hline ind of 1993: & 9.5 & 9.5 & m3 \\
\hline 1984: & 0.0 & 0.0 & m3/yr \\
\hline 1998: & 0.0 & 0.0 & $\mathrm{~m} 3 / \mathrm{yr}$ \\
\hline 1996: & 0.0 & $\overline{0.0}$ & m3/yr \\
\hline 1987: & 0.0 & 0.0 & m3/ny \\
\hline 1888-2002: & 0.0 & 0.0 & m3lyr \\
\hline 2003-2022: & 0.0 & 0.0 & m3lyr \\
\hline
\end{tabular}
RATES OF WASTE GENERATION

MPICAL EPA CODES APPLICABLE

D002B
Number Stored: Number Projected:

IYPICAL ISOTOPIC COMPOSITION

Nuclide Activity

Pu52 2.50E+00 Curies $/ \mathrm{m} 3$

D006A

D007A

D008A

D009A

F001

$\mathrm{FOO2}$

F003

P015 
WASTE STREAM PROFILE FOR THE WIPP TRU WASTE BASELINE INVENTORY REPORT

SITE NAME IN

WASTE TYPE MTRU HANDLING CH

GENERATOR SITE RF

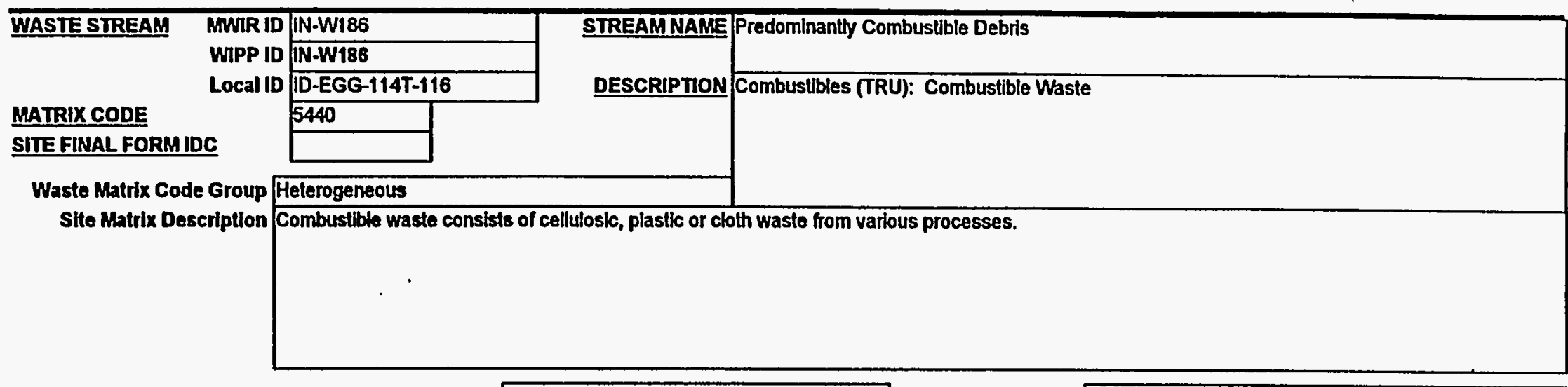

NO MGRATION VARIANCE PETIION ASSIGNMENTID 116

IRUCON CODE

FINAL WASTE FORM DESGRIPTORS:

\begin{tabular}{|c|c|}
\hline Defense TRU Wasto & Mbxed TRU \\
\hline Non-Defense TRU Waste & Non-Mbxed TRU \\
\hline Commercial TRU Waste & Suspect Mbxed TRU \\
\hline Unknown & Unknown \\
\hline
\end{tabular}

Unknown

Unknown

$\square$

TSCA Asbestos
PCBs
Other
N/A
Unknown




\section{WASTE STREAM PROFILE FOR THE WIPP TRU WASTE BASELINE INVENTORY REPORT}

SITENAME IN

WASTE TYPE MTRU HANDLING CH GENERATOR SITE RF

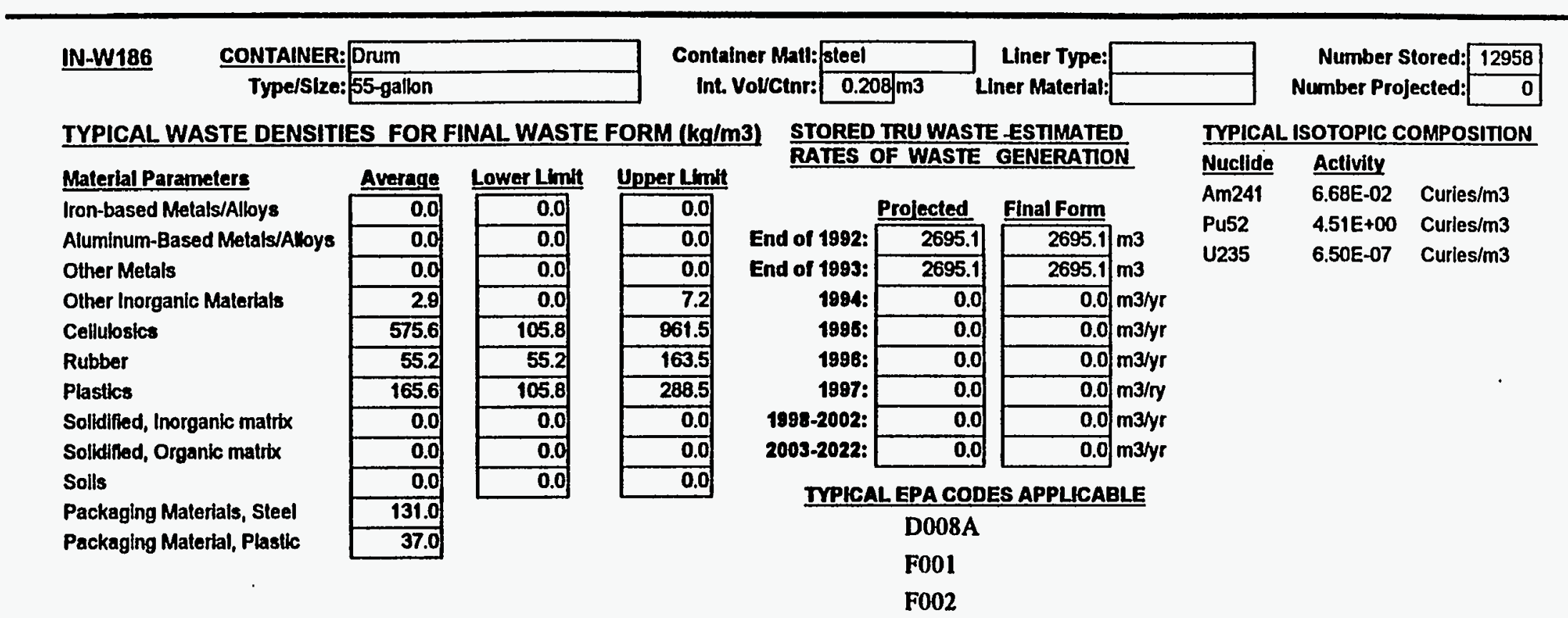




\section{WASTE STREAM PROFILE FOR THE WIPP TRU WASTE BASELINE INVENTORY REPORT}

\section{SITE NAME IN \\ WASTE TYPEMTRU HANDLING CH \\ GENERATOR SITE RF}

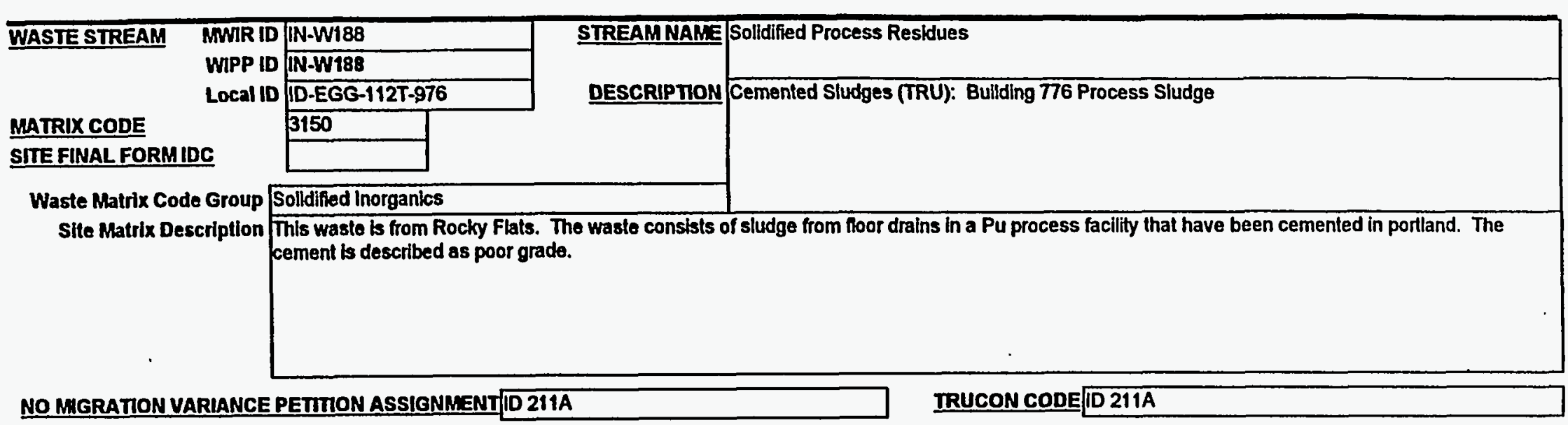

FINAL WASTE FORMDESCRIPTORS:

\begin{tabular}{l|l} 
Defense TRU Wasto \\
Non-Defense TRU Waste \\
Commercial TRU Waste \\
Unknown
\end{tabular}

Defense TRU Wasto

Unknown

$\square$

TSCA Asbestos
PCBs
Other
N/A
Unknown




\section{WASTE STREAM PROFILE FOR THE WIPP TRU WASTE BASELINE INVENTORY REPORT}

SITENAME IN

WASTE TYPE MTRU HANDLING CH GENERATOR SITE RF

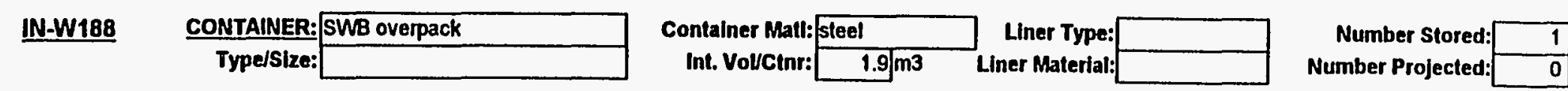

\section{TYPICAL WASTE DENSITIES FOR FINAL WASTE FORM (kg/m3) STORED TRU WASTE ESTMMATED}

\section{Material Parameters}

Iron-based Metals/Alloys

Aluminum-Based Metals/Alloys

Other Metals

Other Inorganic Materials

Cellutosics

Rubber

Plastics

Solldified, Inorganic matrix

Solidified, Organic matrix

Solls

Packaging Materials, Steel

Packaging Material, Plastic

\begin{tabular}{|c|c|}
\hline Averzge & ower LIm \\
\hline 0.0 & 0.0 \\
\hline 0.0 & 0.0 \\
\hline 0.0 & 0.0 \\
\hline 1.5 & 1.5 \\
\hline 15.2 & 0.0 \\
\hline 0.0 & 0.0 \\
\hline 0.0 & 0.0 \\
\hline 4.1 & 3.8 \\
\hline 338.0 & 235.0 \\
\hline 0.0 & 0.0 \\
\hline$\frac{210.0}{180}$ & \\
\hline
\end{tabular}

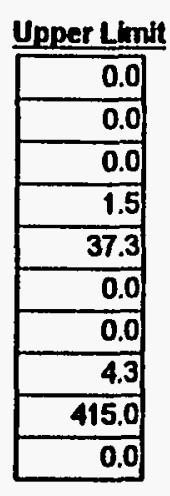

Comments

1 in number stored is the number of SWBs that will result from overpacking 4 cirums/swis. RATES OF WASTE GENERATION

IYPICAL ISOTOPIC COMPOSITION Nuclide Activity

Pu52 3.96E +00 Curies/m3

\begin{tabular}{|c|c|c|c|}
\hline \multirow{2}{*}{ End of 1992: } & Prolected & Final Form & \\
\hline & 0.3 & 1.9 & m3 \\
\hline End of 1993: & 0.3 & 1.9 & m3 \\
\hline 1994: & 0.0 & 0.0 & $\mathrm{~m} 3 / \mathrm{yr}$ \\
\hline 1995: & 0.0 & 0.0 & m3/yr \\
\hline 1998: & 0.0 & 0.0 & $\mathrm{~m} 3 / \mathrm{yr}$ \\
\hline 1997: & 0.0 & $\overline{0.0}$ & $\mathrm{~m} 3 / \mathrm{ry}$ \\
\hline 1998-2002: & 0.0 & 0.0 & m3/yr \\
\hline 2003-2022: & 0.0 & 0.0 & $\mathrm{~m} 3 / \mathrm{yr}$ \\
\hline
\end{tabular}

IYPICAL EPA CODES APPLICABLE

D002B

D006A

D007A

D008A

D009A

D022

D028

F001

F002

F003

P015 
WASTE STREAM PROFILE FOR THE WIPP TRU WASTE BASELINE INVENTORY REPORT

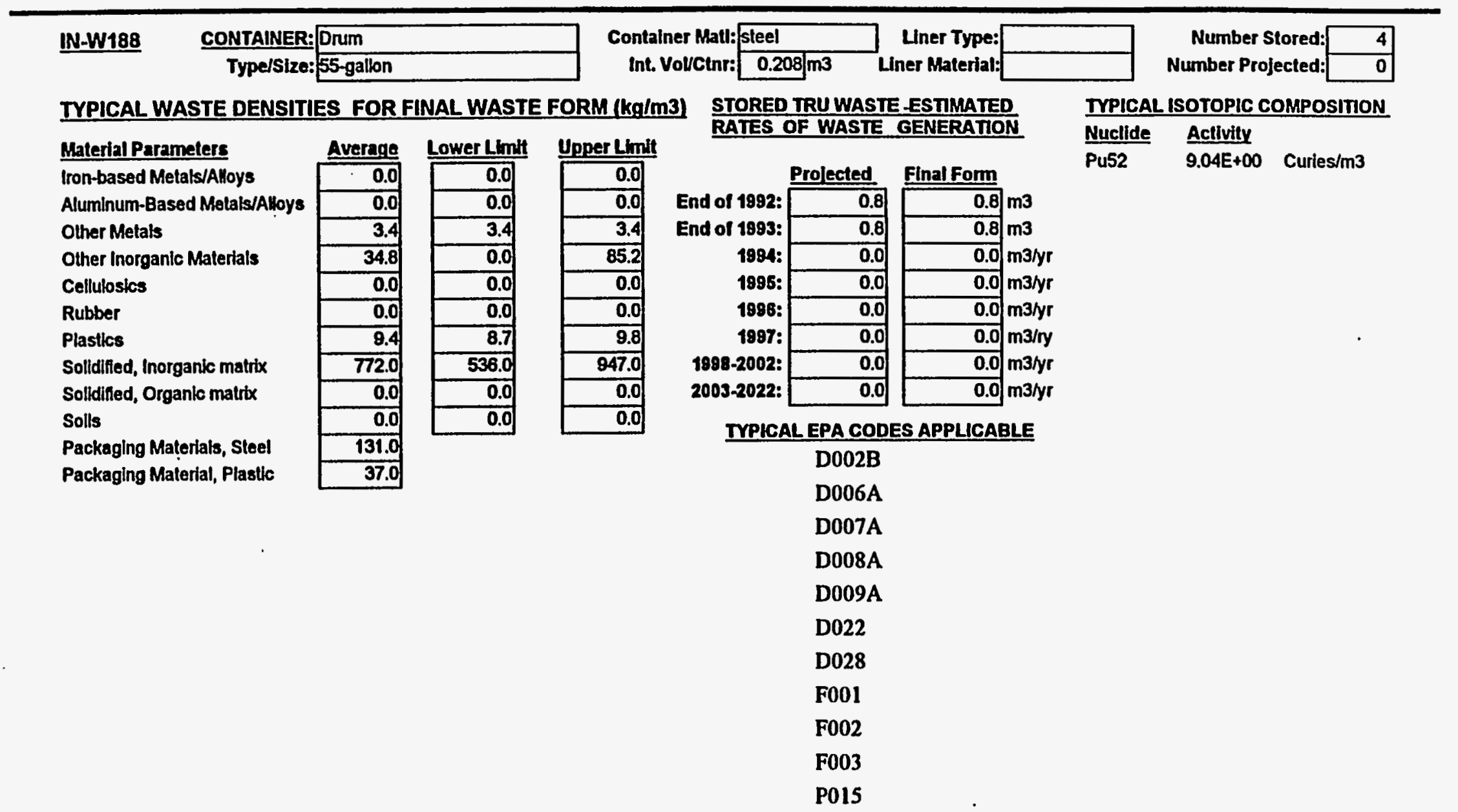




\section{WASTE STREAM PROFILE FOR THE WIPP TRU WASTE BASELINE INVENTORY REPORT}

SITENAME IN

WASTE TYPE MTRU HANDLING CH GENERATOR SITE RF

\begin{tabular}{|c|c|c|c|c|}
\hline \multirow{4}{*}{\multicolumn{2}{|c|}{$\begin{array}{cc}\text { WASTE STREAM } & \text { MWIR ID } \\
\text { WIPP ID } \\
\text { LOCal ID }\end{array}$}} & IN-W189 & \multirow{5}{*}{$\begin{array}{l}\text { STREAMNAME } \\
\text { DESCRIPTION }\end{array}$} & \multirow{2}{*}{ Predominantly Combustible Debris } \\
\hline & & IN-W189 & & \\
\hline & & ID-EGG-109T-464 & & \multirow[t]{3}{*}{ Benelex, Plexiglass (TRU): Benelex and Plexlglass } \\
\hline & & 5440 & & \\
\hline \multicolumn{2}{|c|}{ SITE FINAL FORMIDC } & & & \\
\hline \multirow{2}{*}{\multicolumn{2}{|c|}{$\begin{array}{l}\text { Waste Matrix Code Group } \\
\text { Site Matrix Description }\end{array}$}} & Heterogeneous & & \\
\hline & & \multicolumn{3}{|c|}{$\begin{array}{l}\text { This waste, generated at Rocky Flats Plant, contains malnly Benelex which is a dense, laminated, lignocellulose hardboard made from wood chips and } \\
\text { particles (masontte corp. type 402). The benelex is generally } 2 \text { inches thick. Some of the Benelex has lead shleiding attached to it. Melal hinges, and } \\
\text { angle iron strongbacks are also present. Plexiglass is the other major constifuent in the waste. The plexiglass thickness ranges from } 2 \text { to } 4 \text { inches. } \\
\text { Both the Benelex and the Plexiglass are combustible. }\end{array}$} \\
\hline
\end{tabular}

NO MGRATION VARIANCE PETIION ASSIGNMENTID $221 \mathrm{~A}$

IRUCON CODE ID 221A

\section{FINAL WASTE FORM DESCRIPTORS:}

\begin{tabular}{|c|c|}
\hline Defense TRU Waste & Mbxed TRU \\
\hline Non-Defense TRU Waste & Non-Mbxed TRU \\
\hline Commercial TRU Waste & Suspect Mbxed TRU \\
\hline Unknown & Unknown \\
\hline
\end{tabular}

Rsearch and Devel. Waste
Operations Waste
Residues
Decon and Decommissioning
Environmental Restoration
From Treatment of Wasto
Maintenance

\begin{tabular}{|l|l|l|}
\hline$X$ & TSCA & $\begin{array}{l}\text { Asbestos } \\
\text { PCBs } \\
\text { Other } \\
\text { N/A } \\
\text { Unknown }\end{array}$ \\
\hline$X$ & \\
\hline & & \\
\hline & & \\
\hline
\end{tabular}




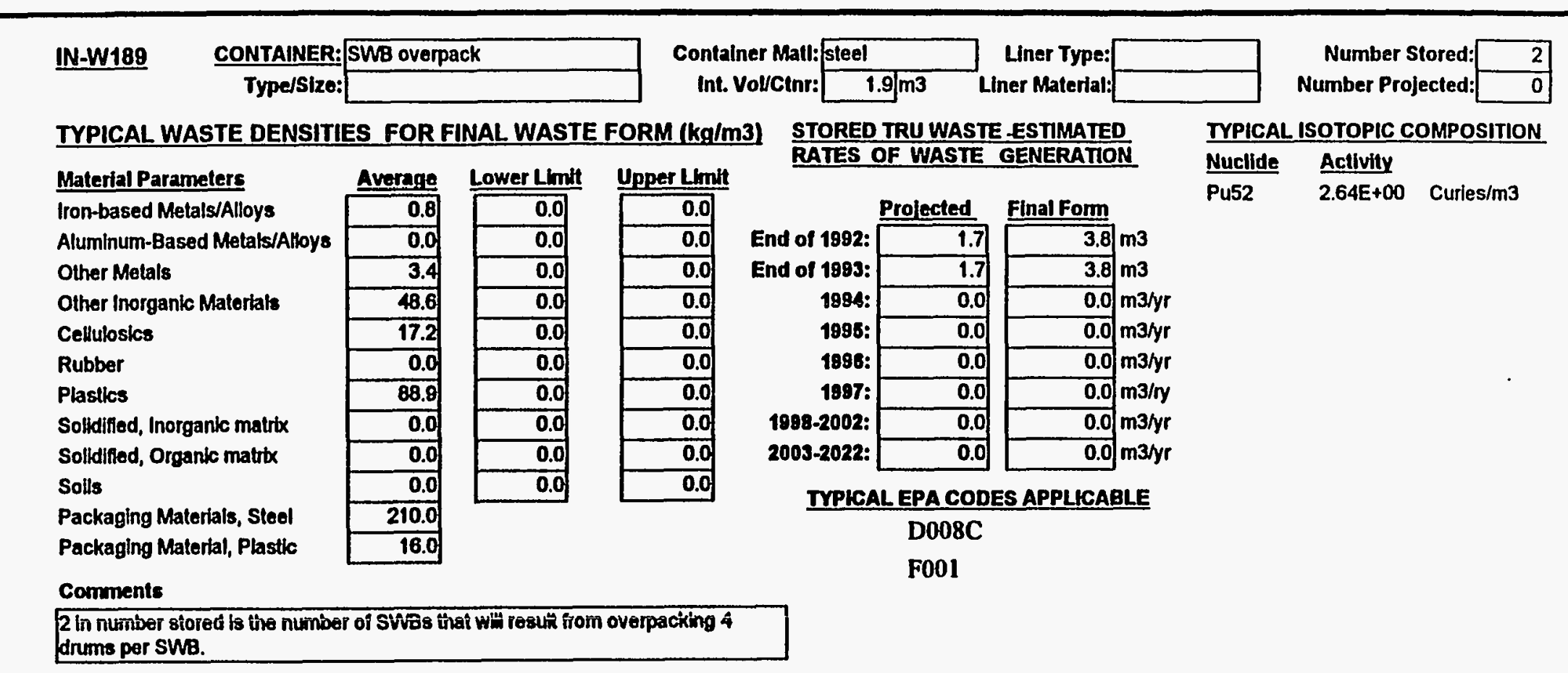


WASTE STREAM PROFILE FOR THE WIPP TRU WASTE BASELINE INVENTORY REPORT

SITE NAME IN WASTE TYPE MTRU HANDLING CH GENERATOR SITE RF

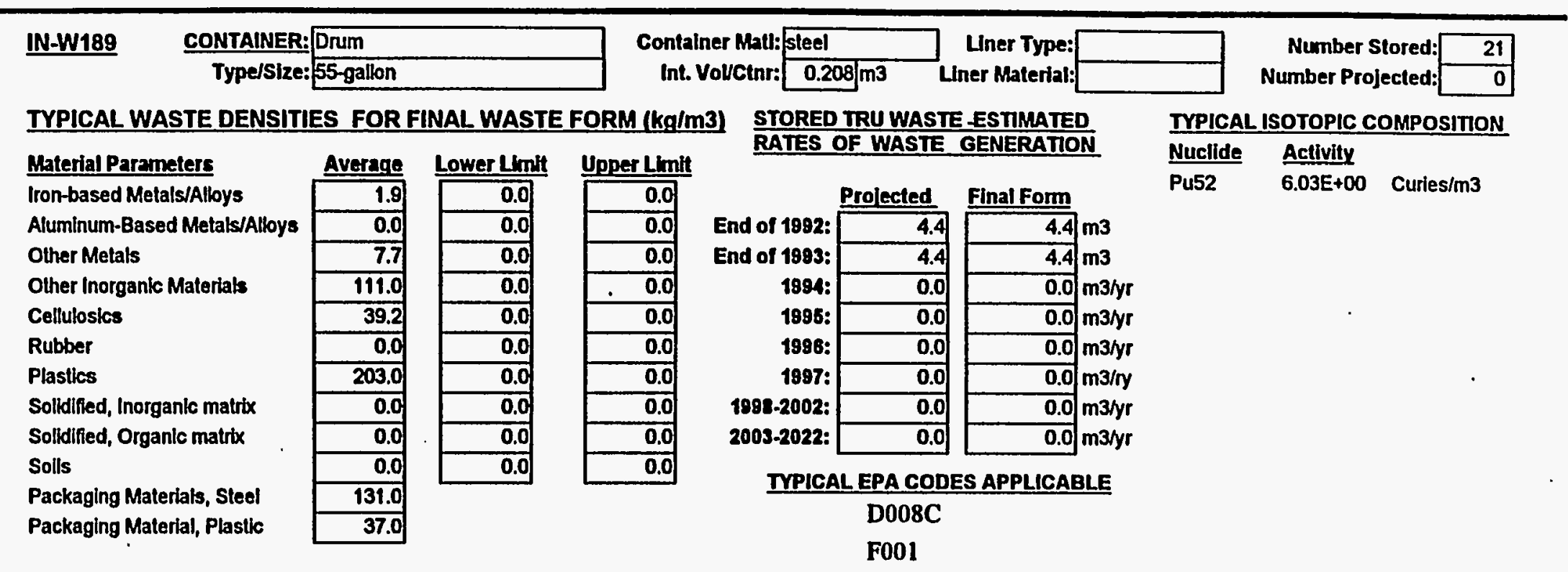


WASTE STREAM PROFILE FOR THE WIPP TRU WASTE BASELINE INVENTORY REPORT

SITE NAME IN WASTE TYPE MTRU HANDLING CH

GENERATOR SITE RF

$\begin{aligned} & \text { WASTE STREAM } \\ & \text { MWIR ID }\end{aligned}$ IN-W197
MATRIX CODE ID
SIIEFINAL FORMIDC
Waste Matrix Code Group
SHte Matrix Description

\section{FINAL WASTE FORM DESCRIPTORS:}

\begin{tabular}{|c|c|}
\hline Defense TRU Waste & Mbxed TRU \\
\hline Non-Defonse TRU Waste & Non-Mixed TRU \\
\hline Commerclal TRU Waste & Suspect Mixed TRU \\
\hline Unknown & Unknown \\
\hline
\end{tabular}

Rsearch and Devel. Waste
Operations Waste
Residues
Decon and Decommissioning
Environmental Restoration
From Treatment of Waste
Maintenance

$\frac{x}{x}$

TSCA Asbestos

PCBs

Other

N/A

Unknown

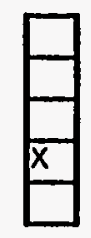




\section{WASTE STREAM PROFILE FOR THE WIPP TRU WASTE BASELINE INVENTORY REPORT}

SITE NAME IN WASTE TYPE MTRU HANDLING CH GENERATOR SITE RF

IN-W197

$$
\text { CONTAINER: SWB overpack }
$$

Container Mall: steel

Int. Vouctnr:

$\frac{\text { steel }}{1.9} \mathrm{~m}^{3}$

Lner Type:

Liner Material:

Number Stored

Number Projected:

TYPICAL WASTE DENSITIES FOR FINAL WASTE FORM $(\mathrm{kg} / \mathrm{m} 3)$

STORED TRU WASTE ESTIMATED

TYPICAL ISOTOPIC COMPOSITION

Material Parameters

Iron-based Metais/Alloys

Aluminum-Based Metals/Alloys

Other Metals

Other Inorganic Materials

Cellulosics

Rubber

Plastics

Solidined, Inorganic matrix

Solldified, Organic matrix

Solls

\begin{tabular}{|r|} 
Average \\
\hline 0.3 \\
\hline 0.0 \\
\hline 0.9 \\
\hline 8.0 \\
\hline 20.8 \\
\hline 4.0 \\
\hline 31.8 \\
\hline 0.0 \\
\hline 0.0 \\
\hline 0.0 \\
\hline 210.0 \\
\hline 16.0 \\
\hline
\end{tabular}

Lower Limit Upper Lmit RATES OF WASTE GENERATION

Packaging Materiałs, Steel

\begin{tabular}{|c|c|}
\hline ower Llontt & Upper Lmi \\
\hline 0.0 & 1.9 \\
\hline 0.0 & 0.0 \\
\hline 0.0 & 5.3 \\
\hline 0.0 & 30.5 \\
\hline 0.7 & 66.1 \\
\hline 0.0 & 26.1 \\
\hline 5.7 & 110.8 \\
\hline 0.0 & 0.0 \\
\hline 0.0 & 0.0 \\
\hline 0.0 & 0.0 \\
\hline
\end{tabular}

Packaging Materlal, Plastic

Comments

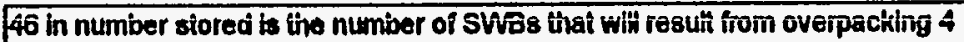

\begin{tabular}{|c|c|c|c|}
\hline & Prolected & Final Form & \\
\hline nd of 1992: & 38.3 & 87.2 & $\mathrm{~m} 3$ \\
\hline f 1893: & 38.3 & 87.2 & m3 \\
\hline 1894: & 0.0 & $\overline{0.0}$ & m3/yr \\
\hline 1995: & 0.0 & 0.0 & m3/yr \\
\hline 1886: & 0.0 & 0.0 & $\mathrm{~m}^{3} / \mathrm{yr}$ \\
\hline 1997: & 0.0 & 0.0 & $m 3 / r y$ \\
\hline $188-2002:$ & 0.0 & 0.0 & $\mathrm{~m} 3 / \mathrm{yr}$ \\
\hline 103-2022: & 0.0 & 0.0 & $m 3 / y r$ \\
\hline
\end{tabular}
drums/SWB.

Nuclide Activity

Am241 3.61E-01 Curies $/ \mathrm{m} 3$

Pu52 2.20E+00 Curies $/ \mathrm{m}^{3}$

U235 4.26E-07 Curies $/ \mathrm{m} 3$

TYPHCAL EPA CODES APPLICABLE

D001C

D002B

D008A

D008C

D022

F001

F002

F003

F005A 


\section{WASTE STREAM PROFILE FOR THE WIPP TRU WASTE BASELINE INVENTORY REPORT}

SITE NANE IN

\section{WASTE TYPE MTRU HANDLING CH GENERATOR SITE RF}

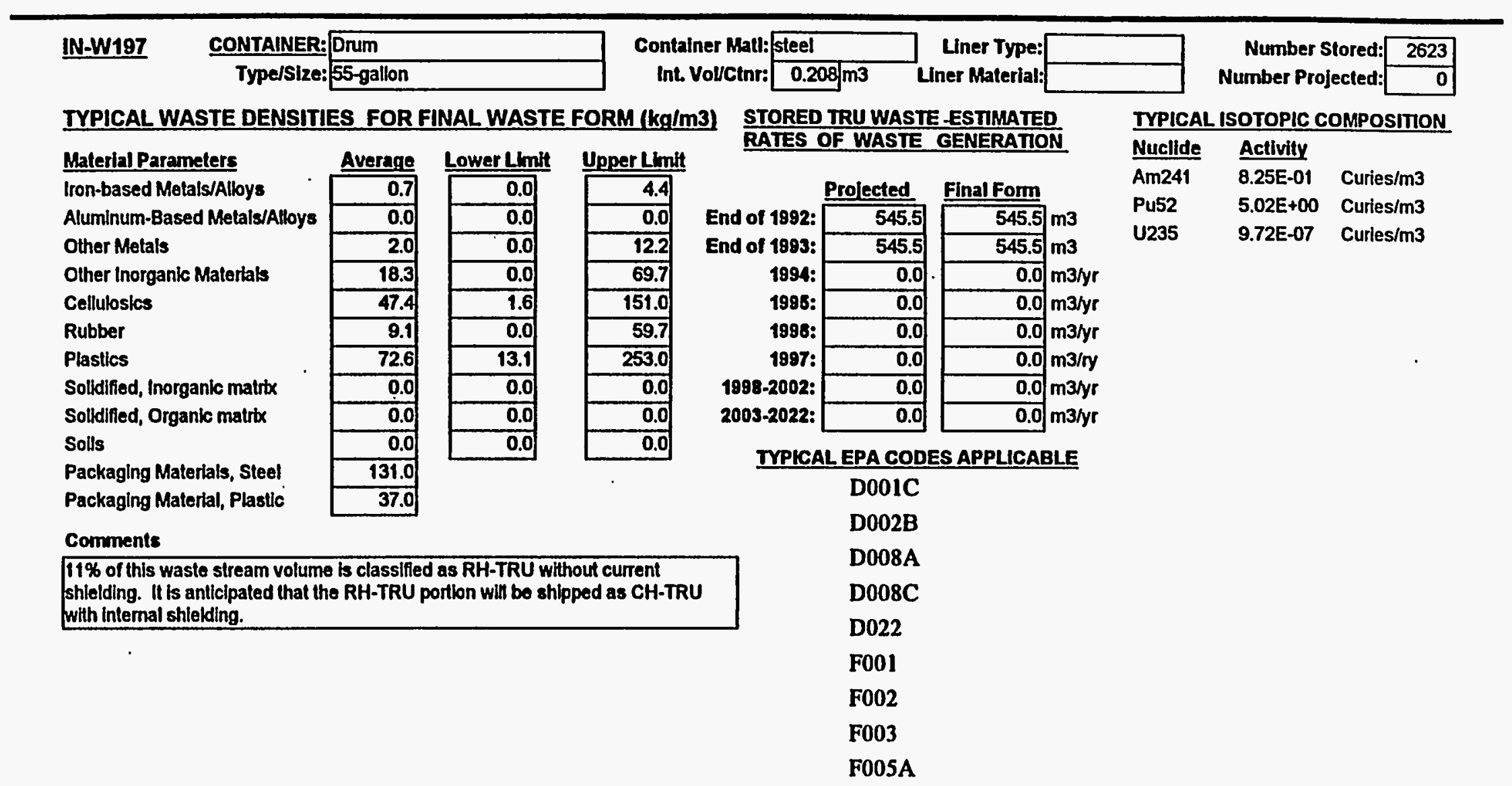


WASTE STREAM PROFILE FOR THE WIPP TRU WASTE BASELINE INVENTORY REPORT

SITE NAME IN WASTE TYPE MTRU HANDLING CH

GENERATOR SITE RF

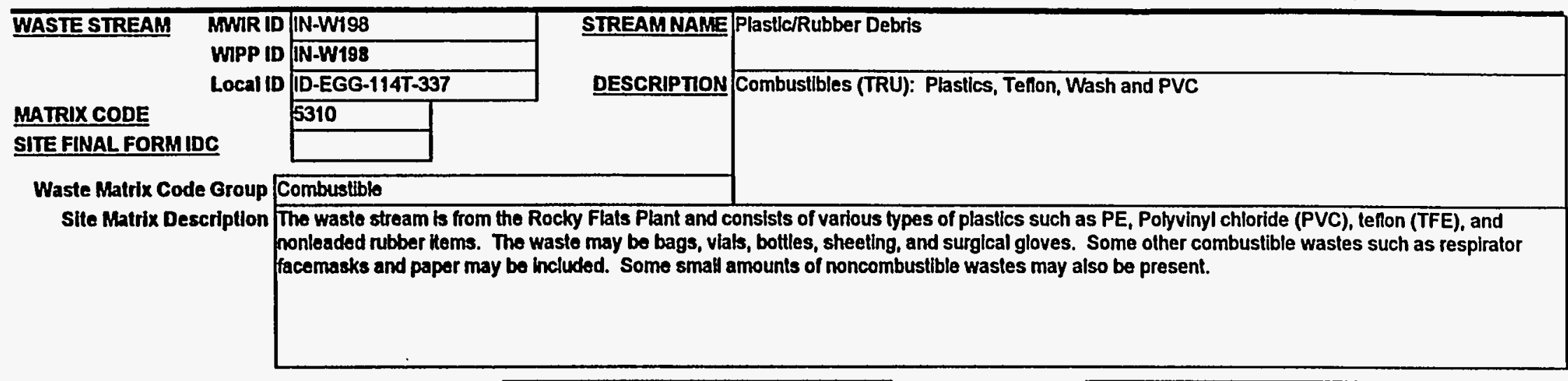

NO MGRATION VARLANCE PETIION ASSIGNMENTID 116;216C

IRUCON CODE ID 216C

\section{FINAL WASTE FORM DESCRIPTORS:}

\begin{tabular}{l|l} 
Defense TRU Waste & $X$ \\
Non-Defense TRU Waste \\
Commerclal TRU Waste \\
Unknown
\end{tabular}

目

Rsearch and Devel. Waste

Operattons Waste

Residues

Decon and Decommissioning

Environmental Restoration

From Treatment of Wasto

Maintenance

\begin{tabular}{|l|l|l|}
\hline$X$ & TSCA Asbestos \\
& PCBs \\
& Other \\
& N/A \\
Unknown & \\
\hline$X$ & & \\
\hline & & \\
\hline
\end{tabular}




\section{WASTE STREAM PROFILE FOR THE WIPP TRU WASTE BASELINE INVENTORY REPORT}

SITE NAME IN WASTE TYPE MTRU HANDLING CH GENERATOR SITE RF

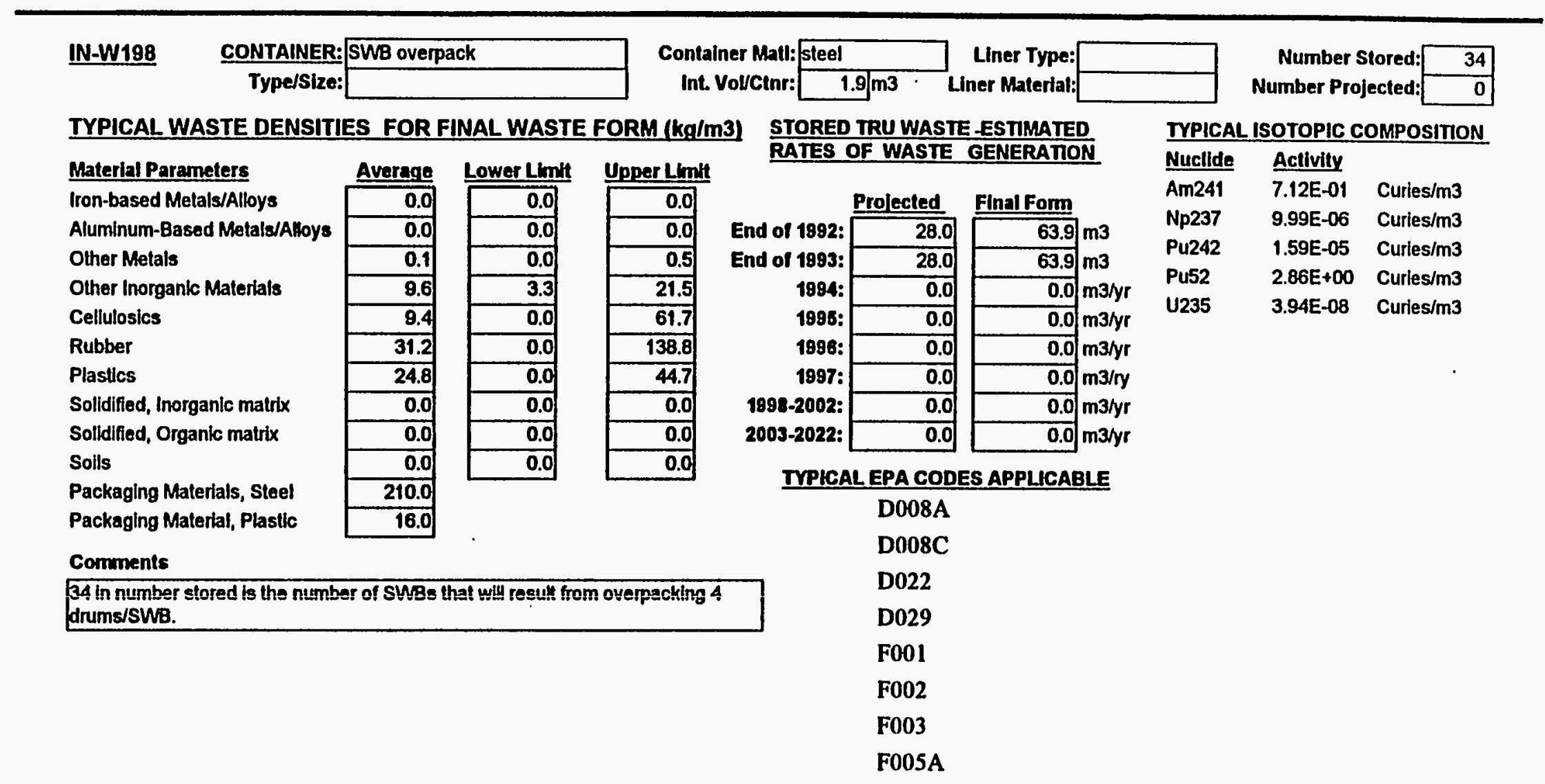




\section{WASTE STREAM PROFILE FOR THE WIPP TRU WASTE BASELINE INVENTORY REPORT}

STTE NAME IN WASTE TYPE MTRU HANDLING CH GENERATOR SITE RF

IN-W198 $\quad \frac{\text { CONTAINER: Drum }}{\text { Type/Size: } 55 \text {-gallon }}$

Container Matl: steel

Int. Voluctur: $0.208 / \mathrm{m}^{3}$

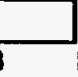

Liner Type:

-

TYPICAL WASTE DENSITIES FOR FINAL WASTE FORM $(\mathrm{kg} / \mathrm{m} 3)$ STORED TRU WASTE ESTMMATED

Material Parameters

Iron-based Metals/Alloys

Aluminum-Based Metals/Alloys

Other Metals

Other Inorganic Materials

Cellutosics

Rubber

Plastics

Solldified, Inorganlc matrix

Solidified, Organic matrix

Solis

Packaging Materials, Steel

Packaging Material, Plastic
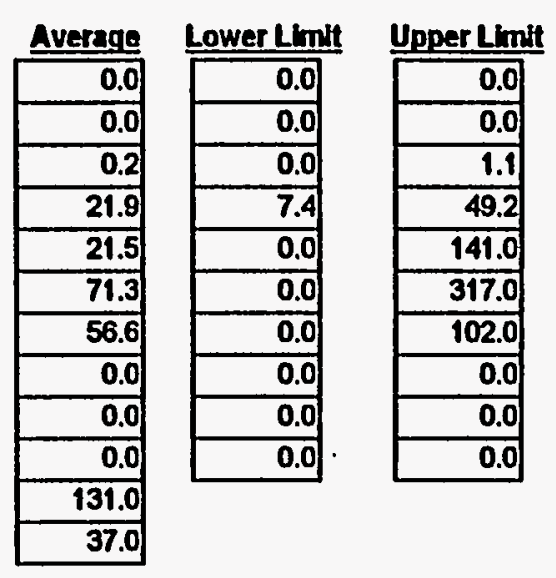

RATES OF WASTE GENERATION

\section{Comments}

13\% of this wasle stream volume is classified as RH-TRU without current

shielding. It is anticipated that the RH-TRU portion will be shipped as CH-TRU

with Internal shlelding.
Number Stored:

Number Projected:

480
0

IYPICAL ISOTOPIC COMPOSITION

Nuclide Activity

Am241 1.63E+00 Curies $/ \mathrm{m3}$

Np237 2.28E-05 Curies/m3

Pu242 3.63E-05 Curies $/ \mathrm{m} 3$

Pu52 6.52E+00 Curies $/ \mathrm{m} 3$

U235 8.99E-08 Curies/m3 


\section{WASTE STREAM PROFILE FOR THE WIPP TRU WASTE BASELINE INVENTORY REPORT}

SITE NAME IN

\section{WASTE TYPE MTRU HANDLING CH GENERATOR SITE RF}

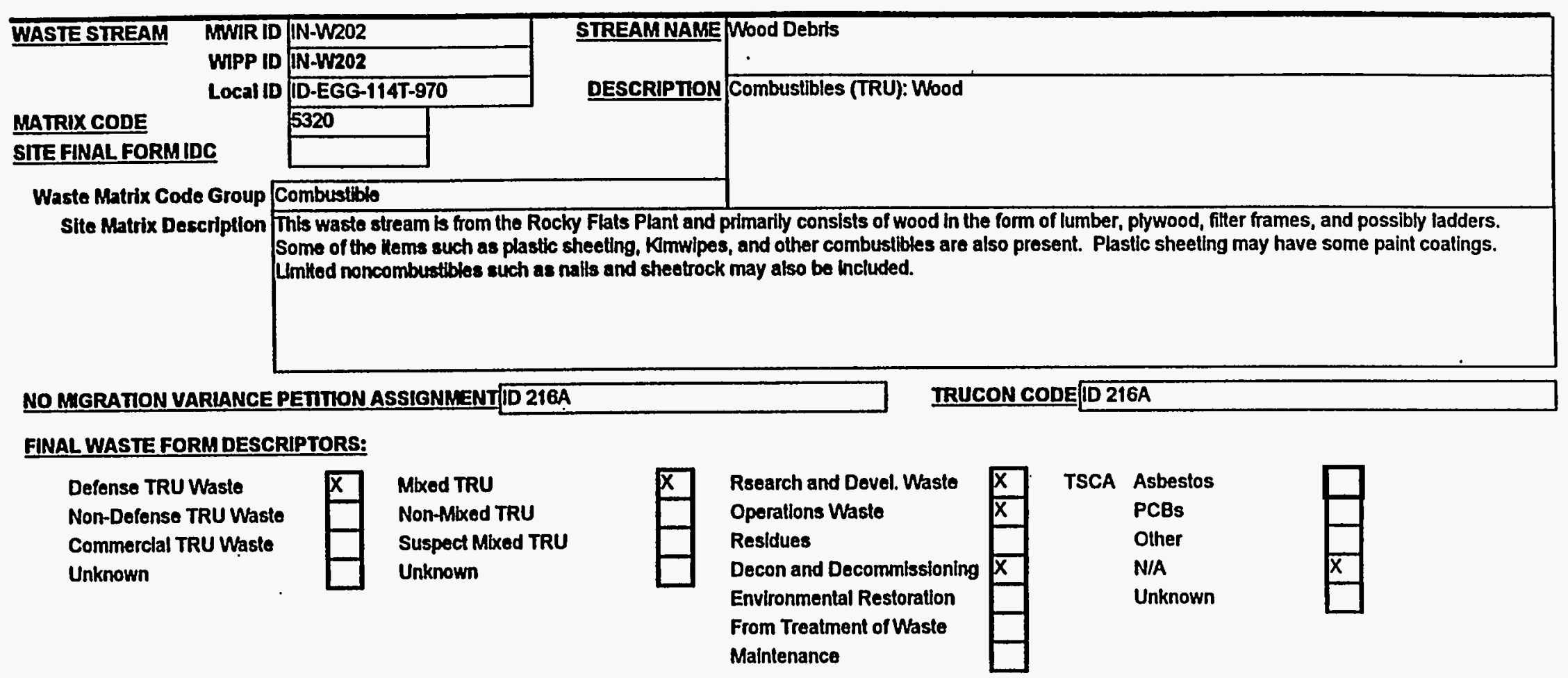




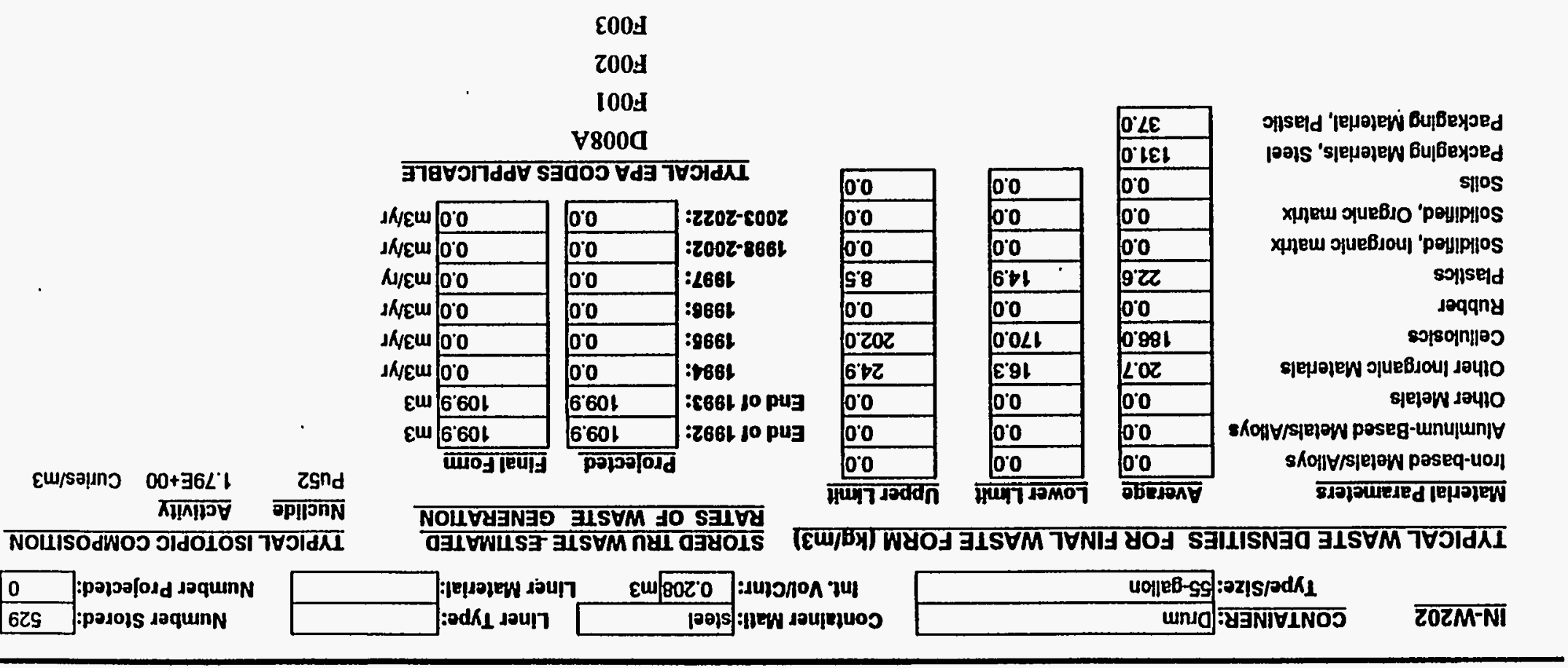




\section{WASTE STREAM PROFILE FOR THE WIPP TRU WASTE BASELINE INVENTORY REPORT}

SITE NAME IN

WASTE TYPEMTRU HANDLING CH GENERATOR SITE MD

$\begin{aligned} & \text { WASTE STREAM } \\ & \text { MWIR ID }\end{aligned}$ IN-W203
MATRIX CODE
SITE FINAL FORM IDC
Wocal ID
Waste Matrix Code Group
Site Matrix Description

\section{FINAL WASTE FORM DESCRIPTORS:}

Defense TRU Wasto

Non-Defense TRU Wasto

Commerclal TRU Waste

Unknown

Mbed TRU

Non-Mbxed TRU

Suspect Mbxed TRU

Unknown

$\square$

Rsearch and Devel. Waste

Operations Waste

Residues

Decon and Decommisstoning $X$

Environmental Restoration

From Trealment of Waste

Maintenance
TSCA Asbestos

PCBs

Other

N/A

Unknown

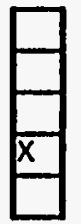




\section{WASTE STREAM PROFILE FOR THE WIPP TRU WASTE BASELINE INVENTORY REPORT}

SITE NAME IN

WASTE TYPE MTRU HANDLING CH GENERATOR SITE MD

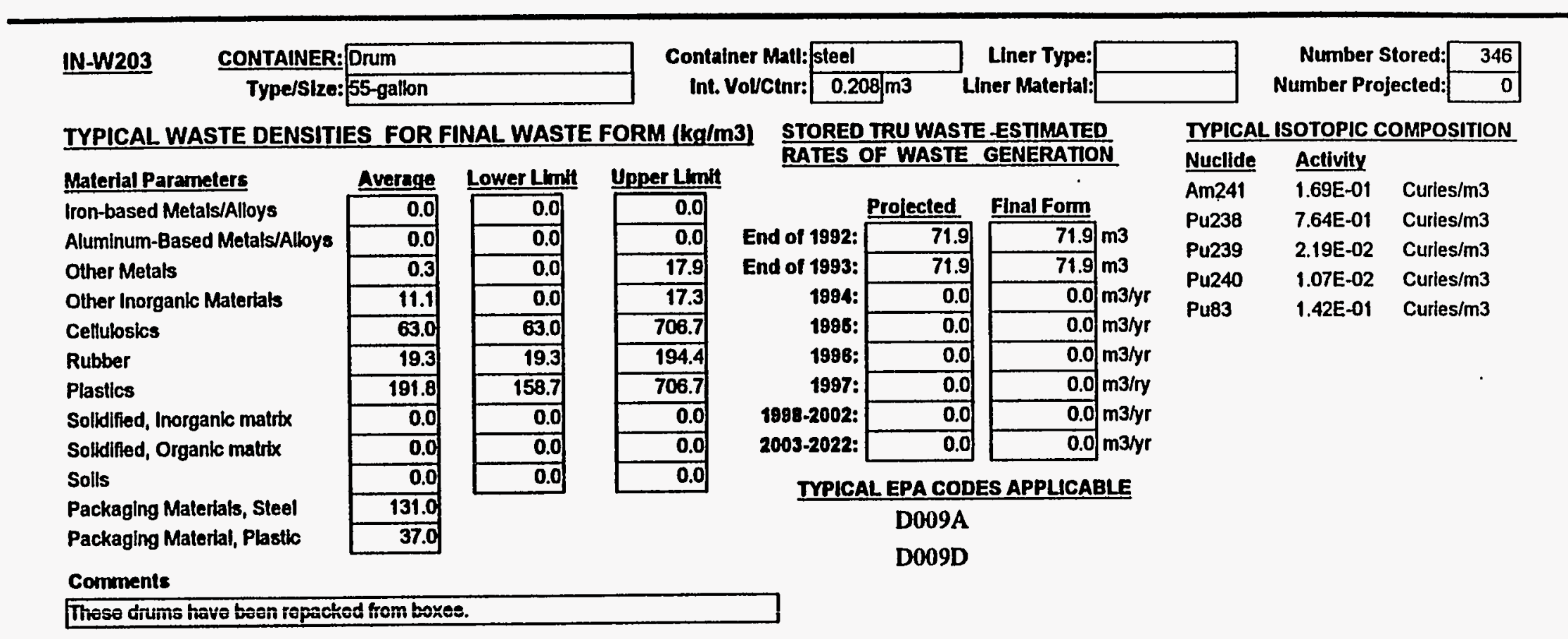




\section{WASTE STREAM PROFILE FOR THE WIPP TRU WASTE BASELINE INVENTORY REPORT}

SITENAME IN

WASTE TYPE MTRU HANDLNG CH GENERATOR SITE MD

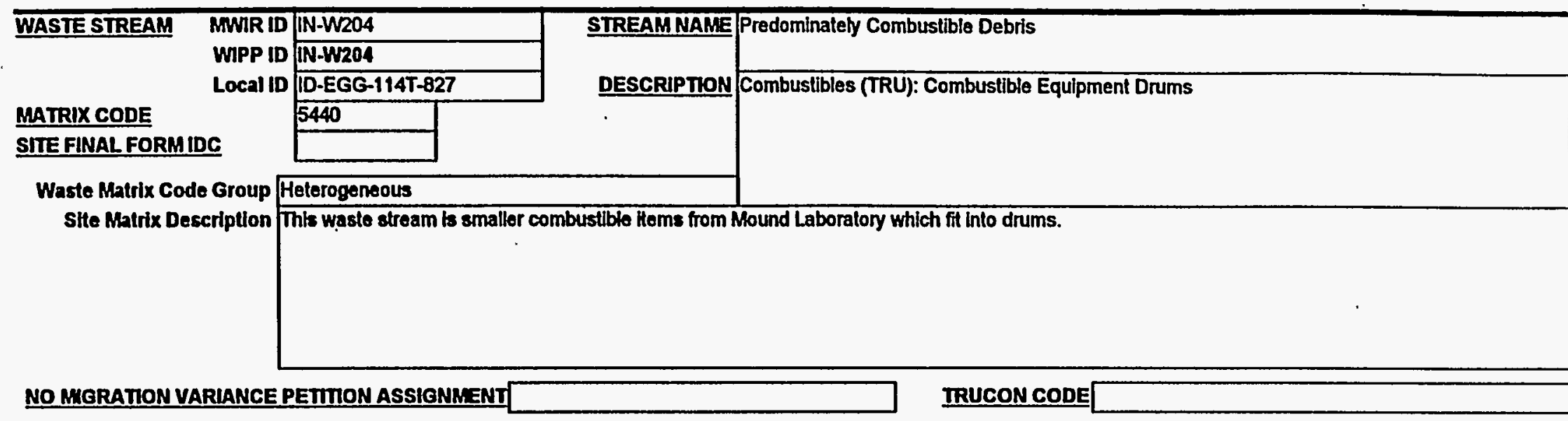

FINAL WASTE FORMDESCRIPTORS:

\begin{tabular}{l|l} 
Dofense TRU Waste \\
Non-Defense TRU Waste \\
Commercial TRU Waste \\
Unknown
\end{tabular}

Unknown

Unknown $\square$
TSCA Asbeslos

PCBs

Other

N/A

Unknown

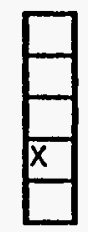

From Treatment of Wast

Maintenance

\begin{tabular}{|l|}
\hline$x$ \\
\hline$x$ \\
\hline$x$ \\
\hline \\
\hline \\
\hline
\end{tabular}




\section{WASTE STREAM PROFILE FOR THE WIPP TRU WASTE BASELINE INVENTORY REPORT}

SITE NAME IN WASTE TYPE MTRU HANDLING CH GENERATOR SITE MD

IN-W204 CONTAINER: Drum

TYPICAL WASTE DENSITIES FOR FINAL WASTE FORM (kg/m3)

Material Parameters Iron-based Melals/Alloys

Aluminum-Based Metals/Alloys

Other Metals

Other Inorganic Materials

Cellulostcs

Rubber

Plastics

Solidified, Inorganic matrix

Soltdified, Organic matrix

Solls

Packaging Malerials, Steel

Packaging Material, Plastic

Comments

1 in number stored is the number of SWBs that will result from overpacking 4 drums/SWB.
201.0

16.0

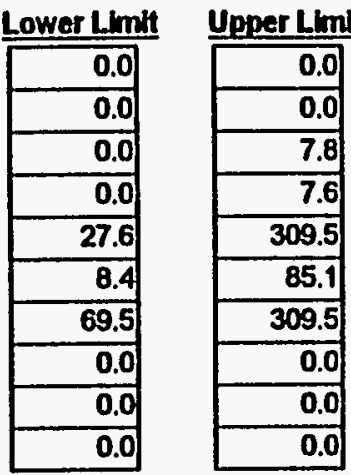

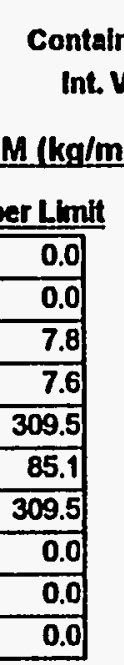
2003-2022:

\section{TYPICAL EPA CODES APPUCABLE}

D008A

D009A

D009D

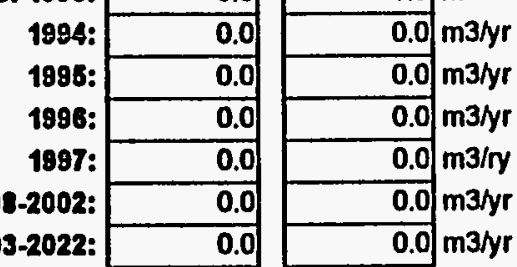

Number Stored: Number Projected:

TYPICAL ISOTOPIC COMPOSITION

Nuclide Activity

Am241 3.36E+00 Curies $/ \mathrm{m} 3$

Pu52 6.89E-02 Curles $/ \mathrm{m}^{3}$

Pu83 4.18E+00 Curles $/ \mathrm{m3}$

\begin{tabular}{|c|c|c|c|c|c|}
\hline ind & $\frac{\text { Propecied }}{0.5}$ & $\frac{\text { Final rom }}{1.9}$ & $m 3$ & $\begin{array}{l}\text { Pu52 } \\
\text { Pu83 }\end{array}$ & $\begin{array}{l}6.89 E-02 \\
4.18 E+00\end{array}$ \\
\hline
\end{tabular}

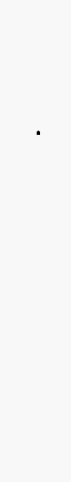


WASTE STREAM PROFILE FOR THE WIPP TRU WASTE BASELINE INVENTORY REPORT

SITE NAME IN

WASTE TYPE MTRU HANDLING CH GENERATOR SITE MD

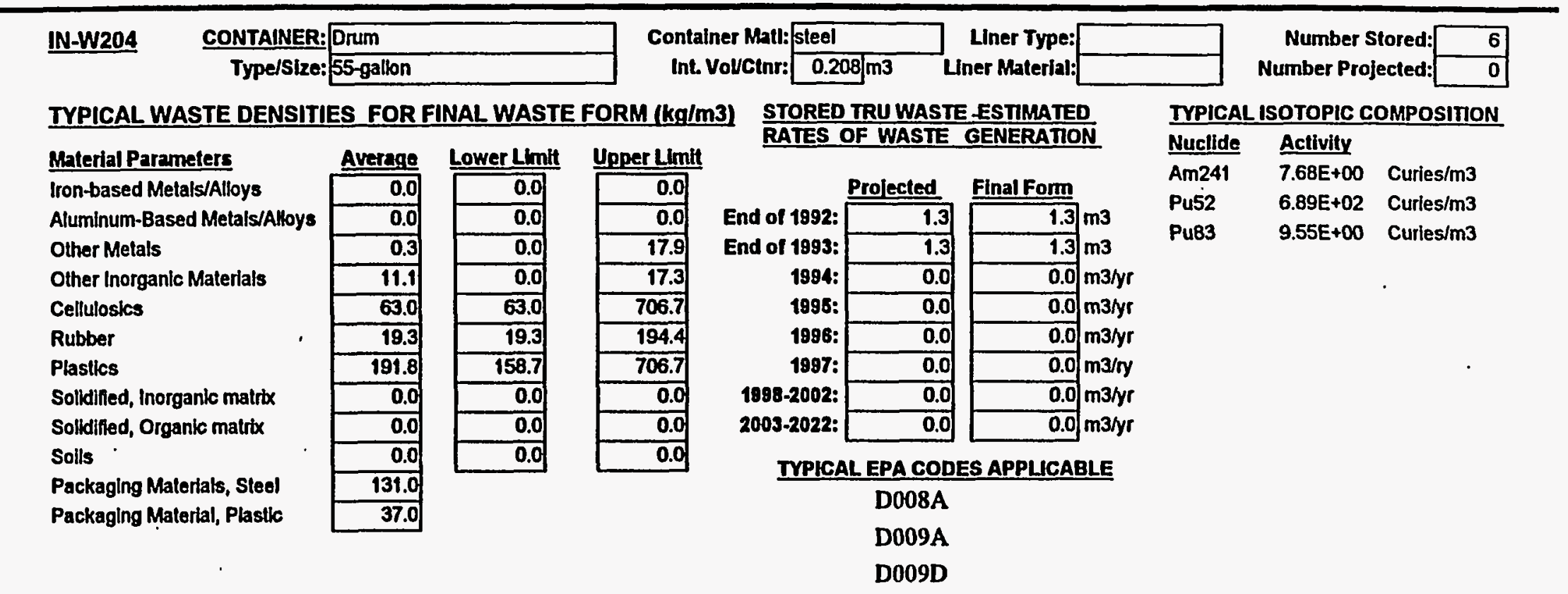


WASTE STREAM PROFILE FOR THE WIPP TRU WASTE BASELINE INVENTORY REPORT

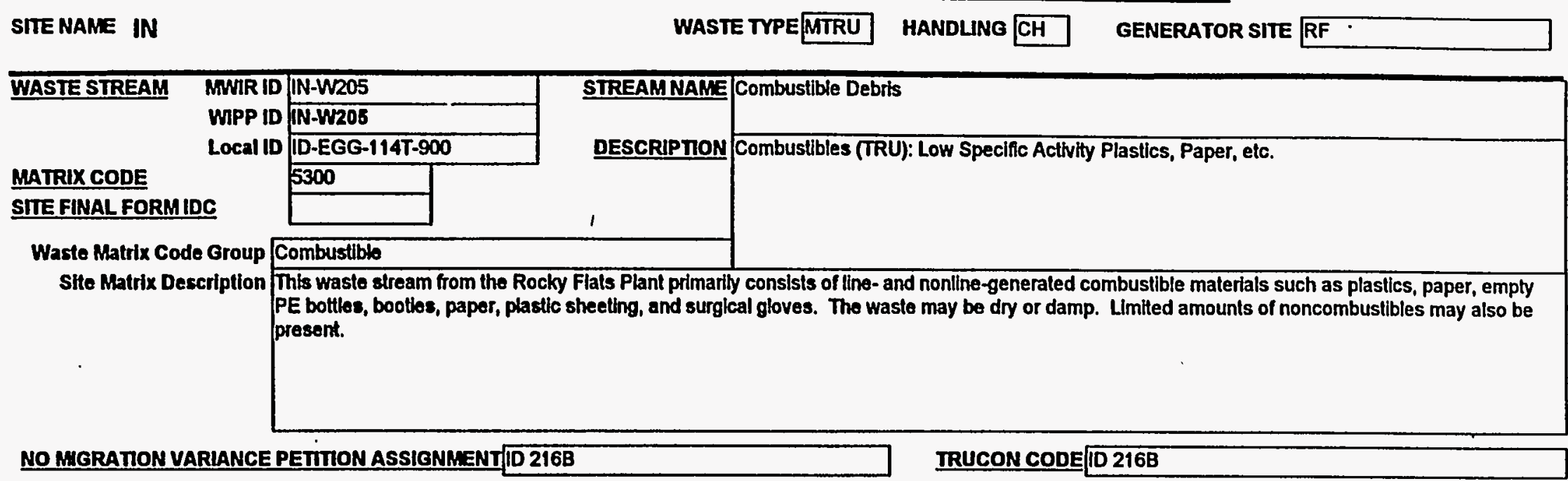

\section{FINAL WASTE FORM DESCRIPTORS:}

\begin{tabular}{l|l|l} 
Defense TRU Waste \\
Non-Defense TRU Waste \\
Commerclal TRU Waste \\
Unknown
\end{tabular}$\quad \square \quad \begin{aligned} & \text { Mixed TRU } \\
& \text { Non-Mixed TRU } \\
& \text { Suspect Mixed TRU } \\
& \text { Unknown }\end{aligned}$

Unknown
Unknown

$\square$

\begin{tabular}{|l|}
\hline$x$ \\
\hline$x$ \\
\hline$x$ \\
\hline \\
\hline \\
\hline
\end{tabular}
TSCA Asbestos
PCBs
Other
N/A
Unknown

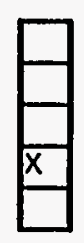


SITE NAME IN

WASTE TYPE MTRU HANDLING CH GENERATOR SITE RF

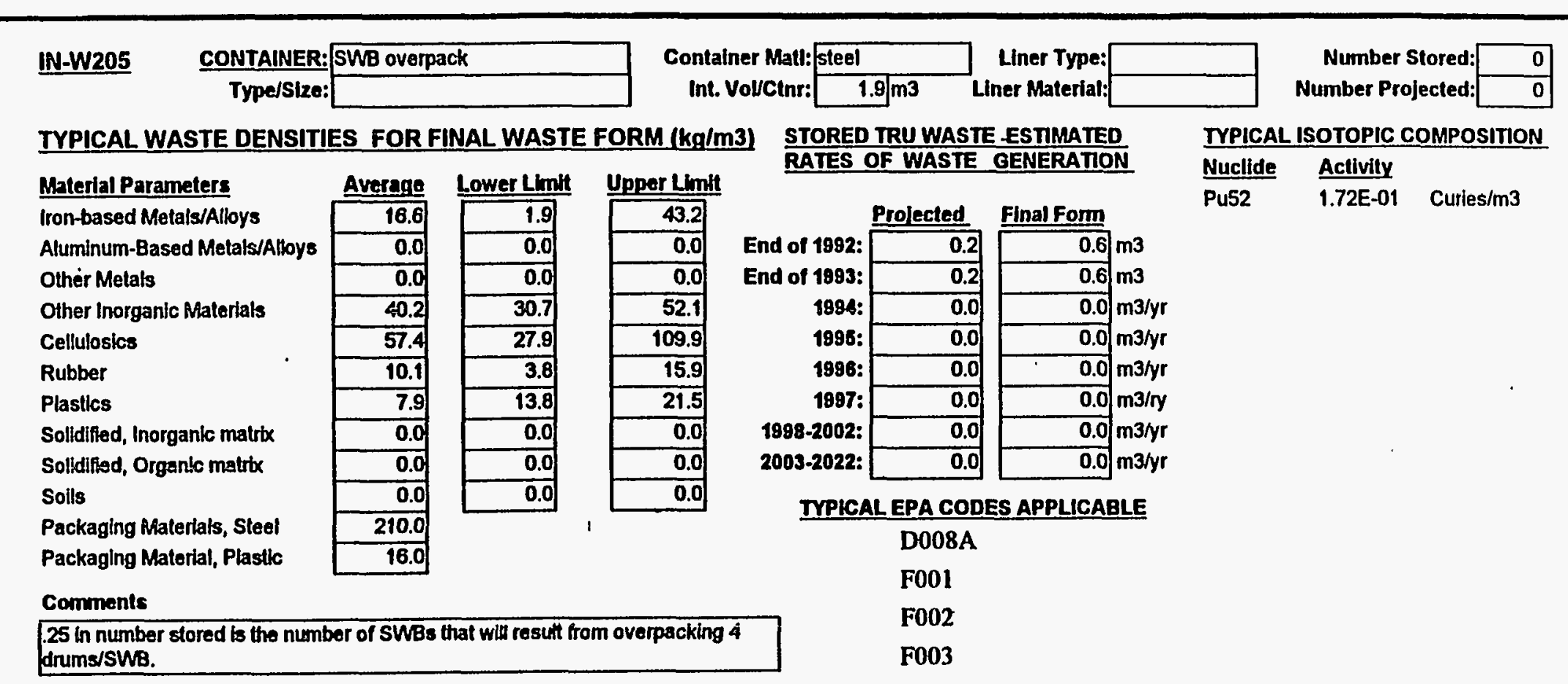




\section{WASTE STREAM PROFILE FOR THE WIPP TRU WASTE BASELINE INVENTORY REPORT}

SITE NAME IN

WASTE TYPE MTRU HANDLING CH GENERATOR SITE RF

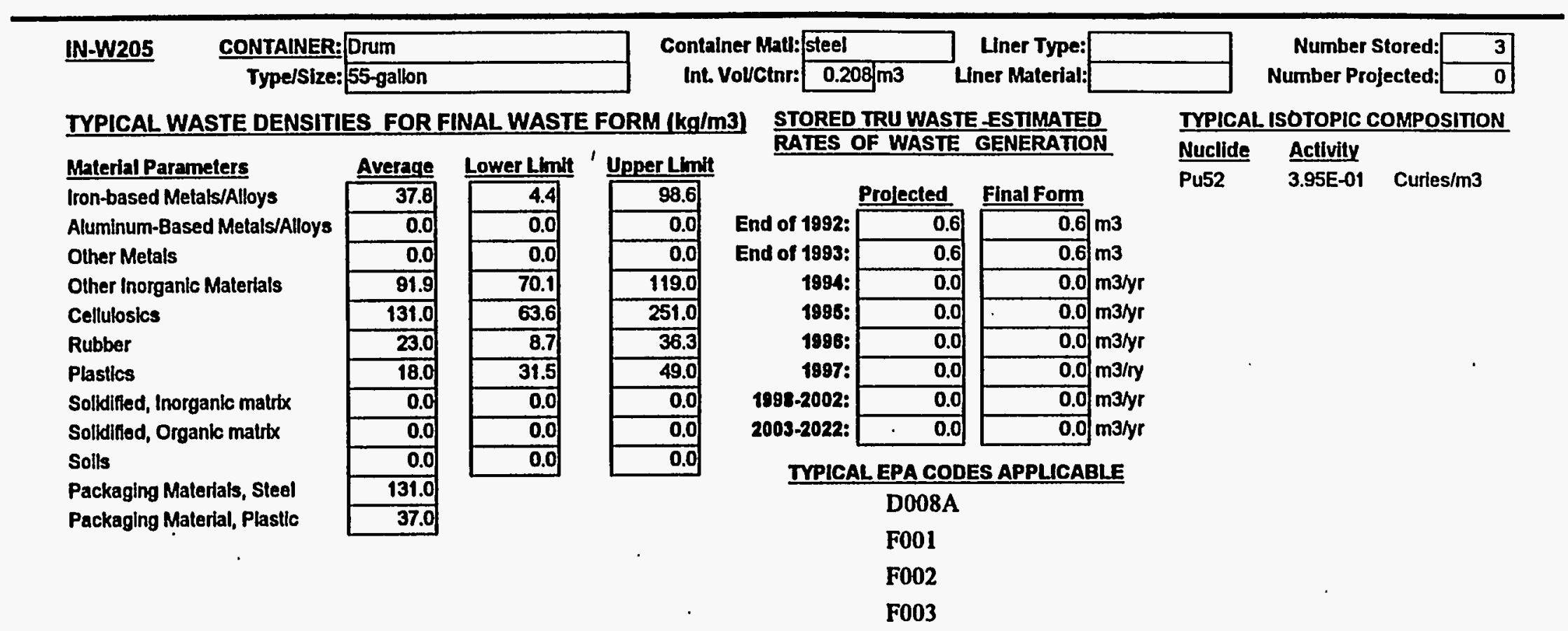


WASTE STREAM PROFILE FOR THE WIPP TRU WASTE BASELINE INVENTORY REPORT

SITENAME IN

WASTE TYPE MTRU HANDLING CH GENERATOR SITE MD

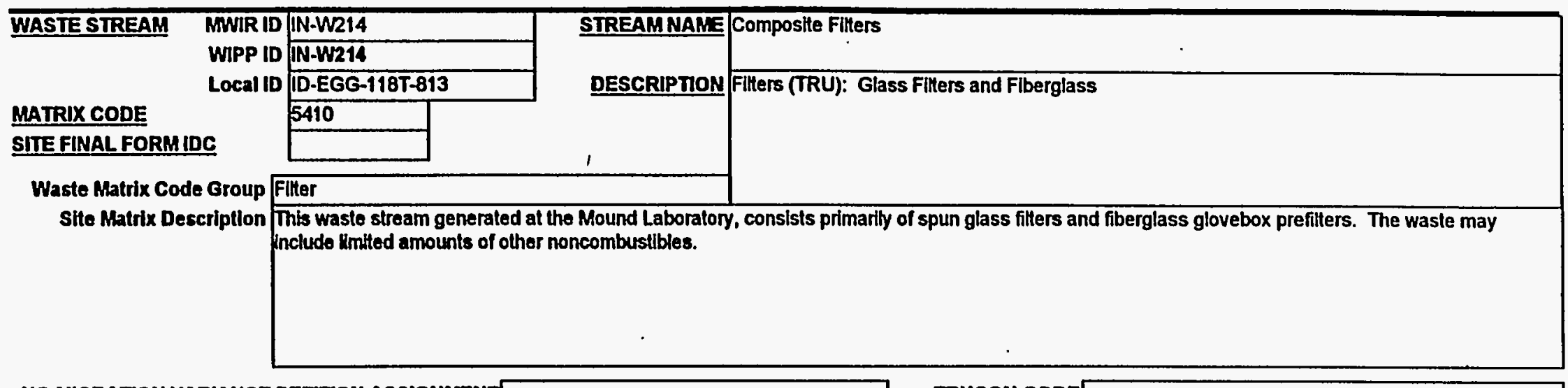

NO MGRATION VARIANCE PETITION ASSIONMENT IRUCON CODE

FINAL WASTE FORM DESCRIPTORS:

Defense TRU Waste

Non-Defense TRU Wasto

Commerclal TRU Wasto

Unknown

\begin{tabular}{|l|}
\hline \\
\hline \\
\hline
\end{tabular}

Mbxed TRU

Non-Mbxed TRU

Suspect Mixed TRU

Unknown

$\square$

\begin{tabular}{|l|}
\hline$x$ \\
\hline$x$ \\
\hline$x$ \\
\hline \\
\hline \\
\hline
\end{tabular}

TSCA Asbestos

PCBs

Other

N/A

Unknown

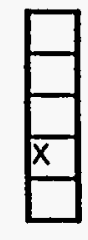

From Treatment of Whste

Malntenance 
WASTE STREAM PROFILE FOR THE WIPP TRU WASTE BASELINE INVENTORY REPORT

IN-W214 CONTAINER: SWB overpack

TYPICAL WASTE DENSITIES

Material Parameters

Iron-based Metals/Alloys

Aluminum-Based Melals/Altoys

Other Metals

Other Inorganlc Materials

Cellulosics

Rubber

Plastics

Solkdified, Inorganic matrix

Solidified, Organic matrbx

Soils

Packaging Materials, Steel

Packaging Material, Plastic

\begin{tabular}{|r|}
\hline Average \\
\hline 0.0 \\
\hline 0.0 \\
\hline 0.0 \\
\hline 85.3 \\
\hline 2.1 \\
\hline 0.0 \\
\hline 0.0 \\
\hline 0.0 \\
\hline 0.0 \\
\hline 0.0 \\
\hline 210.0 \\
\hline 16.0 \\
\hline
\end{tabular}

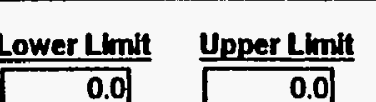

Container Matt: Steel

int. Volvcenr:

$1.9 \mathrm{m3}$

Liner Type:

Liner Materiat:

$\square$

Number Stored

Number Projected

IYPICAL ISOTOPIC COMPOSITION STORED TRU WASTE ESTIMATED

Nuclide Activity

$\begin{array}{lll}\text { Pu238 } & 3.36 E+02 & \text { Curies } / \mathrm{m}^{3} \\ \text { Pu239 } & 2.99 E+00 & \text { Curies } / \mathrm{m3}\end{array}$

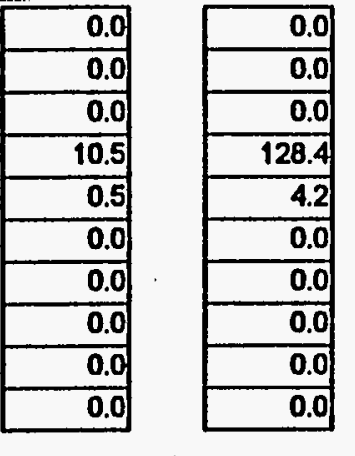

1

\begin{tabular}{|c|c|c|c|}
\hline & Prolected & Final Form & \\
\hline End of 1982: & 0.2 & 0.4 & $\mathrm{m3}$ \\
\hline ind of 1993: & 0.2 & 0.4 & $\mathrm{m3}$ \\
\hline 1894: & 0.0 & 0.0 & $\mathrm{~m} 3 / \mathrm{y}$ \\
\hline 1995: & 0.0 & 0.0 & $\mathrm{~m} 3 / \mathrm{yr}$ \\
\hline 1996: & $\overline{0.0}$ & 0.0 & $\mathrm{~m} 3 / \mathrm{yr}$ \\
\hline 1897: & 0.0 & 0.0 & $\mathrm{~m} 3 / \mathrm{ry}$ \\
\hline 1988-2002: & 0.0 & 0.0 & $\mathrm{~m} 3 / \mathrm{y}$ \\
\hline 2003-2022: & 0.0 & 0.0 & $\mathrm{~m} 3 / \mathrm{y}$ \\
\hline
\end{tabular}

TYPICAL EPA CODES APPLICABLE

D001C

D002B

D009A

D009D

\section{Comments}

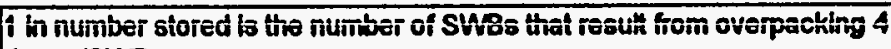

drums/SWB. 


\section{WASTE STREAM PROFILE FOR THE WIPP TRU WASTE BASELINE INVENTORY REPORT}

GENERATOR SITE MD

\begin{tabular}{|c|c|c|c|c|c|c|c|c|c|c|c|}
\hline IN-W214 $\frac{\text { CONTAINER: }}{\text { Type/Size: }}$ & \begin{tabular}{|l|} 
Drum \\
55 -gallon \\
\end{tabular} & & $\begin{array}{l}\text { Contal } \\
\text { Int. }\end{array}$ & Container Matt: steel & $8 \sqrt{m 3}$ & $\begin{array}{l}\text { Liner Type: } \\
\text { Iner Material: }\end{array}$ & & & \multicolumn{2}{|c|}{$\begin{array}{l}\text { Number Stored: } \\
\text { Number Projected: }\end{array}$} & 3 \\
\hline \multicolumn{4}{|c|}{ TYPICAL WASTE DENSITIES FOR FINAL WASTE FORM (kg/m3) } & \multirow{2}{*}{\multicolumn{4}{|c|}{$\begin{array}{l}\text { STORED TRU WASTE ESTIMATED } \\
\text { RATES OF WASTE GENERATION }\end{array}$}} & \multicolumn{4}{|c|}{ IYPICAL ISOTOPIC COMPOSITION } \\
\hline Material Parameters & Average & Lower Limit & I Upper Limit & & & & & Nuclide & \multirow{3}{*}{$\begin{array}{l}\text { Activity } \\
7.66 E+02 \\
6.83 E+00\end{array}$} & \multirow{3}{*}{\multicolumn{2}{|c|}{$\begin{array}{l}\text { Curies } / \mathrm{m3} \\
\text { Curies/m3 }\end{array}$}} \\
\hline Iron-based Metals/Alloys & 0.0 & 0.0 & 0.0 & \multirow[b]{2}{*}{ End of 1992: } & Projected & \multicolumn{2}{|l|}{ Final Form } & Pu238 & & & \\
\hline Aluminum-Based Melals/Alloys & 0.0 & 0.0 & 0.0 & & 0.5 & $0.5 \mathrm{n}$ & m3 & Pu239 & & & \\
\hline Other Metals & 0.0 & 0.0 & 0.0 & End of 1993: & 0.5 & $0.5 \mathrm{n}$ & m3 & & & & \\
\hline Other Inorganic Materials & 194.7 & 24.0 & 293.3 & 1994: & 0.0 & 0.0 & $\mathrm{~m} 3 / \mathrm{yr}$ & & & & \\
\hline Cellulosics & 4.8 & 1.2 & 9.6 & 1985: & 0.0 & $0.0 \mathrm{n}$ & $\mathrm{m} 3 / \mathrm{yr}$ & & & & \\
\hline Rubber & 0.0 & 0.0 & 0.0 & 1998: & 0.0 & $0.0 \mathrm{n}$ & $m 3 / y r$ & & & & \\
\hline Plastics & 0.0 & 0.0 & 0.0 & 1997: & 0.0 & $0.0 \mathrm{n}$ & $\mathrm{m} 3 / \mathrm{ry}$ & & & & \\
\hline Solldified, Inorganic matrtx & 0.0 & 0.0 & 0.0 & 1998-2002: & 0.0 & $0.0 \mathrm{n}$ & $\mathrm{m} 3 / \mathrm{yr}$ & & & & \\
\hline Solldified, Organic matrix & 0.0 & 0.0 & 0.0 & 2003-2022: & 0.0 & 0.0. & m3/yr & & & & \\
\hline Solls & 0.0 & 0.0 & 0.0 & TYPICA & LE EPA COD & ES APPLICAB & LLE & & & & \\
\hline Packaging Materials, Steel & 131.0 & & & & $\mathrm{Dn01C}$ & & & & & & \\
\hline Packaging Material, Plastic & 37.0 & & & & & & & & & & \\
\hline & & & & & D002B & & & & & & \\
\hline & & & & & D009A & & & & & & \\
\hline . & & & & & D009D & & & & & & \\
\hline
\end{tabular}




\section{WASTE STREAM PROFILE FOR THE WIPP TRU WASTE BASELINE INVENTORY REPORT}

\section{SITE NAME IN WASTE TYPEMTRU HANDLING CH GENERATOR SITE RF}

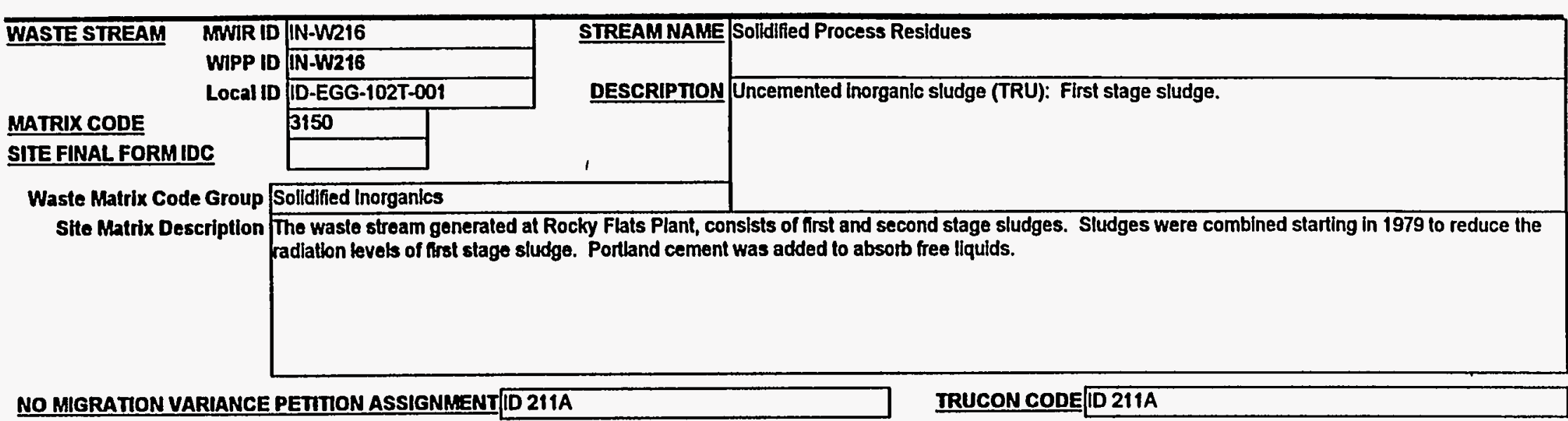

\section{FINAL WASTE FORM DESCRIPTORS:}

\begin{tabular}{l|l|l} 
Defense TRU Waste & $X$ & $\begin{array}{l}\text { Mixed TRU } \\
\text { Non-Mixed TRU } \\
\text { Non-Defense TRU Waste } \\
\text { Commerclal TRU Waste } \\
\text { Unknown }\end{array}$ \\
\hline
\end{tabular}

Unknown

$x$
$x$
$\square$
$\square$
$\square$

\section{TSCA Asbestos \\ PCBs \\ Other \\ N/A \\ Unknown}

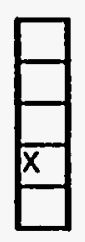




\section{WASTE STREAM PROFILE FOR THE WIPP TRU WASTE BASELINE INVENTORY REPORT}

SITE NAME IN WASTE TYPE MTRU HANDLING CH GENERATOR SITE RF

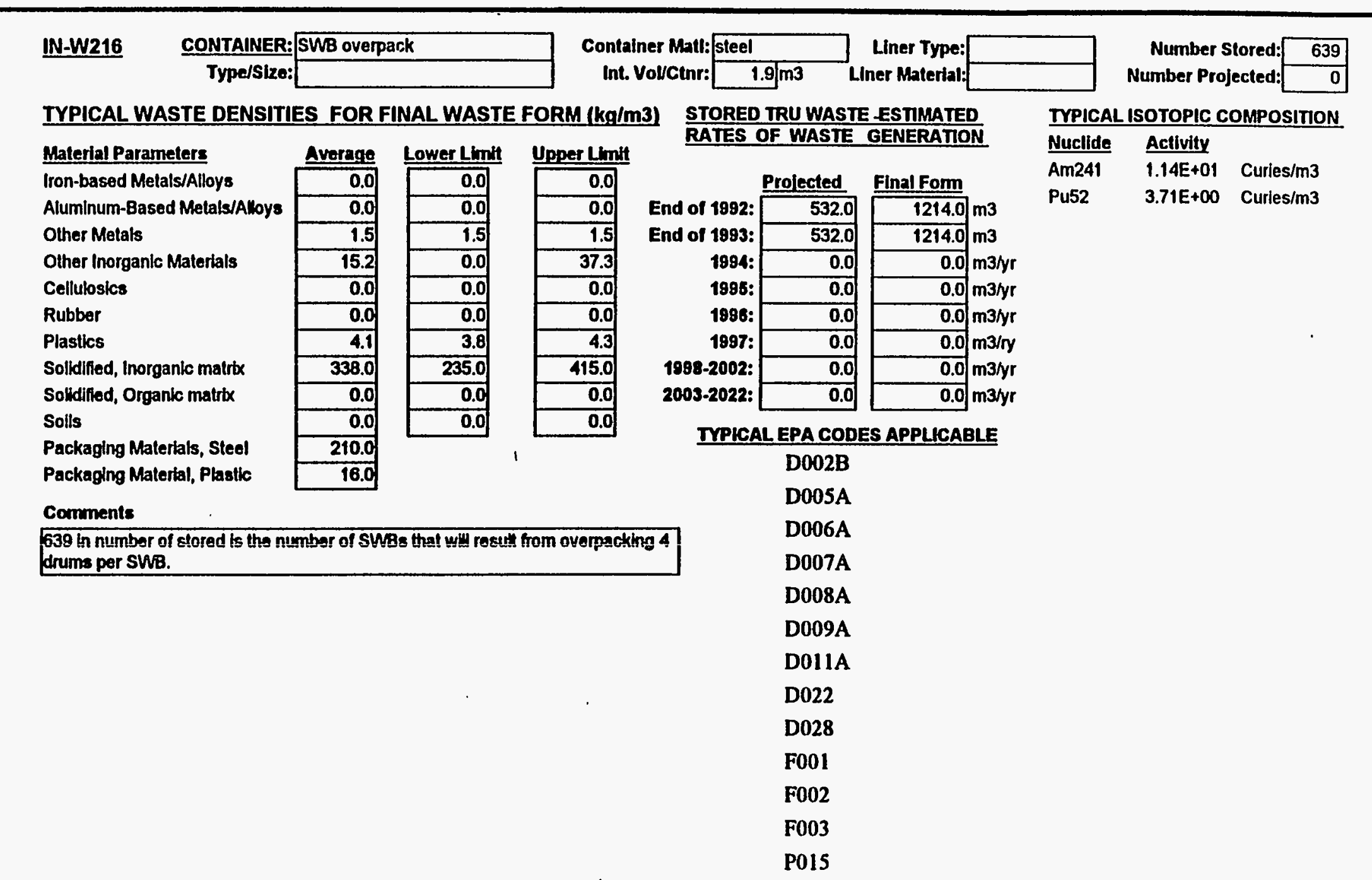




\section{WASTE STREAM PROFILE FOR THE WIPP TRU WASTE BASELINE INVENTORY REPORT}

SITE NAME IN WASTE TYPE MTRU HANDLING CH GENERATOR SITE RF

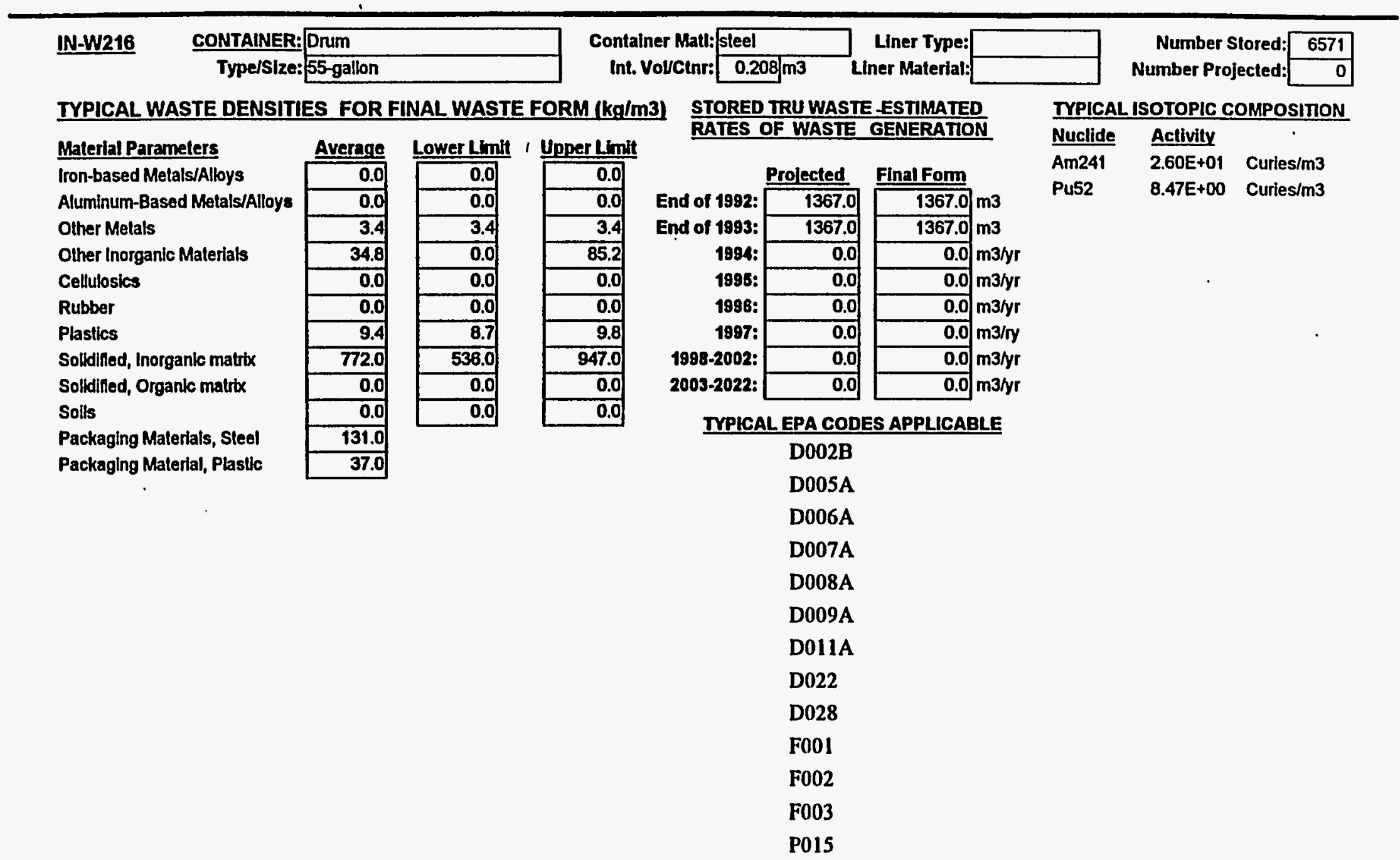


WASTE STREAM PROFILE FOR THE WIPP TRU WASTE BASELINE INVENTORY REPORT

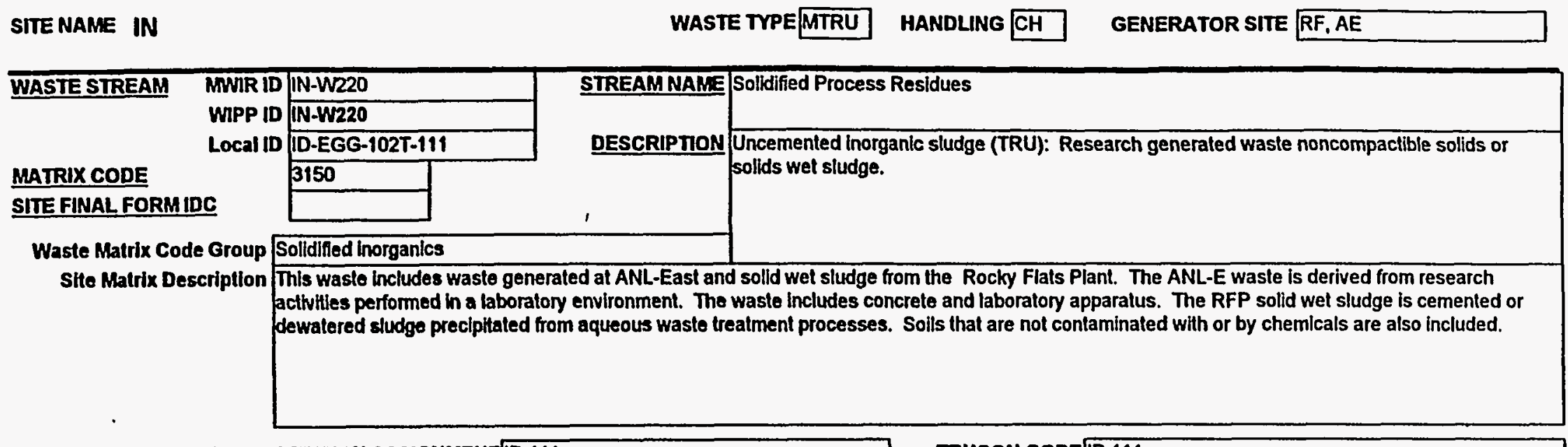

\section{NO MGGATION VARIANCE PETIION ASSIGNMENTID 111}

TRUCON CODE ID 111

\section{FINAL WASTE FORM DESCRIPTORS:}

\section{Defense TRU Waste \\ Non-Defense TRU Waste \\ Commerclal TRU Waste \\ Unknown

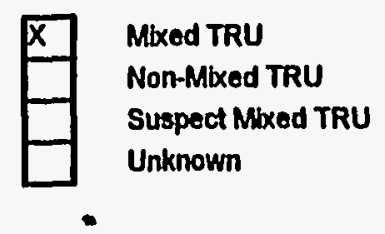

Footnotes

ID 111 only applies to the RF waste.
Rsearch and Devel. Wasle

Operatlons Wasto

Residues

Decon and Decommissioning

Environmental Restoration

From Treatment of Waste

Mainlenance
TSCA Asbeslos

PCBs

Other

N/A

Unknown

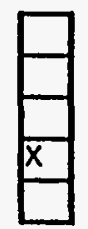




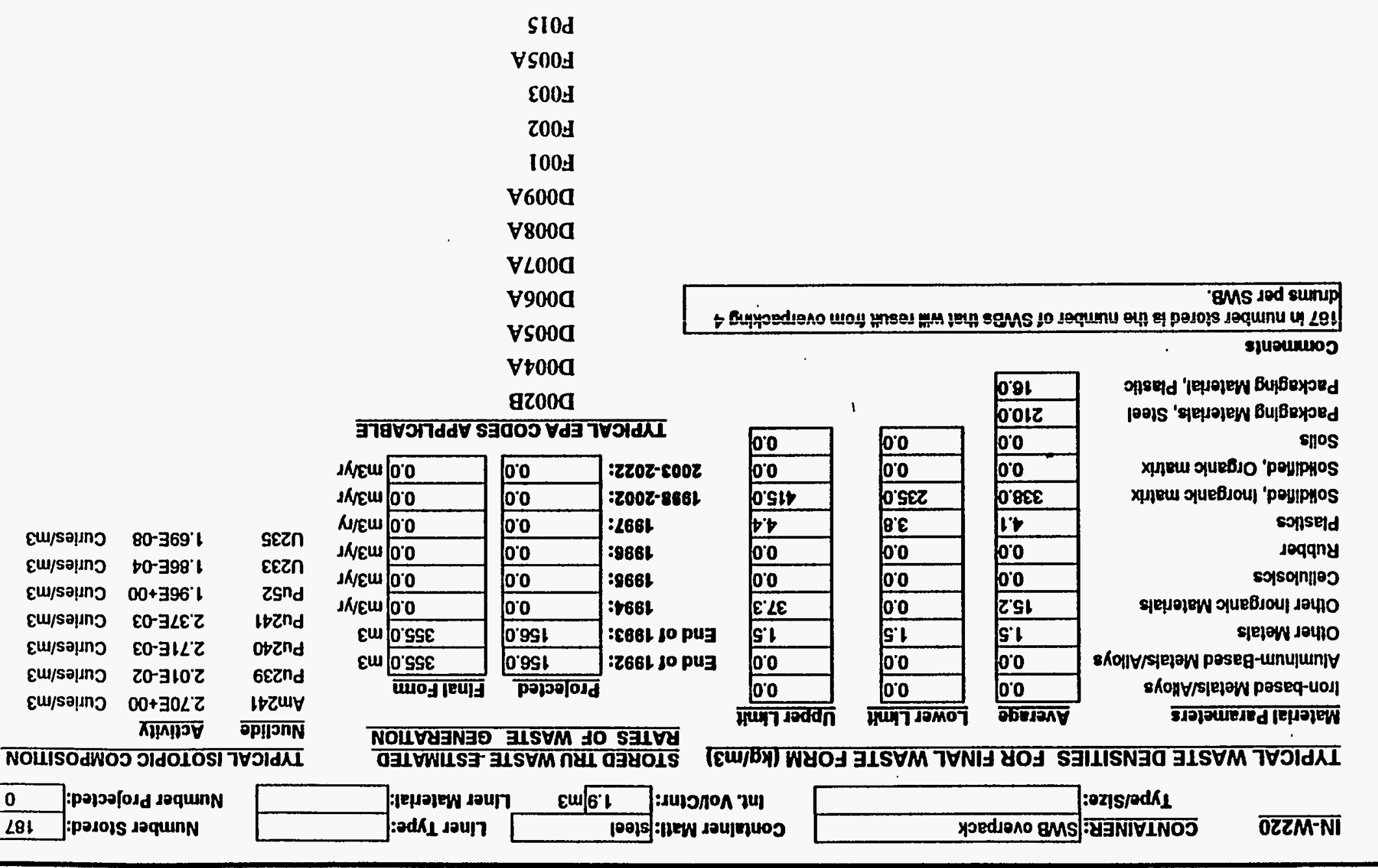




\section{WASTE STREAM PROFILE FOR THE WIPP TRU WASTE BASELINE INVENTORY REPORT}

SITE NAME IN

WASTE TYPE MTRU HANDLING CH GENERATOR SITE RF, AE

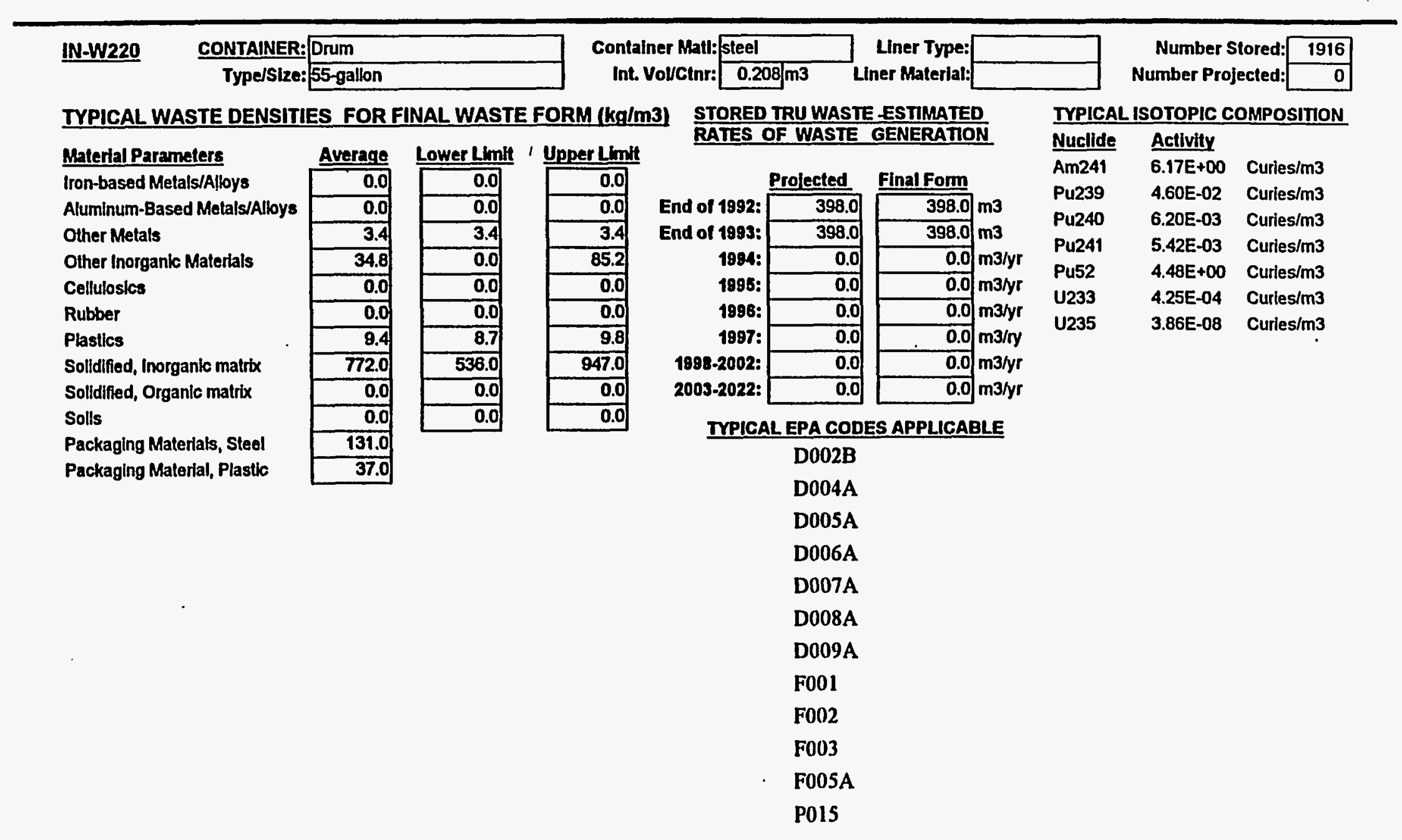




\section{WASTE STREAM PROFILE FOR THE WIPP TRU WASTE BASELINE INVENTORY REPORT}

SITE NAME IN

WASTE TYPE MTRU HANDLING CH GENERATOR SITE RF

\begin{tabular}{|c|c|c|c|}
\hline WASTE STREAM MWIRID & $\frac{\mid N-W 221}{1 N-W 221}$ & & Absorbed Aqueous Llquids \\
\hline Local ID & ID-EGG-102T-113 & DESCRIPTION & Uncemented inorganic sludge (TRU): solld lab waste. \\
\hline MATRIX CODE & 3113 & & \\
\hline SITE FINAL FORMIDC & & , & \\
\hline Waste Matrix Code Group $\sqrt{\mathbf{S}}$ & Solldified Inorganics & & \\
\hline Stte Matrix Description 5 & Solid lab wasto consts & d or absorbed neu & itralized aqueous laboratory waste. \\
\hline
\end{tabular}

NO MGRATION VARIANCE PETIION ASSIGNMENT [D 113

IRUCON CODE $1 \mathrm{D} 113$

\section{FINAL WASTE FORMDESCRIPTORS:}

Defense TRU Waste

Non-Defense TRU Waste

Commerciai TRU Waste

Unknown

$\square$

\section{Mbed TRU}

Non-Mixed TRU

Suspect Mbxed TRU

Unknown

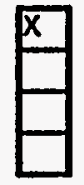

Rsearch and Devel. Waste Operatlons Wasto

Residues

Decon and Decommissioning

Environmental Restoration

From Treatment of Waste

Maintenance

\begin{tabular}{|l|}
\hline$x$ \\
\hline$x$ \\
\hline \\
\hline \\
\hline
\end{tabular}

TSCA Asbestos

PCBs

Other

N/A

Unknown 
WASTE STREAM PROFILE FOR THE WIPP TRU WASTE BASELINE INVENTORY REPORT

SITE NAME IN WASTE TYPEMTRU HANDLINOCH GENERATOR SITE RF

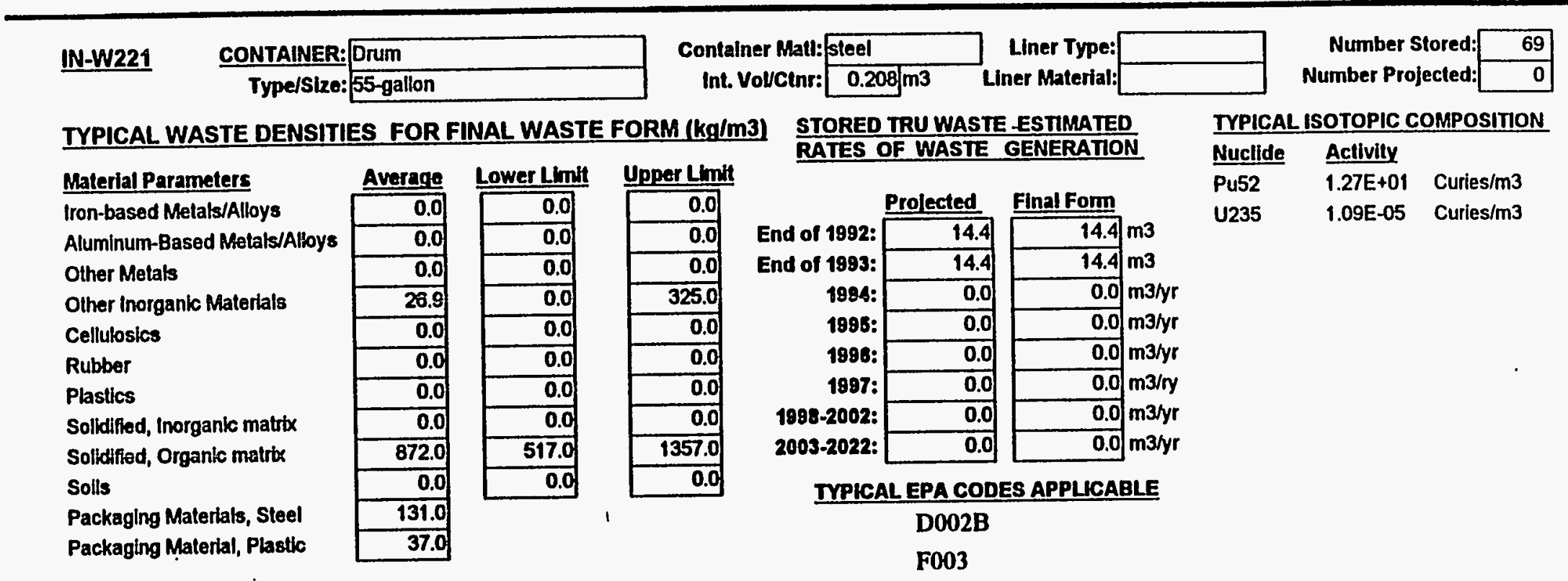




\section{WASTE STREAM PROFILE FOR THE WIPP TRU WASTE BASELINE INVENTORY REPORT}

SITENAME IN

WASTE TYPE MTRU HANDLING CH GENERATOR SITE RF

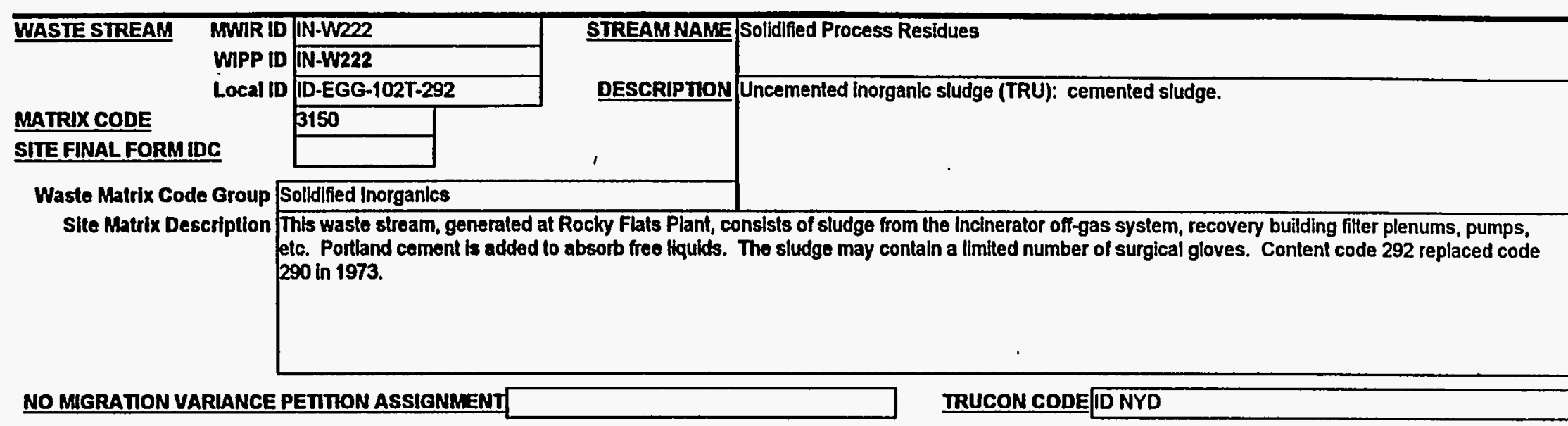

\section{FINAL WASTE FORM DESCRIPTORS:}

Defense TRU Waste

Non-Defense TRU Wasto

Commerclal TRU Waste

Unknown

$x$

Mixed TRU

Non-Mixed TRU

Suspect Mlxed TRU

Unknown

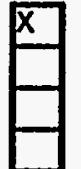

Rsearch and Devel Wasto

Operations Waste

Resldues

Decon and Decommissioning

Environmental Resloration

From Treatment of Waste

Maintenance

\begin{tabular}{|l|}
\hline$x$ \\
\hline$x$ \\
\hline$x$ \\
\hline \\
\hline \\
\hline
\end{tabular}

TSCA Asbestos

PCBs

Other

N/A

Unknown

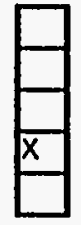




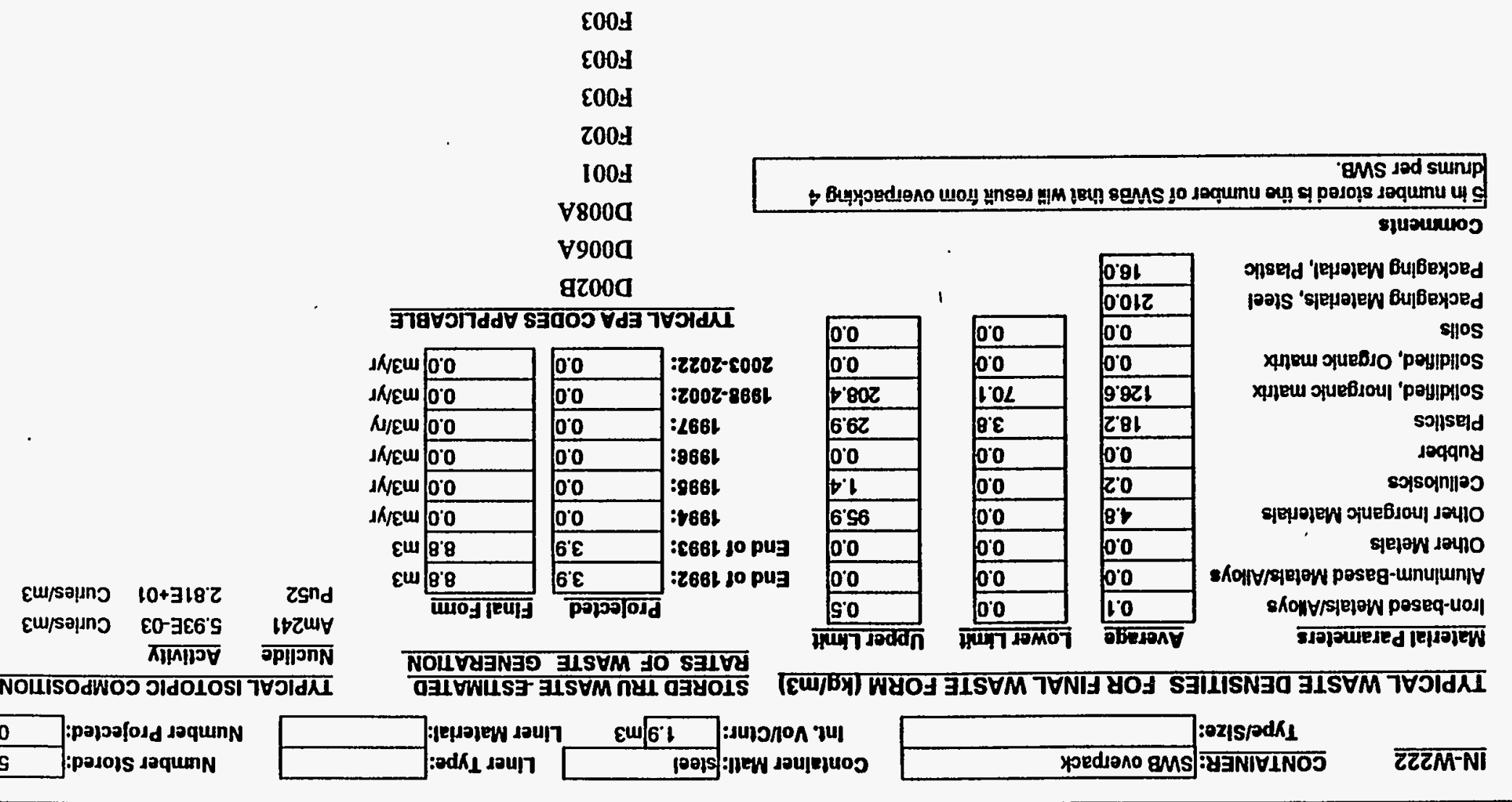


WASTE STREAM PROFILE FOR THE WIPP TRU WASTE BASELINE INVENTORY REPORT

SITE NAME IN

WASTE TYPE MTRU HANDLING CH GENERATOR SITE RF

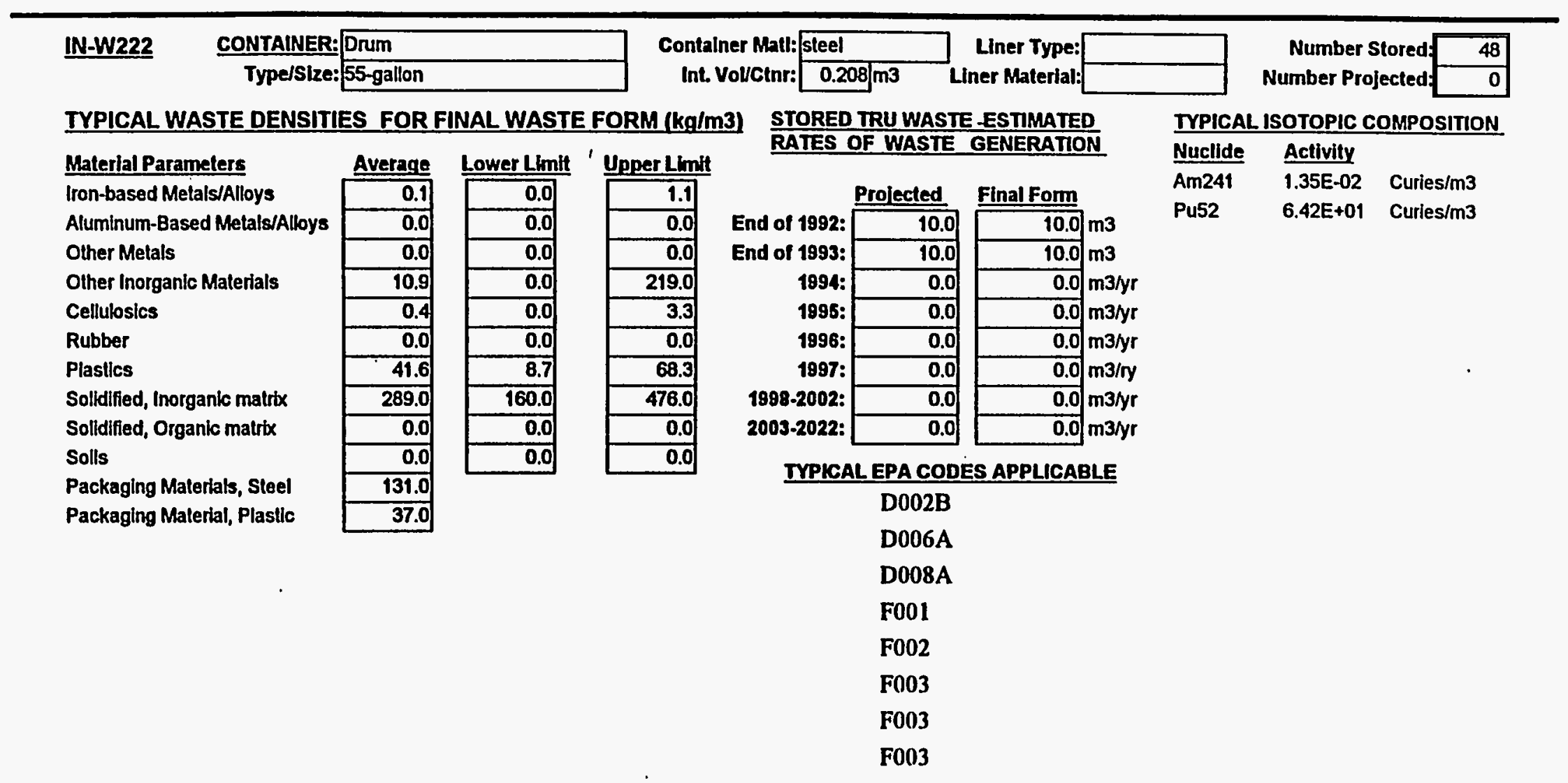




\section{WASTE STREAM PROFILE FOR THE WIPP TRU WASTE BASELINE INVENTORY REPORT}

SITE NAME IN

WASTE TYPE MTRU HANDLING CH GENERATOR SITE RF

WASTE STREAM $\begin{aligned} & \text { MWIR ID } \\ & \text { WIPP ID }\end{aligned}$ IN-W225
LOCal ID
MATRIX CODE
SITE FINAL FORMIDC
Waste Matrix Code Group
Site Matrix Description

\section{NO MIGRATION YARIANCE PETIION ASSIGNMENT ID 121; 221A}

IRUCON CODE ID 221A

\section{FINAL WASTE FORM DESCRIPTORS:}

Defense TRU Waste

Non-Defense TRU Waste

Commercial TRU Waste

Unknown

X

Mixed TRU

Non-Mbxed TRU

Suspect Mixed TRU

Unknown

$\square$

Rsearch and Devel. Waste Operations Waste

Residues

Decon and Decommissioning Environmental Restoration From Treatment of Waste Maintẹnance
TSCA Asbestos

PCBs

Olher

N/A

Unknown

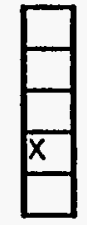




\section{WASTE STREAM PROFILE FOR THE WIPP TRU WASTE BASELINE INVENTORY REPORT}

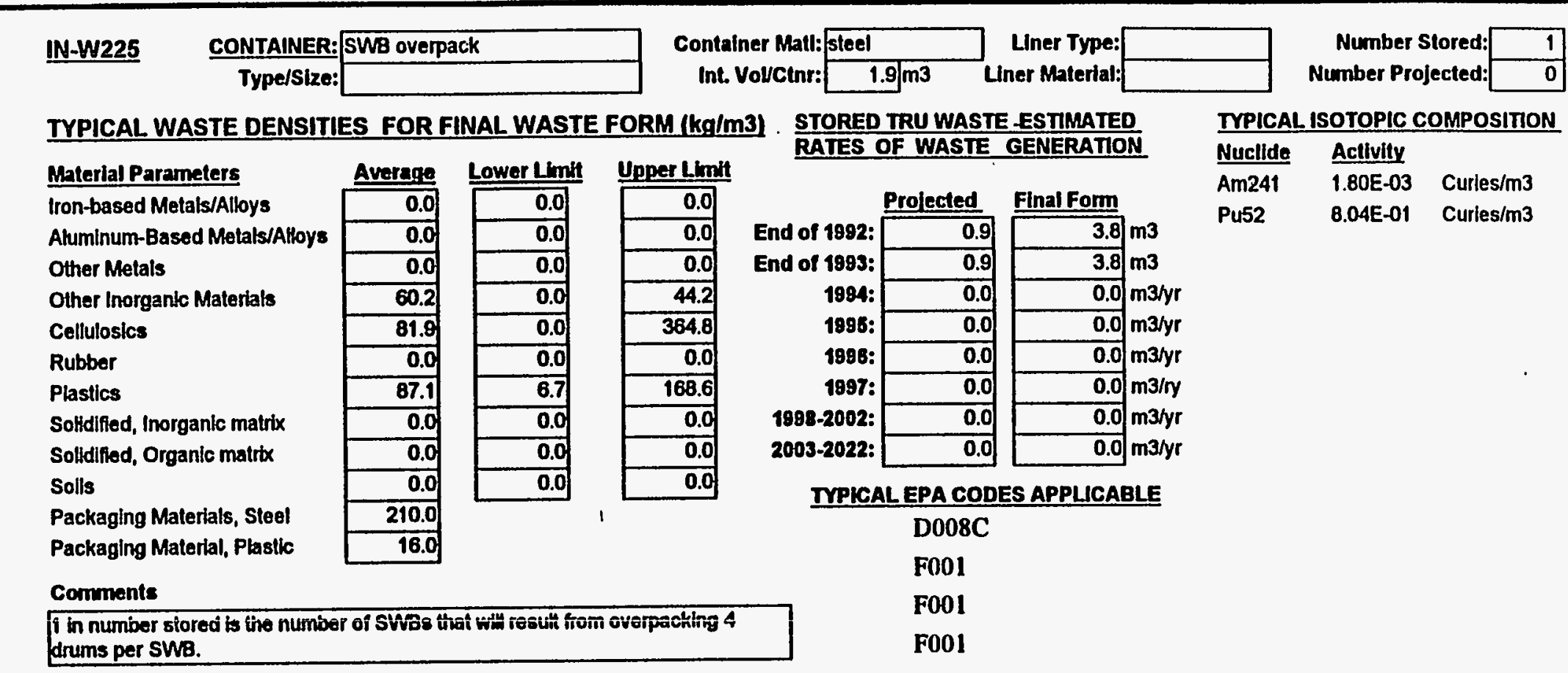




\section{WASTE STREAM PROFILE FOR THE WIPP TRU WASTE BASELINE INVENTORY REPORT}

SITENAME IN

\section{WASTE TYPE MTRU HANDLING CH GENERATOR SITE RF}

IN-W225

CONTAINER: Drum

Container Matt: steel

Int. Volletnr: $0.208 \mathrm{~m} 3$

Liner Type: Liner Material:

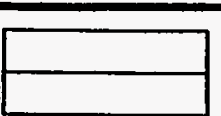

Number Stored: Number Projected

TYPICAL WASTE DENSITIES FOR FINAL WASTE FORM $(\mathrm{kg} / \mathrm{m} 3)$

Materlal Parameters

Iron-based Metals/Alloys

Aluminum-Based Metals/Alloys

Olher Metals

Other Inorganic Malerials

Cellulosics

Rubber

Plastics

Solldified, Inorganic matrix

Solldified, Organic matrix

Solls

Packaging Materlals, Steel

Packaging Material, Plastic

\begin{tabular}{|c|c|c|}
\hline Average & Lower Llmit & ' Upper Limit \\
\hline 0.0 & 0.0 & 0.0 \\
\hline 0.0 & 0.0 & 0.0 \\
\hline 0.0 & 0.0 & 0.0 \\
\hline 37.0 & $\overrightarrow{0.0}$ & 101.0 \\
\hline 187.0 & $\overline{0.0}$ & 833.0 \\
\hline 0.0 & $\overline{0.0}$ & 0.0 \\
\hline 199.0 & 15.3 & 385.0 \\
\hline$\overline{0.0}$ & $\overline{0.0}$ & 0.0 \\
\hline 0.0 & 0.0 & 0.0 \\
\hline 0.0 & 0.0 & 0.0 \\
\hline
\end{tabular}

STORED TRU WASTE ESTIMATED RATES OF WASTE GENERATION

\begin{tabular}{|c|c|c|c|}
\hline & Prolected & Final Form & \\
\hline End of 1992: & 2.3 & 2.3 & m3 \\
\hline id of 1993: & 2.3 & 2.3 & m3 \\
\hline 1994: & $\overline{0.0}$ & 0.0 & m3/yr \\
\hline 1995: & $\overline{0.0}$ & 0.0 & m3/yr \\
\hline 1998: & 0.0 & 0.0 & m3/yr \\
\hline 1987: & 0.0 & 0.0 & $m 3 / n$ \\
\hline 1998-2002: & 0.0 & 0.0 & m3/yr \\
\hline 2003-2022: & 0.0 & $\overline{0.0}$ & $m 3 / y r$ \\
\hline
\end{tabular}

TYPICAL ISOTOPIC COMPOSITION

Nuclide Activity

Am241 4.11E-03 Curies/m3

Pu52 1.84E+00 Curies $/ \mathrm{m}^{3}$

IYPICAL EPA CODES APPLICABLE

D008C

F001

F001

F001 
WASTE STREAM PROFILE FOR THE WIPP TRU WASTE BASELINE INVENTORY REPORT

SITE NAME IN

WASTE TUPE MTRU HANDLING CH GENERATOR SITE RF

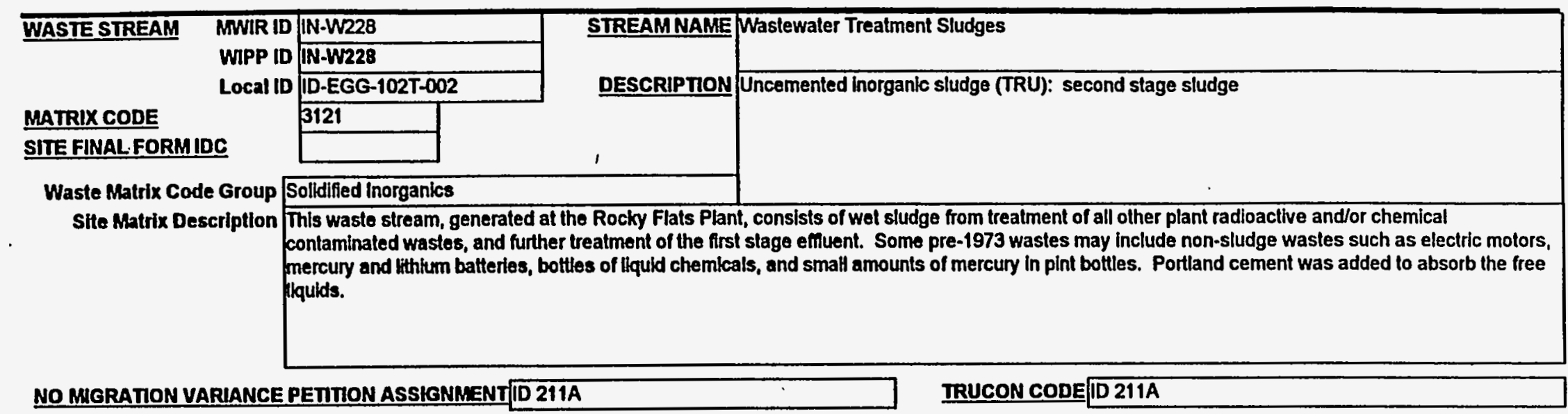

\section{FINAL WASTE FORM DESCRIPTORS:}

\begin{tabular}{l|l|l|l|l|l|l}
$\begin{array}{l}\text { Defense TRU Waste } \\
\text { Non-Defense TRU Waste } \\
\text { Commercial TRU Waste } \\
\text { Unknown }\end{array}$ & $\square$ & $\begin{array}{l}\text { Mixed TRU } \\
\text { Non-Mbed TRU } \\
\text { Suspect Mbed TRU } \\
\text { Unknown }\end{array}$
\end{tabular}

Rsearch and Devel. Waste
Operations Waste
Residues
Decon and Decommissioning
Environmental Restoration
From Treatment of Waste
Maintenance

TSCA Asbestos

PCBs

Other

N/A

Unknown

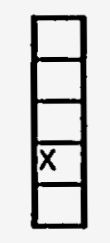


WASTE STREAM PROFILE FOR THE WIPP TRU WASTE BASELINE INVENTORY REPORT

SITE NAME IN WASTE TYPE MTRU HANDLINO CH

GENERATOR SITE RF

IN-W228

\begin{tabular}{c|} 
CONTAINER: SWB overpack \\
Type/SIze:
\end{tabular}

Container Matt: steel int. Volveinr:

$1.9 \mathrm{m3}$

Liner Type: Liner Material:

TYPICAL. WASTE DENSITIES FOR FINAL WASTE FORM $(\mathrm{kg} / \mathrm{m} 3)$

Material Parameters

Iron-based Metals/Alloys

Aluminum-Based Metals/Alloys

Other Metals

Other Inorganic Materials

Cellulosics

Rubber

Plastlcs

Solldified, Inorganle matrix

Solidified, Organkc matrix

Soils

Packaging Materials, Steel

Packaging Material, Plastlc

\begin{tabular}{|r|} 
Average \\
\hline 0.0 \\
\hline 0.0 \\
\hline 0.0 \\
\hline 0.9 \\
\hline 0.1 \\
\hline 0.0 \\
\hline 1.4 \\
\hline 145.4 \\
\hline 0.0 \\
\hline 0.0 \\
\hline 210.0 \\
\hline 16.0 \\
\hline
\end{tabular}

\section{Lower Limit Upper Limit}

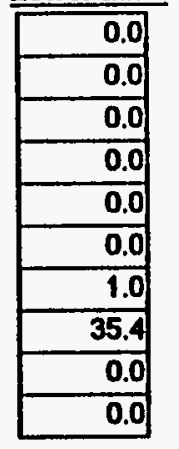

16.0

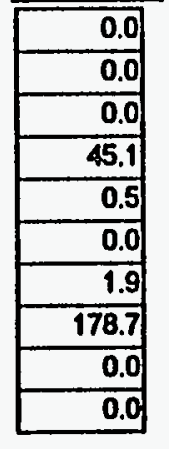

STORED TRU WASTE ESTIMATED RATES OF WASTE GENERATION

End of 1992:

Final Form

\begin{tabular}{|c|c|c|}
\hline 206.0 & 471.0 & m3 \\
\hline 206.0 & 471.0 & m3 \\
\hline 0.0 & 0.0 & $\mathrm{~m} 3 / \mathrm{yr}$ \\
\hline 0.0 & 0.0 & $\mathrm{~m} 3 / \mathrm{yr}$ \\
\hline 0.0 & $\overrightarrow{0.0}$ & m3/yr \\
\hline 0.0 & 0.0 & $\mathrm{~m} 3 / \mathrm{n}$ \\
\hline 0.0 & $\overline{0.0}$ & $\mathrm{~m} 3 / \mathrm{yr}$ \\
\hline 0.0 & 0.0 & m3/yr \\
\hline
\end{tabular}

TYPICAL EPA CODES APPLICABLE

D002B

D003E

D005A

D006A

D007A

D008A

D009A

D009D

D011A

D022

D028

F001

F002

F003

$\mathrm{F003}$

F003
Number Stored: 248

Number Projected:

TYPICAL ISOTOPIC COMPOSITION

Nuclide Activity

Am241 1.62E-01 Curies/m3

Pu52 2.94E-01 Curies/m3

$$
\text { N }-90
$$




\section{WASTE STREAM PROFILE FOR THE WIPP TRU WASTE BASELINE INVENTORY REPORT}

IN-W228 $\quad \frac{\text { CONTAINER: }}{\text { Type/Size: } 55 \text {-gallon }}$

TYPICAL WASTE DENSITIES FOR FINAL WASTE FORM $1 \mathrm{~kg} / \mathrm{m} 3$

Material Parameters

Iron-based Metals/Alloys

Aluminum-Based Motals/Alloys

Other Metals

Other Inorganic Materials

Cellulosics

Rubber

Plastics

Solldifled, Inorganic matrix

Solldified, Organic matrix

Solls

Packaging Materiałs, Steel

Packaging Material, Plastlo

$\begin{array}{r}\begin{array}{r}\text { Contain } \\ \text { Int. }\end{array} \\ \text { (kg/m } \\ \hline \text { Limit } \\ \hline 0.0 \\ \hline 0.0 \\ \hline 0.0 \\ \hline 03.0 \\ \hline 1.1 \\ \hline 0.0 \\ \hline 4.4 \\ \hline 408.0 \\ \hline 0.0 \\ \hline 0.0 \\ \hline\end{array}$

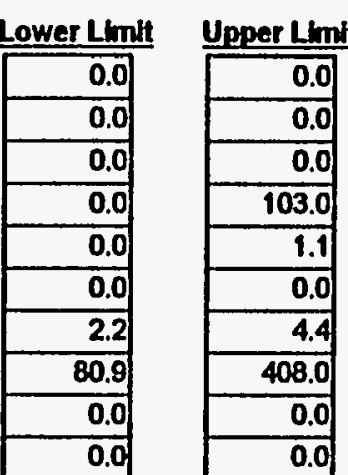

Container Matl: steol

Linr: $0.208 \mathrm{gm} 3$ Liner Material:

STORED TRU WASTE -ESTIMATED

RATES OF WASTE GENERATION

\begin{tabular}{|c|c|c|c|}
\hline & Prolected & Final Form & \\
\hline 1992: & 532.0 & $\overline{532.0}$ & m3 \\
\hline 883: & 532.0 & 532.0 & m3 \\
\hline 1994: & 0.0 & 0.0 & $\mathrm{~m} 3 / \mathrm{yr}$ \\
\hline 1986: & 0.0 & 0.0 & $\mathrm{~m} 3 / \mathrm{yr}$ \\
\hline 1996: & $\overline{0.0}$ & $\overline{0.0}$ & $\mathrm{~m} 3 / \mathrm{yr}$ \\
\hline 1997: & 0.0 & 0.0 & $\mathrm{~m} 3 / \mathrm{ny}$ \\
\hline 88-2002: & 0.0 & 0.0 & $\mathrm{~m} 3 / \mathrm{yr}$ \\
\hline $003-2022:$ & 0.0 & 0.0 & $\mathrm{~m} 3 / \mathrm{yr}$ \\
\hline
\end{tabular}

TYPLCAL EPA CODES APPLICABLE
D002B
D003E
D005A
D006A
D007A
D008A
D009A
D009D
D011A
D022
D028
F001
F002
F003
F003
$\mathrm{FOO3}$

Number Stored: 2559 Number Projected

TYPICAL ISOTOPIC COMPOSITION

Nuclide Activily

Am241 3.71E-01 Curies/m3

Pu52 6.72E-01 Curies/m3 


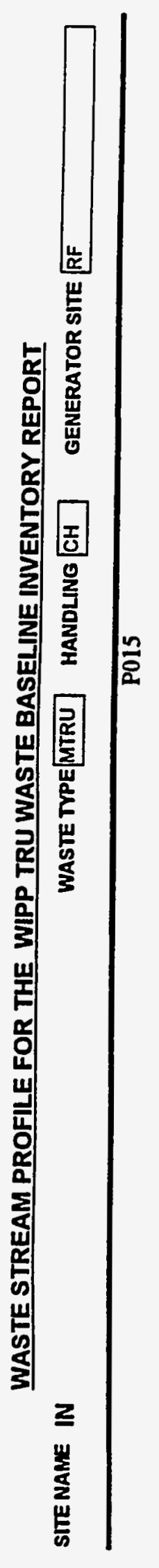

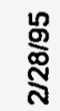

m
$\vdots$

\begin{tabular}{l} 
! \\
$\vdots$ \\
\multirow{2}{*}{} \\
$\vdots$
\end{tabular} 


\section{WASTE STREAM PROFILE FOR THE WIPP TRU WASTE BASELINE INVENTORY REPORT}

SITE NAME IN

WASTE TYPEMTRU HANDLING CH GENERATOR SITE RF

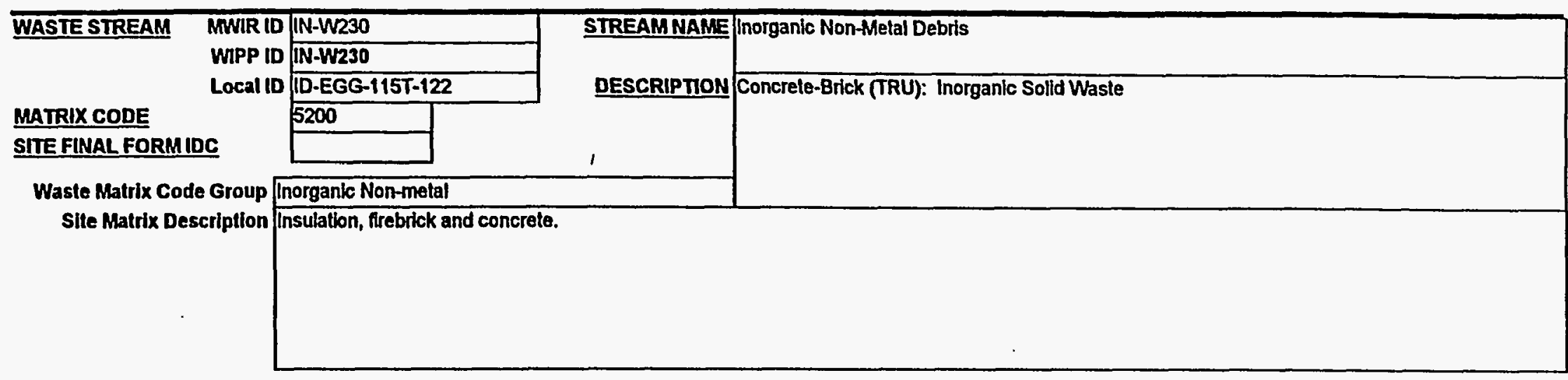

NO MIGRATION VARIANGE PETIION ASSIGNMENT DD 122

IRUCON CODE ID 122

FINAL WASTE FORM DESGRIPTORS:

Defense TRU Waste

Non-Delense TRU Waste

Commercial TRU Waste

Unknown

5

Mixed TRU

Non-Mbxed TRU

Suspect Mixed TRU

Unknown

$\square$

\begin{tabular}{|l|}
\hline$x$ \\
\hline$x$ \\
\hline$x$ \\
\hline \\
\hline \\
\hline
\end{tabular}

TSCA Asbestos

PCBs

Other

N/A

Unknown

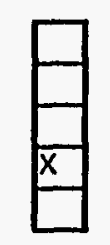



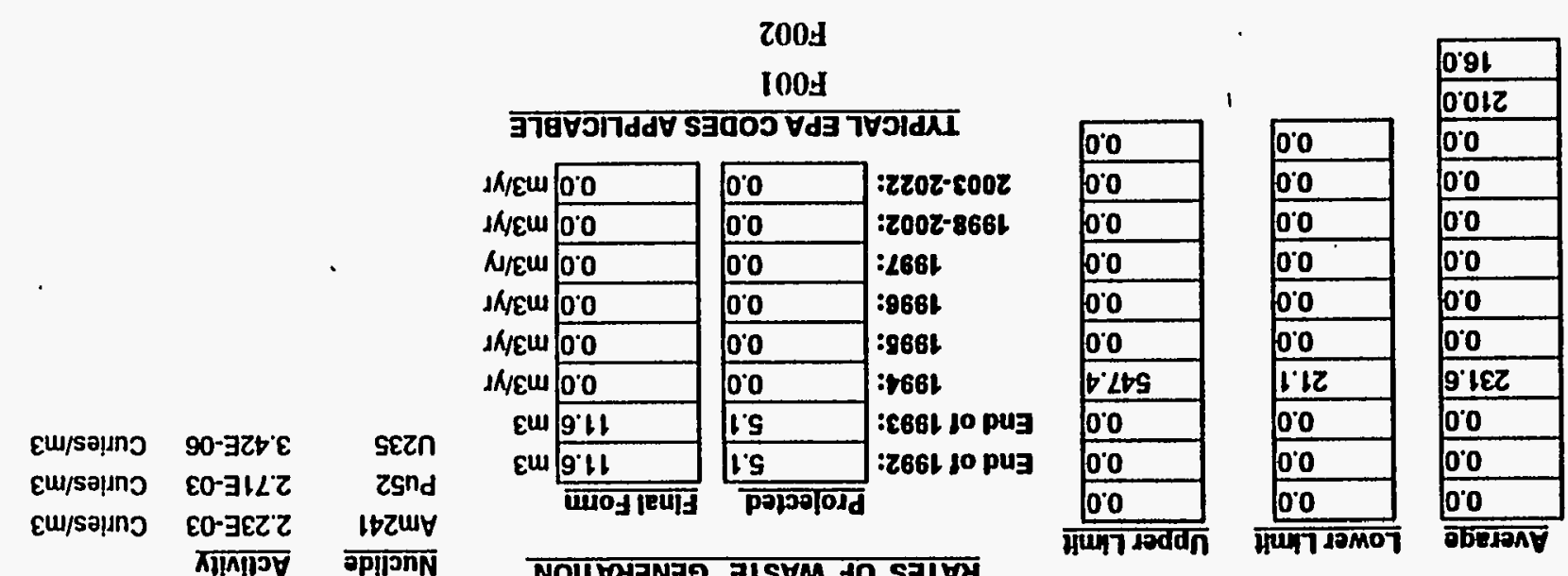

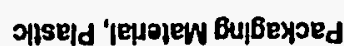
pajs 'słepajew bujbeyoed

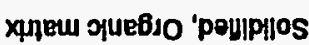

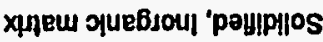

sगाseid

$$
\text { seqqiny }
$$

sojsojn॥ण

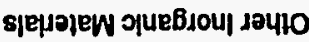

sjelaw sayno

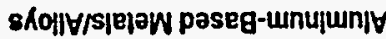

sho\|ly/S|ejaw peseq-uod

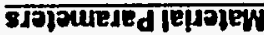

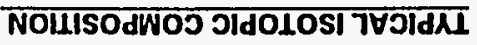

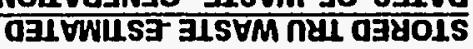

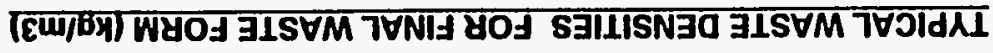

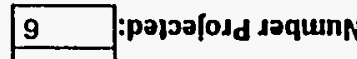

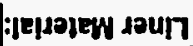
:odK1 souा7 


\section{WASTE STREAM PROFILE FOR THE WIPP TRU WASTE BASELINE INVENTORY REPORT}

SITE NAME IN WASTE TYPE MTRU HANDLING CH GENERATOR SITE RF

\begin{tabular}{|c|c|c|c|c|c|c|c|c|c|c|c|}
\hline IN-W230 & \begin{tabular}{|l} 
Drum \\
55 -gallon \\
\end{tabular} & & \multicolumn{2}{|c|}{\begin{tabular}{r|r} 
Container Matt: & sleel \\
Int. VoluCtnr: & $0.2 C$
\end{tabular}} & $08 \mathrm{m3}$ & $\begin{array}{l}\text { Liner Type: } \\
\text { Liner Material: }\end{array}$ & & & \multicolumn{2}{|c|}{$\begin{array}{l}\text { Number Stored: } \\
\text { Number Projected: }\end{array}$} & $\begin{array}{r}63 \\
0 \\
\end{array}$ \\
\hline \multirow{2}{*}{\multicolumn{4}{|c|}{ TYPICAL WASTE DENSITIES FOR FINAL WASTE FORM $(\mathrm{kg} / \mathrm{m} 3)$}} & \multirow{2}{*}{\multicolumn{4}{|c|}{$\begin{array}{l}\text { STORED TRU WASTE ESTIMATED } \\
\text { RATES OF WASTE GENERATION }\end{array}$}} & \multicolumn{4}{|c|}{ TYPICAL ISOTOPIC COMPOSITION } \\
\hline & Avarame & Lawerlimit & Unper Imit & & & & & Nuclide & & \multirow{4}{*}{\multicolumn{2}{|c|}{$\begin{array}{l}\text { Curies } / \mathrm{m} 3 \\
\text { Curies } / \mathrm{m} 3 \\
\text { Curies } / \mathrm{m} 3\end{array}$}} \\
\hline Materlal Parameters & $\frac{\text { Averege }}{0.0}$ & 0.0 & 0.0 & \multirow{3}{*}{$\begin{array}{l}\text { End of 1992: } \\
\text { End of 1993: }\end{array}$} & Proiected & \multicolumn{2}{|l|}{ Final Form } & \multirow{3}{*}{$\begin{array}{l}\text { Am241 } \\
\text { Pu52 } \\
\text { U235 }\end{array}$} & \multirow{3}{*}{$\begin{array}{l}\frac{}{5.08 E-03} \\
6.18 E+01 \\
7.80 E-06\end{array}$} & & \\
\hline Aluminum-Based Metals/Alloys & 0.0 & 0.0 & 0.0 & & 13.1 & 7) & $\operatorname{lm} 3$ & & & & \\
\hline Other Metals & 0.0 & 0.0 & 0.0 & & 13.1 & 13.1 & m3 & & & & \\
\hline Other inorganic Materials & 528.8 & 48.1 & 1250.0 & 1994: & 0.0 & 0.0 & $\mathrm{~m} 3 / \mathrm{yr}$ & & & & \\
\hline Cellutosics & 0.0 & 0.0 & 0.0 & 1995: & 0.0 & 0.0 & m3/yr & & & & \\
\hline Rubber & 0.0 & 0.0 & 0.0 & 1896: & 0.0 & 0.0 & $\mathrm{~m} 3 / \mathrm{yr}$ & & & & \\
\hline Plastics & 0.0 & 0.0 & 0.0 & 1997: & 0.0 & 0.0 & $\mathrm{~m} 3 / \mathrm{ry}$ & & & & - \\
\hline Solldified, Inorganic matrix & 0.0 & 0.0 & 0.0 & 1898-2002: & 0.0 & 0.0 & m3/yr & & & & \\
\hline Solldified, Organic matrix & 0.0 & 0.0 & 0.0 & 2003-2022: & 0.0 & 0.0 & m3/yr & & & & \\
\hline Solls & 0.0 & 0.0 & 0.0 & $T$ & $=P A$ & & & & & & \\
\hline Packaging Materials, Steel & 131.0 & & & & F001 & & & & & & \\
\hline Packaging Material, Plastic & 37.0 & & & & F002 & & & & & & \\
\hline
\end{tabular}


WASTE STREAM PROFILE FOR THE WIPP TRU WASTE BASELINE INVENTORY REPORT

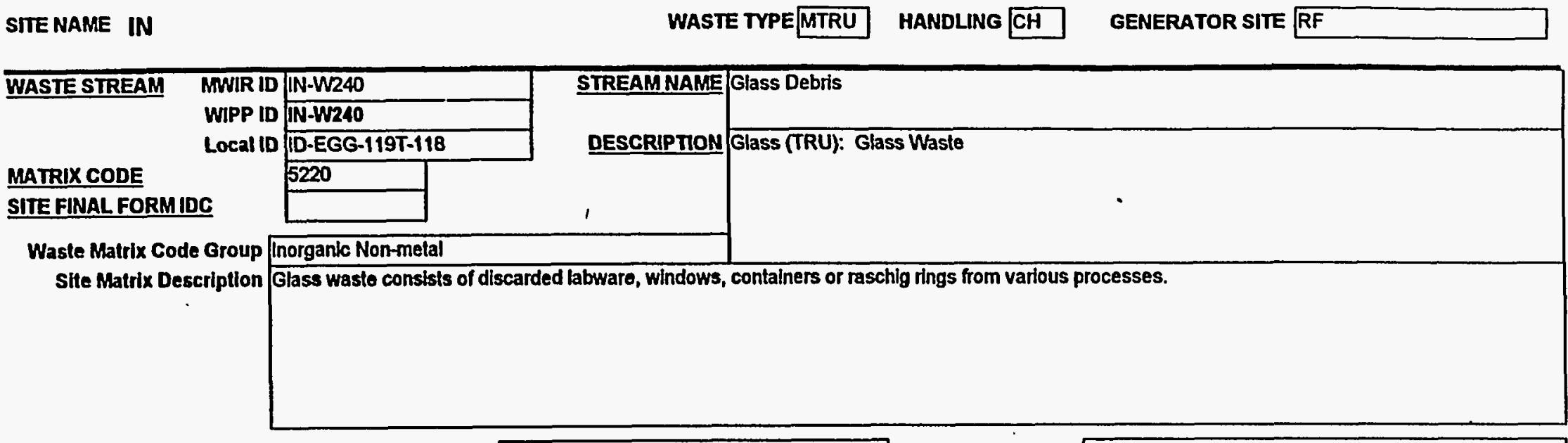

NO MUGRATION VARIANGE PETITION ASSIGNMENTID 118 IRUCON CODE ID 118

\section{FINAL WASTE FORM DESCRIPTORS:}

\begin{tabular}{l|lll|}
$\begin{array}{l}\text { Defense TRU Waste } \\
\text { Non-Defense TRU Waste } \\
\text { Commerclal TRU Waste } \\
\text { Unknown }\end{array}$ & $\square$ & $\begin{array}{l}\text { Mbed TRU } \\
\text { Non-Mlxed TRU } \\
\text { Suspect Mixed TRU. } \\
\text { Unknown }\end{array}$ & \\
\hline
\end{tabular}

Rsearch and Devel. Waste
Operations Waste
Residues
Decon and Decommissioning
Environmental Restoration
From Treatment of Waste
Maintenance

TSCA Asbestos

PCBs

Other

N/A

Unknown 


\section{WASTE STREAM PROFILE FOR THE WIPP TRU WASTE BASELINE INVENTORY REPORT}

SITE NAME IN

WASTE TYPE MTRU HANDLINO CH GENERATOR SITE RF

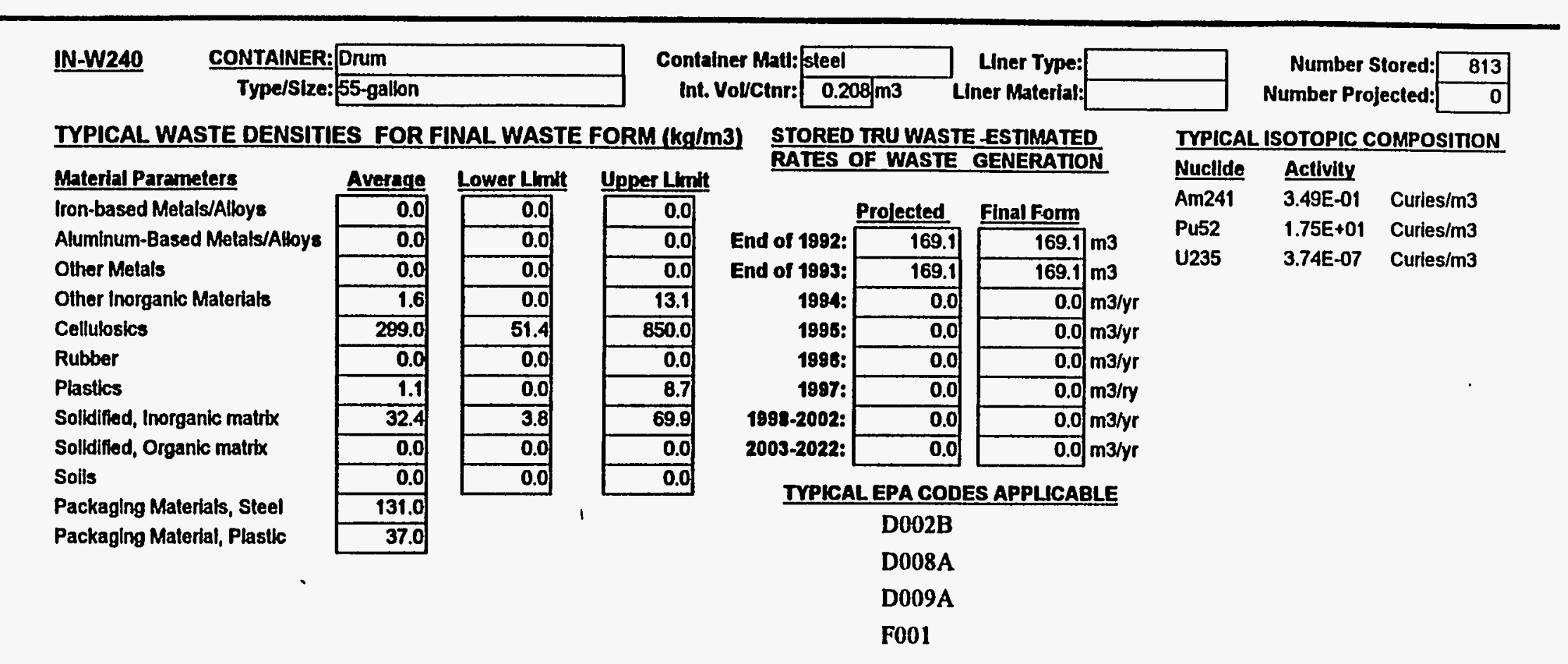


WASTE STREAM PROFILE FOR THE WIPP TRU WASTE BASELINE INVENTORY REPORT

SITENAME IN

WASTE TYPE MTRU HANDLING CH GENERATOR SITE RF

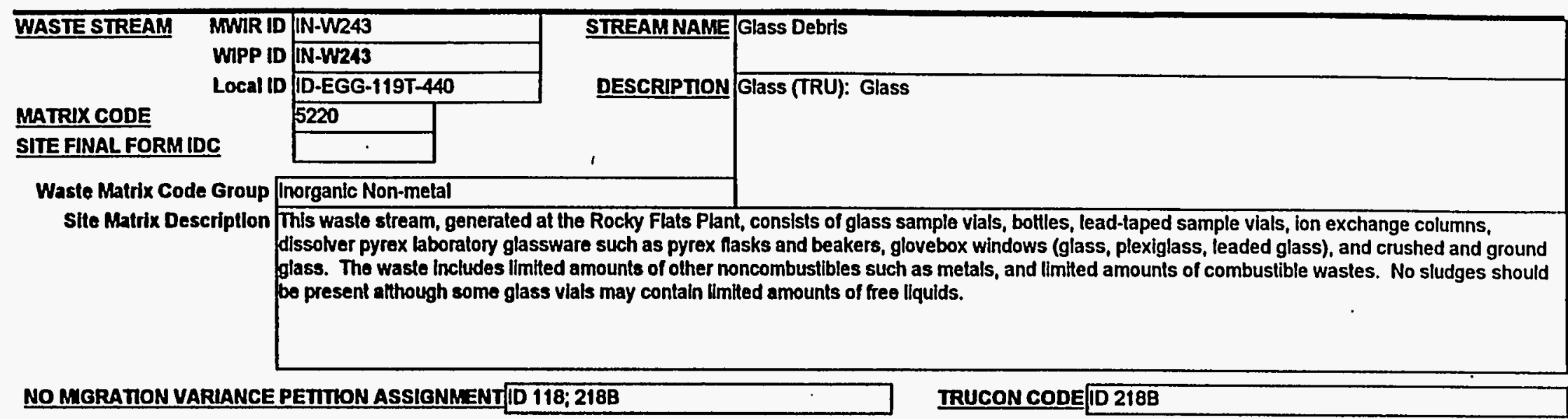

FINAL WASTE FORM DESCRIPTORS:

\begin{tabular}{l|l}
$\begin{array}{l}\text { Defense TRU Waste } \\
\text { Non-Defense TRU Waste } \\
\text { Commerclal TRU Waste } \\
\text { Unknown }\end{array}$ & $\square$
\end{tabular}

Unknown

$\square$

TSCA Asbestos

PCBs

Other

N/A

Unknown

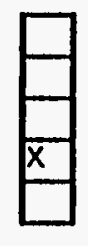




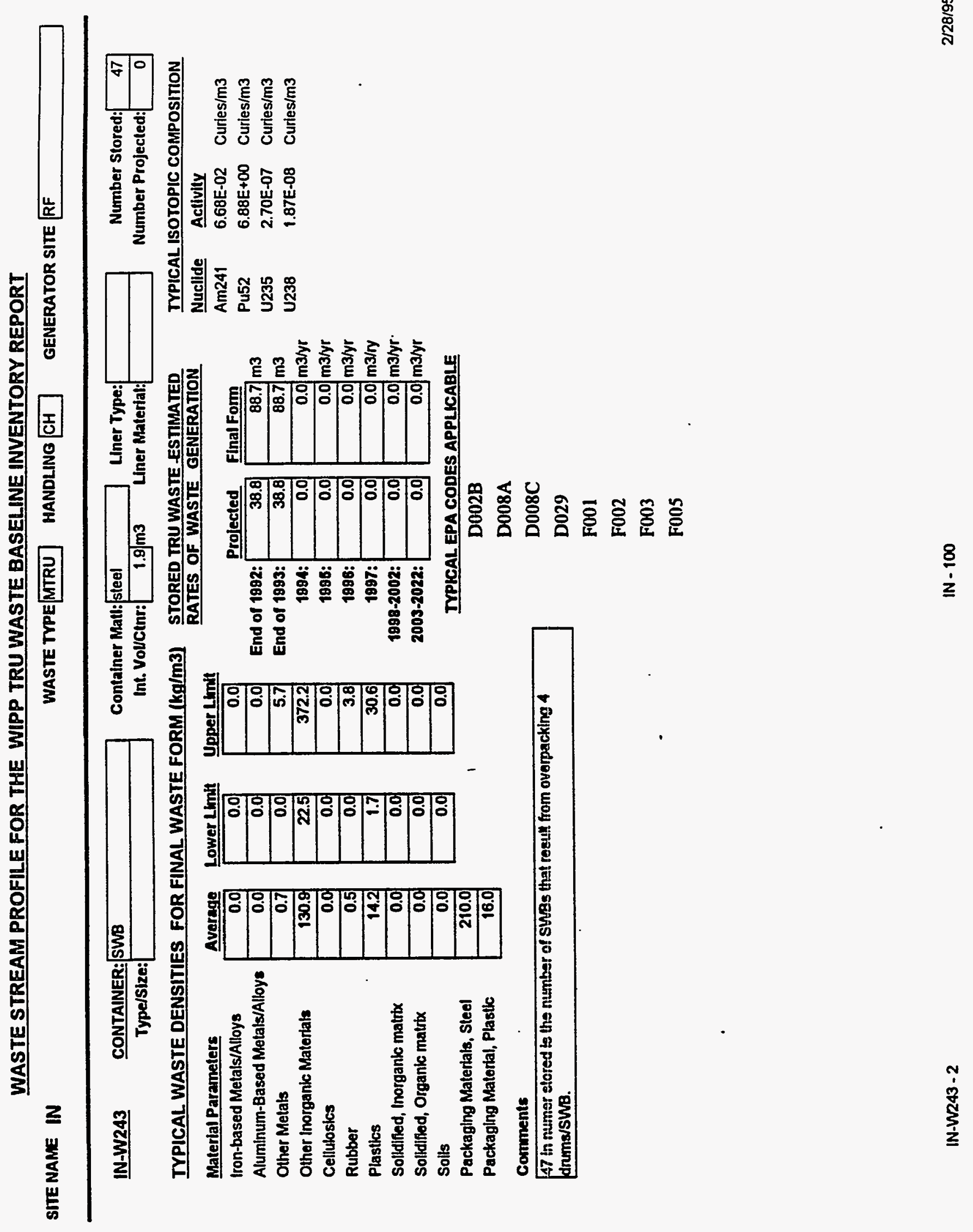


WASTE STREAM PROFILE FOR THE WIPP TRU WASTE BASELINE INVENTORY REPORT

SITE NAME IN WASTE TYPE MTRU HANDLING CH GENERATOR SITE RF

IN-W243 $\frac{\text { CONTAINER: Drum }}{\text { Type/SIze: } 55 \text {-gallon }}$

Contalner Matl: steel Liner Type:

Int. VolvCtnr: $0.208 \mathrm{m3}$ Liner Material:

Number Stored:

Number Projected:

707

TYPICAL WASTE DENSITIES FOR FINAL WASTE FORM $(\mathrm{kg} / \mathrm{m} 3)$

STORED TRU WASTE ESTIMATED

RATES OF WASTE GENERATION

Materlal Parameters

Iron-based Metals/Alloys

Aluminum-Based Metals/Alloys

Other Melals

Other Inorganic Materials

Cellulosics

Rubber

Plastics

Solldified, Inorganic matrix

Solldified, Organic matrix

Solls

Packaging Materlals, Steel

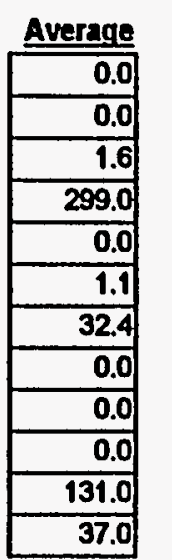

Packaging Material, Plastlc

Lower Limit I UpperLimit

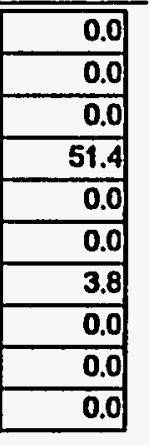

\begin{tabular}{|r|}
\hline 0.0 \\
\hline 0.0 \\
\hline 13.1 \\
\hline 850.0 \\
\hline 0.0 \\
\hline 8.7 \\
\hline 69.9 \\
\hline 0.0 \\
\hline 0.0 \\
\hline 0.0 \\
\hline
\end{tabular}

Comments

$13 \%$ of thls waste stream volume is classlied as RH-TRU whout current

shielding. It is anticipated that the RH-TRU portion will be shlpped as CH-TRU

with internal shielding.

\begin{tabular}{|c|c|c|c|}
\hline & Prolected & Final Form & \\
\hline End of 1992: & 147.0 & 147.0 & m3 \\
\hline Id of 1993: & 147.0 & 147.0 & m3 \\
\hline 1994: & 0.0 & 0.0 & m3/yr \\
\hline 1995: & 0.0 & 0.0 & m3/yr \\
\hline 1996: & 0.0 & $\overline{0.0}$ & $\mathrm{~m} 3 / \mathrm{yr}$ \\
\hline 1897: & 0.0 & 0.0 & $\mathrm{~m} 3 / \mathrm{ry}$ \\
\hline 1988-2002: & 0.0 & 0.0 & $\mathrm{~m} 3 / \mathrm{yr}$ \\
\hline $03-2022$ & 0.0 & 0.0 & $\mathrm{~m} 3 / \mathrm{yr}$ \\
\hline
\end{tabular}

IYPLCAL EPA CODES APPLICABLE

D002B

D008A

D008C

D029

F001

F002

F003

F005
TYPICAL ISOTOPIC COMPOSITION

Nuclide Activity

Am241 1.53E-01 Curies/m3

Pu52 1.57E+01 Curies $/ \mathrm{m}^{3}$

U235 6.16E-07 Curies $/ \mathrm{m} 3$

U238 4.26E-08 Curies $/ \mathrm{m}^{3}$ 
WASTE STREAM PROFILE FOR THE WIPP TRU WASTE BASELINE INVENTORY REPORT

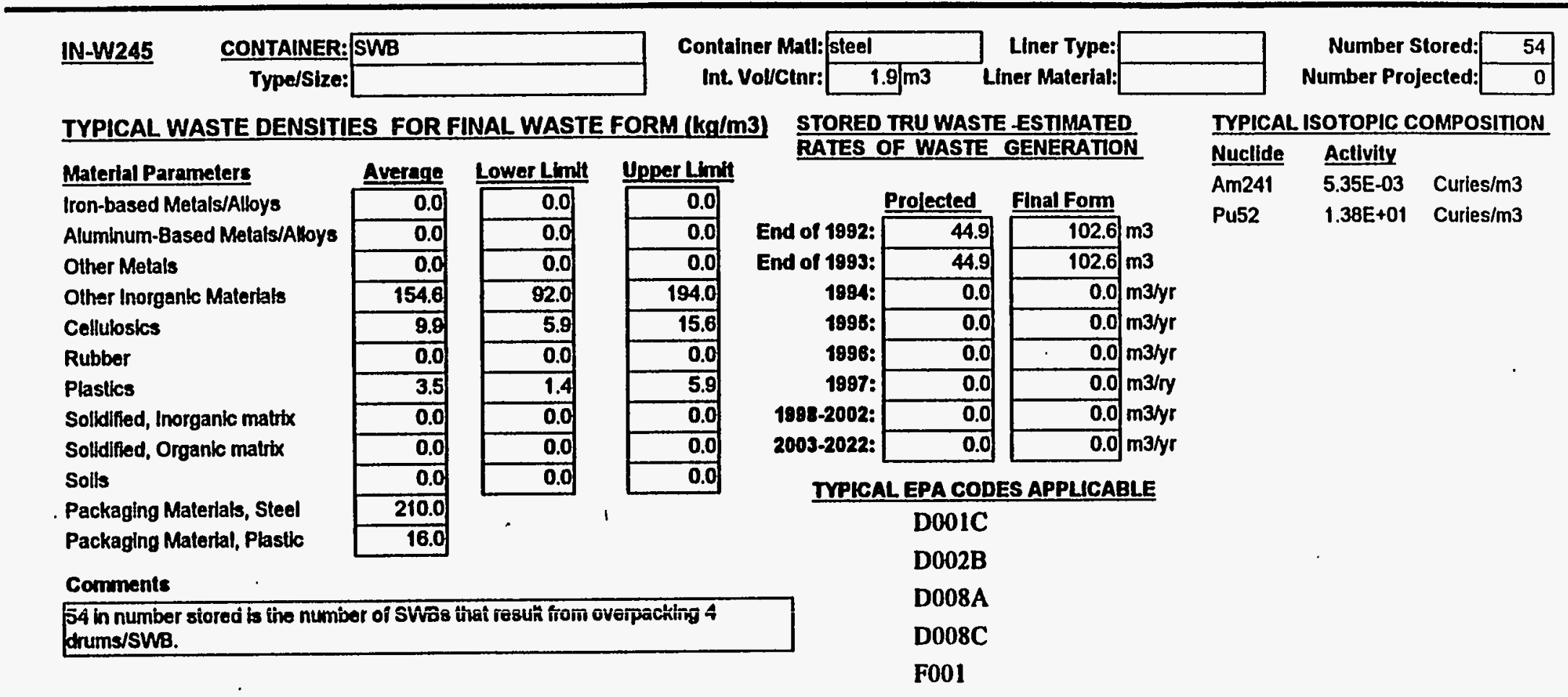


WASTE STREAM PROFILE FOR THE WIPP TRU WASTE BASELINE INVENTORY REPORT

SITE NAME IN WASTE TYPE MTRU HANDLING CH GENERATOR SITE RF

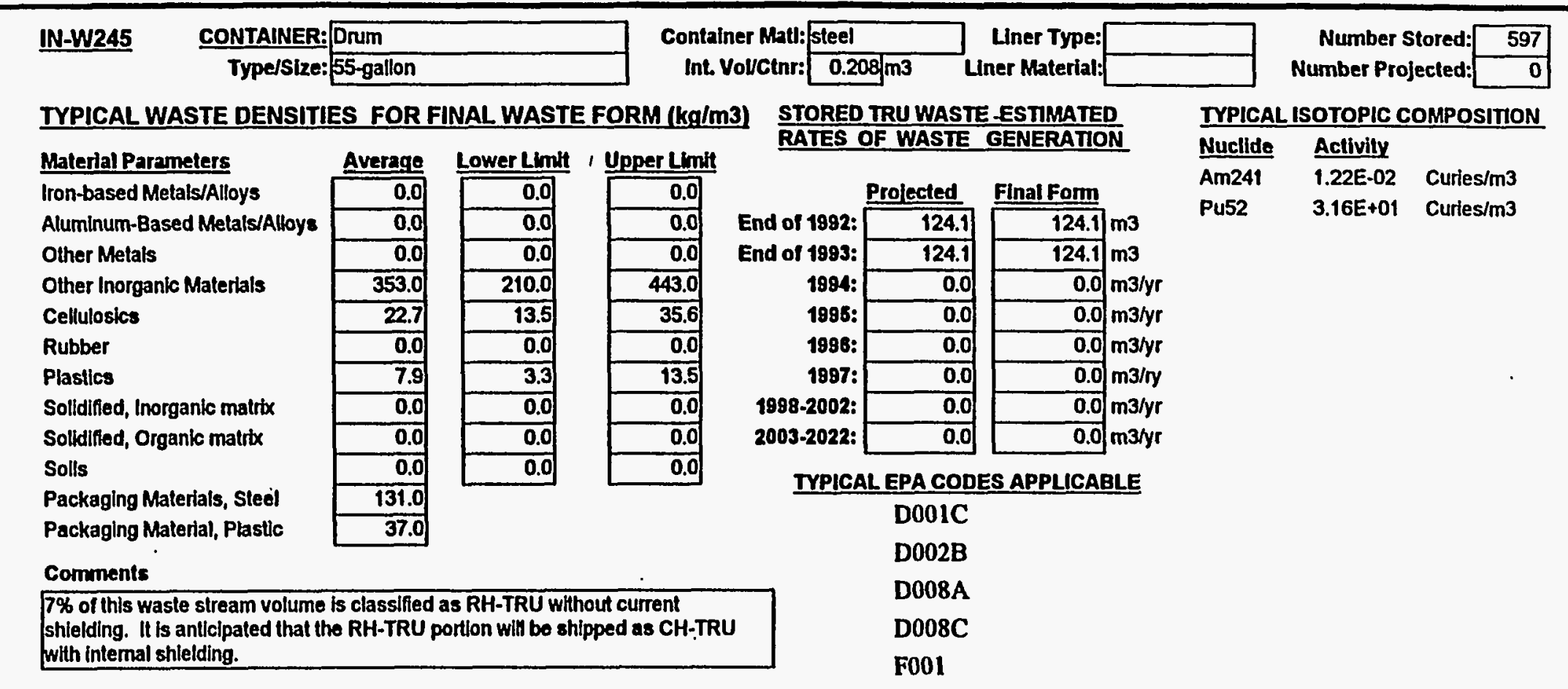


WASTE STREAM PROFILE FOR THE WIPP TRU WASTE BASELINE INVENTORY REPORT

SITENAME IN

WASTE TYPE MTRU HANDLING CH GENERATOR SITE RF

\begin{tabular}{|c|c|c|c|c|}
\hline WASTE STREAM & MWIR ID & IN-W24? & STREAMNAME & Uncalegorized Unknown \\
\hline & WIPP ID & IN-W247 & & \\
\hline & Local ID & ID-EGG-119T-442 & DESCRIPTION & Glass (TRU): Leached Rashig Rings \\
\hline MATRIX CODE & & 8900 & & \\
\hline SITE FINAL FORH & & & 1 & \\
\hline Waste Matrix $\dot{c}$ & Group 11 & Inorganic Non-metal & & \\
\hline Site Matrix D & cription & $\begin{array}{l}\text { This waste stream, ge } \\
\text { tanks. Content code } \\
\text { Rashlg Rings. The rir } \\
\text { resistant borosillcato } \\
\text { abovo-dlscard amoun } \\
\text { may be contaminated }\end{array}$ & $\begin{array}{l}\text { Rochy Flats Plant } \\
\text { ed Rashig Rings we } \\
11.75 \text { inches high a } \\
8-13.8 \text { welght } \% \text { B } \\
\text { m, wero leached wil } \\
\text { nounts of oll. }\end{array}$ & $\begin{array}{l}\text { th consists of boronated glass rings used to minimize neutron multiplication in liquid storage } \\
\text { vas used from } 1971-79 \text { as a separate stream, and then combined with content code } 442 \text {, Leached } \\
\text { and } 1.5 \text { inch in diameter, with a } 0.25 \text { inch wal thickness. The rings are heat and chemical } \\
8203 \text {, with an isotople content of } 10 \mathrm{~B} / 11 \mathrm{~B} \text { of not less than } 0.24 \text {. Some of the rings, which had } \\
\text { ith nitric acid to recover the plutonium and then rinsed with water, and dried. Some of the rings }\end{array}$ \\
\hline
\end{tabular}

FINAL WASTE FORM DESCRIPTORS:

\begin{tabular}{|c|c|}
\hline Defense TRU Waste & Mbxed TRU \\
\hline Non-Defense TRU Waste & Non-Mlxed TRU \\
\hline Commerclal TRU Waste & Suspect Mixed TRU \\
\hline Unknown & Unknown \\
\hline
\end{tabular}

Rsearch and Devel. Waste
Operations Waste
Residues
Decon and Decommissioning
Environmental Restoration
From Treatment of Waste
Maintenance
TSCA Asbestos
PCBs
Other
N/A

Unknown

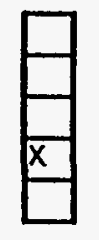




\section{WASTE STREAM PROFILE FOR THE WIPP TRU WASTE BASELINE INVENTORY REPORT}

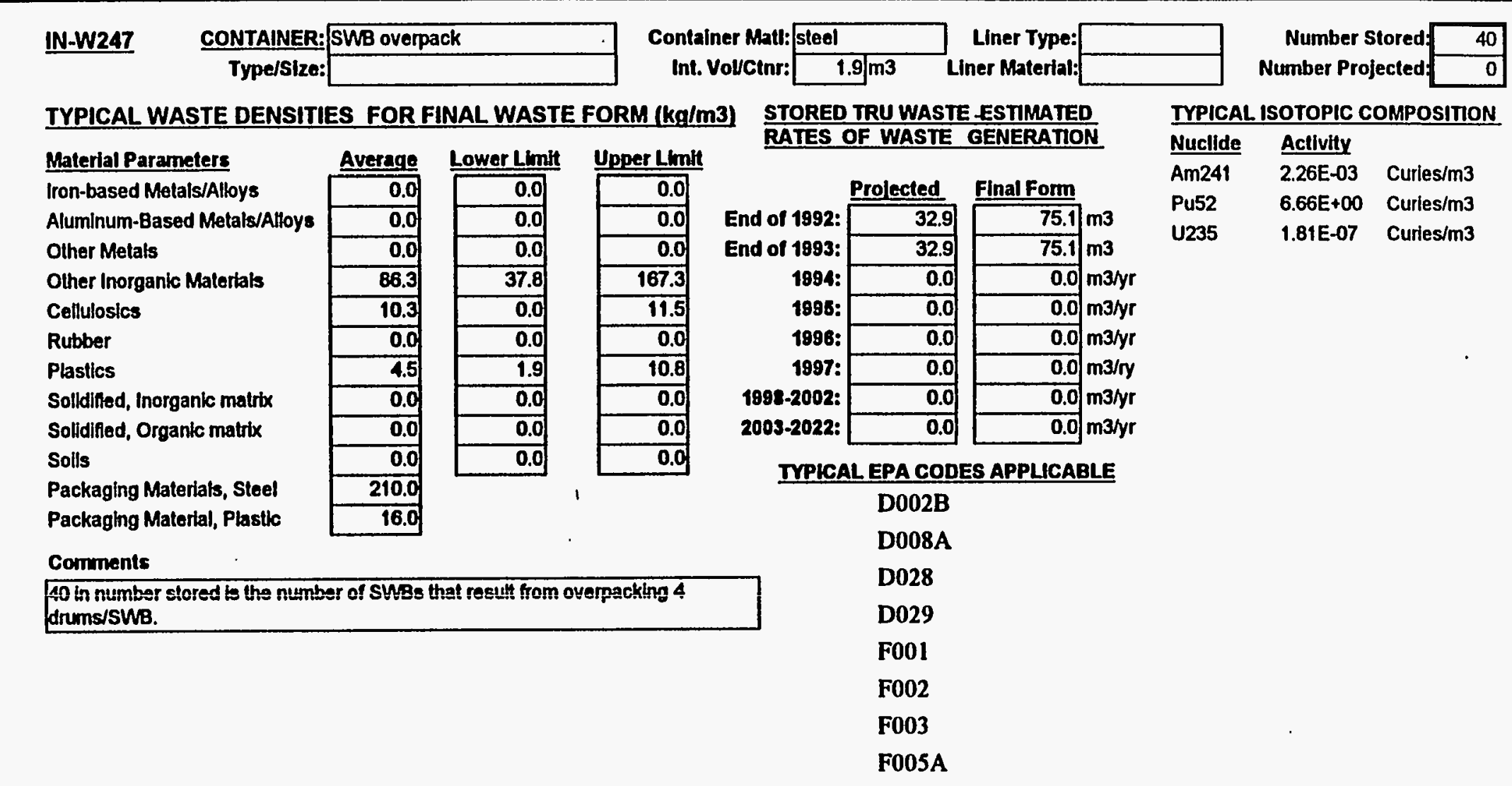




\section{WASTE STREAM PROFILE FOR THE WIPP TRU WASTE BASELINE INVENTORY REPORT}

SITE NAME IN

WASTE TYPE MTRU HANDLING CH GENERATOR SITE RF

IN-W247

CONTAINER: Drum

Contalner Matt: steel

Int. Voucenr: $\frac{\text { Liner Type: }}{0.208 / \mathrm{m}^{3}}$ Liner Materlat:

Number Stored:

Number Projected:

801

TYPICAL WASTE DENSITIES FOR FINAL WASTE FORM $(\mathrm{kg} / \mathrm{m} 3)$

Material Parameters

Iron-based Metals/Alloys

Aluminum-Based Metals/Alloys

Other Metals

Other Inorganic Materials

Cellulosics

Rubber

Plastics

Solidified, Inorganic matrix

Solidified, Organle matrix

Solls

Packaging Malerials, Steel

Packaging Material, Plastic

\begin{tabular}{r|} 
Average \\
\hline 0.0 \\
\hline 0.0 \\
\hline 0.0 \\
\hline 197.0 \\
\hline 23.6 \\
\hline 0.0 \\
\hline 10.3 \\
\hline 0.0 \\
\hline 0.0 \\
\hline 0.0 \\
\hline 131.0 \\
\hline 37.0 \\
\hline
\end{tabular}

Lower Limit ' Upper Limit

STORED TRU WASTE ESTMMATED

RATES OF WASTE GENERATION

\section{Comments}

$6 \%$ of this waste stream volume is classified as RH-TRU without current

shielding. It is anticipated that the RH-TRU portion will be shipped as CH-TRU

IYPICAL ISOTOPIC COMPOSITION

with internal shlelding.

\begin{tabular}{|c|c|c|c|}
\hline & Prolected & Final Form & \\
\hline End of 1982: & 166.6 & 166.6 & m3 \\
\hline End of 1993: & 166.6 & 166.6 & m3 \\
\hline 1994: & 0.0 & 0.0 & $\mathrm{~m} 3 / \mathrm{yr}$ \\
\hline 1985: & 0.0 & 0.0 & $\mathrm{~m} 3 / \mathrm{yr}$ \\
\hline 1986: & 0.0 & 0.0 & $\mathrm{~m} 3 / \mathrm{yr}$ \\
\hline 1887: & 0.0 & 0.0 & m3/ry \\
\hline 1988-2002: & 0.0 & $\overline{0.0}$ & $\mathrm{~m} 3 / \mathrm{yr}$ \\
\hline 2003-2022: & 0.0 & 0.0 & m3/yr \\
\hline
\end{tabular}

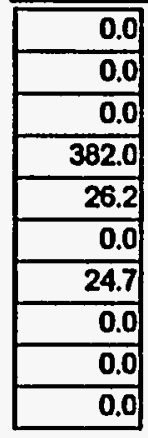

TYPICAL EPA COOES APPLICABLE

D002B

D008A

D028

D029

F001

F002

F003

F005A
Nuclide Activity

Am241 5.17E-03 Curies/m3

Pu52 1.52E+01 Curies/m3

U235 4.11E-07 Curies $/ \mathrm{m} 3$ 0 


\section{WASTE STREAM PROFILE FOR THE WIPP TRU WASTE BASELINE INVENTORY REPORT}

SITE NAME IN

WASTE TYPEMTRU HANDLING CH GENERATOR SITE MD

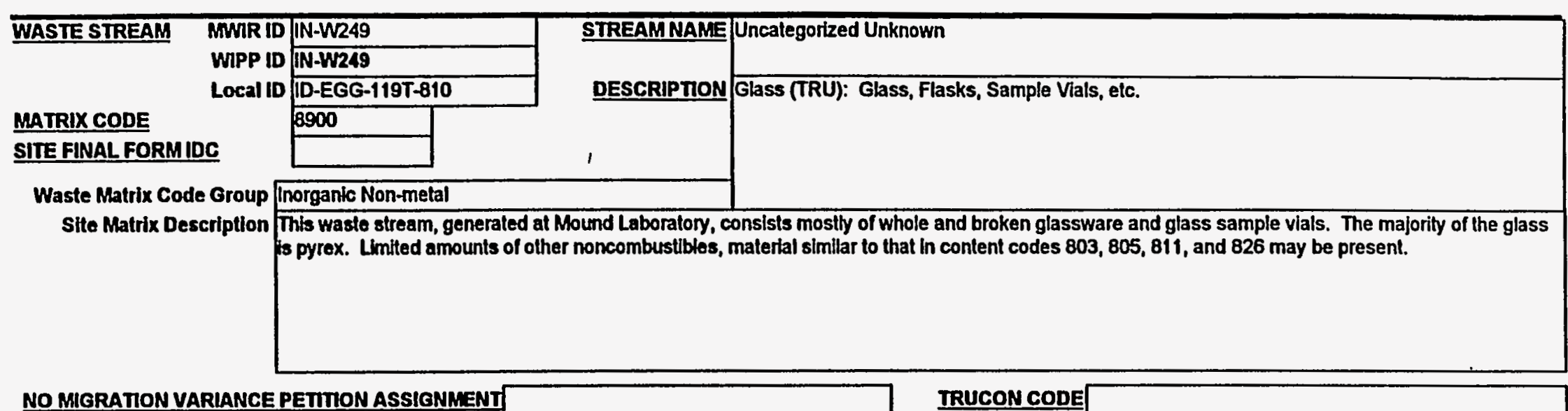

NO MIGRATION VARLANCE PETITION ASSIGNMEN

IRUCON CODE

\section{FINAL WASTE FORM DESCRIPTORS:}

\begin{tabular}{|c|c|c|}
\hline Defense TRU Waste & $x$ & Mbxed TRU \\
\hline Non-Defense TRU Waste & & Non-Mbred TRU \\
\hline Commerclal TRU Wasto & & Suspect Mbed TRU. \\
\hline Unknown & & Unknown \\
\hline
\end{tabular}

Rsearch and Devel. Waste
Operations Wasto
Residues
Decon and Decommisstoning
Environmental Restoralion
From Treatment of Waste

\begin{tabular}{|l|}
\hline$x$ \\
\hline$x$ \\
\hline$x$ \\
\hline \\
\hline \\
\hline
\end{tabular}

TSCA Asbestos
PCBs
Other
N/A
Unknown

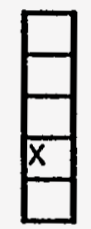

Maintenance 


\section{WASTE STREAM PROFILE FOR THE WIPP TRU WASTE BASELINE INVENTORY REPORT}

SITE NAME IN

WASTE TYPE MTRU HANDLING CH GENERATOR SITE MD

IN-W249 CONTAINER: SWB

Container Matl: steel
Int. VolvCinr: $1.9 / \mathrm{m3}$

STORED TRU WASTE ESTIMATED

Material Parameters

Iron-based Metals/Alloys

Aluminum-Based Metals/Alioys

Other Metals

Other Inorganic Materials

Cellubsics

Rubber

Plastics

Solidified, Inorganic matrbx

Solldified, Organic matrix

Solls

Packaging Materlats, Steel

Packaging Materlal, Plastlc

\begin{tabular}{|r|} 
Average \\
\hline 0.0 \\
\hline 0.0 \\
\hline 0.7 \\
\hline 130.9 \\
\hline 0.0 \\
\hline 0.5 \\
\hline 14.2 \\
\hline 0.0 \\
\hline 0.0 \\
\hline 0.0 \\
\hline 210.0 \\
\hline 16.0 \\
\hline
\end{tabular}

\begin{tabular}{|r|}
\hline Lower Limit \\
\hline 0.0 \\
\hline 0.0 \\
\hline 0.0 \\
\hline 22.5 \\
\hline 0.0 \\
\hline 0.0 \\
\hline 1.7 \\
\hline 0.0 \\
\hline 0.0 \\
\hline 0.0 \\
\hline
\end{tabular}

Upper Lmint

\begin{tabular}{|r|}
\hline $\mathbf{0 . 0}$ \\
\hline $\mathbf{0 . 0}$ \\
\hline $\mathbf{5 . 7}$ \\
\hline $\mathbf{3 7 2 . 2}$ \\
\hline $\mathbf{0 . 0}$ \\
\hline $\mathbf{3 . 8}$ \\
\hline $\mathbf{3 0 . 6}$ \\
\hline $\mathbf{0 . 0}$ \\
\hline $\mathbf{0 . 0}$ \\
\hline $\mathbf{0 . 0}$ \\
\hline
\end{tabular}

।
RATES OF WASTE GENERATION

\begin{tabular}{|c|c|c|c|}
\hline & Prolected & Final Form & \\
\hline End of 1992: & 0.8 & 1.5 & $\mathrm{m3}$ \\
\hline End of 1893: & 0.8 & 1.5 & m3 \\
\hline 1894: & 0.0 & 0.0 & $m 3 / y r$ \\
\hline 1998: & 0.0 & 0.0 & m3/yr \\
\hline 1986: & 0.0 & 0.0 & m3/yr \\
\hline 1987: & 0.0 & 0.0 & $\mathrm{~m} 3 / \mathrm{n}$ \\
\hline 1988-2002; & 0.0 & 0.0 & $\mathrm{~m} 3 / \mathrm{yr}$ \\
\hline 2003-2022: & 0.0 & 0.0 & $\mathrm{~m} 3 / \mathrm{yr}$ \\
\hline
\end{tabular}

IYPICAL EPA CODES APPLICABLE

D009A

D009D
Number Stored:

Number Projected

IYPICAL ISOTOPIC COMPOSITION

Nuclide Activity

Pu238 2.60E +02 Curies $/ \mathrm{m} 3$

Pu239 1.87E+00 Curies $/ \mathrm{m} 3$ 
WASTE STREAM PROFILE FOR THE WIPP TRU WASTE BASELINE INVENTORY REPORT

SITE NAME IN WASTE TYPE MTRU HANDLING CH GENERATOR SITE MD

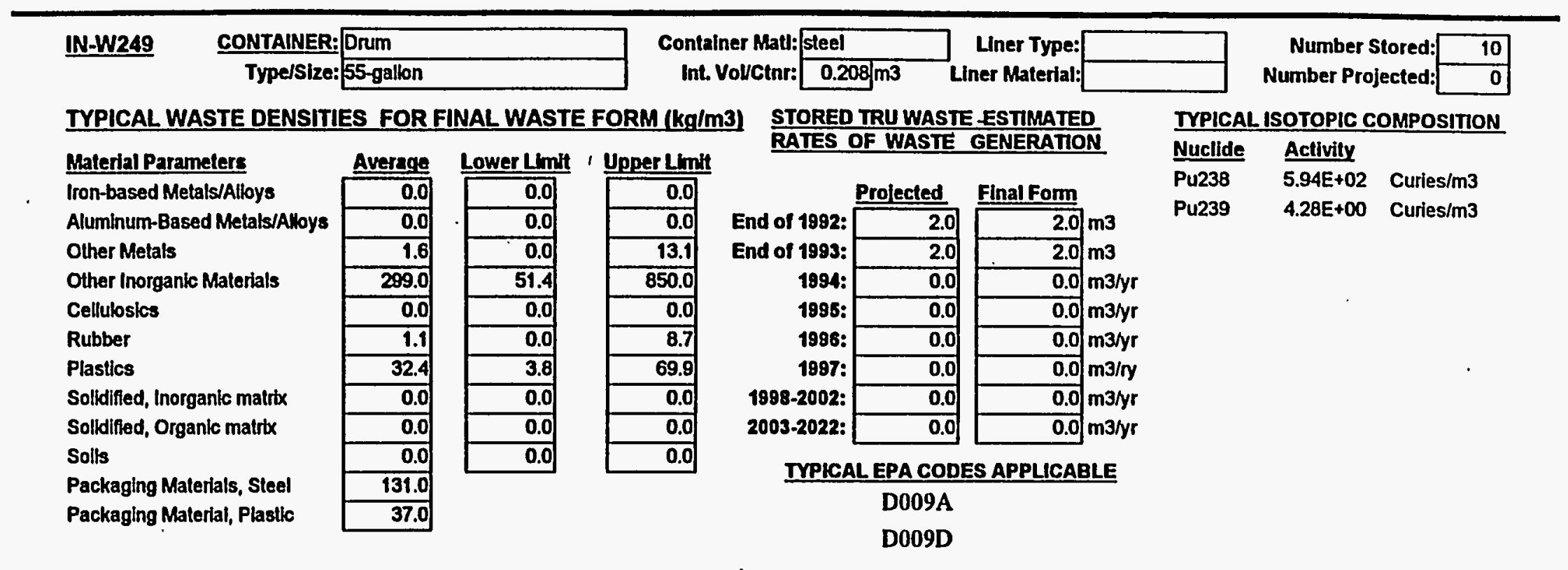


WASTE STREAM PROFILE FOR THE WIPP TRU WASTE BASELINE INVENTORY REPORT

SITE NAME IN WASTE TYPE MTRU HANDLING CH GENERATOR SITE RF

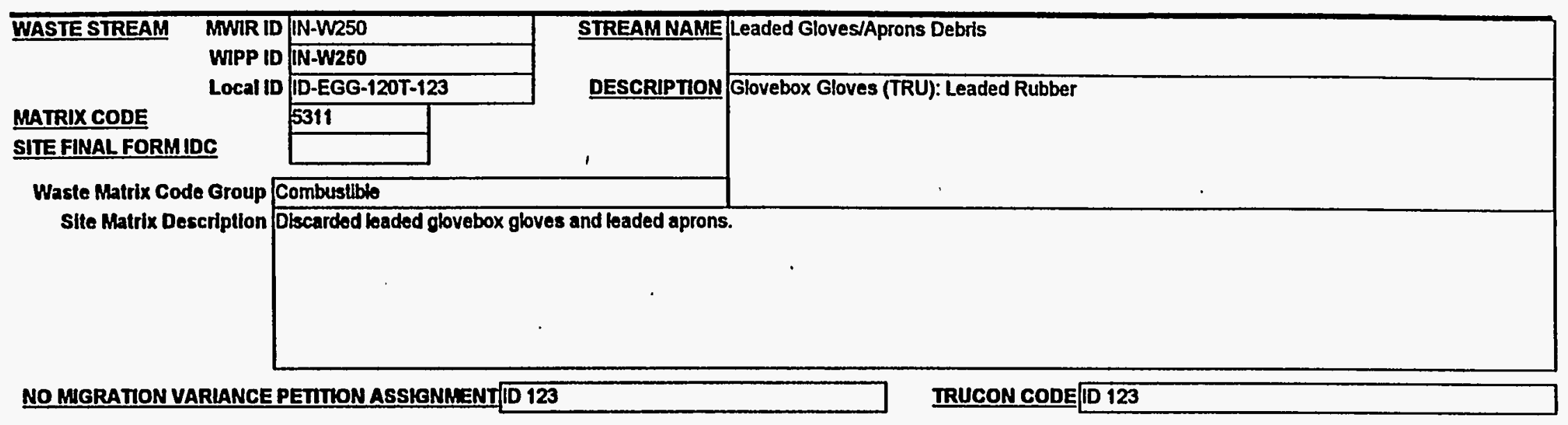

FINAL WASTE FORM DESCRIPTORS:

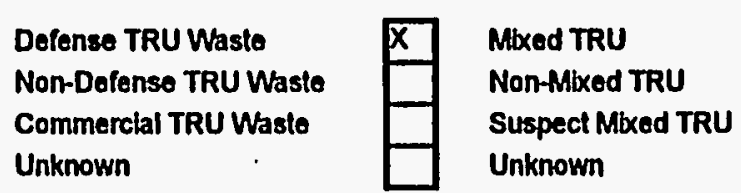

$\begin{aligned} & \text { Rsearch and Devel. Waste } \\ & \text { Operations Waste } \\ & \text { Residues }\end{aligned}$
$\begin{aligned} & \text { Decon and Decommisstoning } \\ & \text { Environmental Restoration }\end{aligned}$
$\begin{aligned} & \text { From Treatment of Waste } \\ & \text { Maintenance }\end{aligned}$




\section{WASTE STREAM PROFILE FOR THE WIPP TRU WASTE BASELINE INVENTORY REPORT}

SITE NAME IN WASTE TYPE MTRU HANDLING CH GENERATOR SITE RF

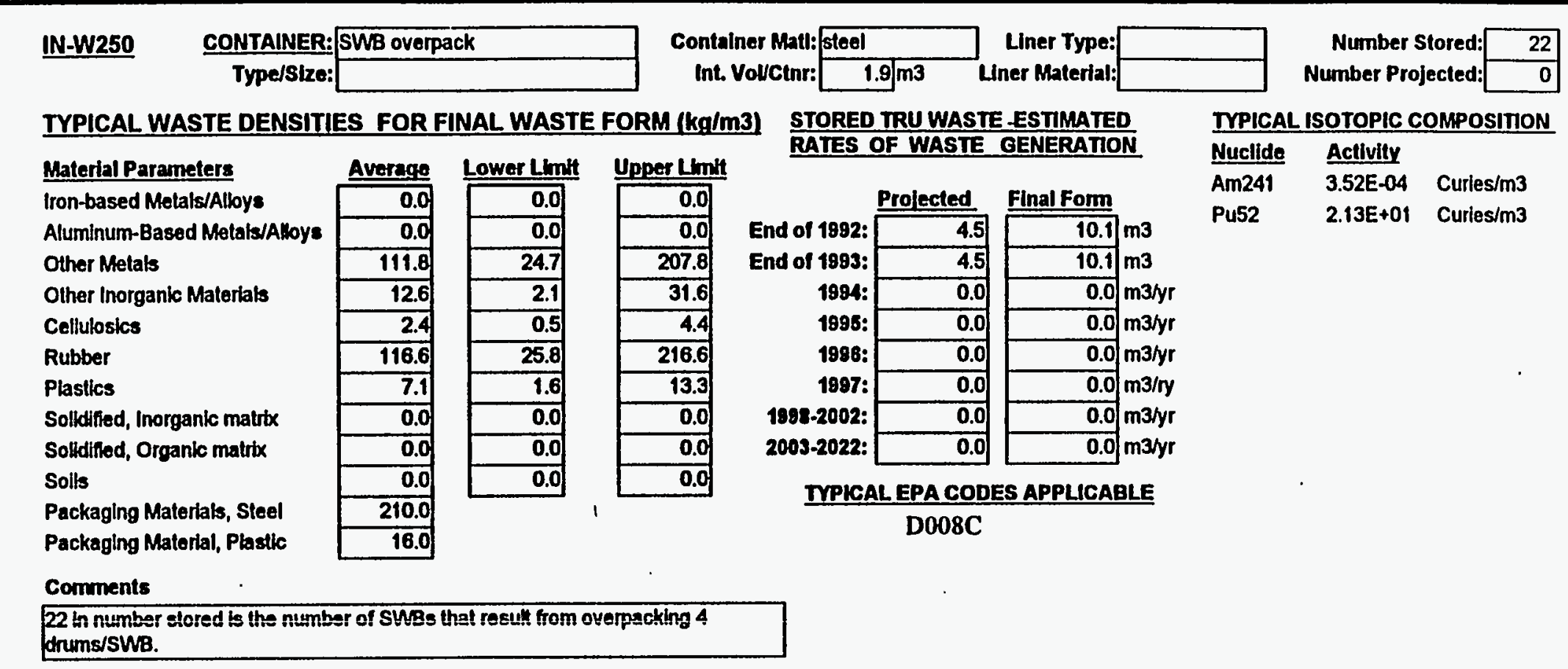




\section{WASTE STREAM PROFILE FOR THE WIPP TRU WASTE BASELINE INVENTORY REPORT}

SITE NAME IN WASTE TYPEMTRU HANDLING CH GENERATOR SITE RF

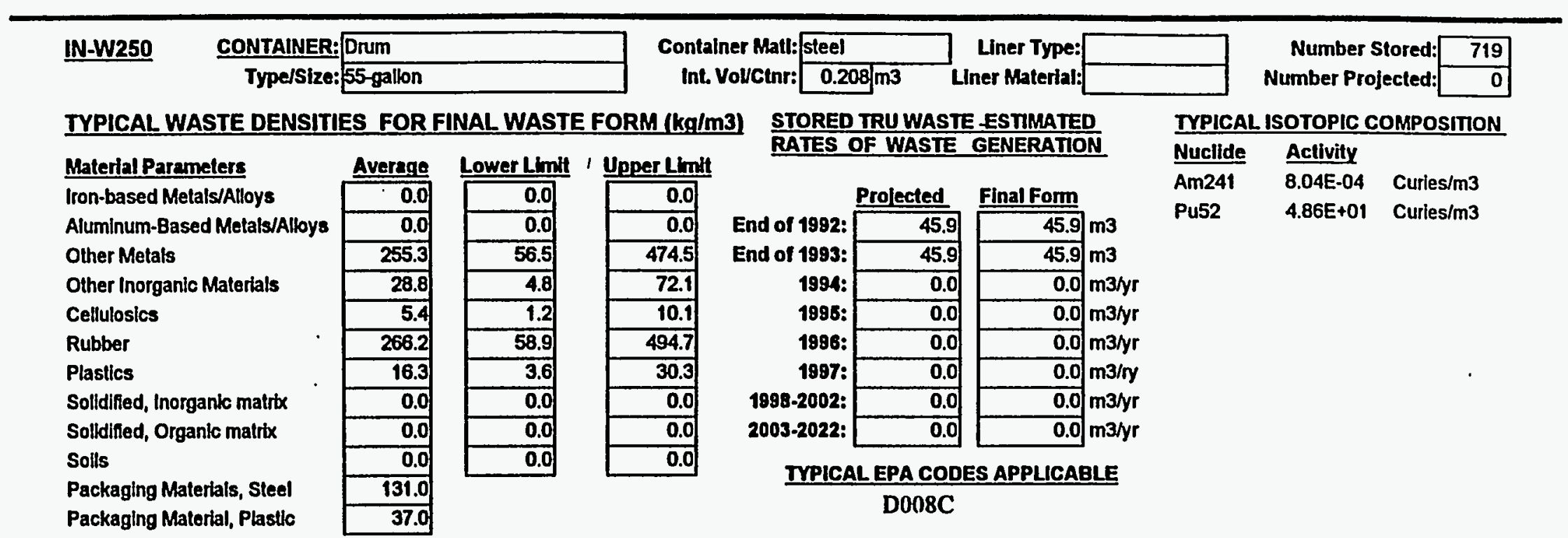




\section{WASTE STREAM PROFILE FOR THE WIPP TRU WASTE BASELINE INVENTORY REPORT}

STIE NAME IN

WASTE TYPE MTRU HANDLING CH GENERATOR SITE RF

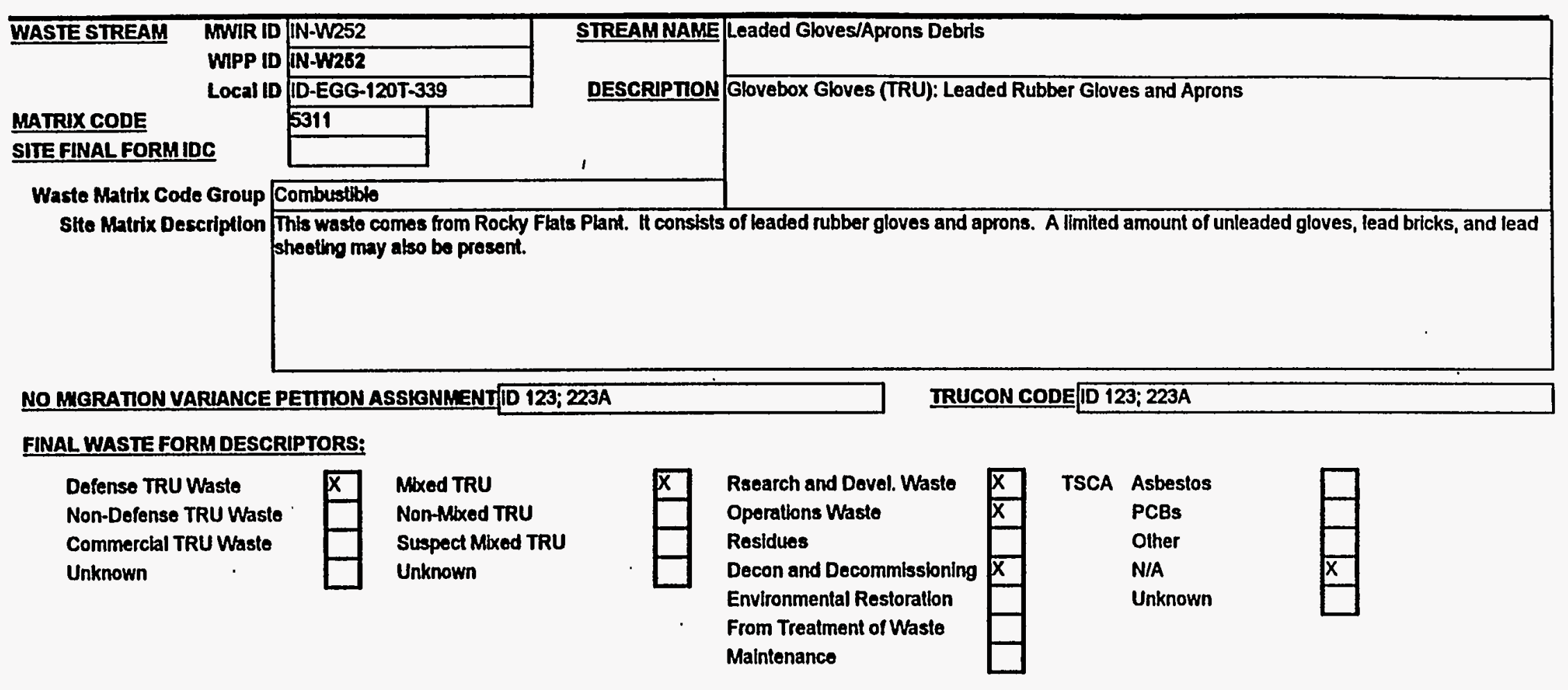


WASTE STREAM PROFILE FOR THE WIPP TRU WASTE BASELINE INVENTORY REPORT

IN-W252

$$
\text { CONTAINER: SWB overpack }
$$

Container Matt: steel

Int. Volvetnr:

$1.9 \mathrm{m3}$

Liner Type:
Liner Material:

Number Stored:

Number Projected

IYPICAL WASTE DENSITIES FOR FINAL WASTE FORM $(\mathrm{kg} / \mathrm{m} 3)$

STORED TRU WASTE -ESTIMATED RATES OF WASTE GENERATION

Material Parameters

Iron-based Metals/Altoys

Aluminum-Based Metals/Arloys

Other Metals

Other Inorganic Materials

Cellulosics

Rubber

Plastics

Solidified, Inorganke matrix

Solldified, Organlc matrbx

Solis

\begin{tabular}{|r|}
\hline Averege \\
\hline 0.0 \\
\hline 0.0 \\
\hline 0.0 \\
\hline 8.4 \\
\hline 1.6 \\
\hline 179.5 \\
\hline 5.3 \\
\hline 0.0 \\
\hline 0.0 \\
\hline 0.0 \\
\hline 210.0 \\
\hline 16.0 \\
\hline
\end{tabular}

Lower Limit Upper Lmit

\begin{tabular}{|c|c|c|c|}
\hline & Prolected & Final Form & \\
\hline End of 1992: & 37.2 & 85.0 & $\mathrm{m3}$ \\
\hline nd of 1983: & 37.2 & 85.0 & m3 \\
\hline 1994: & 0.0 & $\overline{0.0}$ & m3/yr \\
\hline 1995: & 0.0 & 0.0 & $\mathrm{~m} 3 / \mathrm{yr}$ \\
\hline 1988: & 0.0 & 0.0 & $m 3 / y r$ \\
\hline 1997: & 0.0 & 0.0 & $\mathrm{~m} 3 / \mathrm{ry}$ \\
\hline 1988-2002: & 0.0 & 0.0 & $m 3 / y r$ \\
\hline 2003-2022: & 0.0 & 0.0 & $\mathrm{~m} 3 / \mathrm{yr}$ \\
\hline
\end{tabular}

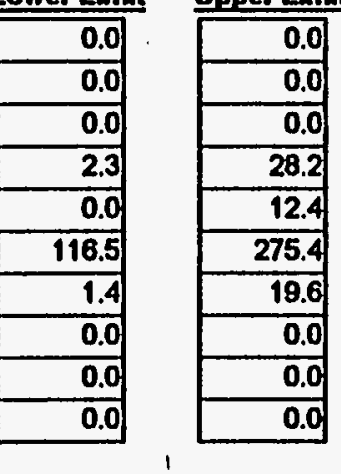

IYPICAL ISOTOPIC COMPOSITION

Nuclide Actlvity

Am241 1.13E-01 Curies/m3

Pu52 2.33E+01 Curies/m3

IVPKCAL EPA CODES APPLICABLE

D008C

D022

D028

D029

F001

F002

F003

F005A

drums/SWB.

$$
\text { FOOSA }
$$




\section{WASTE STREAM PROFILE FOR THE WIPP TRU WASTE BASELINE INVENTORY REPORT}

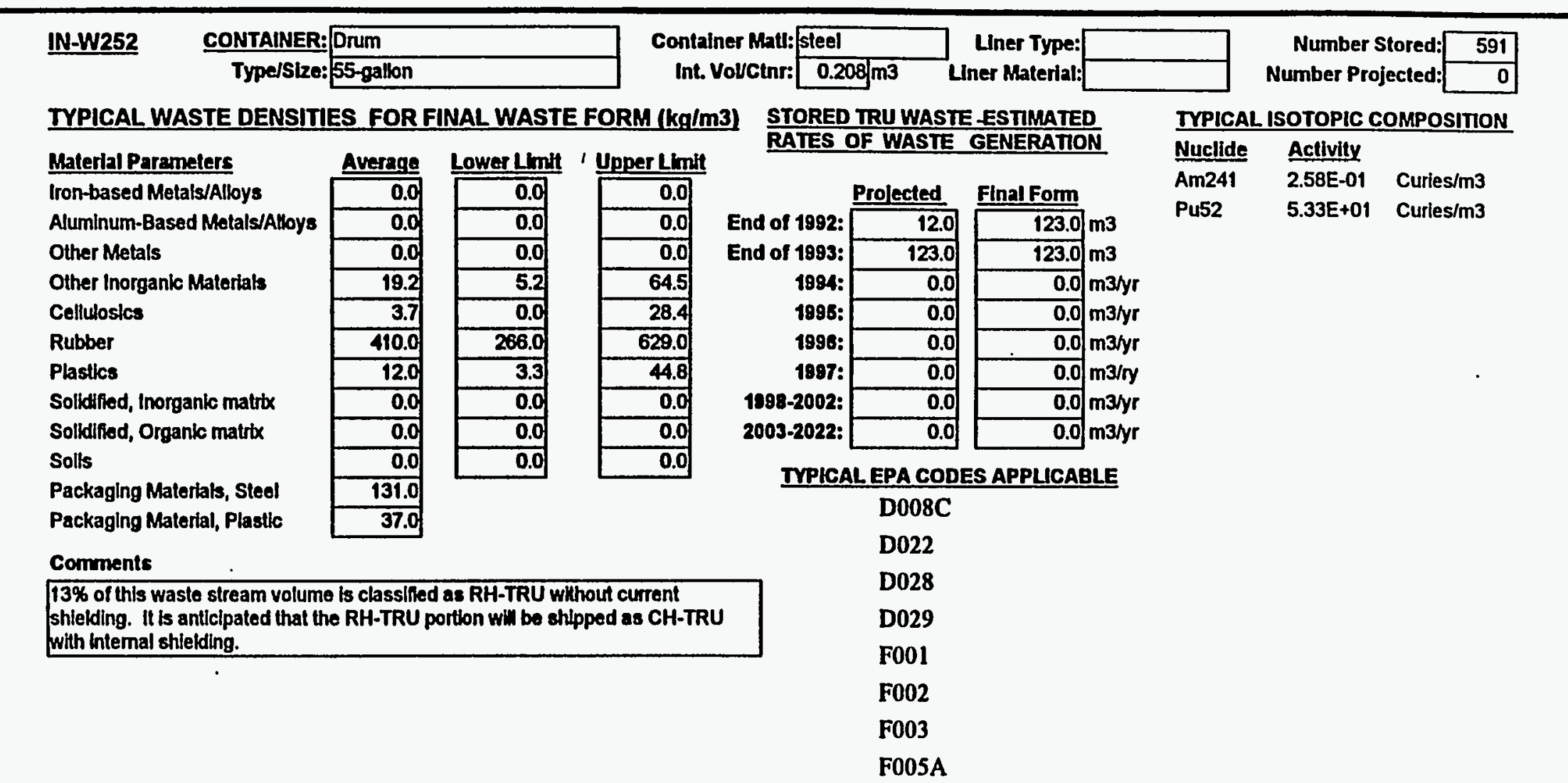


WASTE STREAM PROFILE FOR THE WIPP TRU WASTE BASELINE INVENTORY REPORT

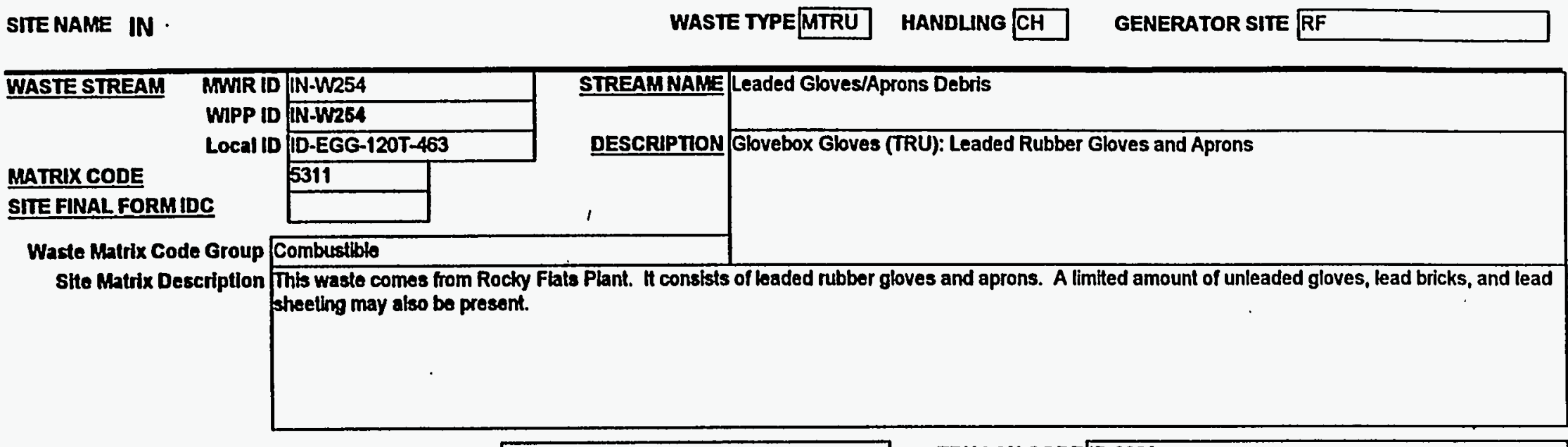

NO MGRATION VARIANCE PETINON ASSIGNMENT ID 223A IRUCON CODE

\section{FINAL WASTE FORM DESCRIPTORS:}

Defense TRU Waste

Non-Defense TRU Waste

Commerclal TRU Wasle

Unknown

$\square$

Mbeed TRU

Non-Mlxed TRU

Suspect Mixxed TRU

Unknown

$\square$

Rsearch and Devel. Waste
Operations Waste
Residues
Decon and Decommissioning
Environmental Restoration
From Treatmenl of Waste
Maintenance

\begin{tabular}{lll} 
TSCA Asbestos & \\
PCBs & \\
Other & \\
N/A & \\
Unknown & & \\
\hline
\end{tabular}




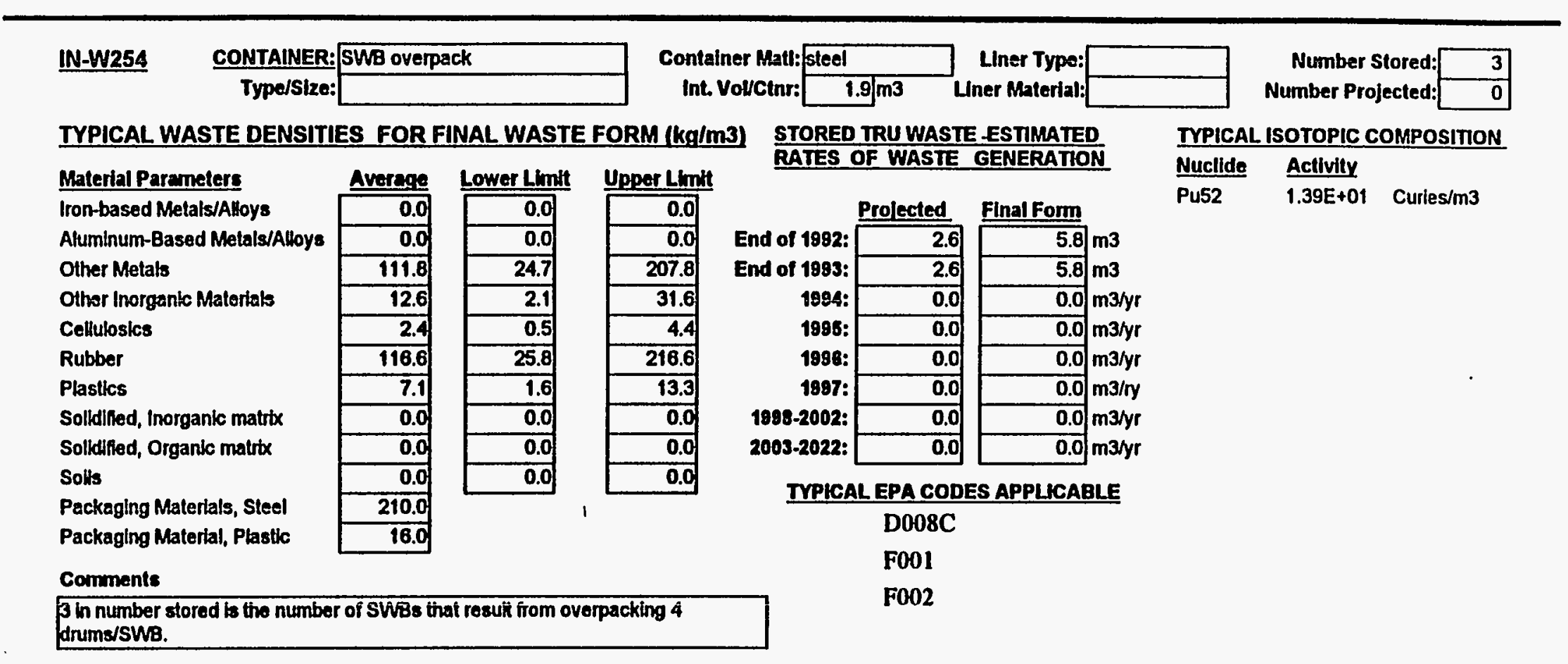


WASTE STREAM PROFILE FOR THE WIPP TRU WASTE BASELINE INVENTORY REPORT

SITE NAME IN WASTE TYPE MTRU HANDLING CH GENERATOR SITE RF

IN-W254 CONTAINER: Drum

\begin{tabular}{|c|c|c|c|c|}
\hline Container Matt: & steel & Liner Type: & Number Stored: & 35 \\
\hline Int. Volvctnr: & $0.208 / \mathrm{m3}$ & Liner Material: & Number Projected: & 0 \\
\hline
\end{tabular}

TYPICAL WASTE DENSITIES FOR FINAL WASTE FORM (kg/m3) STORED TRU WASTE.ESTIMATED

Material Parameters

Iron-based Metals/Alloys

Aluminum-Based Metals/Alloys

Other Metals

Other Inorganic Materials

Cellulosics

Rubber

Plastics

Solldified, Inorganic matrix

Solidified, Organic matrix

Solls

Packaging Materials, Steel

Packaging Material, Plastic

\begin{tabular}{|r|}
\hline Average \\
\hline 0.0 \\
\hline 0.0 \\
\hline 255.3 \\
\hline 28.8 \\
\hline 5.4 \\
\hline 266.2 \\
\hline 16.3 \\
\hline 0.0 \\
\hline 0.0 \\
\hline 0.0 \\
\hline 131.0 \\
\hline 37.0 \\
\hline
\end{tabular}

RATES OF WASTE GENERATION

\section{Comments}

$13 \%$ of this waste stream volume is classified as RH-TRU without current

\begin{tabular}{|c|c|}
\hline OWe & , Upr \\
\hline 0.0 & 0.0 \\
\hline 0.0 & 0.0 \\
\hline 56.5 & 474.5 \\
\hline 4.8 & $\overline{72.1}$ \\
\hline 1.2 & 10.1 \\
\hline 58.9 & 494.7 \\
\hline$\overline{3.6}$ & 30.3 \\
\hline 0.0 & 0.0 \\
\hline 0.0 & 0.0 \\
\hline 0.0 & 0.0 \\
\hline
\end{tabular}

\begin{tabular}{|c|c|c|c|}
\hline & Prolected & Final Form & \\
\hline End of 1992: & 7.6 & 7.6 & $\mathrm{~m} 3$ \\
\hline Id of 1993: & 7.6 & 7.6 & m3 \\
\hline 1984: & 0.0 & 0.0 & $\mathrm{~m} 3 / \mathrm{yr}$ \\
\hline 1995: & 0.0 & 0.0 & $\mathrm{~m} 3 / \mathrm{yr}$ \\
\hline 1886: & 0.0 & 0.0 & $\mathrm{~m} 3 / \mathrm{yr}$ \\
\hline 1997: & 0.0 & 0.0 & $\mathrm{~m} 3 / \mathrm{ry}$ \\
\hline 198-2002: & 0.0 & 0.0 & m3/yr \\
\hline 003-2022: & 0.0 & 0.0 & m3/yr \\
\hline
\end{tabular}

TYPICAL ISOTOPIC COMPOSITION

\section{Nuclide Activity}

Pu52 3.18E+01 Curies/m3

shielding. It is anticipaled that the RH-TRU portion will be shlpped as CH-TRU with inlernal shlelding. 


\section{WASTE STREAM PROFILE FOR THE WIPP TRU WASTE BASELINE INVENTORY REPORT}

SITENAME IN

WASTE TYPE MTRU HANDLING CH GENERATOR SITE MD

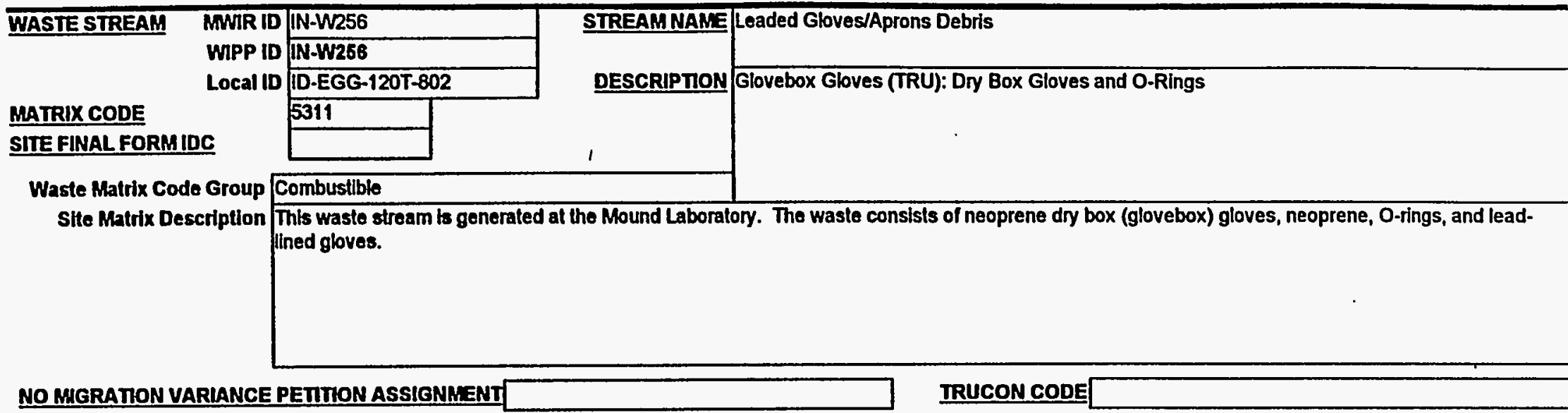

\section{FINAL WASTE FORM DESCRIPTORS:}

\begin{tabular}{l|ll} 
Defense TRU Waste & $X$ & $\begin{array}{l}\text { Mbxed TRU } \\
\text { Non-Defense TRU Waste } \\
\text { Commerclal TRU Waste } \\
\text { Unknown }\end{array}$ \\
\hline
\end{tabular}

Unknown

$\square$

\begin{tabular}{|l|}
\hline$x$ \\
\hline$x$ \\
\hline$x$ \\
\hline \\
\hline \\
\hline
\end{tabular}

TSCA Asbestos

PCBs

Other

N/A

Unknown

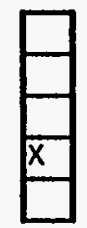




\section{WASTE STREAM PROFILE FOR THE WIPP TRU WASTE BASELINE INVENTORY REPORT}

SITENAME IN

WASTE TYPE MTRU HANDLING CH GENERATOR SITE MD

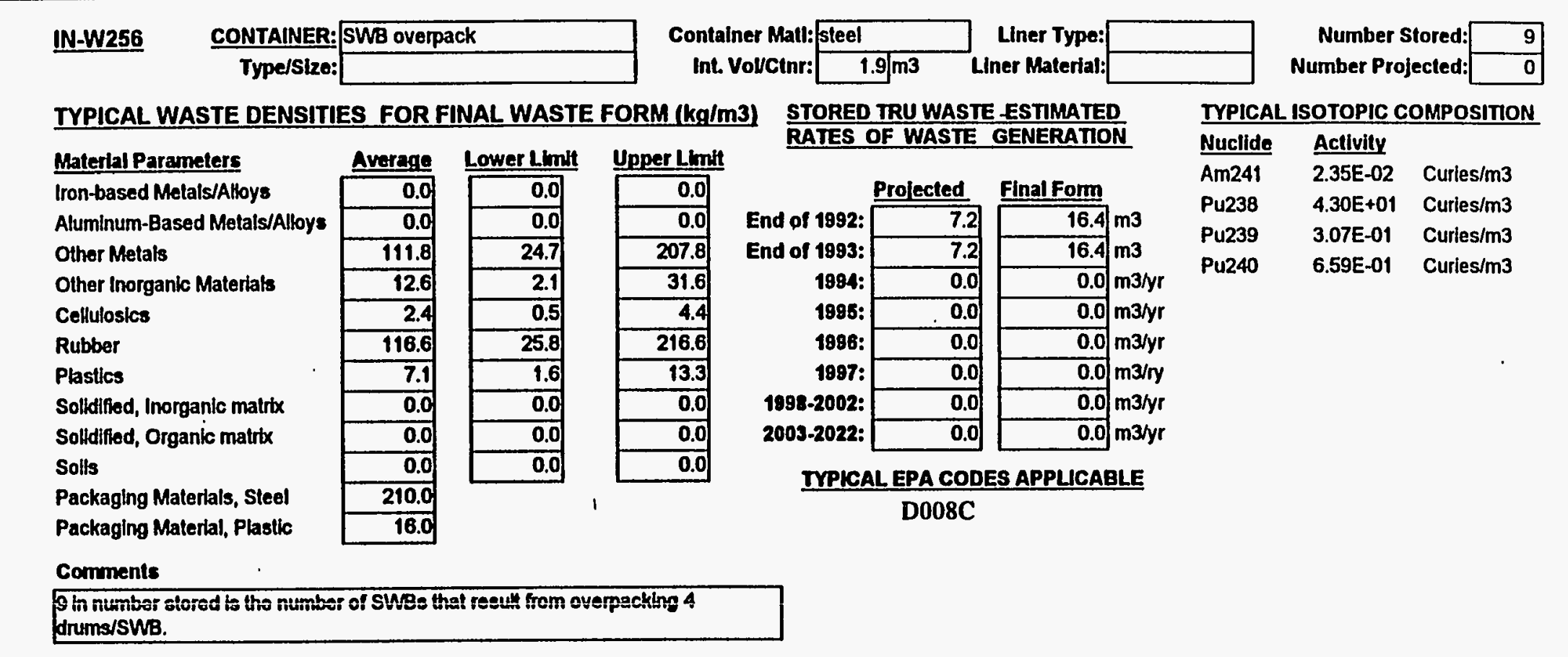




\section{WASTE STREAM PROFILE FOR THE WIPP TRU WASTE BASELINE INVENTORY REPORT}

SITE NAME IN

WASTE TYPE MTRU HANDLING CH GENERATOR SITE MD

IN-W256

CONTAINER: Drum

Container Matl: steel

Int. VolvCtnr: $0.208 \mathrm{~m} 3$

Liner Type:

Liner Material:

TYPICAL WASTE DENSITIES FOR FINAL WASTE FORM (kg/m3)

Materlal Parameters

Iron-based Metals/Alloys

Aluminum-Based Melals/Alloys

Olher Metals

Other Inorganle Materials

Cellulosics

Rubber

Plastics

Solldified, Inorganic matrtx

Solldified, Organic matrix

Soils

Packaging Materials, Steel

Packaging Materlal, Plastic
STORED TRU WASTE ESTIMATED RATES OF WASTE GENERATION

Upper Linit

\begin{tabular}{|r|}
\hline Lower Limit \\
\hline 0.0 \\
\hline 0.0 \\
\hline 56.5 \\
\hline 4.8 \\
\hline 1.2 \\
\hline 58.9 \\
\hline 3.6 \\
\hline 0.0 \\
\hline 0.0 \\
\hline 0.0 \\
\hline
\end{tabular}

\begin{tabular}{|r|}
\hline 0.0 \\
\hline 0.0 \\
\hline 474.5 \\
\hline 72.1 \\
\hline 10.1 \\
\hline 494.7 \\
\hline 30.3 \\
\hline 0.0 \\
\hline 0.0 \\
\hline 0.0 \\
\hline
\end{tabular}

37.0

$$
\text { En }
$$

Number Stored: Number Projected:

IYPICAL ISOTOPIC COMPOSITION

Nuclide Activity

Am241 5.36E-02 Curies/m3

Pu238 9.82E+01 Curies $/ \mathrm{m}^{3}$

Pu239 7.00E-01 Curies/m3

Pu240 1.50E+00 Curies $/ \mathrm{m} 3$ 
WASTE STREAM PROFILE FOR THE WIPP TRU WASTE BASELINE INVENTORY REPORT

SITE NAME IN

WASTE TYPE MTRU HANDLING CH GENERATOR SITE AE

\begin{tabular}{|c|c|c|c|c|}
\hline \multirow[t]{3}{*}{ WASTE STREAM } & MWIR ID & IN-W259 & \multirow{3}{*}{$\begin{array}{l}\text { STREAMNAME } \\
\text { DESCRIPTION }\end{array}$} & \multirow{2}{*}{ Heterogeneaus Debris } \\
\hline & \multirow{3}{*}{$\begin{array}{l}\text { WIPP ID } \\
\text { Local iD }\end{array}$} & IN-W/269 & & \\
\hline & & ID-EGG-144T-104 & & \multirow[t]{4}{*}{ Radioactive Sources (TRU): Alpha Hot Cell Waste } \\
\hline \multirow{2}{*}{\multicolumn{2}{|c|}{$\begin{array}{l}\text { MATIRIX CODE } \\
\text { SITE FINAL FORMIDC }\end{array}$}} & 5400 & & \\
\hline & & & 1 & \\
\hline \multicolumn{4}{|c|}{ Waste Matrix Code Group Heterogeneous } & \\
\hline \multicolumn{2}{|c|}{ Ste Matrix Descriptlon } & \multicolumn{3}{|c|}{$\begin{array}{l}\text { This waste stream, generated at Argonne National Laboralory-East, contalns alpha hof cell waste. Noncombustible and combustible waste are } \\
\text { segregated. Combustible wastes include: paper, plastic and PVC containers, rubber O-rings and gloves, rags, and Q-tips. Noncombustible wasles } \\
\text { include: lab equlpment, tools, fixtures, glassware, pipe, tubing, fitting, fastners, firebrick, ferrous and nonferrous metal scraps and parts, and small } \\
\text { electric motors. Sodlum in the wasto is reacted with ethyl alcohol, mbxed with pellelized clay, and dried. Nitrates and oxidizing agents are neutralized } \\
\text { or reduced, mbed with pelletized clay, and } 72 \text { to ferrour or ferric salts. }\end{array}$} \\
\hline
\end{tabular}

\section{FINAL WASTE FORMDESCRIPTORS:}

\begin{tabular}{l|ll} 
Defense TRU Wasle & $X$ & $\begin{array}{l}\text { Mixed TRU } \\
\text { Non-Mixed TRU } \\
\text { Non-Defense TRU Waste } \\
\text { Commerclal TRU Waste } \\
\text { Unknown }\end{array}$ \\
\hline & $\square$ & \\
Unknown
\end{tabular}

Rsearch and Devel. Waste

Operations Waste

Residues

Decon and Decommissloning Environmental Restoration

From Treatment of Waste Maintenance

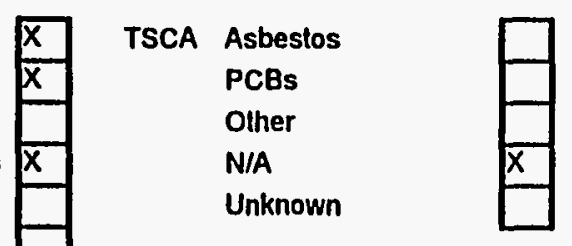


WASTE STREAM PROFILE FOR THE WIPP TRU WASTE BASELINE INVENTORY REPORT

SITE NAME IN

WASTE TYPEMTRU HANDLING CH GENERATOR SITE AE

\begin{tabular}{|c|c|c|c|c|c|c|c|c|c|c|c|}
\hline$\frac{\text { CONTAINER: }}{\text { Type/SIze: }}$ & \begin{tabular}{|l} 
Drum \\
55 -gallon
\end{tabular} & & $\begin{array}{l}\text { Cont: } \\
\text { Int }\end{array}$ & Container Matt: steel & $08 / \mathrm{m}^{3}$ & $\begin{array}{l}\text { Liner Type: } \\
\text { iner Materlat: }\end{array}$ & & & \multicolumn{2}{|c|}{$\begin{array}{l}\text { Number Stored: } \\
\text { Number Projected: }\end{array}$} & $\frac{283}{0}$ \\
\hline \multicolumn{4}{|c|}{ IYPICAL WASTE DENSITIES FOR FINAL WASTE FORM $(\mathrm{kg} / \mathrm{m} 3)$} & \multicolumn{4}{|c|}{ STORED TRU WASTE -ESTIMATED } & \multicolumn{4}{|c|}{ TYPICAL ISOTOPIC COMPOSITION } \\
\hline Material Parametere & Avrang & I nuer I mitt & Ilnner I mh & RATES & OF WASTE & GENERATIO & & Nuclide & Actlvity & & \\
\hline Iron-based Melals/Alloys & $\overline{96.2}$ & 0.0 & 1634.6 & & Prolected & Final Form & & Pu239 & 2.45E-01 & Curles & \\
\hline Aluminum-Based Metals/Alloys & 0.0 & 0.0 & 1.6 & End of 1892: & 58.8 & 58.8 & m3 & Pu240 & 2.71E-02 & Curies & \\
\hline Other Metals & 0.1 & 0.0 & 22.7 & End of 1983: & $\overline{58.8}$ & $\overline{58.8}$ & m3 & & & Curles & \\
\hline Other Inorganic Materbals & 2.4 & 0.0 & 24.0 & 1984: & 0.0 & 0.0 & $\mathrm{~m} 3 / \mathrm{yr}$ & & & & \\
\hline Cellulosics & 80.9 & 0.0 & 184.8 & 1985: & 0.0 & 0.0 & $\mathrm{~m} 3 / \mathrm{yr}$ & & & & \\
\hline Rubber. & 7.3 & 0.0 & 16.4 & 1996: & 0.0 & $\overrightarrow{0.0}$ & m3/yr & & & & \\
\hline Plastics & 64.9 & 0.0 & 149.0 & 1997: & 0.0 & 0.0 & $m 3 / r y$ & & & & · \\
\hline Solidlifed, Inorganle matrbx & 0.0 & 0.0 & 0.0 & 1988-2002: & 0.0 & 0.0 & $m 3 / y r$ & & & & \\
\hline Solidlfied, Organic matrix & 0.0 & 0.0 & 0.0 & 2003-2022: & 0.0 & 0.0 & $\mathrm{~m} 3 / \mathrm{yr}$ & & & & \\
\hline Solis & 0.0 & 0.0 & 0.0 & & 19 & $\operatorname{cose}$ - 25 & $\mathbf{E}=$ & & & & \\
\hline $\begin{array}{l}\text { Packaging Materials, Steel } \\
\text { Packaging Material, Plastlc }\end{array}$ & $\frac{131.0}{37.0}$ & & & & D008A & & & - & & & \\
\hline
\end{tabular}


WASTE STREAM PROFILE FOR THE WIPP TRU WASTE BASELINE INVENTORY REPORT

SITE NAME IN

WASTE TYPEMTRU HANDLING CH GENERATOR SITE BT

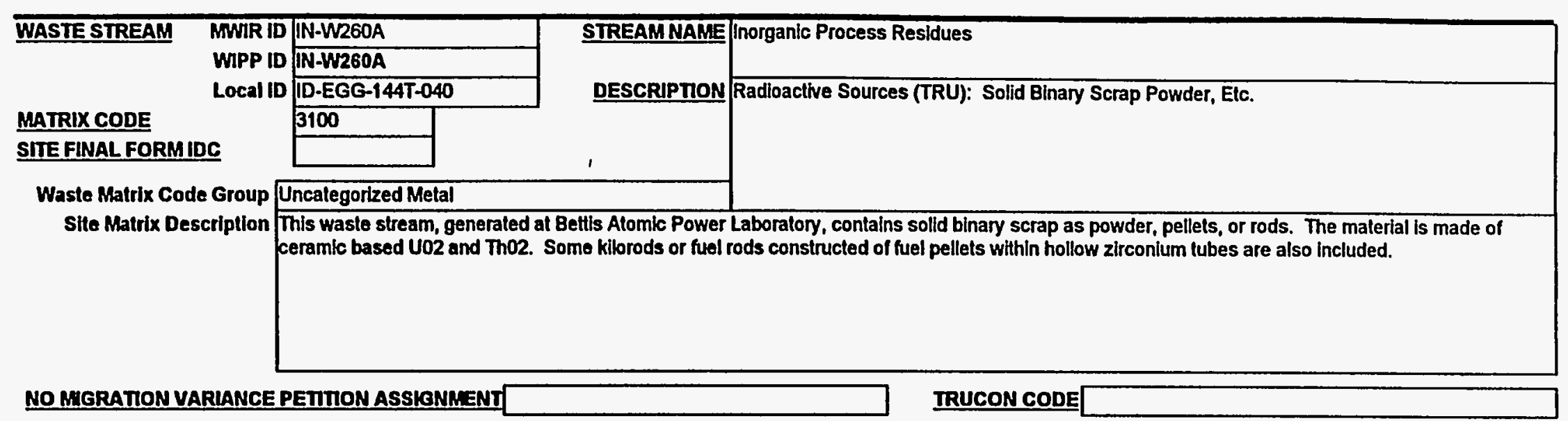

\section{FINAL WASTE FORM DESCRIPTORS:}

\begin{tabular}{|c|c|}
\hline Defense TRU Waste & Mbxed TRU \\
\hline Non-Defense TRU Waste & Non-Mbed TRंU \\
\hline Commercial TRU Wasto & Suspect Mixed TRU \\
\hline Unknown & Unknown \\
\hline
\end{tabular}

Rsearch and Devel. Waste
Operallons Waste
Residues
Decon and Decommissioning
Environmental Restoration
From Trealment of Waste
Malntenance

\begin{tabular}{|l|}
\hline$x$ \\
\hline$x$ \\
\hline$x$ \\
\hline \\
\hline \\
\hline
\end{tabular}

TSCA Asbestos

PCBs

Other

N/A

Unknown 
WASTE STREAM PROFILE FOR THE WIPP TRU WASTE BASELINE INVENTORY REPORT

STIE NAME IN

WASTE TYPE MTRU HANDLING CH GENERATOR SITE BT

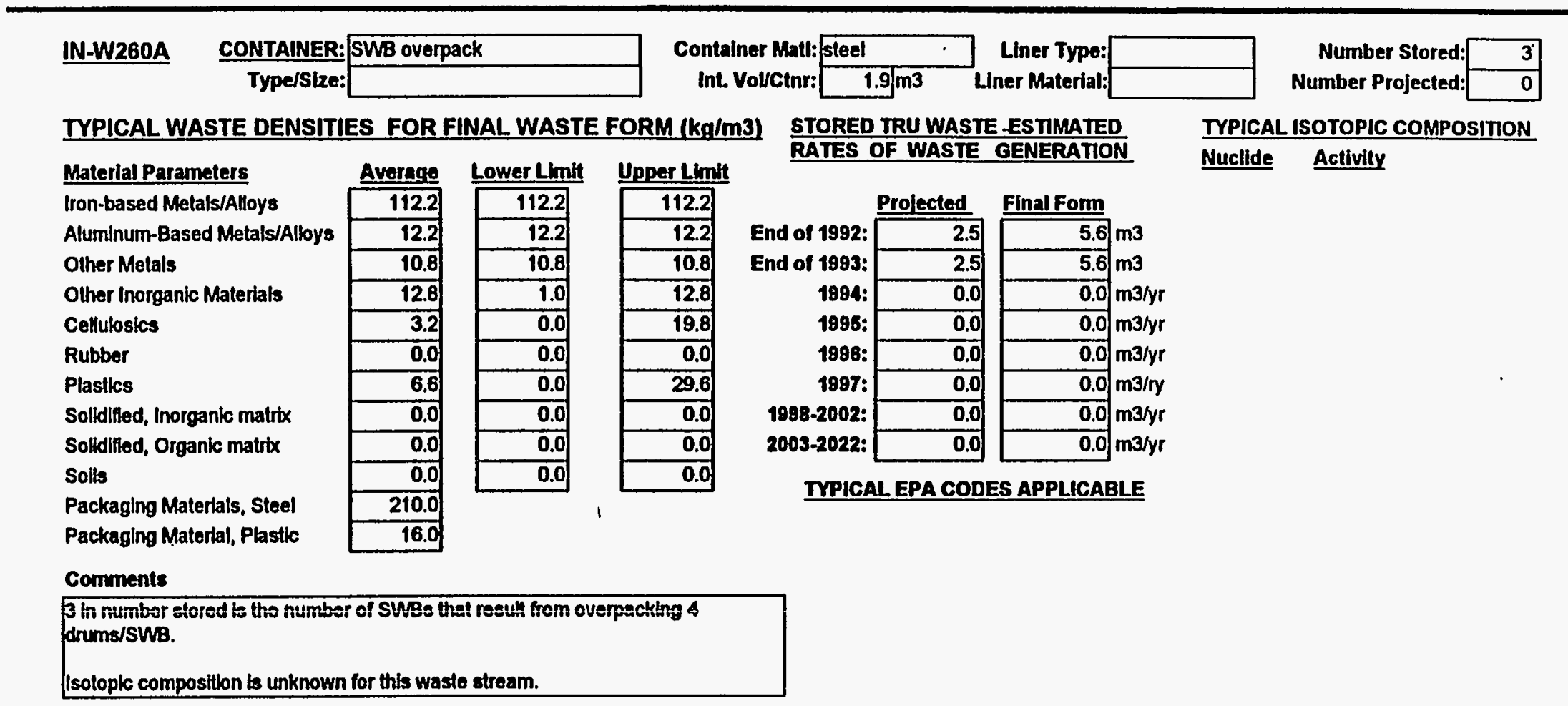


WASTE STREAM PROFILE FOR THE WIPP TRU WASTE BASELINE INVENTORY REPORT

SITE NAME IN WASTE TYPE MTRU HANDLING CH GENERATOR SITE BT

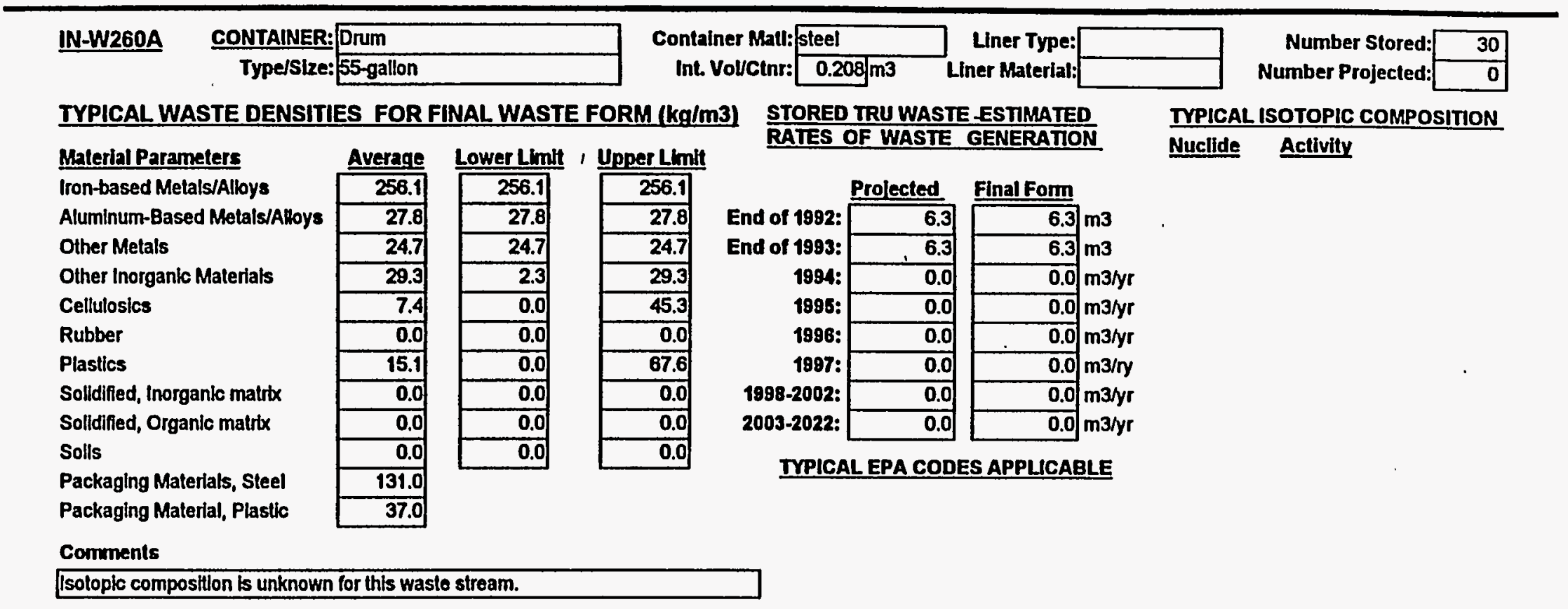




\section{WASTE STREAM PROFILE FOR THE WIPP TRU WASTE BASELINE INVENTORY REPORT}

SITE NAME IN

WASTE TYPE MTRU HANDLING RH GENERATOR SITE BT

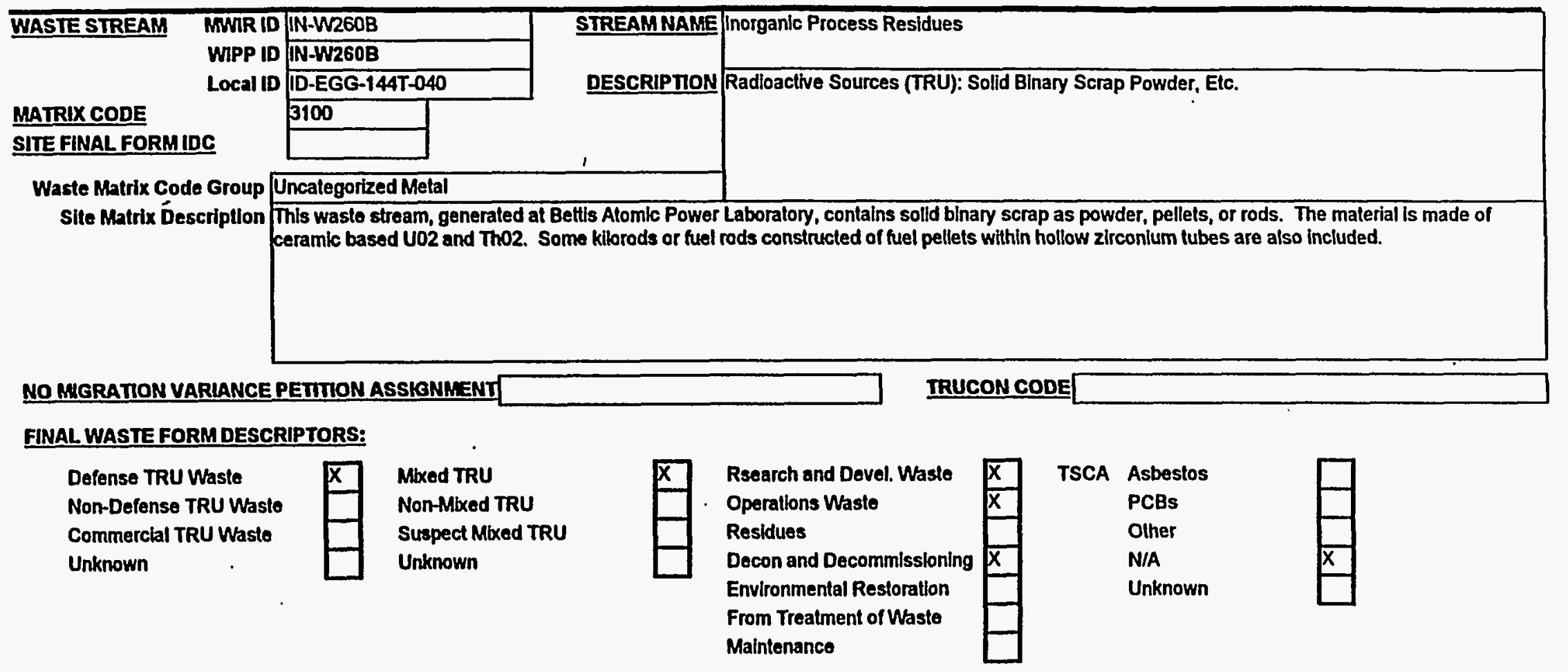




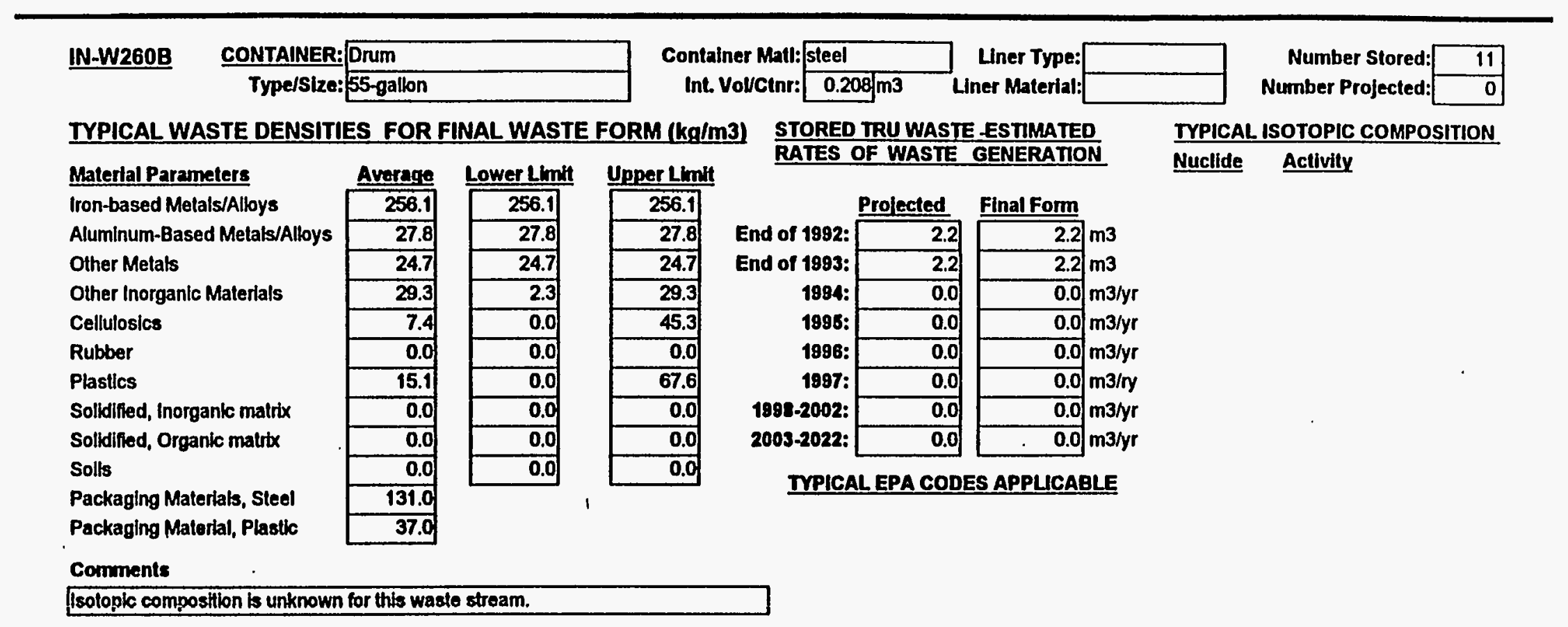


WASTE STREAM PROFILE FOR THE WIPP TRU WASTE BASELINE INVENTORY REPORT

SITE NAME IN

WASTE TYPE MTRU HANDLING CH GENERATOR SITE MD

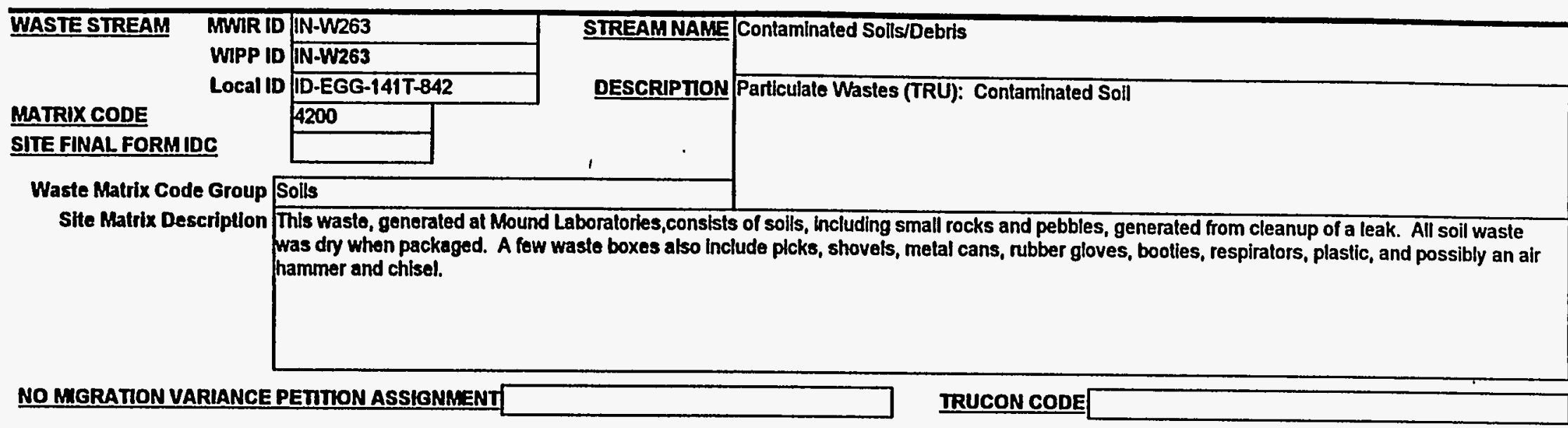

\section{FINAL WASTE FORM DESCRIPTORS:}

Defense TRU Waste

Non-Defense TRU Wasto

Commerclal TRU Waste

Unknown

$\square$

Mixed TRU

Non-Mbed TRU

Suspect Mixed TRU

Unknown

Rsearch and Devel. Wasto

Operations Waste

Residues

Decon and Decommissioning $X$

Environmental Restoralion

From Treatment of Waste

Maintenance
TSCA Asbestos

PCBs

Olher

N/A

Unknown

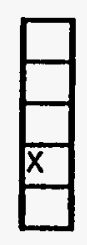




\section{WASTE STREAM PROFILE FOR THE WIPP TRU WASTE BASELINE INVENTORY REPORT}

SITE NAME IN

WASTE TYPE MTRU HANDLING CH GENERATOR SITE MD

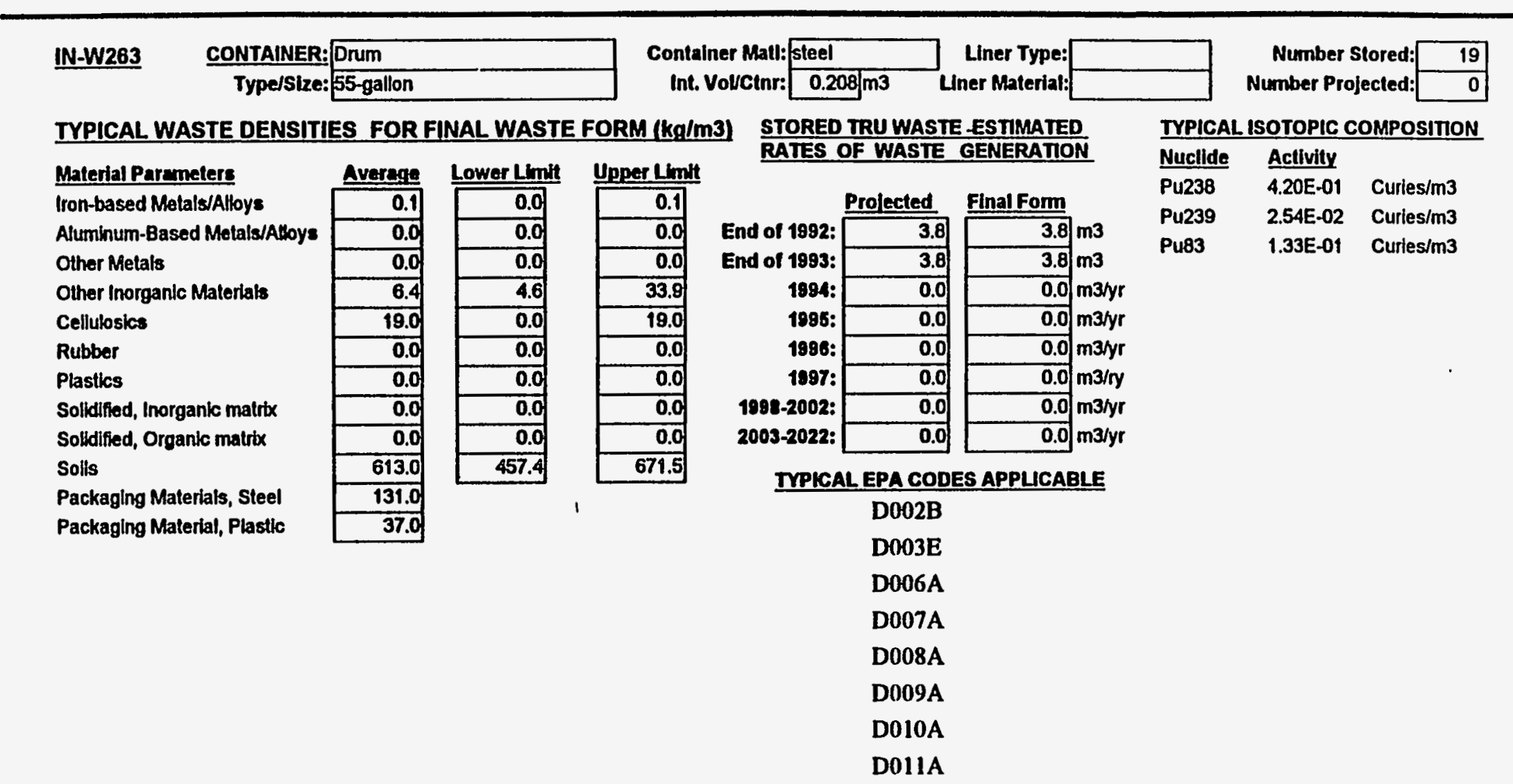




\section{WASTE STREAM PROFILE FOR THE WIPP TRU WASTE BASELINE INVENTORY REPORT}

SITE NAME IN WASTE TYPEMTRU HANDLING CH GENERATOR SITE RF

\begin{tabular}{|c|c|c|c|c|}
\hline \multirow{4}{*}{\multicolumn{2}{|c|}{$\begin{array}{ll}\text { WASTE STREAM MMIRID } \\
\text { WIPP ID } \\
\text { LOCal ID } \\
\text { MATRIX CODE }\end{array}$}} & IN-W265 & \multirow{3}{*}{$\begin{array}{l}\text { STREAMNAME } \\
\text { DESGRIPTION }\end{array}$} & \multirow[t]{2}{*}{ Predominately Inorganic Non-metal Debris } \\
\hline & & NN-W265 & & \\
\hline & & ID-EGG-141T-374 & & \multirow[t]{4}{*}{ Particulate Wastes (TRU): Blacktop, Concrete, Dirt and Sand } \\
\hline & & 5430 & & \\
\hline \multicolumn{2}{|c|}{ SITE FINAL FORMIDC } & & 1 & \\
\hline \multirow{2}{*}{\multicolumn{2}{|c|}{$\begin{array}{l}\text { Waste Matrix Code Group } \\
\text { site Matrix Description }\end{array}$}} & Helerogeneous & & \\
\hline & & \multicolumn{3}{|c|}{$\begin{array}{l}\text { This wasto contalns blacktop, concrete, reinforced concrete, clnderblocks, bricks, dirt and sand. Limited amounts of waste may be damp. A limited } \\
\text { amount may contain combustibtes such as coveralts and gloves. The waste is generated from cleanup of spills and leaks, process changes, } \\
\text { maintenance, and D\&D operations. Portland cement is added to containers that contain wet or damp wasle. }\end{array}$} \\
\hline
\end{tabular}

NO MGRATION VARIANCE PETITION ASSIGNMENTID 121

IRUCON CODE 10121

FINAL WASTE FORM DESCRIPTORS:

Defense TRU Waste

Non-Defense TRU Waste

Commerclal TRU Waste

Unknown

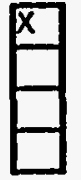

Mixed TRU

Non-Mixed TRU

Suspect Moxed TRU

Unknown

$\square$

Rsearch and Devel. Waste
Operations Waste
Residues
Decon and Decommissioning
Environmental Restoration
From Treatment of Waste
Maintenance

\begin{tabular}{ll|} 
TSCA Asbeslos & \\
PCBs & \\
Other & \\
N/A & \\
Unknown &
\end{tabular}




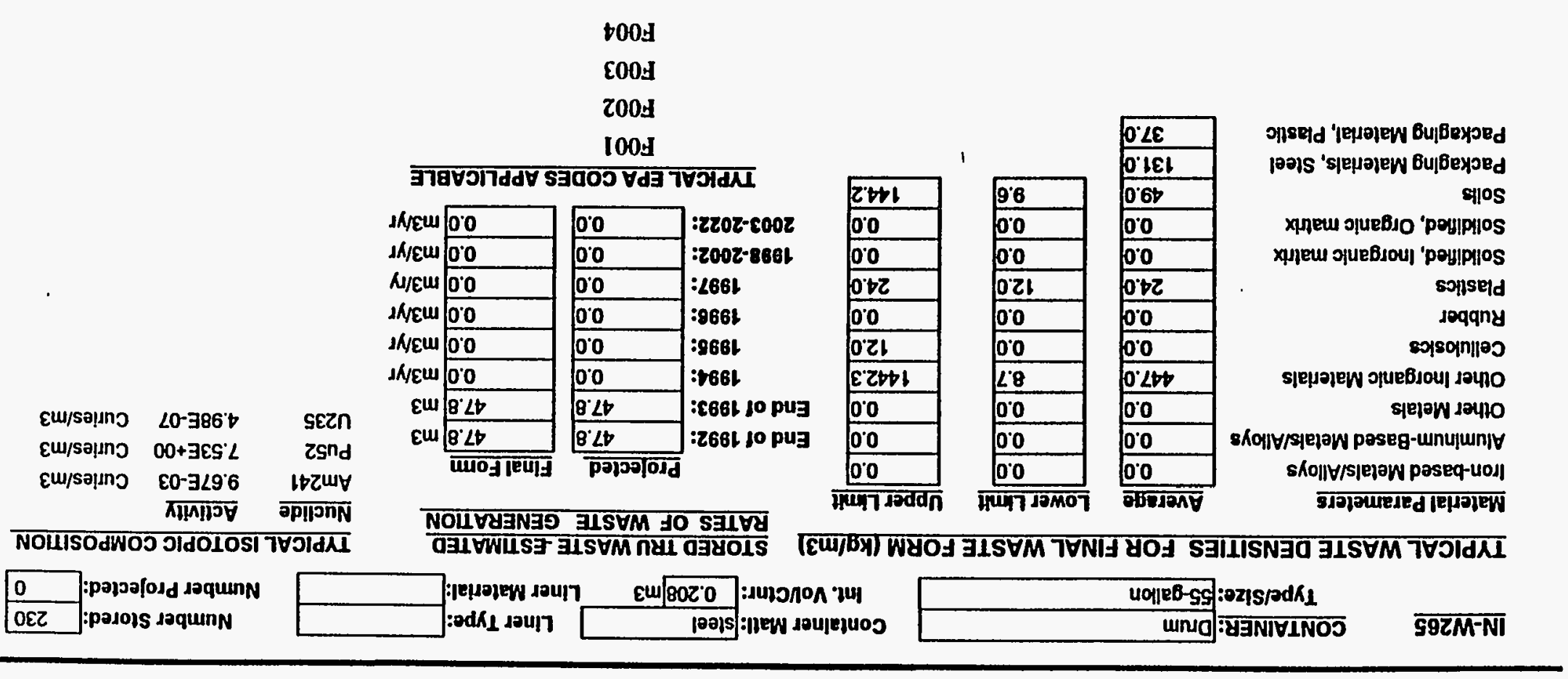


WASTE STREAM PROFILE FOR THE WIPP TRU WASTE BASELINE INVENTORY REPORT

SITE NAME IN

WASTE TYPE MTRU

HANDLING CH

GENERATOR SITE IN, AW

\begin{tabular}{|c|c|c|c|}
\hline WASTE STREAM & D/IN-W269A & \multirow{3}{*}{$\begin{array}{l}\text { STREAMNAME } \\
\text { DESCRIPTON }\end{array}$} & \multirow[t]{2}{*}{ Debris Waste } \\
\hline WIPP ID & D IN-W269A & & \\
\hline Local ID & DID-EGG-141T-150 & & Particulato Wastes (TRU): Laboralory Waste \\
\hline MATRIX CODE & 5000 & & \\
\hline SITEFINAL FORMIDC & & 1 & \\
\hline \multicolumn{2}{|c|}{ Waste Matrix Code Group Helerogeneous } & & . \\
\hline Site Matrix Description & \multicolumn{3}{|c|}{$\begin{array}{l}\text { This waste stream, generated at Idaho Nalional Engineering Laboratory, contalns laboratory waste from ANL-Wincluding fluxwire, fission counters, } \\
\text { HEDL samples, analytical samples dissolved and absorbed on Oil-Dil, glassware, vials, miscellaneous waste from gloveboxes, dissolved pellets } \\
\text { absorbed on Oil-Dri, enriched and normal U308 pellels, aluminum foll and capsules, TREAT waste capsules, chlorinated lon exchange resins, Pu } \\
\text { sources, and irradlated GE ca??. Lab waste from ICPP includes Kmwipes, trash, glassware, dissolved camples absorbed in Oil-Dri, analytical } \\
\text { samples, gloves, etc. }\end{array}$} \\
\hline
\end{tabular}

NO MGRATON YARIANCE PETIONON ASSIGNMENT

IRUGON CODE

\section{FINAL WASTE FORM DESCRIPTORS:}

\begin{tabular}{l|l} 
Defense TRU Waste \\
Non-Defense TRU Waste \\
Commercial TRU Waste \\
Unknown
\end{tabular}$\quad \square \quad \begin{aligned} & \text { Mixed TRU } \\
& \text { Non-Mbeed TRU } \\
& \text { Suspect Mbxed TRU } \\
& \text { Unknown }\end{aligned}$

Unknown

$\square$

TSCA Asbestos
PCBs
Other
N/A
Unknown

From Treatment of Waste

Maintenance

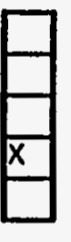




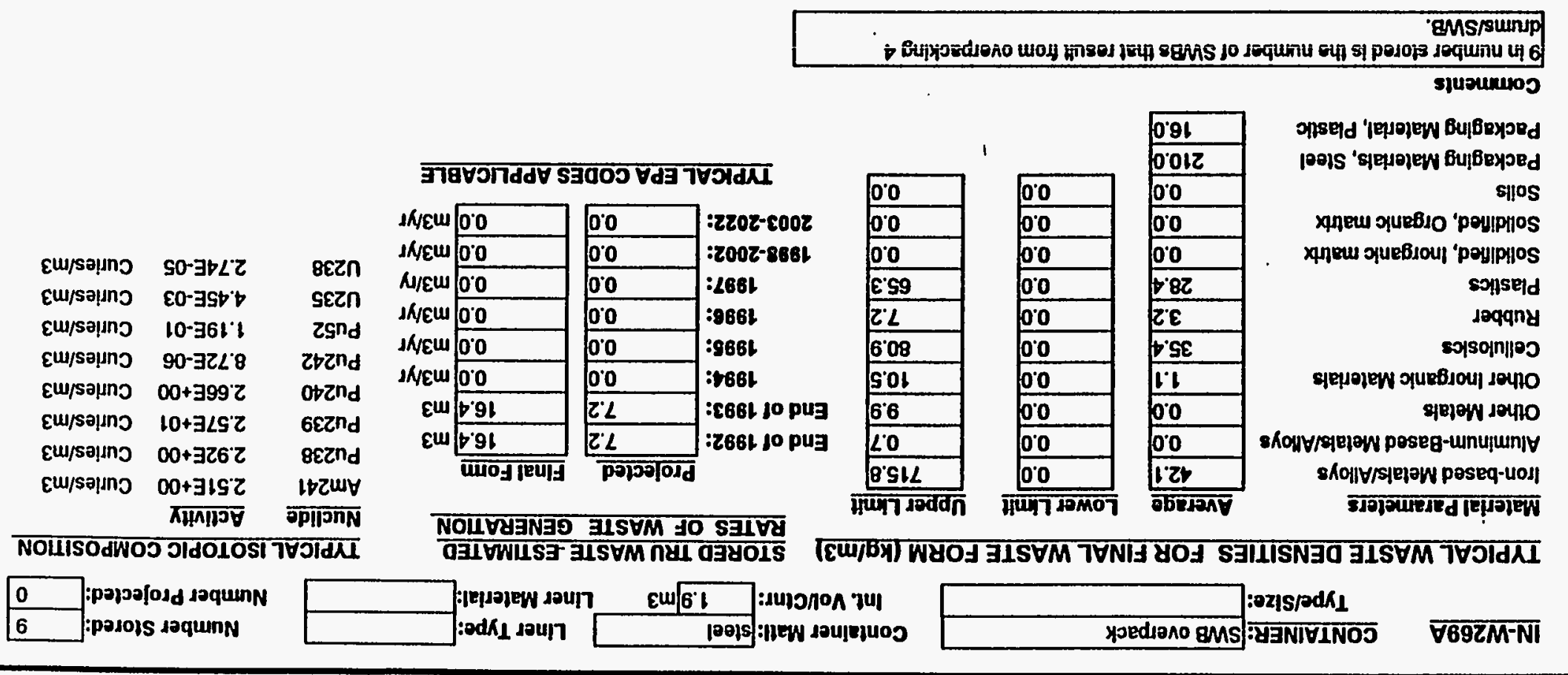




\section{WASTE STREAM PROFILE FOR THE WIPP TRU WASTE BASELINE INVENTORY REPORT}

SITENAME IN

IN-W269A CONTAINER: $\frac{\text { Drum }}{\text { Type/Size: } 55 \text {-gallon }}$

\section{TYPICAL. WASTE DENSITIES FOR FINAL WASTE FORM $(\mathrm{kg} / \mathrm{m} 3)$}

\section{Material Parameters}

Iron-based Metals/Alloys

Aluminum-Based Metals/Alloys

Other Metals

Other Inorganic Maleriats

Cellulosics

Rubber

Plastics

Solldified, Inorganic matrix

Solldified, Organic matrix

Soils

Packaging Materials, Steel

Packaging Material, Plastlo

\begin{tabular}{|r|}
\hline Average \\
\hline 96.2 \\
\hline 0.0 \\
\hline 0.1 \\
\hline 2.4 \\
\hline 80.9 \\
\hline 7.3 \\
\hline 64.9 \\
\hline 0.0 \\
\hline 0.0 \\
\hline 0.0 \\
\hline 131.0 \\
\hline 37.0 \\
\hline
\end{tabular}

\begin{tabular}{c} 
Lower Limit \\
\hline 0.0 \\
\hline 1634.6 \\
\hline
\end{tabular}

\begin{tabular}{|r|}
\hline 0.0 \\
\hline 0.0 \\
\hline 0.0 \\
\hline 0.0 \\
\hline 0.0 \\
\hline 0.0 \\
\hline 0.0 \\
\hline \\
\hline 0.0 \\
\hline 184.8 \\
\hline 16.4 \\
\hline 149.0 \\
\hline 0.0 \\
\hline 0.0 \\
\hline 0.0 \\
\hline
\end{tabular}

Container Matl:

Int. Volvctnr:

\section{Lower Limit ， Upper Limit}

STORED TRU WASTE ESTIMATED RATES OF WASTE GENERATION

\begin{tabular}{r|r|} 
& Prolected \\
\hline End of 1992: & 18.4 \\
\hline End of 1993: & 18.4 \\
\hline $1994:$ & 0.0 \\
\hline $1998:$ & 0.0 \\
\hline $1998:$ & 0.0 \\
\hline $1997:$ & 0.0 \\
\hline $1998-2002:$ & 0.0 \\
\hline $2003-2022:$ & 0.0 \\
\hline
\end{tabular}

Final Form

$18.4 \mathrm{m3}$

$18.4 \mathrm{m3}$

TYPICAL EPA CODES APPLICABLE
Number Stored: Number Projected IYPICAL ISOTOPIC COMPOSITION Nuclide Activily

Am241 5.73E+00 Curles $/ \mathrm{m} 3$

Pu238 6.66E $+\infty 0$ Curies $/ \mathrm{m} 3$

Pu239 5.86E+01 Curies/m3

Pu240 6.07E+00 Curies $/ \mathrm{m} 3$

Pu242 1.99E-05 Curles/m3

Pu52 2.71E-01 Curies/m3

U235 1.02E-02 Curles $/ \mathrm{m} 3$

U238 6.25E-05 Curles/m3 
WASTE STREAM PROFILE FOR THE WIPP TRU WASTE BASELINE INVENTORY REPORT

SITE NAME IN $\cdot$ WASTE TYPE MTRU HANDLING RH GENERATOR SITE IN,AW

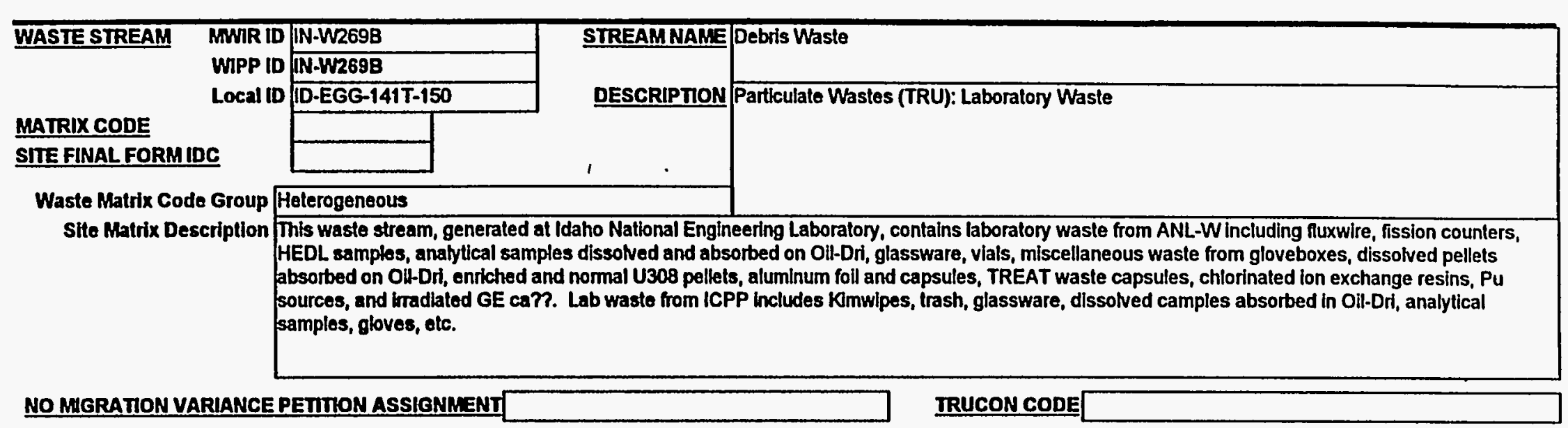

\section{FINAL. WASTE FORM DESCRIPTORS:}

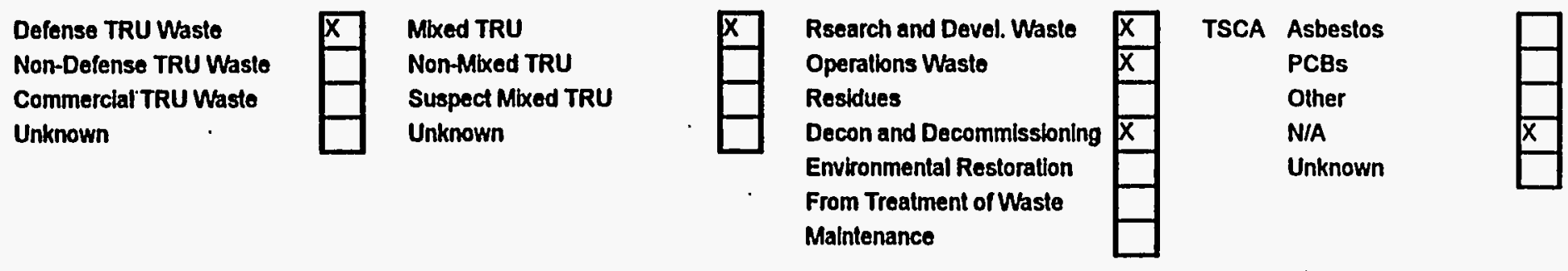




\section{WASTE STREAM PROFILE FOR THE WIPP TRU WASTE BASELINE INVENTORY REPORT}

SITE NAME IN WASTE TYPE MTRU HANDLING RH

GENERATOR SITE IN, AW

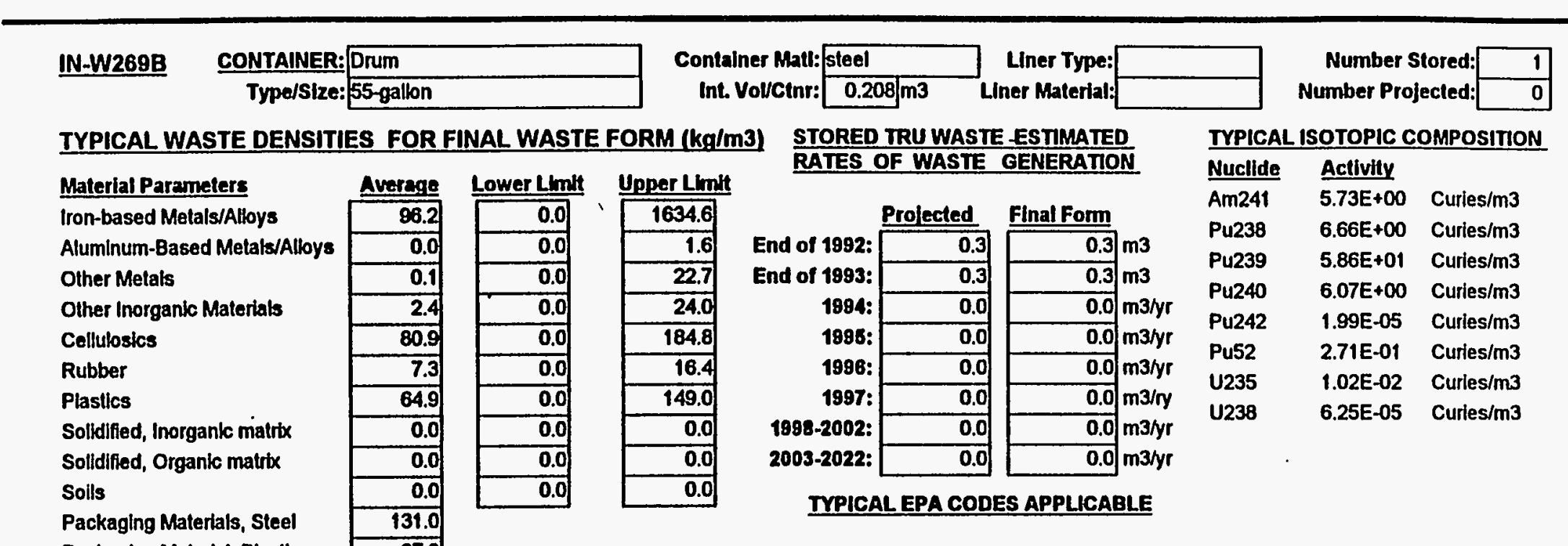


WASTE STREAM PROFILE FOR THE WIPP TRU WASTE BASELINE INVENTORY REPORT

SITE NAME IN WASTE TYPE MTRU HANDLING CH

GENERATOR SITE MD

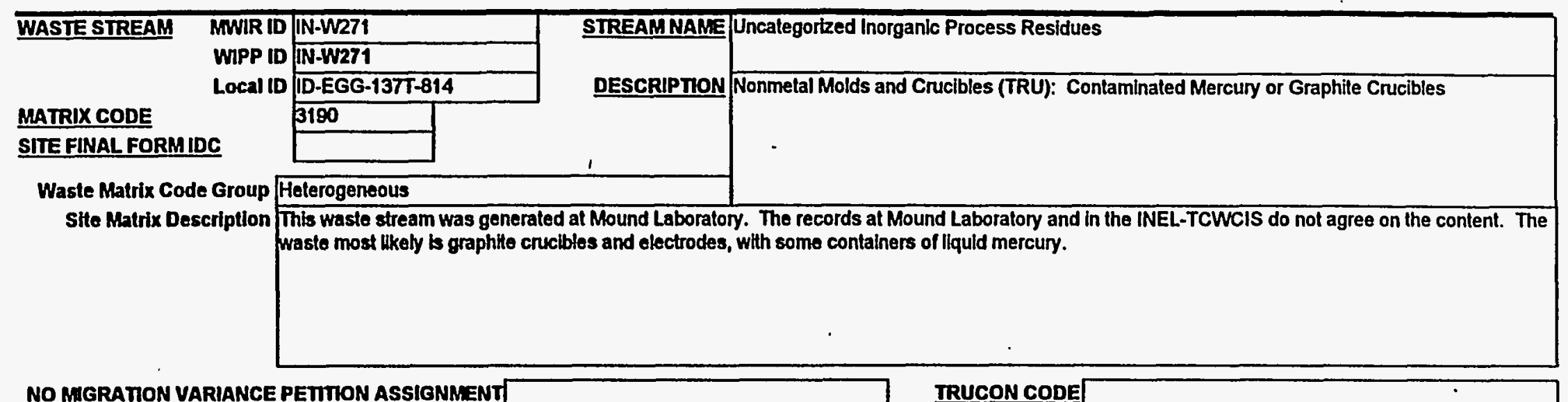

NO MGRATION VARIANCE PETITON ASSIGNMENT

IRUCON CODE

\section{FINAL WASTE FORM DESCRIPTORS:}

\begin{tabular}{l|l|l} 
Defense TRU Waste & $X$ & $\begin{array}{l}\text { Mixed TRU } \\
\text { Non-Mixed TRU } \\
\text { Non-Defense TRU Waste } \\
\text { Commerclal TRU Waste } \\
\text { Unknown }\end{array}$ \\
\cline { 2 - 2 } \\
Unknown
\end{tabular}

Rsearch and Devel. Waste

Operations Waste

Residues

Decon and Decommissloning

Environmental Restoralion

From Treatment of Waste

Malntenance

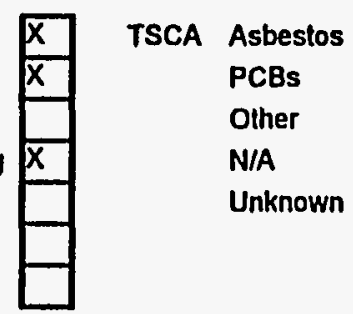

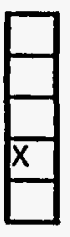


WASTE STREAM PROFILE FOR THE WIPP TRU WASTE BASELINE INVENTORY REPORT

SITE NAME IN WASTE TYPE MTRU HANDLING CH GENERATOR SITE MD

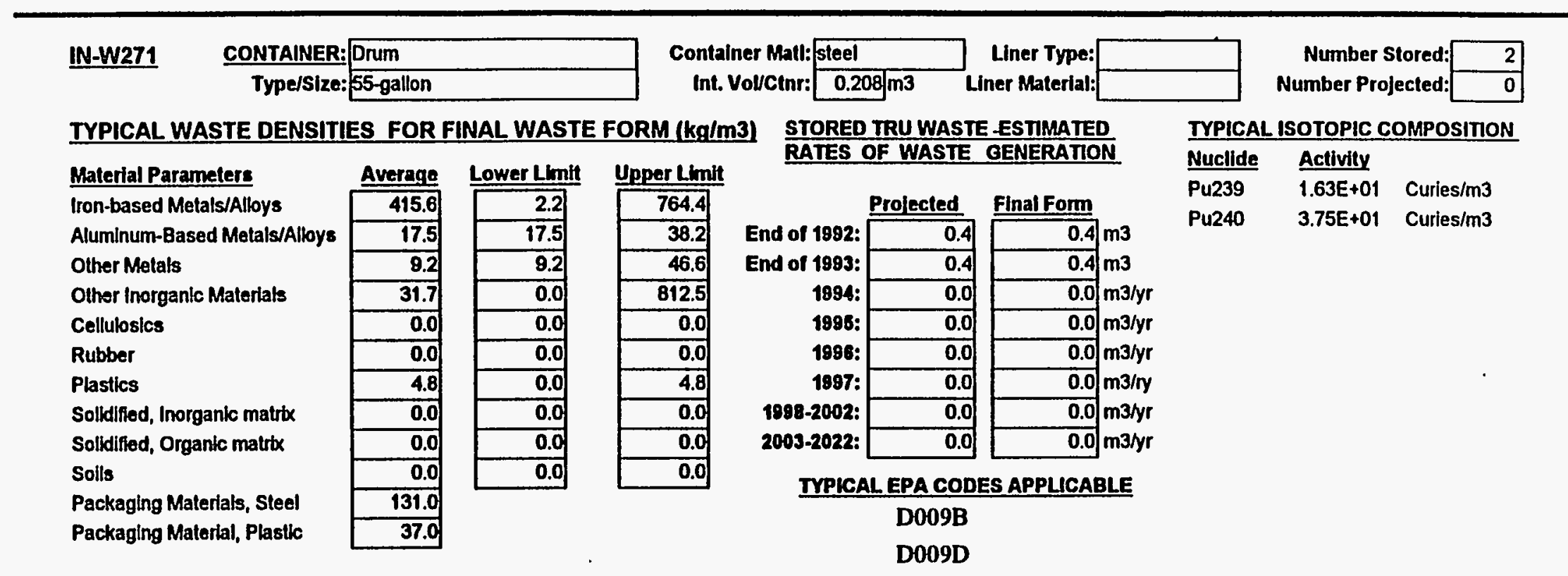


WASTE STREAM PROFILE FOR THE WIPP TRU WASTE BASELINE INVENTORY REPORT

SITE NAME IN WASTE TYPE MTRU HANDLING CH

GENERATOR SITE RF

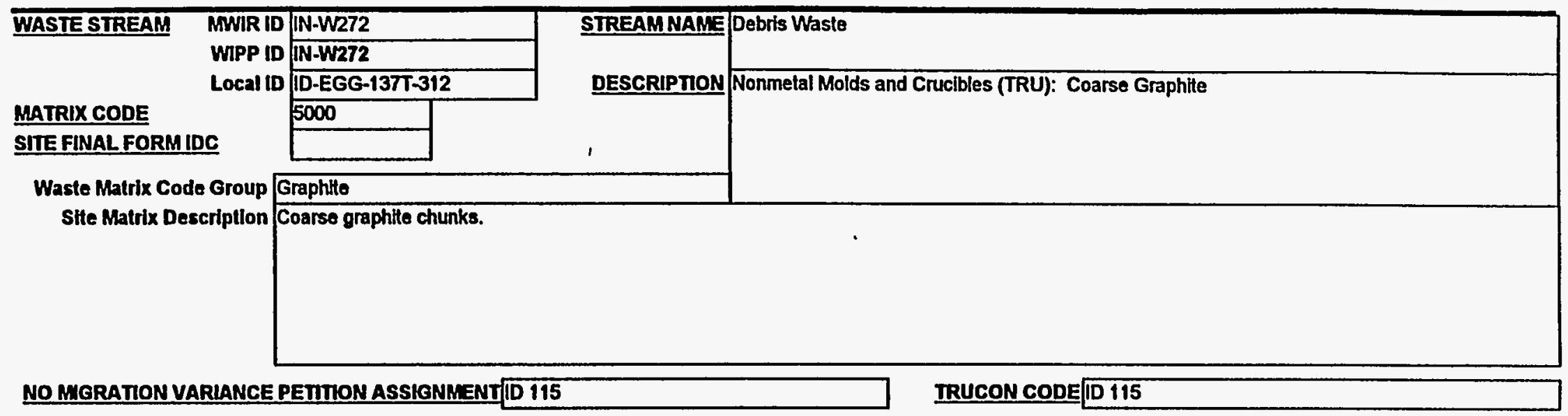

FINAL WASTE FORM DESCRIPTORS:

\begin{tabular}{l|l} 
Defense TRU Waste \\
Non-Defense TRU Waste \\
Commercial TRU Waste \\
Unknown
\end{tabular}$\quad \begin{aligned} & \text { Mlxed TRU } \\
& \text { Non-Mbxed TRU } \\
& \text { Suspect Mbxed TRU } \\
& \text { Unknown }\end{aligned}$

Rsearch and Devel. Waste
Operations Waste
Residues
Decon and Decommissioning
Environmental Restoralion
From Treatment of Wasto
Maintenance
TSCA Asbestos
PCBs
Other
N/A
Unknown

Maintenance

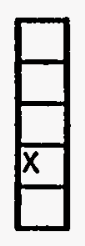




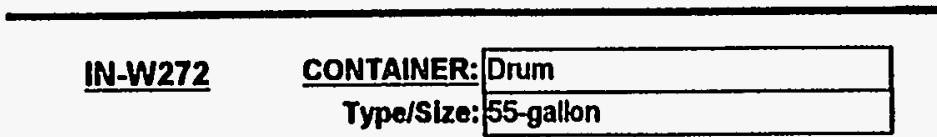

TYPICAL WASTE DENSITIES FOR FINAL WASTE FORM $(\mathrm{kg} / \mathrm{m} 3)$

\section{Material Parameters}

Iron-based Metals/Alloys

Aluminum-Based Metals/Alloys

Other Melals

Other Inorganic Matertals

Cellulosics

Rubber

Plastics

Solkdified, Inorganic matrix

Solidified, Organic matrix

Solls

Packaging Materlals, Steel

Packaging Malerial, Plastlc

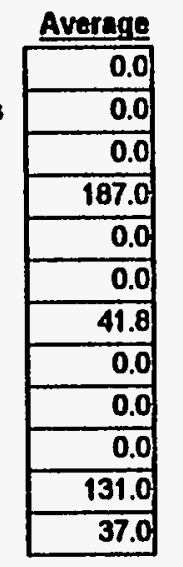

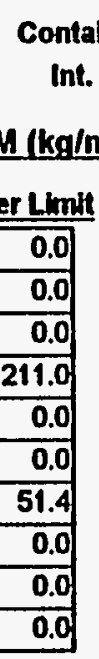

Aainer Matl: steel

Int. Voulcinr:

RATES OF WASTE GENERATION

\begin{tabular}{r|r|} 
& Prolected \\
\hline End of 1992: & 1.9 \\
\hline End of 1993: & 1.9 \\
\hline $1994:$ & 0.0 \\
\hline $1995:$ & 0.0 \\
\hline $1996:$ & 0.0 \\
\hline $1997:$ & 0.0 \\
\hline $1998-2002:$ & 0.0 \\
\hline $2003-2022:$ & 0.0 \\
\hline
\end{tabular}

Final Form

\begin{tabular}{|r|l|}
\hline 1.9 & $\mathrm{~m} 3$ \\
\hline 1.9 & $\mathrm{m3}$ \\
\hline 0.0 & $\mathrm{~m} 3 / \mathrm{yr}$ \\
\hline 0.0 & $\mathrm{~m} 3 / \mathrm{yr}$ \\
\hline 0.0 & $\mathrm{~m} 3 / \mathrm{yr}$ \\
\hline 0.0 & $\mathrm{~m} 3 / \mathrm{ry}$ \\
\hline 0.0 & $\mathrm{~m} 3 / \mathrm{yr}$ \\
\hline 0.0 & $\mathrm{~m} 3 / \mathrm{yr}$ \\
\hline
\end{tabular}

TYPLCAL EPA CODES APPLICABLE

F001

F002
Number Stored: Number Projected:

TYPICAL ISOTOPIC COMPOSITION

Nuclide Activity

Pu52 1.76E+02 Curies/m3 
WASTE STREAM PROFILE FOR THE WIPP TRU WASTE BASELINE INVENTORY REPORT

SITENAME IN WASTE TYPE MTRU HANDLING CH GENERATOR SITE RF

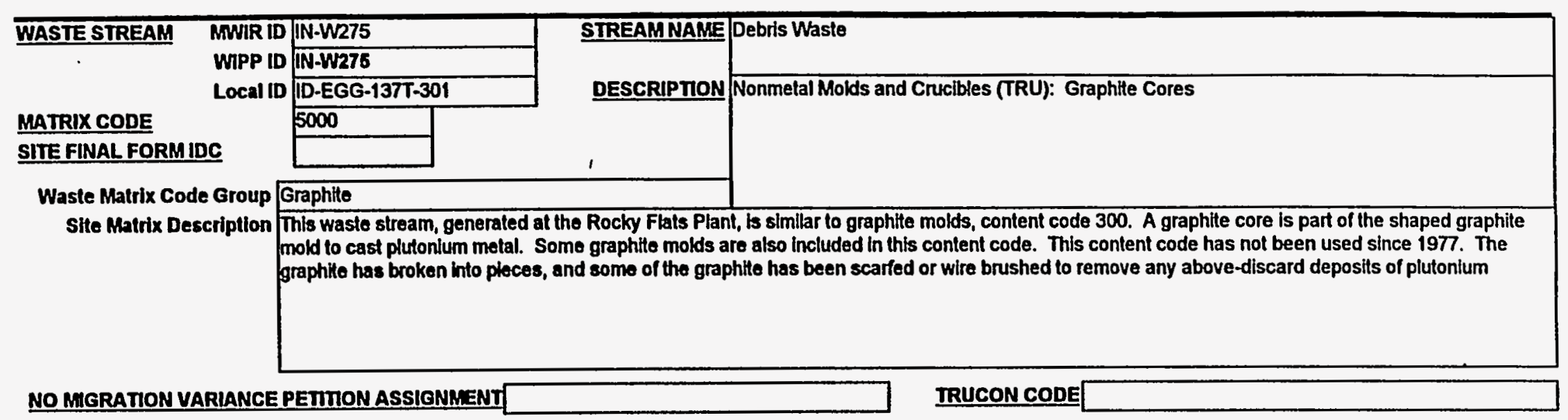

\section{FINAL WASTE FORM DESCRIPTORS:}

\begin{tabular}{l|l} 
Defense TRU Waste \\
Non-Defense TRU Waste \\
Commerclal TRU Waste \\
Unknown
\end{tabular}$\quad \begin{aligned} & \text { Mixed TRU } \\
& \text { Non-Mbxed TRU } \\
& \text { Suspect Mixed TRU } \\
& \text { Unknown }\end{aligned}$

Rsearch and Devel. Waste
Operations Waste
Residues
Decon and Decommissioning
Environmental Restoration
From Treatment of Waste
Maintenance

\begin{tabular}{|l|}
\hline$x$ \\
\hline$X$ \\
\hline \\
\hline \\
\hline \\
\hline \\
\hline
\end{tabular}

Asbestos

PCBs

Other

N/A

Unknown

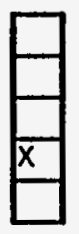

Maintenance 


\section{WASTE STREAM PROFILE FOR THE WIPP TRU WASTE BASELINE INVENTORY REPORT}

SITE NAME IN

\section{WASTE TYPE MTRU HANDLING CH GENERATOR SITE RF}

IN-W275 CONTAINER: SWB overpack

TYPICAL WASTE DENSITIES FOR FINAL WASTE FORM (kg/m3)

Material Parameters

Iron-based Metals/Alloys

Aluminum-Based Metals/Alloys

Other Metals

Other Inorganic Materials

Cellulosics

Rubber

Plastics

Solidified, Inorganic matrix

Solidified, Organic matrix

Solls

Packaging Materials, Steel

Packaging Material, Plastlc

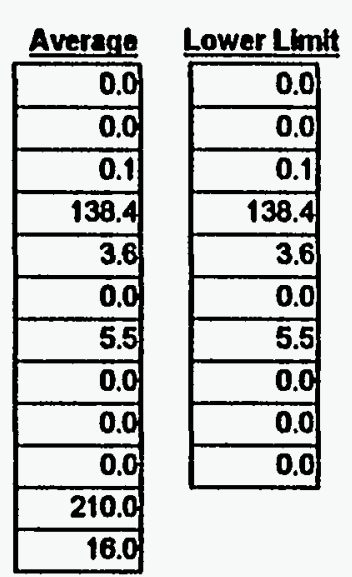

\begin{tabular}{|r|}
\hline Upper Linit \\
\hline 0.0 \\
\hline 0.0 \\
\hline 0.1 \\
\hline 138.4 \\
\hline 3.6 \\
\hline 0.0 \\
\hline 5.5 \\
\hline 0.0 \\
\hline 0.0 \\
\hline 0.0 \\
\hline
\end{tabular}

.

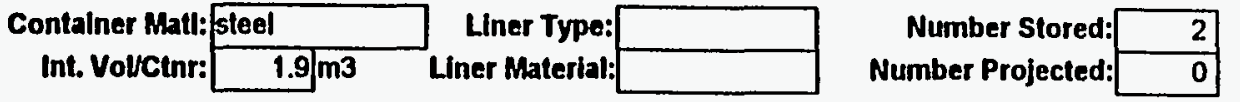

STORED TRU WASTE ESTIMATED RATES OF WASTE GENERATION
TYPICAL ISOTOPIC COMPOSITION

\section{Nuclide Activity}

Am241 2.38E-02 Curies/m3

Pu52 1.51E+01 Curies $/ \mathrm{m3}$

\begin{tabular}{|c|c|c|c|}
\hline & Prolected & Final Form & \\
\hline End of 1992: & 1.8 & 4.1 & $\mathrm{~m} 3$ \\
\hline End of 1993: & 1.0 & 4.1 & m3 \\
\hline 1994: & $\overline{0.0}$ & 0.0 & m3/yr \\
\hline 1996: & 0.0 & 0.0 & $\mathrm{~m} 3 / \mathrm{yr}$ \\
\hline 1996: & 0.0 & 0.0 & m3/yr \\
\hline 1997: & 0.0 & 0.0 & $\mathrm{~m} 3 / \mathrm{ny}$ \\
\hline 1988-2002: & 0.0 & 0.0 & m3/yr \\
\hline 2003-2022: & 0.0 & 0.0 & malyr \\
\hline
\end{tabular}

Comments

2 in number stored ts the number of SWBs that resuk from overpacking 4 drums/SWB. 


\section{WASTE STREAM PROFILE FOR THE WIPP TRU WASTE BASELINE INVENTORY REPORT}

SITE NAME IN

WASTE TYPEMTRU HANDLING CH GENERATOR SITE RF

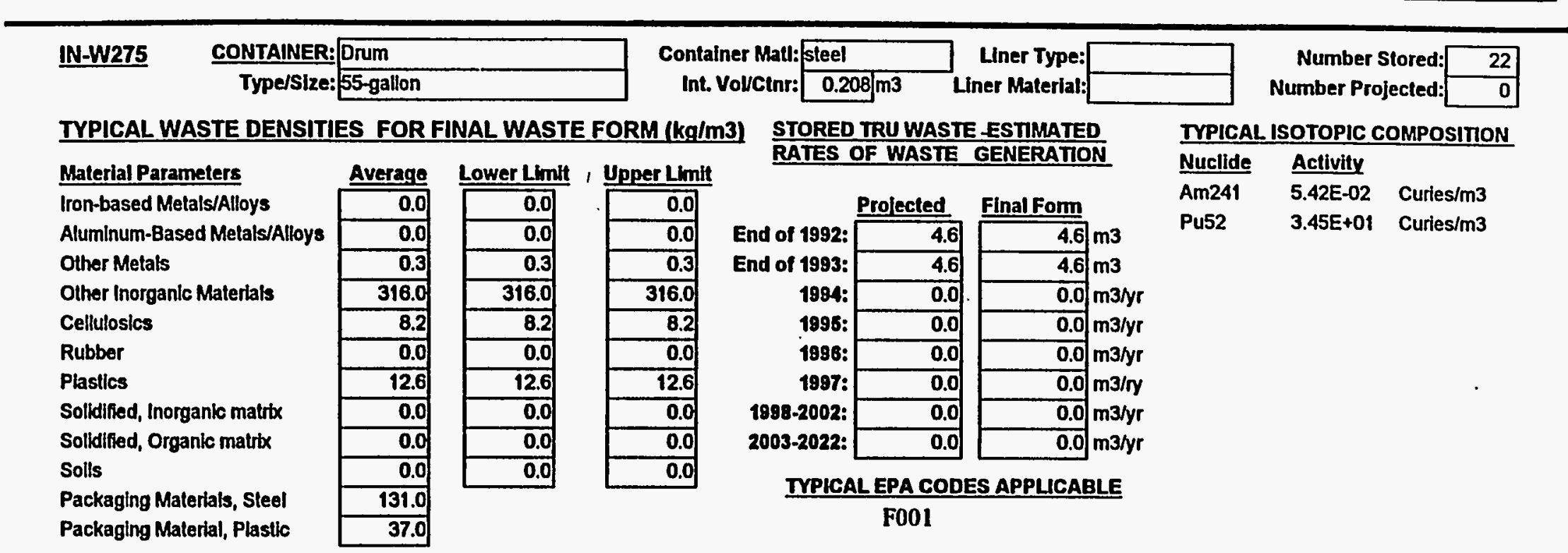




\section{WASTE STREAM PROFILE FOR THE WIPP TRU WASTE BASELINE INVENTORY REPORT}

SITE NAME IN

WASTE TYPE MTRU HANDLING CH GENERATOR SITE RF

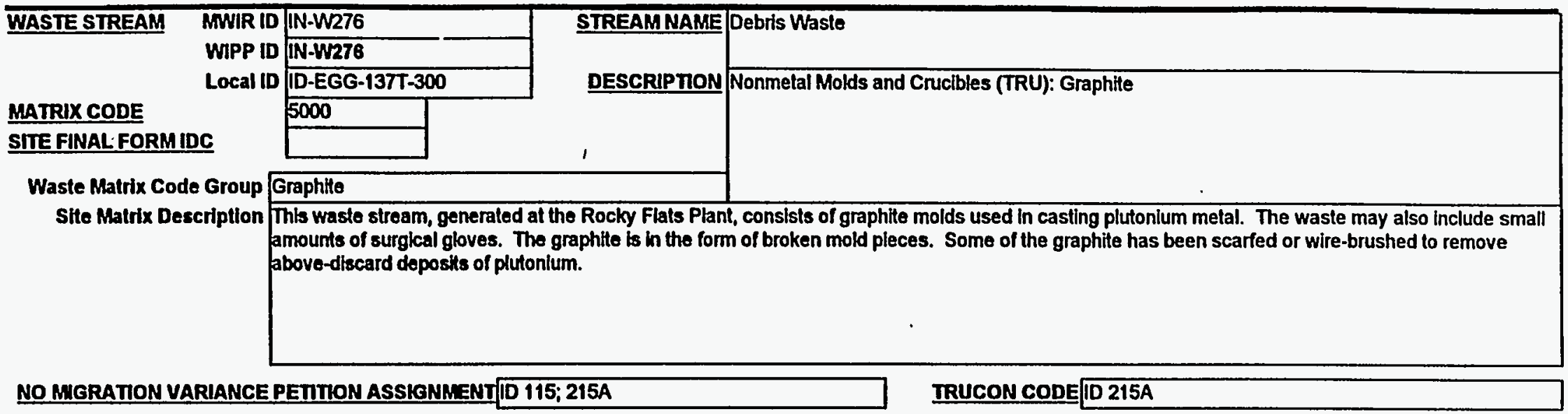

\section{FINAL WASTE FORM DESCRIPTORS:}

\begin{tabular}{|c|c|}
\hline $\begin{array}{l}\text { Defense TRU Waste } \\
\text { Non-Defense TRU Wt }\end{array}$ & Mlxed TRU \\
\hline lal TRU & Suspect Mixed TRU \\
\hline kn & Unknown \\
\hline
\end{tabular}

Rsearch and Devel. Waste
Operations Waste
Residues
Decon and Decommissioning
Environmental Restoration
From Treatment of Waste
Maintenance

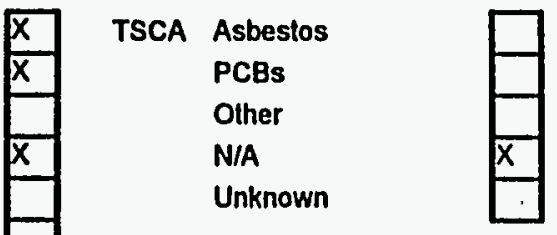




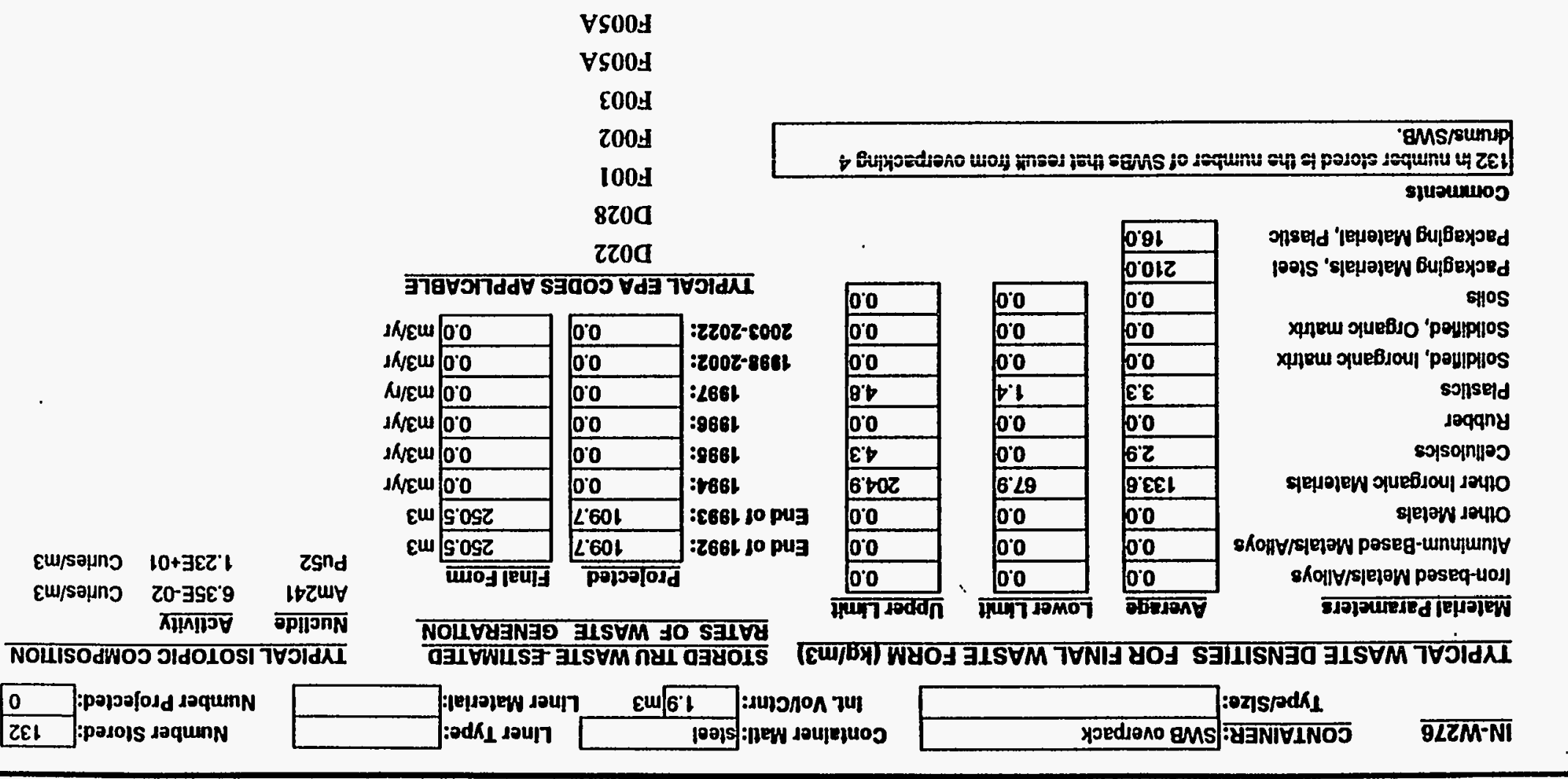


WASTE STREAM PROFILE FOR THE WIPP TRU WASTE BASELINE INVENTORY REPORT

IN-W276 $\quad \frac{\text { CONTAINER: Drum }}{\text { Type/Size: 55-gallon }}$

Contalner Matl:

Number Stored: 1356

Int. Vol/Ctnr: $0.208 \mathrm{m3} \quad$ Liner Material:

Number Projected:

\section{TYPICAL WASTE DENSITIES FOR FINAL WASTE FORM $(\mathrm{kg} / \mathrm{m} 3)$ STORED TRU WASTE -ESTIMATED}

Material Parameters

Iron-based Metals/Alloys

Aluminum-Based Metals/Alloys

Other Metals

Other Inorganic Materials

Cellulosics

Rubber

Plastics

Solidified, Inorganic matrix

Solldified, Organic matrix

Soils

Packaging Materials, Steel

Packaging Material, Plastic RATES OF WASTE GENERATION

\section{Upper Limit}

\begin{tabular}{|r|}
\hline 0.0 \\
\hline 0.0 \\
\hline 0.0 \\
\hline 468.0 \\
\hline 9.8 \\
\hline 0.0 \\
\hline 10.9 \\
\hline 0.0 \\
\hline 0.0 \\
\hline 0.0 \\
\hline
\end{tabular}

IYPICAL ISOTOPIC COMPOSITION

Nuclide Actlvity

Am241 1.45E-01 Curies $/ \mathrm{m} 3$

Pu52 2.82E+01 Curies $/ \mathrm{m}^{3}$

\begin{tabular}{|c|c|c|c|}
\hline & Prolected & Final Form & \\
\hline End of 1892: & 282.0 & 282.0 & m3 \\
\hline nd of 1883: & 282.0 & 282.0 & m3 \\
\hline 1984: & 0.0 & 0.0 & $\mathrm{~m} 3 / \mathrm{yr}$ \\
\hline 1995: & 0.0 & 0.0 & $\mathrm{~m} 3 / \mathrm{yr}$ \\
\hline 1998: & 0.0 & 0.0 & $\mathrm{~m} 3 / \mathrm{yr}$ \\
\hline 1987: & 0.0 & 0.0 & $\mathrm{~m} 3 / \mathrm{n}$ \\
\hline 1998-2002: & 0.0 & 0.0 & $\mathrm{~m} 3 / \mathrm{yl}$ \\
\hline 2003-2022: & 0.0 & 0.0 & $\mathrm{~m} 3 / \mathrm{yr}$ \\
\hline
\end{tabular}

TYPICAL EPA CODES APPLICABLE

D022

D028

F001

F002

F003

F005A

F005A 


\section{WASTE STREAM PROFILE FOR THE WIPP TRU WASTE BASELINE INVENTORY REPORT}

SITE NAME IN

WASTE TYPE MTRU HANDLING CH

GENERATOR SITE MD

\begin{tabular}{|c|c|c|c|c|}
\hline \multirow{4}{*}{\multicolumn{2}{|c|}{$\begin{array}{ll}\text { WASTE STREAM } & \text { MWIR ID } \\
& \text { WIPP ID } \\
& \text { LOCal ID } \\
\text { MATRIX CODE } & \end{array}$}} & DIN-W280 & \multirow{3}{*}{$\begin{array}{l}\text { STREAMNAME } \\
\text { DESCRIPTION }\end{array}$} & \multirow[t]{2}{*}{ Metal Debris } \\
\hline & & $D \longdiv { \text { IN-W280 } }$ & & \\
\hline & & ID-EGG-132T-803 & & \multirow{3}{*}{ Metals (TRU): Metal, Equipment, Pipes, Valves, Etc. } \\
\hline & & \begin{tabular}{|l|l|}
5100 \\
\end{tabular} & \multirow{2}{*}{1} & \\
\hline \multicolumn{2}{|c|}{ SITE FINAL FORM IDC } & & & \\
\hline \multicolumn{4}{|c|}{ Waste Matrix Code Group Uncategorized Metal } & \\
\hline \multicolumn{2}{|c|}{ Site Matrix Description } & \multicolumn{3}{|c|}{$\begin{array}{l}\text { This waste comes from Mound Laboratory. It consists of stainless steel, carbon steel, and small amounts of aluminum-metal wastes in the form of } \\
\text { valves, plping, wrenches, nuts, bolts, stainless steel tubing, spatulas, pans, hotplales, ringstands, etc. Limited amounts of combustible and } \\
\text { noncombustlble wasle also present from content codes } 810,811,812,813,814,826 \text {, and } 832 \text {. Content code } 812 \text { is spent ion-exchange resin and } \\
\text { content code } 832 \text { is containers of llquild mercury. Most of the waste is metal waste that is primarily from D\&D operatlons. Some of the metals were } \\
\text { teached with nitric acld, ultrasonically cleaned and dried to remove above-discard amounts of plutonium. }\end{array}$} \\
\hline
\end{tabular}

\section{FINAL WASTE FORM DESCRIPTORS:}

\begin{tabular}{l|l} 
Defense TRU Waste \\
Non-Defense TRU Waste \\
Commercial-TRU Waste \\
Unknown
\end{tabular}
Operations Wasto

Residues

Decon and Decommisstoning $X$

Environmental Restoration

From Treatment of Waste

Maintenanco

\begin{tabular}{|l|}
\hline$x$ \\
\hline$x$ \\
\hline$x$ \\
\hline$\square$ \\
\hline
\end{tabular}

TSCA Asbestos
PCBs
Other
N/A
Unknown

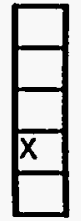


WASTE STREAM PROFILE FOR THE WIPP TRU WASTE BASELINE INVENTORY REPORT

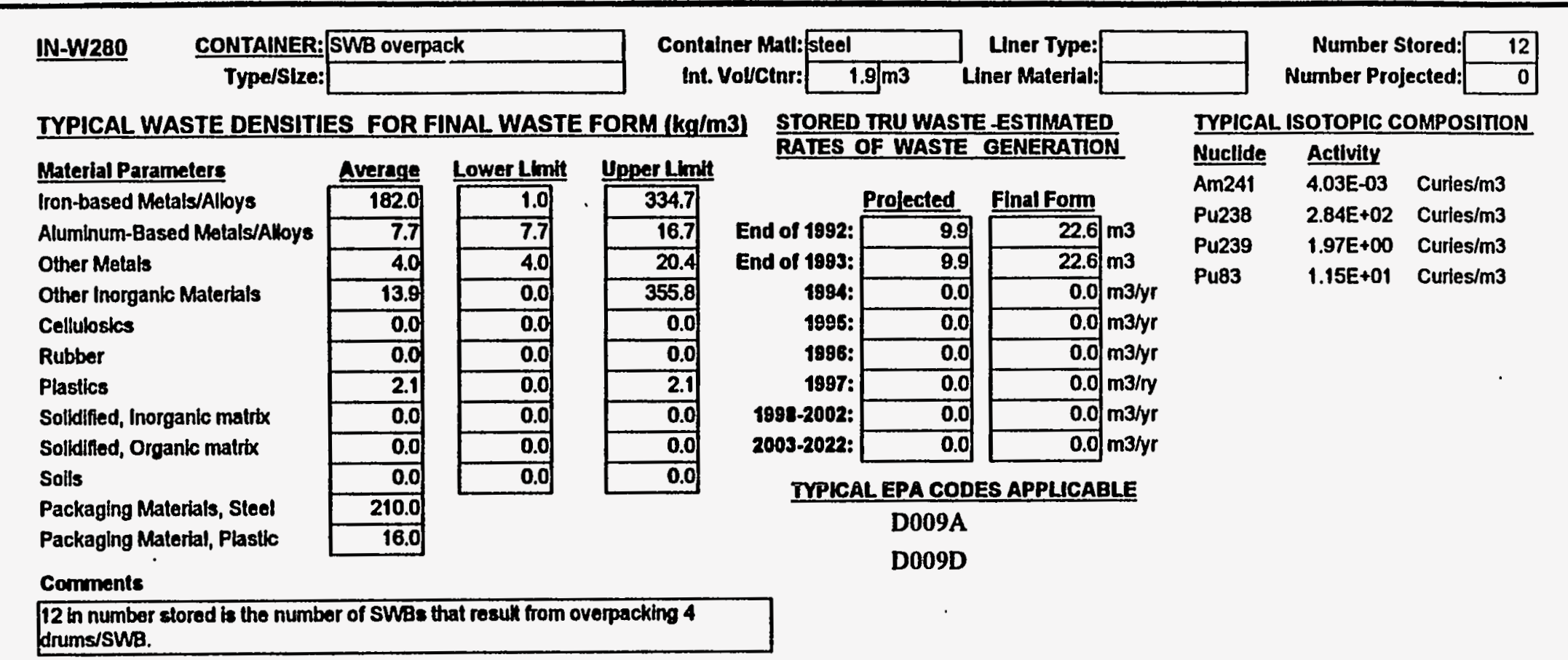




\section{WASTE STREAM PROFILE FOR THE WIPP TRU WASTE BASELINE INVENTORY REPORT}

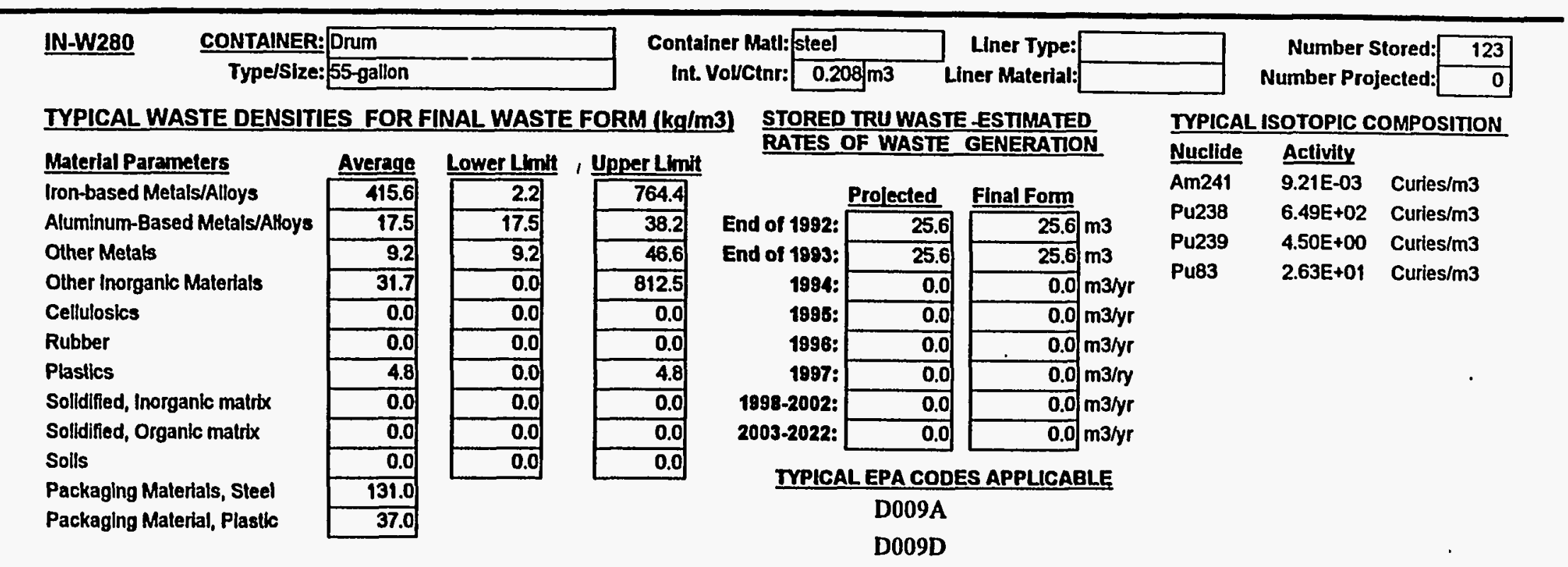


WASTE STREAM PROFILE FOR THE WIPP TRU WASTE BASELINE INVENTORY REPORT

SITE NAME IN

WASTE TYPE MTRU HANDLING CH GENERATOR SITE MD

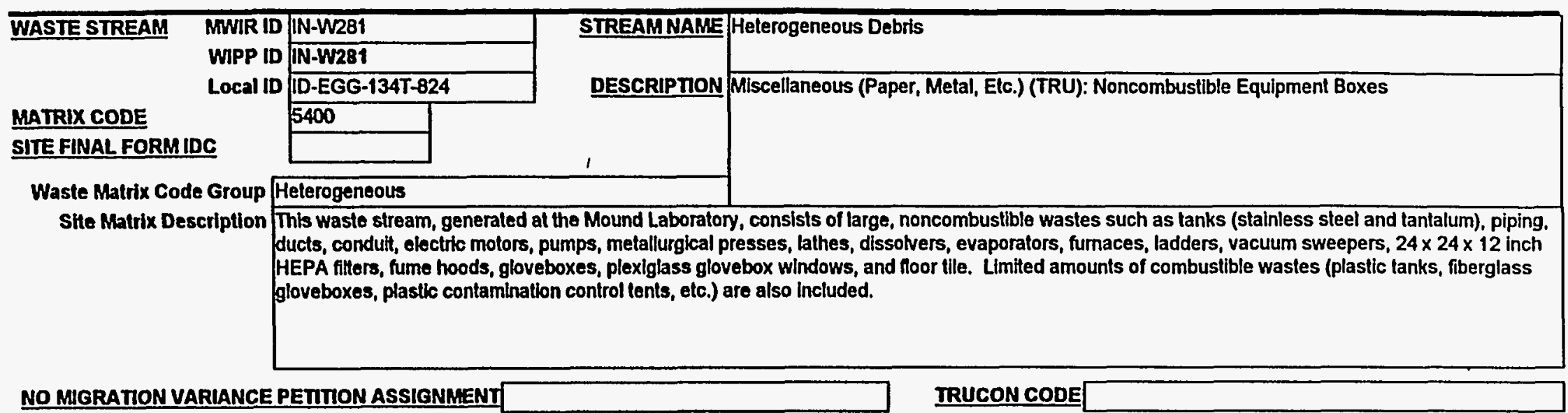

NO MIGRATION VARIANCE PETITION ASSIGNMENT

IRUCON CODE

\section{FINAL WASTE FORM DESCRIPTORS:}

Defense TRU Waste

Non-Defense TRU Waste

Commercial TRU Waste

Unknown

$\square$

Mbxed TRU

Non-Mbed TRU

Suspect Mixed TRU

Unknown

$\square$

TSCA Asbestos

PCBs

Other

NIA

Unknown

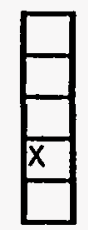




\section{WASTE STREAM PROFILE FOR THE WIPP TRU WASTE BASELINE INVENTORY REPORT}

SITE NAME IN

WASTE TYPE MTRU HANDLINO CH GENERATOR SITE MD

IN-W281 $\quad \frac{\text { CONTAINER: }}{\text { Type/Slze: }}$ 5rum

Container Matt: steel

int. Volvetnr: $\frac{\text { Liner Type: }}{0.208 \mathrm{m3}}$ Liner Material:

Number Stored: 1672

TYPICAL WASTE DENSITIES FOR FINAL WASTE FORM $(\mathrm{kg} / \mathrm{m} 3)$

Material Parameters

Iron-based Motals/Alloys

Aluminum-Based Metals/Alloys

Other Melals

Other Inorganic Matertals

Cellulosics

Rubber

Plastics

Solidified, Inorganic matrix

Solidified, Organlc maltix

Solis

Packaging Materlals, Steel

Packaging Material, Plastic

\begin{tabular}{|c|c|c|}
\hline Average & Lower Limit & Upper Llmt \\
\hline 682.0 & 2.2 & 764.4 \\
\hline 28.7 & 17.5 & 38.2 \\
\hline 15.1 & 9.2 & 46.6 \\
\hline 24.9 & 0.0 & 812.5 \\
\hline 0.0 & 0.0 & 0.0 \\
\hline 0.0 & 0.0 & 0.0 \\
\hline 4.8 & 0.0 & 4.8 \\
\hline 0.0 & 0.0 & 0.0 \\
\hline 0.0 & 0.0 & 0.0 \\
\hline 0.0 & 0.0 & 0.0 \\
\hline 131.0 & & \\
\hline 37.0 & & \\
\hline
\end{tabular}

STORED TRU WASTE ESTIMATED RATES OF WASTE GENERATION

End of 1992:

TYPICAL EPA CODES APPLICABLE

D005A

D006A

D007A

D008A

D009A

D010A

D011A 


\section{WASTE STREAM PROFILE FOR THE WIPP TRU WASTE BASELINE INVENTORY REPORT}

SITENAME IN

WASTE TYPE MTRU HANDLING CH GENERATOR SITE RF

\begin{tabular}{|c|c|c|c|c|}
\hline \multirow{4}{*}{\multicolumn{2}{|c|}{$\begin{array}{ll}\text { WASTE STREAM } & \text { MWIR ID } \\
& \text { WIPP ID } \\
& \text { Local ID } \\
\text { MATRIX CODE } & \end{array}$}} & IN-W283 & \multirow{3}{*}{$\begin{array}{l}\text { STREAMNAME } \\
\text { DESCRIPTION }\end{array}$} & \multirow[t]{2}{*}{ Heterogeneous Debris } \\
\hline & & IN-W/283 & & \\
\hline & & DD-EGG-134T-241 & & \multirow[t]{4}{*}{ Miscellaneous (Paper, Metal, Etc.) (TRU): Americium Process Residue } \\
\hline & & 5400 & & \\
\hline \multicolumn{4}{|c|}{ SITE FINAL FORMIDC } & \\
\hline \multirow{2}{*}{\multicolumn{2}{|c|}{$\begin{array}{l}\text { Waste Matrix Code Group } \\
\text { Site Matrix Description }\end{array}$}} & Heterogeneous & & \\
\hline & & \multicolumn{3}{|c|}{$\begin{array}{l}\text { This wasle stream, generated at the Rocky Flats Plant, consists of pliping, flanges, valves, lools, equipment, PVC piping, glassware (flasks, broken lon } \\
\text { exchange columns, etc.), glass filters, PE bottles, leaded glovebox gloves, paper, and plastics. Wastes were shipped only in } 1972 \text { and } 1973 \text {, from } \\
\text { renovations of the americlum recovery line. Some of the containers are lead-lined. }\end{array}$} \\
\hline
\end{tabular}

\section{FINAL WASTE FORM DESCRIPTORS:}

\begin{tabular}{l|l} 
Defense TRU Waste \\
Non-Defense TRU Waste \\
Commercial TRU Waste \\
Unknown
\end{tabular}

Rsearch and Devel. Waste
Operations Waste
Residues
Decon and Decommissioning
Environmental Resloration
From Treatment of Waste
Maintenance

\begin{tabular}{|l|}
\hline$x$ \\
\hline$x$ \\
\hline \\
\hline \\
\hline \\
\hline
\end{tabular}

\begin{tabular}{ll|} 
TSCA Asbestos & \\
PCBs & \\
Other & \\
N/A & \\
Unknown & \\
&
\end{tabular}




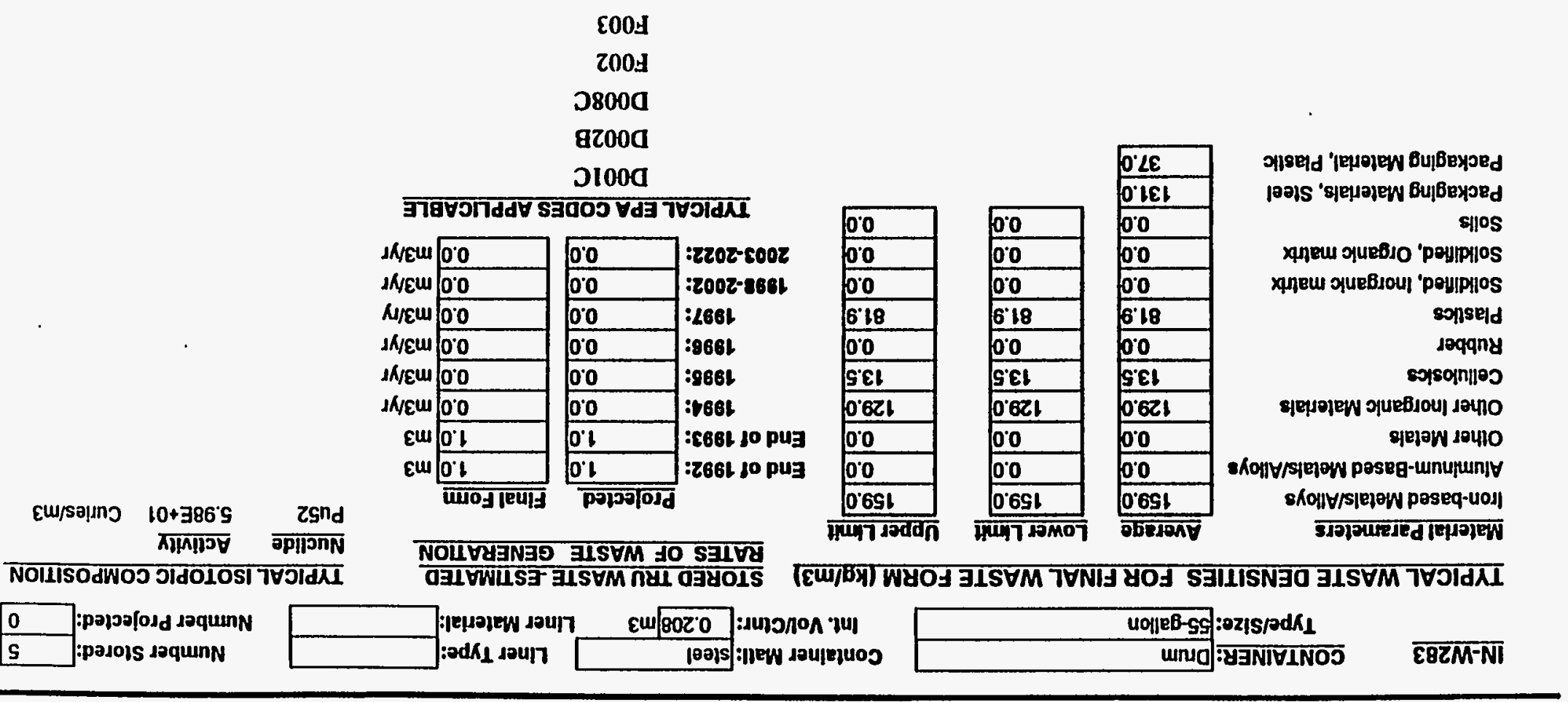


WASTE STREAM PROFILE FOR THE WIPP TRU WASTE BASELINE INVENTORY REPORT

SITE NAME IN

WASTE TYPE MTRU HANDLING CH

GENERATOR SITE BC

\begin{tabular}{|c|c|c|c|}
\hline WASTE STREAM MWIR ID & IN-W285 & STREAMNAME & Heterogeneous Debris \\
\hline WIPP ID & IN-W285 & & \\
\hline Local ID & ID-EGG-134T-201 & DESCRIPTION & Miscellaneous (Paper, Metal, Etc.) (TRU): Noncombustible Solids \\
\hline MATRIX CODE & 5400 & & \\
\hline SITE FINAL FORMIDC & & 1 & 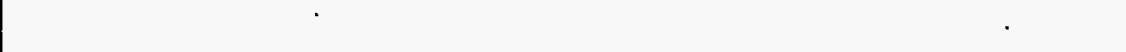 \\
\hline Waste Matrix Code Group $[\mathrm{F}$ & Heterogeneous & & \\
\hline Stte Matrix Description 7 & $\begin{array}{l}\text { This waste stream, } g \\
\text { equipment, lead brick }\end{array}$ & $\begin{array}{l}\text { ittelle Columbus La } \\
\text { and filters. }\end{array}$ & boratories, contains noncombustible items such as tools, crucibles, piping, valves, pleces of \\
\hline
\end{tabular}

NO MGRATION VARLANCE PETITION ASSIGNMENT

IRUCON CODE

FINAL WASTE FORM DESCRIPTORS:

$\left.\begin{array}{l|ll}\text { Defense TRU Waste } \\ \text { Non-Defense TRU Waste } \\ \text { Commerclal TRU Waste } \\ \text { Unknown }\end{array}\right) \begin{aligned} & \text { Mixed TRU } \\ & \text { Non-Mbxed TRU } \\ & \text { Suspect Mbxed TRU } \\ & \text { Unknown }\end{aligned}$

Rsearch and Devel. Waste
Operalions Waste
Residues
Decon and Decommissioning
Environmental Restoralion
From Treatment of Waste
Maintenance

TSCA Asbestos

PCBs

Other

N/A

Unknown

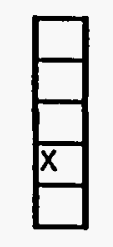




\section{WASTE STREAM PROFILE FOR THE WIPP TRU WASTE BASELINE INVENTORY REPORT}

SITE NAME IN

\section{WASTE TYPE MTRU HANDLING CH GENERATOR SITE BC}

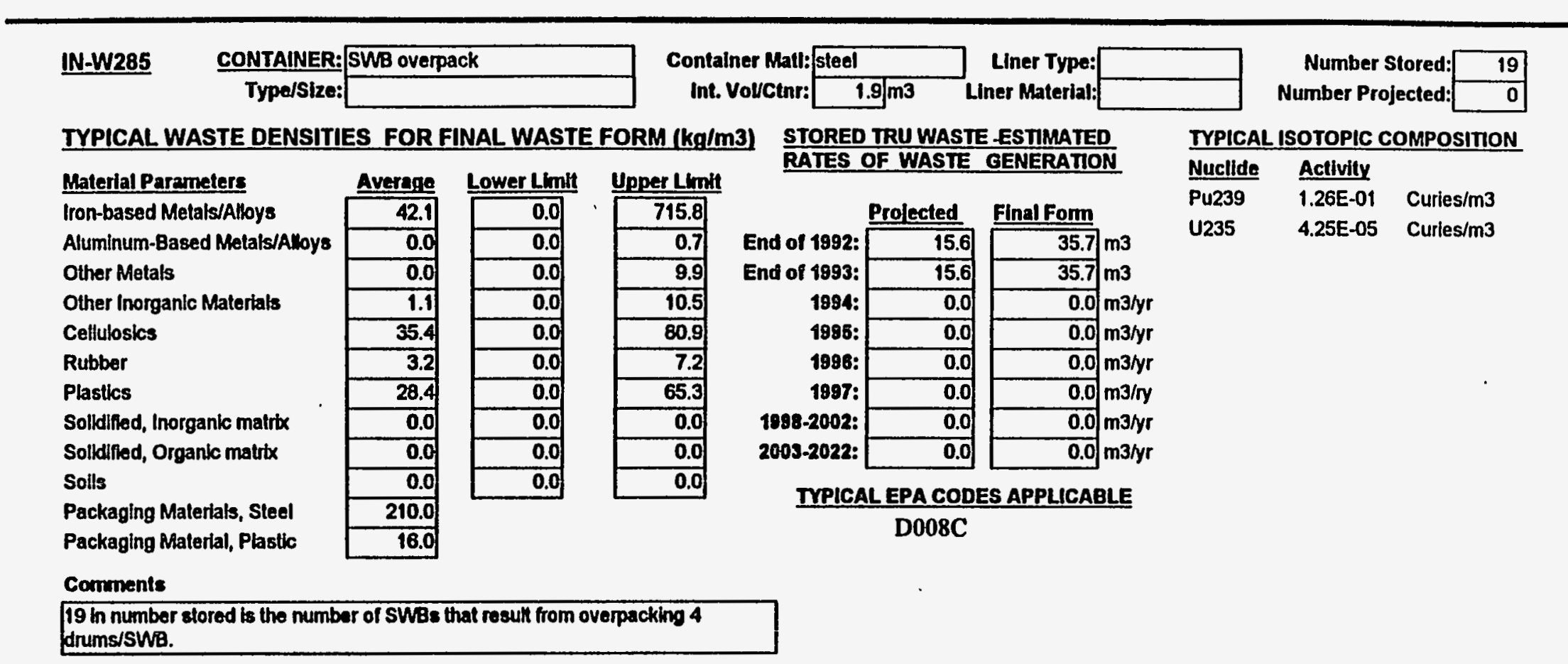




\section{WASTE STREAM PROFILE FOR THE WIPP TRU WASTE BASELINE INVENTORY REPORT}

SITENAME IN WASTE TYPE MTRU HANDLING CH GENERATOR SITE BC

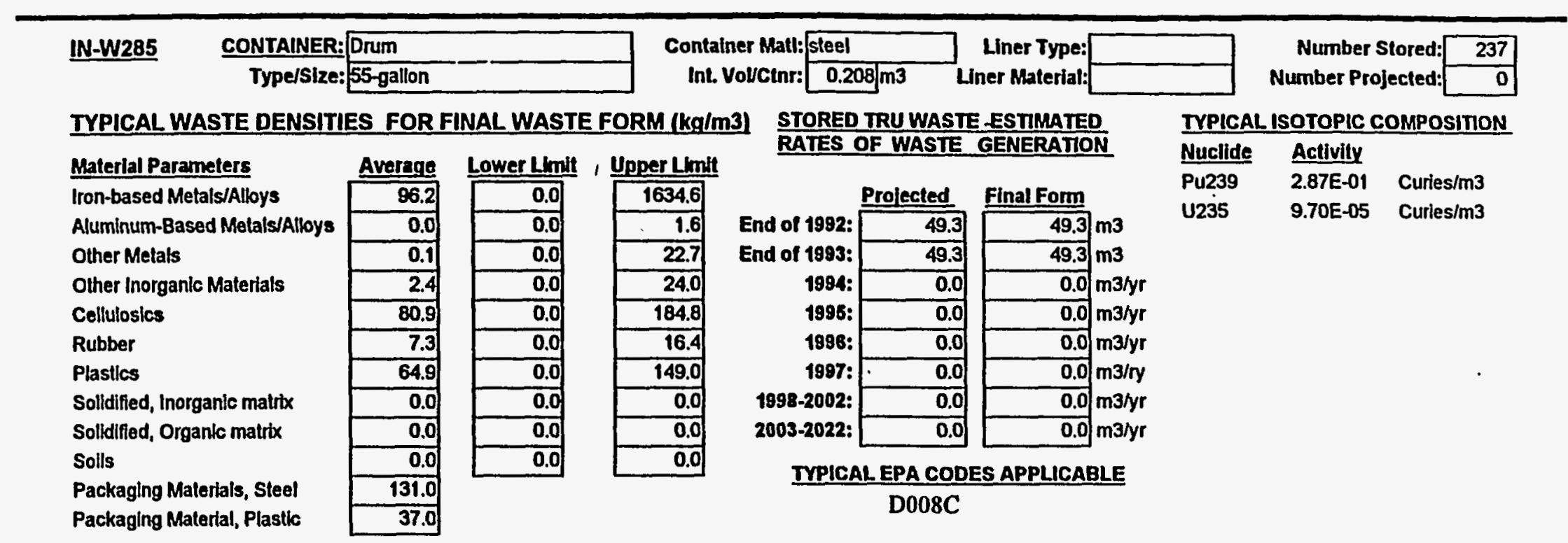




\section{WASTE STREAM PROFILE FOR THE WIPP TRU WASTE BASELINE INVENTORY REPORT}

\section{SITE NAME IN WASTE TYPE MTRU HANDLING CH GENERATOR SITE AE}

\begin{tabular}{|c|c|c|c|c|}
\hline \multirow{4}{*}{\multicolumn{2}{|c|}{$\begin{array}{ll}\text { WASTE STREAM } & \text { MWIR ID } \\
& \text { WPP ID } \\
\text { Local ID } & \\
\text { MATRIX CODE } & \end{array}$}} & IN-W287 & \multirow{5}{*}{$\begin{array}{l}\text { STREAMNAME } \\
\text { DESCRIPTION }\end{array}$} & \multirow[t]{2}{*}{ Metal Debris } \\
\hline & & IN-W287 & & \\
\hline & & ID-EGG-134T-101 & & \multirow[t]{4}{*}{ Miscellaneous (Paper, Metal, Etc.) (TRU): Cut Up Gloveboxes } \\
\hline & & 5100 & & \\
\hline \multicolumn{2}{|c|}{ SITE FINAL FORMIDC } & & & \\
\hline \multicolumn{2}{|c|}{ Waste Matrix Code Group } & Uncategorized Metal & & \\
\hline \multicolumn{2}{|c|}{ Site Matrix Description } & \multicolumn{3}{|c|}{$\begin{array}{l}\text { This wasle stream, generated at Argonne National Laboralory-East, conlains glovebox sections and associated equipment from decontamination and } \\
\text { decommissioning operations. The waste is predominantly noncombustible. There may be some lead (EP toxic, waste code DO08) present. }\end{array}$} \\
\hline
\end{tabular}

\section{FINAL WASTE FORM DESCRIPTORS:}

\begin{tabular}{l|l} 
Defense TRU Waste \\
Non-Defense TRU Waste \\
Commercial TRU Wasto \\
Unknown
\end{tabular}$\quad \square \quad \begin{aligned} & \text { Mlxed TRU } \\
& \text { Non-Mixed TRU } \\
& \text { Suspect Mixed TRU } \\
& \text { Unknown }\end{aligned}$

Rsearch and Devel. Waste
Operations Waste
Residues
Decon and Decommissioning
Environmental Restoralion
From Treatment of Waste
Maintenance

TSCA Asbestos

PCBs

Other

N/A

Unknown

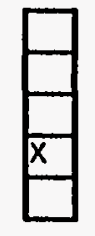




\section{WASTE STREAM PROFILE FOR THE WIPP TRU WASTE BASELINE INVENTORY REPORT}

SITENAME IN

WASTE TYPEMTRU HANDLING CH GENERATOR SITE AE

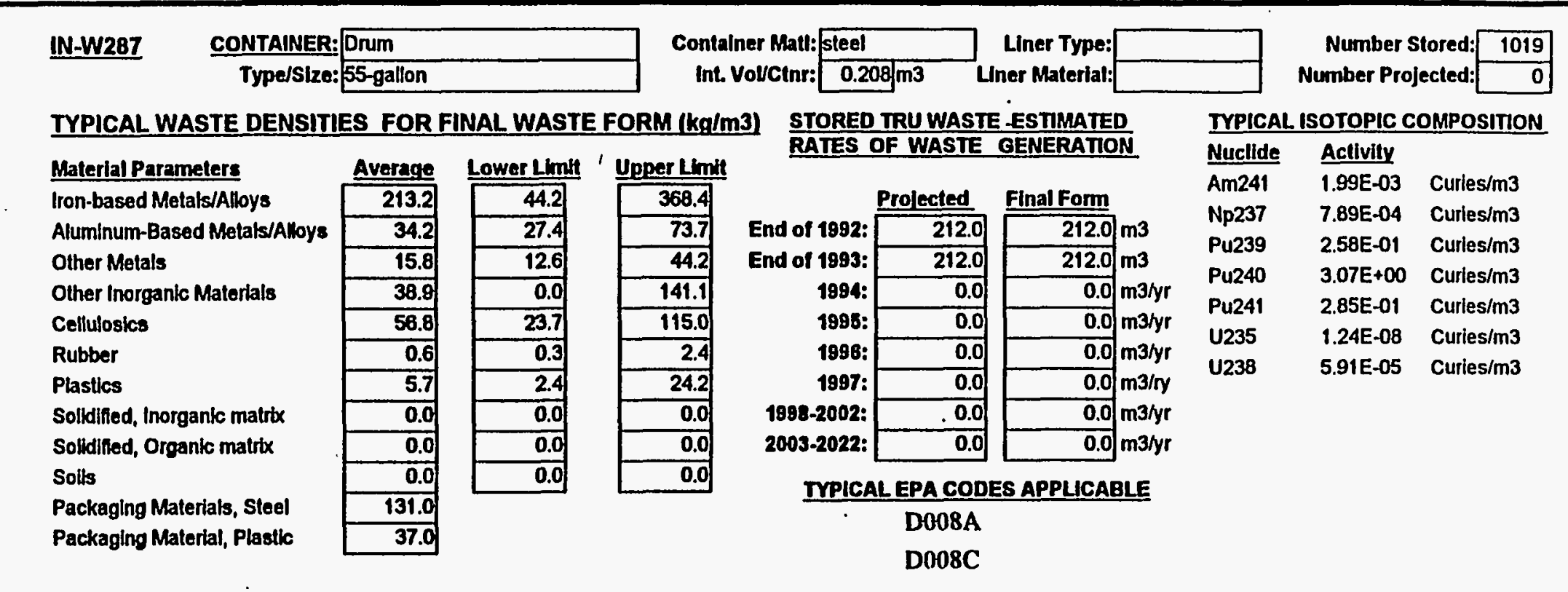


WASTE STREAM PROFILE FOR THE WIPP TRU WASTE BASELINE INUENTORY REPORT

SITENAME IN WASTE TYPE MTRU HANDLING CH

GENERATOR SITE RF, AE

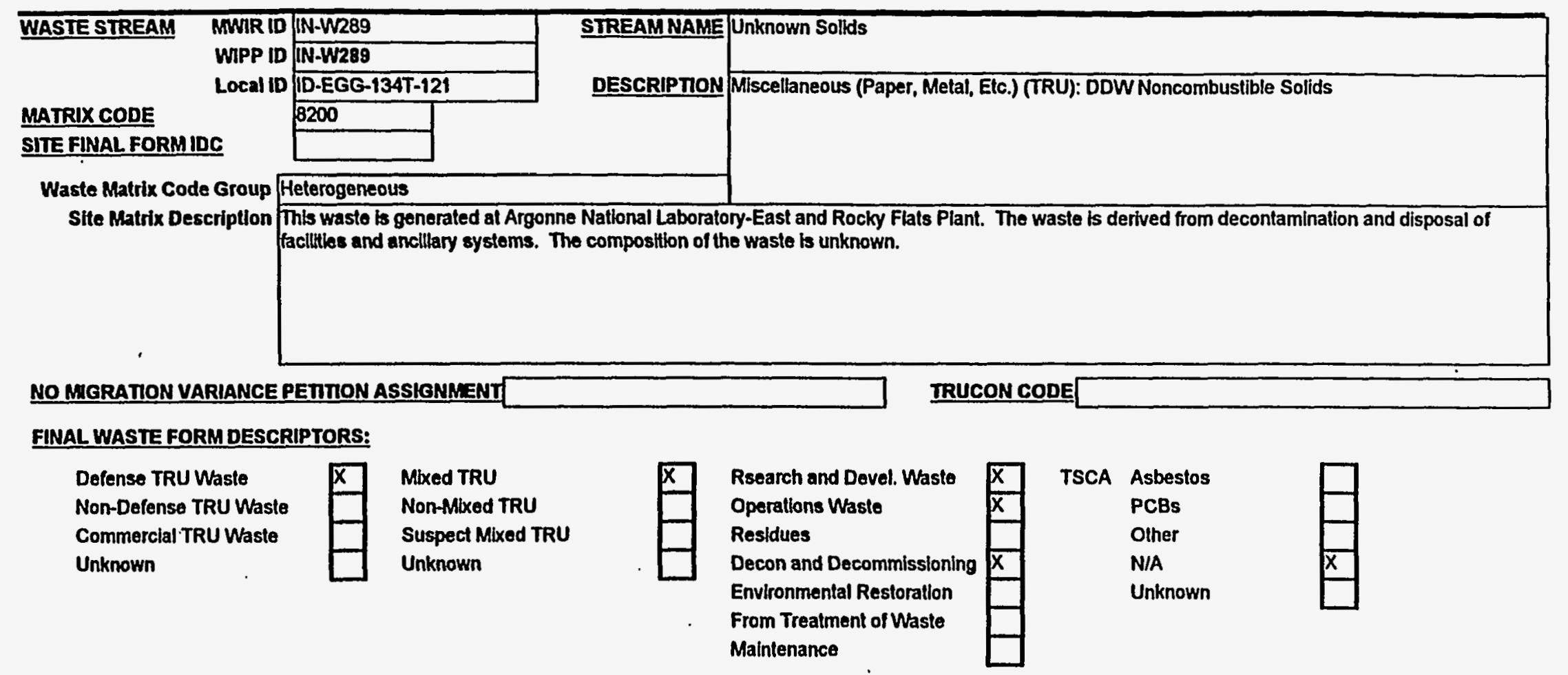




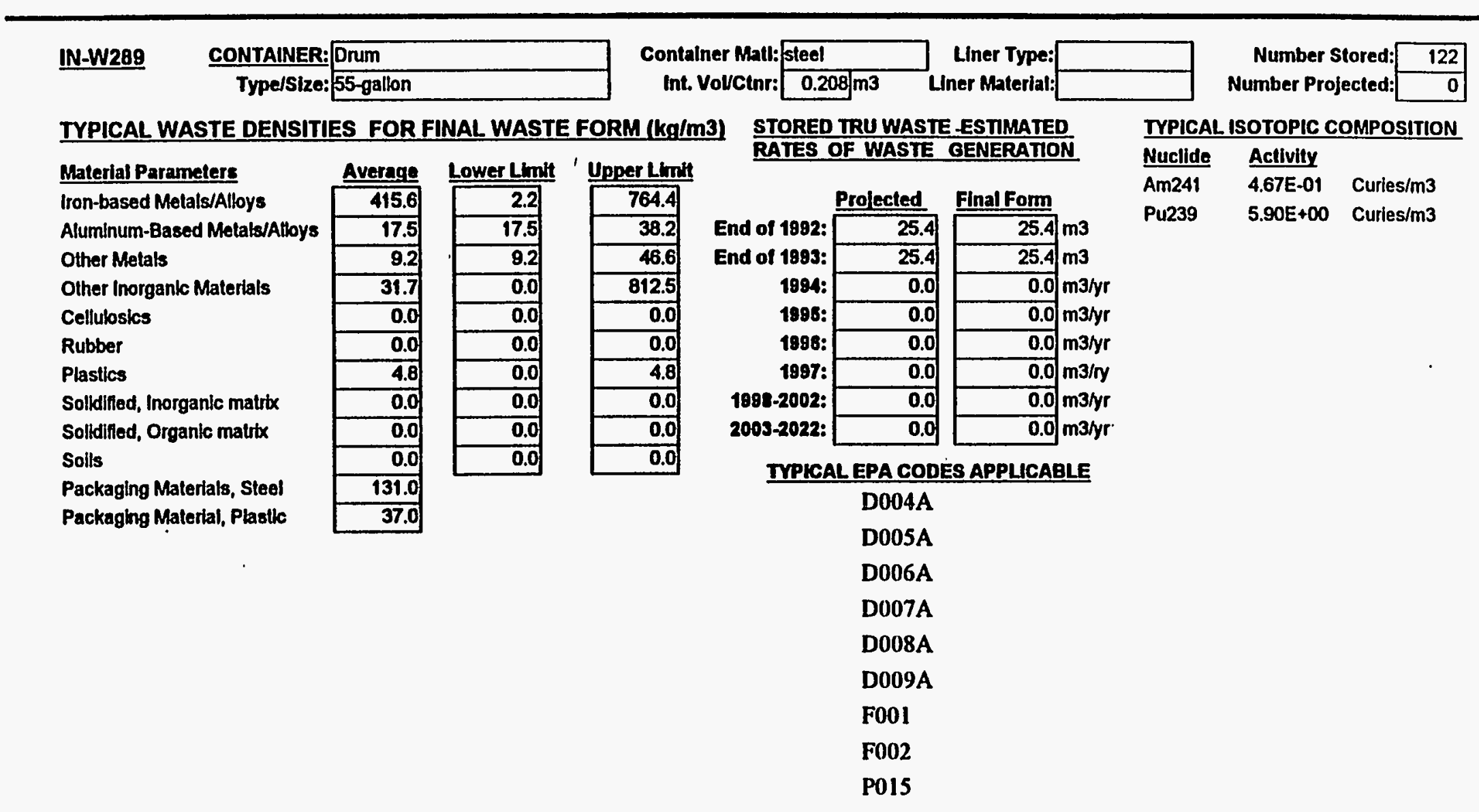




\section{WASTE STREAM PROFILE FOR THE WIPP TRU WASTE BASELINE INVENTORY REPORT}

SITE NAME IN

WASTE TYPE MTRU HANDLING CH

GENERATOR SITE AE

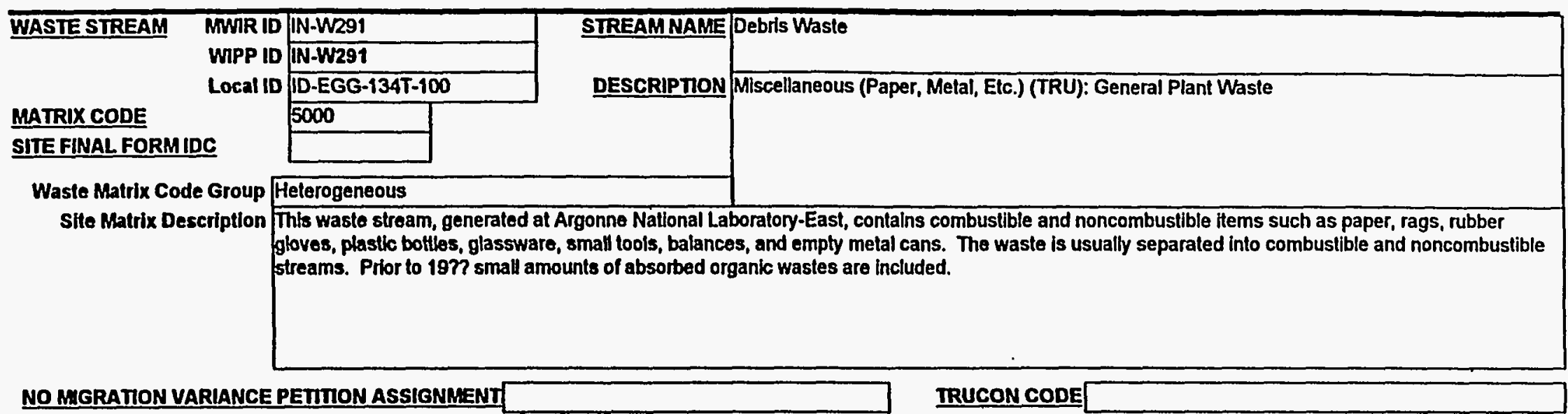

\section{FINAL WASTE FORM DESCRIPTORS:}

Defense TRU Waste

Non-Defense TRU Waste

Commerclal TRU Waste

Unknown

$\square$

Mixed TRU

Non-Mixed TRU

Suspect Mixed TRU

Unknown
TSCA Asbestos

PCBs

Other

N/A

Unknown

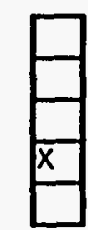

From Treatment of

Maintenance

\begin{tabular}{|l|}
\hline$x$ \\
\hline$x$ \\
\hline$x$ \\
\hline \\
\hline \\
\hline
\end{tabular}


WASTE STREAM PROFILE FOR THE WIPP TRU WASTE BASELINE INVENTORY REPORT

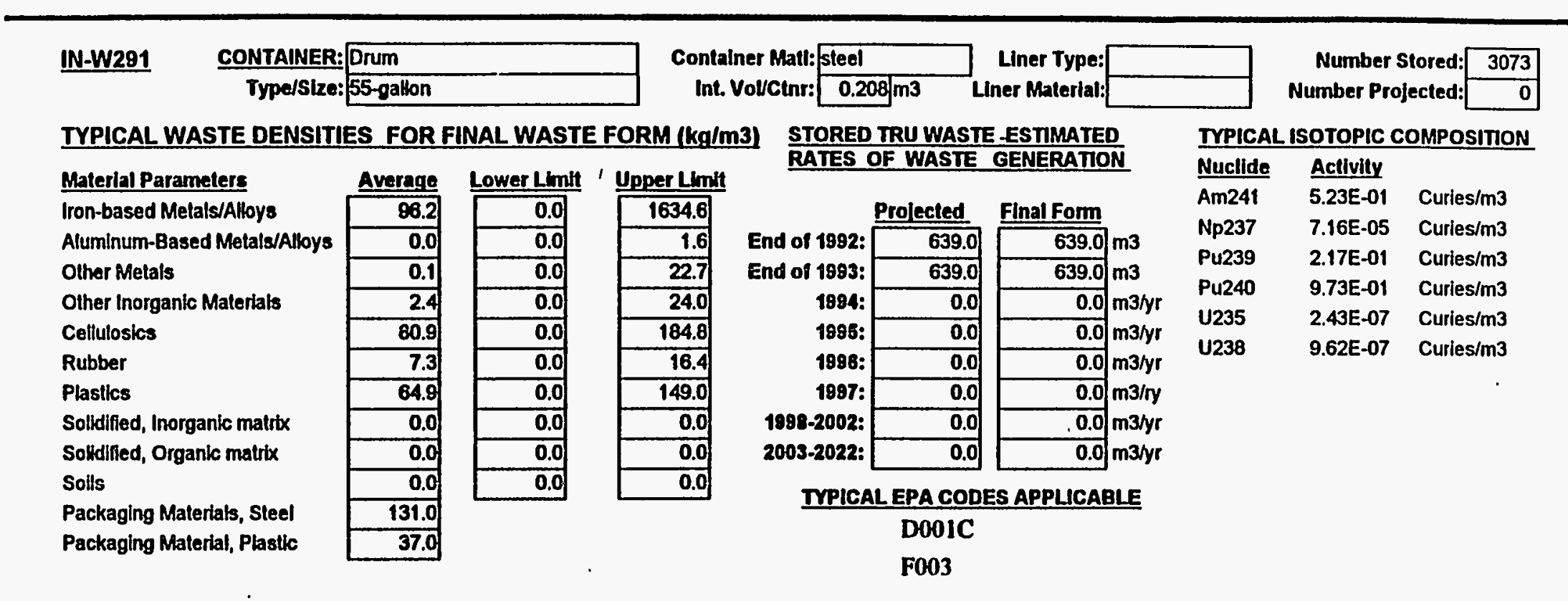


WASTE STREAM PROFILE FOR THE WIPP TRU WASTE BASELINE INVENTORY REPORT

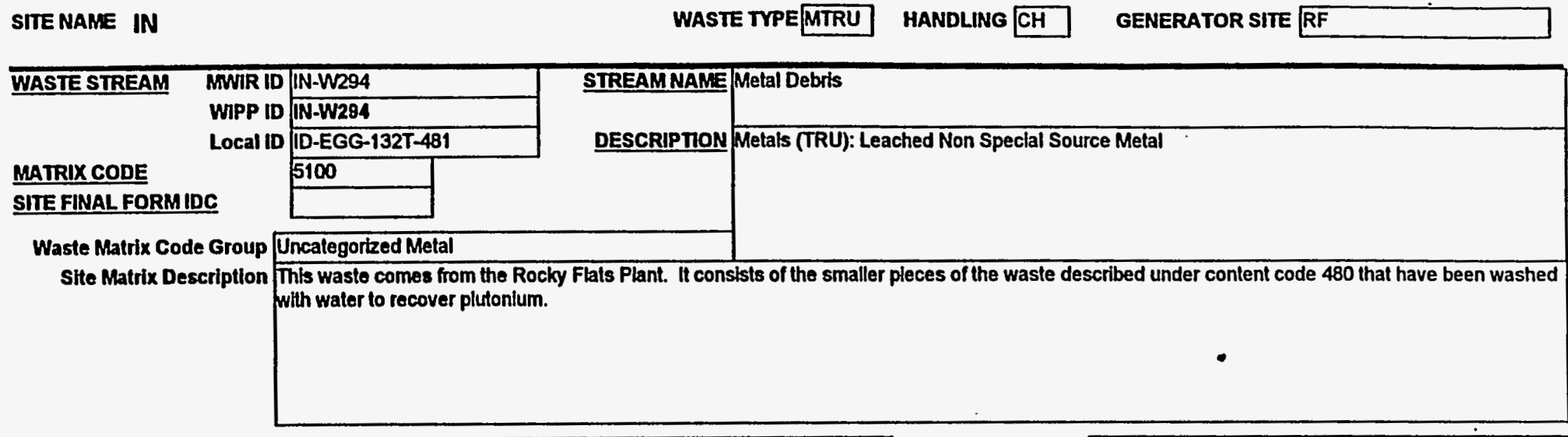

NO MUGRATION VARIANCE PETITION ASSIGNMENT ID 217C IRUCON CODE ID 217C

FINAL WASTE FORMDESCRIPTORS:

\begin{tabular}{|c|c|}
\hline Defense TRU Waste & Mbxed TRU \\
\hline Non-Defense TRU Waste & Non-Mbed TRU \\
\hline Commerclal TRU Waste & Suspect Mbxed TRU \\
\hline Unknown & Unknown \\
\hline
\end{tabular}

Rsearch and Devel. Waste
Operatlons Waste
Residues
Decon and Decommissioning
Environmental Restoration
From Trealment of Waste
Maintenance

TSCA Asbestos

PCBs

Other

N/A

Unknown

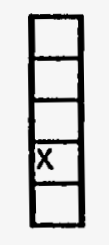


WASTE STREAM PROFILE FOR THE WIPP TRU WASTE BASELINE INVENTORY REPORT

SITE NAME IN WASTE TYPE MTRU HANDLING CH GENERATOR SITE RF

IN-W294 CONTAINER: SWB overpack

Container Matt: steel int. Voucenr:

$1.9 \mathrm{m3}$

Liner Type:
Liner Ahaterlal:

Number Stored: Number Projected:

TYPICAL WASTE DENSITIES FOR FINAL WASTE FORM (kg/m3)

STORED TRU WASTE ESTIMATED

\section{Material Parameters}

Iron-based Metals/Alloys

Aluminum-Based Metals/Alloys

Olher Metals

Other Inorganic Materials

Cellulosics

Rubber

Plastles

Solldified, Inorganic matrix

Solldified, Organic matrix

Solls

Packaging Materials, Steel

Packaging Material, Plastio

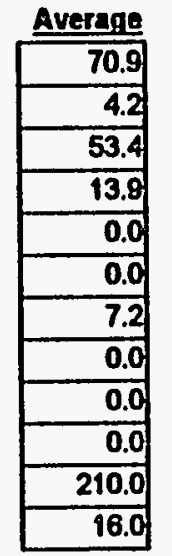

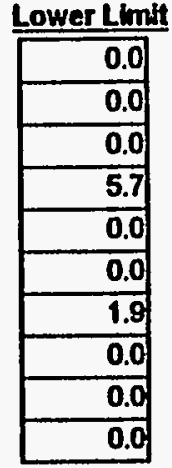

\begin{tabular}{|c|}
\hline 148.5 \\
\hline 21.1 \\
\hline 208.8 \\
\hline$\overline{23.9}$ \\
\hline 0.1 \\
\hline 0.0 \\
\hline 17.2 \\
\hline 0.0 \\
\hline 0.0 \\
\hline 0.0 \\
\hline
\end{tabular}

RATES OF WASTE GENERATION

\begin{tabular}{|c|c|c|c|}
\hline & Prolected & Final Form & \\
\hline End of 1992: & 38.5 & 87.9 & m3 \\
\hline End of 1993: & 38.5 & 87.9 & m3 \\
\hline 1984: & 0.0 & 0.0 & m3/yr \\
\hline 4995: & 0.0 & 0.0 & $\mathrm{~m} 3 / \mathrm{yr}$ \\
\hline 1998: & 0.0 & 0.0 & m3/yr \\
\hline 1997: & 0.0 & 0.0 & $m 3 / n$ \\
\hline 1898-2002: & 0.0 & 0.0 & m3/yr \\
\hline 2003-2022: & $\overline{0.0}$ & 0.0 & m3/yr \\
\hline
\end{tabular}

IYPICALISOTOPIC COMPOSITION

Nuclide Activity

Am241 3.30E-02 Curies/m3

Pu52 1.01E+01 Curies/m3

U235 8.82E-07 Curies/m3

\section{IYPICAL EPA CODES APPLICABLE \\ D008A}

D008C

D022

Fovi

$\mathrm{F} 002$

F005 


\section{WASTE STREAM PROFILE FOR THE WIPP TRU WASTE BASELINE INVENTORY REPORT}

SITE NAME IN WASTE TYPE MTRU HANDLING CH GENERATOR SITE RF

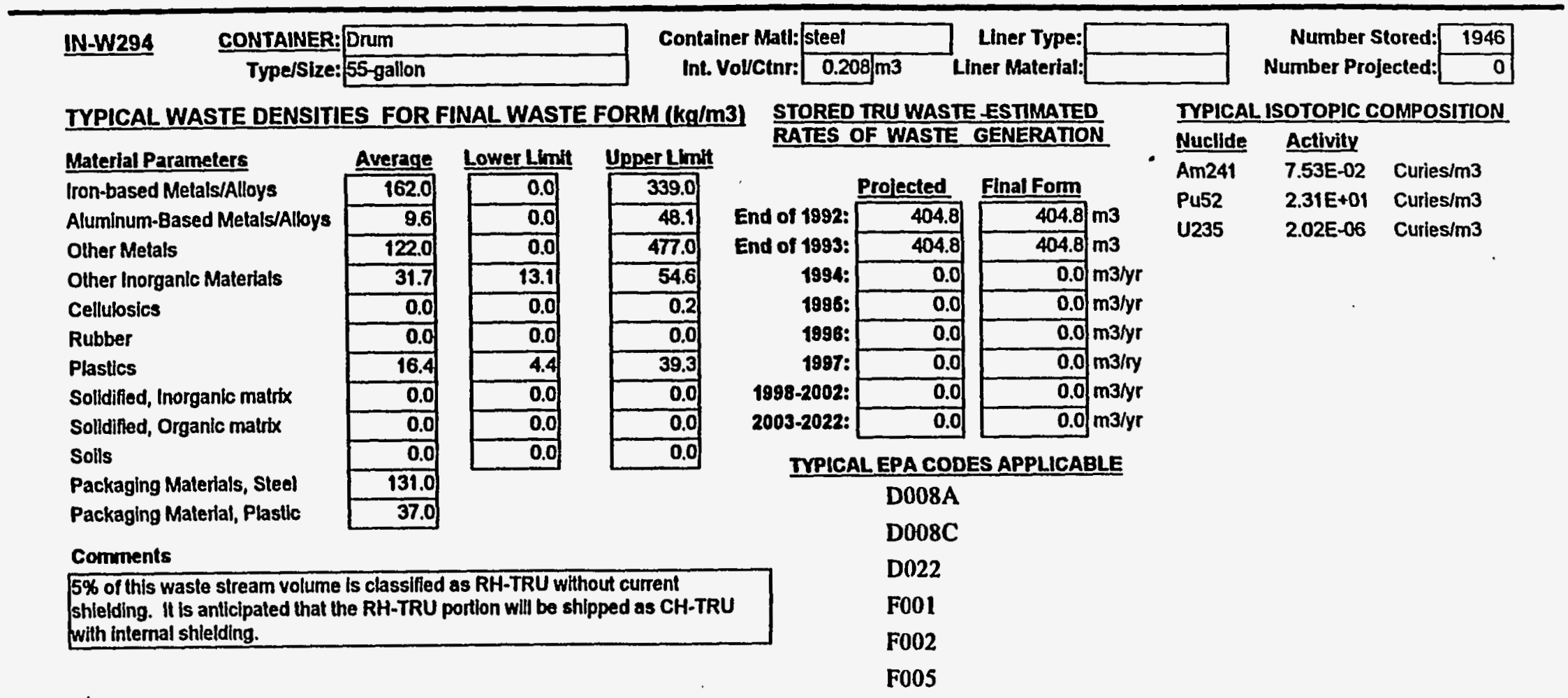




\section{WASTE STREAM PROFILE FOR THE WIPP TRU WASTE BASELINE INVENTORY REPORT}

SITE NAME IN

WASTE TYPE MTRU

HANDLING CH

GENERATOR SITE RF

WASTE STREAM MWIR ID \begin{tabular}{|l|l|l|} 
IN-W296 \\
WIPP ID
\end{tabular}
MATRIX CODE
SITE FINAL FORMIDC
Waste Matrix Code Group
Site Matrix Description

\section{NO MGRATION VARIANCE PETITION ASSIGNMENT ID 117; 217C}

IRUCON CODE ID 217C

\section{FINAL WASTE FORMDESCRIPTORS:}

\begin{tabular}{|c|c|}
\hline Defense TRU Waste & Mbxed TRU \\
\hline Non-Dofense TRU Waste & Non-Mbed TRU \\
\hline Commercial TRU Waste & Suspect Mixed TRU \\
\hline Unknown & Unknown \\
\hline
\end{tabular}

\begin{tabular}{|l|l|l|}
\hline$X$ & & \\
\hline$X$ & & \\
\hline$X S C A$ & $\begin{array}{l}\text { Asbestos } \\
\text { PCBs } \\
\text { OIher } \\
\text { N/A } \\
\text { Unknown }\end{array}$ & \\
\hline & & \\
\hline & & \\
\hline
\end{tabular}




N-W296 CONTAINER: SWB overpack

TYPICAL WASTE DENSITIES FOR FINAL WASTE FORM $(\mathrm{kg} / \mathrm{m} 3$

Material Parameters Iron-based Metats/Alloys

Aluminum-Based Metaks/Alloys

Other Metals

Other Inorganic Matertals

Cellutosics

Rubber

Plastics

Solldified, Inorgank matrix

Solidified, Organic matrix

Soils

Packaging Materlats, Steel

Packaging Materlal, Plastic

\begin{tabular}{|r|}
\hline Averege \\
\hline 25.7 \\
\hline 1.7 \\
\hline 70.1 \\
\hline 6.2 \\
\hline 1.7 \\
\hline 0.8 \\
\hline 11.5 \\
\hline 0.0 \\
\hline 0.0 \\
\hline 0.0 \\
\hline 210.0 \\
\hline 16.0 \\
\hline
\end{tabular}

\section{Lower Limit' ' Upper Limit}

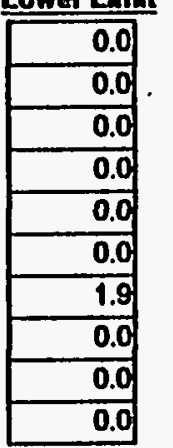

\begin{tabular}{|r|}
\hline 116.5 \\
\hline 14.4 \\
\hline 235.6 \\
\hline 26.1 \\
\hline 7.2 \\
\hline 4.3 \\
\hline 21.5 \\
\hline 0.0 \\
\hline 0.0 \\
\hline 0.0 \\
\hline
\end{tabular}

Comments

62 in number stored ts the number of SWBs that resull from overpacking 4 drums/SWA.

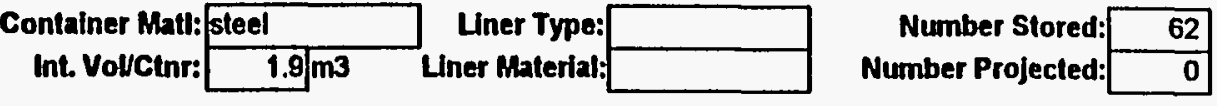

STORED TRU WASTE ESTIMATED RATES OF WASTE GENERATION

\begin{tabular}{r|r|}
\hline & Prolected \\
\hline End of 1992: & 51.4 \\
\hline End of 1993: & 51.4 \\
\hline $1994:$ & 0.0 \\
\hline $1986:$ & 0.0 \\
\hline $1998:$ & 0.0 \\
\hline $1997:$ & 0.0 \\
\hline $1998-2002:$ & 0.0 \\
\hline $2003-2022:$ & 0.0 \\
\hline
\end{tabular}

TYPICAL ISOTOPIC COMPOSIIION Nucllde Activity

Am241 1.11E-02 Curles $/ \mathrm{m}^{3}$

Np237 1.34E-06 Curles/m3

Pu52 2.35E+00 Curles $/ \mathrm{m}^{3}$

U235 4.89E-08 Curles $/ \mathrm{m}^{3}$
TYPICAL EPA CODES APPLICABLE

D008A

D008C

D028

D029

F001

F002

F003

F005A

F005A 


\section{WASTE STREAM PROFILE FOR THE WIPP TRU WASTE BASELINE INVENTORY REPORT}

SITE NAME IN

\section{WASTE TYPE MTRU HANDLING CH GENERATOR SITE RF}

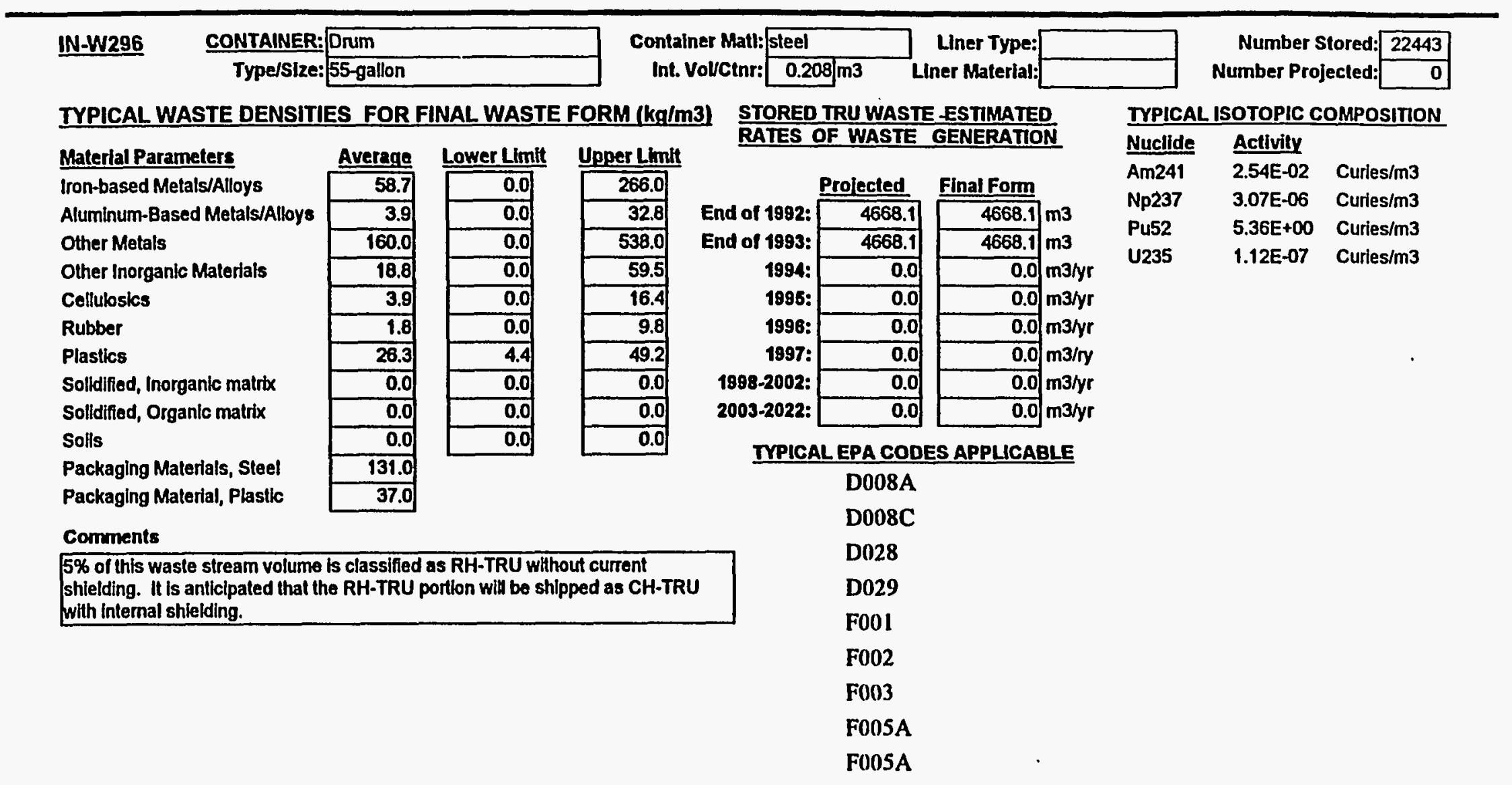




\section{WASTE STREAM PROFILE FOR THE WIPP TRU WASTE BASELINE INVENTORY REPORT}

SITENAME IN

WASTE TYPE MTRU HANDLING CH GENERATOR SITE RF

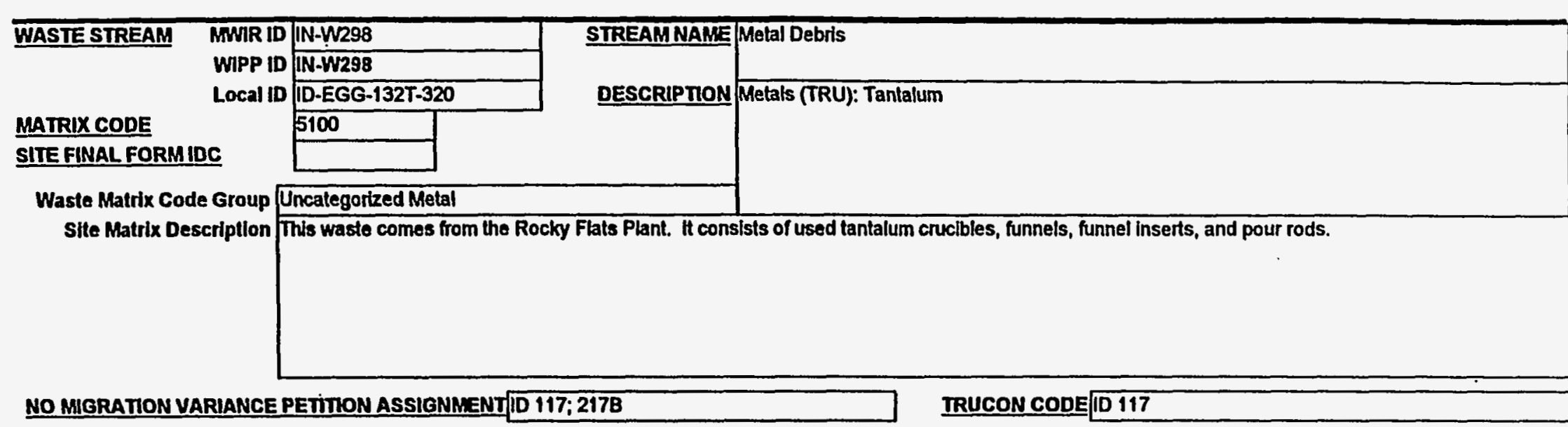

\section{FIMAL WASTE FORM DESCRIPTORS:}

\begin{tabular}{l|l|l} 
Defense TRU Waste \\
Non-Defense TRU Waste \\
Commerclal TRU Waste \\
Unknown
\end{tabular}$\quad \begin{aligned} & \text { Mbxed TRU } \\
& \text { Non-Mixed TRU } \\
& \text { Suspect Mixed TRU } \\
& \text { Unknown }\end{aligned}$

Unknown

$\square$

\begin{tabular}{|l|}
\hline$x$ \\
\hline$x$ \\
\hline$x$ \\
\hline \\
\hline \\
\hline
\end{tabular}

TSCA Asbeslos

PCBs

Other

N/A

Unknown

Treatment of Whaste

Maintenance

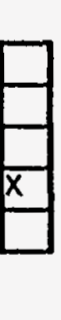




\section{WASTE STREAM PROFILE FOR THE WIPP TRU WASTE BASELINE INVENTORY REPORT}

SITE NAME IN WASTE TYPE MTRU HANDLING CH GENERATOR SITE RF

IN-W298 CONTAINER: SWB overpack

TYPICAL WASTE DENSITIES FOR FINAL WASTE FORM ( $\mathrm{kg} / \mathrm{m} 3)$

Material Parameters

Iron-based Metals/Alloys

Aluminum-Based Metats/Alloys

Other Metals

Other Inorganic Materials

Cellulosics

Rubber

Plastics

Solldified, Inorganic matrix

Solldified, Organic matrix

\section{Soils}

Packaging Materlals, Steel

Packaging Material, Plastic

\begin{tabular}{|r|} 
Average \\
\hline 81.0 \\
\hline 2.8 \\
\hline 17.8 \\
\hline 9.2 \\
\hline 6.0 \\
\hline 0.6 \\
\hline 6.0 \\
\hline 0.0 \\
\hline 0.0 \\
\hline 0.0 \\
\hline 210.0 \\
\hline 16.0 \\
\hline
\end{tabular}

Comments

22 in number stored is the number of SWBs that resuk from overpacking 4

druma/sWo.

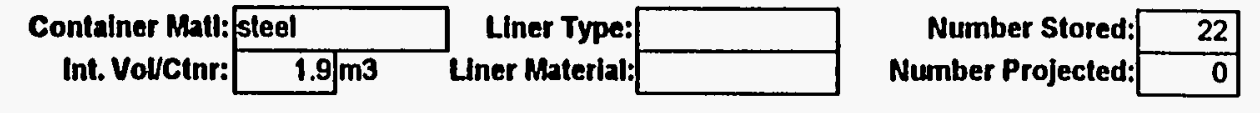

STORED TRU WASTE ESTIMATED RATES OF WASTE GENERATION

TYPICAL ISOTOPIC COMPOSITION

\section{Nuclide Actlvity}

Am241 5.27E-01 Curles/m3

Pu52 3.88E+01 Curies $/ \mathrm{m} 3$

\begin{tabular}{|c|c|c|c|}
\hline & Prolected & Final Form & \\
\hline End of 1992: & 18.2 & $\overline{41.5}$ & m3 \\
\hline End of 1993: & 18.2 & 41.5 & $\mathrm{~m} 3$ \\
\hline 1994: & 0.0 & 0.0 & $\mathrm{~m} 3 / y \mathrm{r}$ \\
\hline 1898: & 0.0 & $\overline{0.0}$ & m3/yr \\
\hline 1996: & 0.0 & 0.0 & $\mathrm{~m} 3 / \mathrm{yr}$ \\
\hline 1887: & 0.0 & $\overline{0.0}$ & $\mathrm{~m} 3 / \mathrm{y}$ \\
\hline 1898-2002: & 0.0 & 0.0 & $\mathrm{~m} 3 / \mathrm{yr}$ \\
\hline 2003-2022: & 0.0 & $\overline{0.0}$ & $\mathrm{~m} 3 / y r$ \\
\hline
\end{tabular}

IYPICALEPA CODES APPLICABLE

D008A

D008C

F001

$\mathrm{F002}$ 


\section{WASTE STREAM PROFILE FOR THE WIPP TRU WASTE BASELINE INVENTORY REPORT}

SITE NAME IN

WASTE TYPE MTRU HANDLING CH GENERATOR SITE RF

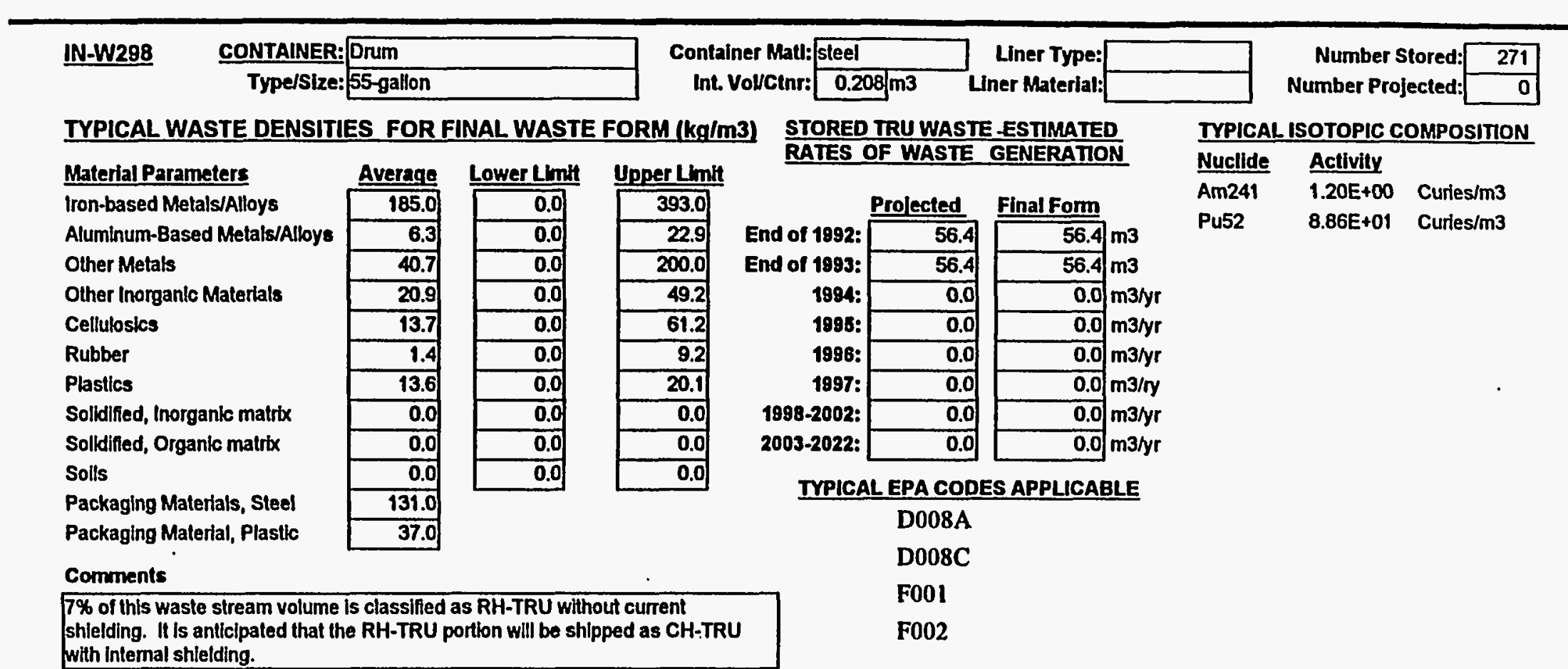




\section{WASTE STREAM PROFILE FOR THE WIPP TRU WASTE BASELINE INVENTORY REPORT}

SITE NAME IN

WASTE TYPE MTRU HANDLING CH GENERATOR SITE RF

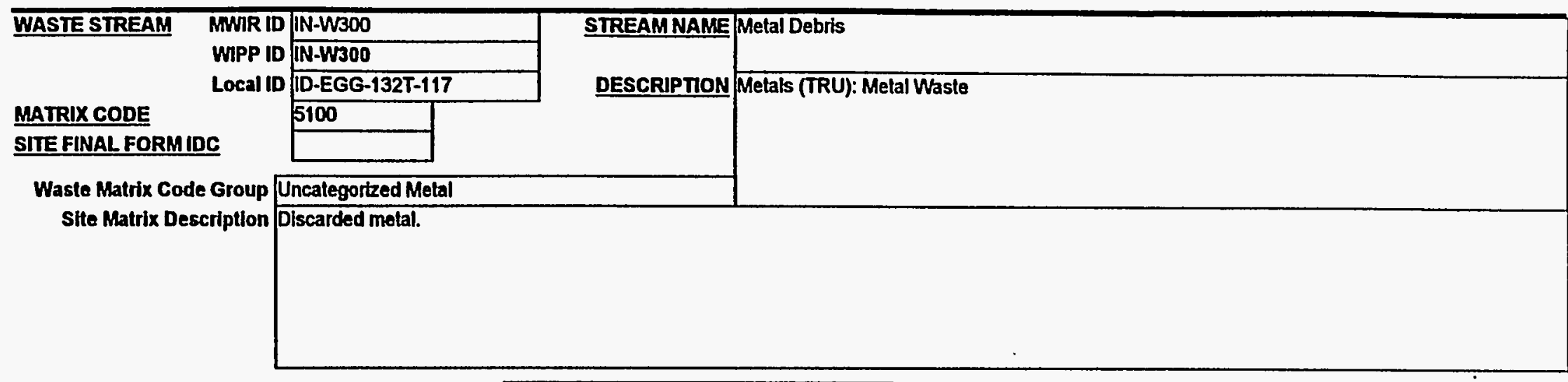

NO MUGRATION VARIANGE PETIMON ASSIGNMENT ID 117

IRUCON CODE ID 117

\section{FINAL WASTE FORM DESCRIPTORS:}

Defense TRU Waste $X$ Mixed TRU

Non-Defense TRU Waste

Commerclal TRU Waste

Non-Mixed TRU

Unknown

Suspect MIxed TRU

Unknown

$\square$

Rearch and Devel Wasto

Operations Waste

Resldues

Decon and Decommissioning

Environmental Restoration

From Treatment of Waste

Maintenance

\begin{tabular}{|l|}
\hline$x$ \\
\hline$x$ \\
\hline$x$ \\
\hline \\
\hline \\
\hline
\end{tabular}

TSCA Asbestos

PCBs

Olher

N/A

Unknown

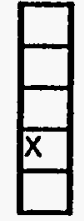




\section{WASTE STREAM PROFILE FOR THE WIPP TRU WASTE BASELINE INVENTORY REPORT}

SITE NAME IN WASTE TYPE MTRU HANDLING CH GENERATOR SITE RF

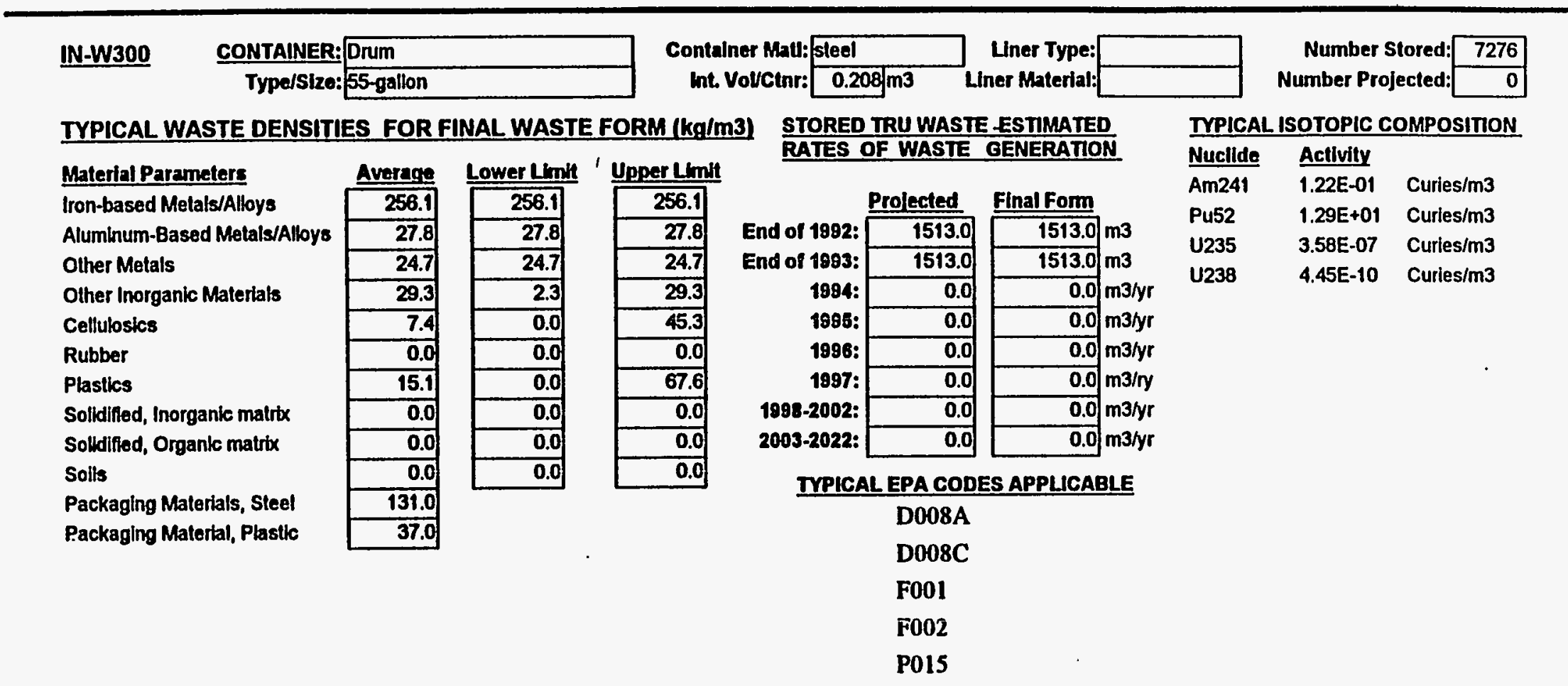




\section{WASTE STREAM PROFILE FOR THE WIPP TRU WASTE BASELINE INVENTORY REPORT}

SITE NAME IN

WASTE TYPE MTRU HANDLING CH GENERATOR SITE BT

WASTE STREAM MWIR ID IN-W302
LOPP ID
MATRIX CODE
SITE FINAL FORM IDC
Waste Matrix Code Group
Site Matrix Description

NO MIGRATION VARIANGE PETIION ASSIGNMENT

IRUCON CODE

\section{FINAL WASTE FORM DESCRIPTORS:}

\section{Defense TRU Waste \\ Non-Defense TRU Waste \\ Commercial TRU Waste \\ Unknown \\ Mbed TRU \\ Non-Mlxed TRU \\ Suspect Mixed TRU \\ Unknown}

X

\begin{tabular}{|l|}
\hline$x$ \\
\hline$x$ \\
\hline \\
\hline$x$ \\
\hline \\
\hline \\
\hline
\end{tabular}

TSCA Asbestos
PCBs
Olher
N/A
Unknown




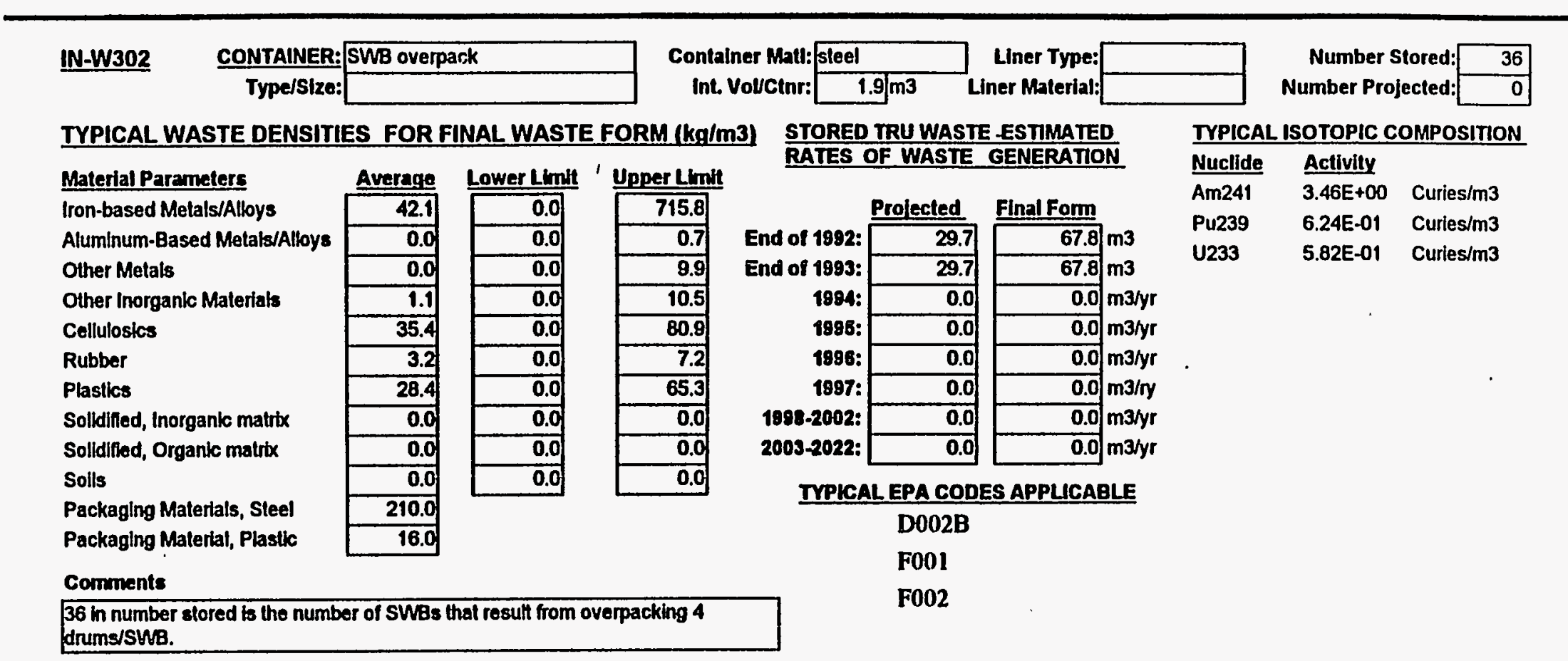


WASTE STREAM PROFILE FOR THE WIPP TRU WASTE BASELINE INVENTORY REPORT

SITE NAME IN WASTE TYPE MTRU HANDLING CH GENERATOR SITE BT

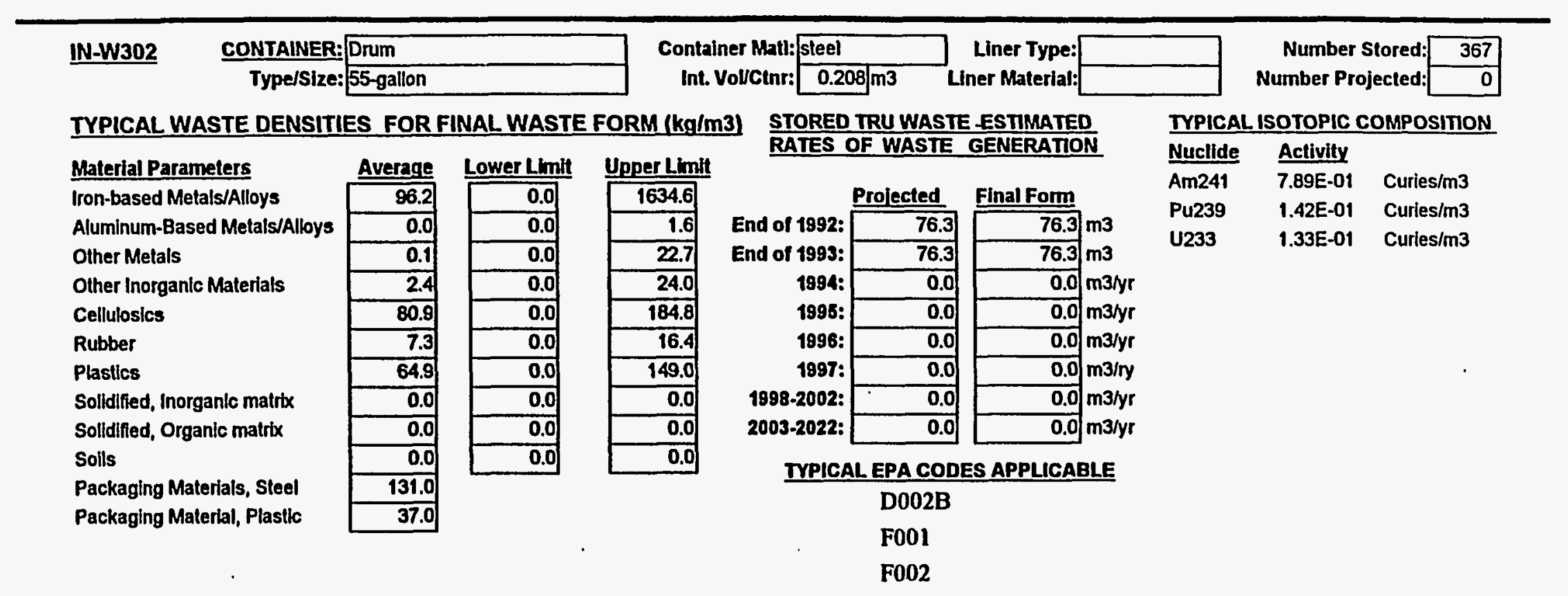




\section{WASTE STREAM PROFILE FOR THE WIPP TRU WASTE BASELINE INVENTORY REPORT}

SITE NAME IN

WASTE TYPETRU HANDLING CH GENERATOR SITE MD

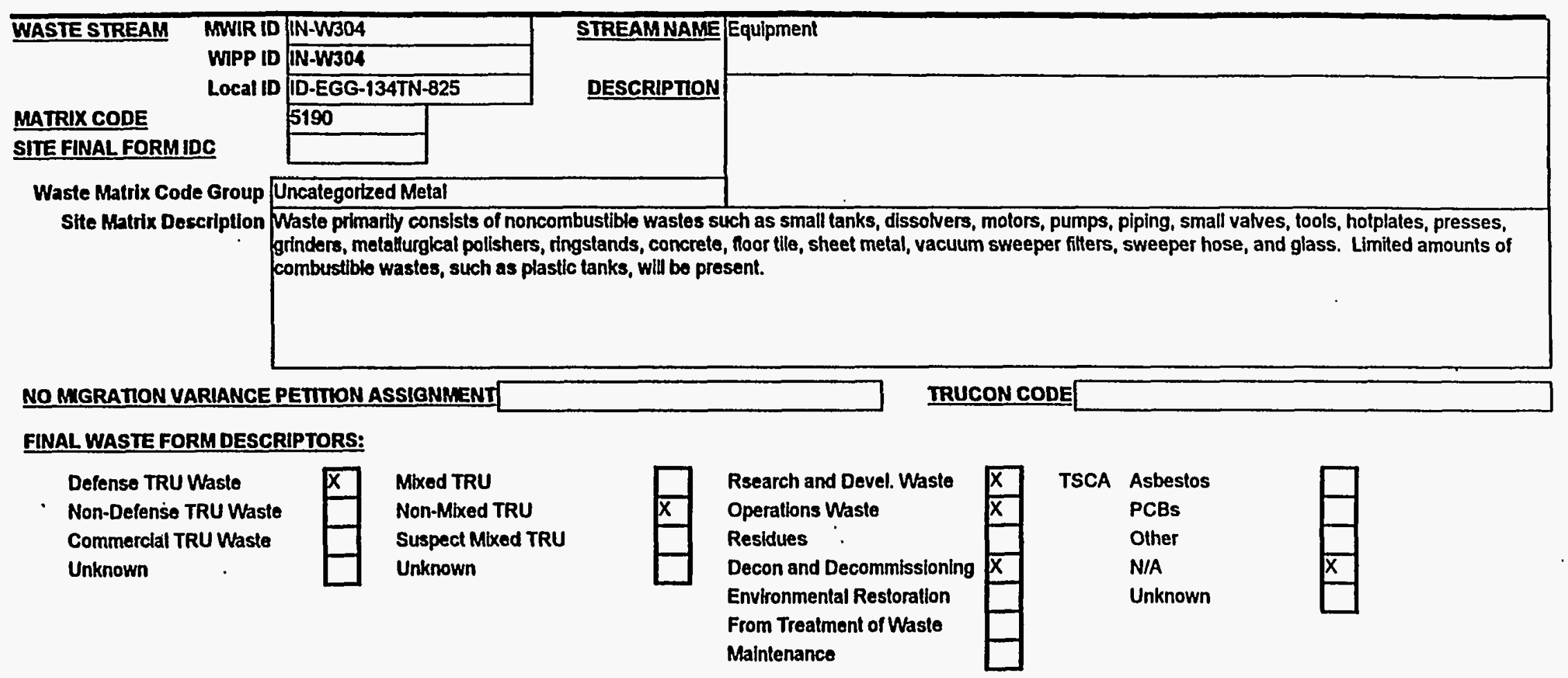




\section{WASTE STREAM PROFILE FOR THE WIPP TRU WASTE BASELINE INVENTORY REPORT}

$$
\text { CONTAINER: } 5 \text { SWB overpack }
$$

Container Matt: steel

Int. Volucinr:

Number Stored:

Number Projected

TYPICAL WASTE DENSITIES FOR FINAL WASTE FORM $(\mathrm{kg} / \mathrm{m} 3)$

STORED TRU WASTE -ESTIMATED

RATES OF WASTE GENERATION

Material Parameters

Iron-based Metals/Alloys

Aluminum-Based Metals/Alloye

Other Metals

Other Inorganlc Materials

Cellulosics

Rubber

Plastics

Solldified, Inorganic matrbx

Solidified, Organic matrix

Soils

\begin{tabular}{|c|c|}
\hline Average & Lower Limit \\
\hline 108.4 & 0.0 \\
\hline 0.0 & 0.0 \\
\hline 19.4 & 0.0 \\
\hline 41.6 & 0.0 \\
\hline 15.1 & 0.0 \\
\hline 0.0 & 0.0 \\
\hline 0.8 & 0.0 \\
\hline 0.0 & 0.0 \\
\hline 0.0 & 0.0 \\
\hline 0.0 & 0.0 \\
\hline 210.0 & \\
\hline 16.0 & \\
\hline
\end{tabular}

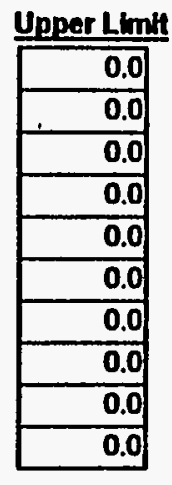

\begin{tabular}{|c|c|c|c|}
\hline & Projected & Final form & \\
\hline ind of 1992: & 10.6 & $\overline{24.2}$ & m3 \\
\hline d of 1983: & 10.6 & 24.2 & m3 \\
\hline 1884: & 0.0 & 0.0 & $\mathrm{~m} 3 / \mathrm{yr}$ \\
\hline 1896: & 0.0 & 0.0 & $\mathrm{~m} 3 / \mathrm{yr}$ \\
\hline 1998: & 0.0 & 0.0 & m3/yr \\
\hline 1997: & $\overline{0.0}$ & 0.0 & $m 3 / r y$ \\
\hline 98-2002: & 0.0 & 0.0 & $\mathrm{~m} 3 / \mathrm{yr}$ \\
\hline $103-202$ & 0.0 & 0.0 & $\mathrm{~m} 3 / y \mathrm{r}$ \\
\hline
\end{tabular}

IYPICAL ISOTOPIC COMPOSITION

Nuclide Activity

Pu238 2.27E+01 Curies/m3

Pu239 1.33E-01 Curies/m3

Pu240 2.77E-02 Curies/m3

Pu52 1.38E-03 Curies/m3

Pu83 2.77E $+\infty 0$ Curies $/ \mathrm{m} 3$

Packaging Materials, Steel

Packaging Material, Plastic

16.0

IVPICAL EPA CODES APPLICABLE

Comments

13 In numbar stored is tho nutmbar of Shas that resut from cverpacking 4

drums/SWB. 


\section{WASTE STREAM PROFILE FOR THE WIPP TRU WASTE BASELINE INVENTORY REPORT}

SITE NAME IN

\section{WASTE TYPETTRU HANDLING CH GENERATOR SITE MO}

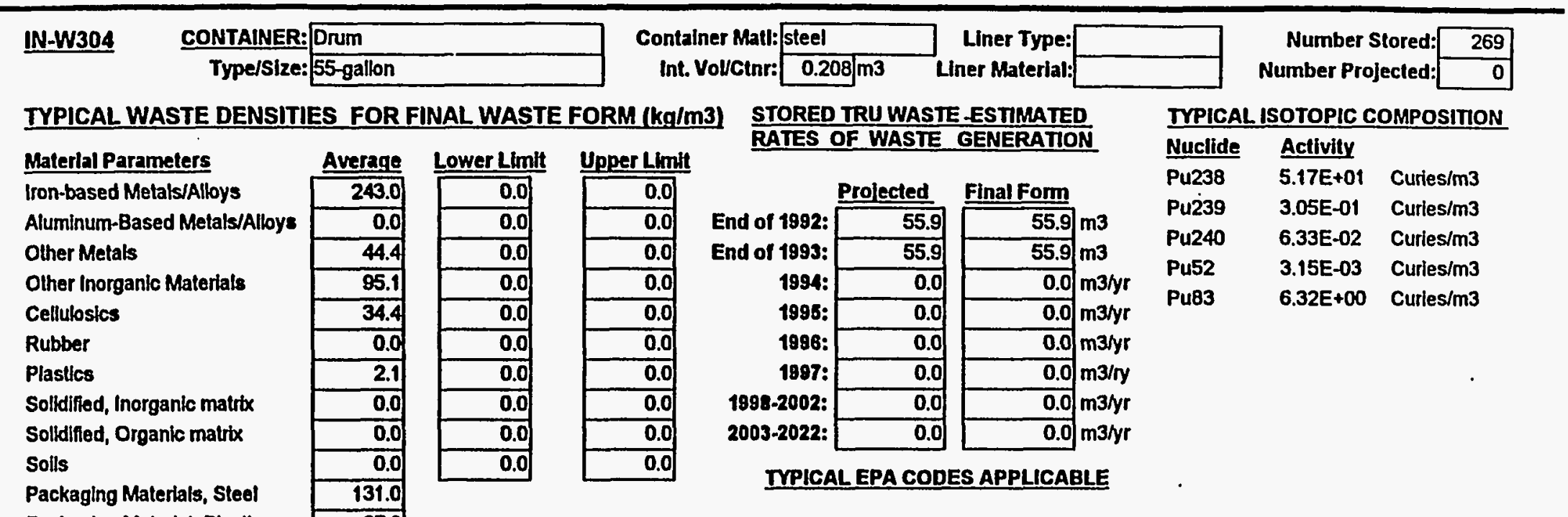




\section{WASTE STREAM PROFILE FOR THE WIPP TRU WASTE BASELINE INVENTORY REPORT}

SITE NAME IN WASTE TYPETRU HANDLING CH GENERATOR SITE MD

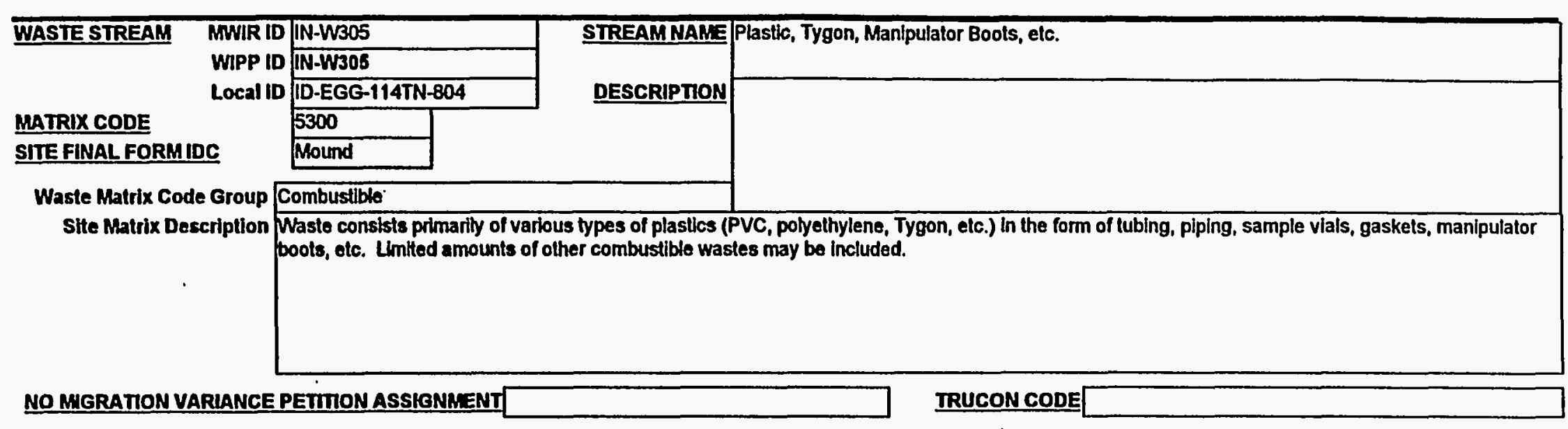

FINAL WASTE FORMDESCRIPTORS:

Non-Defense TRU Waste

Commerclal TRU Waste

Med TRU

Non-Mixed TRU

Suspect Mlxed TRU

Unknown

Unknown

$\square$

Rsearch and Devel. Waste
Operations Waste
Residues
Decon and Decommissioning
Environmental Restoration
From Treatment of Waste
Malnienance

TSCA Asbestos

PCBs

Other

N/A

Unknown

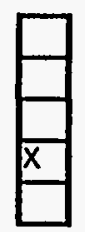




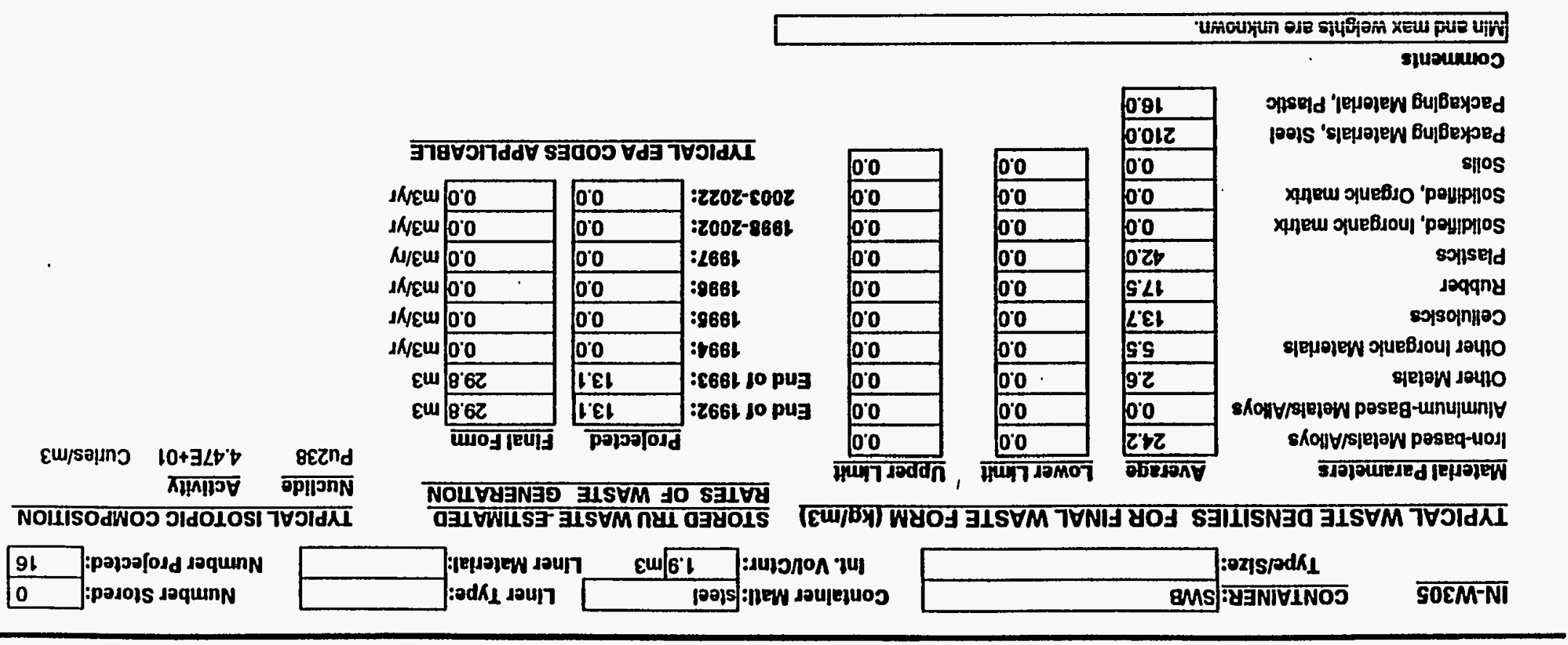




\section{WASTE STREAM PROFILE FOR THE WIPP TRU WASTE BASELINE INVENTORY REPORT}

SITE NAME IN

\section{WASTE TYPE TRU HANDLNG CH GENERATOR SITE MD}

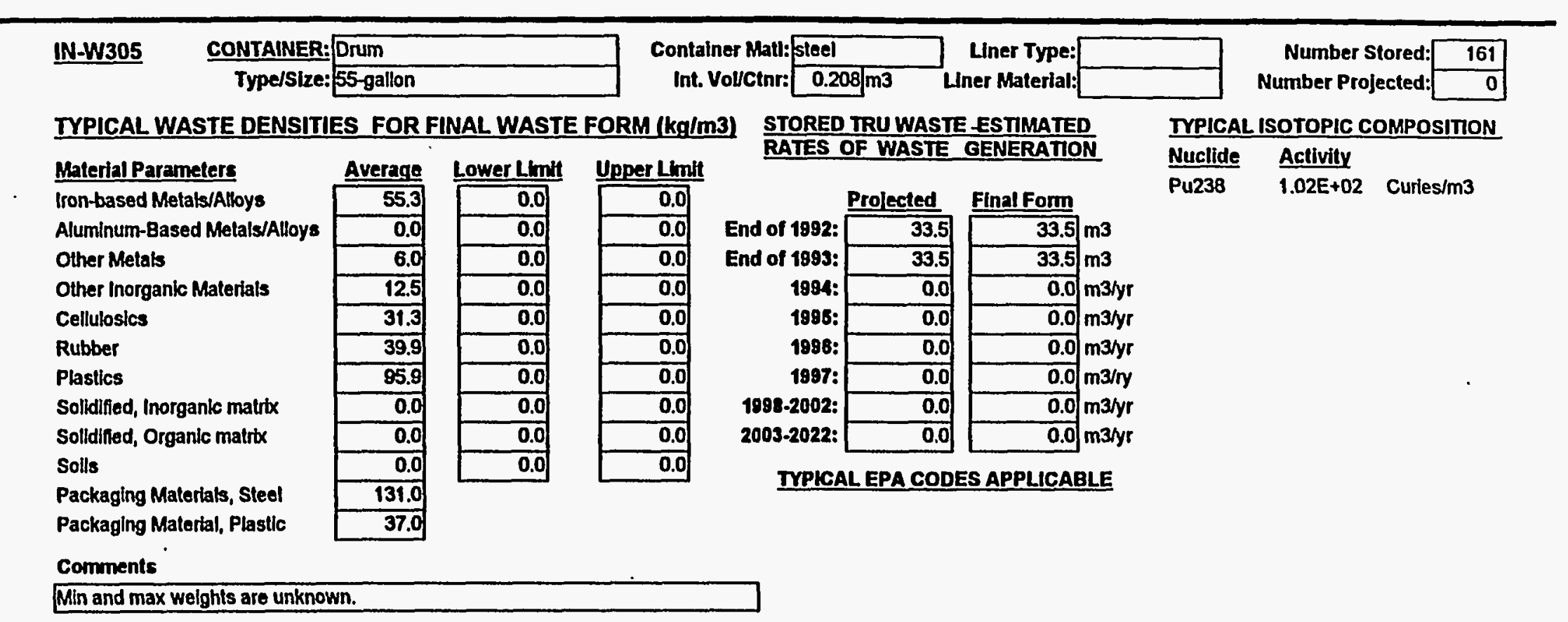




\section{WASTE STREAM PROFILE FOR THE WIPP TRU WASTE BASELINE INVENTORY REPORT}

SITE NAME IN

WASTE TYPE MTRU HANDLING CH GENERATOR SITE RF

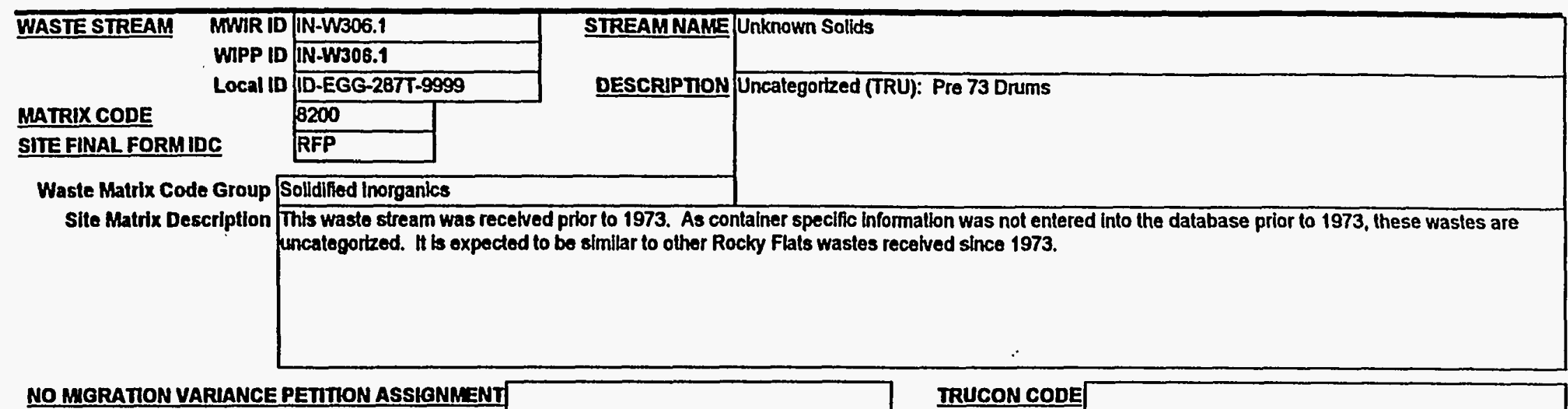

\section{FINAL WASTE FORM DESCRIPTORS:}

\begin{tabular}{l|l} 
Defense TRU Waste \\
Non-Defense TRU Waste \\
Commerctal TRU Waste \\
Unknown
\end{tabular}

Rsearch and Devel. Waste
Operations Waste
Residues
Decon and Decommisstoning
Environmental Restoration
From Treatment of Waste
Maintenance

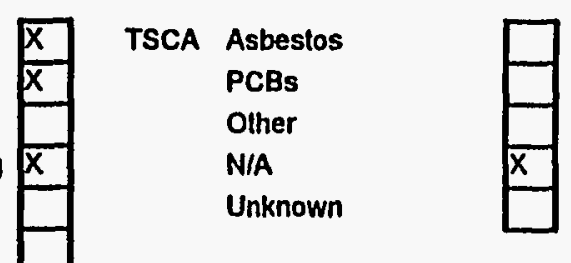




IN-W306.1 CONTAINER: SWB overpack

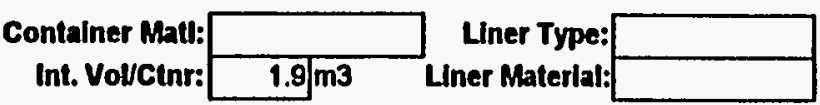

Number Stored Number Projected:

TYPICAL WASTE DENSITIES FOR FINAL WASTE FORM (kg/m3)

\section{Material Parameters}

\section{Lower Linit ' Upper Limit}

STORED TRU WASTE ESTIMATED

IVPICAL ISOTOPIC COMPOSITION RATES OF WASTE GENERATION

Nuclide Activily

Iron-based Metals/Alloys

Aluminum-Based Metals/Alloys

Other Metals

Other Inorganic Materials

Cellulosics

Rubber

Plastics

Solddified, Inorganic matrix

Solldified, Organic matrix

Soils

Packaging Materials, Steel

\begin{tabular}{|r|} 
Average \\
\hline 0.0 \\
\hline 0.0 \\
\hline 0.0 \\
\hline 214.1 \\
\hline 0.0 \\
\hline 0.0 \\
\hline 0.0 \\
\hline 91.5 \\
\hline 0.0 \\
\hline 0.0 \\
\hline 210.0 \\
\hline 16.0 \\
\hline
\end{tabular}

Packaging Material, Plastic

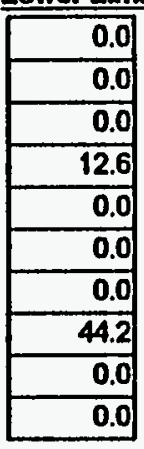

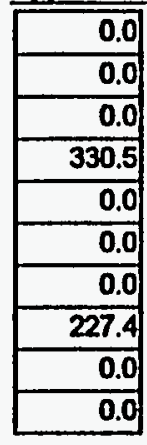

Comments

Number stored (44) is the number of SWBs as a result of overpacking 4 drums/SWB.

\begin{tabular}{|c|c|c|c|}
\hline & Prolected & Final Form & \\
\hline End of 1982: & 9.2 & 20.9 & $\mathrm{~m} 3$ \\
\hline End of 1983: & 9.2 & 20.9 & m3 \\
\hline 1984: & 0.0 & 0.0 & $m 3 / y r$ \\
\hline 1895: & 0.0 & 0.0 & $m 3 / y r$ \\
\hline 1898: & 0.0 & 0.0 & $m 3 / y r$ \\
\hline 1997: & 0.0 & 0.0 & $m 3 / r y$ \\
\hline 1998-2002; & 0.0 & 0.0 & m3/yr \\
\hline 2003-2022: & 0.0 & 0.0 & $\mathrm{~m} 3 / \mathrm{yr}$ \\
\hline
\end{tabular}




\section{WASTE STREAM PROFILE FOR THE WIPP TRU WASTE BASELINE INVENTORY REPORT}

IN-W306.1 CONTAINER:Drum

Type/Size: 55-gallon

Container Matt: steel

int. Vol/Ctnr: $0.208 / \mathrm{m3}$ Liner Material:

Number Stored: 1451

IYPICAL WASTE DENSITIES FOR FINAL WASTE FORM $(\mathrm{kg} / \mathrm{m} 3)$

Material Parameters

Iron-based Metals/Alloys

Aluminum-Based Metals/Alloys

Other Metals

Other Inorganic Materlals

Cellulosics

Rubber

Plastics

Solidified, Inorganic matrix

Solldified, Organic matrix

Solls

Packaging Materlals, Steel

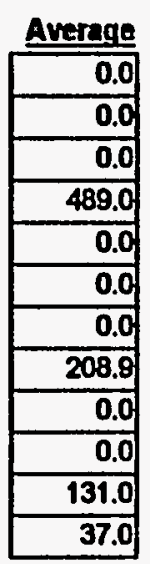

STORED TRU WASTE -ESTMMATED

Number Projected:

Packaging Material, Plastic

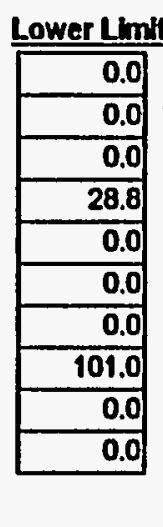
RATES OF WASTE GENERATION

TYPICAL ISOTOPIC COMPOSITION

Upper Limit

Prolected Final Form

\begin{tabular}{|r|}
\hline 0.0 \\
\hline 0.0 \\
\hline 0.0 \\
\hline 754.8 \\
\hline 0.0 \\
\hline 0.0 \\
\hline 0.0 \\
\hline 519.2 \\
\hline 0.0 \\
\hline 0.0 \\
\hline
\end{tabular}

Nuclide Activity

\section{Comments}

$5.7 \%$ of the waste stored is currently characterized as RH-TRU If internal

sheilding is not used. It is anticlpated that all wasto in this waste stream will be

categorized as CH-TRU at the time of shipment to WPP utllizing minimal internat

shielding as necessary. For WTWBIR purposes, all of the waste in this waste

stream is assumed to be $\mathrm{CH}$-TRU. 


\section{WASTE STREAM PROFILE FOR THE WIPP TRU WASTE BASELINE INVENTORY REPORT}

SITE NAME IN WASTE TYPEMTRU

HANDLING $\mathrm{CH}$

GENERATOR SITE RF

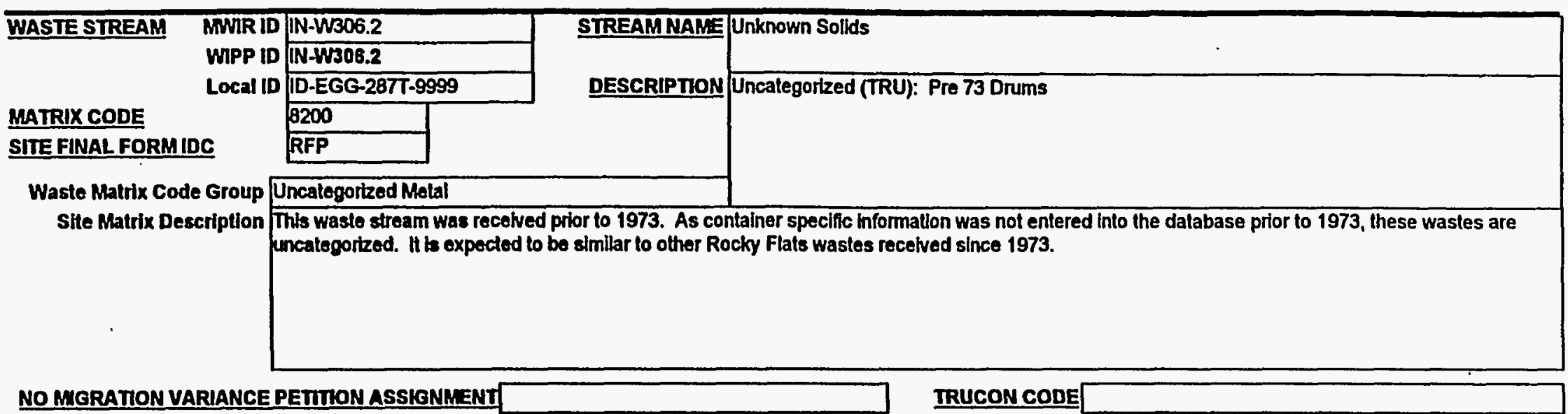

\section{FINAL WASTE FORM DESCRIPTORS:}

\begin{tabular}{|c|c|}
\hline Defense TRU Waste & Mbxed TRU \\
\hline Non-Defense TRU Waste & Non-Mllxed TRU \\
\hline Commerclal TRU Waste & Suspect Mbxed TRU \\
\hline Unknown & Uniknown \\
\hline
\end{tabular}

Reearch and Devel. Waste
Operations Wasto
Residues
Decon and Decommisstoning
Environmental Restoration
From Treatment of Waste
Maintenance

\begin{tabular}{|l|}
\hline$x$ \\
\hline$x$ \\
\hline \\
\hline \\
\hline \\
\hline
\end{tabular}

TSCA Asbestos

PCBs

Olher

N/A

Unknown

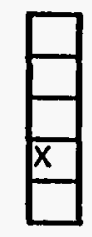

Maintenance

.


IN-W306.2 CONTAINER: SWB overpack

TYPICAL WASTE DENSITIES FOR FINAL WASTE FORM $(\mathrm{kg} / \mathrm{m} 3)$

\section{Material Parameters}

Iron-based Metals/Alloys

Aluminum-Based Metals/Alloys

Other Metals

Other Inorganic Materials

Cellutostcs

Rubber

Plastios

Solldified, Inorgante matrix

Solidified, Organic matrix

Soils

Packaging Materials, Steel

Packaging Material, Plastlc

\begin{tabular}{|r|r|}
\hline Average & Lower Lmit \\
\hline 112.1 \\
\hline 12.2 \\
\hline 10.8 \\
\hline 12.8 \\
\hline 3.2 \\
\hline 0.0 \\
\hline 6.6 \\
\hline 0.0 \\
\hline 12.1 \\
\hline 0.0 \\
\hline 0.0 \\
\hline 0.0 \\
\hline 210.0 \\
\hline 16.0 \\
\hline 0.0 \\
\hline 0.0 \\
\hline 0.0 \\
\hline 0.0 \\
\hline
\end{tabular}

$\begin{aligned} \text { Container Matt: } & \text { Liner Type: } \\ \text { Int. VolvCtnr: } & 1.9 / \mathrm{m3} \quad \text { Liner Material: } \\ & \end{aligned}$

Number Stored Number Projected

\section{Comments}

STORED TRU WASTE ESTIMATED RATES OF WASTE GENERATION

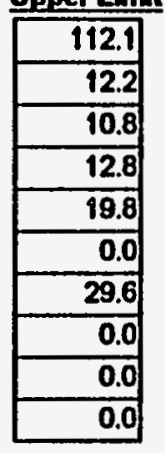

\begin{tabular}{|c|c|c|c|}
\hline & Prolected & Final form & \\
\hline End of 1982: & 9.2 & 20.9 & $\mathrm{m3}$ \\
\hline End of 1893: & 9.2 & 20.9 & $\mathrm{~m} 3$ \\
\hline 1994: & 0.0 & 0.0 & $m 3 / y r$ \\
\hline 4885: & 0.0 & 0.0 & $m 3 / y r$ \\
\hline 1998: & 0.0 & 0.0 & $m 3 / y r$ \\
\hline 1897: & 0.0 & 0.0 & $\mathrm{~m} 3 / \mathrm{ry}$ \\
\hline 1988-2002: & 0.0 & 0.0 & $\mathrm{~m} 3 / \mathrm{yr}$ \\
\hline 2003-2022: & 0.0 & 0.0 & $\mathrm{~m} 3 / \mathrm{yr}$ \\
\hline
\end{tabular}

TYPICAL EPA CODES APPLICABLE
TYPICAL ISOTOPIC COMPOSITION Nuclide Aclivily

Number stored (44) ls the number of SWBs as a recull of overpacking 4

árumsiswo. 


\section{WASTE STREAM PROFILE FOR THE WIPP TRU WASTE BASELINE INVENTORY REPORT}

STIENAME IN

WASTE TYPE MTRU HANDLING CH GENERATOR SITE RF

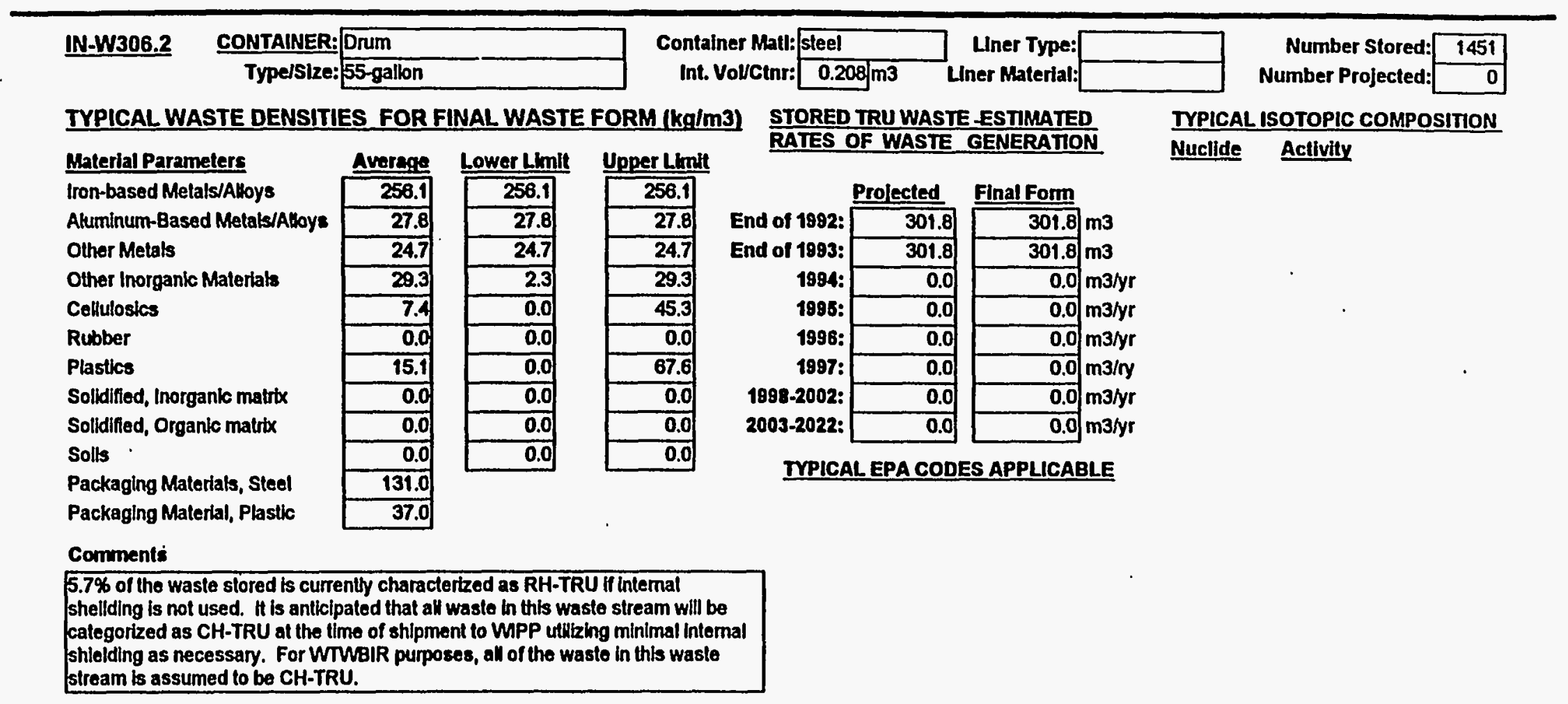


WASTE STREAM PROFILE FOR THE WIPP TRU WASTE BASELINE INVENTORY REPORT

SITE NAME IN WASTE TYPE MTRU HANDLING CH GENERATOR SITE RF

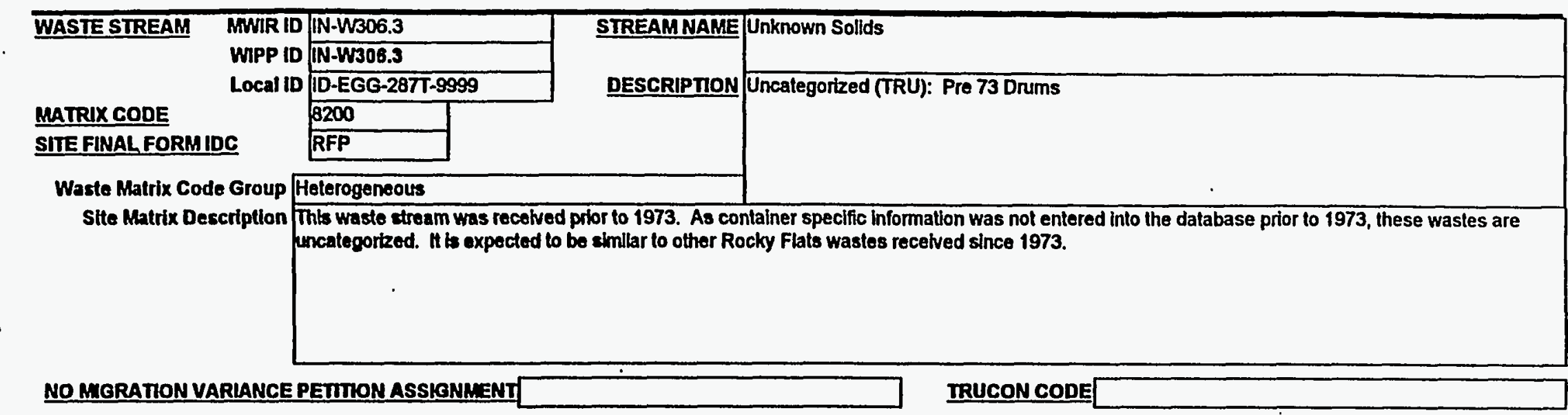

FINAL WASTE FORM DESCRIPTORS:

\begin{tabular}{l|l} 
Defense TRU Wasto \\
Non-Defense TRU Wasto \\
Commerclal TRU Wasto \\
Unknown
\end{tabular}$\quad \begin{aligned} & \text { Mbed TRU } \\
& \text { Non-Mbxed TRU } \\
& \text { Suspect Mbed TRU } \\
& \text { Unknown }\end{aligned}$

Unknown

\begin{tabular}{ll|} 
TSCA Asbestos \\
PCBs \\
Other \\
N/A \\
Unknown
\end{tabular}




\section{WASTE STREAM PROFILE FOR THE WIPP TRU WASTE BASELINE INVENTORY REPORT}

SITE NAME IN

WASTE TYPE MTRU HANDLINO CH GENERATOR SITE RF

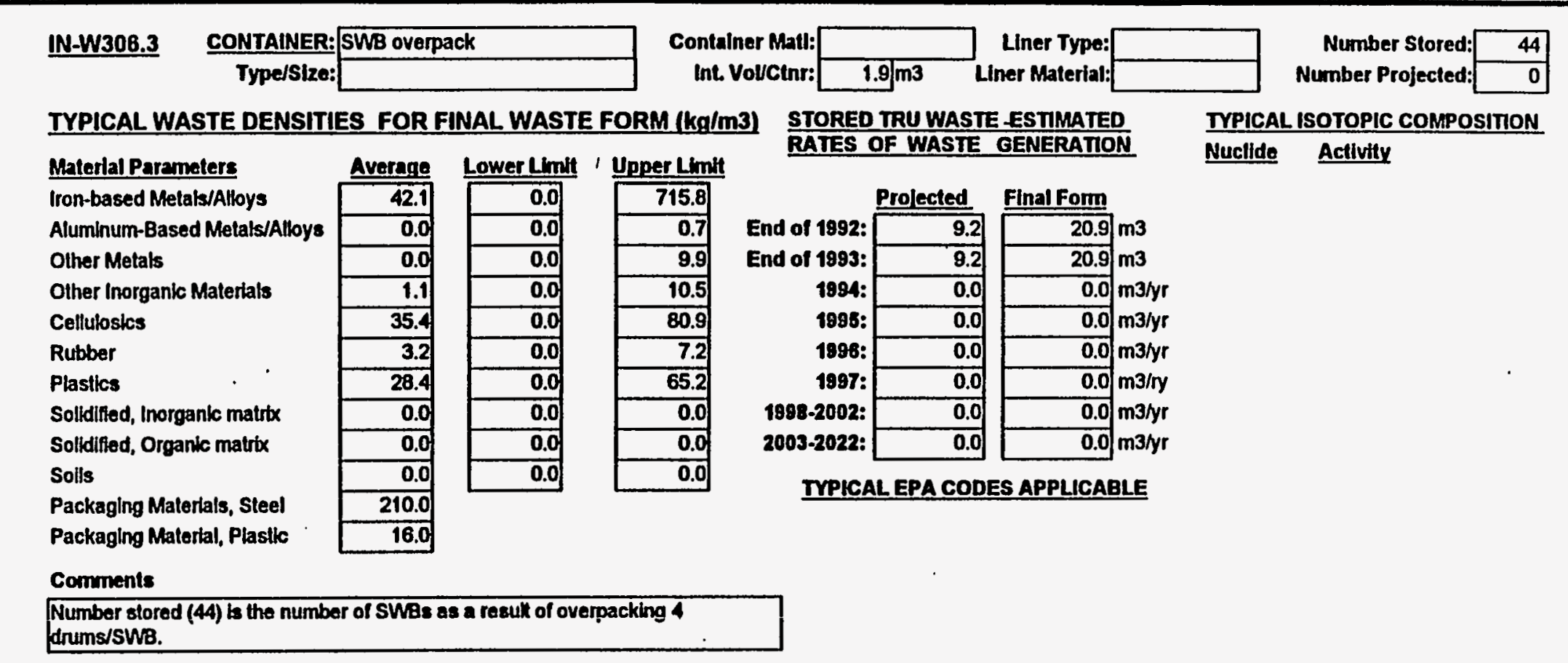


WASTE STREAM PROFILE FOR THE WIPP TRU WASTE BASELINE INVENTORY REPORT

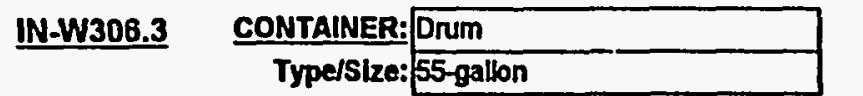

TYPICAL WASTE DENSITIES FOR FINAL WASTE FORM (kg/m3)

Material Parameters

Iron-based Metals/Alloys

Aluminum-Based Metals/Alloys

Other Metals

Other Inorganic Malerials

Cellulosics

Rubber

Plastics

Solldified, Inorganic matrix

Solidified, Organic matrix

Solls

Packaging Materlals, Stẹel

Packaging Material, Plastic

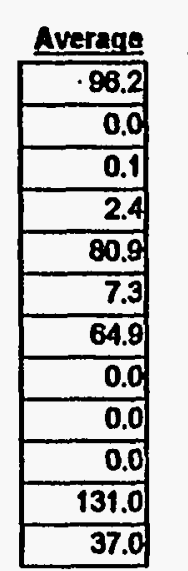

Container Matl: steel

Int. VoluCtnr: $0.208 \mathrm{m3}$ Liner Type:

STORED TRU WASTE-ESTIMATED RATES OF WASTE GENERATION

\section{Upper Limit}

\begin{tabular}{|r|}
\hline 1634.6 \\
\hline 1.6 \\
\hline 22.7 \\
\hline 24.0 \\
\hline 184.8 \\
\hline 16.4 \\
\hline 149.0 \\
\hline 0.0 \\
\hline 0.0 \\
\hline 0.0 \\
\hline
\end{tabular}

Prolected Final Form

\begin{tabular}{r|r}
\hline End of 1982: & 301.8 \\
\hline 301.8 \\
\hline 301.8 \\
\hline
\end{tabular}

1984: 0.0 $0.0 \mathrm{m3} / \mathrm{yr}$

1985: $0.0 \mathrm{0.0} \mathrm{m} 3 / \mathrm{yr}$

1996: 0.0

1987: 0.0

1998-2002: $0.0 \mathrm{0.0} \mathrm{m3} / \mathrm{yr}$

2003-2022:

0.0

$0.0 \mathrm{~m} 3 / \mathrm{yr}$

TYPICAL EPA CODES APPLICABLE

Comments

5.7\% of the waste stored is currently characterized as RH-TRU if inlemal

sheilding is not used. It is anticlpated that all waste in this waste stream will be

categorized as CH-TRU at the time of shipment to WiPP utilizing minimal internal

shlelding as necessary. For WMMIR purposes, all of the waste in this waste

stream is assumed to be CH-TRU. 


\section{WASTE STREAM PROFILE FOR THE WIPP TRU WASTE BASELINE INVENTORY REPORT}

SITE NAME IN

WASTE TYPE MTRU HANDLING CH GENERATOR SITE RF

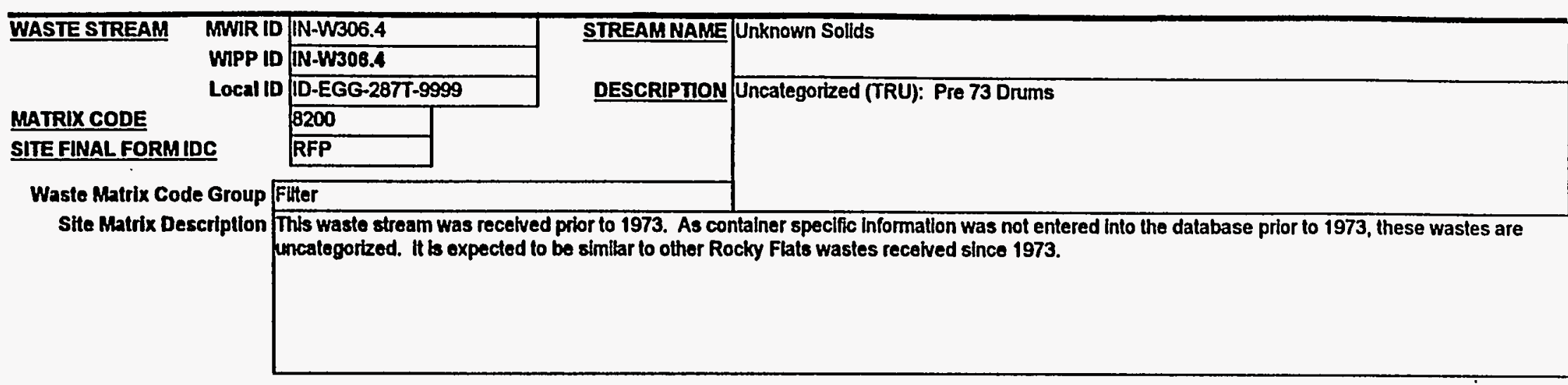

NO MMGRATION VARIANCE PETITION ASSIGNMENT

IRUCON CODE

\section{FINAL WASTE FORMDESCRIPTORS:}

\begin{tabular}{l|l} 
Defense TRU Waste \\
Non-Defense TRU Waste \\
Commercial-TRU Waste \\
Unknown
\end{tabular}$\quad \begin{aligned} & \text { Moxed TRU } \\
& \text { Non-Mixed TRU } \\
& \text { Suspect Mbxed TRU } \\
& \text { Unknown }\end{aligned}$

Rsearch and Devel. Waste Operations Waste

Residues

Decon and Decommissioning $\mathrm{X}$

Environmental Restoration

From Treatment of Waste

Maintenance

\begin{tabular}{|l|}
\hline$x$ \\
\hline$x$ \\
\hline$x$ \\
\hline \\
\hline \\
\hline
\end{tabular}

TSCA Asbestos

PCBs

Other

N/A

Unknown 


\section{WASTE STREAM PROFILE FOR THE WIPP TRU WASTE BASELINE INVENTORY REPORT}

SITE NAME IN

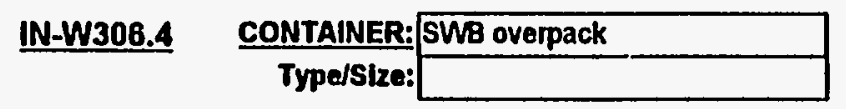

TYPICAL WASTE DENSITIES FOR FINAL WASTE FORM $(\mathrm{kg} / \mathrm{m} 3)$

Material Parameters

Iron-based Metals/Alloys

Aluminum-Based Motals/Alloys

Other Melals

Other Inorganic Materials

Cellulosics

Rubber

Plastics

Solldified, Inorganic matrix

Solldified, Organic malubx

Solls

Packaging Materlals, Steel

Packaging Materlal, Plastlc

\begin{tabular}{|r|}
\multicolumn{1}{|c|}{ Average } \\
\hline 0.0 \\
\hline 0.0 \\
\hline 0.0 \\
\hline 73.7 \\
\hline 0.0 \\
\hline 0.0 \\
\hline 0.0 \\
\hline 0.0 \\
\hline 0.0 \\
\hline 0.0 \\
\hline 210.0 \\
\hline 16.0 \\
\hline
\end{tabular}

\begin{tabular}{|r|}
\hline Lower Limh \\
\hline $\mathbf{0 . 0}$ \\
\hline $\mathbf{0 . 0}$ \\
\hline $\mathbf{0 . 0}$ \\
\hline 21.1 \\
\hline $\mathbf{0 . 0}$ \\
\hline $\mathbf{0 . 0}$ \\
\hline $\mathbf{0 . 0}$ \\
\hline $\mathbf{0 . 0}$ \\
\hline $\mathbf{0 . 0}$ \\
\hline $\mathbf{0 . 0}$ \\
\hline
\end{tabular}

\begin{tabular}{|r|}
\hline Upper Lint \\
\hline 0.0 \\
\hline 0.0 \\
\hline 0.0 \\
\hline 219.0 \\
\hline 0.0 \\
\hline 0.0 \\
\hline 0.0 \\
\hline 0.0 \\
\hline 0.0 \\
\hline 0.0 \\
\hline
\end{tabular}

Container Matt:

int. Volvenr:

$1 . 9 \longdiv { m ^ { 3 } }$

$.9 \sqrt{\mathrm{m} 3}$

STORED TRU WASTE -ESTIMATED RATES OF WASTE GENERATION

\begin{tabular}{|c|c|c|c|}
\hline & Prolected & Final Form & \\
\hline nd of 1992: & $\overline{9.2}$ & 20.9 & $\operatorname{lm} 3$ \\
\hline d of 1993: & 9.2 & $\overline{20.9}$ & m3 \\
\hline 1994: & 0.0 & 0.0 & $\mathrm{~m} 3 / \mathrm{yr}$ \\
\hline 1998: & 0.0 & 0.0 & m3/yr \\
\hline 1996: & 0.0 & 0.0 & m3/yr \\
\hline 1997: & 0.0 & 0.0 & $\mathrm{~m} 3 / \mathrm{ry}$ \\
\hline $998-2002:$ & 0.0 & 0.0 & m3/yr \\
\hline 003-2022: & 0.0 & 0.0 & $\mathrm{~m} 3 / \mathrm{yr}$ \\
\hline
\end{tabular}

IYPICAL EPA CODES APPLICABLE

\section{Comments}

Number stored (44) is the number of SWBs as a result of overpacking 4

drums/SWia.

Number Stored: Number Projected:

IYPICAL ISOTOPIC COMPOSITION

Nuclide Actlvity 


\section{WASTE STREAM PROFILE FOR THE WIPP TRU WASTE BASELINE INVENTORY REPORT}

SITE NAME IN

\section{WASTE TYPEMTRU HANDLNG CH GENERATOR SITE RF}

IN-W306.4 CONTAINER: Drum

Type/Size: 55-gallion

Container Matl: steel

Liner Type:

Number Stored:

Number Projected:

\begin{tabular}{r|}
1451 \\
\hline 0 \\
\hline
\end{tabular}

TYPICAL WASTE DENSITIES FOR FINAL WASTE FORM (kg/m3)

STORED TRU WASTE-ESTIMATED

IYPICAL ISOTOPIC COMPOSITION

Material Parameters

Iron-based Metals/Alloys

Aluminum-Based Metals/Alloys

Other Metals

Other Inorganic Materials

Cellulosics

Rubber

Plastlcs

Solidified, Inorganic matrix

Solidified, Organic matrix

Solls

\begin{tabular}{|c|c|}
\hline Average & Lower Limit \\
\hline 0.0 & 0.0 \\
\hline 0.0 & 0.0 \\
\hline 0.0 & 0.0 \\
\hline 168.3 & 48.1 \\
\hline$\overline{0.0}$ & 0.0 \\
\hline 0.0 & 0.0 \\
\hline 0.0 & 0.0 \\
\hline 0.0 & 0.0 \\
\hline 0.0 & 0.0 \\
\hline 0.0 & 0.0 \\
\hline
\end{tabular}

\begin{tabular}{|r|}
\hline Upper Limit \\
\hline 0.0 \\
\hline 0.0 \\
\hline 0.0 \\
\hline 500.0 \\
\hline 0.0 \\
\hline 0.0 \\
\hline 0.0 \\
\hline 0.0 \\
\hline 0.0 \\
\hline 0.0 \\
\hline
\end{tabular}

RATES OF WASTE GENERATION

Nuclide Activity

Packaging Materlals, Steel

Packaging Malerial, Plastic

131.0

\begin{tabular}{|c|c|c|c|}
\hline & Prolected & Final Form & \\
\hline End of 1992: & $\overline{301.8}$ & 301.8 & m3 \\
\hline ad of 1993: & 301.8 & 301.8 & m3 \\
\hline 1994: & 0.0 & 0.0 & $\mathrm{~m} 3 / \mathrm{yr}$ \\
\hline 1995: & 0.0 & $\overline{0.0}$ & $\mathrm{~m} 3 / y r$ \\
\hline 1998: & 0.0 & 0.0 & $\mathrm{~m} 3 / \mathrm{yr}$ \\
\hline 1997: & $\overline{0.0}$ & $\overline{0.0}$ & m3/ry \\
\hline 1888-2002: & 0.0 & 0.0 & $\mathrm{~m} 3 / \mathrm{yr}$ \\
\hline 003-2022: & $\overline{0.0}$ & $\overline{0.0}$ & m3/yr \\
\hline
\end{tabular}

IYPICAL EPA CODES APPLICABLE

\section{Comments}

$5.7 \%$ of the waste stored is currently characlerized as RH-TRU If Intemal

sheilding is not used. It is anticipated that all waste in this waste stream will be

categorized as CH-TRU at the time of shipment to WPP utllizing minimal internal

shielding as necessary. For WTWBIR purposes, ait of the waste in this waste

stream is assumed to be CH-TRU. 


\section{WASTE STREAM PROFILE FOR THE WIPP TRU WASTE BASELINE INVENTORY REPORT}

SITE NAME IN

WASTE TYPEMTRU HANDLING CH GENERATOR SITE IN, RF

\begin{tabular}{|c|c|c|c|}
\hline WASTE STREAM MWIR ID & \multirow{2}{*}{\begin{tabular}{l|l|l} 
MWIR ID & IN-W308 \\
WMPP ID & IN-W308 \\
\end{tabular}} & \multirow{5}{*}{$\begin{array}{l}\text { STREAMNAME } \\
\text { DESCRIPTION }\end{array}$} & \multirow{2}{*}{ Unknown Solids } \\
\hline WIPP ID & & & \\
\hline Local ID & D-EGG-287T-000 & & \multirow[t]{4}{*}{ Uncategorized (TRU): Not Recorded - Unknown } \\
\hline MATRIX CODE & 8200 & & \\
\hline SITE FINAL FORMIDC & RFP & & \\
\hline \multirow{2}{*}{$\begin{array}{r}\text { Waste Matrix Code Group } \\
\text { stte Matrix Description }\end{array}$} & Unknown & & \\
\hline & $\begin{array}{l}\text { This waste stream, ge } \\
\text { Initial Drum Retrieval } \\
\text { information ts avallabl } \\
\text { presence of hazardou }\end{array}$ & $\begin{array}{l}\text { INEL, contains wa } \\
\text { Most of these wa } \\
\text { is believed to cons } \\
\text { nknown at thits time }\end{array}$ & $\begin{array}{l}\text { aste retrleved from shallow land burial during the INEL Earty Waste Retrieval (EWR) and the } \\
\text { astes are believed to have been initially generated at the Rocky Flats Plant. No content } \\
\text { sist of various types of waste generated by plutonium and nonplutonium operalions. Any } \\
\text { 9. }\end{array}$ \\
\hline
\end{tabular}

NO MGRATION VARIANCE PETIION ASSIGNMENT

IRUCON CODE

\section{FINAL WASTE FORM DESCRIPTORS:}

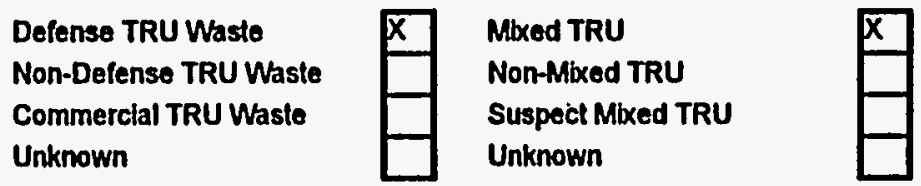
Operations Waste

Residues

Decon and Decommissioning

Environmental Resloration

From Treatment of Wasto

\begin{tabular}{|l|}
\hline$x$ \\
\hline$x$ \\
\hline \\
\hline$x$ \\
\hline \\
\hline \\
\hline
\end{tabular}

TSCA Asbestos

PCBs

Olher

N/A

Unknown

Maintenance

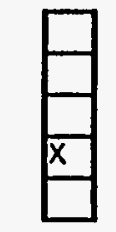


WASTE STREAM PROFILE FOR THE WIPP TRU WASTE BASELINE INVENTORY REPORT

SITE NAME IN

WASTE TYPE MTRU HANDLING CH GENERATOR SITE IN, RF

IN-W308

CONTAINER: SWB overpack

Container Matt:

int. VolvCtnr:

$1.9 \mathrm{m3}$

Uner Type:

י

Number Stored

Number Projected:

377

TYPICAL WASTE DENSITIES FOR FINAL WASTE FORM $(\mathrm{kg} / \mathrm{m} 3)$

STORED TRU WASTE ESTMMATED RATES OF WASTE GENERATION

\section{Materlal Parameters}

Iron-based Metals/Alloys

Aluminum-Based Metals/Alloys

Other Metals

Other Inorganic Materials

Cellulosics

Rubber

Plastice

Solidified, Inorganic matrix

Solidified, Organic matrix

Solls

Packaging Matertals, Steel

Packaging Matertal, Plastic

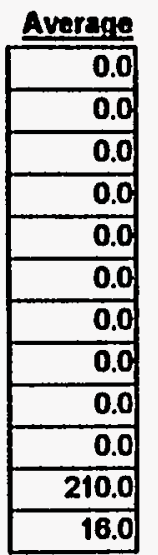

\begin{tabular}{l} 
Lower Limit \\
\hline 0.0 \\
\hline 0.0 \\
\hline 0.0 \\
\hline 0.0 \\
\hline 0.0 \\
\hline 0.0 \\
\hline 0.0 \\
\hline 0.0 \\
\hline 0.0 \\
\hline 0.0 \\
\hline
\end{tabular}

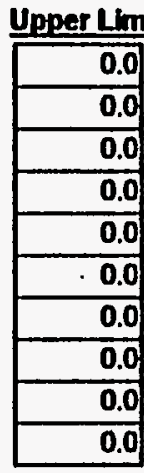

\begin{tabular}{|c|c|}
\hline & Prolected \\
\hline End of 1982: & 312.8 \\
\hline End of 1993: & 312.8 \\
\hline 1884: & 0.0 \\
\hline 1988: & 0.0 \\
\hline 1986: & 0.0 \\
\hline 1897: & 0.0 \\
\hline 1998-2002: & 0.0 \\
\hline 2003-2022: & 0.0 \\
\hline
\end{tabular}

IYPICAL ISOTOPIC COMPOSITION

Nuclide Actlvity

Am241 3.73E-01 Curies/m3

Pu238 2.06E-02 Curies/m3

Pu239 1.44E-01 Curies/m3

Pu52 1.19E-01 Curies/m3

TYPLCAL EPA CODES APPLUCABLE

UNK

\section{Comments}

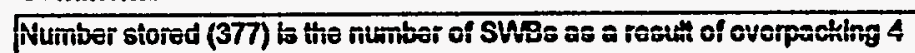

drums/SWB. 


\section{WASTE STREAM PROFILE FOR THE WIPP TRU WASTE BASELINE INVENTORY REPORT}

SITE NAME IN

WASTE TYPE MTRU HANDLING CH GENERATOR SITE IN, RF

IN-W308

CONTAINER: Drum

Container Matt: steel

Int. Volvetnr: $0.208 \mathrm{m3}$

Liner Type:
Liner Material:

:

Number Stored: 4466

Number Projected:

TYPICAL WASTE DENSITIES FOR FINAL WASTE FORM $(\mathrm{kg} / \mathrm{m} 3)$

Material Parameters

Iron-based Metals/Alloys

Aluminum-Based Metals/Alloys

Other Melals

Other Inorganic Malerials

Cellulosics

Rubber

Plastles

Solidified, Inorganle matrix

Solidified, Organic matrix

Solls

Packaging Materials, Steel

Packaging Material, Plastic

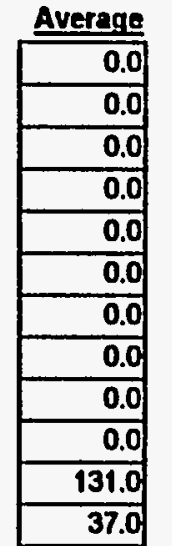

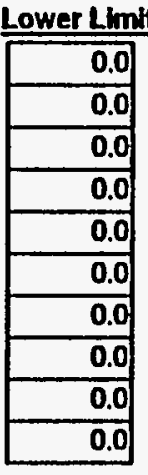

Upper Limit

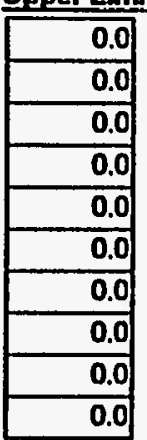

RATES OF WASTE GENERATION

\begin{tabular}{r|r|}
\hline & Projected \\
\hline End of 1992: & 929.0 \\
\hline End of 1993: & 929.0 \\
\cline { 2 - 2 } 1994: & 0.0 \\
\hline $1996:$ & 0.0 \\
\hline $1997:$ & 0.0 \\
\hline $1998-2002:$ & 0.0 \\
\hline $2003-2022:$ & 0.0 \\
\hline 0.0 \\
\hline
\end{tabular}

Final Form

$929.0 \mathrm{m3}$

$929.0 \mathrm{m3}$

$0.0 \mathrm{m3} / \mathrm{yr}$

$0.0 \mathrm{~m} 3 / \mathrm{yr}$

TYPICAL ISOTOPIC COMPOSITION

Nuclide Activity

Am241 8.53E-01 Curies $/ \mathrm{m}^{3}$

Pu238 4.71E-02 Curies $/ \mathrm{m}^{3}$

Pu239 3.29E-01 Curies $/ \mathrm{m}^{3}$

Pu52 2.72E-01 Curies/m3

\section{Comments}

$6.7 \%$ of the waste stored is currently characterized as RH-TRU if Internal

sheilding is not used. It is anticipated that all waste in this waste stream will be

categorized as CH-TRU at the time of shipment to WPP utilizing minimal intemal

shlelding as necessary. For WTWBIR purposes, att of the wasle in this waste

stream is assumed to be CH-TRU.

TYPICAL EPA CODES APPLICABLE

UNK 


\section{WASTE STREAM PROFILE FOR THE WIPP TRU WASTE BASELINE INVENTORY REPORT}

SITE NAME IN

WASTE TYPE MTRU

HANDLING $\mathrm{CH}$

GENERATOR SITE RF

\begin{tabular}{|c|c|c|c|}
\hline WASTE STREAM MWIRID & IN-W309 & STREAMNAME & Organic Setups \\
\hline WIPP ID & IN-W309 & & \\
\hline Local ID & ID-EGG-158T-003 & DESCRIPTION & This waste stream contains liquid organic wasles generated at RFP. About $47 \%$ of the organic \\
\hline MATRIX CODE & 3114 & & waste stream is talthe coolant, which is $60 \%$ Texaco Regal oil and $40 \%$ carbon tetrachloride. \\
\hline SITE FINAL FORMIDC & RFP & & $\begin{array}{l}\text { About } 10 \% \text { of the organic waste stream is trichloroethane. The remainder is other organic } \\
\text { wastes. These llouid wastes were mixed with calcium silicate to form a arease or naste-like }\end{array}$ \\
\hline Waste Matrix Code Group Is & Solldified Organics & & materia \\
\hline Site Matrix Description & & & \\
\hline
\end{tabular}

NO MIGRATION VARLANCE PETIION ASSIGNMENTID 212

IRUCON CODE ID 212

FINAL WASTE FORM DESCRIPTORS:

\begin{tabular}{|c|c|}
\hline Defense TRU Waste & Mbxed TRU \\
\hline Non-Defense TRU Waste & Non-Mbxed TRU \\
\hline Commercial TRU Waste & Suspect Mixed TRU \\
\hline Unknown & Unknown \\
\hline
\end{tabular}

Unknown

Unknown
TSCA Asbestos

PCBs

Olher

N/A

Unknown

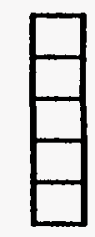

Rsearch and Devel. Waste
Operations Waste
Residues
Decon and Decommissioning
Environmental Restoration
From Treatment of Waste
Malntenance




\section{WASTE STREAM PROFILE FOR THE WIPP TRU WASTE BASELINE INVENTORY REPORT}

SITE NAME IN

WASTE TYPE MTRU HANDLING CH GENERATOR SITE RF

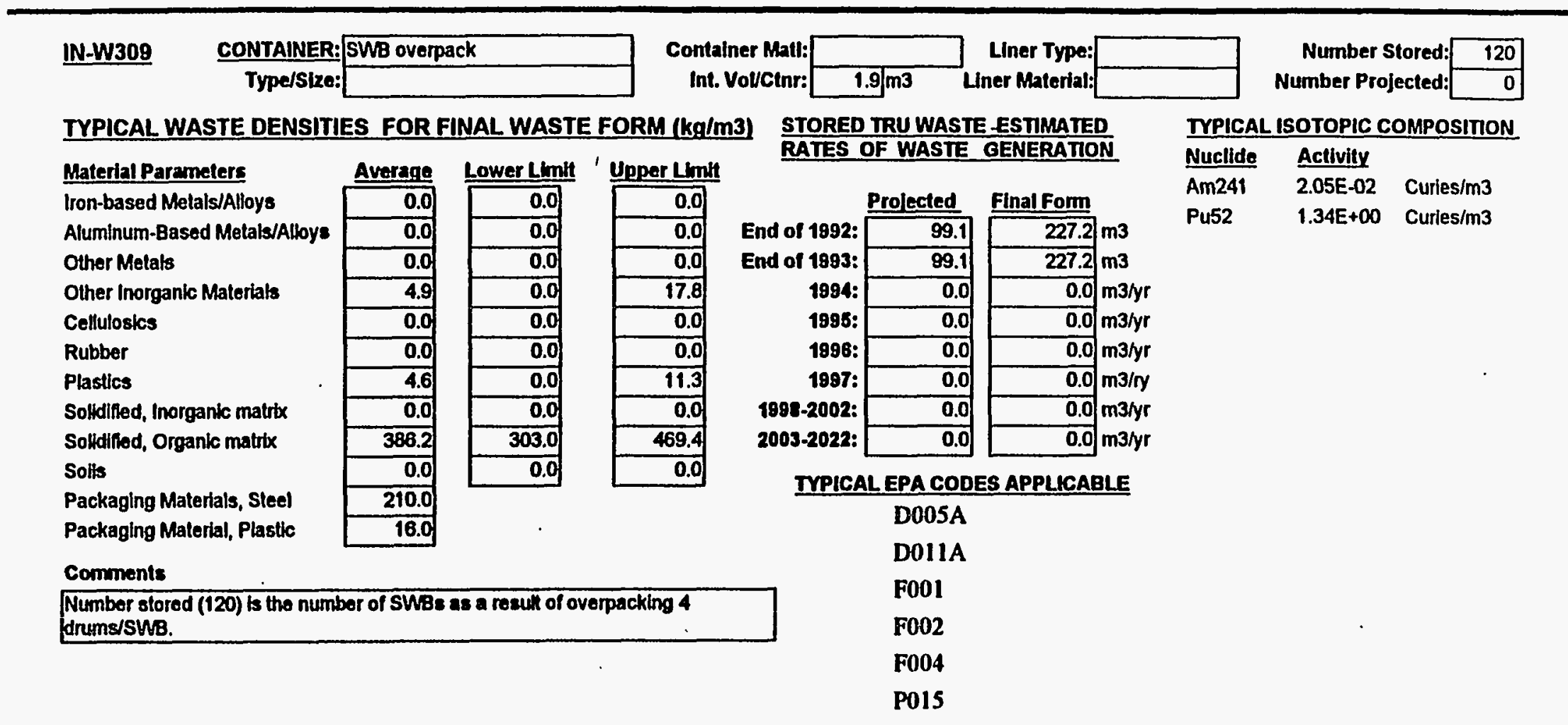


WASTE STREAM PROFILE FOR THE WIPP TRU WASTE BASELINE INVENTORY REPORT

SITE NAME IN

WASTE TYPE MTRU HANDLING CH GENERATOR SITE RF

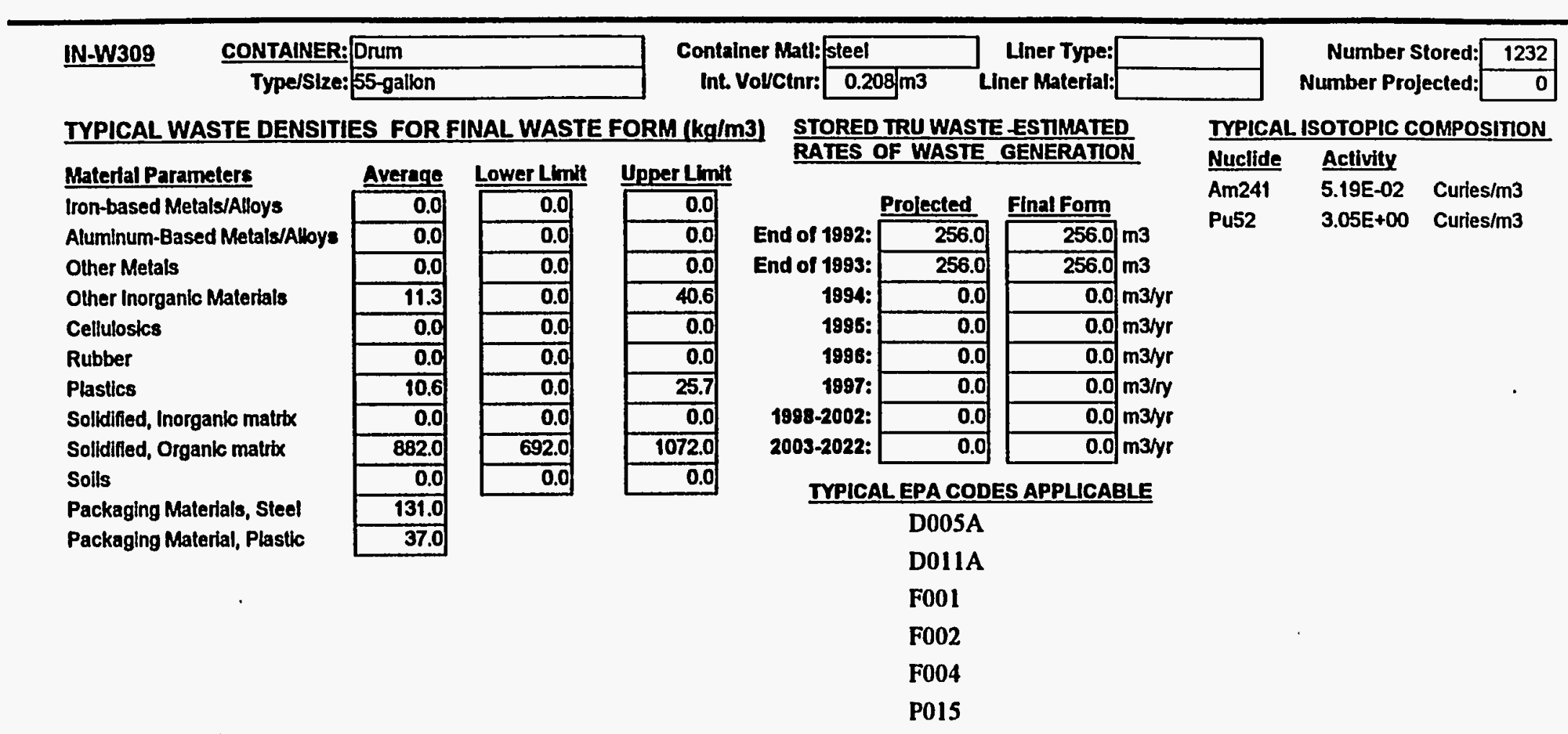




\section{WASTE STREAM PROFILE FOR THE WIPP TRU WASTE BASELINE INVENTORY REPORT}

SITE NAME IN

WASTE TYPE MTRU HANDLING CH GENERATOR SITE RF

\begin{tabular}{|c|c|c|c|}
\hline WASTESTREAM MWIRID & DIN-W311 & STREAMNAME & Salt Waste \\
\hline Local It & D & DESCRIPTION & Salts (TRU): Molten Salts - 30\% Unpulverized \\
\hline MATRIX CODE & 3140 & & \\
\hline SITE FINAL FORMIDC & RFP & & \\
\hline Waste Matrix Code Group & Salt Wasto & & \\
\hline Site Matrix Description & $\begin{array}{l}\text { This waste was genel } \\
\text { specified. }\end{array}$ & Pocky Flats Plant. & Jery Ittle information is avallable about this content code. The composition of the sall itself is not \\
\hline
\end{tabular}

NO MGRATION VARIANGE PETITION ASSIGNMENI

IRUCON CODE

\section{FINAL WASTE FORMDESCRIPTORS:}

\begin{tabular}{l|l} 
Defense TRU Waste \\
Non-Defense TRU Wasto \\
Commercial TRU Waste \\
Unknown
\end{tabular}$\quad \begin{aligned} & \text { Mbxed TRU } \\
& \text { Non-Mbxed TRU } \\
& \text { Suspect Mbxed TRU } \\
& \text { Unknown }\end{aligned}$

$\square$

Rsearch and Devel Waste Operations Wasto

Restdues

Decon and Decommisstoning

Environmental Restoration

From Trealment of Waste

\begin{tabular}{|l|}
\hline$x$ \\
\hline$x$ \\
\hline$x$ \\
\hline \\
\hline \\
\hline
\end{tabular}

TSCA Asbestos

PCBs

Other

N/A

Unknown 


\section{WASTE STREAM PROFILE FOR THE WIPP TRU WASTE BASELINE INVENTORY REPORT}

SITE NAME IN

\section{WASTE TYPE MTRU MANDLING CH GENERATOR SITE RF}

\begin{tabular}{|c|c|c|}
\hline IN-W311 & CONTAINER: & SWB overpack \\
\hline
\end{tabular}

TYPICAL WASTE DENSITIES FOR FINAL WASTE FORM (kg/m3) STORED TRU WASTE-ESTIMATED TYPICAL ISOTOPIC COMPOSITION

\section{Material Parameters}

Iron-based Metals/Alloys

Aluminum-Based Metals/Alloys

Other Metals

Other Inorganic Materials

Cellulosics

Rubber

Plastics

Solidified, Inorganic matrix

Solldified, Organic matrix

\section{Solls}

Packaging Materiats, Steol

Packaging Matorial, Plastic

\begin{tabular}{|r|} 
Average \\
\hline 12.6 \\
\hline 0.0 \\
\hline 51.2 \\
\hline 21.0 \\
\hline 5.7 \\
\hline 0.0 \\
\hline 4.5 \\
\hline 0.0 \\
\hline 0.0 \\
\hline 0.0 \\
\hline 210.0 \\
\hline 6.0 \\
\hline
\end{tabular}

\begin{tabular}{r|}
\hline Lower Lhit \\
\hline 0.0 \\
\hline 0.0 \\
\hline 10.0 \\
\hline 20.8 \\
\hline 0.0 \\
\hline 0.0 \\
\hline 2.9 \\
\hline 0.0 \\
\hline 0.0 \\
\hline 0.0 \\
\hline
\end{tabular}
RATES OF WASTE GENERATION

\section{Upper Linit}

\begin{tabular}{|r|}
\hline 25.3 \\
\hline 0.0 \\
\hline 92.8 \\
\hline 22.8 \\
\hline 11.5 \\
\hline 0.0 \\
\hline 6.0 \\
\hline 0.0 \\
\hline 0.0 \\
\hline 0.0 \\
\hline
\end{tabular}

\section{Comments}

\begin{tabular}{|c|c|c|c|}
\hline & Profected & Final Form & \\
\hline End of 1882: & 1.8 & 4.2 & m3 \\
\hline End of 1893: & 1.8 & 4.2 & m3 \\
\hline 1884: & 0.0 & 0.0 & m3/yr \\
\hline 1886: & 0.0 & 0.0 & $\mathrm{~m} 3 / \mathrm{yr}$ \\
\hline 1986: & 0.0 & 0.0 & m3/yr \\
\hline 1887: & 0.0 & 0.0 & $\mathrm{~m} 3 / \mathrm{ry}$ \\
\hline 1988-2002: & 0.0 & 0.0 & m3/yr \\
\hline 2003-2022: & 0.0 & 0.0 & m3/yr \\
\hline
\end{tabular}

\section{Nuclide Activity}

Am241 4.97E+01 Curles/m3

Pu52 7.07E+02 Curles $/ \mathrm{m3}$

F001

Number atored (2) bs the number of SWBs as a resuk of overpacking 4 inuma/SWB. 


\section{WASTE STREAM PROFILE FOR THE WIPP TRU WASTE BASELINE INVENTORY REPORT}

SITE NAME IN WASTE TYPE MTRU HANDLING CH GENERATOR SITE RF

\begin{tabular}{|c|c|c|c|c|c|c|c|c|c|c|}
\hline IN-W311 $\frac{\text { CONTAINER: }}{\text { Type/Size: }}$ & \begin{tabular}{|l|} 
Drum \\
55 -gallon \\
\end{tabular} & & \multicolumn{3}{|c|}{\begin{tabular}{rl|l} 
Container Matl: & steel \\
Int. VolvCtnr: & $0.208 / \mathrm{m3}^{\prime}$
\end{tabular}} & $\begin{array}{r}\text { Liner Type: } \\
\text { Liner Material: }\end{array}$ & & & \multicolumn{2}{|c|}{$\begin{array}{r}\text { Number Stored: } \\
\text { Number Projected: }\end{array}$} \\
\hline \multicolumn{4}{|c|}{ TYPICAL WASTE DENSITIES FOR FINAL WASTE FORM (kg/m3) } & \multicolumn{4}{|c|}{ STORED TRU WASTE ESTIMATED } & \multicolumn{3}{|c|}{ TYPICAL ISOTOPIC COMPOSITION } \\
\hline Material Parameters & Average & Lower Lint & Upper Limt & PATES C & \multirow[b]{2}{*}{ Prolected } & GENERATIOI & & Nuclide & \multirow{4}{*}{$\begin{array}{l}\text { Activity } \\
1.14 E+02 \\
2.66 E+02\end{array}$} & \multirow{3}{*}{$\begin{array}{l}\text { Curles/m3 } \\
\text { Curies/m3 }\end{array}$} \\
\hline Iron-based Metals/Alloys & 28.8 & 0.0 & 57.7 & \multirow{3}{*}{ End of 1892: } & & Final Form & & Am241 & & \\
\hline Aluminum-Based Metaks/Alloys & 0.0 & $\overline{0.0}$ & 0.0 & & 4.7 & 4.7 & $\mathrm{~m} 3$ & Pu52 & & \\
\hline Other Metals & 117.0 & 22.9 & 212.0 & & 4.7 & 4.7 & m3 & & & \\
\hline Other Inorganic Materials & 49.8 & 47.5 & 52.0 & 1884: & 0.0 & 0.0 & m3/yr & & & \\
\hline Cellulosics & 13.1 & 0.0 & 26.2 & 1995: & 0.0 & 0.0 & m3/yr & & & \\
\hline Rubber & 0.0 & 0.0 & 0.0 & 1996: & $\overline{0.0}$ & 0.0 & $\mathrm{~m} 3 / y r$ & & & \\
\hline Plastics & 10.2 & 6.6 & 13.8 & 1897: & $\overline{0.0}$ & 0.0 & $m 3 / r y$ & & & . \\
\hline Solldified, Inorganle matrix & 0.0 & 0.0 & 0.0 & 1888-2002: & 0.0 & 0.0 & $\mathrm{~m} 3 / \mathrm{yr}$ & & & \\
\hline Solldifed, Organic matrtx & 0.0 & 0.0 & 0.0 & 2003-2022: & 0.0 & 0.0 & m3ryr & & & \\
\hline Solls & 0.0 & 0.0 & 0.0 & & $=0$ & SAPPI ICAD & 96 & & & \\
\hline Packaging Materlals, Steel & 131.0 & & & & EPACOD & & & & & \\
\hline Packaging Material, Plastic & 37.0 & & & & F001 & & & & & \\
\hline
\end{tabular}


WASTE STREAM PROFILE FOR THE WIPP TRU WASTE BASELINE INVENTORY REPORT

SITE NAME IN WASTE TYPE MTRU HANDLING CH GENERATOR SITE RF

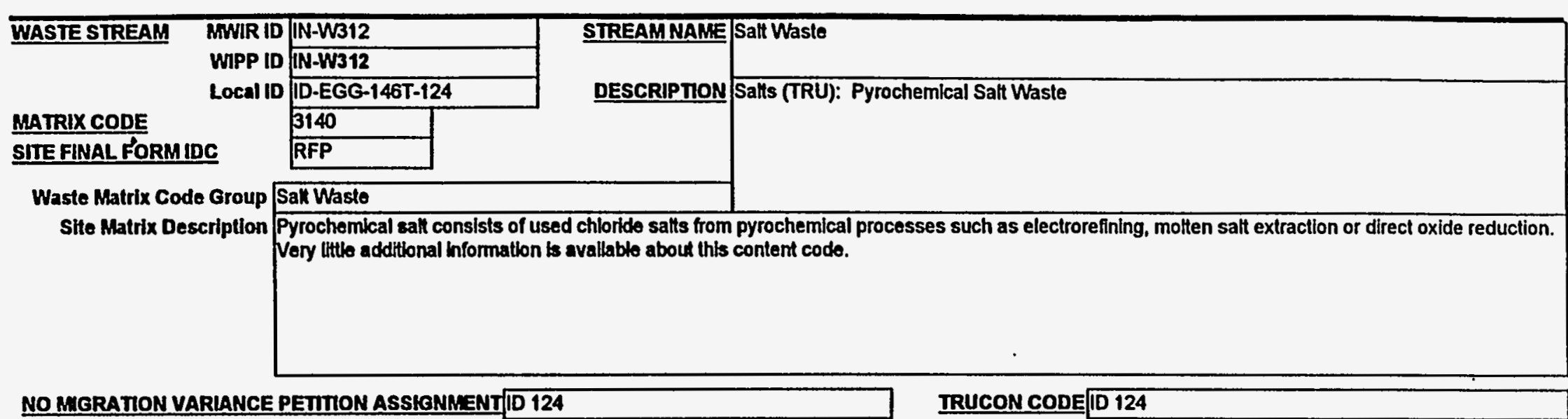

\section{EINAL WASTE FORM DESCRIPTORS:}

\begin{tabular}{|c|c|}
\hline Defenso TRU Wasto & Mbxed TRU \\
\hline Non-Defense TRU Waste & Non-Mbxed TRU \\
\hline Commercle & Suspect Mixed TRU \\
\hline
\end{tabular}

Unknown Operations Wasto

Residues

Decon and Decommissioning

Environmental Restoration From Treatment of Waste

Maintenance

\begin{tabular}{ll}
\hline$x$ \\
\hline$x$ \\
\hline$x$ \\
\hline \\
\hline \\
\hline
\end{tabular}

TSCA Asbestos

PCBs

Other

N/A

Unknown

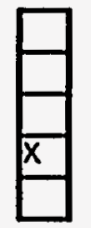




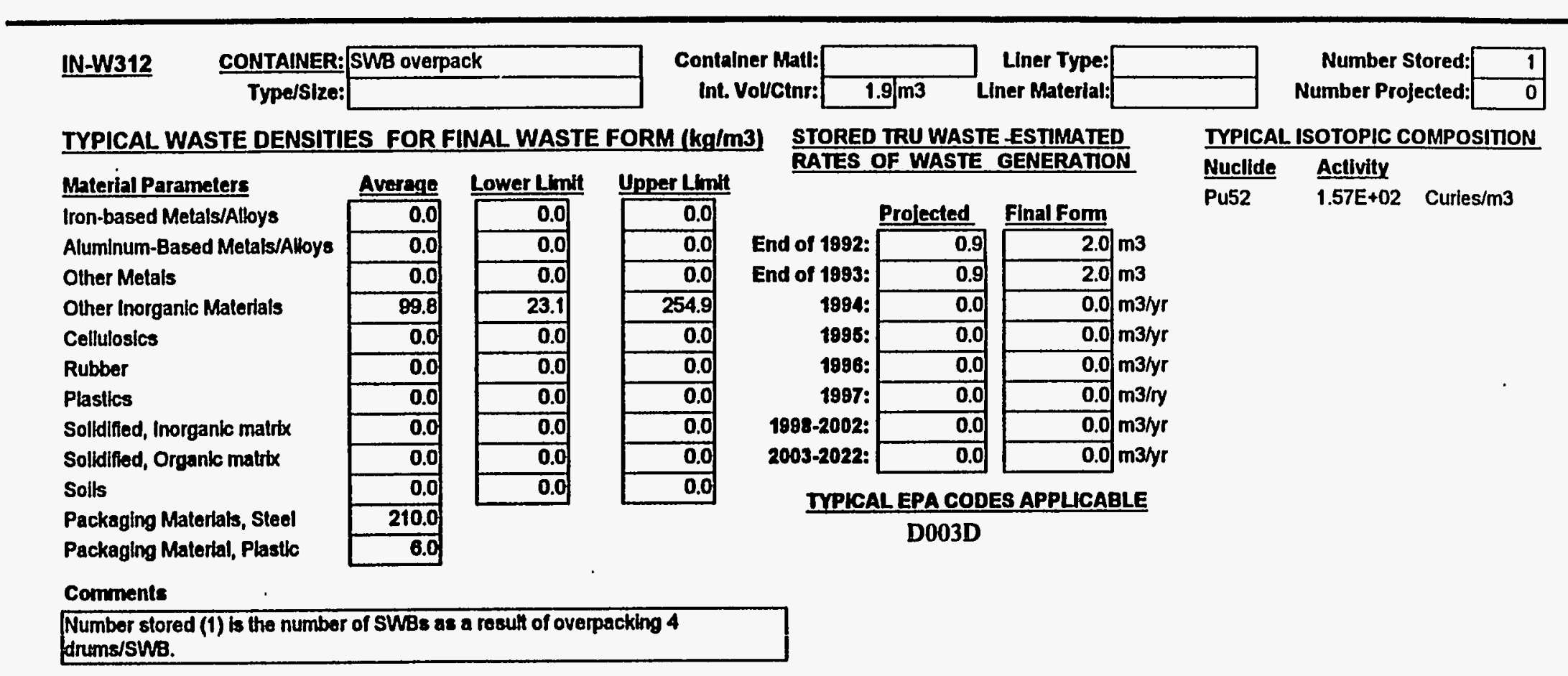




\section{WASTE STREAM PROFILE FOR THE WIPP TRU WASTE BASELINE INVENTORY REPORT}

SITENANE IN WASTE TYPE MTRU HANDLUNG $\mathrm{CH}$

GENERATOR SITE RF

$\underline{\text { N-W312 }}$

\begin{tabular}{c|l} 
CONTAINER: & Drum \\
\hline Type/Size: 55 -gallon \\
\hline
\end{tabular}

Container Matt: steel

int. VolvCenr: $0.208 \mathrm{~m}^{3}$

Liner Type:

Liner Material:

TYPICAL WASTE DENSITIES FOR FINAL WASTE FORM $(\mathrm{kg} / \mathrm{m} 3)$

Material Parameters

Iron-based Metals/Alloys

Aluminum-Based Metals/Alloys

Other Metals

Other Inorganic Materials

Cellulosics

Rubber

Plastics

Solldified, Inorganic matrix

Solldified, Organic matrix

Solls

Packaging Materials, Steel

Packaging Material, Plastic

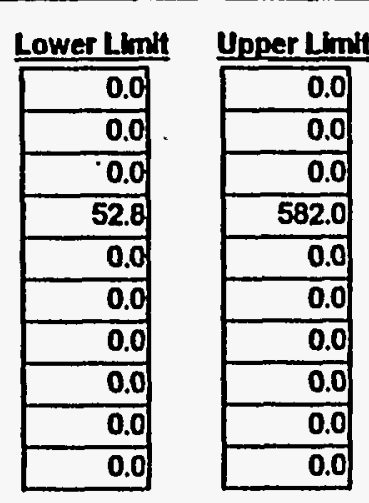

STORED TRU WASTE ESTIMATED

RATES OF WASTE GENERATIDN

\begin{tabular}{|c|c|c|c|}
\hline & Prolected & Final Form & \\
\hline End of 1982: & 2.3 & 2.3 & $\mathrm{~m} 3$ \\
\hline nd of 1993: & 2.3 & 2.3 & m3 \\
\hline 1994: & 0.0 & 0.0 & m3/yr \\
\hline 1998: & 0.0 & 0.0 & m3/yr \\
\hline 1986: & 0.0 & 0.0 & $m 3 / y r$ \\
\hline 1997: & 0.0 & 0.0 & $m 3 / r y$ \\
\hline 1998-2002: & 0.0 & 0.0 & m3lyr \\
\hline 2003-2022: & 0.0 & 0.0 & m3/yr \\
\hline
\end{tabular}

\begin{tabular}{|r|}
\hline 0.0 \\
\hline 0.0 \\
\hline 0.0 \\
\hline 228.0 \\
\hline 0.0 \\
\hline 0.0 \\
\hline 0.0 \\
\hline 0.0 \\
\hline 0.0 \\
\hline 0.0 \\
\hline 0.0 \\
\hline 0.0 \\
\hline 0.0 \\
\hline 0.0 \\
\hline 0.0 \\
\hline 0.0 \\
\hline 0.0 \\
\hline 0.0 \\
\hline 0.0 \\
\hline 0.0 \\
\hline 0.0 \\
\hline 0.0 \\
\hline 0.0 \\
\hline 0.0 \\
\hline 0.0 \\
\hline 0 \\
\hline 0 \\
\hline 0
\end{tabular}

37.0
Number Stored: Number Projected:

TYPICAL ISOTOPIC COMPOSITION

Nuclide Activity

Pu52 3.58E+02 Curies $/ \mathrm{m}^{3}$ 


\section{WASTE STREAM PROFILE FOR THE WIPP TRU WASTE BASELINE INVENTORY REPORT}

SITE NAME IN

WASTE TYPE MTRU HANDLING CH GENERATOR SITE RF

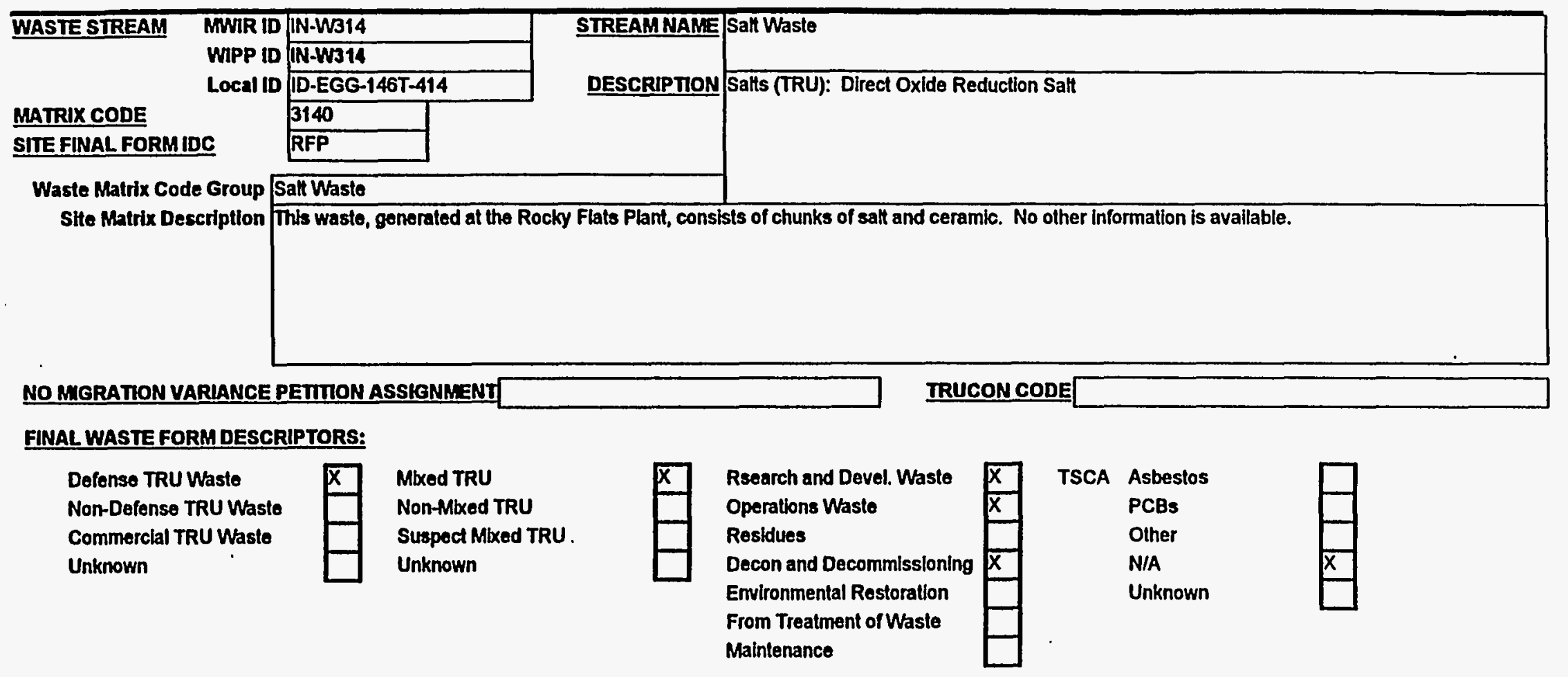


I00A

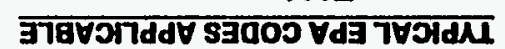
SNEW 00 دNEW 00 N/EW 00 AN/EW 00 دNEW 00 IA/EW 00 gm 20 gut 20

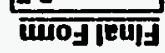

\begin{tabular}{|c|c|}
\hline $0^{\prime} 0$ & \\
\hline $0^{\circ} 0$ & 0 \\
\hline $0^{\prime} 0$ & 0 \\
\hline $0^{\circ} 0$ & 0 \\
\hline $0^{\circ} 0$ & 0 \\
\hline 00 & 0 \\
\hline$E 0$ & 0 \\
\hline$\varepsilon 0$ & \\
\hline
\end{tabular}

$: 2202-8002$ :200z-e6el :266r :9666 :986t : :866 $10 \mathrm{pug}$ :2661 jo pug

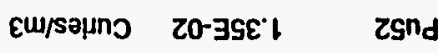

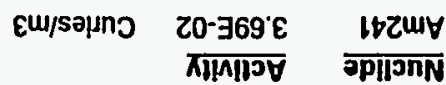
NOIIISOdWOJ J1dOIOSI 7४गdमL
NOLVYINAT IISYM f0 Salvy

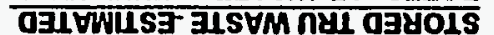

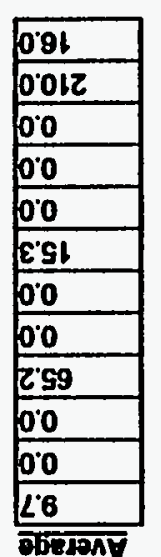

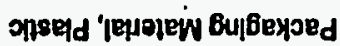
pais 'sjeplejew bujbeyord

$$
\text { 8nos }
$$

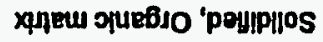

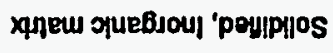

sonse'd

jeqany

sojso|nाओes

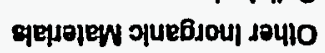

\&еjow Jeपno

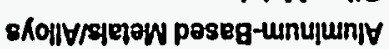

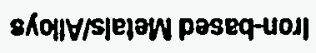

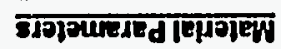




\section{WASTE STREAM PROFILE FOR THE WIPP TRU WASTE BASELINE INVENTORY REPORT}

SITE NAME IN WASTE TYPE MTRU HANDLING CH GENERATOR SITE RF

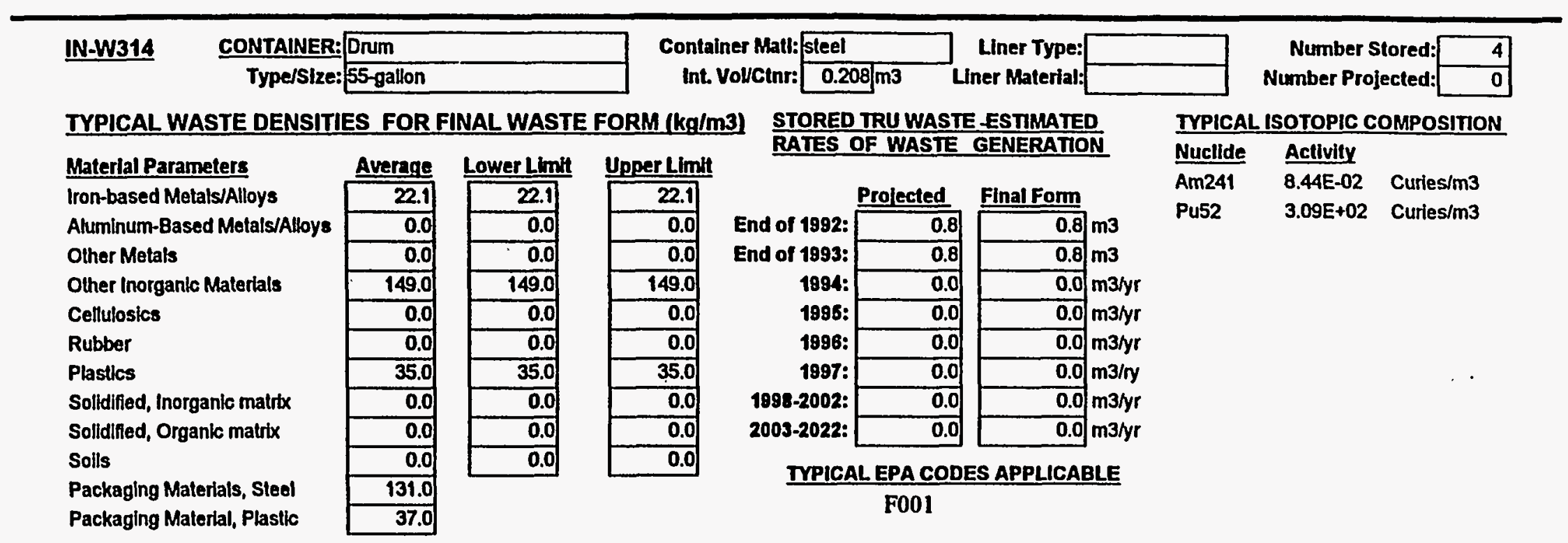




\section{WASTE STREAM PROFILE FOR THE WIPP TRU WASTE BASELINE INVENTORY REPORT}

SITE NAME IN

WASTE TYPE MTRU HANDLING RH GENERATOR SITE IN

\begin{tabular}{|c|c|c|c|}
\hline $\begin{array}{ll}\text { WASTE STREAM MWIR ID } \\
\text { WIPP ID }\end{array}$ & $\begin{array}{l}\text { IN-W322 } \\
\text { IN-W322 } \\
\end{array}$ & STREAMNAME & Sample Fuel \\
\hline Local id & D-EGG-144T-154 & DESCRIPTION & \\
\hline $\begin{array}{l}\text { MATRIX CODE } \\
\text { SITE FINAL FORM IDC }\end{array}$ & 5190 & & \\
\hline Waste Matrix Code Group U & Uncategorized Metal & & \\
\hline Site Matrix Description & Naste consists of actl & sources, a tadrum & needle, small vlals of fuel, and metal containers of experimental fuel capsules. \\
\hline
\end{tabular}

NO MGRATON VARLANCE PETIION ASSIGNMENT IRUCON CODE

\section{FINAL WASTE FORM DESCRIPTORS:}

\begin{tabular}{|c|c|}
\hline $\begin{array}{l}\text { Defense TRU Waste } \\
\text { Non-Defense TRU Waste } \\
\text { Commerclal TRU Waste }\end{array}$ & $\begin{array}{l}\text { Mixed TRU } \\
\text { Non-Mixed TRU } \\
\text { Suspact Mlxed TRL }\end{array}$ \\
\hline & Unknown \\
\hline
\end{tabular}

Rearch and Devel. Waste
Operations Waste
Resldues
Decon and Decommissioning
Environmental Restoration
From Treatment of Waste
Malntenance

\begin{tabular}{|c|c|c|}
\hline X & TSCA & Asbestos \\
\hline $\bar{x}$ & 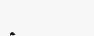 & PCBs \\
\hline & & Other \\
\hline $\bar{x}$ & & N/A \\
\hline & & Unknown \\
\hline
\end{tabular}




\section{WASTE STREAM PROFILE FOR THE WIPP TRU WASTE BASELINE INVENTORY REPORT}

SITE NAMNE IN

WASTE TYPE MTRU HANDLING RH GENERATOR SITE IN

IN-W322 CONTAINER: Drum

TYPICAL WASTE DENSITIES FOR FINAL WASTE FORM $(\mathrm{kg} / \mathrm{m} 3)$

Material Parameters

Iron-based Metals/Alloys

Aluminum-Based Melals/Alloys

Other Metals

Other Inorganic Materiaks

Cellutosics

Rubber

Plastics

Solkdified, Inorganic matrb

Solldilied, Organic matrtx

Solls

Packaging Materlats, Steel Packaging Material, Plastic

\begin{tabular}{|c|c|}
\hline Average & Lower Lim' \\
\hline 0.0 & 0.0 \\
\hline 0.0 & 0.0 \\
\hline 0.0 & 0.0 \\
\hline 0.0 & 0.0 \\
\hline 0.0 & 0.0 \\
\hline 0.0 & 0.0 \\
\hline 0.0 & 0.0 \\
\hline 0.0 & 0.0 \\
\hline 0.0 & 0.0 \\
\hline 0.0 & 0.0 \\
\hline 0.0 & \\
\hline 0.0 & \\
\hline
\end{tabular}

\begin{tabular}{|c|c|c|}
\hline Container Matt: & teel & Liner Type: \\
\hline Int. Volvcinr: & $0.208 / \mathrm{m} 3$ & Liner Material: \\
\hline
\end{tabular}

Number Stored: Number Projected:

STORED TRU WASTE -ESTIMATED RATES OF WASTE GENERATION

IYPICAL ISOTOPIC COMPOSITION

Nuclide Actluily

Pu239 1.46E+01 Curies/m3

Pu240 3.04E+00 Curies $/ \mathrm{m} 3$

U235 3.95E-04 Curies $/ \mathrm{m} 3$

Comments

Waste material welghts are unknown for this wasto stream. 


\section{WASTE STREAM PROFILE FOR THE WIPP TRU WASTE BASELINE INVENTORY REPORT}

SITE NAME IN

WASTE TYPE MTRU HANDLING RH GENERATOR SITE IN, AW

\begin{tabular}{|c|c|c|c|c|}
\hline \multirow{4}{*}{\multicolumn{2}{|c|}{$\begin{array}{ll}\text { WASTE STREAM } & \text { MMR ID } \\
\text { WIPP ID } \\
\text { LOCal ID }\end{array}$}} & D $1 \mathrm{~N}-\mathrm{W} 323$ & STREAMNAME & \multirow[t]{2}{*}{ Predominantly Combustible Debris } \\
\hline & & D 1 -W323 & \multirow{4}{*}{ DESCRIPTION } & \\
\hline & & ID-EGG-144T-153 & & \multirow[t]{3}{*}{ Radloacthe Sources (TRU): Combustible Lab Waste } \\
\hline & & 5440 & & \\
\hline \multicolumn{2}{|c|}{ SITE FINAL FORMIDC } & & & \\
\hline \multicolumn{3}{|c|}{ Waste Matrix Code Group Heterogeneous } & & \\
\hline Site Matrix D & scription & \multicolumn{3}{|c|}{$\begin{array}{l}\text { This waste stream was generated at the Argonne National Laboratory-West and NRF at the INEL. Most of the waste is organic and combustible } \\
\text { malerials including paper, wood, PVC and plastic containers and Hems, rubber gaskels and gloves, leather, rags, towels, Q-tips, tubing, filter media, } \\
\text { abrasive media and metal pleces. Small residuals of moderators and fuel are trapped on the filters. Drums of contact-handled waste are slored at the } \\
\text { Transuranic Storage Area (TSA). Drums of remote-handled waste are stored at the intermediate level transuranic facility (ILTSF). }\end{array}$} \\
\hline
\end{tabular}

NO MGRATION VARLANCE PETITION ASSIGNMENT IRUCONCODE

FINAL WASTE FORM DESCRIPTORS:

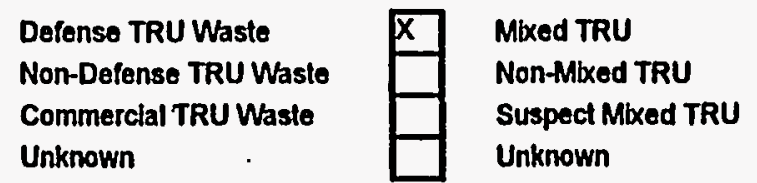

$\square$

Rsearch and Devel. Waste
Operations Waste
Residues
Decon and Decommissioning
Environmental Restoration
From Treatment of Waste
Malntenance

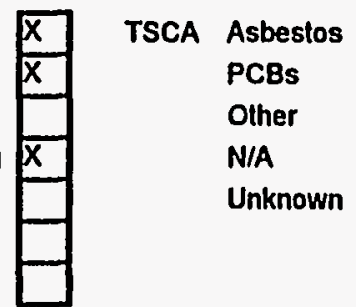

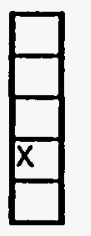




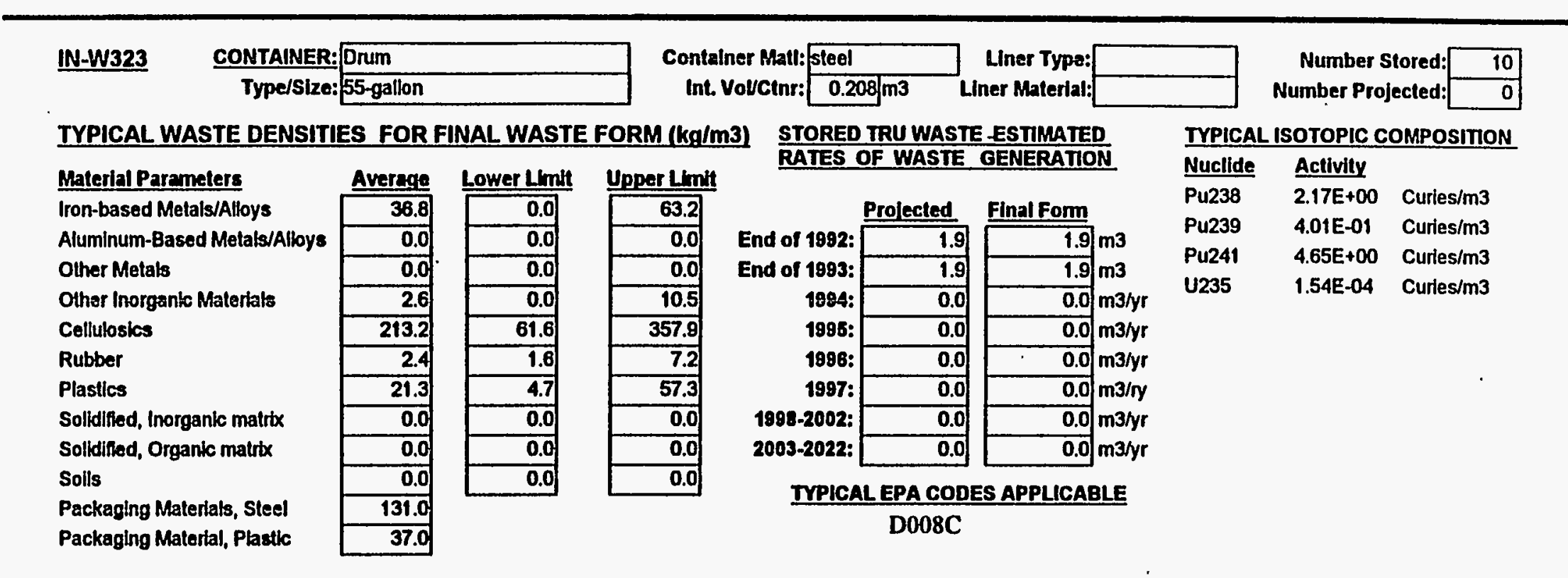




\section{WASTE STREAM PROFILE FOR THE WIPP TRU WASTE BASELINE INVENTORY REPORT}

SITENAME IN WASTE TYPE MTRU HANDLING CH

GENERATOR SITE MD

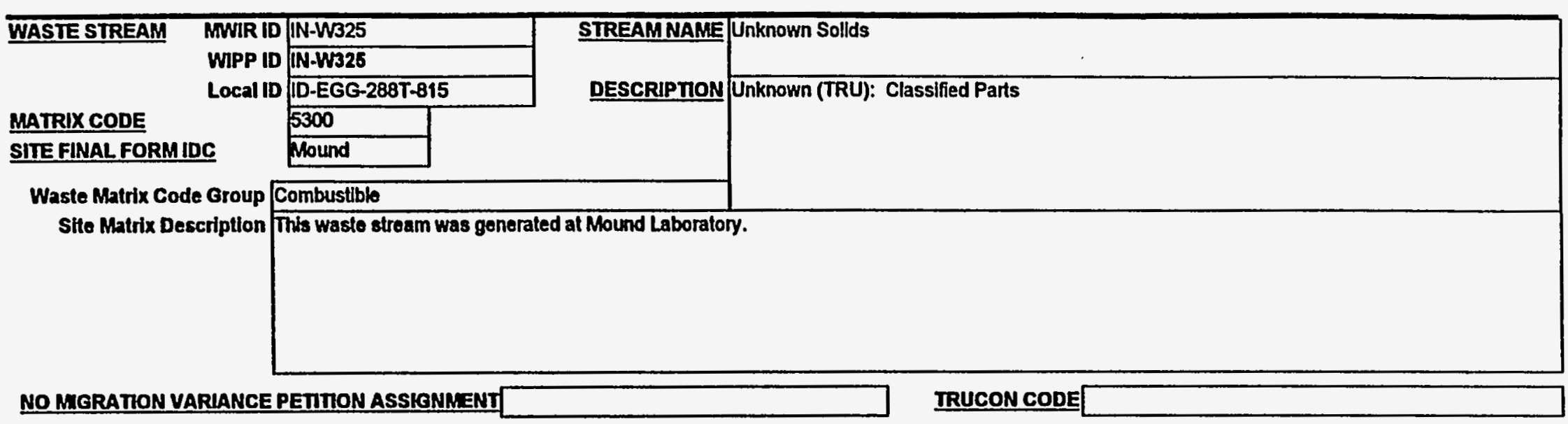

\section{FINAL WASTE FORM DESCRIPTORS:}

\begin{tabular}{l|l}
$\begin{array}{l}\text { Defense TRU Waste } \\
\text { Non-Defense TRU Wasto } \\
\text { Commerclal TRU Waste } \\
\text { Unknown }\end{array}$ & $\square$
\end{tabular}

Unknown

$\square$

\begin{tabular}{|l|}
\hline$x$ \\
\hline$x$ \\
\hline \\
\hline \\
\hline \\
\hline \\
\hline
\end{tabular}


XNก

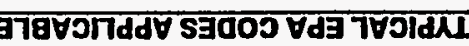

\begin{tabular}{|c|c|}
\hline JNew & 00 \\
\hline SAYEW & 0.0 \\
\hline N/Eu & 0.0 \\
\hline sheus & 0.0 \\
\hline JNEW & 00 \\
\hline LAEW & 0.0 \\
\hline eut & 60 \\
\hline & 60 \\
\hline
\end{tabular}

Ew/salun $10+\exists \varepsilon Z \varepsilon$ 8EZnd

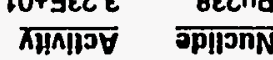

NOIISOdWOJ JdOIOSI 7VJId

\begin{tabular}{|c|c|}
\hline 00 & ]:2z0z-c00z \\
\hline 00 & : $200 z-268 L$ \\
\hline 0.0 & $: \angle 661$ \\
\hline 000 & :8661 \\
\hline 0.0 & :966! \\
\hline $0^{\prime} 0$ & its6i \\
\hline 60 & :ع66เ so pug \\
\hline 60 & :2681 10 pug \\
\hline
\end{tabular}

popogjo

NOILYYINGS BISWM JO SEIVI

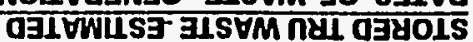

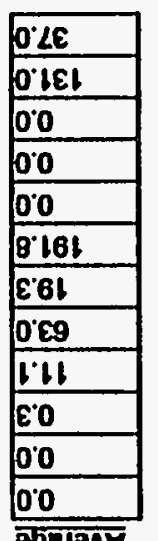

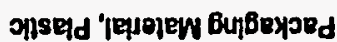

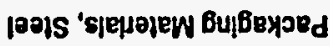
s\|os

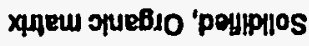

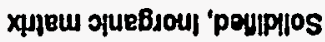

sonsetd

Jeqqny

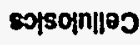

$2+6$

2.902

E⿺L

$6^{\circ} 21$

$0^{\circ} 0$

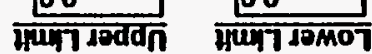

केष्मच

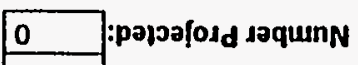

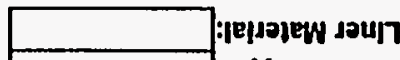
:ədk1 Joun عس[

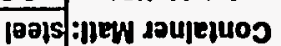
Uo|leQ-GS::ozis/od/ unda :89NIVINOS

$\overline{\text { SZEM-NI }}$ 
WASTE STREAM PROFILE FOR THE WIPP TRU WASTE BASELINE INVENTORY REPORT

SITENAME IN WASTE TYPE MTRU HANDLING CH

GENERATOR SITE MD

WASTE STREAM
MATRIX CODE
SITE FINAL FORM IDC
Waste Matrix Code Group
Site Matrix Descriptlon

NO MIGRATION VARIANCE PETITION ASSIGNRENT

IRUCON CODE

FINAL WASTE FORM DESCRIPTORS:

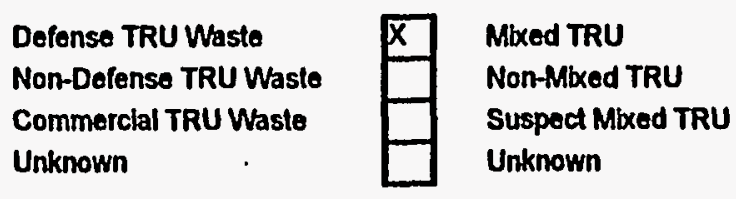

Unknown

Unknown

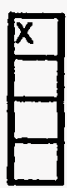

TSCA Asbestos

PCBs

Olher

N/A

Unknown
Decon and Decommissioning Environmental Restoration

From Treatment of Waste Maintenance

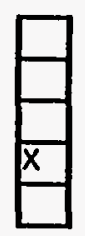




\section{WASTE STREAM PROFILE FOR THE WIPP TRU WASTE BASELINE INVENTORY REPORT}

SITENAME IN WASTE TYPE MTRU HANDLING CH GENERATOR SITE MD

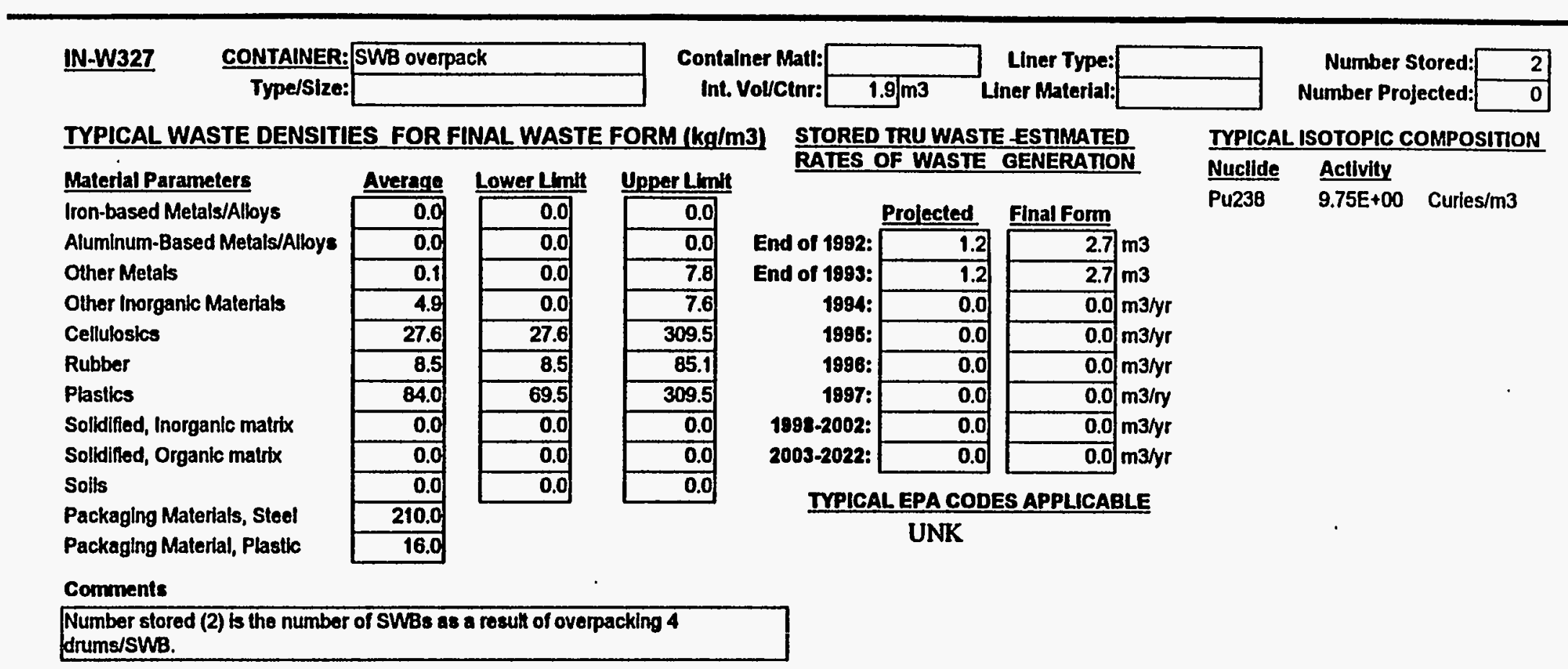


WASTE STREAM PROFILE FOR THE WIPP TRU WASTE BASELINE INVENTORY REPORT

SITE NAME IN WASTE TYPE MTRU HANDLING CH GENERATOR SITE MD

\begin{tabular}{|c|c|c|c|c|c|c|c|c|c|c|c|}
\hline IN-W327 $\frac{\text { CONTAINER: }}{\text { Type/Size: }}$ & \begin{tabular}{|l|} 
Drum \\
55 -gallon
\end{tabular} & & \multicolumn{2}{|c|}{$\begin{array}{r}\text { Container Matt: } \\
\text { Int. VolvCtnr: }\end{array}$} & \begin{tabular}{|l|l|} 
steel \\
$0.208 \mathrm{~m} 3$
\end{tabular} & $\begin{array}{l}\text { Liner Type: } \\
\text { iner Material: }\end{array}$ & & & \multicolumn{2}{|c|}{$\begin{array}{l}\text { Number Stored: } \\
\text { Number Projected: }\end{array}$} & $\begin{array}{r}15 \\
0 \\
\end{array}$ \\
\hline \multicolumn{4}{|c|}{ TYPICAL WASTE DENSITIES FOR FINAL WASTE FORM $(\mathrm{kg} / \mathrm{m} 3)$} & \multicolumn{4}{|c|}{$\begin{array}{l}\text { STORED TRU WASTE ESTMMATED } \\
\text { RATES OF WASTE GENERATION }\end{array}$} & \multicolumn{4}{|c|}{ TYPICAL ISOTOPIC COMPOSITION } \\
\hline $\begin{array}{l}\text { Material Parameters } \\
\text { Iron-based Metals/Alloys }\end{array}$ & Average & $\frac{\text { Lower Lmith }}{0.0}$ & $\frac{\text { Upper Limit }}{0.0}$ & RATES & OF WASTE & GENERATIO & & $\frac{\text { Nuclide }}{\text { Pu238 }}$ & $\frac{\text { Actlvily }}{2.23 E+01}$ & Curies & \\
\hline Aluminum-Based Metals/Alloys & 0.0 & 0.0 & 0.0 & End of 1982: & 3.1 & 3.1 & m3 & & & & \\
\hline Other Metals & 0.3 & 0.0 & 17.9 & End of 1993: & 3.1 & 3.1 & m3 & & & & \\
\hline Other Inorganlc Materlals & 11.1 & 0.0 & 17.3 & 1994: & 0.0 & 0.0 & $\mathrm{~m} 3 / \mathrm{yr}$ & & & & \\
\hline Cellulosics & 63.0 & 63.0 & 706.7 & 1985: & 0.0 & 0.0 & $\mathrm{~m} 3 / y r$ & & & & \\
\hline Rubber & 19.3 & 19.3 & 194.4 & 1986: & 0.0 & 0.0 & $\mathrm{~m} 3 / y r$ & & & & \\
\hline Plastics & 191.8 & 158.7 & 706.7 & 1987: & 0.0 & 0.0 & $\mathrm{~m} 3 / \mathrm{ry}$ & & & & - \\
\hline Solidified, Inorganic matrix & 0.0 & 0.0 & 0.0 & 1888-2002: & 0.0 & 0.0 & m3/yr & & & & \\
\hline Solldifled, Organic matrix & 0.0 & 0.0 & 0.0 & 2003-2022: & 0.0 & 0.0 & $\mathrm{~m} 3 / \mathrm{yr}$ & & & & \\
\hline Soils & 0.0 & 0.0 & 0.0 & TYPICA & AL EPA COD & ES APPLICAE & BLE & & & & \\
\hline $\begin{array}{l}\text { Packaging Materials, Steel } \\
\text { Packaging Material, Plastlc }\end{array}$ & $\frac{131.0}{37.0}$ & & & & UNK & & & & & & \\
\hline
\end{tabular}




\section{WASTE STREAM PROFILE FOR THE WIPP TRU WASTE BASELINE INVENTORY REPORT}

SITE NAME IN

WASTE TYPE MTRU HANDLING CH GENERATOR SITE MD

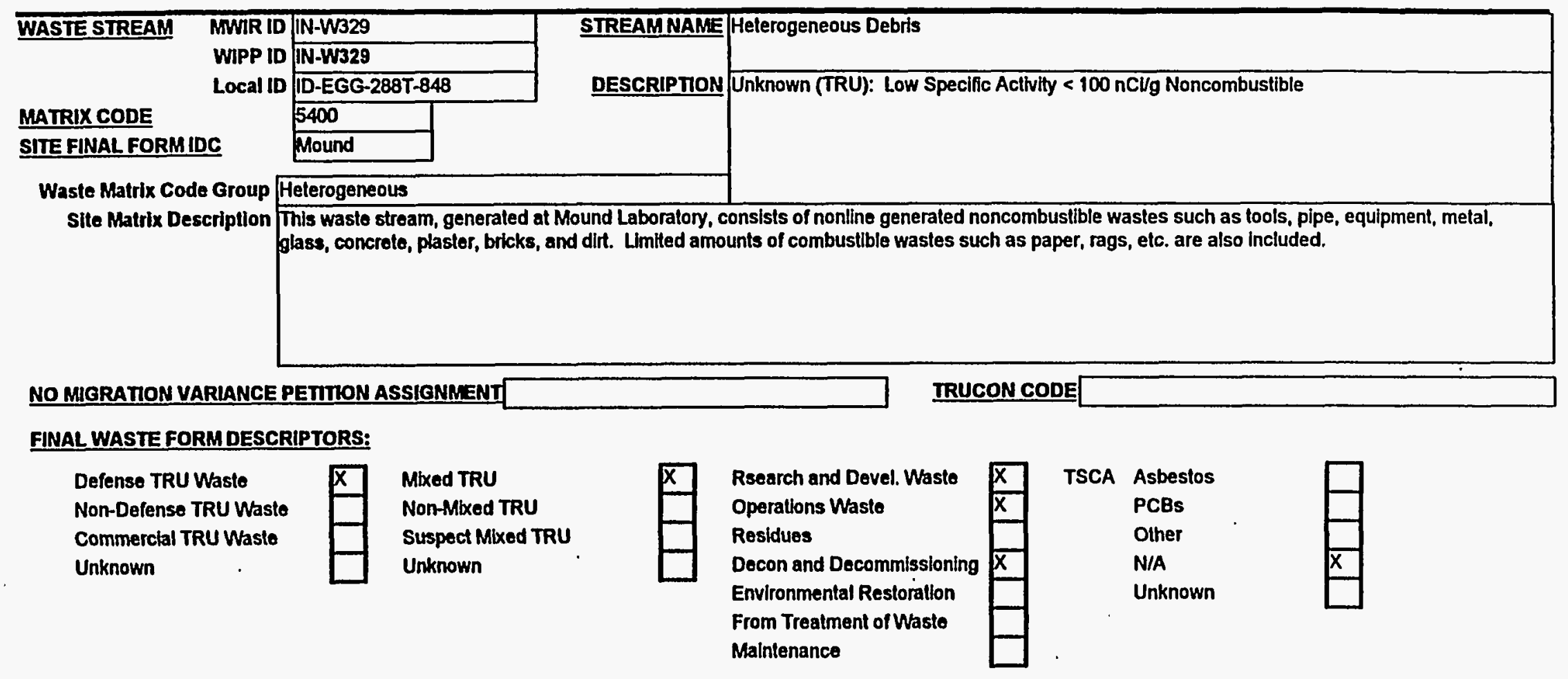




\section{WASTE STREAM PROFILE FOR THE WIPP TRU WASTE BASELINE INVENTORY REPORT}

SITE NAME IN

WASTE TYPE MTRU HANDLING CH GENERATOR SITE MD

IN-W328 $\quad \frac{\text { CONTAINER: }}{\text { Type/Size: }}: \frac{\text { Drum }}{55 \text {-gallon }}$

Contalner Matt: steel

Int. Volveinr: $\frac{0.208 / \mathrm{m}^{3}}{0.001}$

Liner Type:

Type/Size: 55-gallon

TYPICAL WASTE DENSITIES FOR FINAL WASTE FORM $(\mathrm{kg} / \mathrm{m} 3)$

Material Parameters

Iron-based Metals/Alloys

Aluminum-Based Metals/Alloys

Other Metals

Other Inorganic Materials

Cellutosics

Rubber

Plastics

Solidified, Inorganic matrix

Solidified, Organic matrix

Solls

Packaging Matertals, Steol

Packaging Material, Plastic
STORED TRU WASTE ESTMATED

RATES OF WASTE GENERATION

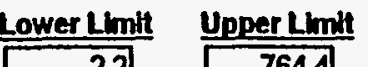

\begin{tabular}{|r|}
\hline 2.2 \\
\hline 17.5 \\
\hline 9.2 \\
\hline 0.0 \\
\hline 0.0 \\
\hline 0.0 \\
\hline 0.0 \\
\hline 0.0 \\
\hline 0.0 \\
\hline 0.0 \\
\hline 36.2 \\
\hline 0.6 \\
\hline 0.0 \\
\hline 0.8 \\
\hline 0.0 \\
\hline 0.0 \\
\hline 0.0 \\
\hline
\end{tabular}

\begin{tabular}{|c|c|c|c|}
\hline & Prolected & Final Form & \\
\hline End of 1992: & 1.1 & 1.1 & m3 \\
\hline End of १983: & $\overline{1.1}$ & 1.1 & m3 \\
\hline 1894: & 0.0 & 0.0 & $\mathrm{~m} 3 / y r$ \\
\hline 1995: & 0.0 & 0.0 & $\mathrm{~m} 3 / \mathrm{yr}$ \\
\hline 1998: & 0.0 & 0.0 & $m 3 / y r$ \\
\hline 1897: & 0.0 & 0.0 & $m 3 / r y$ \\
\hline 1898-2002: & 0.0 & 0.0 & m3/yr \\
\hline 2003-2022: & 0.0 & 0.0 & m3ryr \\
\hline
\end{tabular}

Number Stored:

Number Projected:

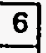

TYPICAL ISOTOPIC COMPOSITON

Nucllde Activity

Pu238 1.22E+02 Curies $/ \mathrm{m}^{3}$

Pu239 5.34E-02 Curies $/ \mathrm{m} 3$ 


\section{WASTE STREAM PROFILE FOR THE WIPP TRU WASTE BASELINE INVENTORY REPORT}

SITE NAME IN

WASTE TYPE MTRU HANDLING CH GENERATOR SITE MD

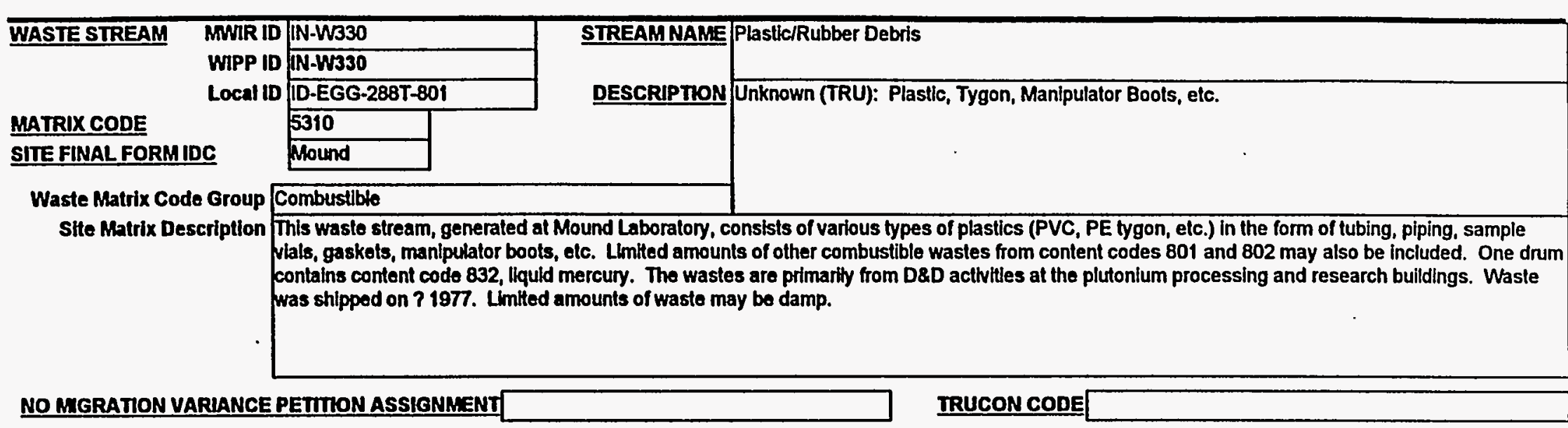

\section{FINAL WASTE FORMDESCRIPTORS:}

\begin{tabular}{l|l}
$\begin{array}{l}\text { Defense TRU Waste } \\
\text { Non-Defense TRU Waste } \\
\text { Commercial TRU Waste } \\
\text { Unknown }\end{array}$ & $\square$
\end{tabular}

Rsearch and Devel. Waste Operations Waste

Residues

Decon and Decommissioning $\bar{x}$

Environmental Restoration

From Treatment of Waste

Maintenance
TSCA Asbestos

PCBs

Other

N/A

Unknown

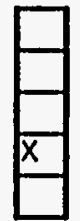




\section{WASTE STREAM PROFILE FOR THE WIPP TRU WASTE BASELINE INVENTORY REPORT}

SITE NAME IN

WASTE TYPE MTRU HANDLINO CH GENERATOR SITE MD

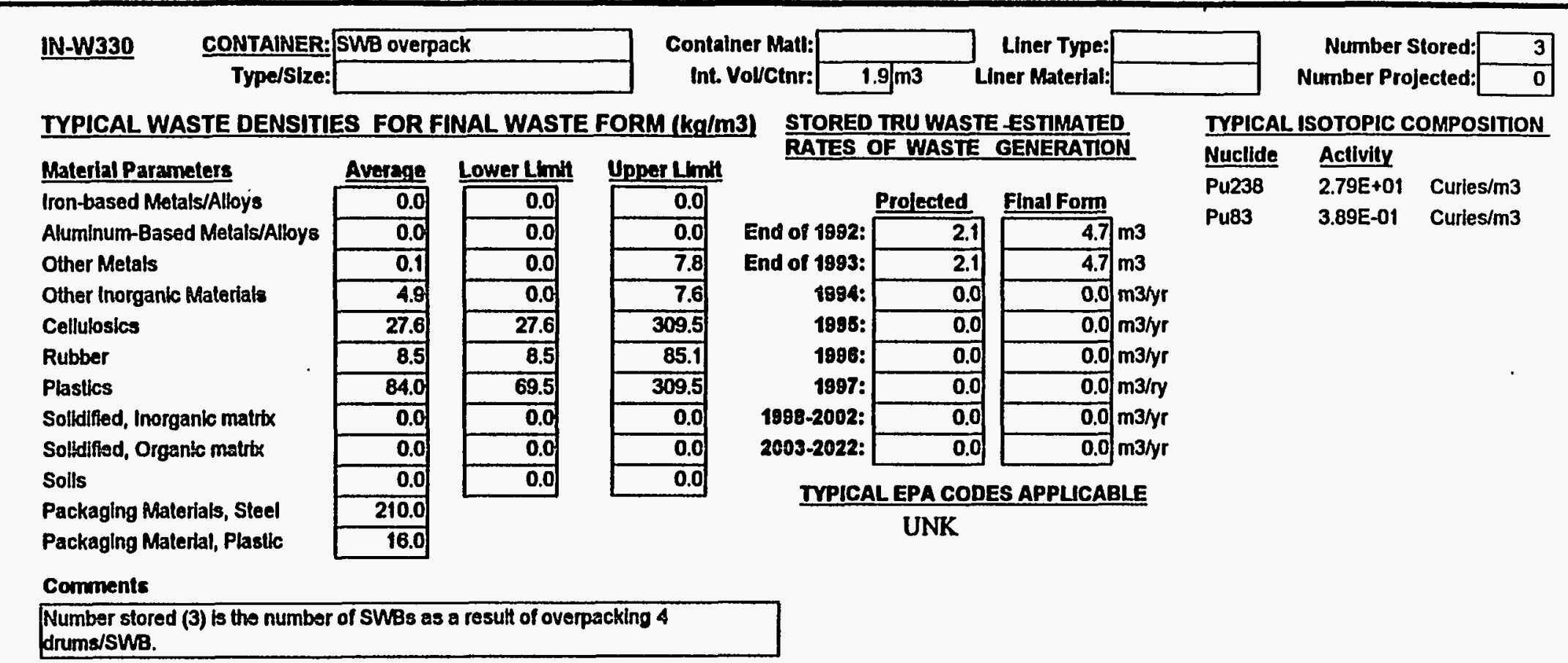




\section{WASTE STREAM PROFILE FOR THE WIPP TRU WASTE BASELINE INVENTORY REPORT}

SITE NAME IN WASTE TYPE MTRU HANDLING CH GENERATOR SITE MD

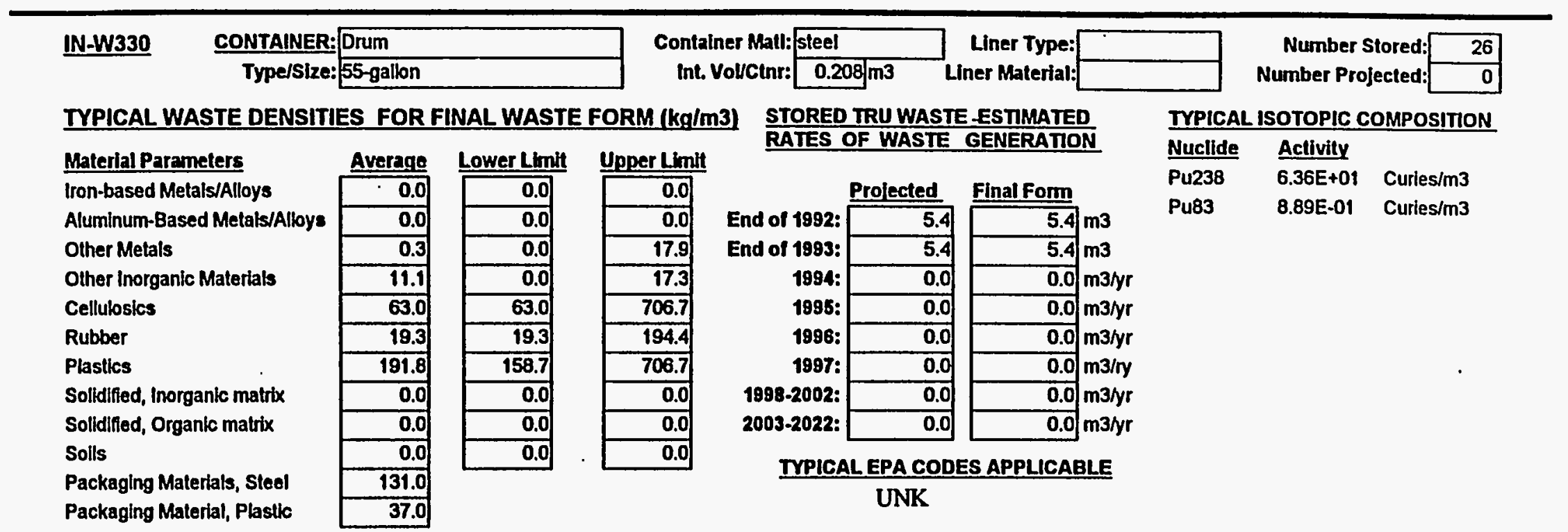




\section{WASTE STREAM PROFILE FOR THE WIPP TRU WASTE BASELINE INVENTORY REPORT}

SITE NAME IN

WASTE TYPE MTRU HANDLING CH GENERATOR SITE BC

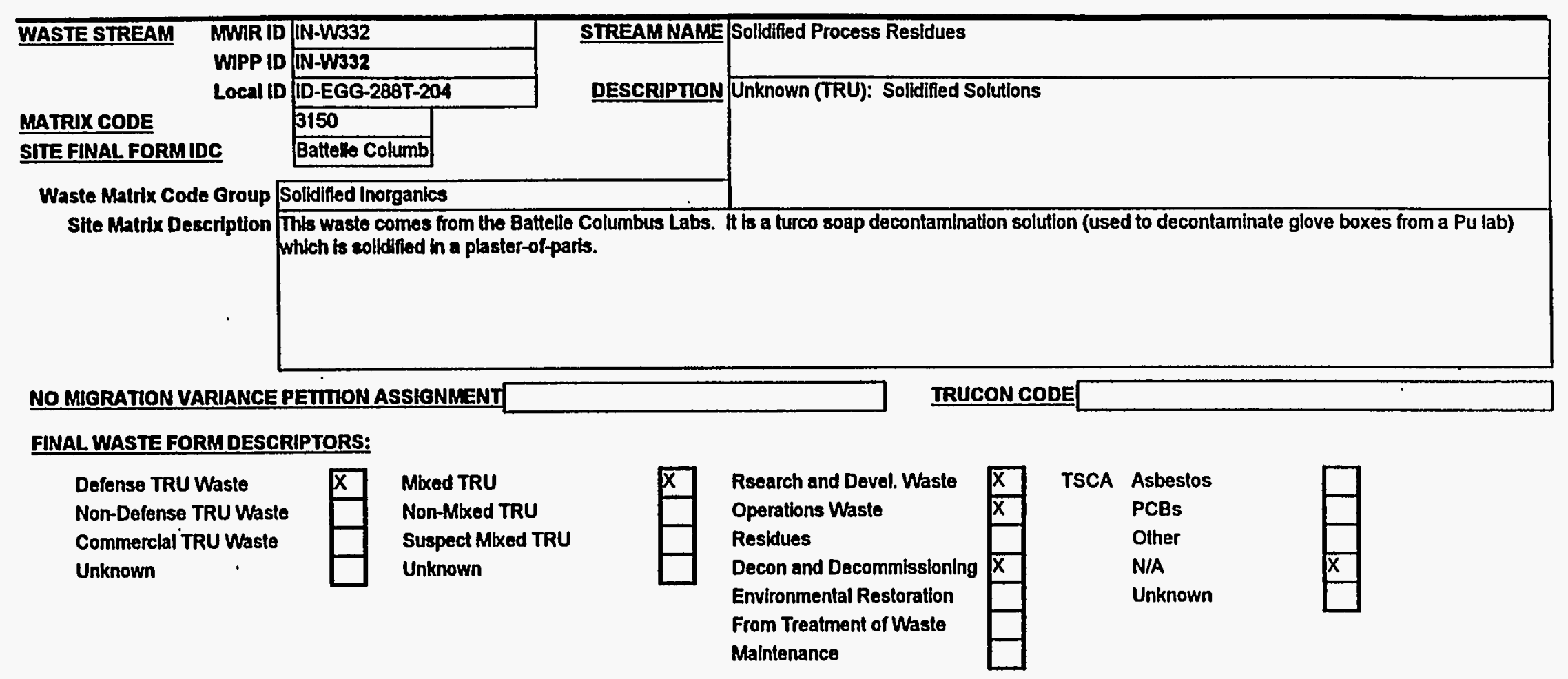




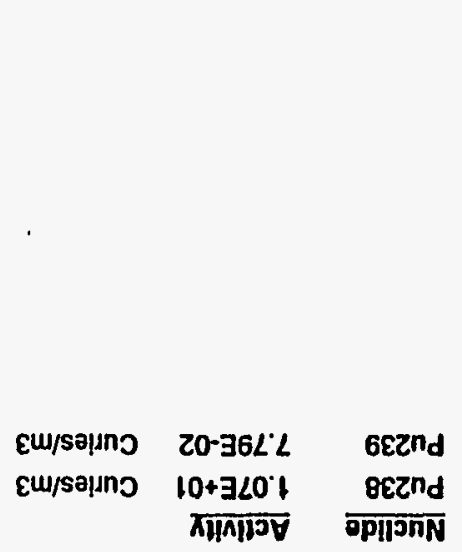

NOIISOdWOJ गामण
XNก

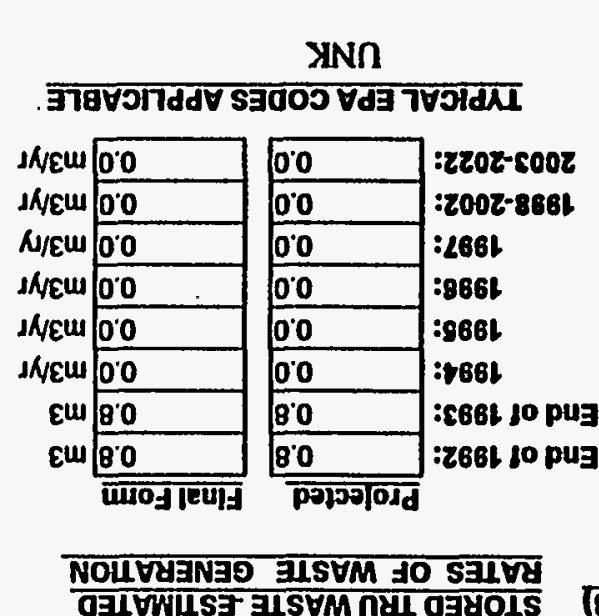

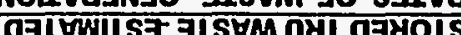
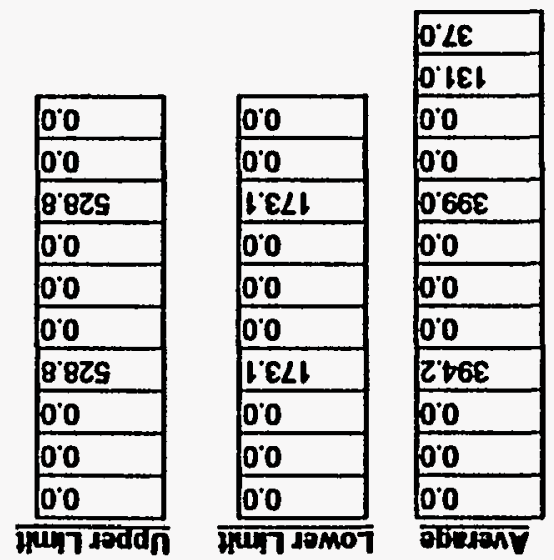

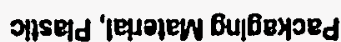

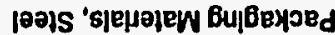

snlos

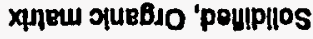

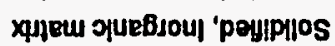

sopseld

Joqqny

so|so|n॥ाओ

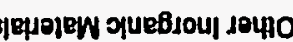

s팋N Jino

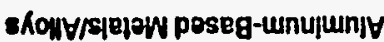

SROAHFIIEIOW PESEq-UOA

गगमापहत्व सागुण

0 :pojor|osd soqumn :pasols soquinn

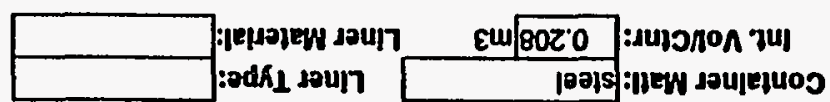

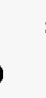

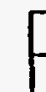

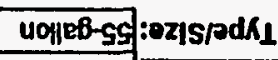

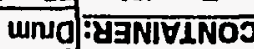

$\overline{\text { ZEEM-NI }}$ 
WASTE STREAM PROFILE FOR THE WIPP TRU WASTE BASELINE INVENTORY REPORT

SITE NAME IN WASTE TYPE MTRU

HANDLING CH

GENERATOR SITE BC

\begin{tabular}{|c|c|c|c|c|}
\hline WASTE STREAM & MWIR ID & IN-W334 & STREAMNAME & Debris Waste \\
\hline & WIPP ID & IN-W334 & & \\
\hline & Local ID & ID.EGG-288T-203 & DESCRIPTION & Unknown (TRU): Paper, Metals, Glass \\
\hline MATRIX CODE & & 5000 & & \\
\hline SITE FINAL FORN & & Battelle Columb & & \\
\hline Waste Matrix Cc & $=$ Group $\longdiv { H }$ & teterogeneous & & \\
\hline Slte Matrix D & cription & $\begin{array}{l}\text { This waste stream, } g \\
\text { oroportions. Combus }\end{array}$ & $\begin{array}{l}\text { altelle Columbus La } \\
\text { dude paper and pap }\end{array}$ & $\begin{array}{l}\text { boratories, contains a mixture of combustible and noncombustible items in roughly equal } \\
\text { per products. Noncombustibles are primarily metal and some glass. }\end{array}$ \\
\hline NO MBGRATION & WCE & nTON ASSIG & & IRUCON CODE \\
\hline
\end{tabular}

\section{FINAL WASTE FORM DESCRIPTORS:}

\begin{tabular}{|c|c|}
\hline Defense TRU Waste & Mbxed TRU \\
\hline Non-Defense TRU Wasto & Non-Mixed TRU \\
\hline Commercial TRU Wasto & Suspect Mbred TRU \\
\hline Unknown & Unknown \\
\hline
\end{tabular}

Rsearch and Devel. Waslo
Operations Waste
Residues
Decon and Decommissioning
Environmental Restoration
From Treatment of Waste
Maintenance

TSCA Asbestos

PCBs

Other

N/A

Unknown'

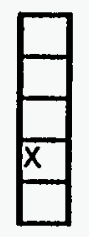




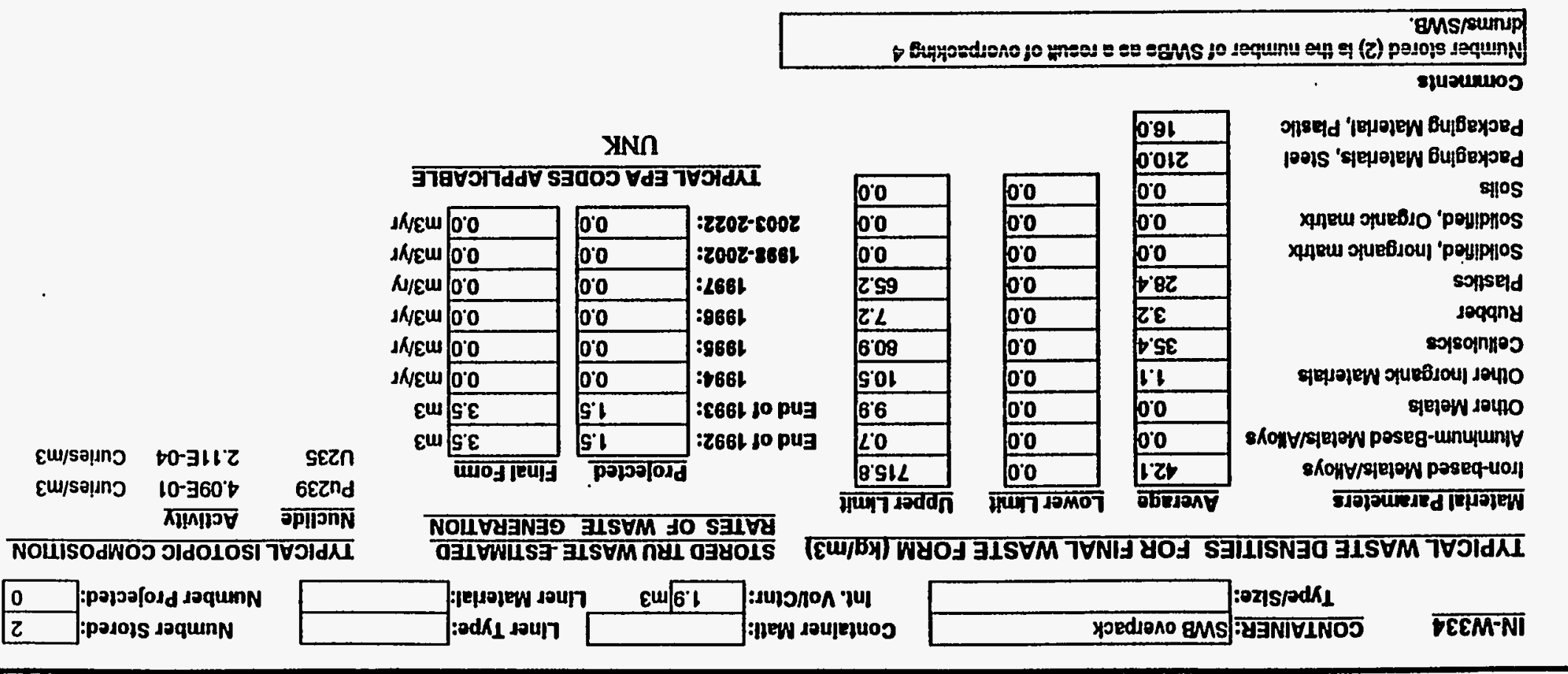




\section{WASTE STREAM PROFILE FOR THE WIPP TRU WASTE BASELINE INVENTORY REPORT}

SITE NAME IN

\section{WASTE TYPE MTRU HANDLING CH GENERATOR SITE BC}

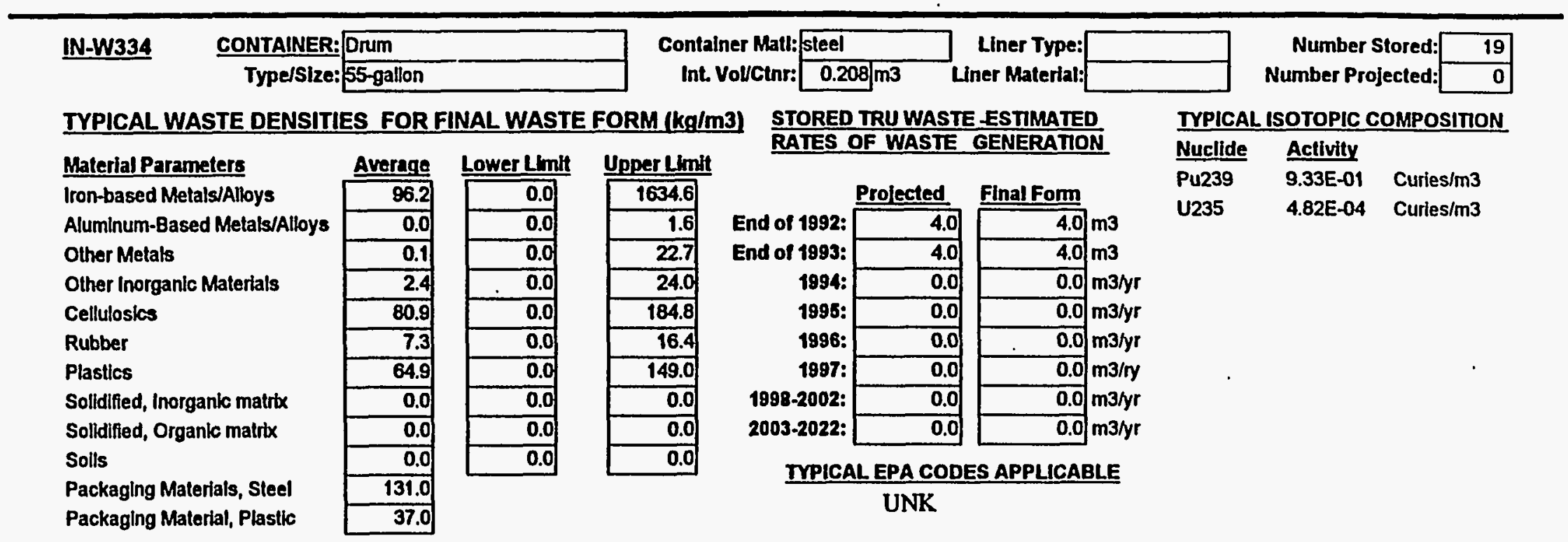




\section{WASTE STREAM PROFILE FOR THE WIPP TRU WASTE BASELINE INVENTORY REPORT}

SITENAME IN

WASTE TYPE MTRU HANDLING CH GENERATOR SITE BC

\begin{tabular}{|c|c|c|c|}
\hline WASTE STREAM MWIRID & IN-W336 & STREAMNAME & Combustible Debris \\
\hline WIPP ID & IN-W336 & & \\
\hline Local ID & ID-EGG-288T-202 & DESCRIPTION & Unknown (TRU): Combustible Solids \\
\hline MATRIX CODE & 5300 & & \\
\hline SITE FINAL FORMIDC & Battelle Columb & & \\
\hline Waste Matrix Code Group [C & Combustible & & 5 \\
\hline Site Matrix Description & $\begin{array}{l}\text { This wasto stream, } 8 \\
\text { structures, shoe cov }\end{array}$ & $\begin{array}{l}\text { altelle Columbus Le } \\
\text { ves, and air hose. }\end{array}$ & $\begin{array}{l}\text { aboratories, contalns such combustible Hems as wood, plastic suits, nylon reinforced plastic tent } \\
\text { The waste is from decontamination and deactivation of the plutonium laboratory. }\end{array}$ \\
\hline
\end{tabular}

NO MGRATION VARIANCE PETIMON ASSIGNMENT

IRUCON CODE

\section{FINAL WASTE FORM DESCRIPTORS:}

Defense TRU Waste

Non-Defense TRU Waste

Commercial TRU Waste

$\square$

Mbxed TRU

Non-Mixed TRU

Suspect Mixed TRU

Unknown

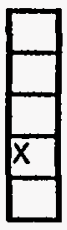

From Treatment of Waste

\begin{tabular}{|l|}
\hline$x$ \\
\hline$x$ \\
\hline \\
\hline$x$ \\
\hline \\
\hline \\
\hline
\end{tabular}

TSCA Asbestos

PCBs

Other

N/A

Unknown

Rsearch and Devel. Waste
Operations Waste
Resldues
Decon and Decommissioning
Environmental Restoration
From Treatment of Waste
Malntenance




\section{WASTE STREAM PROFILE FOR THE WIPP TRU WASTE BASELINE INVENTORY REPORT}

SITENAME IN

WASTE TYPE MTRU HANDLNO CH GENERATOR SITE BC

IN-W336 CONTAINER: Drum

TYPICAL WASTE DENSITIES FOR FINAL WASTE FORM (kg/m3)

Material Parameters

Iron-based Metals/Alloys

Aluminum-Based Metals/ABoys

Other Melals

Other Inorganic Materlats

Cellulosics

Rubber

Plastles

Solldified, Inorganic matrix

Solidified, Organic matrix

Solls

Packaging Materials, Steel

Packaging Materlal, Plastic

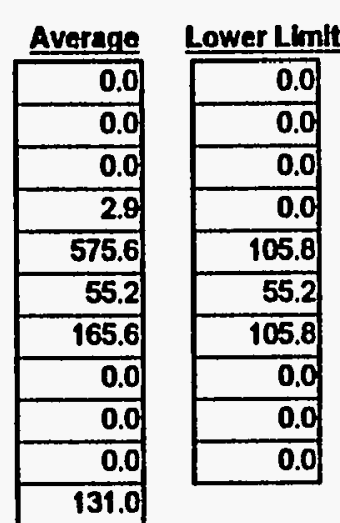

37.0

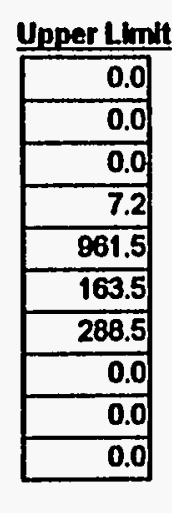

\section{Comments}

The weighls per container in the MiD for boxes are Identical to the welghts per contalner for drums l'd rather use the same $\mathrm{kg} / \mathrm{m3}$. (Chuck Edinborough)

\begin{tabular}{|c|c|c|c|c|}
\hline Container Matl: & steel & Uner Type: & Number Stored: & 20 \\
\hline Int. Volvcenr: & $0.208 / \mathrm{m} 3$ & Liner Materiat: & Number Projected: & 0 \\
\hline
\end{tabular}

TYPICAL ISOTOPIC COMPOSITION

Nuclide Activity

Pu239 1.48E-01 Curies/m3

\begin{tabular}{|c|c|c|c|}
\hline & Prolected & Final Form & \\
\hline End of 1992: & 4.1 & 4.1 & $\mathrm{~m} 3$ \\
\hline nd of 1993: & 4.1 & 4.1 & m3 \\
\hline 1994: & 0.0 & 0.0 & $\mathrm{~m} 3 / \mathrm{yr}$ \\
\hline 1995: & 0.0 & 0.0 & $\mathrm{~m} 3 / \mathrm{yr}$ \\
\hline 1998: & 0.0 & 0.0 & $\mathrm{~m} 3 / \mathrm{yr}$ \\
\hline 1997: & 0.0 & 0.0 & $m 3 / r y$ \\
\hline 1898-2002: & 0.0 & 0.0 & $\mathrm{~m} 3 / \mathrm{yr}$ \\
\hline 2003-2022: & 0.0 & 0.0 & m3/yr \\
\hline
\end{tabular}


WASTE STREAM PROFILE FOR THE WIPP TRU WASTE BASELINE INVENTORY REPORT

SITENAME IN WASTE TYPE MTRU HANDLING RH GENERATOR SITE IN

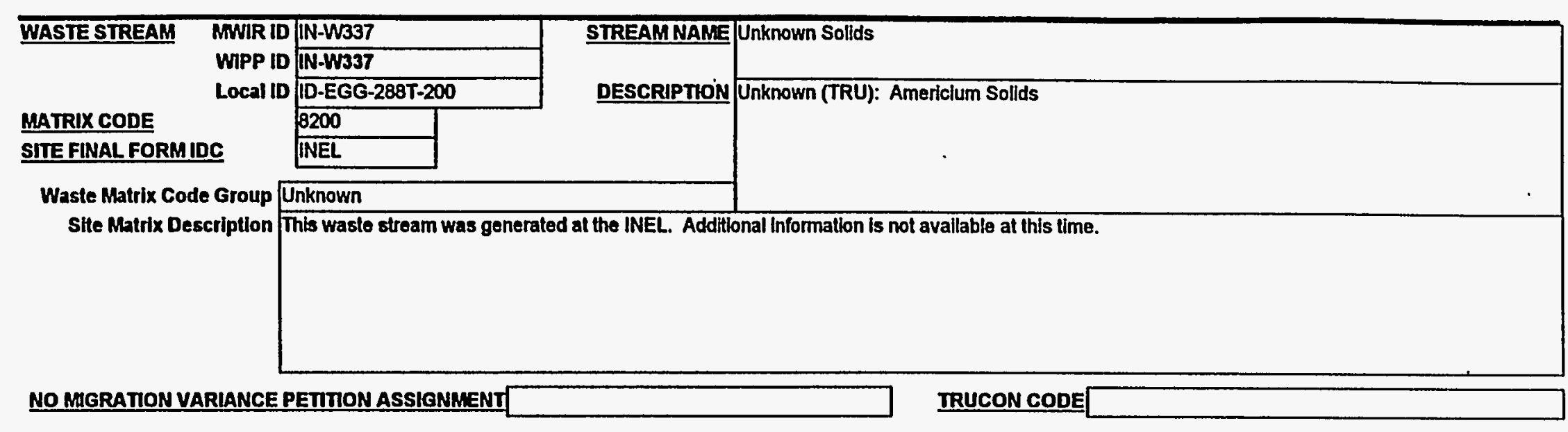

FINAL WASTE FORM DESCRIPTORS:

Defense TRU Waste

Non-Defense TRU Waste

Commercial TRU Waste

Unknown

$x$

Mlxed TRU

Non-Mixed TRU

Suspect Moxed TRU

Unknown
Rsearch and Devel. Waste Operations Waste

Residues

Decon and Decommissloning

Environmental Restoration

From Treatment of Waste

Malntenance
TSCA Asbestos

PCBs

Other

N/A

Unknown 
XNก

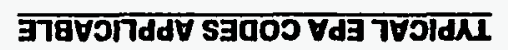

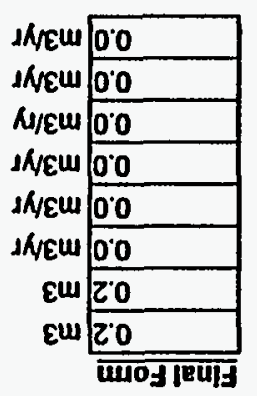

\begin{tabular}{|c|c|}
\hline 00 & 0 \\
\hline $0^{\circ} 0$ & 0 \\
\hline 00 & 0 \\
\hline & 0 \\
\hline & 0 \\
\hline & 0 \\
\hline & 0 \\
\hline & 0 \\
\hline
\end{tabular}

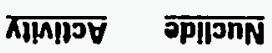

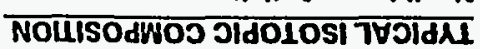

NOIVZINBD IISYM to SaIVY

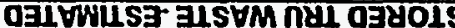

$: 2202-5002$ :200Z-868t

: 2861

:9665

:986L

:6681

:ع68r jo puz :266L 10 pus

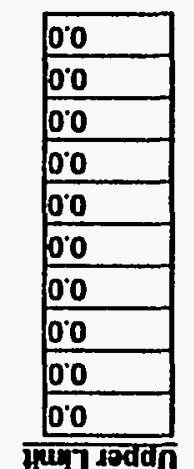

मून ब्ववर
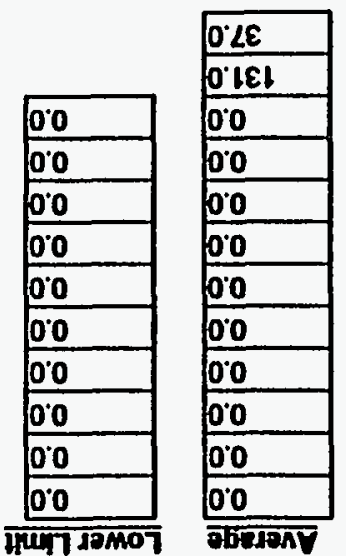

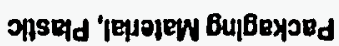

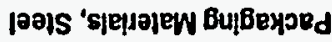

S\|णOS

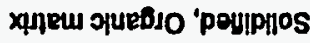

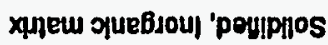

sonsetd

seqqny

sopsonn|los

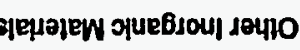

spow dorlo

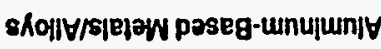

sরony/s|ęow poseq-uod

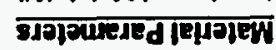

\begin{tabular}{|c|c|c|c|}
\hline 0 & :poloכjosd saqumn & 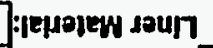 & $\varepsilon w \longdiv { 8 0 Z ^ { \circ } 0 }$ \\
\hline 1 & :posols dequenN & :odk1 doun & 100 \\
\hline
\end{tabular}
:odk1 doun

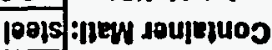

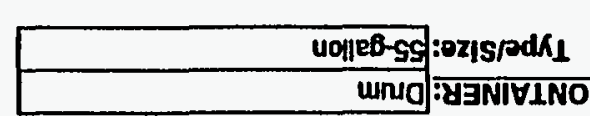

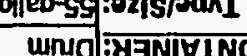

$\overline{\text { LEEM-NI }}$ 


\section{WASTE STREAM PROFILE FOR THE WIPP TRU WASTE BASELINE INVENTORY REPORT}

SITENAME IN

WASTE TYPE MTRU HANDLING CH GENERATOR SITE AW

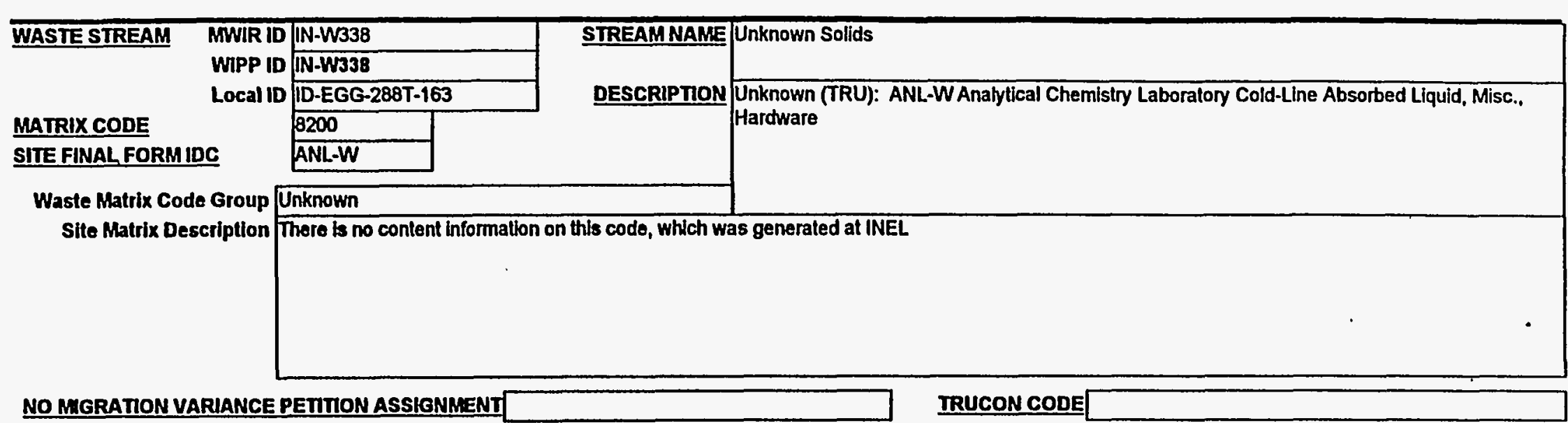

NO MURATION VARIANGE PETITION ASSIGNMENT

IRUCON CODE

\section{FINAL WASTE FORM DESCRIPTORS:}

\begin{tabular}{l|l|l} 
Defense TRU Waste & $X$ & $\begin{array}{l}\text { Mbxed TRU } \\
\text { Non-Mixed TRU } \\
\text { Non-Defense TRU Waste } \\
\text { Commercial TRU Waste } \\
\text { Unknown }\end{array} \quad \square \quad$ \\
$\begin{array}{l}\text { Suspect Mixed TRU } \\
\text { Unknown }\end{array}$
\end{tabular}

$\square$

Rsearch and Devel. Waste
Operations Waste
Residues
Decon and Decommissioning
Environmental Restoration
From Treatment of Waste

\begin{tabular}{|l|}
\hline$x$ \\
\hline$x$ \\
\hline \\
\hline$x$ \\
\hline \\
\hline \\
\hline
\end{tabular}
TSCA Asbestos
PCBs
Other
N/A
Unknown

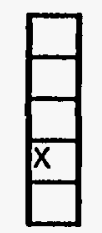

Maintenance 
WASTE STREAM PROFILE FOR THE WIPP TRU WASTE BASELINE INVENTORY REPORT

SITE NAME IN WASTE TYPE MTRU HANDLING CH

GENERATOR SITE AW

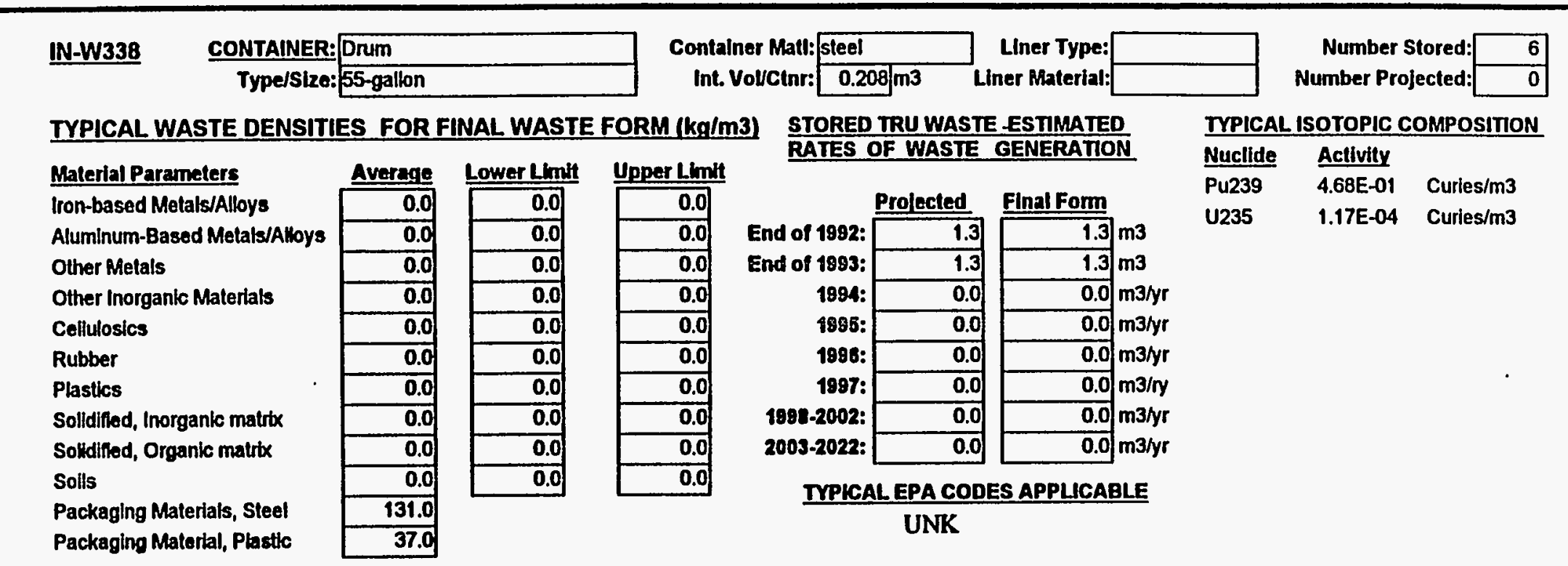


WASTE STREAM PROFILE FOR THE WIPP TRU WASTE BASELINE INVENTORY REPORT

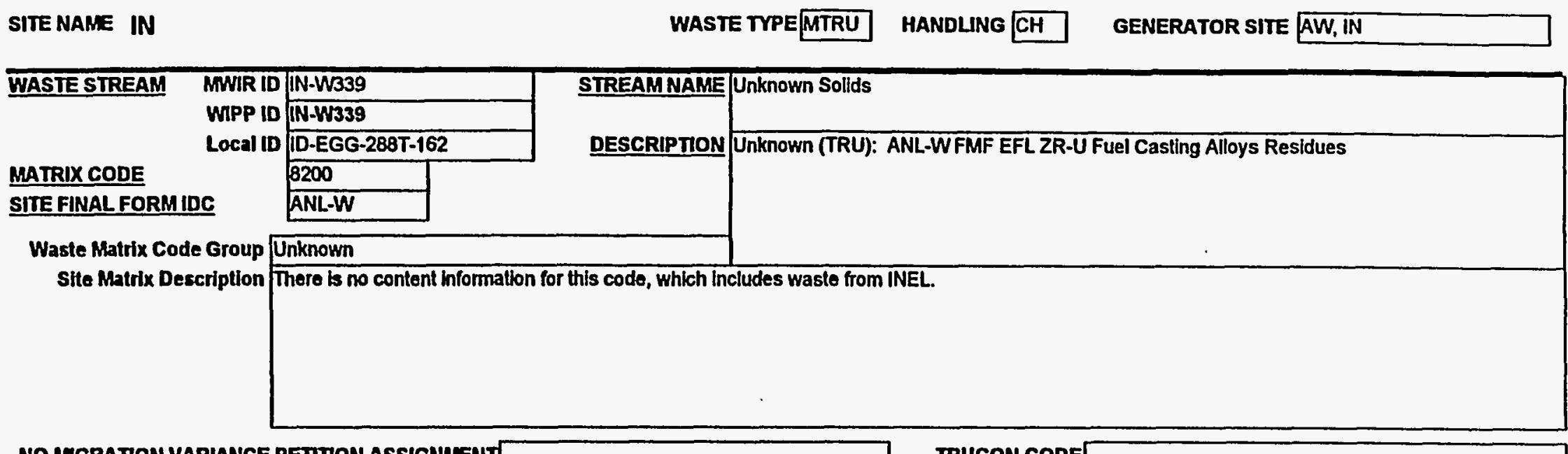

NO MORATION VARIANCE PETITON ASSIGNHENT $\square$ IRUCON CODE

\section{FINAL WASTE FORM DESCRIPTORS:}

Defense TRU Waste

Non-Defense TRU Waste

Commerclal TRU Waste

Unknown

$\square$

Mbxed TRU

Non-Mbed TRU

Suspect Mixed TRU

Unknown $\square$
TSCA Asbestos

PCBs

Other

N/A

Unknown

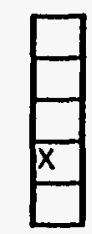

ental Restoration

Treatment of Waste

Maintenance 


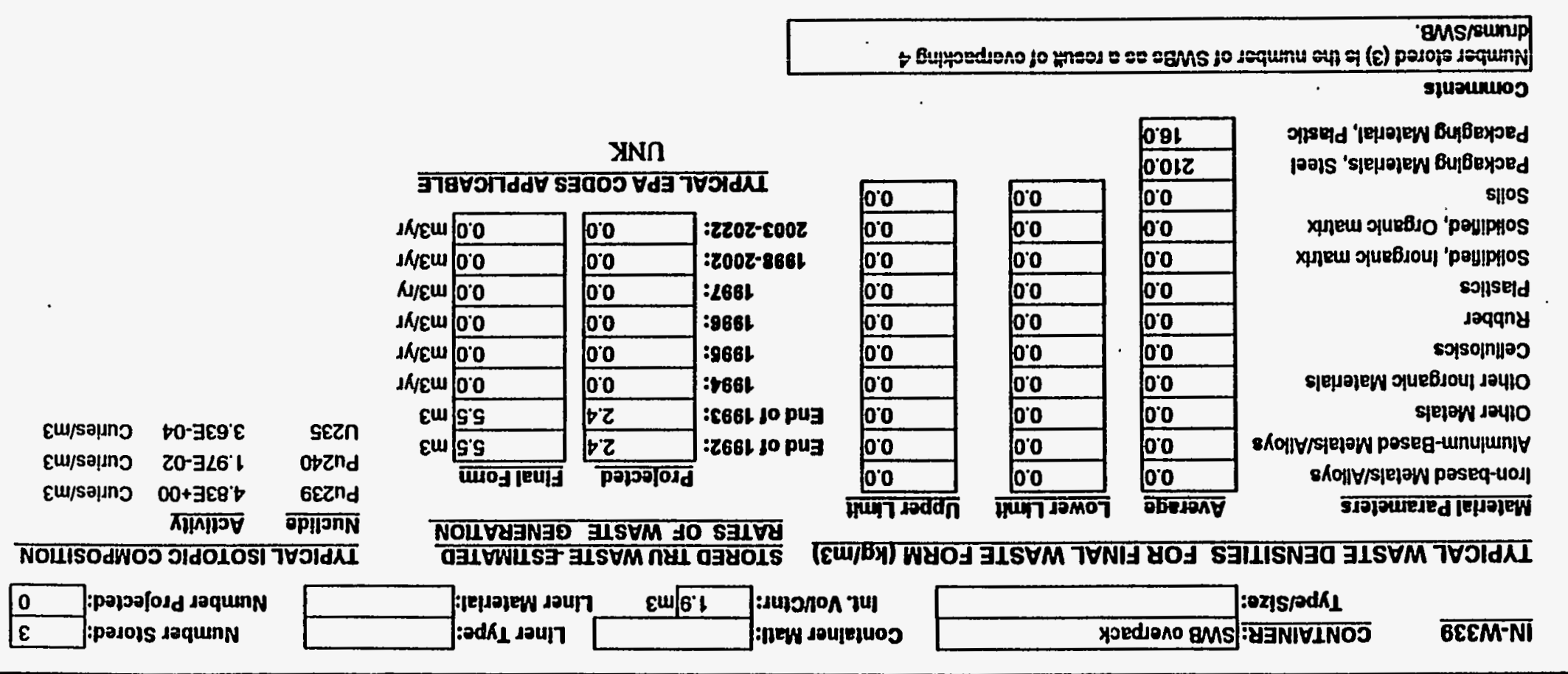




\section{WASTE STREAM PROFILE FOR THE WIPP TRU WASTE BASELINE INVENTORY REPORT}

SITE NAME IN WASTE TYPE MTRU HANDLING CH GENERATOR SITE AW, IN

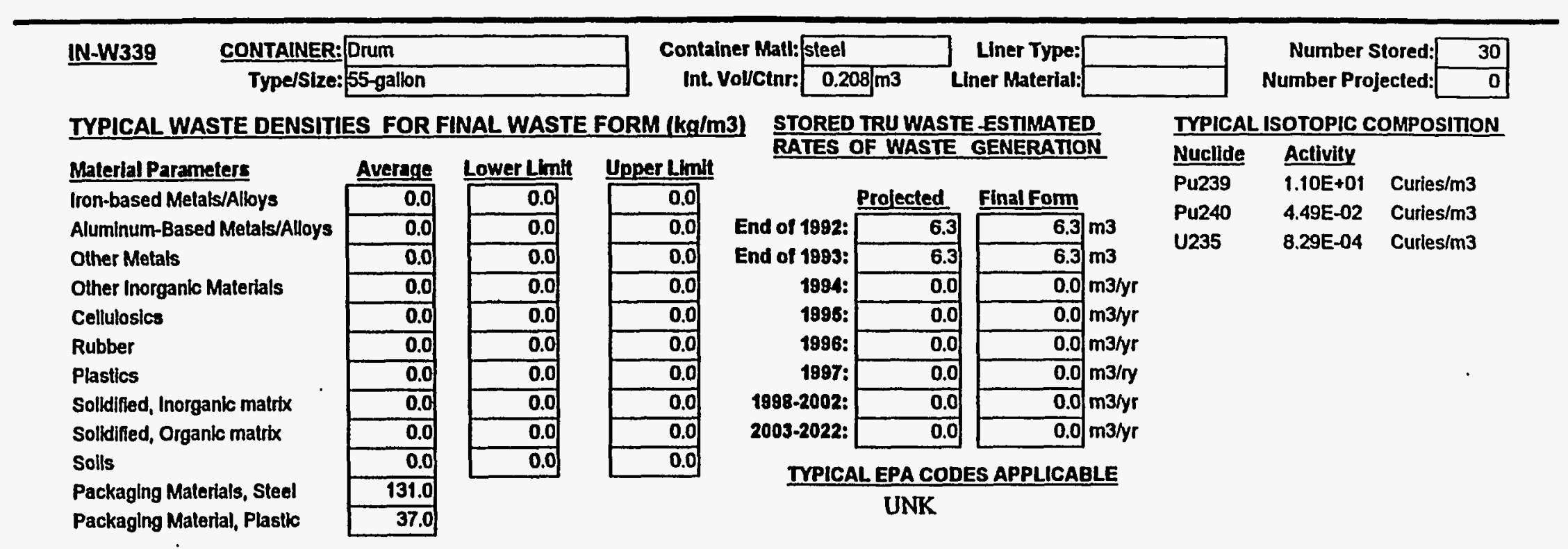




\section{WASTE STREAM PROFILE FOR THE WIPP TRU WASTE BASELINE INVENTORY REPORT}

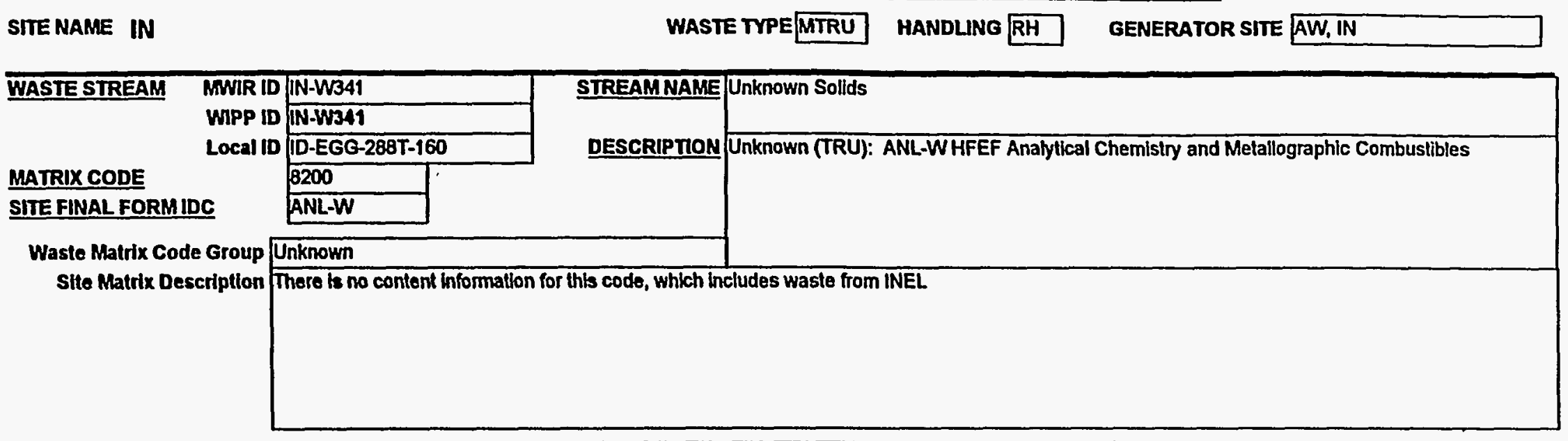

NO MGRATION VARIANCE PETIMON ASSIGNMENT IRUCON CODE

\section{FINAL WASTE FORM DESCRIPTORS}

\section{Defense TRU Waste}

Non-Defense TRU Wasto

Commerclal TRU Wasto

$\square$

Mbxed TRU

Non-Mixed TRU

Suspect Mtxed TRU

Unknown

$\square$

Rsearch and Devel. Waste
Operations Wasle
Residues
Decon and Decommissioning
Environmental Restoration
From Trealment of Waste
Maintenance

\begin{tabular}{|l|}
\hline$x$ \\
\hline$x$ \\
\hline \\
\hline \\
\hline
\end{tabular}

TSCA Asbestos

PCBs

Other

N/A

Unknown 
WASTE STREAM PROFILE FOR THE WIPP TRU WASTE BASELINE INVENTORY REPORT

WN-W341

$$
\begin{array}{cl}
\text { CONTAINER: } & \text { Drum } \\
\text { Type/SIze: } 55 \text {-gallon }
\end{array}
$$

Container Matl: steel

Int. VolJCinr: $0.208 \mathrm{m3} \quad$ Liner Material:

STORED TRU WASTE ESTMMATED RATES OF WASTE GENERATION

\section{Material Parameters}

Iron-based Melals/Alioys

Aluminum-Based Metals/Alloys

Other Metals

Other Inorganic Materials

Cellulosics

Rubber

Plastics

Solidfied, Inorganic matrix

Solidified, Organic matrix

Solls

Packaging Materlals, Steel

Packaging Materlal, Plastlc

\begin{tabular}{l} 
Average \\
\hline $\mathbf{0 . 0}$ \\
\hline 0.0 \\
\hline 0.0 \\
\hline 0.0 \\
\hline 0.0 \\
\hline 0.0 \\
\hline 0.0 \\
\hline 0.0 \\
\hline 0.0 \\
\hline 0.0 \\
\hline 131.0 \\
\hline 37.0 \\
\hline
\end{tabular}

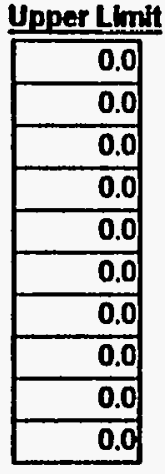

37.0

\begin{tabular}{r|}
\hline Lower Lintt \\
\hline 0.0 \\
\hline 0.0 \\
\hline 0.0 \\
\hline 0.0 \\
\hline 0.0 \\
\hline 0.0 \\
\hline 0.0 \\
\hline 0.0 \\
\hline 0.0 \\
\hline 0.0 \\
\hline
\end{tabular}

\begin{tabular}{r|r|}
\hline & Prolected \\
\hline End of 1992: & 0.2 \\
\cline { 2 - 2 } & $\mathbf{0 . 2}$ \\
\hline $1994:$ & 0.0 \\
\hline $1998:$ & 0.0 \\
\hline $1997:$ & 0.0 \\
\hline $1908-2002:$ & 0.0 \\
\hline $2003-2022:$ & 0.0 \\
\hline & 0.0 \\
\hline
\end{tabular}

Final Form $0.2 \mathrm{~m} 3$

\begin{tabular}{rl}
\hline 0.2 & $\mathrm{~m} 3$ \\
$\mathrm{~m} 3 / \mathrm{yr}$
\end{tabular}

$0.0 \mathrm{~m} 3 / \mathrm{yr}$

$0.0 \mathrm{~m} 3 / \mathrm{yr}$

$0.0 \mathrm{~m} 3 / \mathrm{yr}$

UNK
IYPICAL EPA CODES APPLICABLE
Number Stored Number Projected

TYPICAL ISOTOPIC COMPOSITION

Nuclide Activity

Pu239 9.40E+00 Curies $/ \mathrm{m}^{3}$

U235 1.32E-03 Curies $/ \mathrm{m} 3$ 
WASTE STREAM PROFILE FOR THE WIPP TRU WASTE BASELINE INVENTORY REPORT

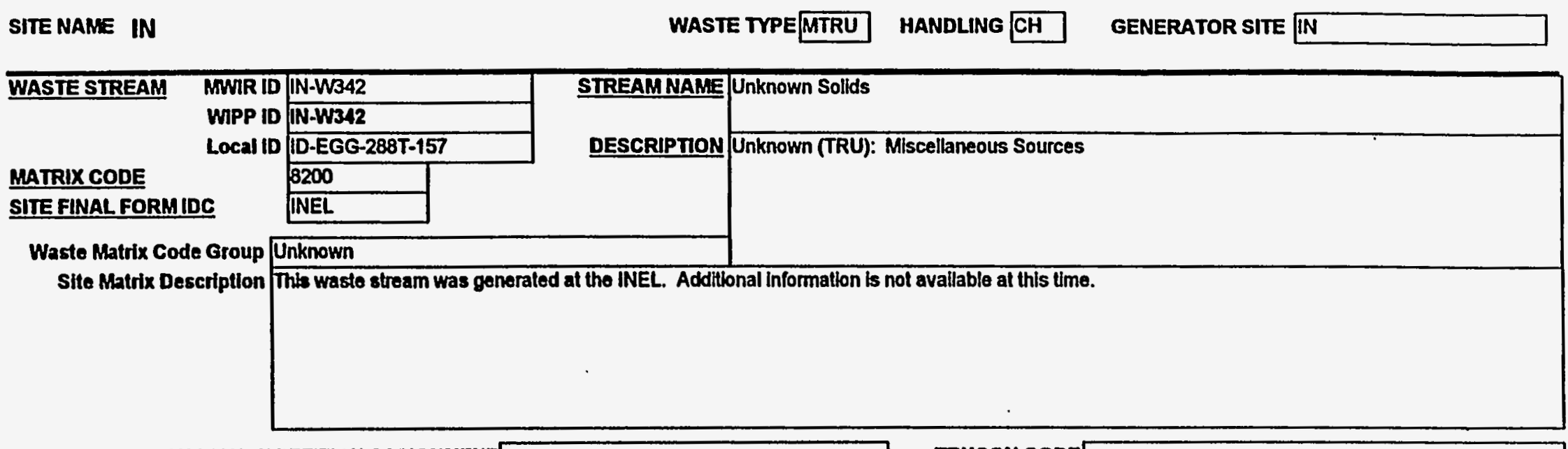

NO MUGRATON VARIANGE PETIION ASSIGNMENT

IRUCON CODE

FINAL WASTE FORMDESCRIPTORS:

\begin{tabular}{|c|c|}
\hline Defense TRU Waste & Mlxed TRU \\
\hline Non-Defense TRU Wasto & Non-Mbed TRU \\
\hline Commercial TRU Waste & Suspect Mbxed TRU \\
\hline Unknown & Unknown \\
\hline
\end{tabular}

Rsearch and Devel. Waste
Operations Waste
Residues
Decon and Decommissioning
Environmental Restoration
From Treatment of Waste
Maintenance

TSCA Asbestos

PCBs

Other

N/A

Unknown

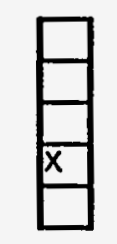




\section{WASTE STREAM PROFILE FOR THE WIPP TRU WASTE BASELINE INVENTORY REPORT}

SITE NAME IN

WASTE TYPE MTRU HANDLING CH GENERATOR SITE IN

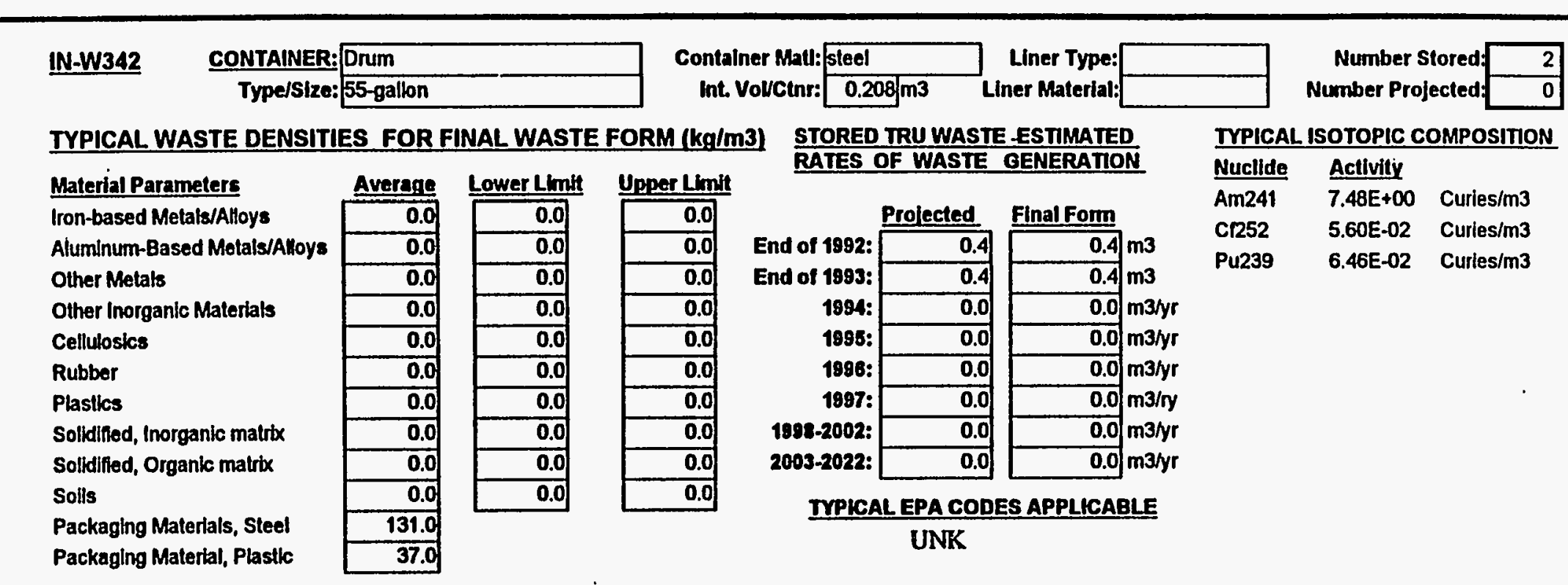


WASTE STREAM PROFILE FOR THE WIPP TRU WASTE BASELINE INVENTORY REPORT

SITE NAME IN WASTE TYPEMTRU HANDLUNG CH GENERATOR SITE IN

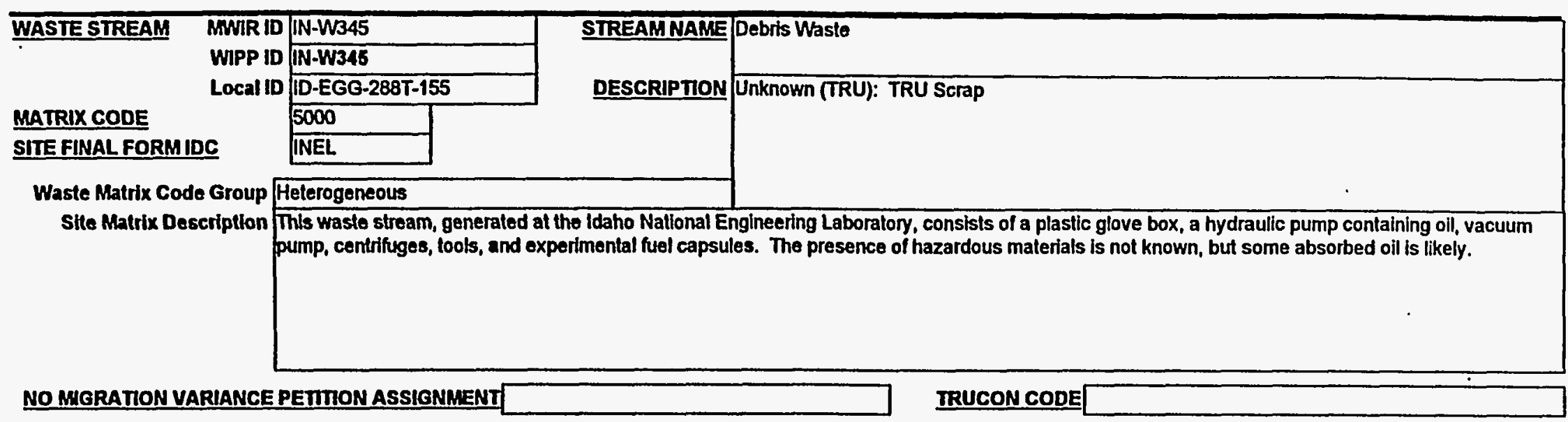

FINAL WASTE FORMDESCRIPTORS:

Defense TRU Waste
Non-Defense TRU Waste
Commerclal TRU Waste
Unknown

$\square$

Rsearch and Devel. Waste
Operations Waste
Residues
Decon and Decommlssioning
Environmental Restoration
From Treatment of Waste
Maintenance

\begin{tabular}{|l|}
\hline$x$ \\
\hline$x$ \\
\hline$x$ \\
\hline \\
\hline \\
\hline
\end{tabular}

$\begin{array}{lll}\text { TSCA Asbestos } & \\ \text { PCBs } & \\ \text { Other } & \\ \text { N/A } & \\ \text { Unknown } & \end{array}$




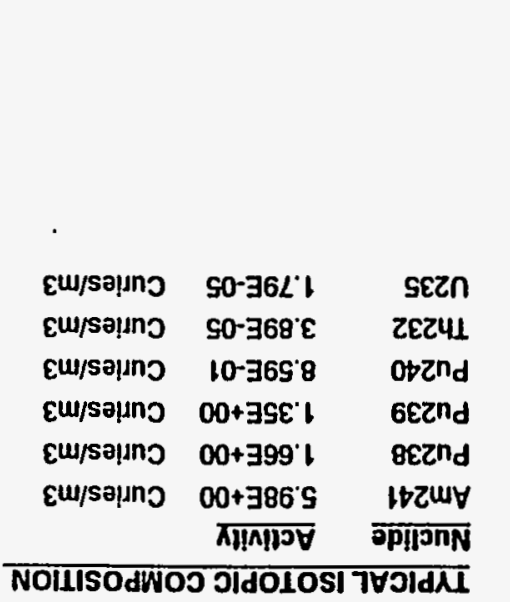

\section{XNก

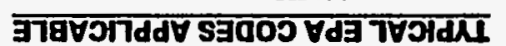

دKEU 00

INEEW OOO

Nisem 00

INEW OOO

دNEW OOO

دस/EW 00

Ew 901

gum 901

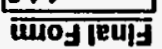

\begin{tabular}{|c|c|}
\hline 0,0 & ]:2z0z-c00z \\
\hline 0 & | :200Z-8886 \\
\hline o'o & $: 266 t$ \\
\hline 00 & :9661 \\
\hline 0.0 & :9661 \\
\hline 0.0 & : 666 \\
\hline 9.61 & : $866 \mathrm{~L} \mathrm{J0} \mathrm{pug}$ \\
\hline 9.61 & : Z66L 10 pug \\
\hline
\end{tabular}

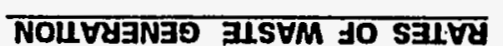

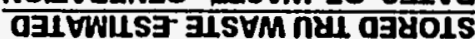

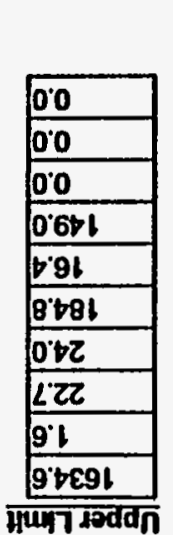

मायन मूd
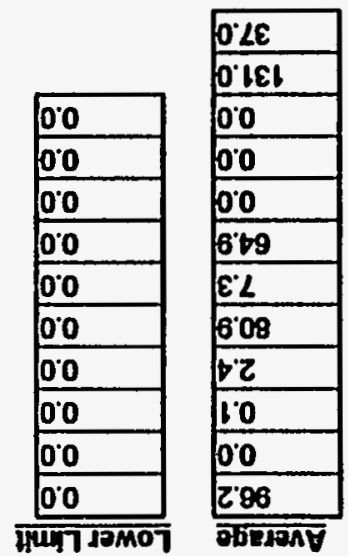

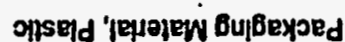

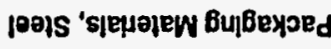

xилеw शquebio 'pou!pilos

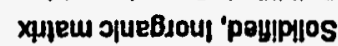

sonsetd

$$
\text { Jeqany }
$$

colso|n॥|नJ

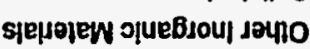

8팋N dә410

SRO|IY/s|ejow poseg-unupunjy

sho\|l $/$ /s|elaw poseq-uol

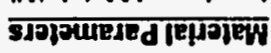




\section{WASTE STREAM PROFILE FOR THE WIPP TRU WASTE BASELINE INVENTORY REPORT}

SITE NAME IN WASTE TYPE MTRU HANDLING CH GENERATOR SITE AE

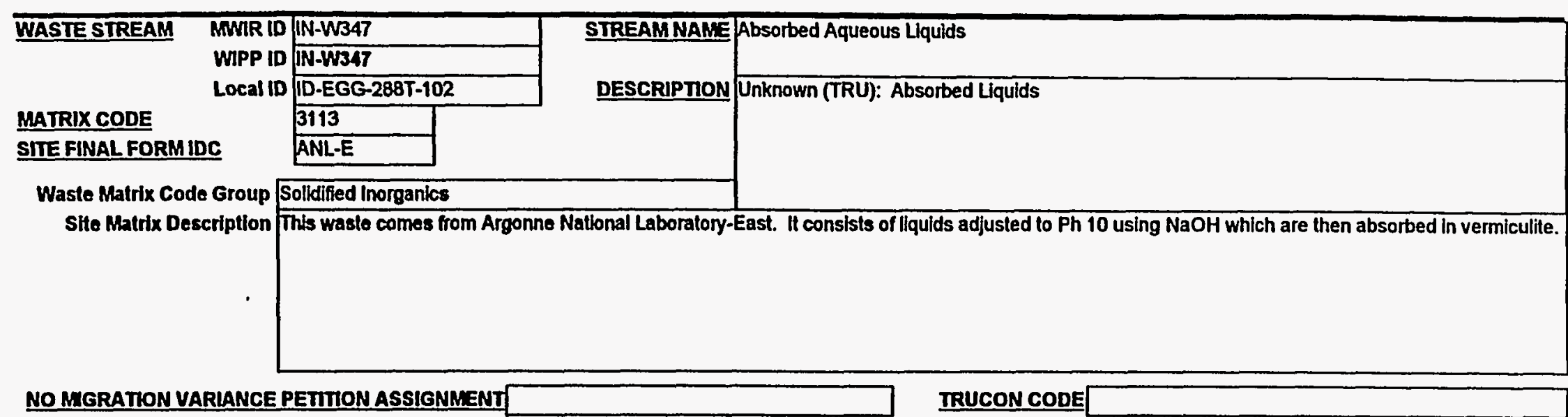

FINAL WASTE FORM DESCRIPTORS:

\begin{tabular}{l|l} 
Defense TRU Waste \\
Non-Defense TRU Waste \\
Commercial TRU Waste \\
Unknown
\end{tabular}

目

Rsearch and Devel. Waste
Operations Waste
Residues
Decon and Decommissioning
Environmental Restoration
From Treatment of Waste
Maintenance

\begin{tabular}{|c|c|c|}
\hline$x$ & TSCA & Asbestos \\
\hline$x$ & & PCBs \\
\hline & & Other \\
\hline $\bar{x}$ & & N/A \\
\hline & & Unknown \\
\hline
\end{tabular}




IN-W347 CONTAINER: SWB overpack

TYPICAL WASTE DENSITIES FOR FINAL WASTE FORM (kg/m3)

\section{Material Parameters}

Iron-based Melals/Alloys

Aluminum-Based Metals/Alloys

Other Metals

Other Inorganic Materials

Cellutosics

Rubber

Plastics

Solldified, Inorganic matrix

Solidified, Organic matrix

Solls

Packaging Materials, Steel

Packaging Material, Plastic

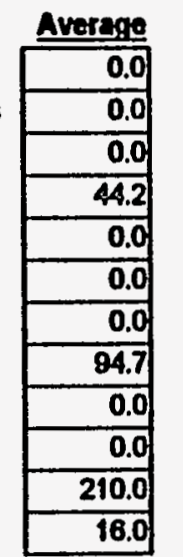

Number Stored: Number Projected.

Contalner Matt: Int. Voucinr:
Liner Type:
Liner Material:

STORED TRU WASTE ESTMMATED RATES OF WASTE GENERATION

\section{Lower Limit Upper Limit}

\begin{tabular}{|r|}
\hline 0.0 \\
\hline 0.0 \\
\hline 0.0 \\
\hline 44.2 \\
\hline 0.0 \\
\hline 0.0 \\
\hline 0.0 \\
\hline 113.7 \\
\hline 0.0 \\
\hline 0.0 \\
\hline
\end{tabular}

\begin{tabular}{|c|c|c|c|}
\hline & & -1 & \\
\hline End of 1992: & 3.5 & 8.0 & m3 \\
\hline End of 1983: & 3.5 & 8.0 & $\mathrm{~m} 3$ \\
\hline 1994: & 0.0 & 0.0 & $\mathrm{~m} 3 / \mathrm{yr}$ \\
\hline 1985: & 0.0 & 0.0 & $\mathrm{~m} 3 / \mathrm{yr}$ \\
\hline 1988: & 0.0 & $\overline{0.0}$ & $\mathrm{~m} 3 / \mathrm{yr}$ \\
\hline 1997: & 0.0 & 0.0 & $\mathrm{~m} 3 / \mathrm{ry}$ \\
\hline 1988-2002: & 0.0 & 0.0 & $\mathrm{~m} 3 / y r$ \\
\hline 2003-2022: & 0.0 & 0.0 & $\mathrm{~m} 3 / \mathrm{yr}$ \\
\hline
\end{tabular}

TYPICAL ISOTOPIC COMPOSITION

Nuclide Activity

Am241 1.57E-02 Curies/m3

Pu239 5.36E-01 Curies/m3

Pu240 9.81E-01 Curies $/ \mathrm{m} 3$

Th232 8.08E-08 Curies $/ \mathrm{m} 3$

U235 2.61E-07 Curies $/ \mathrm{m} 3$

U238 2.78E-06 Curies $/ \mathrm{m} 3$

\section{Comments}

Number stosed (4) ts the number of Shas as a restin of overpacking 4

drums/SWB. 


\section{WASTE STREAM PROFILE FOR THE WIPP TRU WASTE BASELINE INVENTORY REPORT}

SITE NAME IN

WASTE TYPE MTRU HANDLING CH GENERATOR SITE AE

IN-W347 CONTAINER: Drum

TYPICAL WASTE DENSITIES FOR FINAL WASTE FORM (kg/m3)

Material Parameters Iron-based Metals/Alloys

Aluminum-Based Metals/Alloys

Other Metals

Other Inorganic Materials

Cellubsics

Rubber

Plastics

Solldified, Inorganic matrbx Solidined, Organic matrix

Solls

Packaging Materials, Steel

Packaging Material, Plastic

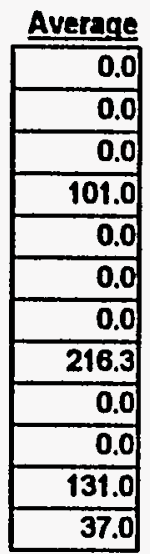

\begin{tabular}{|r|}
\hline Upper Limlt \\
\hline 0.0 \\
\hline 0.0 \\
\hline 0.0 \\
\hline 101.0 \\
\hline 0.0 \\
\hline 0.0 \\
\hline 0.0 \\
\hline 259.6 \\
\hline 0.0 \\
\hline 0.0 \\
\hline
\end{tabular}

Container Matl: steel

Int. VolvCtnr: $0.208 \mathrm{m3}$

Liner Type

Liner Material:

STORED TRU WASTE ESTIMATED RATES OF WASTE GENERATION

End \\ End}

\begin{tabular}{|c|c|c|c|}
\hline & Prolected & Final Form & \\
\hline 1992: & 50.8 & $\overline{50.8}$ & $\mathrm{m3}$ \\
\hline 1993: & 50.8 & 50.8 & $\mathrm{m3}$ \\
\hline 994: & 0.0 & 0.0 & $\mathrm{~m} 3 / \mathrm{yr}$ \\
\hline 1995: & 0.0 & 0.0 & $\mathrm{~m} 3 / \mathrm{yr}$ \\
\hline 1998: & 0.0 & 0.0 & $\mathrm{~m} 3 / \mathrm{yr}$ \\
\hline 1887: & $\overline{0.0}$ & 0.0 & $\mathrm{~m} 3 / \mathrm{ry}$ \\
\hline & $\overline{0.0}$ & 0.0 & m3/yr \\
\hline 02 & 0.0 & 0.0 & $\mathrm{~m} 3 / \mathrm{yr}$ \\
\hline
\end{tabular}

UNK

IYPICAL ISOTOPIC COMPOSITION

Nuclide Activity

Am241 3.58E-02 Curies $/ \mathrm{m} 3$

Pu239 1.22E +00 Curies $/ \mathrm{m}^{3}$

Pu240 . 2.24E+00 Curies $/ \mathrm{m}^{3}$

Th232 1.85E-07 Curies/m3

U235 5.97E-07 Curies $/ \mathrm{m} 3$

U238 6.34E-06 Curies $/ \mathrm{m} 3$ 


\section{WASTE STREAM PROFILE FOR THE WIPP TRU WASTE BASELINE INVENTORY REPORT}

SITE NAME IN

WASTE TYPE MTRU HANDLING RH GENERATOR SITE AE

WASTE STREAM MWID IN-W349
WMPP ID
Local ID-W349

Unknown

Unknown

IRUCON CODE

Rsearch and Devel. Waste
Operations Waste
Residues
Decon and Decommissioning
Environmental Restoration
From Treatment of Waste

\begin{tabular}{|l|}
\hline$x$ \\
\hline$x$ \\
\hline \\
\hline \\
\hline
\end{tabular}

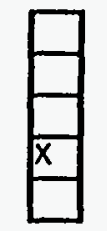




\section{WASTE STREAM PROFILE FOR THE WIPP TRU WASTE BASELINE INVENTORY REPORT}

SITE NAME IN

WASTE TYPE MTRU HANDLING RH GENERATOR SITE AE

IN-W349 CONTAINER: $\frac{\text { Drum }}{\text { Type/Size: } 55 \text {-gallon }}$

Container Matt: steel

Int Volrcenr: $0.208 \mathrm{~m}^{3}$

Number Stored

Number Projected

31

TYPICAL WASTE DENSITIES FOR FINAL WASTE FORM $(\mathrm{kg} / \mathrm{m} 3)$

Material Parameters

Iron-based Metais/Alloys

Aluminum-Based Metals/Alloys

Other Metals

Other Inorganic Materials

Cellutosios

Rubber

Plastlos

Solidified, Inorganle matrox

Solidified, Organic matrix

Solls

\begin{tabular}{|c|c|c|}
\hline Average & Lower Llmit & Upper Linf \\
\hline 0.0 & 0.0 & 0.0 \\
\hline 0.0 & 0.0 & 0.0 \\
\hline 0.0 & 0.0 & 0.0 \\
\hline 0.0 & 0.0 & 0.0 \\
\hline 0.0 & 0.0 & 0.0 \\
\hline 0.0 & 0.0 & 0.0 \\
\hline 0.0 & 0.0 & 0.0 \\
\hline 0.0 & 0.0 & 0.0 \\
\hline 0.0 & 0.0 & 0.0 \\
\hline 0.0 & 0.0 & 0.0 \\
\hline 131.0 & & \\
\hline 37.0 & & \\
\hline
\end{tabular}

STORED TRU WASTE ESTIMATED RATES OF WASTE GENERATION

Packaging Materials, Steel

Packaging Matertal, Plastlc

\begin{tabular}{|c|c|c|c|}
\hline & Prolected & Final Fom & \\
\hline nd of 1992: & 6.4 & 6.4 & $\mathrm{~m} 3$ \\
\hline nd of 1993: & 6.4 & $\overline{6.4}$ & $\mathrm{m3}$ \\
\hline 1994: & 0.0 & 0.0 & $\mathrm{~m} 3 / \mathrm{yr}$ \\
\hline 1995: & 0.0 & 0.0 & m3/yr \\
\hline 1998: & 0.0 & 0.0 & $\mathrm{~m} 3 / y r$ \\
\hline 1997: & 0.0 & 0.0 & $\mathrm{~m} 3 / \mathrm{r} y$ \\
\hline 1998-2002: & 0.0 & 0.0 & $\mathrm{~m} 3 / y r$ \\
\hline 2003-2022: & 0.0 & 0.0 & $m 3 / y r$ \\
\hline
\end{tabular}

IYPICAL ISOTOPIC COMPOSITION

Nuclide Actlvity

Pu239 9.43E-02 Curies/m3

Pu240 6.05E-02 Curies $/ \mathrm{m3}$

IYPICAL EPA CODES APPLICABLE

UNK 
WASTE STREAM PROFILE FOR THE WIPP TRU WASTE BASELINE INVENTORY REPORT

SITE NAME IN WASTE TYPEMTRU HANDLING CH GENERATOR SITE AE

\begin{tabular}{|c|c|c|c|}
\hline WASTE STREAM & IN-W350 & STREAMNAME & Unknown Sollds \\
\hline WIPP ID & $\longdiv { \text { NN-W360 } }$ & & \\
\hline Local ID & $\sqrt{1 \mathrm{D}-E G Q-288 T-106}$ & DESCRIPTION & Unknown (TRU): Special Source Material \\
\hline MATRIX CODE & 8200 & & \\
\hline SITE FINAL FORMIDC & ANL-E & & \\
\hline Waste Matrix Code Group & Unknown & & \\
\hline SHe Matrix Description /T & Thero is no content in & this code, which wa & as generated at ANL-E. \\
\hline
\end{tabular}

\section{FINAL WASTE FORM DESCRIPTORS}

\section{Defense TRU Waste}

Non-Defense TRU Waste

Commerclal TRU Wasto

Unknown

$\square$

Mbxed TRU

Non-Mibed TRU

Suspect Mixed TRU

Unknown

$\square$

Rsearch and Devel. Waste
Operations Waste
Residues
Decon and Decommissioning
Environmental Restoration
From Treatment of Waste
Malntenance

Malntenance

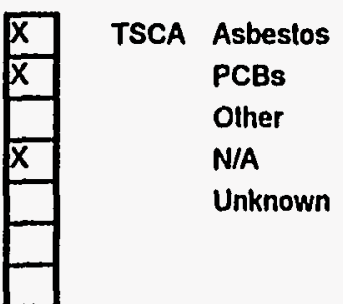




\section{WASTE STREAM PROFILE FOR THE WIPP TRU WASTE BASELINE INVENTORY REPORT}

SITE NAME IN WASTE TYPE MTRU HANDLING CH GENERATOR SITE AE

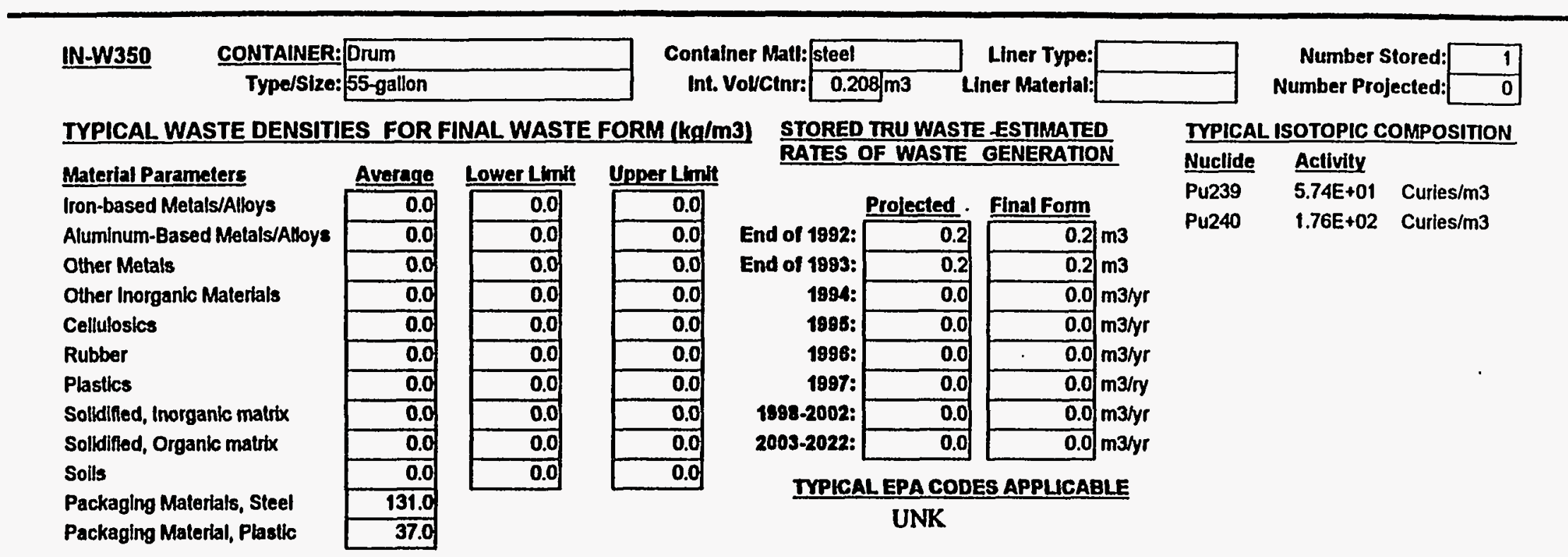


WASTE STREAM PROFILE FOR THE WIPP TRU WASTE BASELINE INVENTORY REPORT

SITE NAME IN WASTE TYPE MTRU HANDLING CH GENERATOR SITE AE

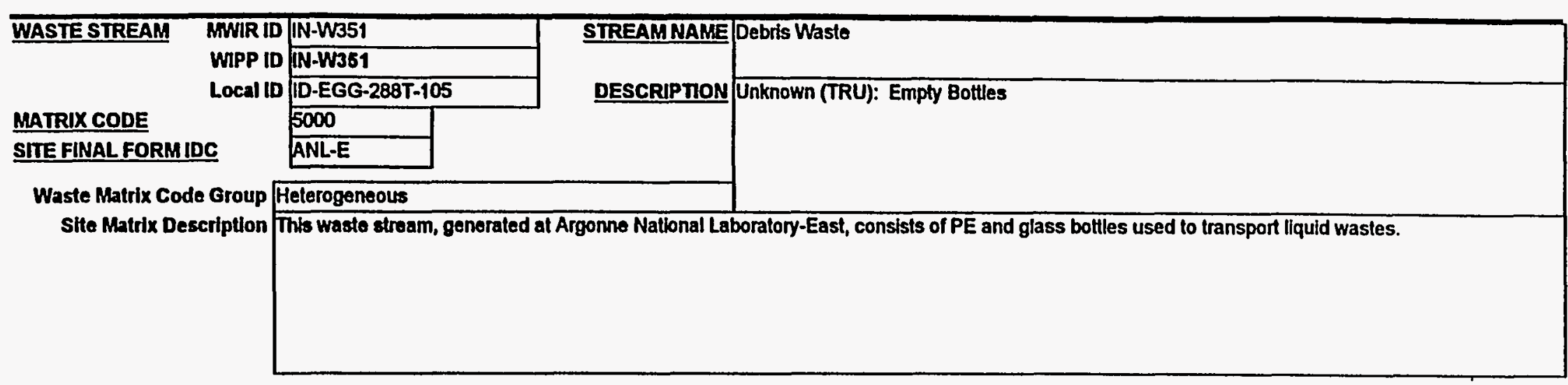

NO MGRATION VARIANCE PETIION ASSIGNMENY $\square$ IRUCON CODE

FINAL WASTE FORM DESCRIPTORS:

\begin{tabular}{|c|c|}
\hline Defense TRU Waste & Mbxed TRU \\
\hline Non-Defense TRU Waste & Non-Mixed TRU \\
\hline Commerclal TRU Wasto & Suspect Mbxed TRU \\
\hline Unknown & Unknown \\
\hline
\end{tabular}

Rsearch and Devel. Waste
Operations Waste
Residues
Decon and Decommisstoning
Environmental Restoration
From Treatment of Waste
Maintenance

\begin{tabular}{l|}
$x$ \\
\hline$x$ \\
\hline$x$ \\
\hline \\
\hline \\
\hline
\end{tabular}

TSCA Asbestos
PCBs
Other
N/A
Unknown


XNN ज78*ग7dम S

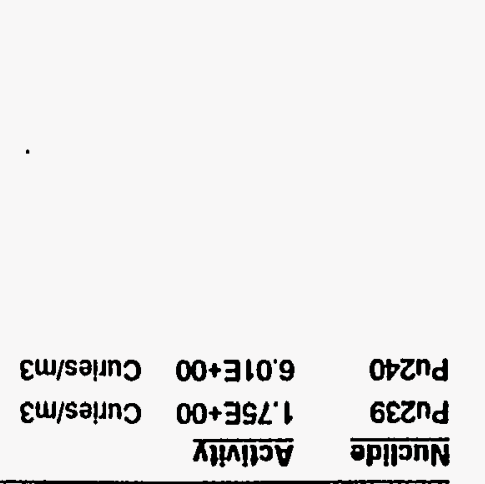

\begin{tabular}{|c|c|c|c|}
\hline دN/EW [O & 00 & 00 & :2z0z-c00z \\
\hline INEW & 00 & 0.0 & :200z-8681 \\
\hline N/EW $[\mathrm{C}$ & 00 & 0.0 & : 2661 \\
\hline ShEm to & 0.0 & 00 & :986b \\
\hline$\triangle$ H/EW & 00 & 00 & :9861 \\
\hline د/EWU & $0^{\prime} 0$ & 00 & : 6861 \\
\hline gur $g$ & $9 !$ & S't & : 8661 to pug \\
\hline gut $\mathrm{E}$ & Sl & S. & :268L J0 pug \\
\hline
\end{tabular}

NOIIVYINGO IISEM tO SaIVZ

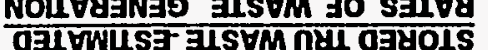

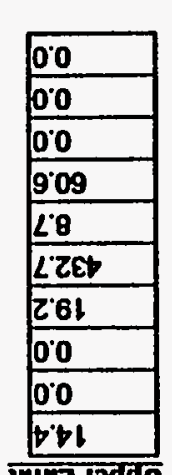

मयन म्बव

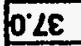

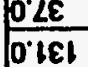

0

00

0.0

0.0

$6: 2$

t't

PEs

00

00

0

00

म्याग
00

OO

00

o'ge

$\varepsilon \dot{\varepsilon}$

L'L8Z

81

00

0.0

0

8 it

बंनुमnV

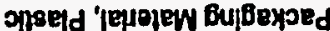

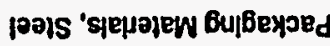

s川os

xqреш भुนebjo 'poypplos

xunew भueBsoul 'poupplos

sonseld

Joqqny

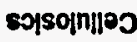

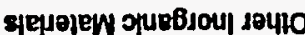

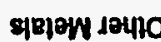

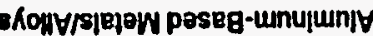

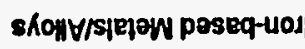

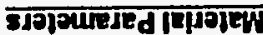

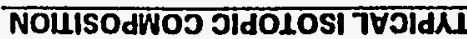

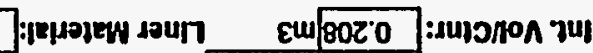
::dKı Jaurn |00|s: :11Ew soujejuos 


\section{WASTE STREAM PROFILE FOR THE WIPP TRU WASTE BASELINE INVENTORY REPORT}

SITE NAME IN

WASTE TYPETRU HANDLING CH GENERATOR SITE BT

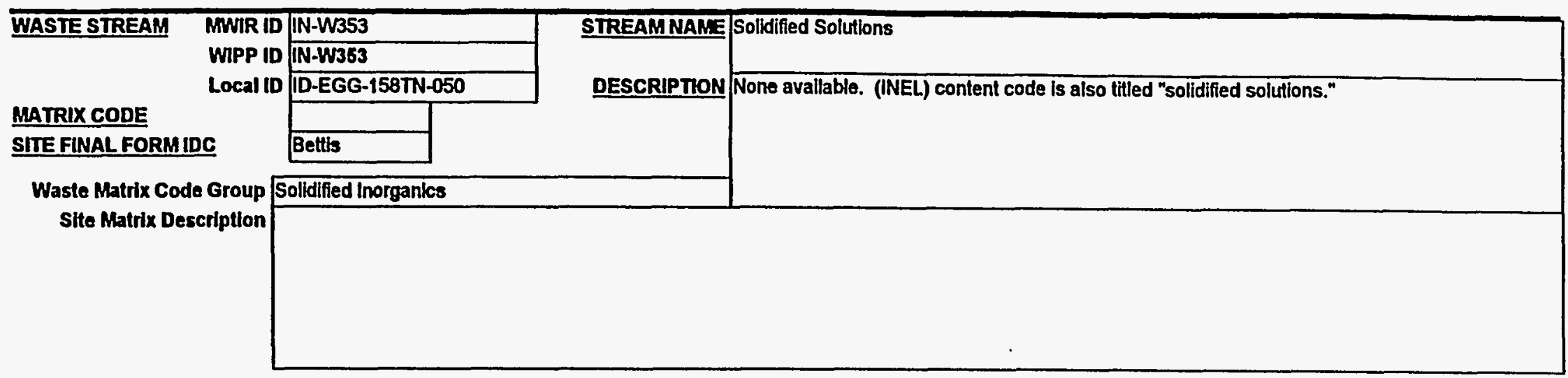

NO MGRATON VARIANCE PETIION ASSIGNMENT

IRUCON CODE

FINAL WASTE FORMDESCRIPTORS: .

Defense TRU Waste

Non-Defense TRU Waste

Commercial TRU Waste

Unknown

$x$

Mlxed TRU

Non-Mbxed TRU

Suspect Mbxed TRU

Unknown

Rsearch and Devel. Waste
Operations Wasto
Residues
Decon and Decommissioning
Environmental Restoration
From Treatment of Wasle
Malntenance

TSCA Asbestos

PCBs

Other

N/A

Unknown

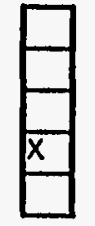




\section{WASTE STREAM PROFILE FOR THE WIPP TRU WASTE BASELINE INVENTORY REPORT}

SITE NAME IN

\section{WASTE TYPETRU HANDLING CH GENERATOR SITE BT}

$\underline{\text { IN-W353 }}$

CONTAINER: Drum

Type/Size: 55-gallon

Container Matt: steel

Int. Vouctnr: $0.208 \mathrm{m3}$

Liner Type:

Number Stored

Number Projected:

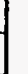

TYPICAL WASTE DENSITIES FOR FINAL WASTE FORM (kg/m3) STORED TRU WASTE -ESTIMATED RATES OF WASTE GENERATION

\section{Materlal Parameters}

Iron-based Metals/Alloys

Aluminum-Based Metals/Alloys

Other Metals

Other Inorganic Materials

Cellulosics

Rubber

Plastics

Solidified, Inorganic matrix

Solidified, Organle matrix

Soils

Packaging Materials, Steel

Packaging Material, Plastic

\begin{tabular}{l} 
Lower Limit \\
\hline 0.0 \\
\hline 0.0 \\
\hline 0.0 \\
\hline 0.0 \\
\hline 0.0 \\
\hline 0.0 \\
\hline 0.0 \\
\hline 0.0 \\
\hline 0.0 \\
\hline 0.0 \\
\hline
\end{tabular}

\section{Upper Limit}

\begin{tabular}{r|}
\hline 0.0 \\
\hline 0.0 \\
\hline 0.0 \\
\hline 0.0 \\
\hline 0.0 \\
\hline 0.0 \\
\hline 0.0 \\
\hline 0.0 \\
\hline 0.0 \\
\hline 0.0 \\
\hline
\end{tabular}

\begin{tabular}{|c|c|c|c|}
\hline & Projected & Final Form & \\
\hline End of 1992: & 0.2 & 0.2 & m3 \\
\hline Id of 1893: & $\overline{0.2}$ & $\overline{0.2}$ & m3 \\
\hline 1994: & $\overline{0.0}$ & 0.0 & $\mathrm{~m} 3 / \mathrm{yr}$ \\
\hline 1988: & 0.0 & 0.0 & m3/yr \\
\hline 1986: & 0.0 & 0.0 & $\mathrm{~m} 3 / \mathrm{yr}$ \\
\hline 1987: & 0.0 & 0.0 & m3/ry \\
\hline 198-2002: & 0.0 & 0.0 & $\mathrm{~m} 3 / \mathrm{yr}$ \\
\hline 103-2022; & $\overline{0.0}$ & 0.0 & m3/yr \\
\hline
\end{tabular}

TYPICAL EPA CODES APPLICABLE
IYPICAL ISOTOPIC COMPOSITION

Nuclide Actlvity

Np237 3.33E-04 Curies/m3

Pu239 1.20E-01 Curies/m3 


\section{WASTE STREAM PROFILE FOR THE WIPP TRU WASTE BASELINE INVENTORY REPORT}

\section{SITE NAME IN \\ WASTE TYPETRU \\ HANDLING CH \\ GENERATOR SITE RF}

\begin{tabular}{|c|c|c|c|}
\hline WASTE STREAM MWIR ID & IN-W35 & & STREAMNAM \\
\hline WIPP ID & IN-W36 & & \\
\hline Local to & $\longdiv { \text { D-EGG } }$ & $6 \mathrm{TN}-412$ & DESCRIPTIO \\
\hline MATRIX CODE & 3140 & & \\
\hline SITE FINAL FORM IDC & RFP & & \\
\hline Waste Matrix Code Group & Salt Wast & & \\
\hline Site Matrix Description & & & \\
\hline NO MUGRATION VARIANCE & PEIIIO & SIGNMENT ID 224A & \\
\hline FINAL WASTE FORM DESC & RIPTORS & & \\
\hline Defense TRU Waste & & Mbxed TRU & \\
\hline Non-Defense TRU Wasle & & Non-Mixed TRU & $x$ \\
\hline Commerclal TRU Wasto & & Suspect Mibed TRU & \\
\hline Unknown & & Unknown & \\
\hline
\end{tabular}

IRUCON CODE ID 224A

Rsearch and Devel. Waste
Operatlons Waste
Residues
Decon and Decommisstoning
Environmental Restoration
From Treatment of Waste
Maintenance

\begin{tabular}{|l|}
\hline$x$ \\
\hline$x$ \\
\hline \\
\hline \\
\hline
\end{tabular}

TSCA Asbestos

PCBs

Other

N/A

Unknown

Mainlenance

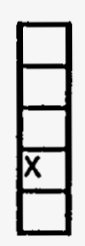




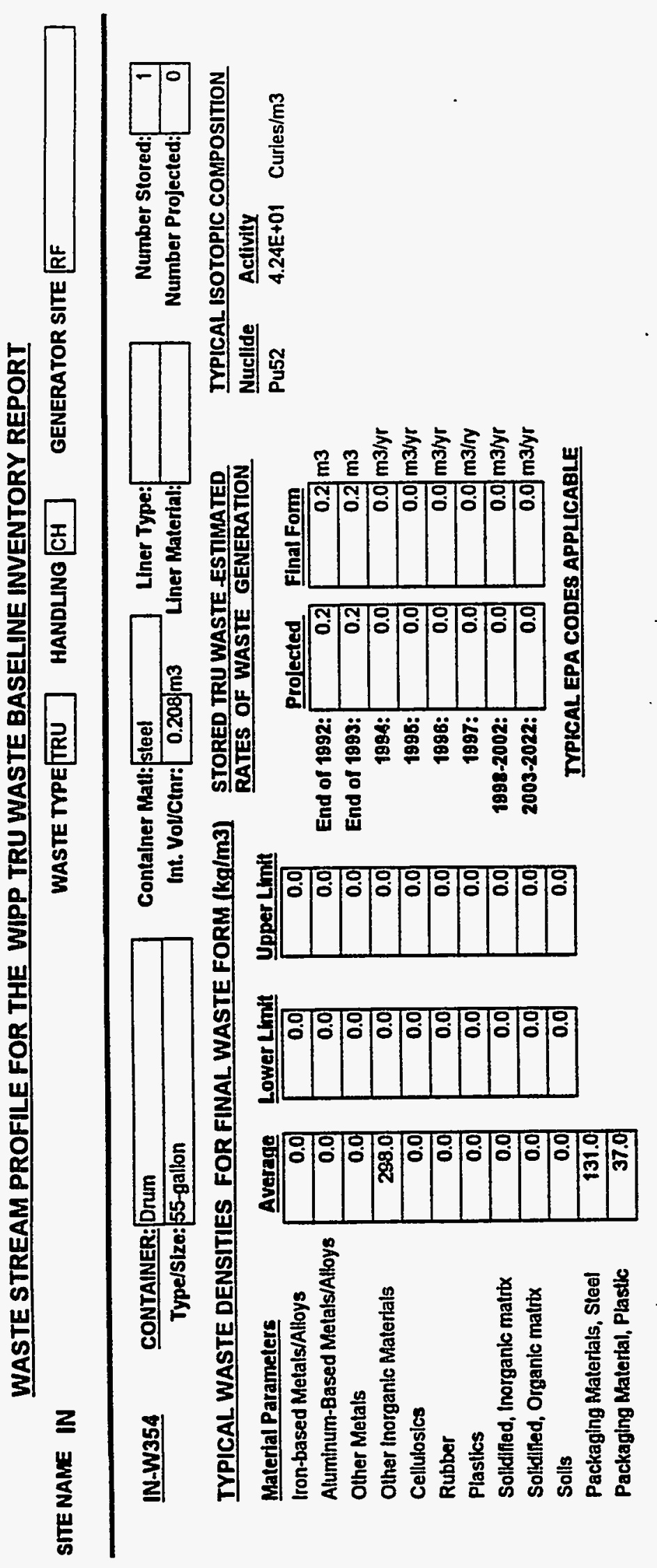


WASTE STREAM PROFILE FOR THE WIPP TRU WASTE BASELINE INVENTORY REPORT

SITE NAME IN WASTE TYPE TRU

HANDLING CH

GENERATOR SITE RF

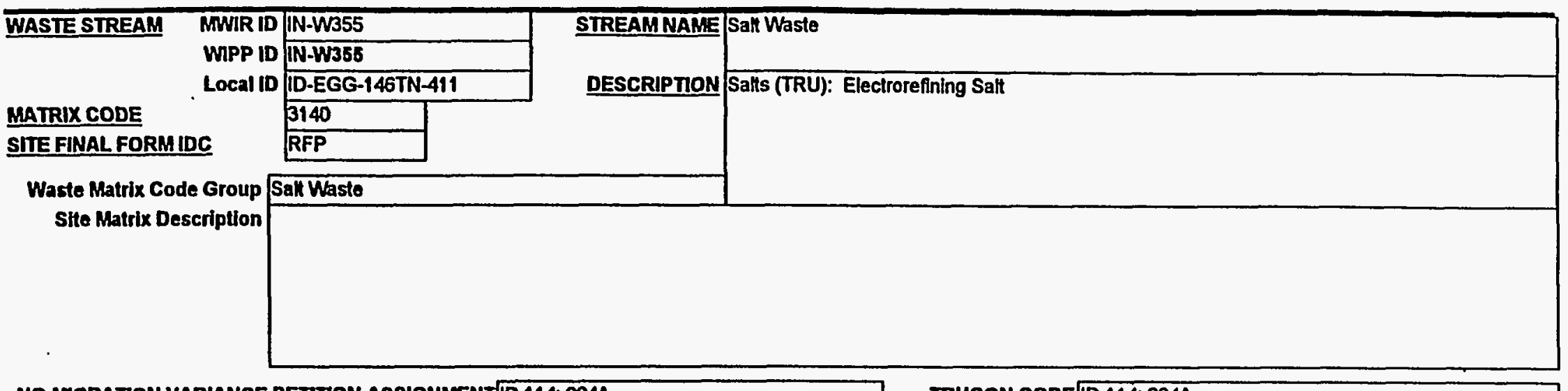

NO MGRATION YARIANCE PETIION ASSIONMENT [D 114; 224A

IRUCON CODE ID 114; 224A

FINAL WASTE FORMDESCRIPTORS:

\begin{tabular}{l|l|l}
$\begin{array}{l}\text { Defense TRU Waste } \\
\text { Non-Defense TRU Waste } \\
\text { Commerctal TRU Waste } \\
\text { Unknown }\end{array}$ & & $\begin{array}{l}\text { Mlxed TRU } \\
\text { Non-Mbed TRU } \\
\text { Suspect Mlxed TRU } \\
\text { Unknown }\end{array}$
\end{tabular}

$\square$

Rsearch and Devel. Waste
Operations Waste
Residues
Decon and Decommissioning
Environmental Restoration
From Treatment of Waste
Mainlenance

\begin{tabular}{|lll|}
\hline$X$ & \begin{tabular}{ll} 
TSCA \\
\hline$X$ \\
\hline$X$ \\
\hline
\end{tabular} & $\begin{array}{l}\text { Asbestos } \\
\text { PCBs } \\
\text { Other } \\
\text { N/A } \\
\text { Unknown }\end{array}$ \\
\hline & & \\
\hline
\end{tabular}


WASTE STREAM PROFILE FOR THE WIPP TRU WASTE BASELINE INVENTORY REPORT

SITE NAME IN

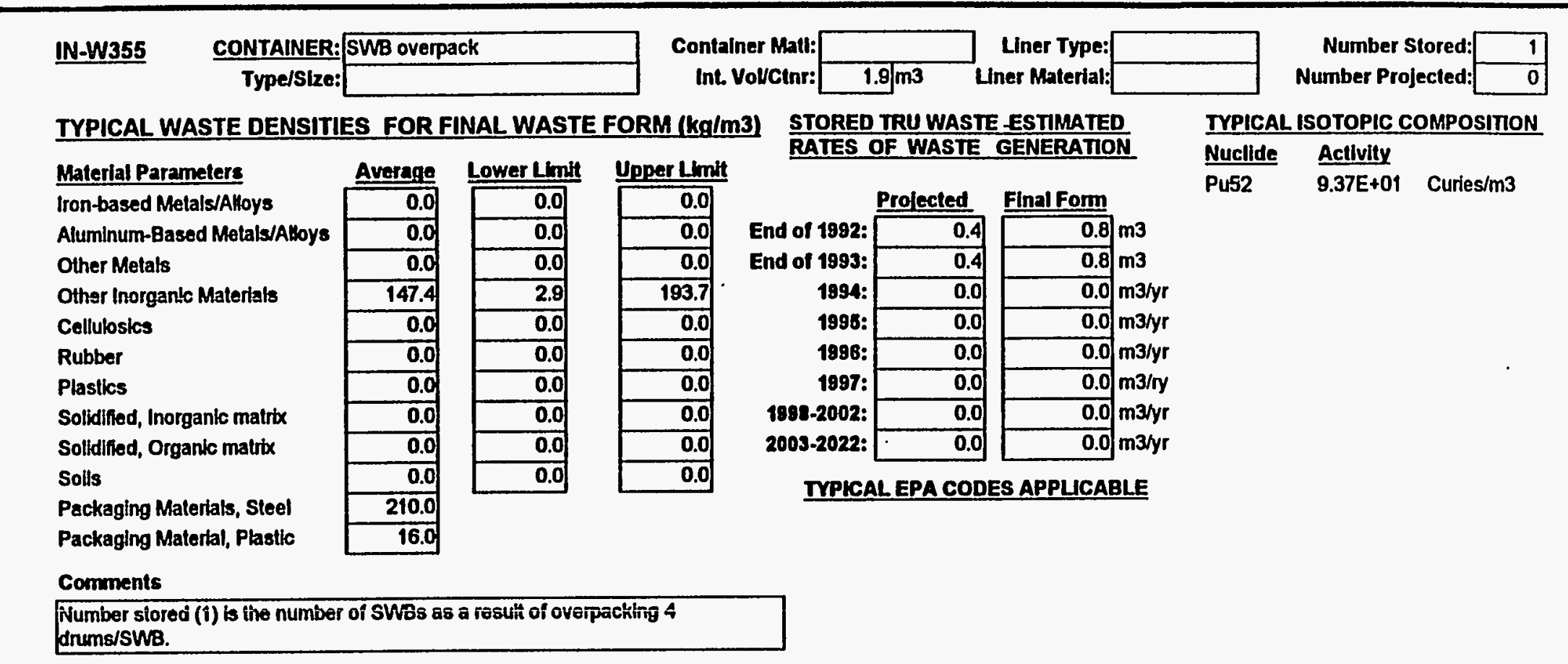


WASTE STREAM PROFILE FOR THE WIPP TRU WASTE BASELINE INVENTORY REPORT

SITENAME IN WASTE TYPETRU HANDLING CH

GENERATOR SITE RF

IN-W355

CONTAINER: Drum

Container Matt: stee

Liner Material:

Number Stored:

Number Projected:

TYPICAL WASTE DENSITIES FOR FINAL WASTE FORM $(\mathrm{kg} / \mathrm{m} 3)$

STORED TRU WASTE ESTMMATED

Materlal Parameters

Iron-based Metals/Alloys

Aluminum-Based Metals/Alloys

Other Metals

Other Inorganic Materials

Cellulosics

Rubber

Plastlcs

Solidified, Inorganlc matrix

Solidinied, Organic maltbx

Solls

\begin{tabular}{|r|}
\hline Average \\
\hline 0.0 \\
\hline 0.0 \\
\hline 0.0 \\
\hline 336.7 \\
\hline 0.0 \\
\hline 0.0 \\
\hline 0.0 \\
\hline 0.0 \\
\hline 0.0 \\
\hline 0.0 \\
\hline 131.0 \\
\hline 37.0 \\
\hline
\end{tabular}

\begin{tabular}{|c|c|}
\hline Lower Limit & Upper Limit \\
\hline 0.0 & 0.0 \\
\hline 0.0 & 0.0 \\
\hline 0.0 & 0.0 \\
\hline 6.7 & 442.3 \\
\hline 0.0 & $\overline{0.0}$ \\
\hline$\overline{0.0}$ & $\overline{0.0}$ \\
\hline$\overline{0.0}$ & $\overline{0.0}$ \\
\hline 0.0 & 0.0 \\
\hline$\overline{0.0}$ & 0.0 \\
\hline 0.0 & 0.0 \\
\hline
\end{tabular}
RATES OF WASTE GENERATION

TYPICAL ISOTOPIC COMPOSITION

Prolected Final Form

Nuclide Activity

Pu52 2.14E+02 Curies/m3

\begin{tabular}{|c|c|c|c|}
\hline \multirow[b]{2}{*}{ End of 1992: } & Prolected & Final Form & \\
\hline & 0.9 & 0.9 & m3 \\
\hline End of 1983: & 0.9 & 0.9 & $\mathrm{~m} 3$ \\
\hline 1994: & 0.0 & 0.0 & m3/yr \\
\hline 1896: & 0.0 & 0.0 & $m 3 / y r$ \\
\hline 1986: & 0.0 & 0.0 & $m 3 / y r$ \\
\hline 1897: & 0.0 & 0.0 & $m 3 / r y$ \\
\hline 1888-2002: & 0.0 & 0.0 & $m 3 / y r$ \\
\hline 2003-2022: & 0.0 & 0.0 & $\mathrm{~m} 3 / y r$ \\
\hline
\end{tabular}

TYPICAL EPA CODES APPLICABLE

Packaging Material, Plastic 


\section{WASTE STREAM PROFILE FOR THE WIPP TRU WASTE BASELINE INVENTORY REPORT}

SITENAME IN WASTE TYPETRU HANDLING CH GENERATOR SITE RF

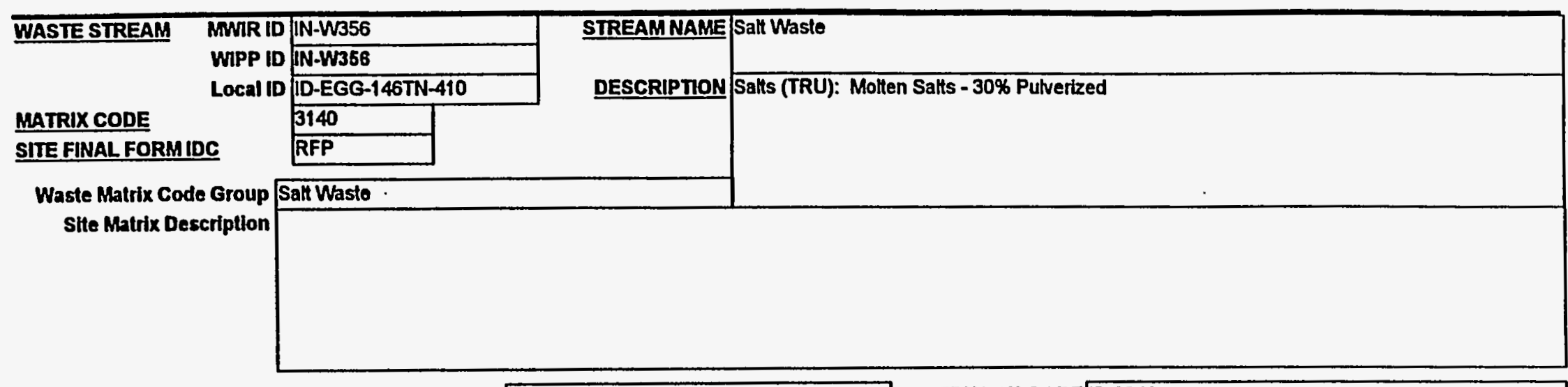

NO MGRATION YARIANCE PETITON ASSIONMENT ID 224A

IRUCON CODE

FINAL WASTE FORMDESCRIPTORS:

Defense TRU Waste

Non-Defense TRU Waste

Commercial TRU Waste

Unknown

$\square$

Mbred TRU

Non-Mixed TRU

Suspect Mixed TRU

Unknown

$\square$

Rearch and Devel. Waste Operations Waste

Residues

Decon and Decommlssioning Environmental Restoration

From Treatment of Waste

Maintenance

$\begin{array}{lll}\text { TSCA } & \begin{array}{l}\text { Asbestos } \\ \text { PCBs } \\ \text { Other } \\ \text { N/A } \\ \text { Unknown }\end{array} & \\ & & \\ & & \\ & & \\ & \end{array}$




\section{WASTE STREAM PROFILE FOR THE WIPP TRU WASTE BASELINE INVENTORY REPORT}

SITE NAME IN

WASTE TVPETRU HANDLING CH GENERATOR SITE RF

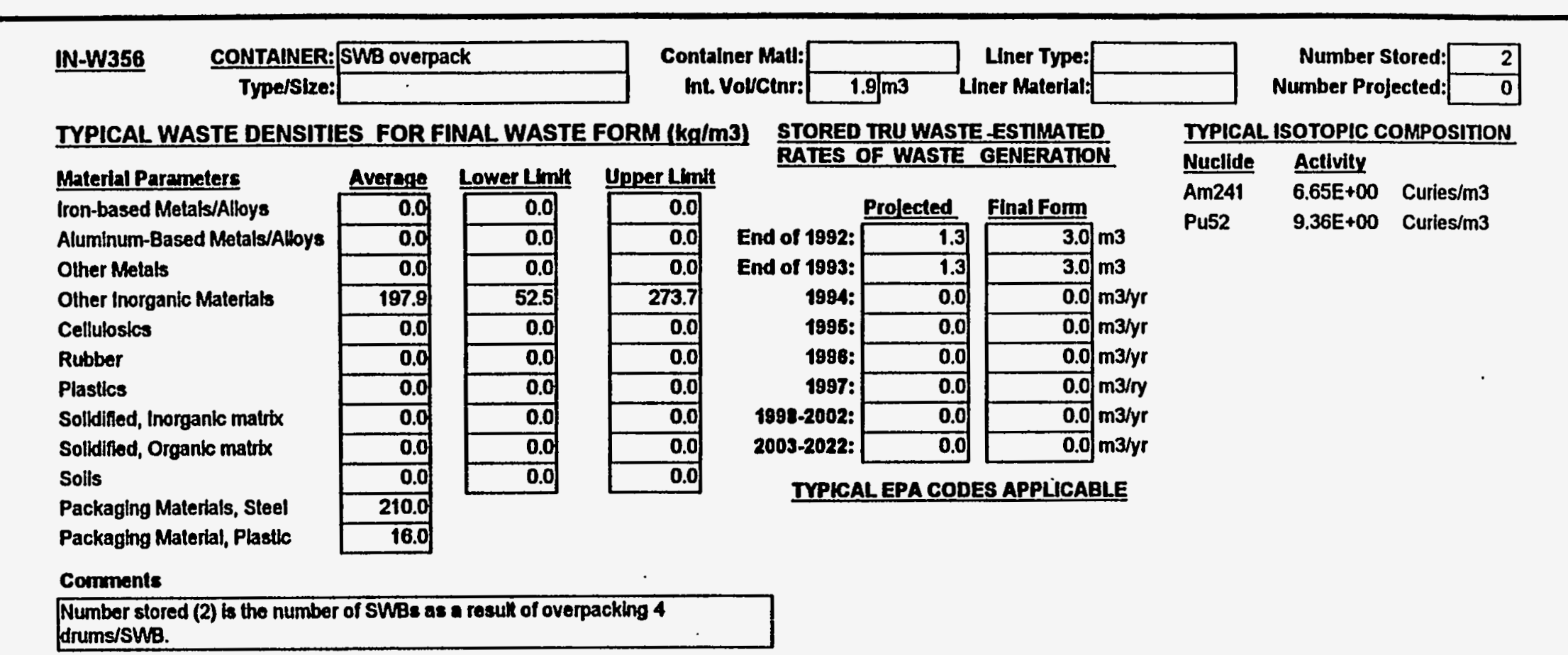




\section{WASTE STREAM PROFILE FOR THE WIPP TRU WASTE BASELINE INVENTORY REPORT}

SITENAME IN WASTE TYPETTUU HANDLING CH GENERATOR SITE RF

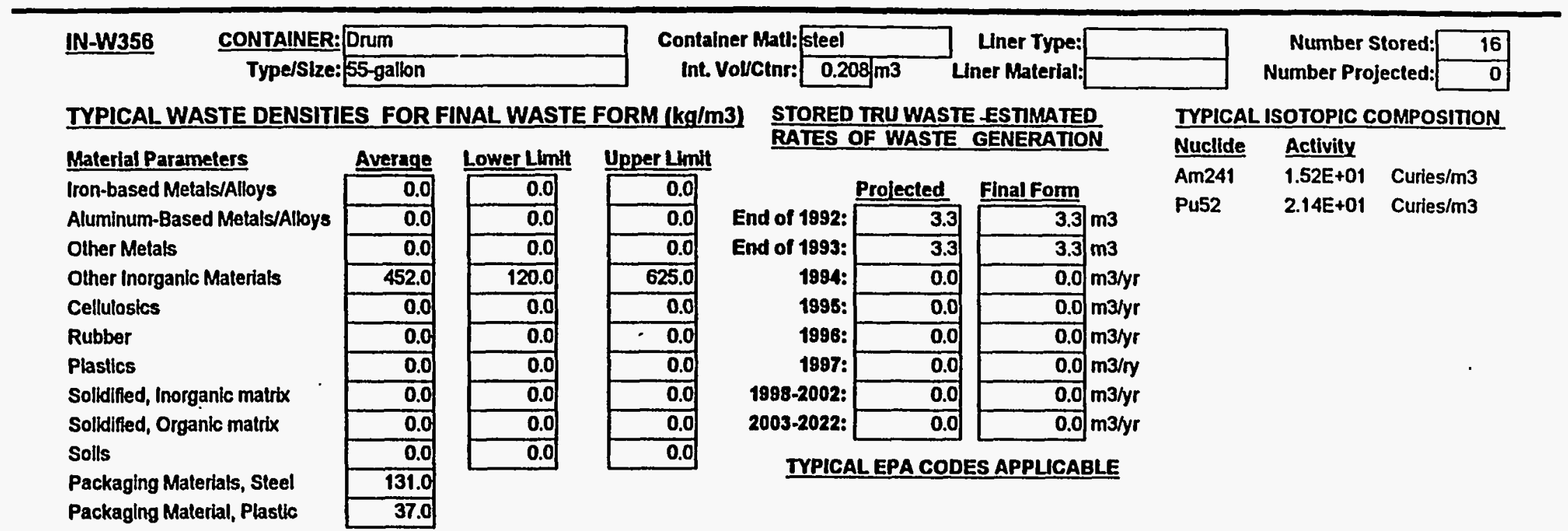


WASTE STREAM PROFILE FOR THE WIPP TRU WASTE BASELINE INVENTORY REPORT

SITE NAME IN WASTE TYPE TRU HANDLING RH GENERATOR SITE IN

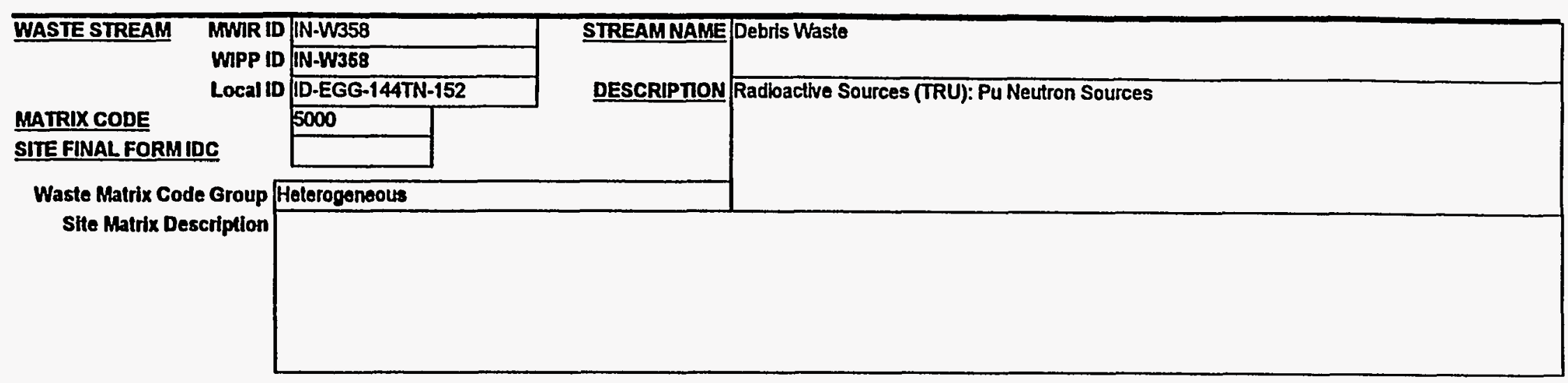

NOMGRATION VARIANCE PETIION ASSIONMENTI

IRUCON CODE

\section{FINAL WASTE FORM DESCRIPTORS:}

\begin{tabular}{l|l|l} 
Defense TRU Waste & $X$ & $\begin{array}{l}\text { Mixed TRU } \\
\text { Non-Defense TRU Waste } \\
\text { Commerclal TRU Waste } \\
\text { Unknown }\end{array}$ \\
Suspect Mixed TRU \\
Unknown
\end{tabular}

Rsearch and Devel Whste Operations Waste

Residues

Decon and Decommissioning

Environmental Restoration

From Treatment of Waste

Malntenance

\begin{tabular}{|l|l|l|}
\hline$X$ & TSCA & $\begin{array}{l}\text { Asbestos } \\
\text { PCBs } \\
\text { Other } \\
\text { N/A } \\
\text { Unknown }\end{array}$ \\
\hline$X$ & \\
\hline & & \\
\hline
\end{tabular}




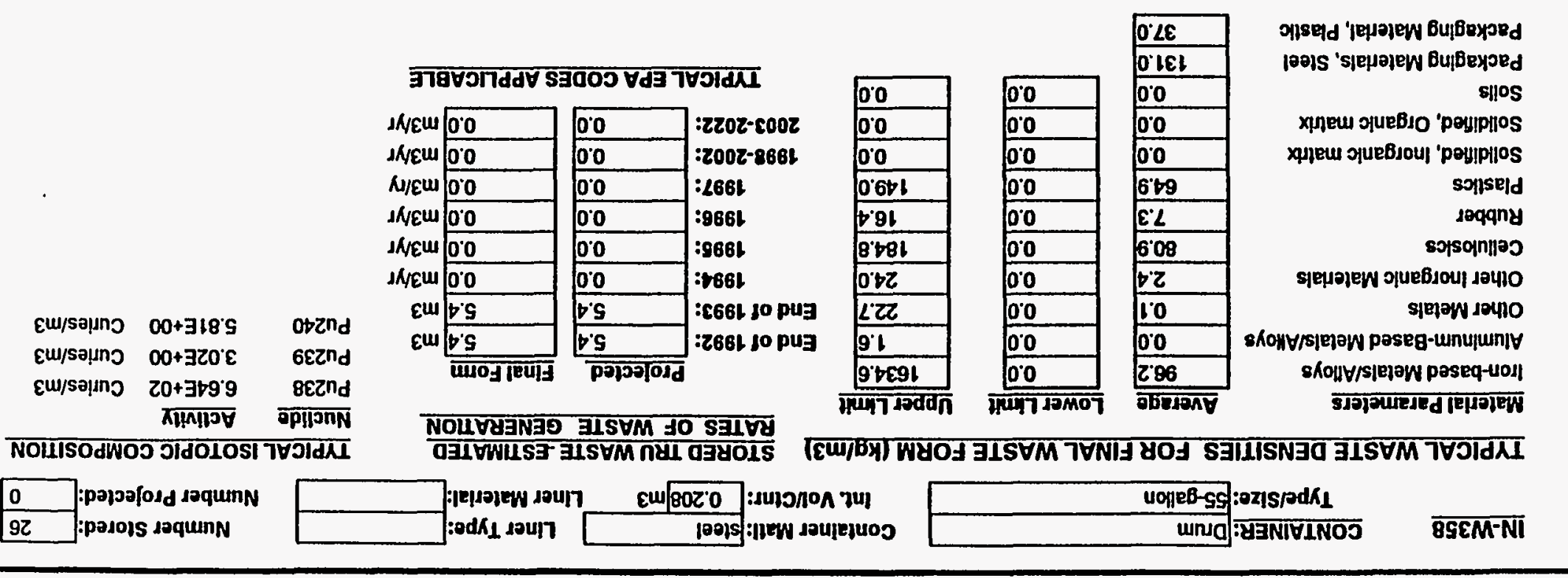




\section{WASTE STREAM PROFILE FOR THE WIPP TRU WASTE BASELINE INVENTORY REPORT}

SITENAME IN WASTE TYPETRU HANDLING RH

GENERATOR SITE

\begin{tabular}{|c|c|c|c|}
\hline WASTE STREAM MWIR ID & IN-W35 & & STREAMNAM \\
\hline WIPP ID & IN-W3E & & \\
\hline Local ip & $\longdiv { I D - E G C }$ & 4 TTN-015 & DESCRIPTIO \\
\hline MATRIX CODE & 8200 & & \\
\hline SITE FINAL FORMIDC & & & \\
\hline Waste Matrix Code Group I & Unknown & & \\
\hline Stte Matrix Descriptlon & & & \\
\hline NO MUGRTION VARIANCE & ETITIO & SSIGNMENT & \\
\hline FINAL WASTE FORM DESCF & RIPTOR & & \\
\hline Defense TRU Waste & $\bar{x}$ & Mixed TRU & \\
\hline Non-Defense TRU Waste & & Non-Mbxed TRU & $\bar{x}$ \\
\hline Commercial TRU Wasto & & Suspect Mbxed TRU & \\
\hline Unknown & & Unknown & \\
\hline
\end{tabular}

Unknown

Unknown

Reearch and Devel. Waste
Operations Waste
Residues
Decon and Decommissioning
Environmental Restoration
From Treatment of Wasto
Maintenance

TSCA Asbestos

PCBs

Other

N/A

Unknown

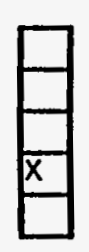




\section{WASTE STREAM PROFILE FOR THE WIPP TRU WASTE BASELINE INVENTORY REPORT}

SITE NAME IN WASTE TYPETTU HANDLING RH GENERATOR SITE

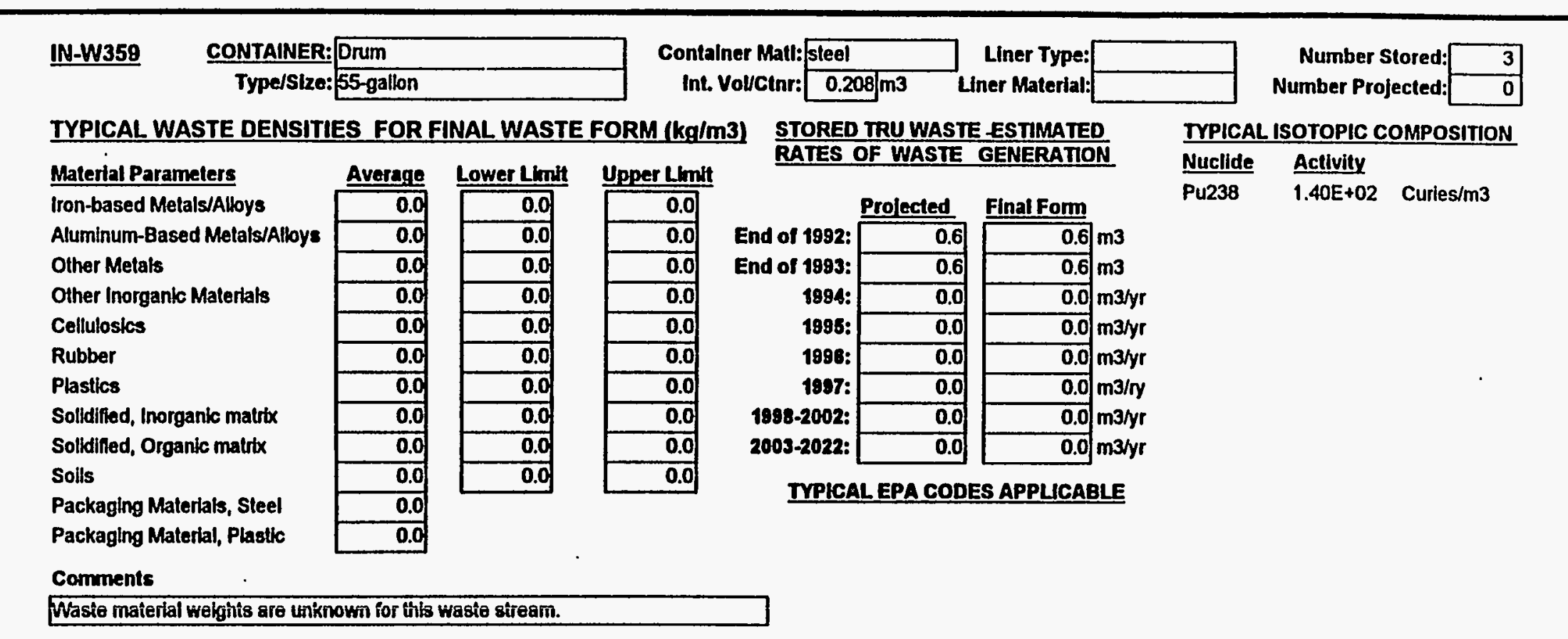




\section{WASTE STREAM PROFILE FOR THE WIPP TRU WASTE BASELINE INVENTORY REPORT}

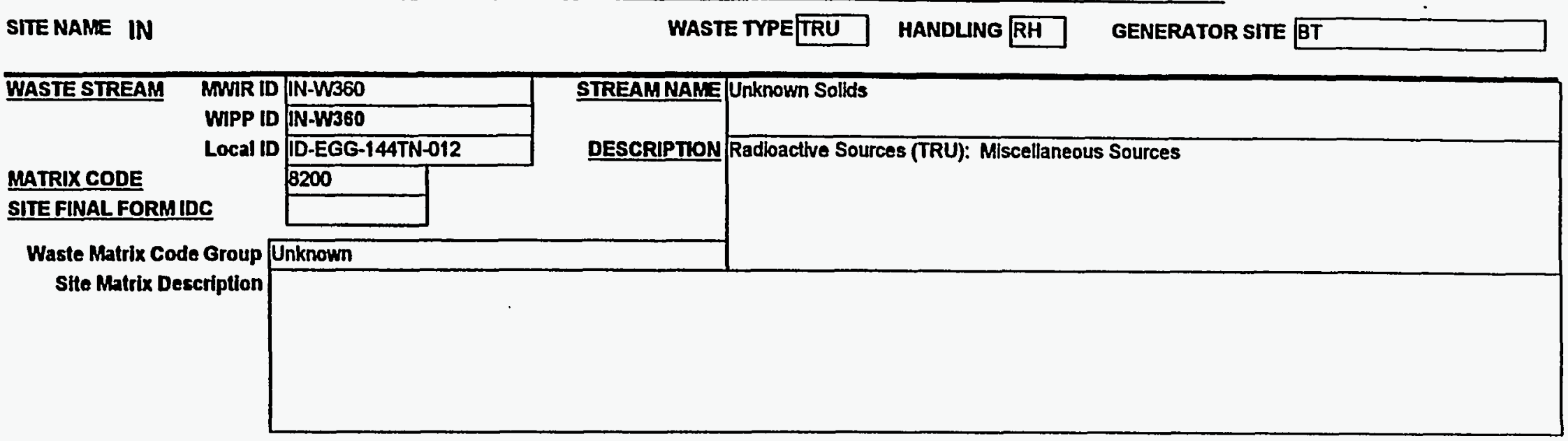

NO MGRATION VARIANCE PETITON ASSIGMMENY IRUCON CODE

\section{FINAL WASTE FORM DESCRIPTORS:}

Defense TRU Waste

Non-Defense TRU Waste

Commerctal TRU Waste

Unknown

$\square$

Mbed TRU

Non-Mixed TRU

Suspect Mbed TRU

Unknown

Rsearch and Devel. Waste
Operations Wasto
Residues
Decon and Decommissioning
Environmental Restoration
From Treatment of Waste
Malntenance

\begin{tabular}{|l|}
\hline$x$ \\
\hline$x$ \\
\hline$x$ \\
\hline \\
\hline
\end{tabular}

TSCA Asbestos

PCBs

Other

N/A

Unknown 


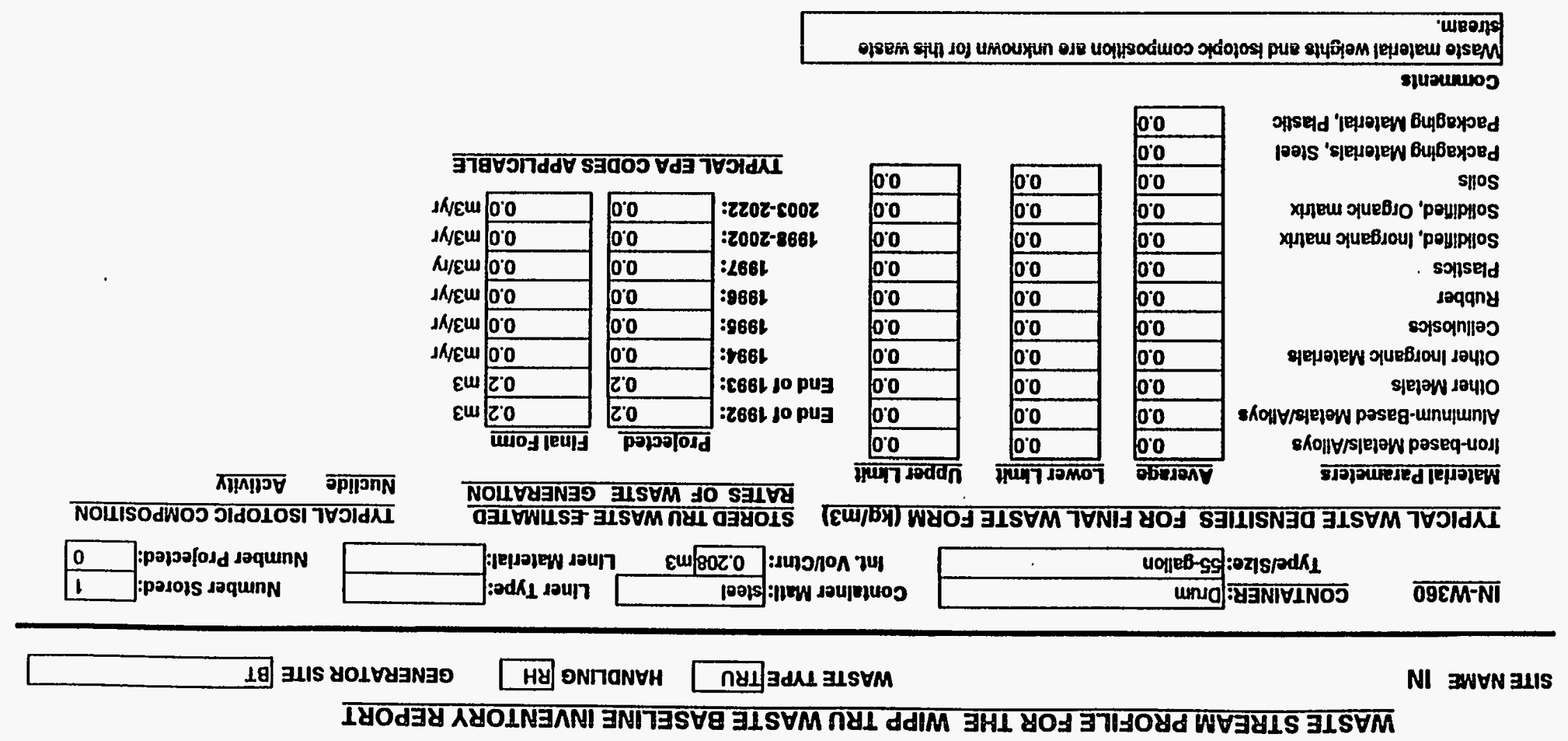


WASTE STREAM PROFILE FOR THE WIPP TRU WASTE BASELINE INVENTORY REPORT

SITE NAME IN

WASTE TYPE TRU HANDLING CH GENERATOR SITE RF

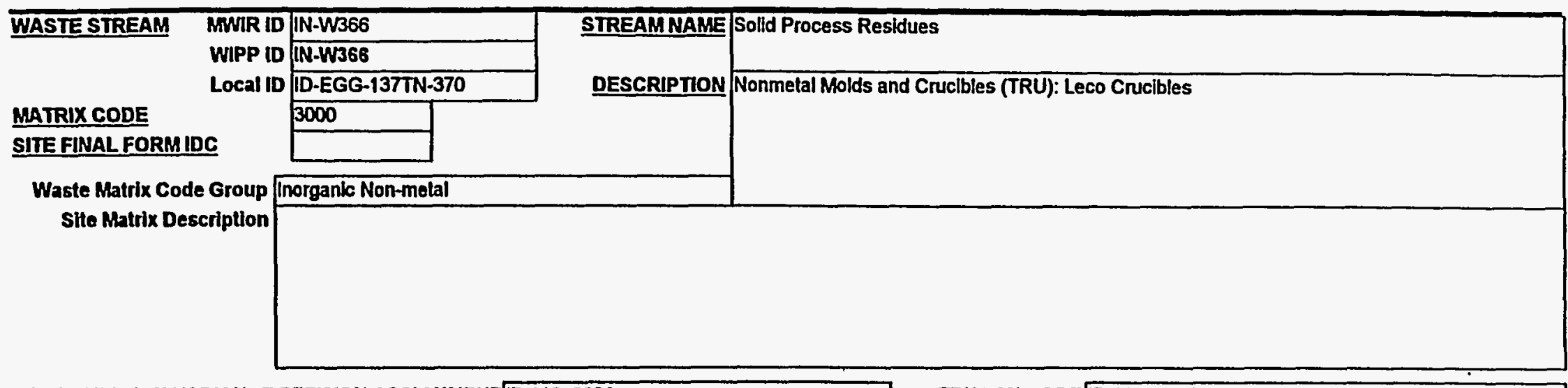

NO MGRATION VARIANCE PETITON ASSIGNMENTID 118; 222A

IRUCON CODE ID 118;222A

FINAL WASTE FORM DESCRIPTORS:

Defense TRU Waste

Non-Defense TRU Waste

Commerctal TRU Waste

Unknown

$\square$

Mbxed TRU

Nan-Mixed TRU

Suspect Mbxed TRU

Unknown

$\square$

TSCA Asbestos

PCBs

Other

N/A

Unknown

From Treatment of Waste

Maintenance 


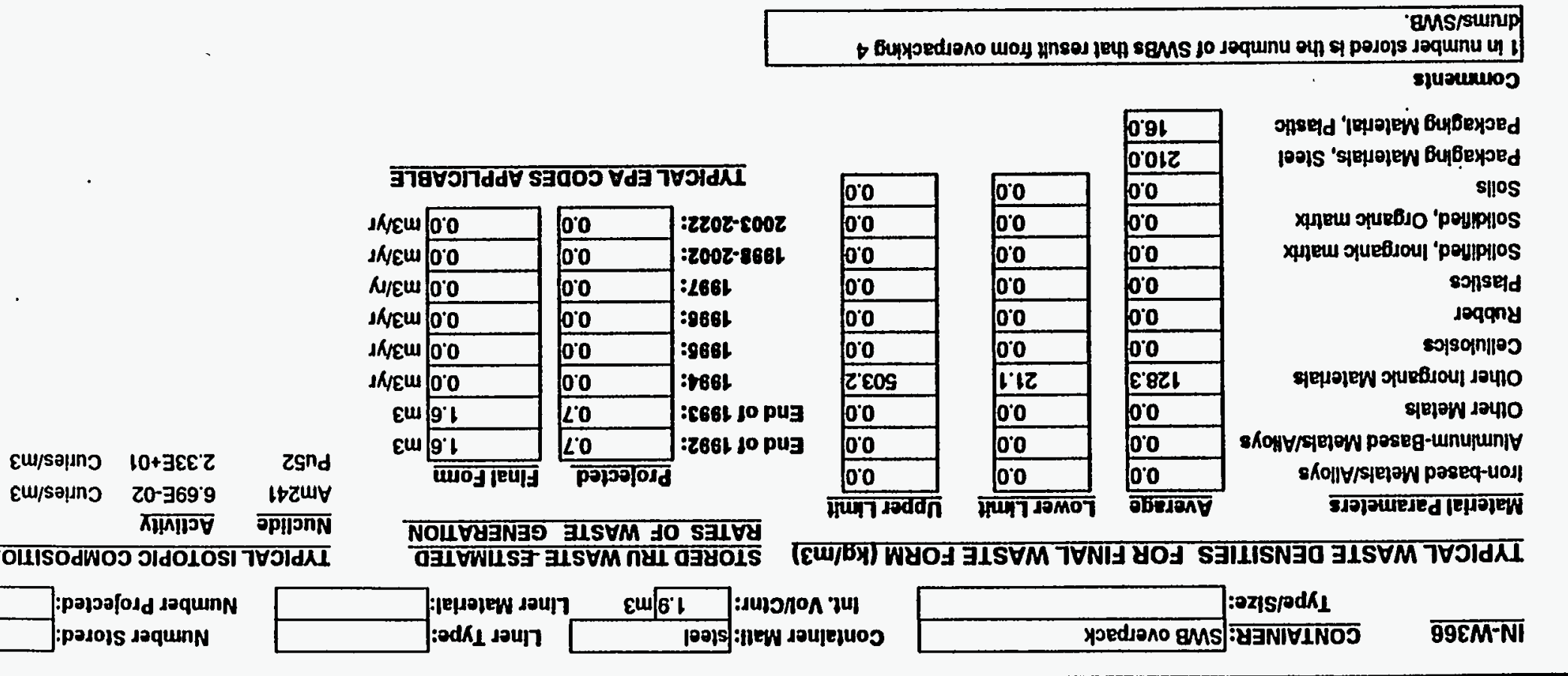




\section{WASTE STREAM PROFILE FOR THE WIPP TRU WASTE BASELINE INVENTORY REPORT}

SITENAME IN WASTE TYPE TRU HANDLING CH GENERATOR SITE RF

\begin{tabular}{|c|c|c|c|c|c|c|c|c|c|c|c|}
\hline IN-W366 $\frac{\text { CONTAINER: }}{\text { Type/SIzE: }}$ & \multicolumn{2}{|l|}{ 5rum } & \multicolumn{3}{|c|}{$\begin{aligned} \text { Container Matl: } & \text { steel } \\
\text { Int. VolvCtnr: } & 0.208 / \mathrm{m3}\end{aligned}$} & $\begin{array}{r}\text { Liner Type: } \\
\text { Iner Material: }\end{array}$ & & & \multicolumn{2}{|c|}{$\begin{array}{l}\text { Number Stored: } \\
\text { Number Projected: }\end{array}$} & $\begin{array}{l}9 \\
0\end{array}$ \\
\hline \multicolumn{4}{|c|}{ TYPICAL WASTE DENSITIES FOR FINAL WASTE FORM (kg/m3) } & \multicolumn{4}{|c|}{ STORED TRU WASTE ESTIMATED } & \multicolumn{4}{|c|}{ IYPICAL ISOTOPIC COMPOSITION } \\
\hline Material Parameters & Average & Lower Limit & Upper Limit & \multicolumn{4}{|c|}{ RATES OF WASTE GENERATION } & \multirow{3}{*}{$\begin{array}{l}\text { Nuclide } \\
\text { Am241 } \\
\text { Pu52 }\end{array}$} & \multirow{3}{*}{$\begin{array}{l}\text { Activity } \\
1.53 E-01 \\
5.32 E+01\end{array}$} & \multirow{3}{*}{\multicolumn{2}{|c|}{$\begin{array}{l}\text { Curies } / \mathrm{m3} \\
\text { Curies/m3 }\end{array}$}} \\
\hline Iron-based Metals/Alloys & 0.0 & 0.0 & 0.0 & \multirow{2}{*}{ End of 1992: } & Prolected & \multicolumn{2}{|l|}{ Final Form } & & & & \\
\hline Aluminum-Based Metals/Alloys & 0.0 & 0.0 & 0.0 & & 1.8 & 1.8 & m3 & & & & \\
\hline Other Metals & 0.0 & 0.0 & 0.0 & End of 1893: & 1.8 & 1.8 & m3 & & & & \\
\hline Other Inorganic Materials & 293.0 & 48.1 & 1149.0 & 1984: & 0.0 & 0.0 & $\mathrm{~m} 3 / y r$ & & & & \\
\hline Cellulosics & 0.0 & 0.0 & 0.0 & 1995: & 0.0 & 0.0 & $m 3 / y r$ & & & & \\
\hline Rubber & 0.0 & 0.0 & 0.0 & 1996: & 0.0 & 0.0 & m3ryr & & & & \\
\hline Plastics & 0.0 & 0.0 & 0.0 & 1997: & 0.0 & 0.0 & $m 3 / r y$ & & & & \\
\hline Solldified, Inorganle matitx & 0.0 & 0.0 & 0.0 & 1998-2002: & 0.0 & 0.0 & $m 3 / y r$ & & & & \\
\hline Solidified, Organic matrix & 0.0 & 0.0 & 0.0 & 2003-2022: & 0.0 & 0.0 & $m 3 / y r$ & & & & \\
\hline Solls & 0.0 & 0.0 & 0.0 & TYPICA & EPA CO & ApPIICAP & BIE & & & & \\
\hline Packaging Materials, Steel & 131.0 & & & & & & BLE & & & & \\
\hline Packaging Material, Plastic & 37.0 & & & & & & & & & & \\
\hline
\end{tabular}




\section{WASTE STREAM PROFILE FOR THE WIPP TRU WASTE BASELINE INVENTORY REPORT}

SITE NAME IN

WASTE TYPE TRU HANDLNG CH GENERATOR SITE RF

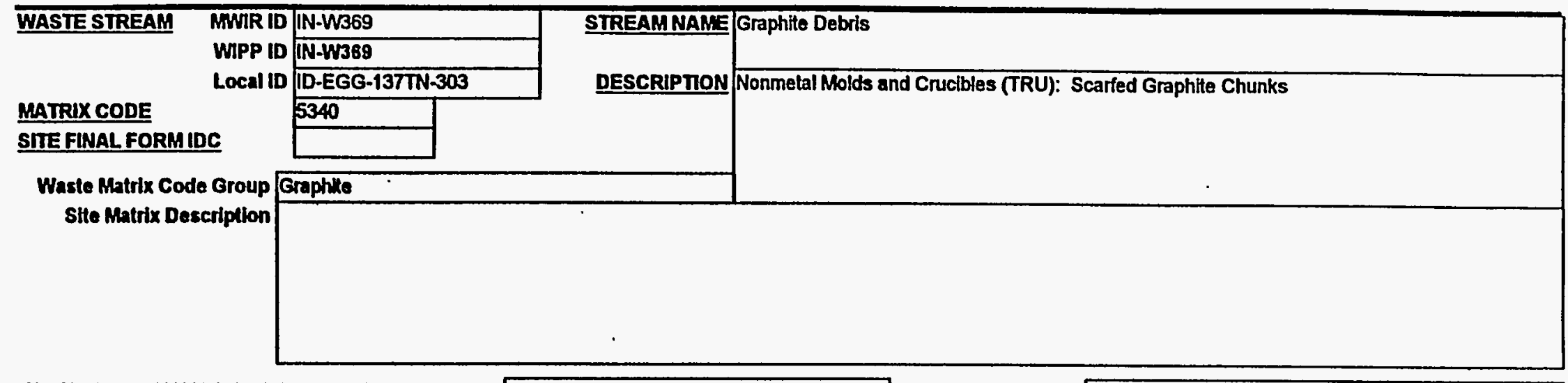

NO MGRATION VARLANCE PETIION ASSKONMENTID 115

IRUCON CODE

FINAL WASTE FORM DESCRIPTORS:

Defonse TRU Wasto

Non-Defense TRU Waste

Commercial TRU Wasto

Unknown

\begin{tabular}{l}
\hline$x$ \\
\hline \\
\hline
\end{tabular}

Mbod TRU

Non-Mxed TRU

Suspect Mbed TRU

Unknown

X

Rsoarch and Devel. Wasto

Operations Waste

Resldues

Decon and Decommissloning

Environmental Restoration

From Treatment of Waste

Malntenance

\begin{tabular}{|c|c|}
\hline TSCA & Asbestos \\
\hline & PCBs \\
\hline & Other \\
\hline & N/A \\
\hline & Unknown \\
\hline
\end{tabular}




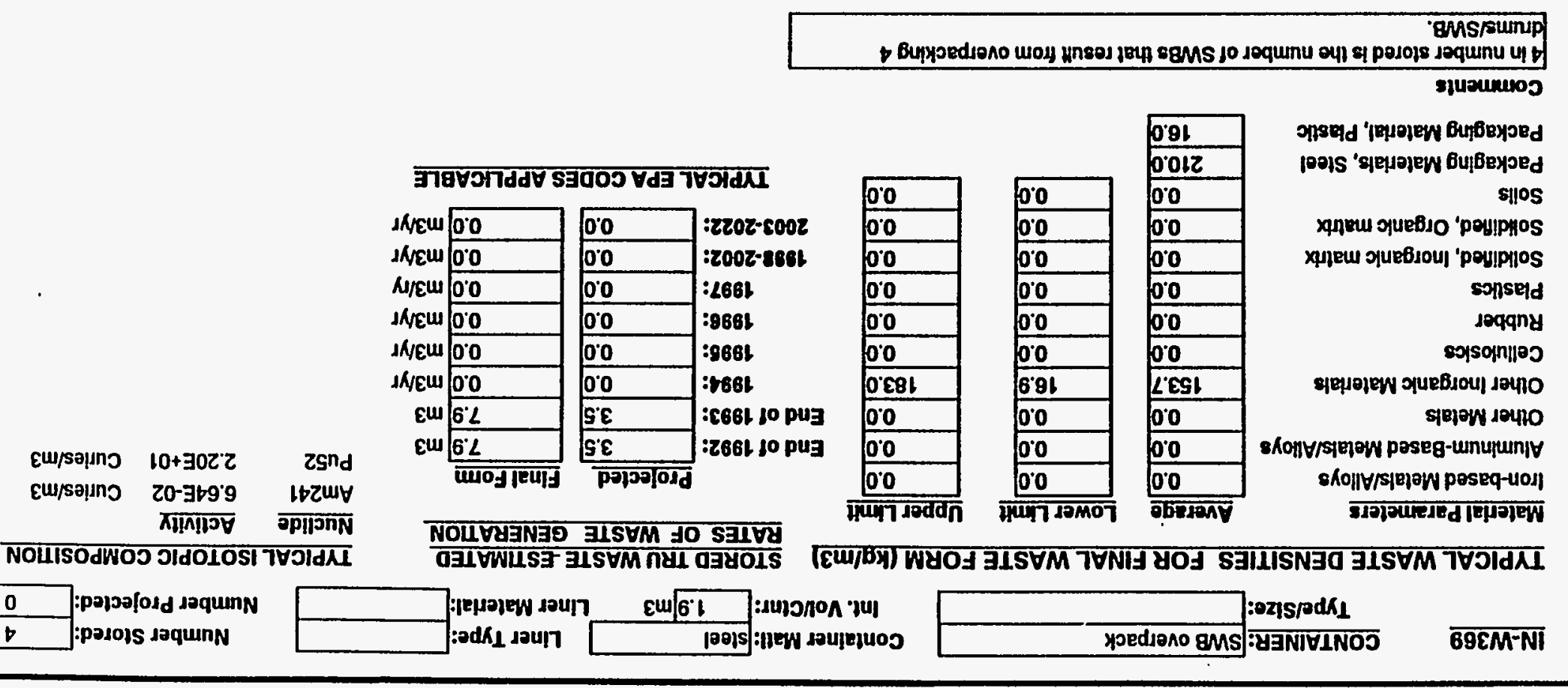




\section{WASTE STREAM PROFILE FOR THE WIPP TRU WASTE BASELINE INVENTORY REPORT}

SITE NAME IN

WASTE TYPEERU HANDLINO CH GENERATOR SITE RF

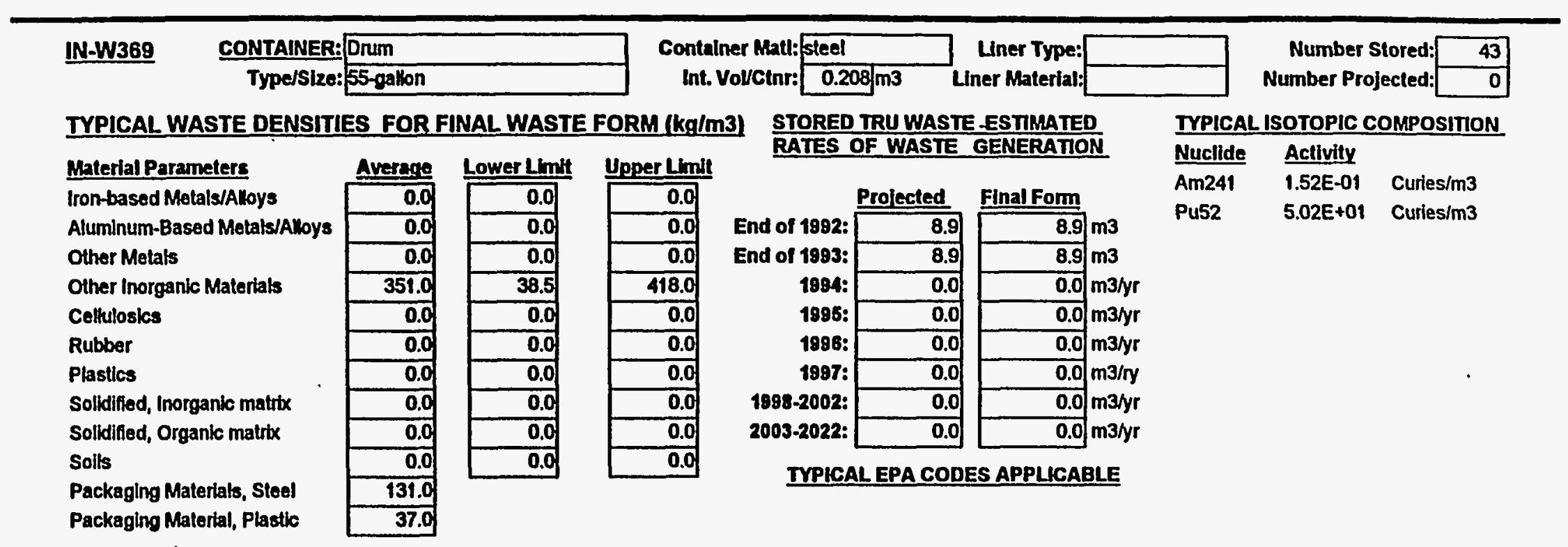




\section{WASTE STREAM PROFILE FOR THE WIPP TRU WASTE BASELINE INVENTORY REPORT}

SITE NAME IN

WASTE TYPE TRU HANDLING CH GENERATOR SITE RF

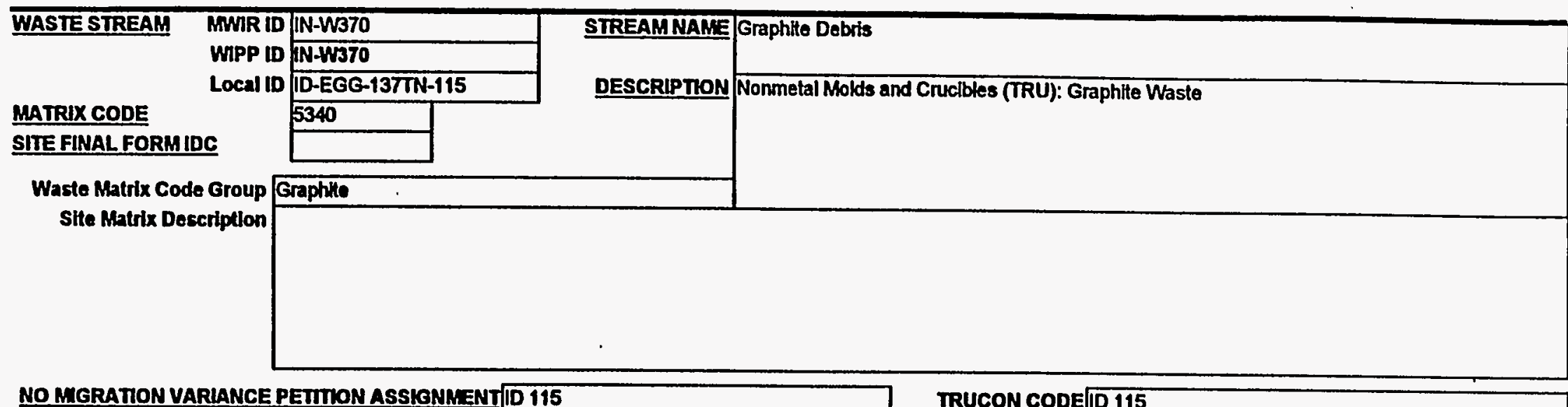

\section{FINAL WASTE FORM DESCRIPTORS:}

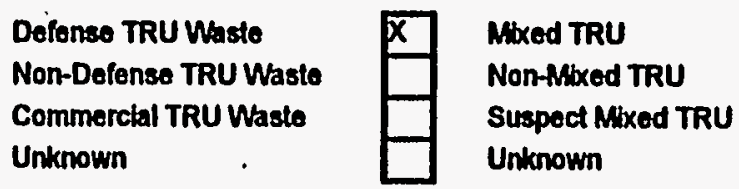

$\square$

Rsearch and Devel. Waste

Operations Wasto

Resldues

Decon and Decommissioning

Environmental Restoration

From Treatment of Waste

Mainienance

\begin{tabular}{lll}
\hline$X$ & TSCA \\
\hline$X$ & $\begin{array}{l}\text { Asbestos } \\
\text { PCBs } \\
\text { Olher } \\
\text { N/A } \\
\text { Unknown }\end{array}$ \\
\hline$X$
\end{tabular}




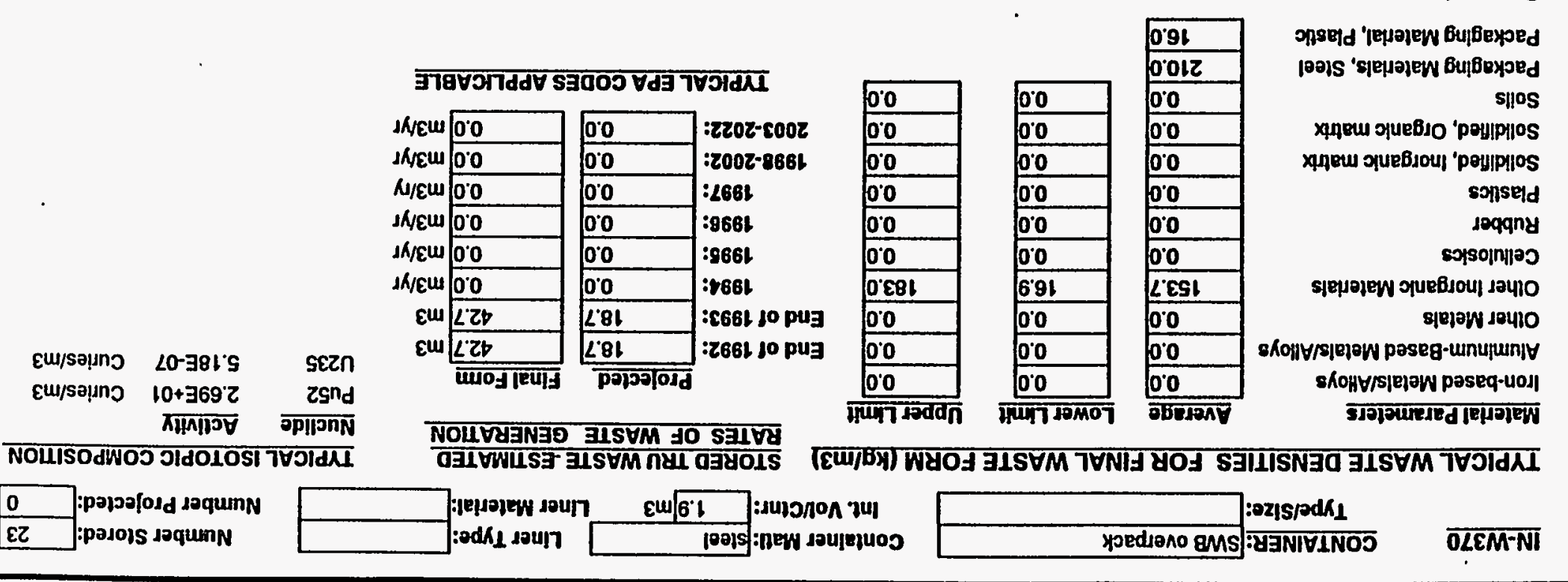




\section{WASTE STREAM PROFILE FOR THE WIPP TRU WASTE BASELINE INVENTORY REPORT}

SITENAME IN

\section{WASTE TYPETRU HANDLING CH GENERATOR SITE RF}

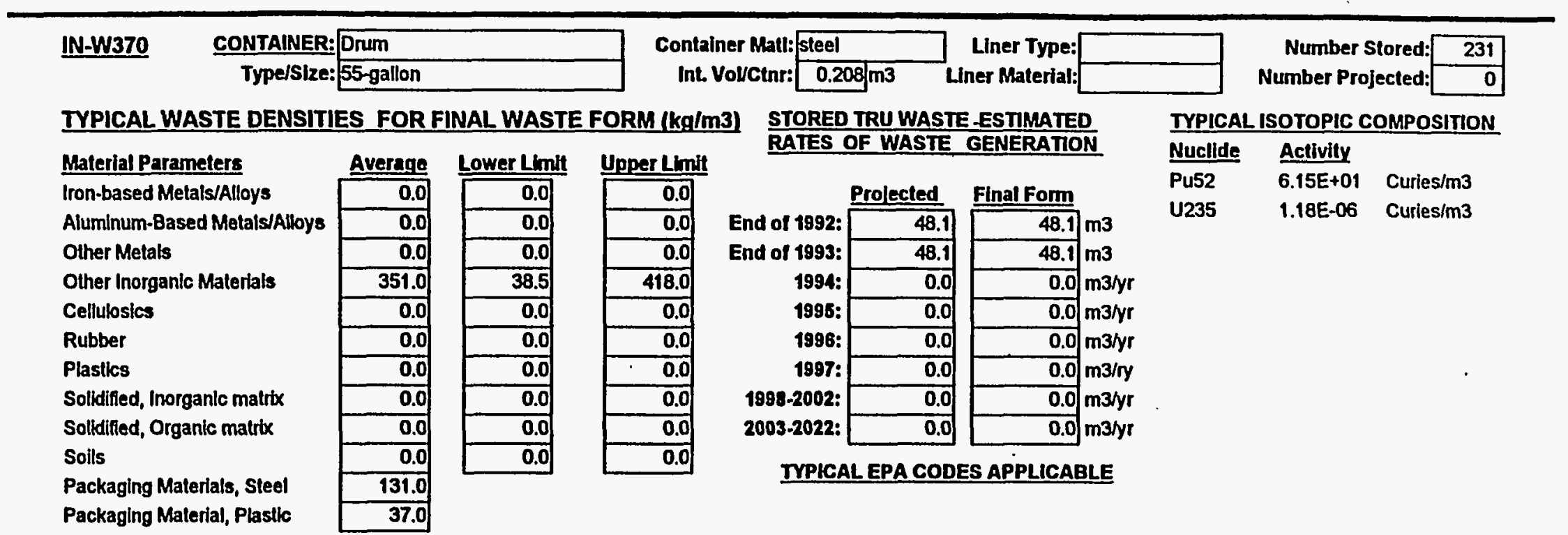




\section{WASTE STREAM PROFILE FOR THE WIPP TRU WASTE BASELINE INVENTORY REPORT}

SITE NAME IN

WASTE TYPE TRU HANDLING CH GENERATOR SITE RF

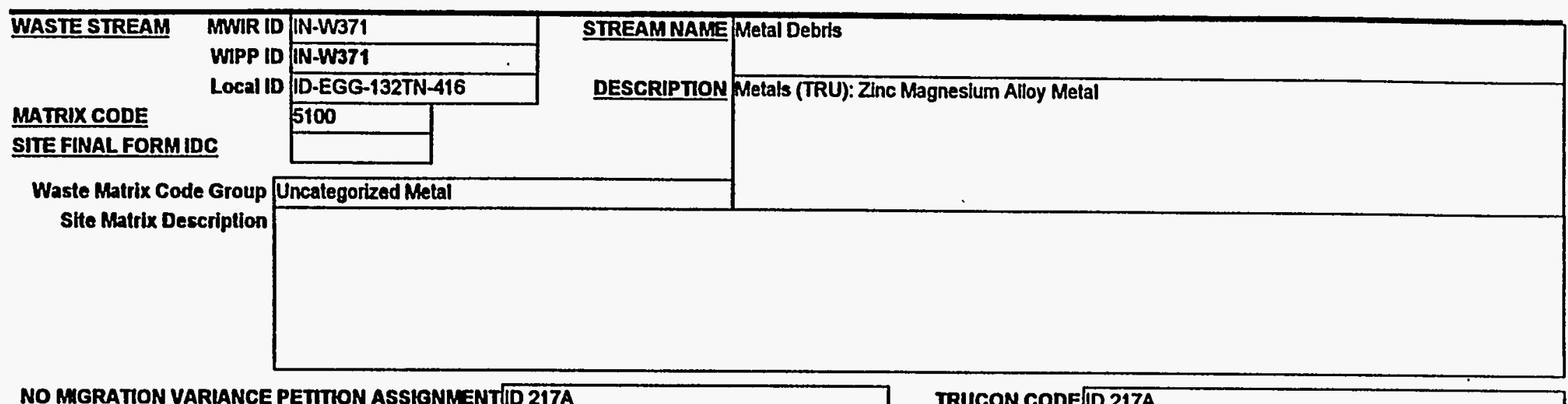

NO MIGRATION VARLANCE PEIIION ASSIGNIMENTID 217A

IRUCON CODE ID 217A

\section{FINAL WASTE FORM DESCRIPTORS:}

\begin{tabular}{l|l} 
Defense TRU Waste \\
Non-Defense TRU Waste \\
Commercial TRU Waste \\
Unknown
\end{tabular}$\quad \square \quad \begin{aligned} & \text { Mbxed TRU } \\
& \text { Non-Mixed TRU } \\
& \text { Suspect Mixed TRU } \\
& \text { Unknown }\end{aligned}$

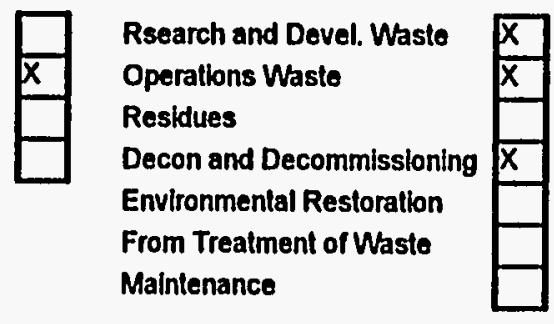

TSCA Asbestos

PCBs

Other

N/A

Unknown 


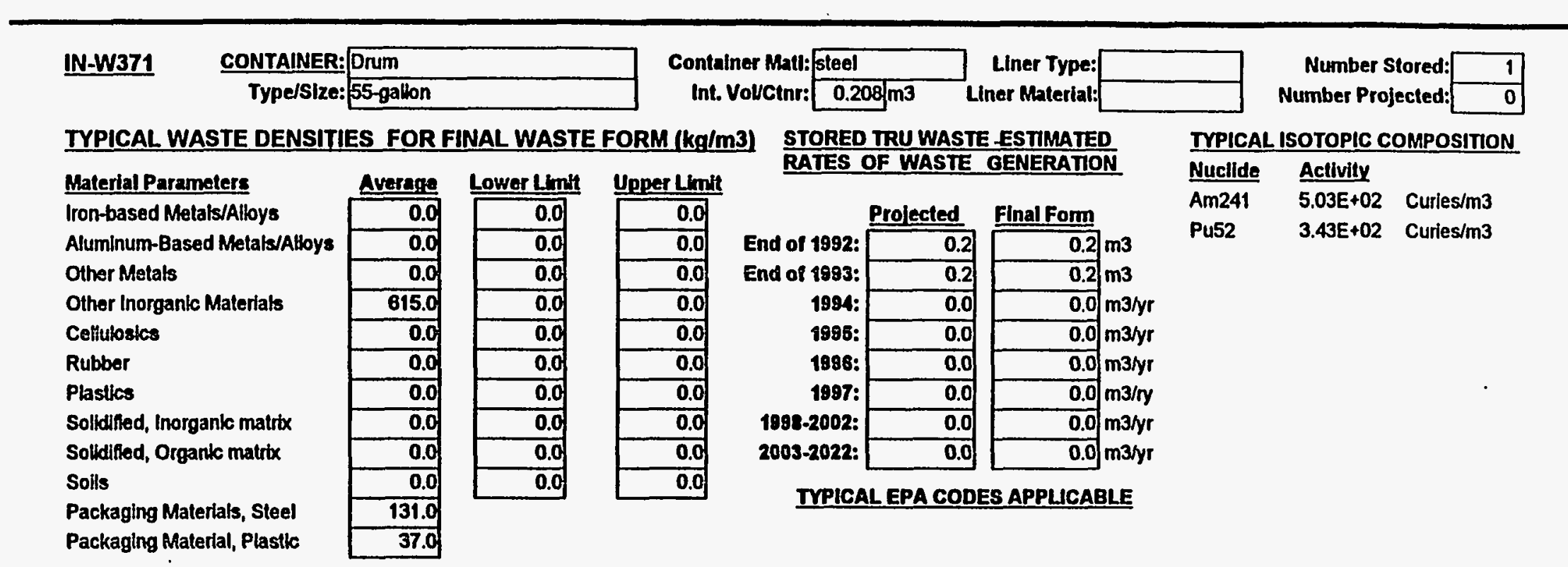




\section{WASTE STREAM PROFILE FOR THE WIPP TRU WASTE BASELINE INVENTORY REPORT}

SITE NAME IN

WASTE TYPE TRU HANDLING RH GENERATOR SITE BT

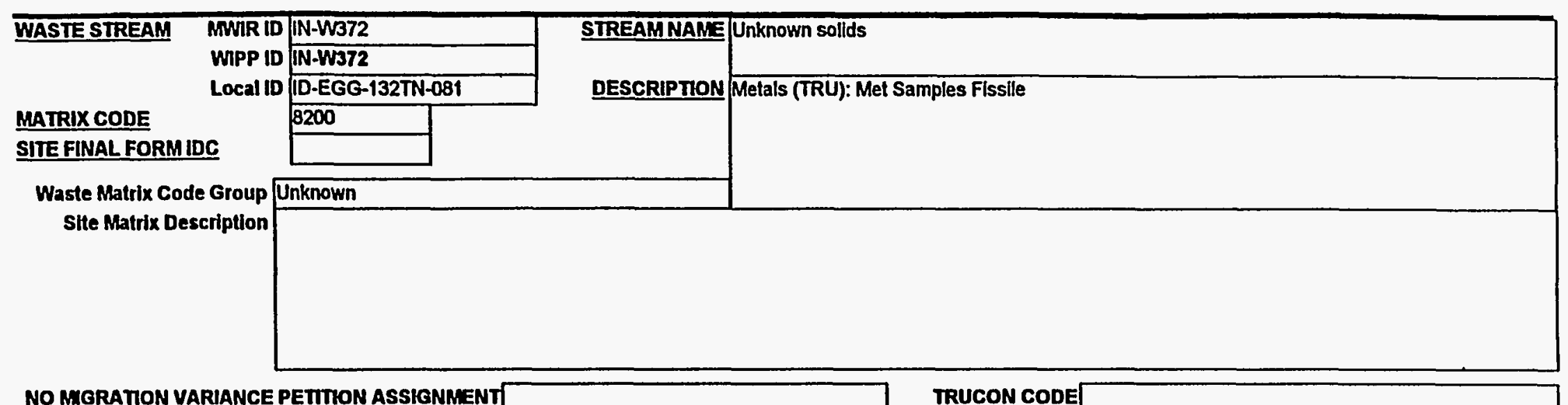

\section{NOMORATIONVARIANCEPETIMONAS}

\section{IRUCON CODE}

\section{FINAL WASTE FORMDESCRIPTORS:}

\begin{tabular}{l|l} 
Defense TRU Waste \\
Non-Defense TRU Waste \\
Commerclal TRU Waste \\
Unknown
\end{tabular}$\quad \begin{aligned} & \text { Mbed TRU } \\
& \text { Non-Mixed TRU } \\
& \text { Suspect Mixed TRU } \\
& \text { Unknown }\end{aligned}$

Rsearch and Devel. Waste

Operations Waste

Residues

Decon and Decommissioning

Environmental Restoration

From Treatment of Waste

- Mainlenance

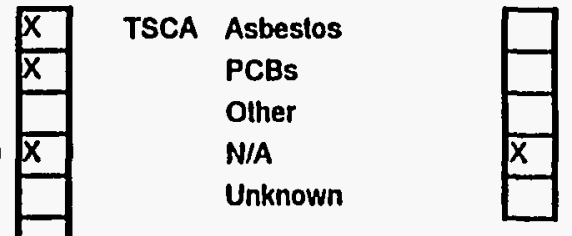




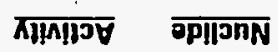

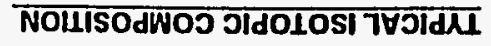

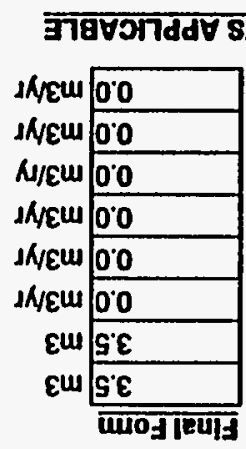

\begin{tabular}{|c|}
\hline 000 \\
\hline $0^{\prime} 0$ \\
\hline 0.0 \\
\hline 0.0 \\
\hline 0.0 \\
\hline 00 \\
\hline$S^{\prime} \varepsilon$ \\
\hline $\mathrm{S}^{\prime} \mathrm{E}$ \\
\hline
\end{tabular}

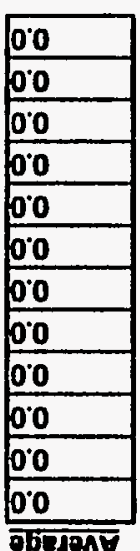

NoI1

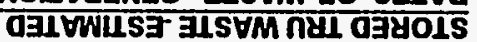

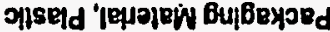
jools 'slejojew bujbeyod snos

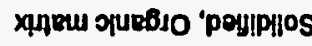
хијеس эuebjoul 'poulpyos

solseid

$$
\text { Joqquy }
$$

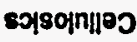

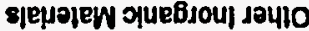

\&џejow douno

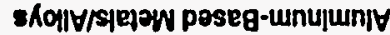
sKoㅂ/s|ejoW paseq-uOJ!

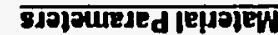

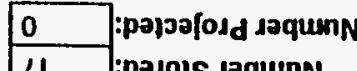

\begin{tabular}{|l|l}
\hline & jefpiew souा \\
\hline & :od/1 douा7
\end{tabular}

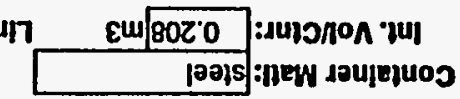




\section{WASTE STREAM PROFILE FOR THE WIPP TRU WASTE BASELINE INVENTORY REPORT}

SITENAME IN

WASTE TYPETRU HANDLING CH GENERATOR SITE RF

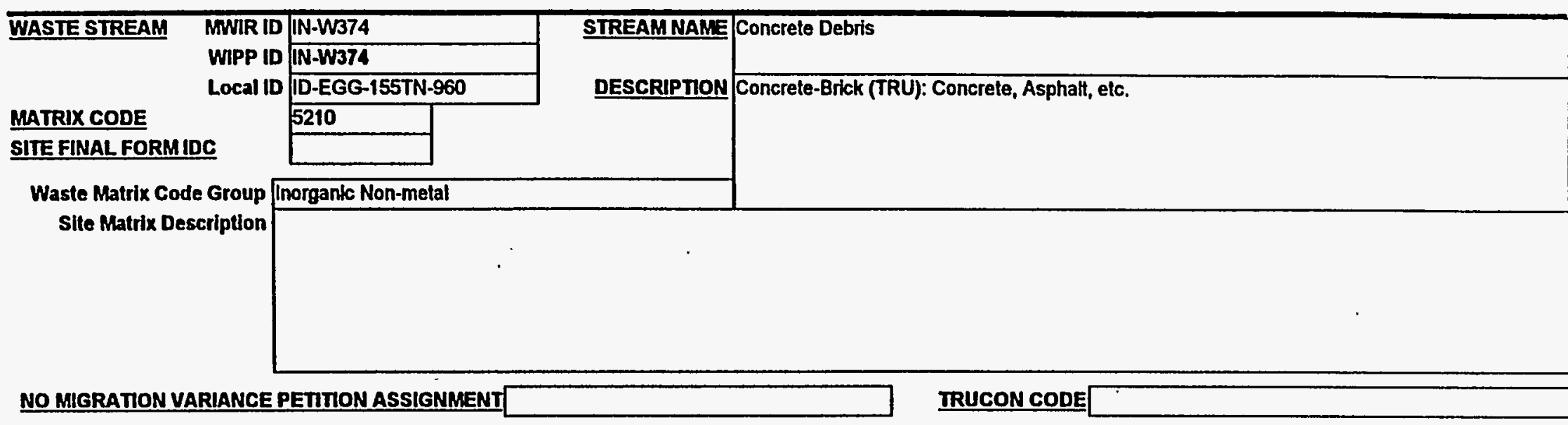

\section{FINAL WASTE FORM DESCRIPTORS:}

Defense TRU Waste

Non-Defense TRU Waste

Commerclal TRU Waste

Unknown

$\square$

Mbxed TRU

Non-Mixed TRU

Suspect Miked TRU

Unknown

Rsearch and Devel. Waste
Operations Waste
Residues
Decon and Decommissioning
Environmental Restoration
From Treatment of Waste
Maintenance

TSCA Asbestos

PCBs

Other

N/A

Unknown

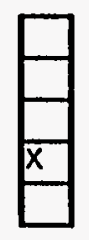



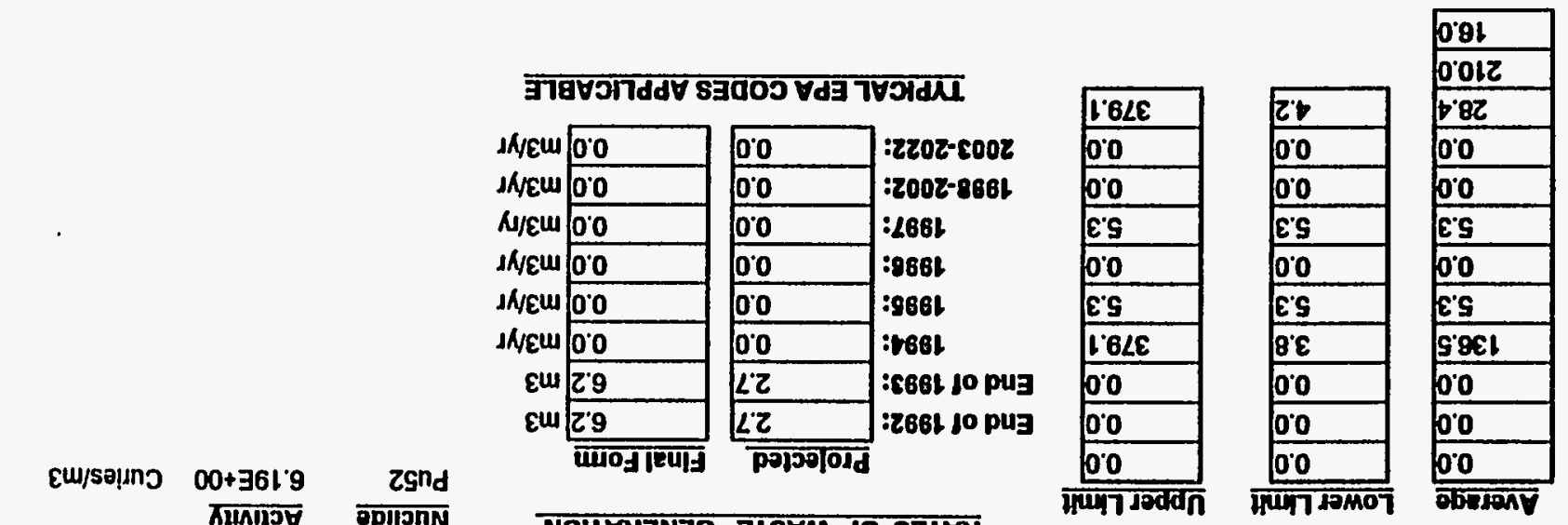

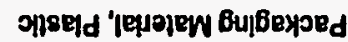

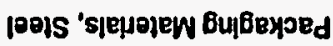
xцpew भiuefıo 'poyiphos

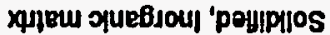
sonsedd Jeqqny sołs어피이

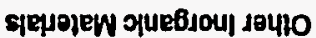

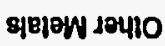

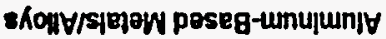

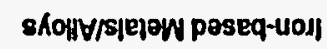

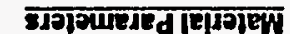

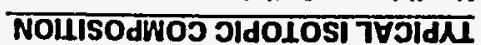

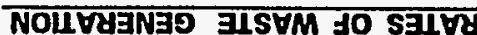

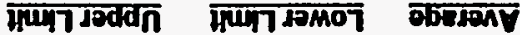

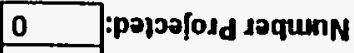

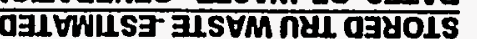

\section{द्याठBत्र}
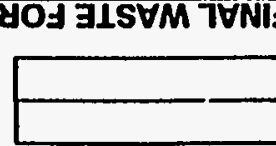

पOJ S3IISN 30 IIS

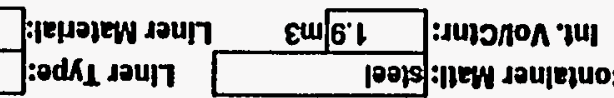

$\overline{\text { VEEM-NI }}$ 


\section{WASTE STREAM PROFILE FOR THE WIPP TRU WASTE BASELINE INVENTORY REPORT}

SITENAME IN WASTE TYPETTRU HANDLING CH GENERATOR SITE RF

IN-W374

$$
\text { CONTAINER: Drum }
$$

Container Matl: steel

Int Vol/Cinr: $0.208 \mathrm{~m}^{3}$ Liner Material:

TYPICAL WASTE DENSITIES FOR FINAL WASTE FORM (kg/m3)

STORED TRU WASTE ESTIMATED

\section{Material Paramelers}

Iron-based Metals/Alloys

Aluminum-Based Metals/Alloys

Other Metals

Other Inorganic Materials

Cellulosics

Rubber

Plastics

Sollidined, Inorganic matrix

Solldified, Organle matrix

Solls

Packaging Materlals, Sleel

Packaging Material, Plastic

\begin{tabular}{|} 
Average \\
\hline 0.0 \\
\hline 0.0 \\
\hline 0.0 \\
\hline 311.6 \\
\hline 12.0 \\
\hline 0.0 \\
\hline 12.0 \\
\hline 0.0 \\
\hline 0.0 \\
\hline 64.9 \\
\hline 131.0 \\
\hline 37.0 \\
\hline
\end{tabular}

\begin{tabular}{l} 
Lower Limit \\
\hline $\mathbf{0 . 0}$ \\
\hline 0.0 \\
\hline 0.0 \\
\hline $\mathbf{8 . 7}$ \\
\hline $\mathbf{1 2 . 0}$ \\
\hline $\mathbf{0 . 0}$ \\
\hline $\mathbf{1 2 . 0}$ \\
\hline 0.0 \\
\hline 0.0 \\
\hline 9.6 \\
\hline
\end{tabular}

\begin{tabular}{|r|}
\hline Upper Limit \\
\hline 0.0 \\
\hline 0.0 \\
\hline 0.0 \\
\hline 865.8 \\
\hline 12.0 \\
\hline 0.0 \\
\hline 12.0 \\
\hline 0.0 \\
\hline 0.0 \\
\hline 865.8 \\
\hline
\end{tabular}
RATES OF WASTE GENERATION

Comments

4 in number stored is the number of SWBs that result from overpacking 4

\begin{tabular}{|c|c|c|c|}
\hline \multirow{2}{*}{ End of 1992: } & Prolected & \multicolumn{2}{|l|}{ Final Form } \\
\hline & 7.0 & & m3 \\
\hline d of 1993: & 7.0 & 7.0 & m3 \\
\hline 1994: & 0.0 & 0.0 & $\mathrm{~m} 3 / \mathrm{yr}$ \\
\hline 189 & 0.0 & 0.0 & $\mathrm{~m} 3 / \mathrm{yr}$ \\
\hline 1996: & 0.0 & 0.0 & $m 3 / y r$ \\
\hline 1997: & 0.0 & 0.0 & $\mathrm{~m} 3 / \mathrm{n}$ \\
\hline 398-20 & 0.0 & 0.0 & $\mathrm{~m} 3 / \mathrm{yr}$ \\
\hline 20 & 0.0 & 0.0 & \\
\hline
\end{tabular}
drums/SWB.
TYPICAL EPA CODES APPLICABLE
Number Stored: Number Projected:

TYPICAL ISOTOPIC COMPOSITION Nuclide Activity

Pu52 1.41E+01 Curies/m3 


\section{Knolls Atomic Power Laboratory - Schnecetedy}




\section{KNOLLS ATOMIC POWER LABORATORY (KA) - SCHENECTADY, NY WASTE STAEAM PROFILES}

The following modifications were made by the WTWBIR team in developing the KA waste stream profiles:

- The container numbers in waste stream KA-W016 were changed to match the volumes provided on the form. 
WASTE STREAM PROFILE FOR THE WIPP TRU WASTE BASELINE INVENTORY REPORT

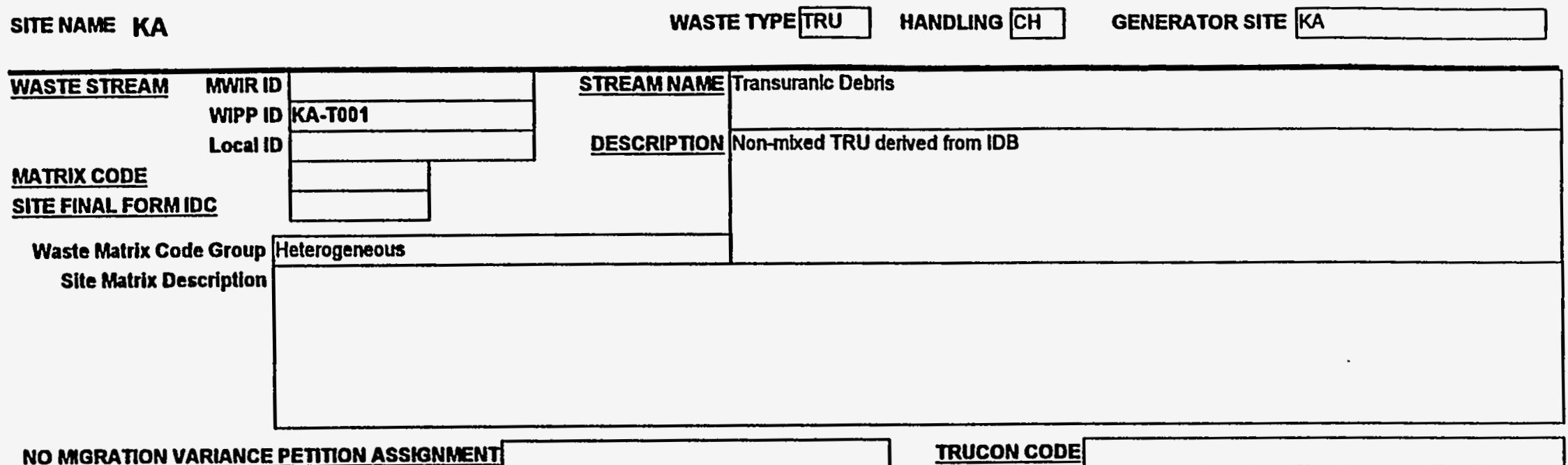

NO MGRATION VARLANCE PETIION ASSHGNMENT

IRUCON CODE

FINAL WASTE FORMDESCRIPTORS:

Defense TRU Waste

Non-Defense TRU Waste

Commercial TRU Waste

Mbxed TRU

Non-Mixed TRU

Unknown

Suspect Mixed TRU

Unknown

Rsearch and Devel. Waste
Operations Waste
Residues
Decon and Decommissioning
Environmental Restoration
From Treaiment of Waste
Maintenance

TSCA Asbestos

PCBs

Other

N/A

Unknown

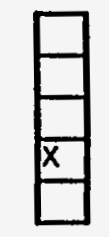




\section{WASTE STREAM PROFILE FOR THE WIPP TRU WASTE BASELINE INVENTORY REPORT}

SITE NAME KA

\section{WASTE TYPETTRU HANDLING CH GENERATOR SITE KA}

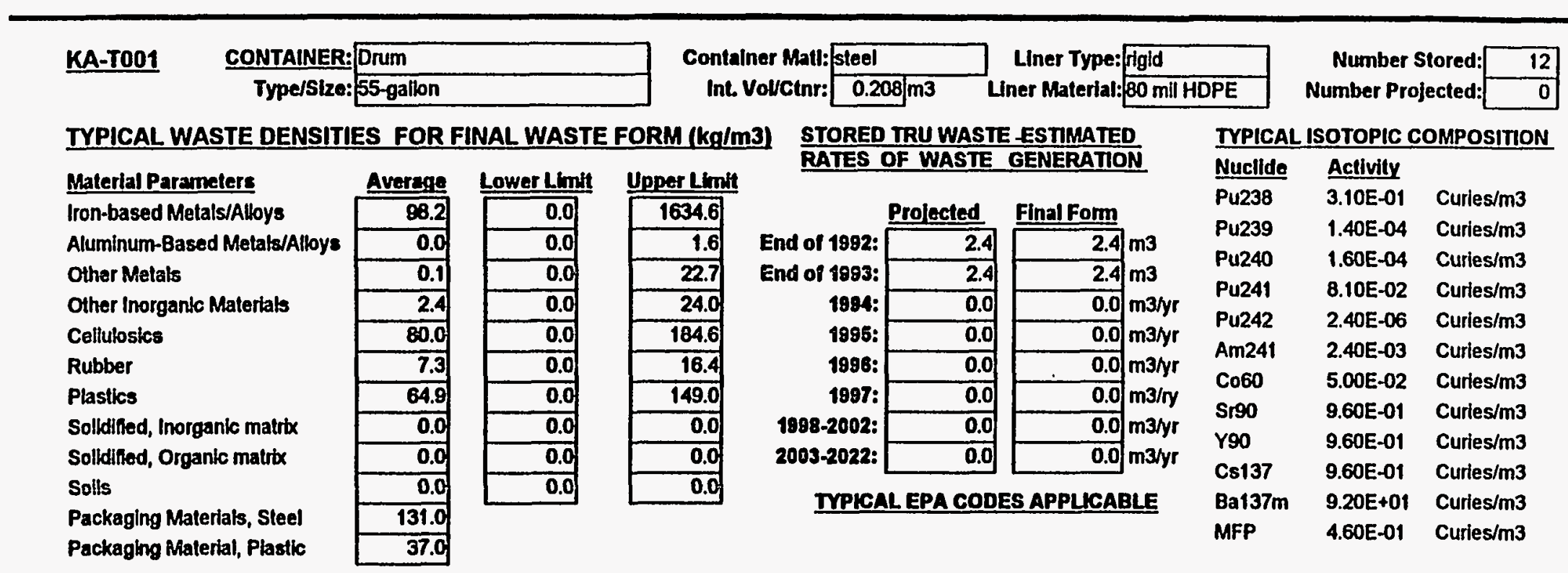


WASTE STREAM PROFILE FOR THE WIPP TRU WASTE BASELINE INVENTORY REPORT

SITE NAME KA

WASTE TYPE MTRU HANDLING RH

GENERATOR SITE KA

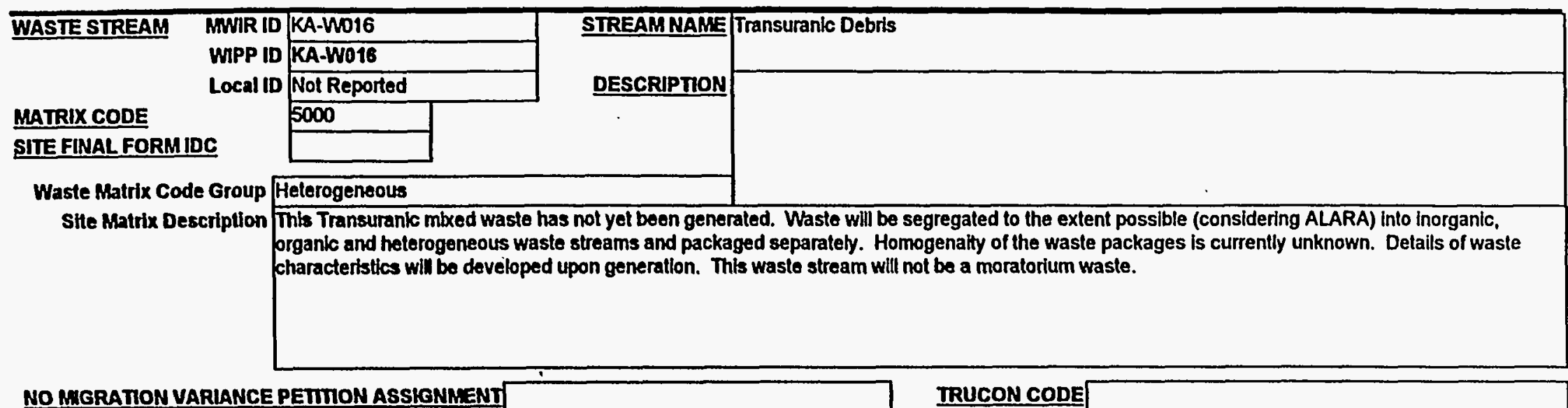

\section{FINAL WASTE FORM DESCRIPTORS:}

Defense TRU Waste

Non-Defense TRU Wasle

Commerclal TRU Wasle

Unknown

$\square$

Mbxed TRU

Non-Mixed TRU

Suspect Mixed TRU

Unknown

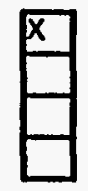

TSCA Asbestos

PCBs

Other

N/A

Unknown
From Treatment of Whaste

Maintenance

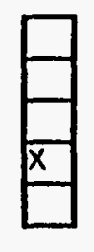


WASTE STREAM PROFILE FOR THE WUPP TRU WASTE BASELINE INVENTORY REPORT

KA-W016

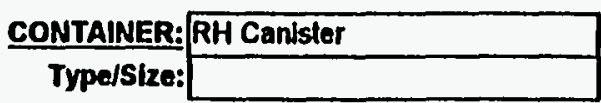

Container Matl: Steelhead

int. Voucinr:
Uner Type:

Uner Material:

TYPICAL WASTE DENSITIES FOR FINAL WASTE FORM (kg/m3) STORED TRU WASTE ESTMATED

Material Parameters

Iron-based Motals/Alloys

Aluminum-Based Metals/Alloys

Other Melals

Other Inorganic Materials

Cellulosics

Rubber

Plastics

Solldified, Inorganic matrix

Solidified, Organle matrix

Solls

Packaging Materiats, Steel

Packaging Matertal, Plastic

\begin{tabular}{|r|} 
Average \\
\hline $\mathbf{8 0 . 2}$ \\
\hline 0.0 \\
\hline 0.1 \\
\hline 2.4 \\
\hline 80.0 \\
\hline 7.3 \\
\hline 64.9 \\
\hline 0.0 \\
\hline 0.0 \\
\hline 0.0 \\
\hline 0.0 \\
\hline 0.0 \\
\hline
\end{tabular}

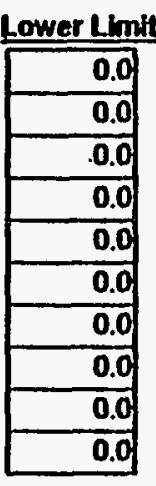

Upper Limt RATES OF WASTE GENERATION

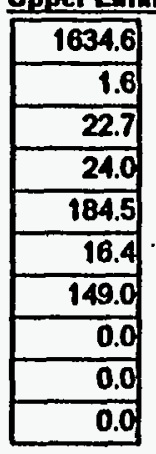

Footnotes

The yearty generation rates were adjusted to match the $25.2 \mathrm{m3}$ of projected waste reported in the WTWBIR waste stream profiles and the Phase II MMMR.

\begin{tabular}{|c|c|c|c|}
\hline & Prolected & Flnal Form & \\
\hline 32: & 11.23 & $\overline{11.23}$ & m3 \\
\hline & 11.27 & 11.27 & m3 \\
\hline 1894: & 0.87 & 0.87 & m3/yr \\
\hline 1895: & 0.87 & 0.87 & $\mathrm{~m} 3 / \mathrm{yr}$ \\
\hline 1996: & 0.87 & 0.87 & $\mathrm{~m} 3 / \mathrm{yr}$ \\
\hline 1997: & $0 . \overline{07}$ & 0.87 & $m 3 / n$ \\
\hline $3-20$ & 0.87 & 0.87 & m3/yr \\
\hline D03-2022: & 0.87 & 0.87 & $\mathrm{~m} 3 / \mathrm{yr}$ \\
\hline
\end{tabular}

IYPICAL EPA CODES APPLKCABLE

D004A

D005A

D006A

D007A

D008A

D009A

D009B

D009C

D010A

D011A

D018

D035

D039

D040

F001

F002
Number Stored: 13

Number Projected:
TYPICAL ISOTOPIC COMPOSITION

Nuclide Actlvily

Pu238 3.10E-01 Curies/m3

Pu239 1.40E-04 Curies/m3

Pu240 1.60E-04 Curles/m3

Pu241 8.10E-02 Curies $/ \mathrm{m}^{3}$

Pu242 2.40E-06 Curlesim3

Am241 2.40E-03 Curles/m3

Co60 5.00E-02 Curles $/ \mathrm{m}^{3}$

Sr90 9.60E-01 Curies $/ \mathrm{m}^{3}$

Y90 9.60E-01 Curles/m3

C8137 9.60E-01 Curles/m3

Ma137m 9.20E-01 Curies/m3

MFP 4.60E-01 Curles/m3 


\section{Los Alamos National Laboratory}




\section{LOS ALAMOS NATIONAL LABORATORY (LA) \\ WASTE STREAM PROFILES}

The following modifications were made by the WTWBIR team in developing the LA waste stream profiles:

- Final Waste Form Groups were not assigned by LA but by the WTWBIR team in order to permit roll-ups of the data. However, the Final Waste Form Groups are based on the descriptions and parameters provided by LA.

- For the years 1994 to 2022, LA reported cumulative volumes instead of volumes generated per year. The WTWBIR team has modified the site reported data so that volumes can be consistently rolled-up across all the sites.

- Packaging material parameters were incorrectly reported by LA. These were discussed with LA and corrected by the WTWBIR team. 


\section{WASTE STREAM PROFILE FOR THE WIPP TRU WASTE BASELINE INVENTORY REPORT}

\section{SITE NAME LA \\ WASTE TYPETRU HANDLING CH GENERATOR SITE LA}

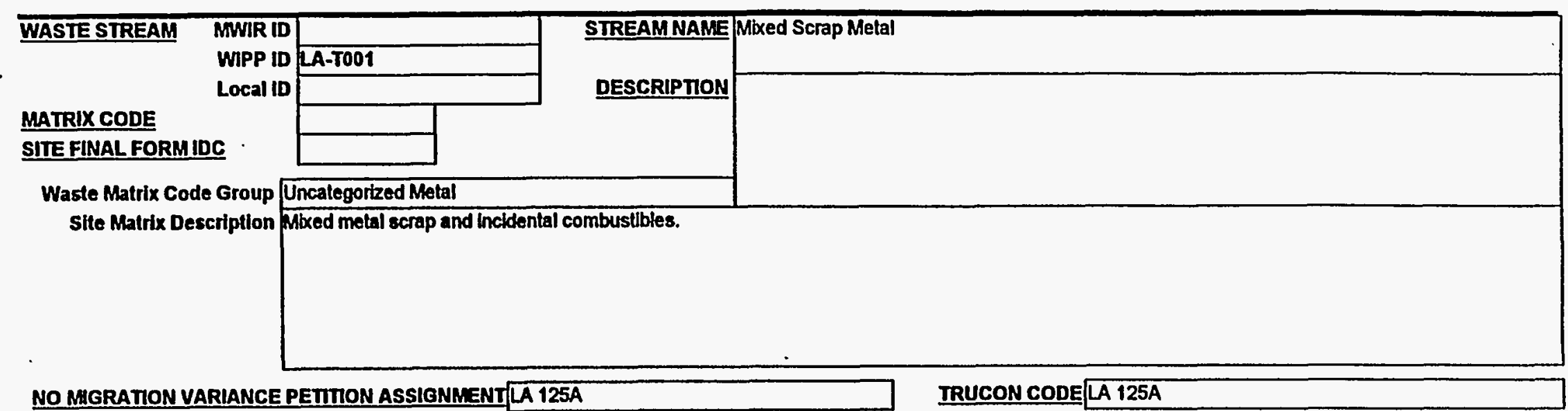

FINAL WASTE FORM DESCRIPTORS:

\begin{tabular}{l|l} 
Defense TRU Waste \\
Non-Defense TRU Waste \\
Commercial TRU Waste \\
Unknown
\end{tabular}

Rsearch and Devel. Waste Operatlons Waste

Residues

Decon and Decommlssioning

Environmental Restoration

From Treatment of Waste

Maintenance

\begin{tabular}{|ll|}
\hline TSCA & $\begin{array}{l}\text { Asbestos } \\
\text { PCBs } \\
\text { Olher } \\
\text { N/A } \\
\text { Unknown }\end{array}$ \\
\hline & \\
\hline & \\
\hline
\end{tabular}




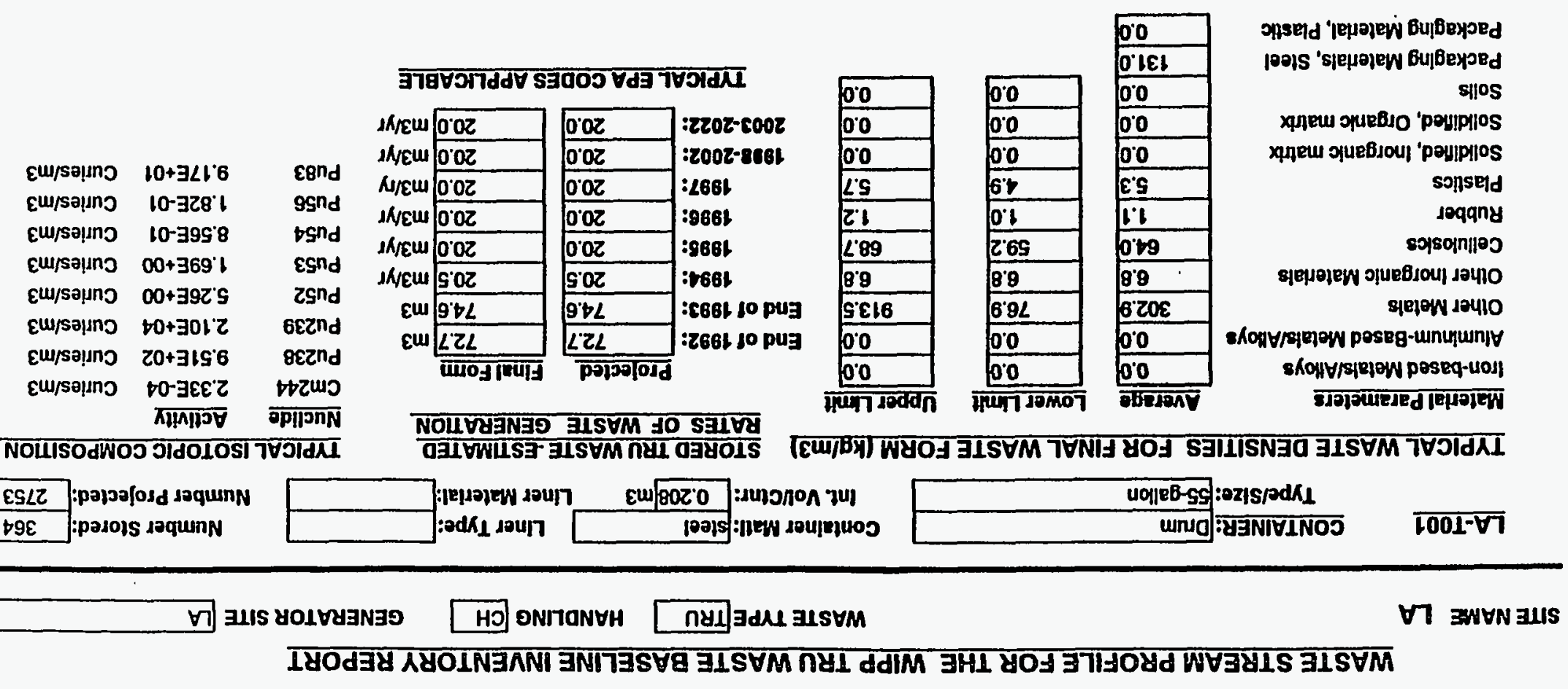


WASTE STREAM PROFILE FOR THE WIPP TRU WASTE BASELINE INVENTORY REPORT

SITE NAME LA

WASTE TYPETRU

HANDLINO CH

GENERATOR SITE LA

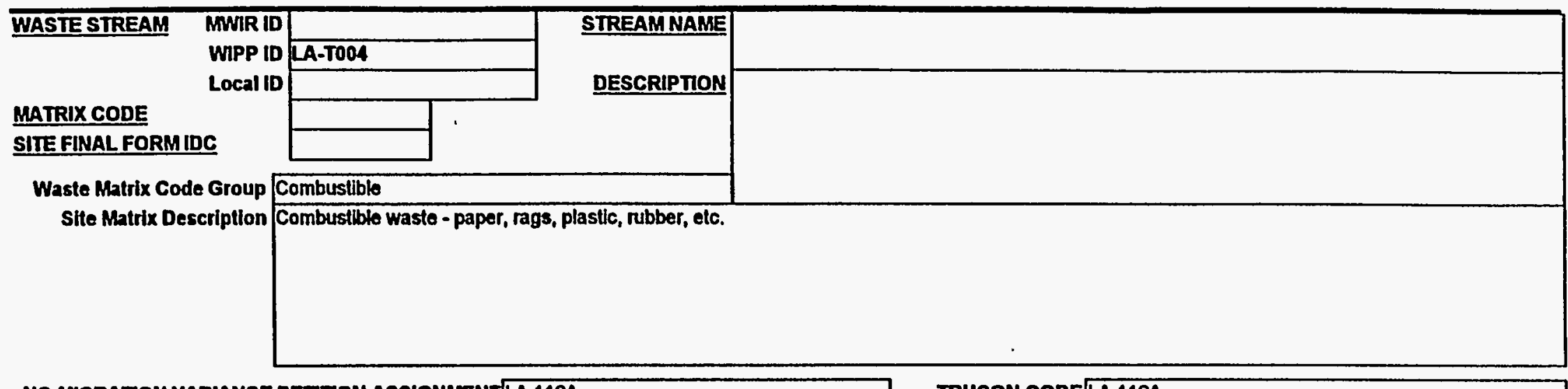

NO MGRATION VARIANCE PETIION ASSIONMENT LA 116A

IRUCON CODE LA 116A

FINAL WASTE FORM DESCRIPTORS:

\begin{tabular}{l|l}
$\begin{array}{l}\text { Defense TRU Waste } \\
\text { Non-Defense TRU Waste } \\
\text { Commerclal TRU Waste } \\
\text { Unknown }\end{array}$ & $\square$
\end{tabular}

$\square$

Rsearch and Devel. Waste
Operations Wasto
Residues
Decon and Decommissioning
Environmental Restoration
From Treatment of Waste
Maintenance

TSCA Asbestos

PCBs

Other

N/A

Unknown

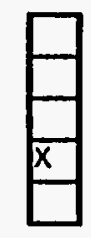

Maintenance 


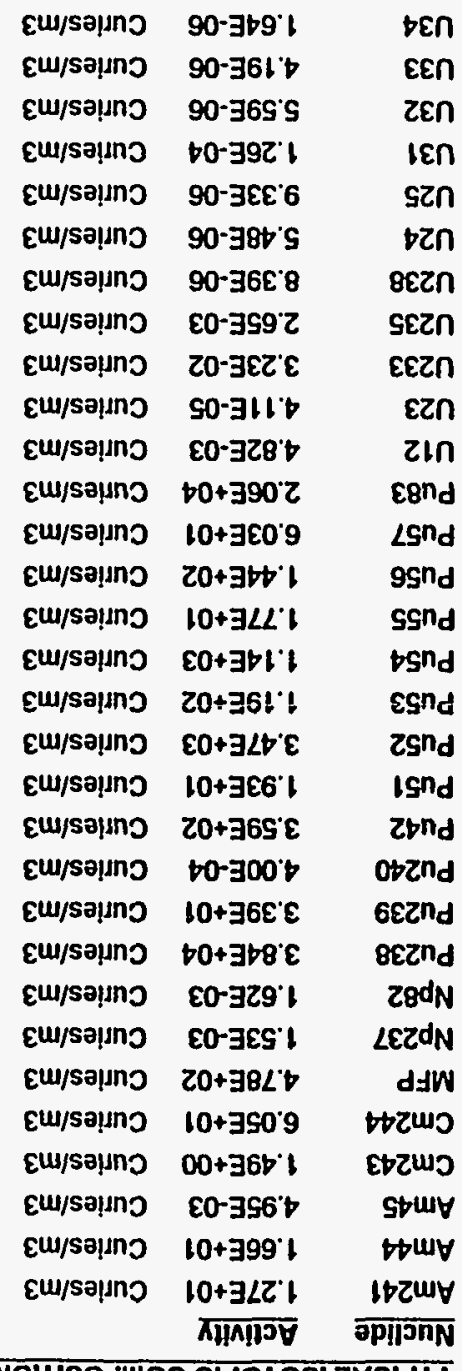

$\varepsilon$

en

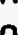

ezzn

SEZn

EZn

2In

cend

asnd

snd

snd

and

zind

snd

abnd

ind

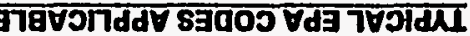

LAfEW 0.09

دNEWU 0.09

N//عw 0.09

SHEW 0.09

SNEW D.09

دNEU 000

gw 6. Sis!

gm L66t

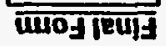

\begin{tabular}{|l|}
\hline 0.09 \\
\hline 0.09 \\
\hline 0.09 \\
\hline 0.09 \\
\hline 0.09 \\
\hline 0.09 \\
\hline $6.515 !$ \\
\hline L66b! \\
\hline p.2501010
\end{tabular}

$: 2202-8002$

:2002-868t

:268L

:8661

:96BL

:\$661

:c66r 10 pug

:2681 $10 \mathrm{pug}$

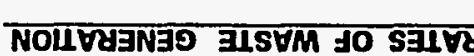

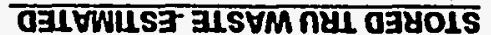
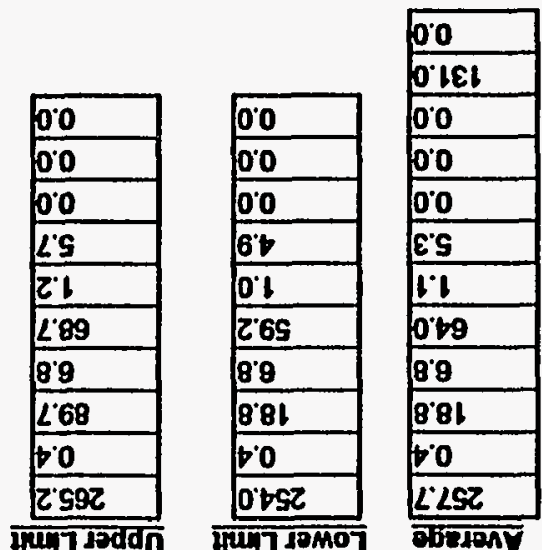

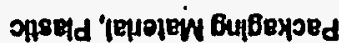

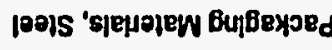

spos

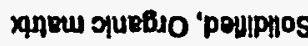

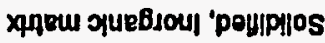

solpseid

joqqny

sotsomntio

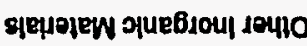

gejow Jerno

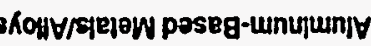

sho|17/s|ejow poseq-uou

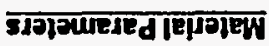

8028 :pojoo[0 sd JoquenN

L6ZL :posols soquinN

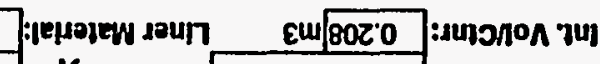
:odk 1 doun

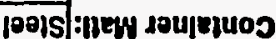

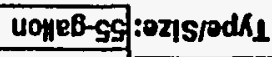

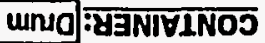

$\overline{\mathbf{1 0 0 I - \forall 7}}$ 
5.21E-05 Curles/m3

6.19E-03 Curies/m3

4.83E-03 Curies $/ \mathrm{m} 3$ 


\section{WASTE STREAM PROFILE FOR THE WIPP TRU WASTE BASELINE INVENTORY REPORT}

\section{SITE NAME LA WASTE TYPE TRU HANDLING CH GENERATOR SITE LA}

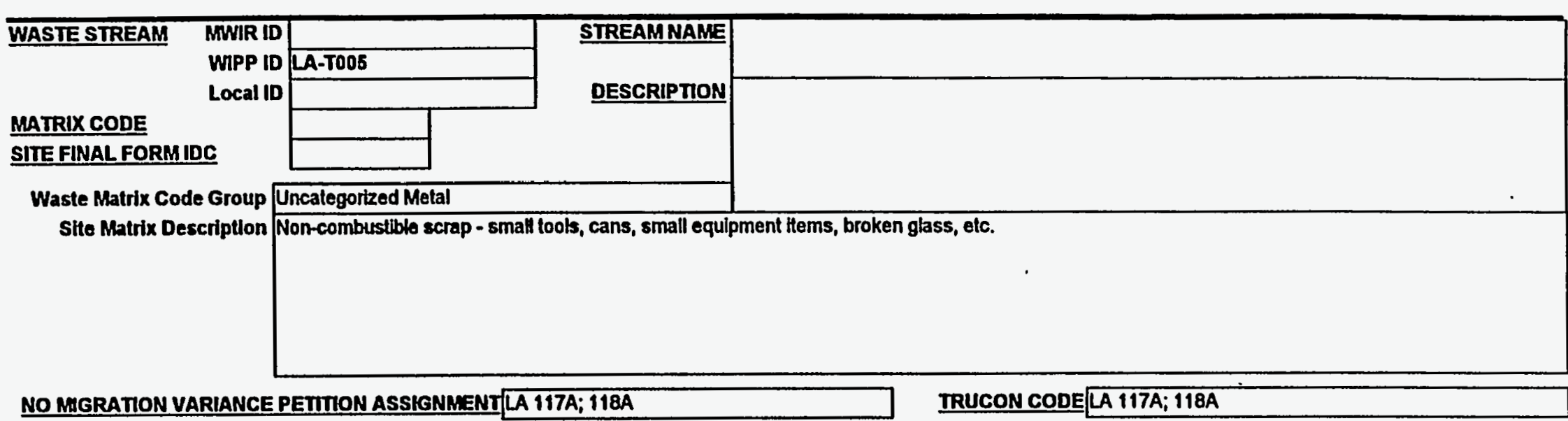

\section{FINAL WASTE FORMDESCRIPTORS:}

\begin{tabular}{l|l}
$\begin{array}{l}\text { Defense TRU Waste } \\
\text { Non-Defense TRU Waste } \\
\text { Commercial TRU Waste } \\
\text { Unknown }\end{array}$ & \\
\hline
\end{tabular}$\quad \begin{aligned} & \text { Mixed TRU } \\
& \text { Non-Mixed TRU } \\
& \text { Suspect Mixed TRU } \\
& \text { Unknown }\end{aligned}$

Rsearch and Devel. Waste Operations Waste

Residues

Decon and Decommissioning

Environmental Restoration

From Trealment of Wasto

Maintenance

\begin{tabular}{l}
$x$ \\
\hline \\
\hline \\
\hline \\
\hline
\end{tabular}

TSCA Asbestos

PCBs

Other

N/A

Unknown 
WASTE STREAM PROFILE FOR THE WIPP TRU WASTE BASELINE INVENTORY REPORT

LA-T005

$$
\begin{array}{cl}
\text { CONTAINER: } & \text { Drum } \\
\text { Type/Size: } 55 \text {-gallon }
\end{array}
$$

Container Matl: Steel

Int. Voucinr: $0.208 \mathrm{m3}$
Number Stored: 6975 Number Projected: 5449
TYPICAL WASTE DENSITIES FOR FINAL WASTE FORM ( $\mathrm{kg} / \mathrm{m} 3)$ STORED TRU WASTE ESTIMATED

Material Parameters

Iron-based Melais/Alloys

Aluminum-Based Metals/Alloys

Other Metals

Other Inorganic Materials

Cellulosics

Rubber

Plastics

Solidified, Inorganic matrix

Solidified, Organic matrix

Soils

Packaging Materials, Steel

Packaging Material, Plastic

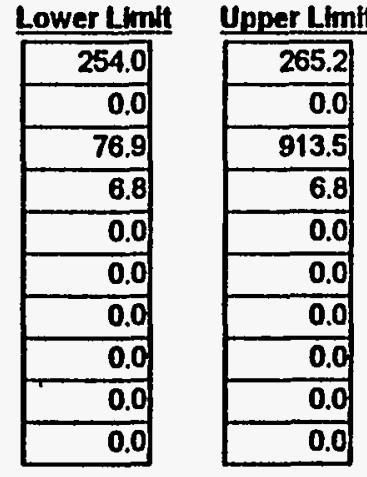

131.0

\begin{tabular}{|c|c|c|}
\hline & Prolected & Final Form \\
\hline End of 1992: & 1433.5 & 1433.5 \\
\hline ad of 1883: & 1449.1 & 1449.1 \\
\hline 1984: & 40.0 & 40.0 \\
\hline 1986: & 40.0 & 40.0 \\
\hline 1896: & 40.0 & 40.0 \\
\hline 1897: & 40.0 & 40.0 \\
\hline 1988-2002: & 40.0 & 40.0 \\
\hline 2003-2022: & 40.0 & 40.0 \\
\hline
\end{tabular}

RATES OF WASTE GENERATION

IYPICAL EPA CODES APPLICABLE
TYPICAL ISOTOPIC COMPOSITION

Nucilde Activity

Ac227 4.37E-01 Curies/m3

Am241 6.00E+01 Curles/m3

Am44 1.55E+01 Curies $/ \mathrm{m} 3$

Am45 2.08E-01 Curies/m3

Bk249 1.00E-03 Curles $/ \mathrm{m}^{3}$

Cd109 2.65E+03 Curies/m3

CR249 1.00E-03 Curles/m3

Cm242 1.02E-03 Curies/m3

Cm244 1.62E+02 Curies/m3

Co60 1.00E-03 Curies/m3

MFP 5.68E+01 Curies $/ \mathrm{m} 3$

Np237 2.59E-03 Curies/m3

Np82 1.86E-03 Curies/m3

Pa231 1.11E-03 Curies $/ \mathrm{m} 3$

Po210 1.00E-03 Curles/m3

Pu238 3.09E+04 Curies $/ \mathrm{m} 3$

Pu239 6.49E+01 Curies/m3

Pu242 3.87E-02 Curies/m3

Pu41 9.00E-02 Curies $/ \mathrm{m} 3$

Pu42 3.23E+02 Curies $/ \mathrm{m} 3$

Pu51 3.99E+02 Curies/m3

Pu52 1.94E+04 Curies $/ \mathrm{m} 3$

Pu53 6.92E+02 Curies/m3

Pu54 1.30E+03 Curies/m3

Pu55 1.69E+02 Curies $/ \mathrm{m} 3$

Pu56 1.33E+02 Curies/m3

Pu57 1.74E+02 Curies $/ \mathrm{m} 3$

Pu83 2.90E+04 Curies/m3

Ra226 9.05E-01 Curies/m3

U12 5.55E-02 Curies $/ \mathrm{m} 3$

U15 6.76E-04 Curies/m3 


\section{WASTE STREAM PROFILE FOR THE WIPP TRU WASTE BASELINE INVENTORY REPORT}

$\begin{array}{lll}\text { U23 } & 7.14 E-06 & \text { Curies } / \mathrm{m} 3 \\ \text { U233 } & 4.08 E+01 & \text { Curies } / \mathrm{m} 3 \\ \text { U235 } & 1.98 E-03 & \text { Curies } / \mathrm{m} 3 \\ \text { U29 } & 3.98 E-07 & \text { Curies } / \mathrm{m} 3 \\ \text { U31 } & 3.91 E-05 & \text { Curies } / \mathrm{m} 3 \\ \text { U32 } & 2.26 E-04 & \text { Curies } / \mathrm{m} 3 \\ \text { U33 } & 2.99 E-06 & \text { Curies } / \mathrm{m} 3 \\ \text { U34 } & 7.62 E-05 & \text { Curies } / \mathrm{m} 3 \\ \text { U35 } & 6.24 E-05 & \text { Curies } / \mathrm{m} 3 \\ \text { U36 } & 3.72 E-04 & \text { Curies } / \mathrm{m3} \\ \text { U37 } & 8.00 E-05 & \text { Curies } / \mathrm{m} 3 \\ \text { U38 } & 1.42 E-03 & \text { Curies } / \mathrm{m} 3 \\ \text { U39 } & 3.34 E-03 & \text { Curies } / \mathrm{m} 3 \\ \text { U70 } & 9.47 E-03 & \text { Curies } / \mathrm{m} 3 \\ \text { U81 } & 1.16 E-02 & \text { Curies } / \mathrm{m} 3\end{array}$


WASTE STREAM PROFILE FOR THE WIPP TRU WASTE BASELINE INVENTORY REPORT

\begin{tabular}{|c|c|c|c|}
\hline SITE NAME LA & & WASTE TYPE TRU & HANDLING CH GENERATOR SITE LA \\
\hline $\begin{array}{ll}\text { WASTESTREAM MWIR ID } \\
\text { WIPP ID }\end{array}$ & LA-TO06 & STREAMNAME & \\
\hline $\begin{array}{l}\text { Local ID } \\
\text { MATRIX CODE } \\
\text { SITE FINAL FORMIDC }\end{array}$ & 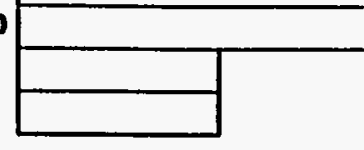 & DESCRIPTION & \\
\hline Waste Matrix Code Group $\mathbf{S}$ & Solldified Inorganics & & \\
\hline Site Matrix Description $\bar{C}$ & Cemented process restdues. & & \\
\hline
\end{tabular}

NO MURATION VARIANCE PETIION ASSIGNMENT LA 114A

IRUCON CODE LA 114A

FINAL WASTE FORM DESCRIPTORS:

\begin{tabular}{|c|c|}
\hline Defense TRU Waste & Mbxed TRU \\
\hline Non-Defense TRU Waste & Non-Mbed TRU \\
\hline $\begin{array}{l}\text { Commerclal TRU Waste } \\
\text { Unknown }\end{array}$ & $\begin{array}{l}\text { Suspect Mixed TRU } \\
\text { Unknown }\end{array}$ \\
\hline
\end{tabular}

$\square$

\begin{tabular}{l}
$\begin{array}{l}\text { Rsearch and Devel. Waste } \\
\text { Operations Waste } \\
\text { Residues }\end{array}$ \\
$\begin{array}{l}\text { Decon and Decommissioning } \\
\text { Environmental Restoration } \\
\text { From Treatment of Waste } \\
\text { Malntenance }\end{array}$ \\
\hline \\
\\
\end{tabular}

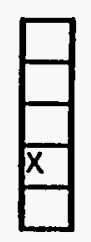




\begin{tabular}{|c|c|c|}
\hline Inכ & SO- $\exists 6 b^{\circ} L$ & $8 \varepsilon n$ \\
\hline u/so|jno & So- $\exists 99 \cdot 9$ & gezn \\
\hline !!no & $60-\exists \angle b 6$ & EEZก \\
\hline u/sẹ!no & $20+\exists \angle 0^{\prime} 9$ & EBnd \\
\hline u/sa|jno & $00+\exists b s 2 z$ & Gsnd \\
\hline w/sə!ınว & $\varepsilon 0-\exists|t\rangle$ & snd \\
\hline w/sa!̣no & $00+38<' S$ & rsnd \\
\hline u/səu!no & $20-3601$ & isnd \\
\hline u/sa!̣nว & $10-3 E b / S$ & epond \\
\hline u/sə|ฺnก & $10-\exists 8 \varepsilon^{\prime}$ & $6 \varepsilon z n_{d}$ \\
\hline /sąın & $90-\exists 90^{\circ} \mathrm{L}$ & \\
\hline
\end{tabular}

NOIISOdWOJ गावOIOSI 78Ddय

\begin{tabular}{|c|c|c|c|}
\hline \multicolumn{4}{|c|}{ 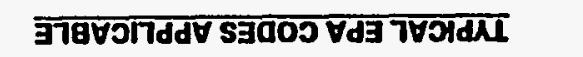 } \\
\hline shew & 0.1 & 01 & |:2zoz-c00z \\
\hline SNEW & 0.1 & 0.1 & :200z-8686 \\
\hline N/EW & 0.1 & 01 & $: 2681$ \\
\hline shqu & 0.1 & 01 & :866t \\
\hline دNEWW & 0.1 & 0.1 & :9661 \\
\hline$د / / \varepsilon W$ & 5 & $\mathrm{~S}^{\prime}$ & : 8661 \\
\hline cus & sit & 96 & :8681 jo pug \\
\hline sw & sit & sto & : 266เ jo pug \\
\hline
\end{tabular}

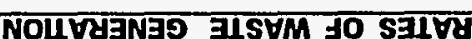

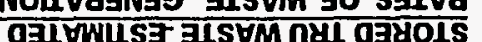

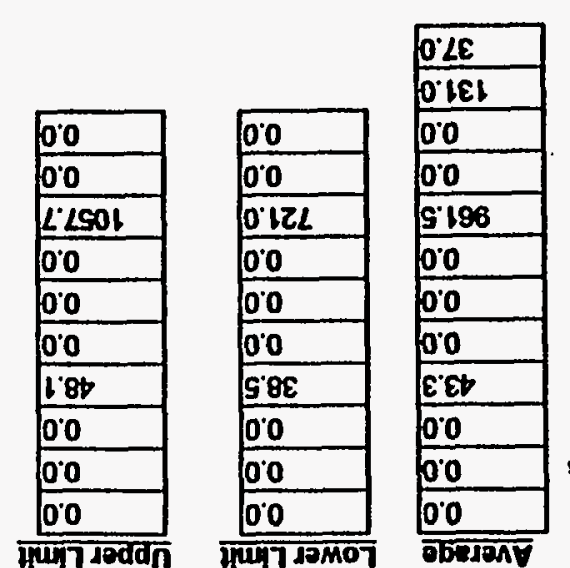

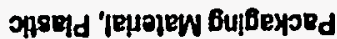
[əa)s 's|ejpjew Bujbeyoed

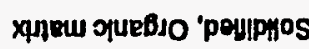

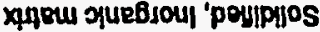

sonsetd

Jeqqny

cojsojnies

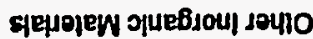

sjelaw serno

Roty/s|ejow poseg-unupunit

shonf/S|Ejow poseq-uod

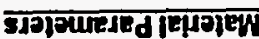




\section{WASTE STREAM PROFILE FOR THE WIPP TRU WASTE BASELINE INVENTORY REPORT}

SITE NAME LA

WASTE TYPE TRU HANDLING CH GENERATOR SITE LA

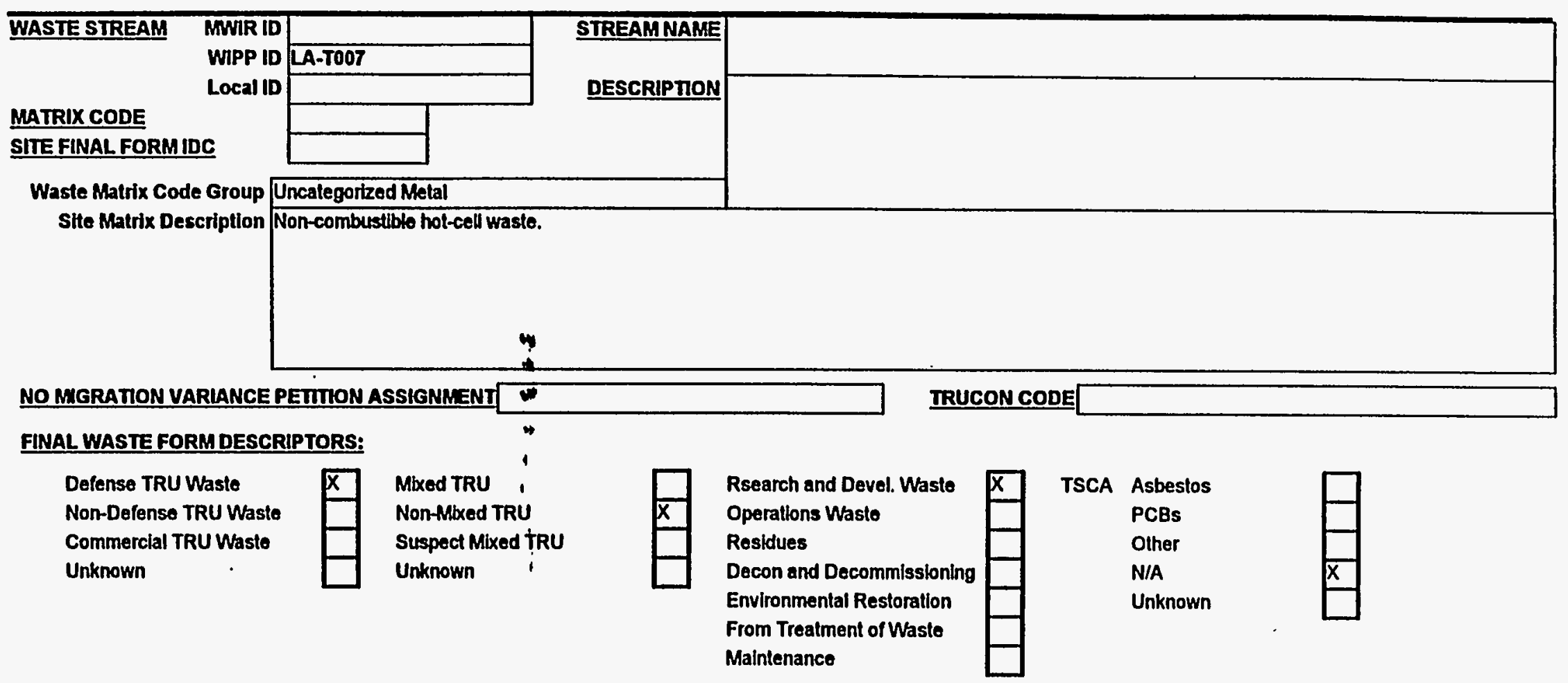




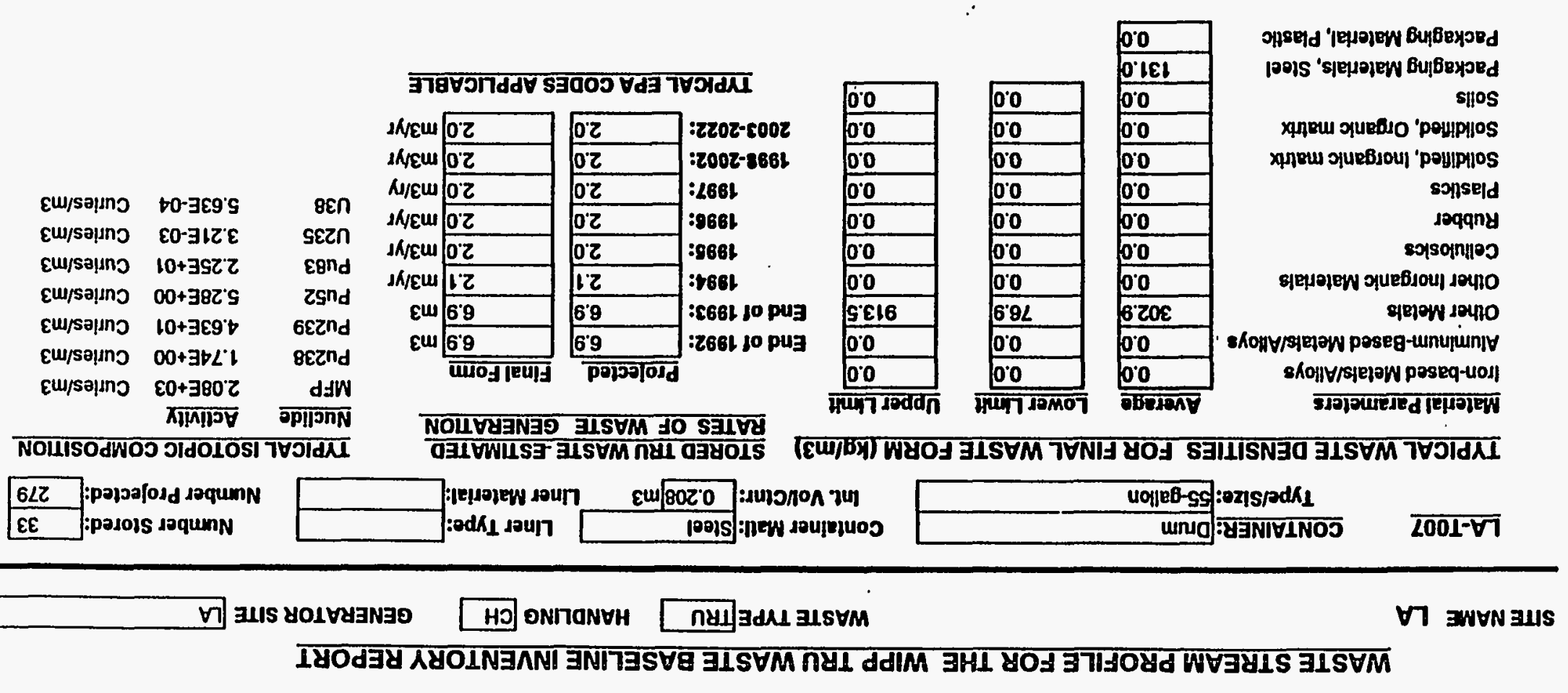




\section{WASTE STREAM PROFILE FOR THE WIPP TRU WASTE BASELINE INVENTORY REPORT}

SITE NAME LA WASTE TYPETRU HANDLING CH GENERATOR SITE LA

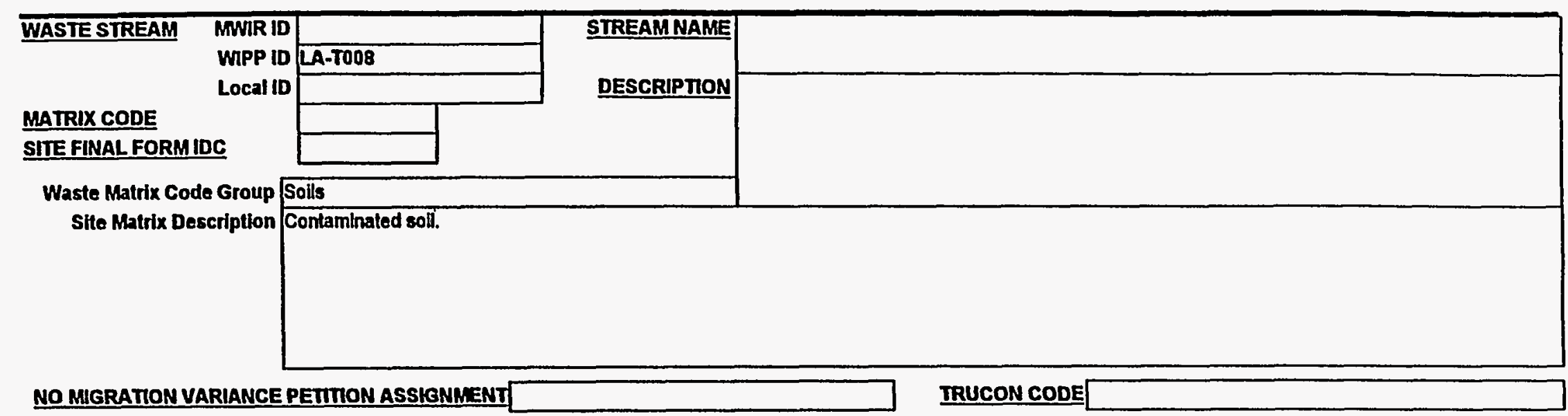

\section{FINAL WASTE FORM DESCRIPTORS:}

\begin{tabular}{l|l}
$\begin{array}{l}\text { Defense TRU Waste } \\
\text { Non-Defense TRU Waste } \\
\text { Commerclal TRU Waste } \\
\text { Unknown }\end{array}$ & $\square$
\end{tabular}

$\square$

Rsearch and Devel. Waste
Operaltons Waste
Residues
Decon and Decommlssioning
Environmenlal Restoration
From Treatment of Waste
Maintenance

\begin{tabular}{|c|c|c|}
\hline$x$ & TSCA & Asbestos \\
\hline & & PCBs \\
\hline & & Other \\
\hline & & N/A \\
\hline & & Unknown \\
\hline & & \\
\hline & & \\
\hline
\end{tabular}

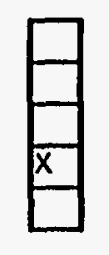




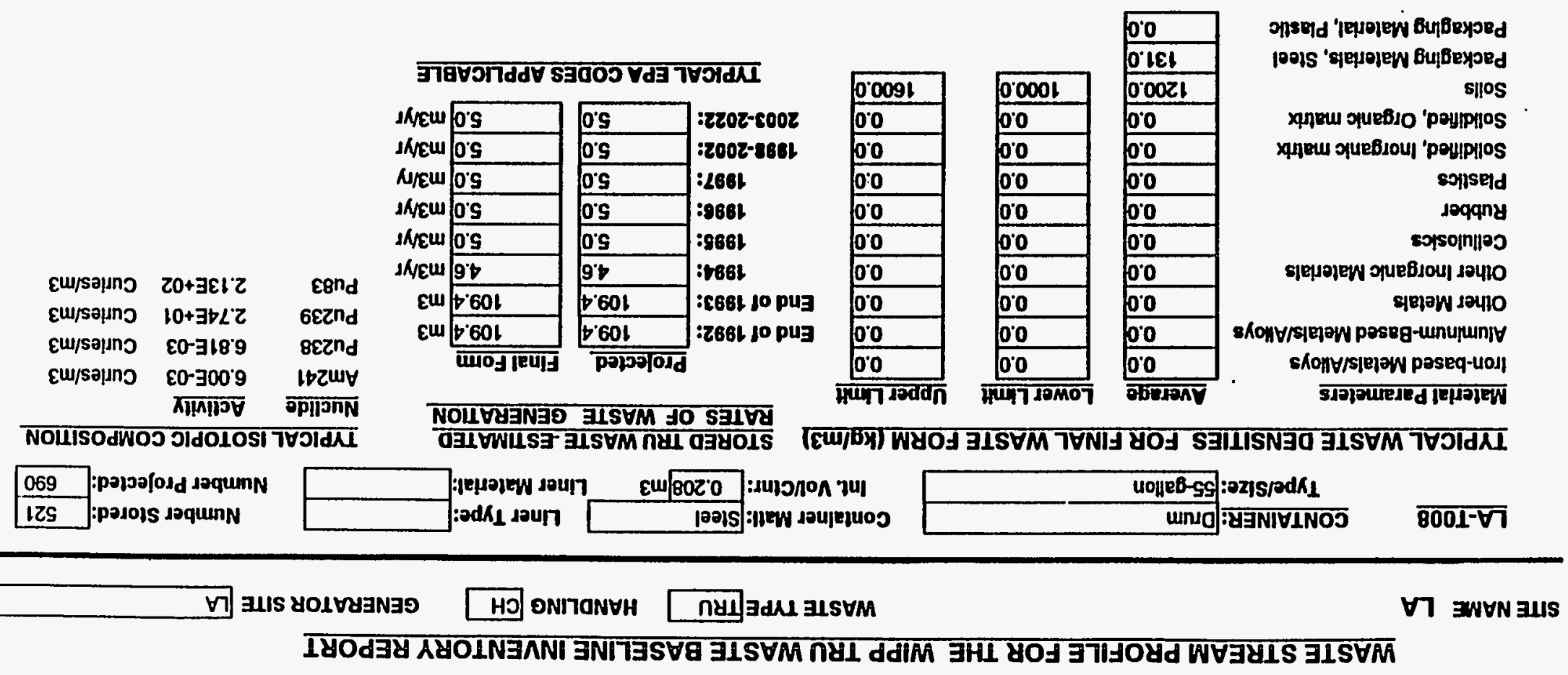




\section{WASTE STREAM PROFILE FOR THE WIPP TRU WASTE BASELINE INVENTORY REPORT}

SITENAME LA

WASTE TYPE TRU HANDLING CH GENERATOR SITE LA

WASTE STREAM MWIR ID
SIIE FINAL FORMIDC
Waste Matrix Code Group Uncalogorized Metal
Site Matrix Description Melal from gloveboxes \& equipment repackaged from FRP boxes.

NO MGRATION VARIANCE PETIION ASSIGNMENT

IRUCON CODE

\section{FINAL WASTE FORMDESCRIPTORS:}

Defense TRU Wasto

Non-Defense TRU Waste

Commercial TRU Wasto

Unknown

$x$

Mixed TRU

Non-Mixed TRU

Suspect Mixed TRU

Unknown

$\square$

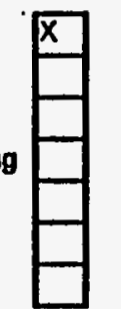

TSCA Asbestos
PCBs
Other
N/A
Unknown

Treatment of Waste

Maintenance

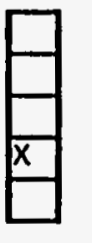



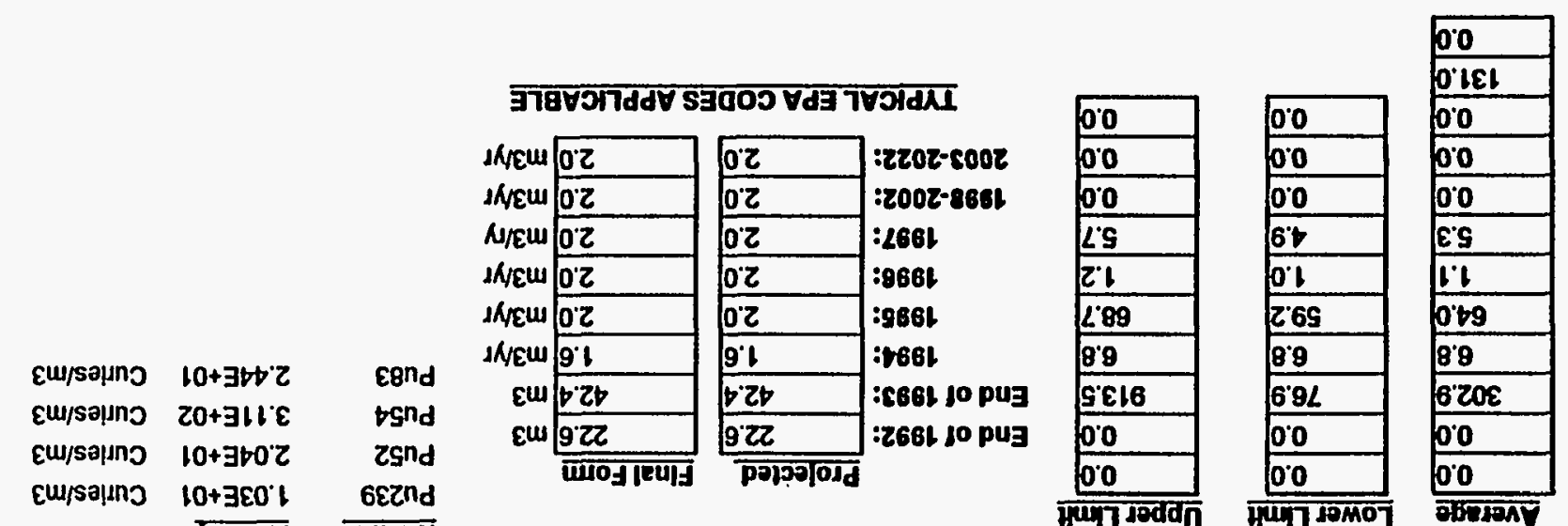

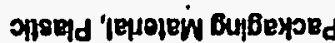
povs 'slepriew Bujbryord

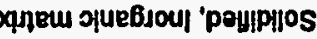

sollseyd seqqny sơsọn!100

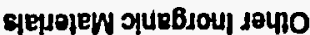
gejew Jouno

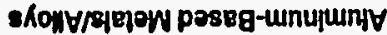

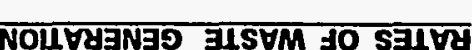

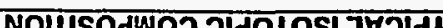

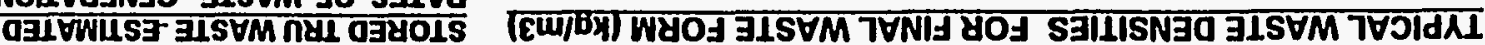
:odK 1 sour

$\overline{6001-\forall 7}$ 
WASTE STREAM PROFILE FOR THE WIPP TRU WASTE BASELINE INVENTORY REPORT

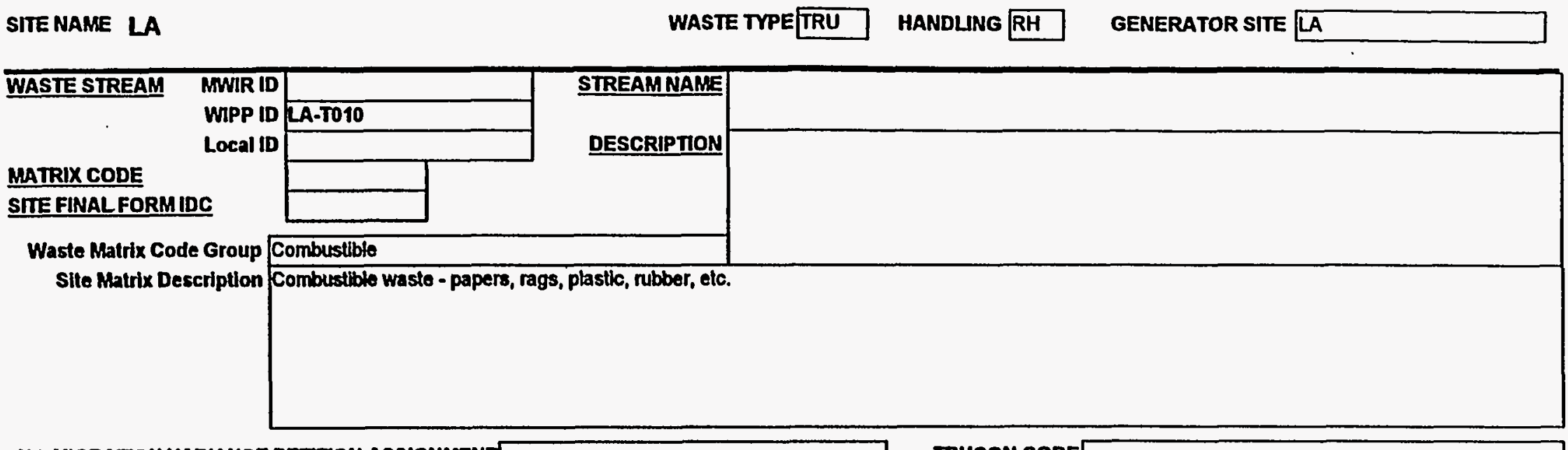

NO MGRATION VARIANCE PETIION ASSIGNMENT $\square$ IRUCON CODE

\section{FINAL WASTE FORM DESCRIPTORS:}

\begin{tabular}{l|l} 
Defense TRU Waste \\
Non-Defense TRU Waste \\
Commerclal TRU Waste \\
Unknown
\end{tabular}$\quad \square \begin{aligned} & \text { Mbxed TRU } \\
& \text { Non-Mbxed TRU } \\
& \text { Suspect Mixed TRU } \\
& \text { Unknown }\end{aligned}$

Rsearch and Devel. Waste
Operations Waste
Residues
Decon and Decommissioning
Environmental Restoration
From Treatment of Waste
Malntenance

TSCA Asbestos

PCBs

Other

N/A

Unknown

Malntenance

, 


\section{SITE NAME LA WASTE TYPETRU MANDLING RH GENERATOR SITE LA}

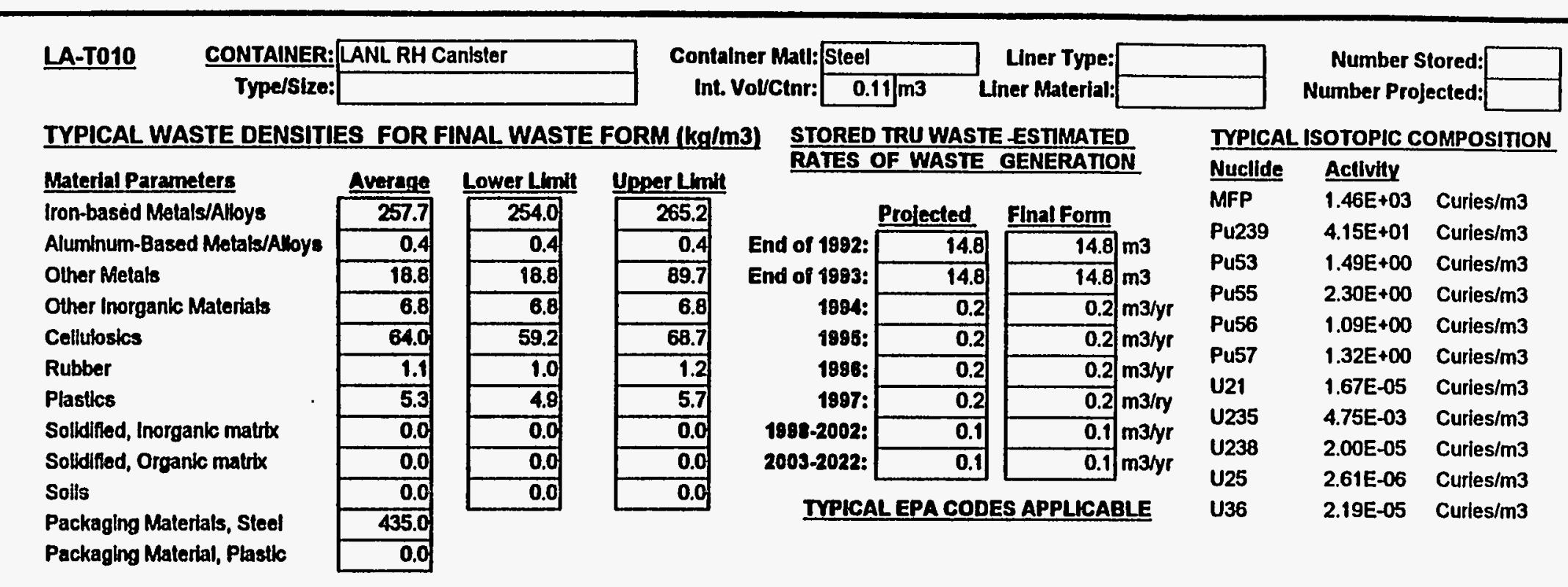




\section{WASTE STREAM PROFILE FOR THE WIPP TRU WASTE BASELINE INVENTORY REPORT}

SITE NAME LA WASTE TYPETTUU HANDLING RH GENERATOR SITE LA

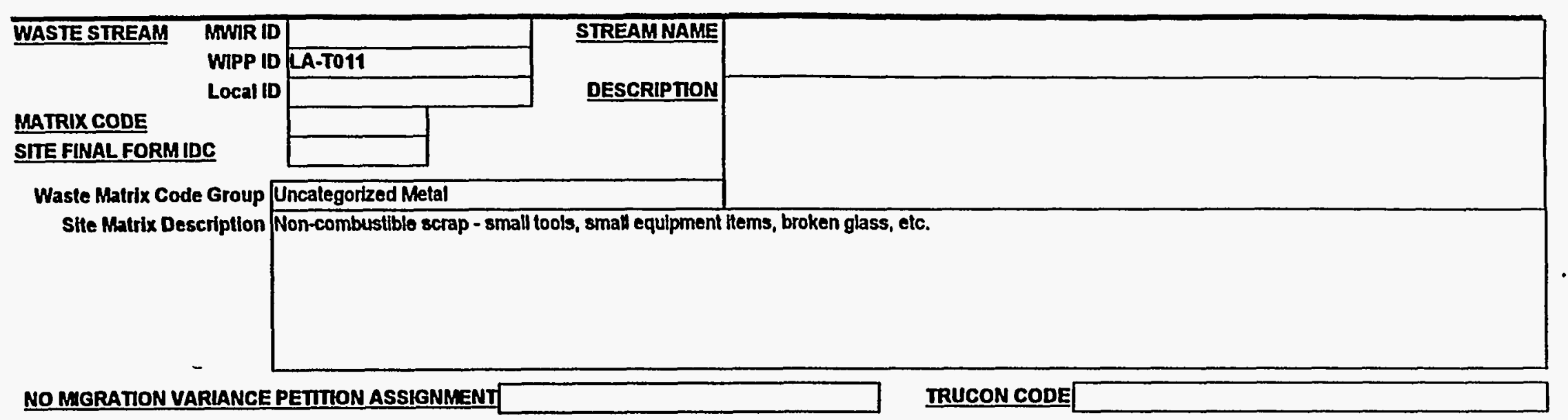

FINAL WASTE FORMDESCRIPTORS:

\begin{tabular}{l|l}
$\begin{array}{l}\text { Defense TRU Waste } \\
\text { Non-Defense TRU Waste } \\
\text { Commercial TRU Waste } \\
\text { Unknown }\end{array}$ & $\square$
\end{tabular}

Rsearch and Devel. Waste Operallons Wasto

Resldues

Decon and Decommissioning

Environmental Restoration

From Trealment of Waste

Maintenance

X

TSCA Asbestos

PCBs

Other

N/A

Unknown 


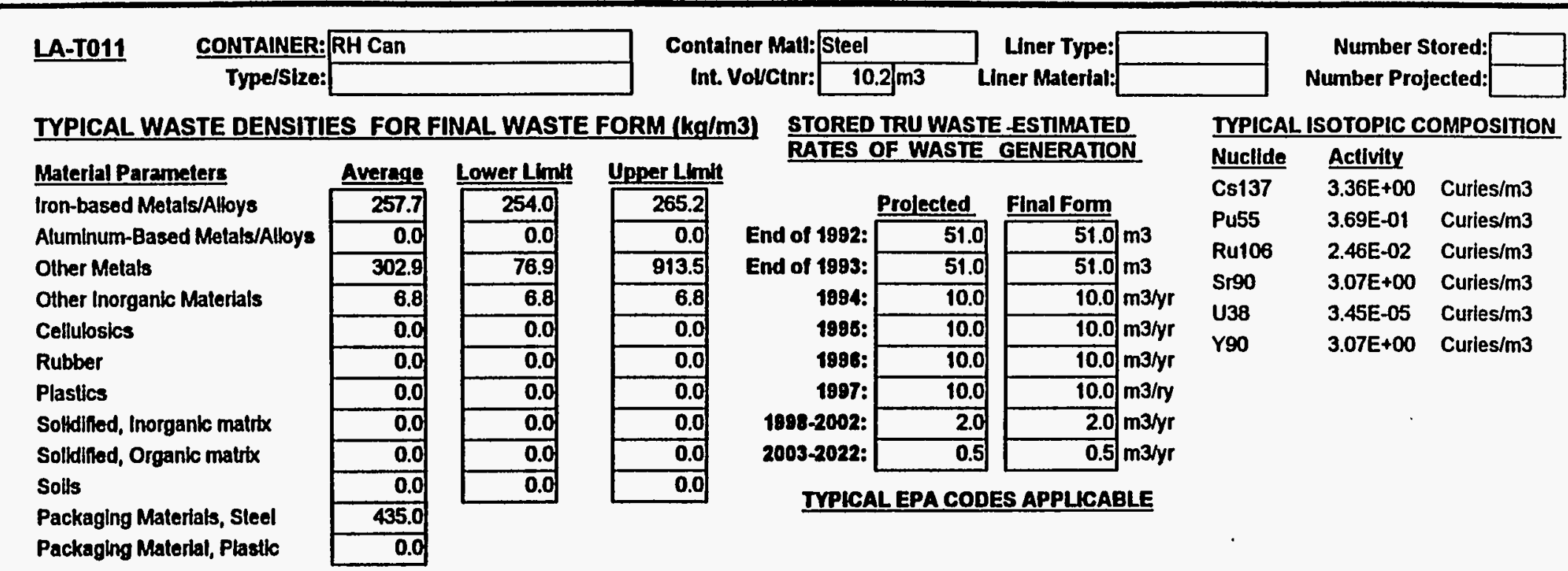




\section{WASTE STREAM PROFILE FOR THE WIPP TRU WASTE BASELINE INVENTORY REPORT}

SITE NAME LA

WASTE TYPETRU HANDLING RH GENERATOR SITE LA

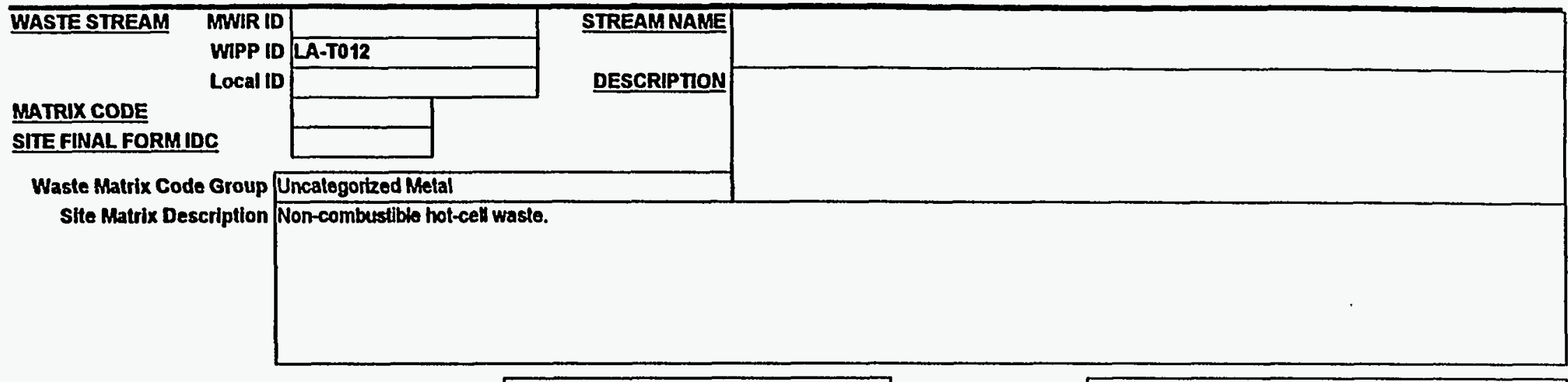

NO MGRATION VARLANCE PETITON ASSIGNMENTI

IRUCON CODE

FINAL WASTE FORM DESCRIPTORS:

Defense TRU Waste

Non-Defense TRU Waste

Commercial TRU Waste

Unknown

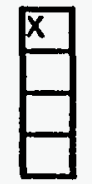

Mixed TRU

Non-Mixed TRU

Suspect Mixed TRU

Unknown

Rsearch and Devel. Waste
Operations Waste
Residues
Decon and Decommissioning
Environmental Restoration
From Treatment of Waste
Maintenance

Rsearch and Devel. Waste

Operations Waste

Decon and Decommissioning

From Treat

Maintenance
TSCA Asbestos

PCBs

Other

N/A

Unknown

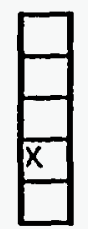




\section{WASTE STREAM PROFILE FOR THE WIPP TRU WASTE BASELINE INVENTORY REPORT}

SITE NAME LA

WASTE TYPETRU HANDLING RH GENERATOR SITE LA

LA-T012 CONTAINER: RHCan

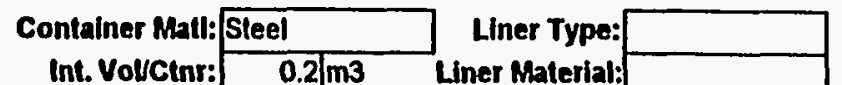

Number Stored Number Projected:

\section{TYPICAL WASTE DENSITIES FOR FINAL WASTE FORM $(\mathrm{kg} / \mathrm{m3})$ STORED TRU WASTE ESTIMATED}

Material Parameters Iron-based Metals/Alloys

Aluminum-Based Metals/Alloys

Other Metals

Other Inorganic Materials

Cellulosics

Rubber

Plastics

Solidified, Inorganic matrix Solidined, Organic matrix

Solls

Packaging Malerials, Steel

Packaging Material, Plastic

\begin{tabular}{|r|} 
Average \\
\hline 0.0 \\
\hline 0.0 \\
\hline 302.0 \\
\hline 0.0 \\
\hline 0.0 \\
\hline 0.0 \\
\hline 0.0 \\
\hline 0.0 \\
\hline 0.0 \\
\hline 0.0 \\
\hline 435.0 \\
\hline 0.0 \\
\hline
\end{tabular}

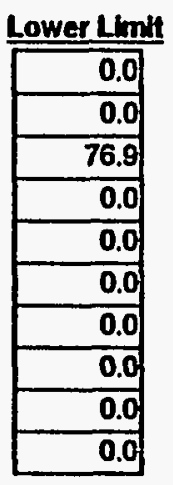

\begin{tabular}{|r|}
\hline Upper Limit \\
\hline 0.0 \\
\hline 0.0 \\
\hline 913.5 \\
\hline 0.0 \\
\hline 0.0 \\
\hline 0.0 \\
\hline 0.0 \\
\hline 0.0 \\
\hline 0.0 \\
\hline 0.0 \\
\hline
\end{tabular}

RATES OF WASTE GENERATION

\begin{tabular}{r|r|} 
& Prolected \\
\hline End of 1992: & 10.5 \\
\hline End of 1993: & 10.5 \\
\hline 1994: & 0.5 \\
\hline 1995: & 0.5 \\
\hline $1998:$ & 0.5 \\
\hline $1997:$ & 0.5 \\
\hline 1980-2002: & 0.1 \\
\hline $2003-2022:$ & 0.1 \\
\hline
\end{tabular}

Final Form

TYPICAL ISOTOPIC COMPOSITION

Nuclide Activily

MFP 1.87E+03 Curies/m3

Pu239 3.24E+01 Curies $/ \mathrm{m} 3$

U235 3.36E-03 Curles/m3

TYPICAL EPA CODES APPLICABLE 
WASTE STREAM PROFILE FOR THE WIPP TRU WASTE BASELINE INVENTORY REPORT

SITE NAME LA

WASTE TYPE MTRU HANDLING CH GENERATOR SITE LA

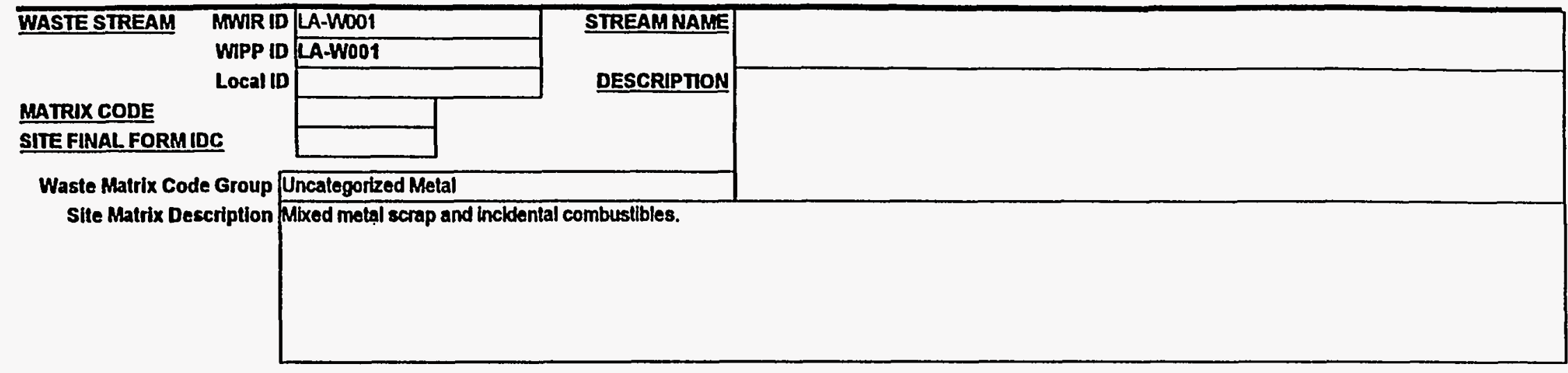

NO MGRATION VARIANCE PETIION ASSIGNMENT LA 125A

IRUCON CODE LA 125A

FINAL WASTE FORMDESCRIPTORS:

\begin{tabular}{l|l} 
Defense TRU Waste \\
Non-Defense TRU Waste \\
Commerclal TRU Waste \\
Unknown
\end{tabular}$\quad \square \quad \begin{aligned} & \text { Mixed TRU } \\
& \text { Non-Mbed TRU } \\
& \text { Suspect Mibed TRU } \\
& \text { Unknown }\end{aligned}$

Rsearch and Devel. Waste

Operatlons Waste

Residues

Decon and Decommissloning

Environmental Restoration

From Treatment of Waste

Maintenance

\begin{tabular}{|l|l|}
\hline TSCA & $\begin{array}{l}\text { Asbestos } \\
\text { PCBs } \\
\text { Other } \\
\text { N/A } \\
\text { Unknown }\end{array}$ \\
\hline & \\
\hline
\end{tabular}




\section{WASTE STREAM PROFILE FOR THE WIPP TRU WASTE BASELINE INVENTORY REPORT}

LA-WOO

CONTAINER: Drum

Container Matl: Steel

Liner Type:

Number Stored: 10507

TYPICAL WASTE DENSITIES FOR FINAL WASTE FORM (kg/m3)

STORED TRU WASTE ESTIMATED

Material Parameters

Iron-based Metals/Alloys

Aluminum-Based Metals/Alloys

Other Metats

Other Inorganic Materials

Cellulosics

Rubber

Plastlos

Solldified, Inorganic matrix

Solidifled, Organic matrix

Soils

Packaging Materials, Steel

Packaging Matertal, Plastic

\begin{tabular}{|r|} 
Average \\
\hline 0.0 \\
\hline 0.0 \\
\hline 302.9 \\
\hline 6.0 \\
\hline 64.0 \\
\hline 1.1 \\
\hline 5.2 \\
\hline 0.0 \\
\hline 0.0 \\
\hline 0.0 \\
\hline 131.0 \\
\hline 0.0 \\
\hline
\end{tabular}

\begin{tabular}{r|}
\hline Lower L.mit \\
\hline 0.0 \\
\hline 0.0 \\
\hline 76.9 \\
\hline 6.8 \\
\hline 59.2 \\
\hline 1.0 \\
\hline 4.9 \\
\hline 0.0 \\
\hline 0.0 \\
\hline 0.0 \\
\hline
\end{tabular}

\section{Upper Llnit}

\begin{tabular}{|r|}
\hline 0.0 \\
\hline 0.0 \\
\hline 913.5 \\
\hline 6.8 \\
\hline 68.7 \\
\hline 1.2 \\
\hline 5.4 \\
\hline 0.0 \\
\hline 0.0 \\
\hline 0.0 \\
\hline
\end{tabular}

0.0

\begin{tabular}{|c|c|c|c|}
\hline & Prolected & Final Form & \\
\hline End of 1992: & 2206.4 & 2206.4 & $\mathrm{~m} 3$ \\
\hline End of 1993: & 2206.4 & 2206.4 & m3 \\
\hline 1994: & 4.6 & 4.6 & $\mathrm{m} 3 / \mathrm{yr}$ \\
\hline 1995: & 5.0 & 5.0 & m3/yr \\
\hline 1996: & 5.0 & 5.0 & $\mathrm{~m} 3 / \mathrm{yr}$ \\
\hline 1997: & 5.0 & 5.0 & $\mathrm{~m} 3 / \mathrm{ry}$ \\
\hline 1988-2002: & 5.0 & 5.0 & $\mathrm{~m} 3 \mathrm{hr}$ \\
\hline 2003-2022: & 5.0 & 5.0 & $\mathrm{~m} 3 / \mathrm{yr}$ \\
\hline
\end{tabular}

IYPLCAL EPA CODES APPLKCABLE DoO1C
Number Projected: 690

TYPICAL ISOTOPIC COMPOSITION

Nuclide Activity

Am241 7.46E-03 Curies $/ \mathrm{m} 3$

Am44 0.00E+00 Curies $/ \mathrm{m}^{3}$

Ba137m 1.43E+00 Curies $/ \mathrm{m} 3$

C1251 1.60E-03 Curies $/ \mathrm{m} 3$

Cs137 1.52E+00 Curies $/ \mathrm{m} 3$

Eu155 6.13E-02 Curies $/ \mathrm{m} 3$

H3 $0.00 E+00$ Curies $/ \mathrm{m} 3$

MAP - 5.00E-02 Curies/m3

MFP 6.01E+02 Curies $/ \mathrm{m} 3$

Np237 4.00E-10 Curies/m3

Pm147 8.68E-02 Curies/m3

Pu238 3.95E+03 Curies/m3

Pu239 4.32E+02 Curies/m3

Pu42 8.04E-01 Curies/m3

Pu51 6.52E-02 Curies/m3

Pu52 4.60E+02 Curies $/ \mathrm{m}^{3}$

Pu53 2.26E-01 Curies/m3

Pus4 2.74E+01 Curies/m3

Pu55 4.24E+00 Curies $/ \mathrm{m3}$

Pu56 2.56E +00 Curles $/ \mathrm{m} 3$

Pu83 9.70E-02 Curies/m3

Ra226 1.30E-03 Curles/m3

Rh106 1.12E-02 Curies/m3

Ru106 1.12E-02 Curies/m3

Sb125 6.19E-02 Curies/m3

Sr90 1.39E +00 Curies $/ \mathrm{m3}$

Te125m 2.57E-02 Curies/m3

U12 2.02E-03 Curies $/ \mathrm{m}^{3}$

U233 $\quad 0.00 E+00$ Curies $/ \mathrm{m}^{3}$

U235 3.09E-02 Curies/m3

U238 2.00E-06 Curies/m3 


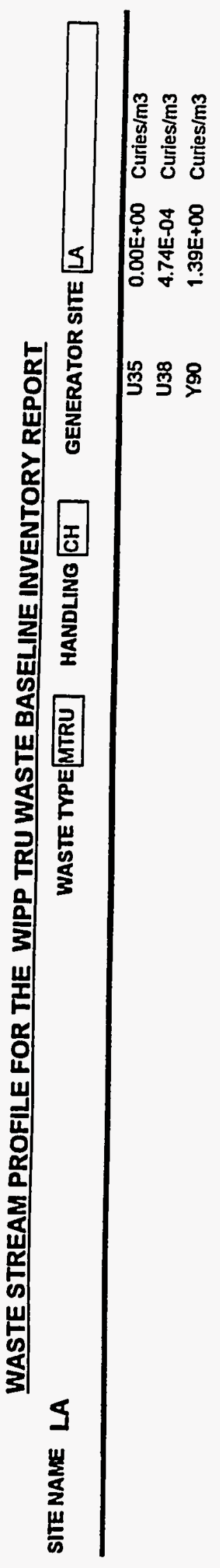

$\stackrel{\text { N }}{\dot{s}}$

$\frac{7}{8}$ 


\section{WASTE STREAM PROFILE FOR THE WIPP TRU WASTE BASELINE INVENTORY REPORT}

SITE NAME LA

WASTE TYPE MTRU HANDLING CH GENERATOR SITE LA

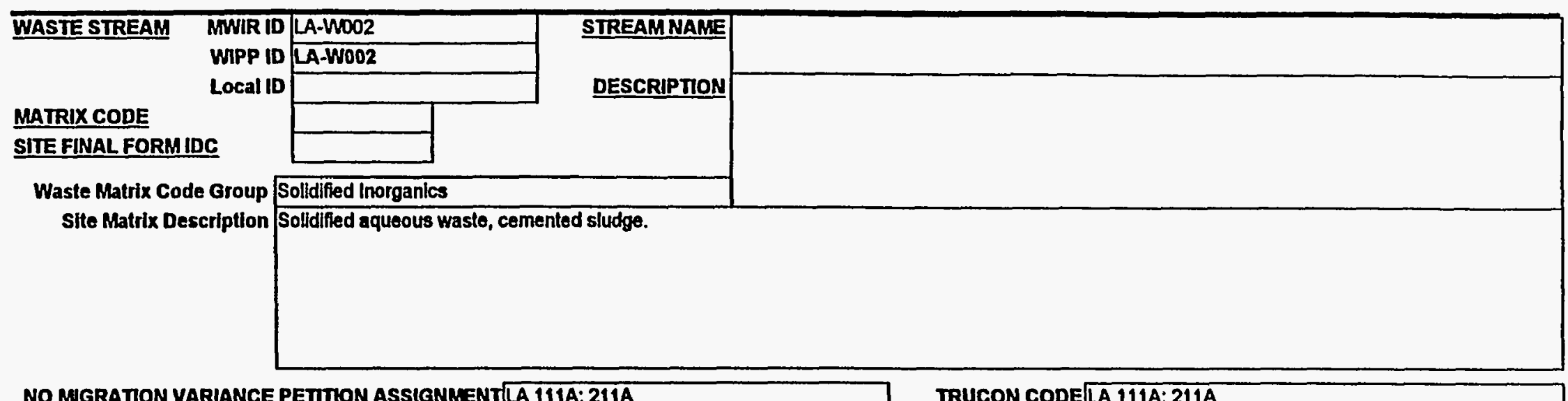

NO MUGATION VARIANCE PETIIION ASSIGNMENT LA 111A; 211A

IRUCON CODE LA 111A; 211A

\section{FINAL WASTE FORMDESCRIPTORS:}

Defense TRU Waste

Non-Defense TRU Waste

Commerclal TRU Waste

Unknown

X

Mbed TRU

Non-Mixed TRU

Suspect Mixed TRU

Unknown

Rsearch and Devel. Waste
Operatlons Waste
Residues
Decon and Decommlssioning
Environmental Restoration
From Treatment of Waste
Maintenance

$\square$
TSCA Asbestos

PCBs

Other

NIA

Unknown $\square$ 


\begin{tabular}{|c|c|c|}
\hline d/salth & EO-تSt' & $18 n$ \\
\hline$\mu / s \theta \mu n \rho$ & $80 . \exists 8 L^{\circ}$ & oezn \\
\hline u/se!ıno & $20-\exists 0 t^{\prime} Z$ & sezn \\
\hline u/so|ıno & $20-\exists 00 ' Z$ & EEzก \\
\hline u/sopuno & $\varepsilon 0-\exists 8 \varepsilon ' s$ & $\ln$ \\
\hline u/seunno & $60-360^{\circ} 1$ & 8841 \\
\hline u/səuฺnว & $00+\exists \varepsilon L Z Z$ & Itbznd \\
\hline u/soụno & $20+\exists ̣ b \varepsilon 8$ & $6 \varepsilon z n_{d}$ \\
\hline u/sopuno & $20+39 b^{\prime} \mid$ & $8 \varepsilon z n_{d}$ \\
\hline u/sə|̣no & $00+\exists \angle \nabla^{\prime} 6$ & $d \exists w$ \\
\hline u/se|ung & $t 0+\exists 6 \varepsilon !$ & ItZuस \\
\hline 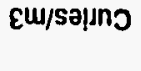 & 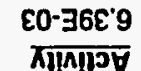 & $\frac{\text { ObZW }}{\text { aplJnN }}$ \\
\hline
\end{tabular}

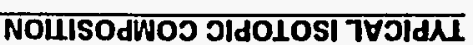

\begin{tabular}{|c|c|c|c|}
\hline \multicolumn{4}{|c|}{ arooa } \\
\hline \multicolumn{4}{|c|}{ 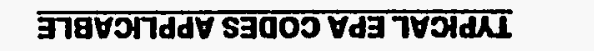 } \\
\hline AREW & $0.0 z$ & 0.02 & ]:2202-8002 \\
\hline دKEU & $0.0 z$ & 0.02 & $: 2002-8061$ \\
\hline K/EW & 0.02 & 0.02 & $: \angle 682$ \\
\hline دKfEW & 0.02 & 0.02 & :968t \\
\hline LKEW & 0.02 & 0.02 & :966 \\
\hline IN/EW & 0.02 & 0.02 & :r66t \\
\hline Em & O'ESOE & O'ESOE & : 8661 jo pug \\
\hline \&w & LOSOE & tosos & :266เ jo pug \\
\hline & ब1rog & papa & \\
\hline
\end{tabular}

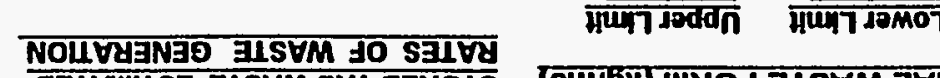

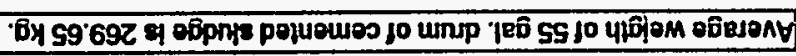

slueunuos

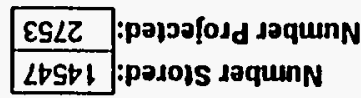

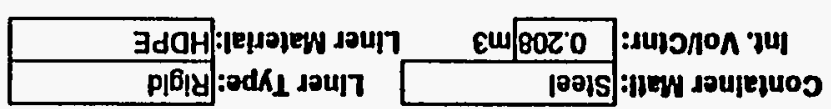

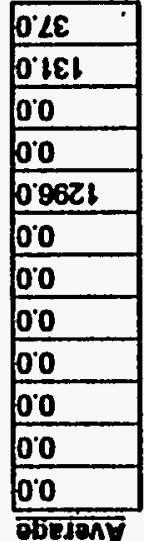

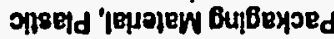

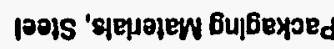

silos

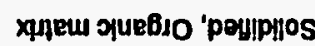

хұлеw эuebsoul 'poy!phos

sopsseid

deqqny

soysopnjes

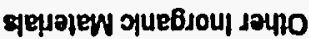

sepow dorno

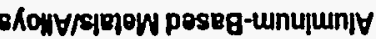

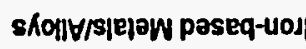

अगुज्ताएवासमगुल

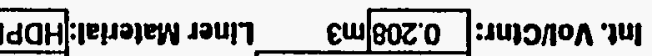

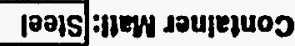

\begin{tabular}{|c|c|c|}
\hline uONeb-gS & $: 0 z / 5 / o d K_{\perp}$ & \\
\hline unio & :४घNIVINOD & $\overline{200 M-\nabla 7}$ \\
\hline
\end{tabular}

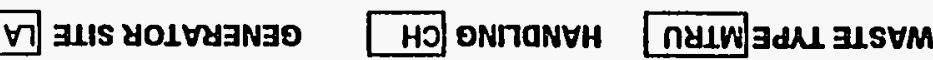

ชา BNYN ZuS 
WASTE STREAM PROFILE FOR THE WIPP TRU WASTE BASELINE INVENTORY REPORT

SITE NAME LA

WASTE TYPE MTRU

HANDLINO CH

GENERATOR SITE LA

WASTE STREAM MWIR ID LA-WO03
WIPP ID LA-W003
Local ID

NO MMGRATION UARIANCE PETITON ASSIGNMENT LA1118; 2118

IRUCON CODE LA 111B; 211B

FINAL WASTE FORMDESCRIPTORS:

Defense TRU Waste

Non-Defense TRU Waste

Commercial TRU Wasto

Unknown

$\square$

Mixed TRU

Non-Mixed TRU

Suspect Mbxed TRU

Unknown
TSCA Asbeslos

PCBs

Other

N/A

Unknown

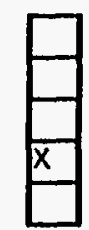

Malntenance 
WASTE STREAM PROFILE FOR THE WIPP TRU WASTE BASELINE INVENTORY REPORT

SITE NAME LA

WASTE TYPE MTRU HANDLING CH GENERATOR SITE LA

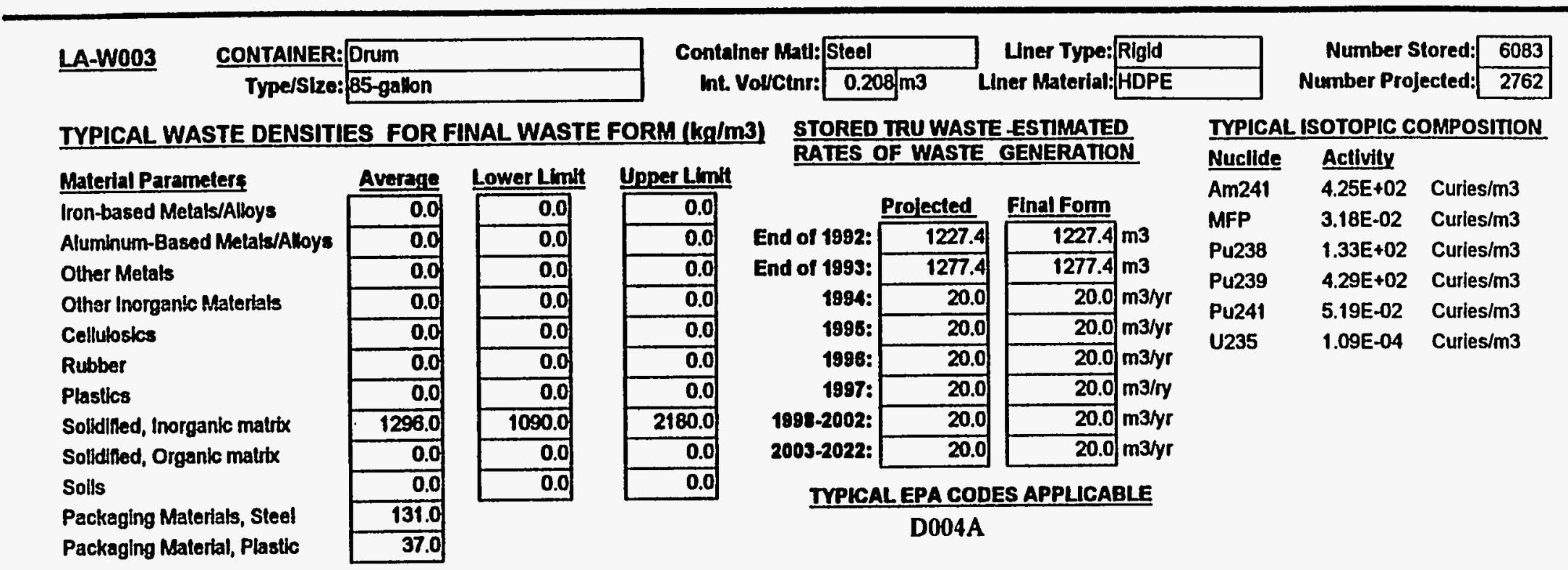


WASTE STREAM PROFILE FOR THE WIPP TRU WASTE BASELINE INVENTORY REPORT

SITE NAME LA

WASTE TYPE MTRU HANDLING CH GENERATOR SITE LA

\begin{tabular}{l|l|l|l|}
\hline WASTE STREAM & MWIR ID LA-WOO4 \\
\hline
\end{tabular}

NO MIGRATION VARIANCE PETIION ASSIGNMENT LA 116A

IRUCON CODE LA 116A

FINAL WASTE FORM DESCRIPTORS:

\begin{tabular}{l|l} 
Defense TRU Waste \\
Non-Defense TRU Waste \\
Commercial TRU Waste \\
Unknown
\end{tabular}

$\square$

$\begin{aligned} & \text { Rsearch and Devel. Waste } \\ & \text { Operations Wasto } \\ & \text { Resldues }\end{aligned}$
$\begin{aligned} & \text { Decon and Decommlssioning } \\ & \text { Environmental Restoration } \\ & \text { From Treatment of Waste } \\ & \text { Maintenance }\end{aligned}$

$\square$




\begin{tabular}{|c|c|c|}
\hline u/sə]/no & $\varepsilon 0-308 ' s$ & $6 \varepsilon$ \\
\hline Eu/sə!̣n & $\varepsilon 0-\exists \varepsilon 0^{\circ} !$ & $8 \varepsilon r$ \\
\hline eu/se!uno & $\$ 0-3 \varepsilon Z \cdot Z$ & \\
\hline ג/səünכ & so- $\exists 6 Z^{\prime \prime}$ & \\
\hline w/sə|!no & $90-\exists 09 \varepsilon$ & \\
\hline u/sejuno & $\angle 0^{-} \exists 8 \varepsilon^{\prime} !$ & \\
\hline Eu/səupn & $90-\exists 9 L L$ & \\
\hline w/sepno & $80-360 \%$ & \\
\hline u/sə!ınว & $\varepsilon 0+\exists Z \sigma \cdot \tau$ & $\varepsilon$ \\
\hline u/səun & $10+\exists B L Z$ & 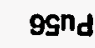 \\
\hline u/seןนnว & $20+396 \cdot 2$ & \\
\hline :u/sə̣|ฺno & $10+\exists \angle S^{\prime} \downarrow$ & 4 \\
\hline Ew/sapno & co+JZg's & \\
\hline Eu/sọno & $10+\exists Z 6^{\circ} b$ & \\
\hline Eu/so|ın & $10-390 \mathrm{Z}$ & $6 \varepsilon 2 n$ \\
\hline عw/sə!ınว & $\varepsilon 0+396 !$ & BEZn \\
\hline 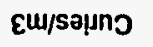 & $00.39 L L$ & \\
\hline$\varepsilon w / s \partial \mid \mu n \jmath$ & $20-3092$ & $9 b$ \\
\hline Eu/sə!ınว & $80-3926$ & st \\
\hline$w / s \partial \mu n$ & $10+\exists 8 L !$ & \\
\hline & ス!!n!ाइ & 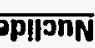 \\
\hline
\end{tabular}

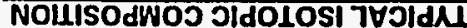

$\forall S 000$

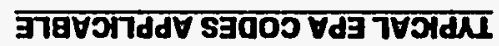

ANEW OTS

$د / \mathrm{EW}$ O'SZ

N/EW 0 SS

دNEW O'SZ

INEW 0 SS

SNEW 9'or

EW b'Zsz

gil B' ISZ

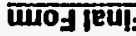

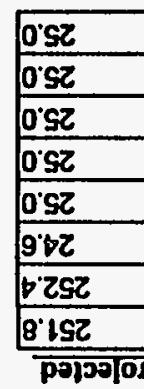

NOLIVYANGO IISHM JO SIIVY

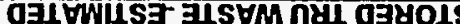

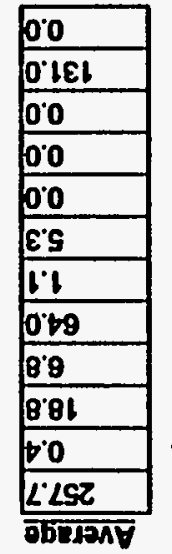

msed 'peqpien Guibeyord pois 'seprojew Gujbeyord

sios

хqлеш quebı 'poyptios

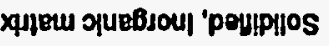

solfsedd

jeqquy

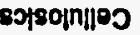

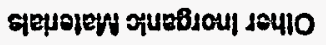

Sejow Jouno

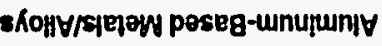

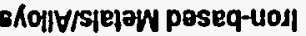

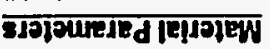

6ptE :pojojolos doquinn

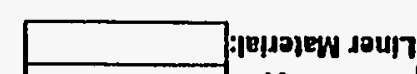
:ed 1 1อuा

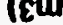

GISVM 7VJIdXI




\section{WASTE STREAM PROFILE FOR THE WIPP TRU WASTE BASELINE INVENTORY REPORT}

SITE NAME LA

WASTE TYPE MTRU HANDLING CH GENERATOR SITE LA

\begin{tabular}{|c|c|c|c|}
\hline WASTE STREAM MWIRID & LA- W005 & STREAMNAME & \\
\hline WIPP ID & LA-W005 & & \\
\hline Local ID & & DESCRIPTION & \\
\hline MATRIX CODE & & & \\
\hline SITE FINAL FORMIDC & & & \\
\hline Waste Matrix Code Group & Jncategorized Metal & & \\
\hline Site Matrix Description $\overline{\widehat{A}}$ & Jon-combustlble scraf & , cans, small equip & ment thems, broken glass, etc. \\
\hline
\end{tabular}

NO MUGRATION VARLANCE PETIION ASSIGNMENTLA 117A; 118A

IRUCON CODE LA 117A; 118A

FINAL WASTE FORM DESCRIPTORS:

Defense TRU Waste

Non-Defense TRU Waste

Commerclal TRU Waste

Unknown

$\square$

Mixed TRU

Non-Mbxed TRU

Suspect Mixed TRU

Unknown

$\square$

\begin{tabular}{l|l}
$\begin{array}{l}\text { Rsearch and Devel. Waste } \\
\text { Operations Waste }\end{array}$ & $\begin{array}{l}\text { TSCA } \\
\text { Residues }\end{array}$ \\
$\begin{array}{l}\text { Decon and Decommissioning } \\
\text { PCBs } \\
\text { Environmental Restoration } \\
\text { Orom Treatment of Waste } \\
\text { Maintenance }\end{array}$ & $\begin{array}{l}\text { N/A } \\
\text { Unknown }\end{array}$ \\
& \\
&
\end{tabular}

TSCA Asbestos

PCBs

Other

N/A

Unknown

From Treatment of Whaste

Maintenance 


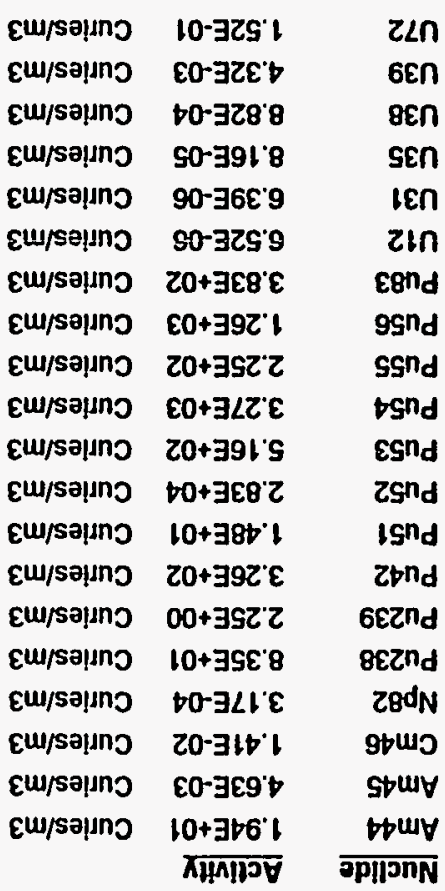

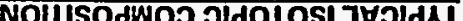

\begin{tabular}{|c|c|c|c|}
\hline \multicolumn{4}{|c|}{ V900a } \\
\hline \multicolumn{4}{|c|}{ 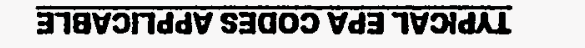 } \\
\hline دA/EW & D'sz & $0 \cdot 92$ & ]:2802-8002 \\
\hline INEW & $0: S 2$ & 0.92 & $: 2002-8681$ \\
\hline N/EW & 0.92 & $0^{\circ} \mathrm{SZ}$ & :L661 \\
\hline AR/EW & $0^{\prime} s z$ & 0.52 & : $: 9861$ \\
\hline АK/EW & $0^{\circ} 92$ & $0^{\circ} \mathrm{SZ}$ & :986l \\
\hline ShEW & I.SZ & Isz & : $\$ 686$ \\
\hline Eul & $62 \mathrm{ZIZ}$ & $6 \cdot 212$ & :8981 jo puछ \\
\hline EW & $\angle 2 \angle O Z$ & $\angle \angle L O Z$ & :266L 10 pug \\
\hline & 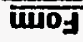 & $\overline{\text { pगj }}$ & \\
\hline
\end{tabular}
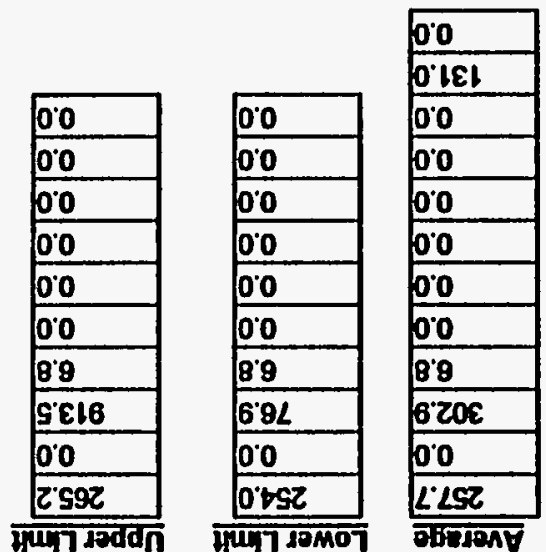

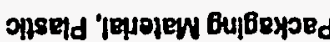

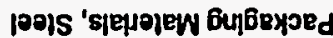
s\|los

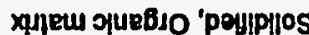

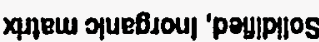

sonsełd

Jeqqny

sopsopnles

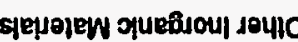

gำ에 seuno

8Roy

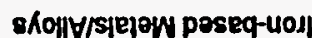

इगग्याटम्गारागएक

8116 :porjofosd JoqunN 6E01 :posols saqunN

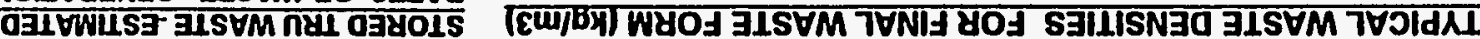

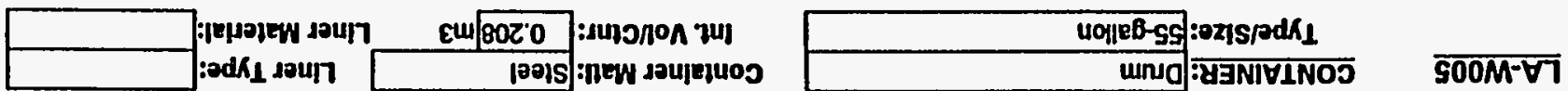




\section{WASTE STREAM PROFILE FOR THE WIPP TRU WASTE BASELINE INVENTORY REPORT}

SITE NAME LA

WASTE TYPEMTRU HANDLING CH

GENERATOR SITE LA

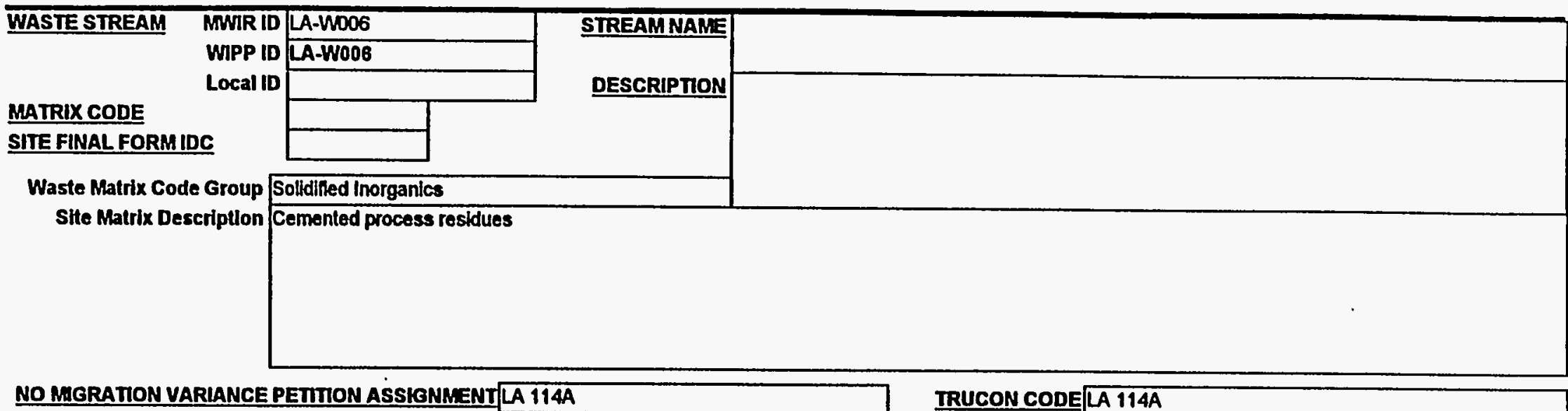

NO MGRATION VARIANCE PETIION ASSIONMENT LA 114A IRUCON CODE LA 114A FINAL WASTE FORMDESCRIPTORS:

\begin{tabular}{|c|c|}
\hline Defense TRU Waste & Mbxed TRU \\
\hline Non-Dofense TRU Waste & Non-Mbed TRU \\
\hline Commercial TRU Waste & Suspect Mlxed TRU \\
\hline Unknown & Unknown \\
\hline
\end{tabular}

Unknown

\begin{tabular}{ll}
$X$ \\
\hline \\
\hline \\
\hline \\
\hline
\end{tabular}

\begin{tabular}{lll} 
TSCA Asbestos & \\
PCBs & \\
Other & \\
N/A & \\
Unknown & \\
\hline
\end{tabular}




\section{WASTE STREAM PROFILE FOR THE WIPP TRU WASTE BASELINE INVENTORY REPORT}

SITE NAME LA

WASTE TYPE MTRU HANDLING CH GENERATOR SITE LA

LA-WO06 $\quad \frac{\text { CONTAINER: }}{\text { Type/SIzo: }}$ 55-gallon

\section{TYPICAL WASTE DENSITIES FOR FINAL WASTE FORM (kg/m3)}

Material Parameters

Iron-based Melals/Alloys

Aluminum-Based Metals/Alloys

Other Metals

Other Inorganic Materials

Cellulosics

Rubber

Plastics

Solidified, Inorganic matrix

Solidified, Organic matrix

Soils

Packaging Materials, Sleel

Packaging Material, Plastic

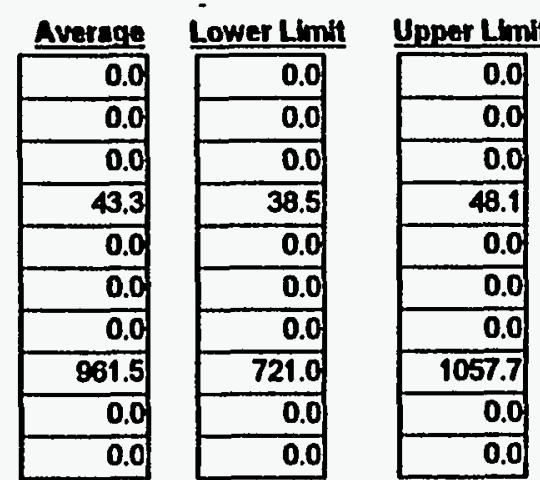

37.0 \begin{tabular}{r|l|l|} 
Container Matt: & Steol & Liner Type: \\
Int. Volgid \\
\hline $0.208 / \mathrm{m} 3$ & Liner Material: & HDPE \\
\hline
\end{tabular}

Number Stored: 2516

Number Projected: 6588
STORED TRU WASTE ESTIMATED RATES OF WASTE GENERATION

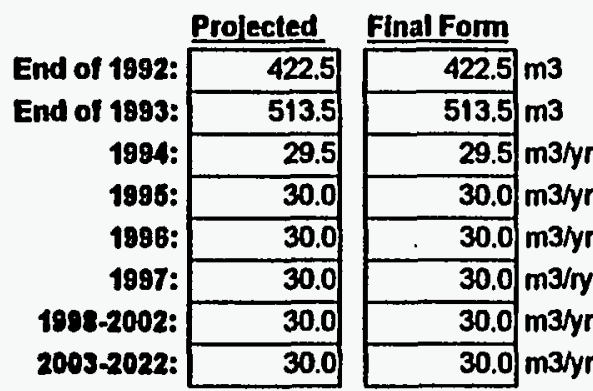

TYPICAL EPA CODES APPLICABLE DO07A
TYPICAL ISOTOPIC COMPOSITION

Nuclide Activity

Am241 1.32E+03 Curies $/ \mathrm{m}^{3}$

Am214 1.41E+04 Curies $/ \mathrm{m}^{3}$

Am45 3.70E-01 Curies $/ \mathrm{m} 3$

C1249 9.77E-05 Curies/m3

Cm46 1.36E-02 Curies $/ \mathrm{m}^{3}$

MFP $\quad 0.00 E+00$ Curies $/ \mathrm{m} 3$

Pu238 1.31E+01 Curies $/ \mathrm{m}^{3}$

Pu239 1.49E+01 Curies/m3

Pu41 1.80E-01 Curies/m3

Pu42 6.87E+02 Curles/m3

Pu51 1.40E+02 Curies/m3

Pu52 1.53E+04 Curles/m3

Pu53 1.13E+03 Curies/m3

Pu54 1.01E+03 Curies/m3

Pu55 2.63E+02 Curies $/ \mathrm{m}^{3}$

Pu56 3.08E+02 Curies $/ \mathrm{m3}$

Pu57 1.50E +02 Curies $/ \mathrm{m} 3$

Pu83 2.69E+03 Curles $/ \mathrm{m}^{3}$

Th228 0.00E +00 Curies $/ \mathrm{m}^{3}$

Th88 2.29E-03 Curies/m3

U12 2.47E-01 Curles/m3

U15 1.21E-03 Curies/m3

U22 1.71E-04 Curies $/ \mathrm{m}^{3}$

U23 2.70E-03 Curies/m3

U235 3.21E-03 Curies/m3

U32 7.34E-04 Curies/m3

U33 4.10E-04 Curies/m3

U34 1.36E-04 Curies/m3

U35 1.41E-04 Curies/m3

U36 1.63E-03 Curies/m3

U37 1.90E-04 Curies $/ \mathrm{m} 3$ 


\section{WASTE STREAM PROFILE FOR THE WIPP TRU WASTE BASELINE INVENTORY REPORT}

SITE NAME LA

WASTE TYPE MTRU HANDLING CH

GENERATOR SITE LA 


\section{WASTE STREAM PROFILE FOR THE WIPP TRU WASTE BASELINE INVENTORY REPORT}

SITE NAME LA

WASTE TYPE MTRU HANDLING CH GENERATOR SITE LA

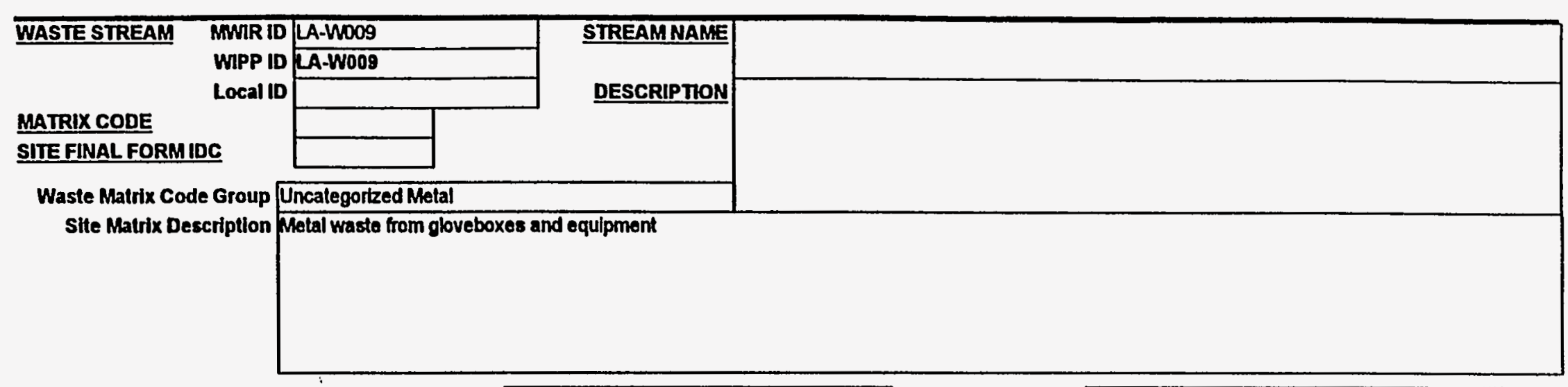

NO MIGRATION VARIANGE PETITION ASSIGNMENT

IRUCON CODE

\section{FINAL WASTE FORMDESCRIPTORS:}

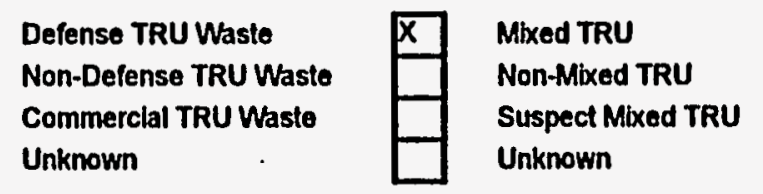

Rsearch and Devel. Waste Operations Waste

Residues

Decon and Decommissioning

Environmental Restoration

From Treatment of Waste

Maintenance

\begin{tabular}{ll}
$X$ \\
\hline \\
$\square$ \\
$\square$
\end{tabular}

TSCA Asbestos

PCBs

Other

N/A

Unknown

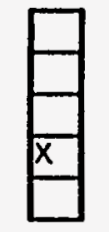




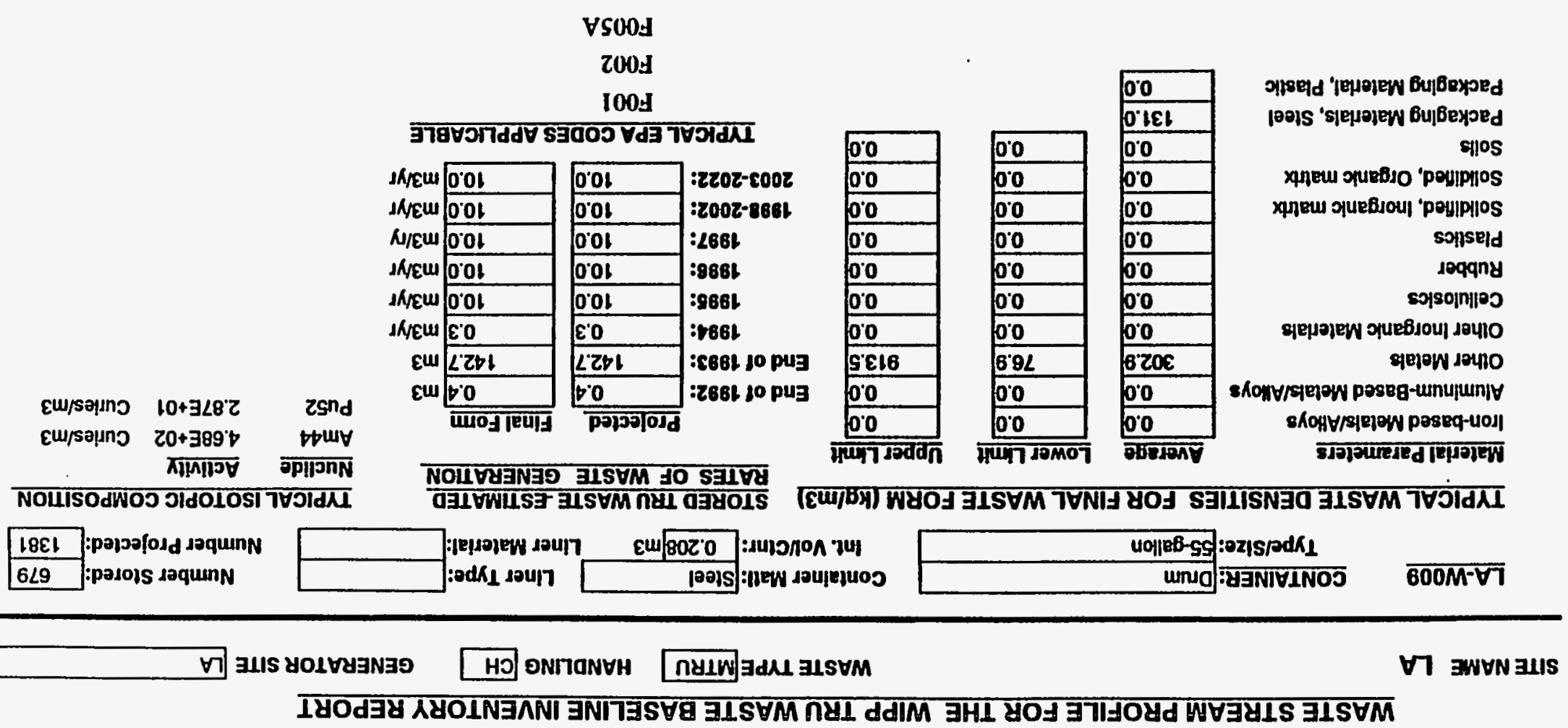




\section{WASTE STREAM PROFILE FOR THE WIPP TRU WASTE BASELINE INVENTORY REPORT}

STIE NAME LA WASTE TYPE MTRU HANDLINO RH GENERATOR SITE LA

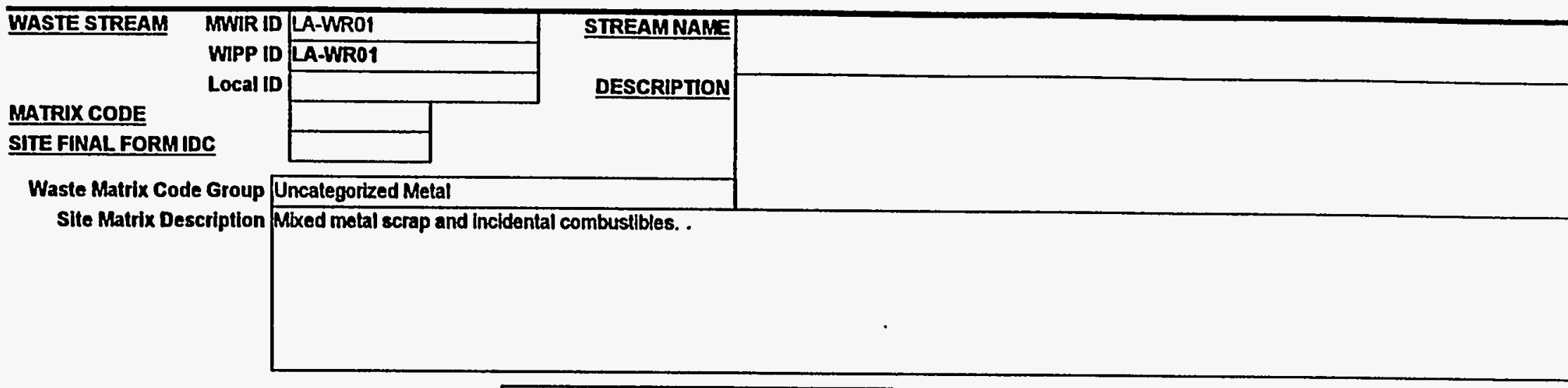

NO MIGRATION VARIANCE PETITON ASSIGNMENT

IRUCON CODE

\section{FINAL WASTE FORM DESCRIPTORS:}

\begin{tabular}{l|l|l}
$\begin{array}{l}\text { Defense TRU Waste } \\
\text { Non-Defense TRU Waste } \\
\text { Commerclal TRU Waste } \\
\text { Unknown }\end{array}$ & $\begin{array}{l}\text { Mixed TRU } \\
\text { Non-Mlixed TRU } \\
\text { Suspect Mixed TRU } \\
\text { Unknown }\end{array}$
\end{tabular}

$\square$

Rsearch and Devel. Waste
Operations Waste
Residues
Decon and Decommissioning
Environmental Restoration
From Treatment of Waste
Maintenance

TSCA Asbestos
PCBs
Other
N/A
Unknown




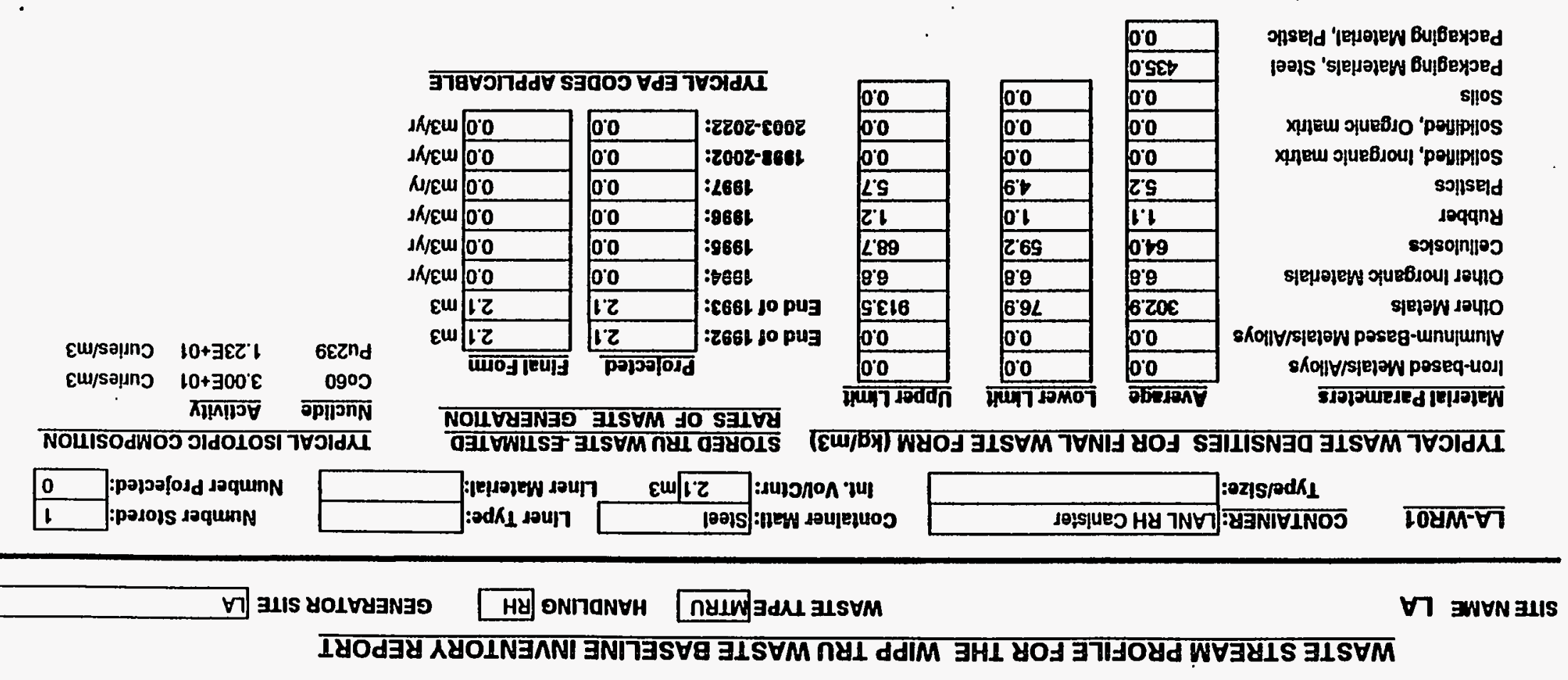




\section{WASTE STREAM PROFILE FOR THE WIPP TRU WASTE BASELINE INVENTORY REPORT}

SITE NAME LA

WASTE TYPE MTRU HANDLING RH GENERATOR SITE LA

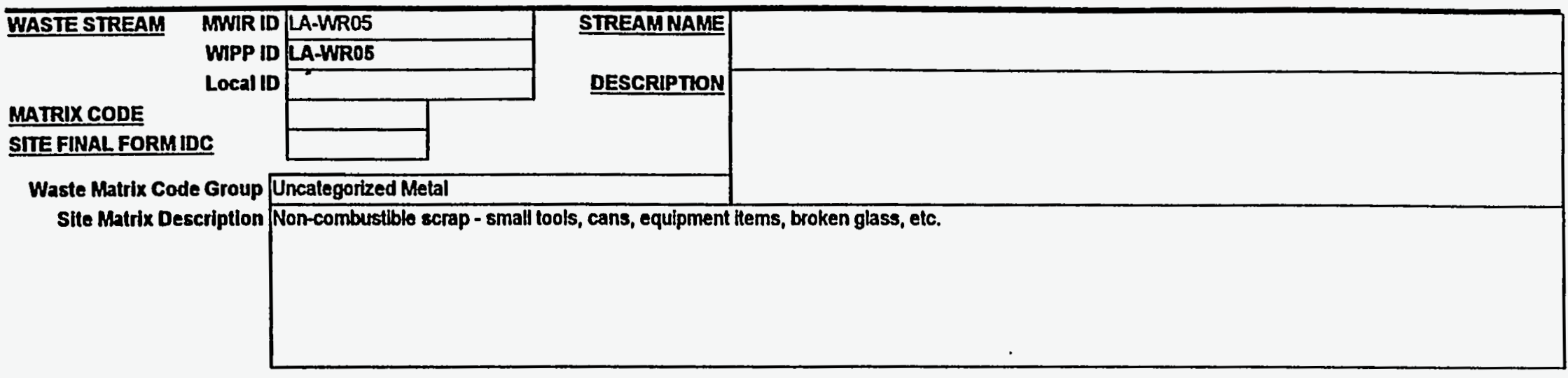

NO MGRATION VARIANCE PETIION ASSIGNMENT

IRUCON CODE

FINAL WASTE FORM DESCRIPTORS:

Defense TRU Waste

Non-Defense TRU Waste

Commercial TRU Waste

X

Mixed TRU

Non-Mixed TRU

Suspect Mbed TRU

Unknown

Rsearch and Devel. Wasle
Operallons Waste
Residues
Decon and Decommissioning
Environmental Restoration
From Treatment of Waste
Maintenance

TSCA Asbestos

PCBs

Other

N/A

Unknown

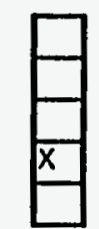




\section{WASTE STREAM PROFILE FOR THE WIPP TRU WASTE BASELINE INVENTORY REPORT}

\section{SITE NAME LA WASTE TYPE MTRU HANDLING RH GENERATOR SITE LA}

LA-WR05 CONTAINER: LANL RH Canister

TYPICAL WASTE DENSITIES FOR FINAL WASTE FORM $(\mathrm{kg} / \mathrm{m} 3)$

Material Parameters

Iron-based Melals/Alloys

Aluminum-Based Metals/Alloys

Other Metals

Other Inorganic Materials

Cellulosics

Rubber

Plastles

Solldified, Inorgank matrix

Solidified, Organic matrix

Soils

Packaging Materials, Steel

Packaging Material, Plastic

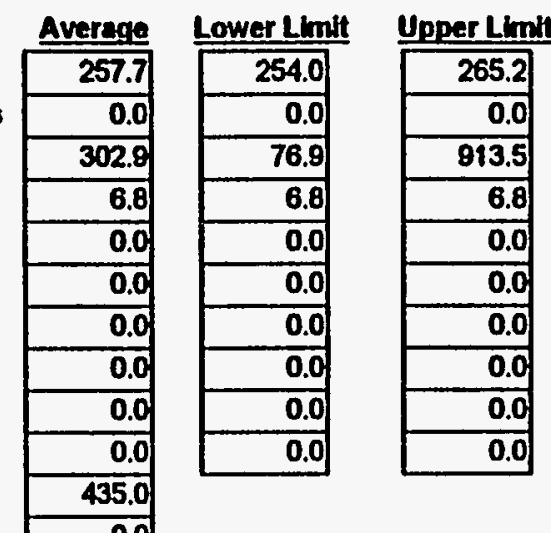

0.0

\section{Container Matl: Steel \\ int. Vouctnr:

$1 / \mathrm{m} 3$ \\ Liner Type: \\ Liner Material:}

STORED TRU WASTE.ESTIMATED

RATES OF WASTE GENERATION

\begin{tabular}{|c|c|c|c|}
\hline & Prolected & Final Form & \\
\hline End of 1992: & 0.0 & 0.0 & $\mathrm{~m} 3$ \\
\hline End of 1993: & 12.9 & 12.9 & m3 \\
\hline 1994: & 1.0 & 1.0 & $\mathrm{~m} 3 / \mathrm{yr}$ \\
\hline 1886: & 1.0 & 1.0 & $m 3 / y i$ \\
\hline 1998: & 1.0 & 1.0 & $\mathrm{~m} 3 / \mathrm{yr}$ \\
\hline 1997: & 1.0 & 1.0 & $\mathrm{~m} 3 / \mathrm{n}$ \\
\hline 1898-2002: & 0.2 & 0.2 & $m 3 / y r$ \\
\hline 2003-2022: & 0.5 & 0.5 & $m 3 / y r$ \\
\hline
\end{tabular}

TYPICAL ISOTOPIC COMPOSITION

Nuclide Activity

Ba137m 2.71E+03 Curies/m3

Cs137 2.89E+03 Curies $/ \mathrm{m3}$

Eu155 5.40E+01 Curies $/ \mathrm{m} 3$

Pm147 1.65E+02 Curies/m3

Pu239 1.34E+02 Curies $/ \mathrm{m} 3$

Rh106 2.12E+01 Curies/m3

Ru106 2.12E+01 Curies/m3

Sb125 1.18E+02 Curies/m3

Sr90 2.64E +03 Curies $/ \mathrm{m3}$

Te125m 4.88E+01 Curies/m3

Li235 1.14E-04 Curies/m3

Y90 2.64E+03 Curies/m3 


\section{Lawrence Berkeley Laboratory}




\section{LAWRENCE BERKELEY LABORATORY (LB) WASTE STREAM PROFILES}

The following assumptions/modifications were made by the WTWBIR team in developing the LB waste stream profiles:

- LB Final Waste Form Groups were modified to be consistent with the nomenclature used in the WTWBID. These changes included word and spelling changes. The assigned Final Waste Form Groups are consistent with the information provided by LB.

- The reported volume for the single LB waste stream was divided equally among the four different isotopic mixtures. 


\section{WASTE STREAM PROFILE FOR THE WIPP TRU WASTE BASELINE INVENTORY REPORT}

SITE NAME LB

WASTE TYPETRU HANDLING CH GENERATOR SITE LB

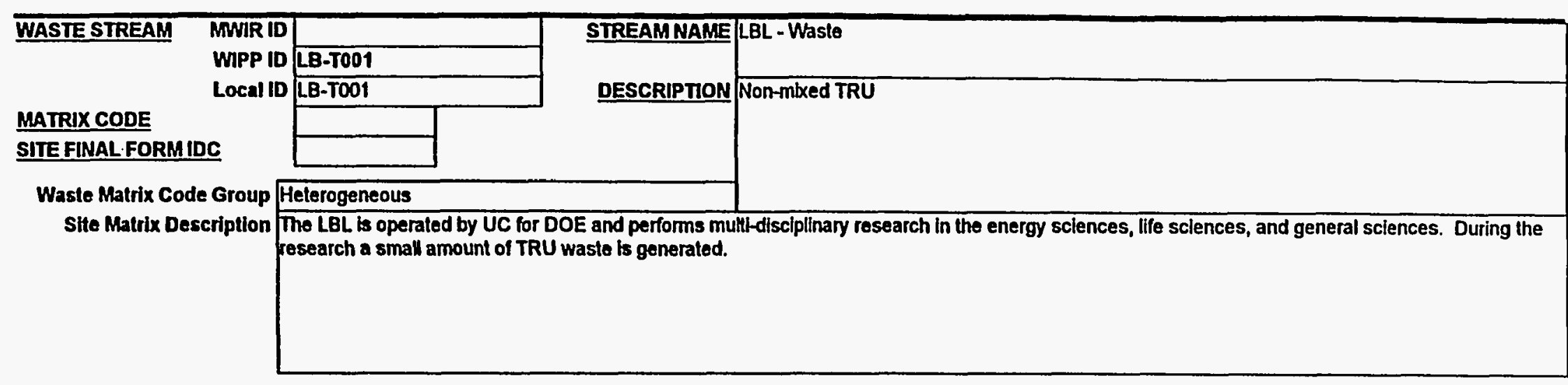

NO MGRATON YARIANGE PETIMON ASSIGNMENT

IRUCON CODE

\section{FINAL WASTE FORM DESCRIPTORS:}

\begin{tabular}{l|l} 
Defense TRU Waste \\
Non-Defense TRU Waste \\
Commerclal TRU Waste \\
Unknown
\end{tabular}$\quad \square \quad \begin{aligned} & \text { Mbed TRU } \\
& \text { Non-Mixed TRU } \\
& \text { Suspect Mixed TRU } \\
& \text { Unknown }\end{aligned}$

Rsearch and Devel. Waste
Operations Waste
Residues
Decon and Decommissioning
Environmental Restoration
From Trealment of Waste
Maintenance

TSCA Asbestos

PCBs

Other

N/A

Unknown

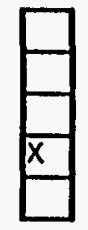

Maintenance 


\section{WASTE STREAM PROFILE FOR THE WIPP TRU WASTE BASELINE INVENTORY REPORT}

LE-T001

$$
\text { CONTAINER: Drum }
$$

Container Matt: Steel

Int. Voucenr: $0.208 / \mathrm{m3}$

Liner Type:
Liner Materlal:

IYPICAL WASTE DENSITIES FOR FINAL WASTE FORM (kg/m3)

Materlal Parameters

Iron-based Motals/Alloys

Aluminum-Based Melala/Alloys

Other Melals

Other Inorganic Ahaterials

Cellulosics

Rubber

Plasilics

Solldified, Inorganic matrix

Solidified, Organic matrix

Solls

Packaging Materials, Steel

Packaging Matertal, Plastic

\begin{tabular}{|r|} 
Average \\
\hline 390.0 \\
\hline 0.0 \\
\hline 425.0 \\
\hline 0.0 \\
\hline 150.0 \\
\hline 0.0 \\
\hline 450.0 \\
\hline 0.0 \\
\hline 150.0 \\
\hline 0.0 \\
\hline 131.0 \\
\hline 0.0 \\
\hline
\end{tabular}

\begin{tabular}{r|}
\hline Lower Limit \\
\hline 40.0 \\
\hline 0.0 \\
\hline 50.0 \\
\hline 0.0 \\
\hline 60.0 \\
\hline 0.0 \\
\hline 150.0 \\
\hline 0.0 \\
\hline 50.0 \\
\hline 0.0 \\
\hline
\end{tabular}

STORED TRU WASTE ESTIMATED RATES OF WASTE GENERATION

\section{Upper Llmit}

\begin{tabular}{|r|}
\hline 800.0 \\
\hline 0.0 \\
\hline 850.0 \\
\hline 0.0 \\
\hline 200.0 \\
\hline 0.0 \\
\hline 600.0 \\
\hline 0.0 \\
\hline 250.0 \\
\hline 0.0 \\
\hline
\end{tabular}

Prolected Final Form

\begin{tabular}{l|l|}
\hline End of 1983: & 0.210 \\
\hline 0.210 \\
\hline
\end{tabular}

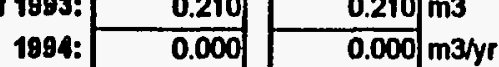

1995: $0.105 \quad 0.105 \mathrm{~m} 3 / \mathrm{yr}$

1998: $0.000 \quad 0.000 \mathrm{~m} 3 / \mathrm{yr}$

1997: $0.000 \quad 0.000 \mathrm{m3} / \mathrm{ry}$

1998-2002: $0.040 \mathrm{0.040} \mathrm{m3} / \mathrm{yr}$

2003-2022: $0.040 \quad 0.040 \mathrm{~m} 3 / \mathrm{yr}$

IYPICAL EPA CODES APPLICABLE
Number Stored: Number Projected:

\section{Comments}

lron-based motal approx. 5\%

Other metals approx. 5\%

Cellulosics - paper approx. 50\%

Plaslics approx. 30\%

Solidified organic matrix approx. $10 \%$

Drum \#1

IYPICAL ISOTOPIC COMPOSIIION

Nuclide Activity

Am241 6.73E-03 Curies $/ \mathrm{m}^{3}$

Np237 7.21E-03 Curies/m3

Pu239 7.69E-03 Curles/m3

Ra226 1.92E-05 Curies/m3 
WASTE STREAM PROFILE FOR THE WIPP TRU WASTE BASELINE INVENTORY REPORT

LB-T001 CONTAINER: $\frac{\text { Drum }}{\text { Type/Size: } 55 \text {-gallon }}$

Containet Matl: Steel LInet Type:

Int. VolvCtnr: $0.208 \mathrm{m3} \quad$ Liner Material:

Number Stored:

Number Projected:

$\begin{array}{r}\hline \\ \hline 5 \\ \hline\end{array}$

TYPICAL WASTE DENSITIES FOR FINAL WASTE FORM $(\mathrm{kg} / \mathrm{m} 3)$

STORED TRU WASTE ESTIMATED

Material Parameters

Iron-based Metals/Alloys

Aluminum-Based Metals/Alloys

Other Metals

Other Inorganic Materials

Cellulosics

Rubber

Plastics

Solidified, Inorganic matrix

Solidified, Organic matrix

Soils

Packaging Materlals, Steel

Packaging Material, Plastic

\begin{tabular}{|r|} 
Average \\
\hline 390.0 \\
\hline 0.0 \\
\hline 425.0 \\
\hline 0.0 \\
\hline 150.0 \\
\hline 0.0 \\
\hline 450.0 \\
\hline 0.0 \\
\hline 150.0 \\
\hline 0.0 \\
\hline 131.0 \\
\hline 0.0 \\
\hline
\end{tabular}

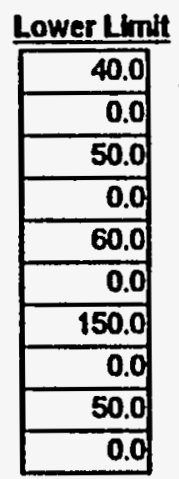
RATES OF WASTE GENERATION

IYPICAL ISOTOPIC COMPOSITION

\section{Upper Limit}

\begin{tabular}{|r|}
\hline 800.0 \\
\hline 0.0 \\
\hline 850.0 \\
\hline 0.0 \\
\hline 200.0 \\
\hline 0.0 \\
\hline 600.0 \\
\hline 0.0 \\
\hline 250.0 \\
\hline 0.0 \\
\hline
\end{tabular}

\begin{tabular}{r|r|}
\hline End of 1892: & Profecled \\
\hline End of 1893: & 0.210 \\
\hline $1984:$ & 0.210 \\
\hline $1995:$ & 0.000 \\
\hline $1898:$ & 0.105 \\
\hline $1997:$ & 0.000 \\
\hline $1898-2002:$ & 0.000 \\
\hline $2003-2022:$ & 0.040 \\
\hline & 0.040 \\
\hline
\end{tabular}

Nuclide Activity

Am241 2.99E-02 Curies/m3

Am243 3.37E-02 Curies/m3

CR49 1.95E-03 Curies $/ \mathrm{m} 3$

Pu238 2.45E-04 Curies $/ \mathrm{m} 3$

Pu242 4.28E-04 Curies/m3

Ra226 1.32E-02 Curies/m3

IYPICAL EPA CODES APPLICABLE

\section{Comments}

Iron-based metal approx. 5\%

Other melais approx. $5 \%$

Cellulosics - paper approx. 50\%

Plastlcs approx. $30 \%$

Solidified organic matrix approx. $10 \%$

Drum \#2 


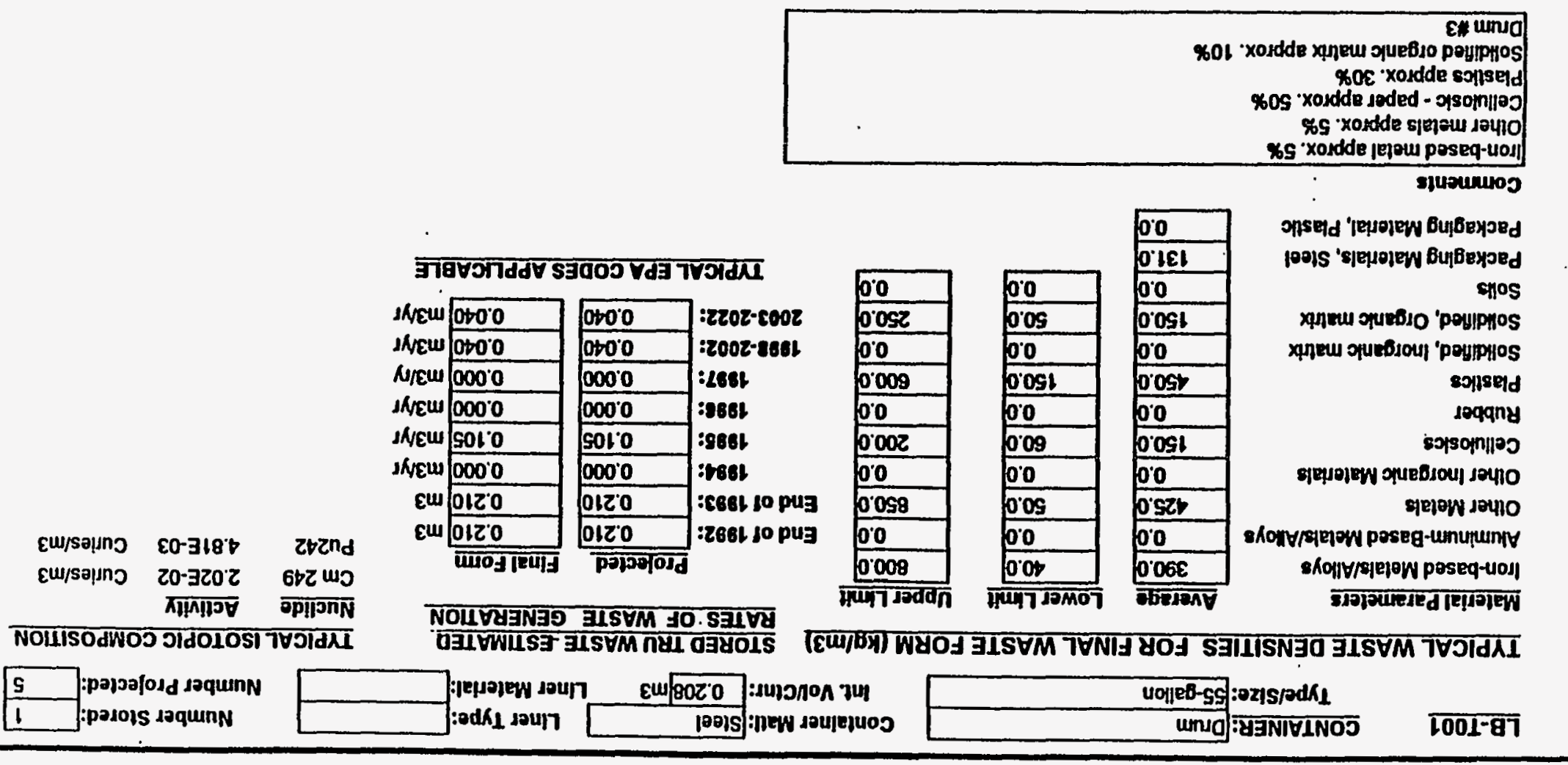

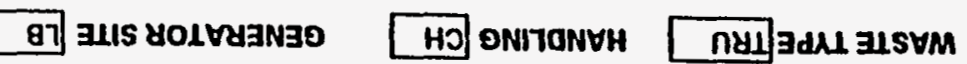


WASTE STREAM PROFILE FOR THE WIPP TRU WASTE BASELINE INVENTORY REPORT

LB-TO01 CONTALNER: Drum

TYPICAL WASTE DENSITIES FOR FINAL WASTE FORM (kg/m3)

Material Parameters

Iron-based Metals/Alloys

Aluminum-Based Metals/Alloys

Other Melals

Other Inorganic Materials

Cellulosics

Rubber

Plastics

Solidified, Inorganic matrix

Solidified, Organic matrix

Solls

Packaging Materials, Steel

Packaging Material, Plastlc

\begin{tabular}{|c|c|c|}
\hline Average & Lower Limit & Upper Limt \\
\hline 390.0 & 40.0 & 800.0 \\
\hline 0.0 & 0.0 & 0.0 \\
\hline 425.0 & 50.0 & 850.0 \\
\hline 0.0 & 0.0 & 0.0 \\
\hline 150.0 & 60.0 & 200.0 \\
\hline 0.0 & 0.0 & 0.0 \\
\hline 450.0 & 150.0 & 600.0 \\
\hline 0.0 & 0.0 & 0.0 \\
\hline 150.0 & 50.0 & 250.0 \\
\hline 0.0 & 0.0 & 0.0 \\
\hline
\end{tabular}

0.0

Container Matt: S

Int. Vouctnr:
Number Stored Number Projected:

\section{Comments}

lron-based metal approx. 5\%

Other metals approx. $5 \%$

Cellutosics - paper approx. $50 \%$

Plastics approx. $30 \%$

Solidified organic matrix approx. 10\%

Drum $\$ 4$

STORED TRU WASTE ESTIMATED RATES OF WASTE GENERATION

\begin{tabular}{|c|c|c|c|}
\hline \multirow{2}{*}{ End of 1992: } & Prolected & Final Form & \\
\hline & 0.210 & $\overline{0.210}$ & $\mathrm{m3}$ \\
\hline & 0.210 & $\overline{0.210}$ & m3 \\
\hline 1994: & 0.000 & 0.000 & $\mathrm{~m} 3 \mathrm{yr}$ \\
\hline 1995: & 0.105 & 0.105 & m3/yr \\
\hline 1996: & 0.000 & 0.000 & $\mathrm{~m} 3 / \mathrm{yr}$ \\
\hline 1997: & $\overline{0.000}$ & 0.000 & m3/ry \\
\hline 1998-2002: & 0.040 & 0.040 & m3/yr \\
\hline 2003-2022: & 0.040 & 0.040 & $m 3 / y r$ \\
\hline
\end{tabular}

TYPICAL EPA CODES APPLICABLE
TYPICAL ISOTOPIC COMPOSIMON

Nuclide Activity

Am241 6.33E-02 Curies $/ \mathrm{m} 3$

Am243 4.81E-03 Curies $/ \mathrm{m} 3$

CR49 1.20E-03 Curies $/ \mathrm{m}^{3}$

CR250 4.81E-05 Curies $/ \mathrm{m} 3$

Cm244 1.21E-02 Curies $/ \mathrm{m}^{3}$

Es253 4.81E-04 Curles $/ \mathrm{m} 3$

Es254 5.29E-03 Curies $/ \mathrm{m3}$

Np237 5.77E-06 Curles $/ \mathrm{m3}$

Pu240 5.05E-03 Curies/m3

Pu242 4.84E-03 Curies/m3

Ra226 2.06E-02 Curles/m3

U233 4.81E-03 Curies/m3 